\author{
UNIVERSIDADE DE SÃO PAULO \\ FACULDADE DE FILOSOFIA, LETRAS E CIÊNCIAS HUMANAS \\ DEPARTAMENTO DE GEOGRAFIA \\ PROGRAMA DE PÓS-GRADUAÇÃO EM GEOGRAFIA HUMANA
}

\author{
José de Sousa Sobrinho
}

\title{
O camponês geraizeiro no Oeste da Bahia: as terras de uso comum e a propriedade capitalista da terra
}

\section{Versão Corrigida}

São Paulo 2012 


\author{
UNIVERSIDADE DE SÃO PAULO \\ FACULDADE DE FILOSOFIA, LETRAS E CIÊNCIAS HUMANAS \\ DEPARTAMENTO DE GEOGRAFIA \\ PROGRAMA DE PÓS-GRADUAÇÃO EM GEOGRAFIA HUMANA
}

\author{
José de Sousa Sobrinho
}

\title{
O camponês geraizeiro no Oeste da Bahia: as terras de uso comum e a propriedade capitalista da terra
}

Tese apresentada ao Departamento de Geografia da Faculdade de Filosofia, Letras e Ciências Humanas da Universidade de São Paulo, para obtenção do título de Doutor em Geografia Humana.

Orientador: Prof. Dr. Ariovaldo Umbelino de Oliveira

Versão corrigida

O exemplar corrigido encontra-se no CAPH da FFLCH

De acordo:

Prof. Dr. Ariovaldo Umbelino de Oliveira

São Paulo

2012 


\section{FOLHA DE APROVAÇÃO}

Autor: José de Sousa Sobrinho

Título: O camponês geraizeiro no Oeste da Bahia: as terras de uso comum e a propriedade capitalista da terra

Orientador: Prof. Dr. Ariovaldo Umbelino de Oliveira

Tese apresentada ao Departamento de Geografia da Faculdade de Filosofia, Letras e Ciências Humanas da Universidade de São Paulo, para obtenção do título de Doutor. Área de Concentração: Geografia Humana.

Prof. Dr(a).

Banca Examinadora

Instituição: Assinatura:

Prof. Dr(a).

Instituição: Assinatura:

Prof. Dr(a).

Instituição:

Assinatura:

Prof. Dr(a).

Instituição: Assinatura:

Prof. Dr(a).

Instituição: Assinatura:

Aprovado em: 
Dedico à Dona Vitoriana, minha mãe. 


\section{AGRADECIMENTOS}

Chegar ao final desta tese foi para mim uma tarefa muito grande e difícil. Não teria conseguido se na trajetória percorrida, faltasse-me as valiosas ajudas de muitos amigos e companheiros.

Mesmo correndo o risco de cometer injustiças, esquecendo-me de alguns nomes, quero agradecer:

Ao Professor Ariovaldo Umbelino de Oliveira, mestre no ensino e na luta, pela oportunidade que me concedeu de prosseguir caminhando e aprendendo, e pela coragem de enfrentar comigo os desafios na realização desta tese;

Às Professoras Valéria de Marcos e Larissa Mies Bombardi, pelas críticas, sugestões e incentivos especialmente durante o exame de qualificação;

Ao Professor Heinz Dieter Heidemann pelo incentivo e apoio de sempre;

À Professora Marta Inêz de Medeiros Marques pelos valiosos ensinamentos sobre o campesinato;

À Professora Ely Estrela (in memoriam) pela amizade, pelas ricas trocas no grupo de estudos sobre o vale do São Francisco, e pelas indicações de contatos na cidade de Santa Maria da Vitória.

Às Professoras Terezinha de Jesus Andreoli Pinto, Telma Mary Kaneko e ao Professor Felipe Rebelo Lourenço, cuja compreensão e contribuição para a minha formação foram grandiosas, lembrarei e agradecerei sempre;

Aos meus familiares:

Vitoriana das Dores de Jesus, minha mãe, pelos exemplos de vida, incentivos e ensinamentos que me fortalecem;

Nina, minha companheira pela contribuição e paciência;

Francisco, meu queridíssimo filho, pela compreensão e paciência com as ausências do papai. Finalmente, meu filho, o papai está "terminando o doutorado."

Mazinha, Antonio, Sousa, Cilene meus irmãos. Em especial à mana Corrinha, por toda força que me deu ajudando-me na transcrição das entrevistas e nos cuidados com o Francisco. Aos cunhados Márcio, Josivaldo e à Darci. 
Tio Antonio e Tia Maria e aos primos: Chico, Alemão, Lucicléia, Adão, Célio, por ter gentilmente cedido o sítio onde passei uma temporada escrevendo esta tese. Especialmente ao tio Antonio pela valiosa companhia enquanto lá estive.

Aos meus amigos e companheiros do Grupo de Estudos do Vale do São Francisco "Chico Velho":

Camila, Olívia e Suelen e, de modo muito especial, ao Erick por estar sempre presente e disposto a ajudar no que precisei.

As leituras em grupo e os debates têm contribuído muito para a minha chegada até aqui.

Vitor, D. Maria e especialmente à Mônica, sempre a disposição para me socorrer nos momentos de desespero;

Vicente Eudes, que tanto tem me ajudado nos momentos de sufoco;

Mateus pela companhia nas andanças pelos gerais e auxílio na elaboração das figuras;

Aos amigos do Laboratório de Controle Biológico-FCF-USP: Mirian, Satiko, Wesley, Guilherme, Paulinho pela colaboração no dia a dia, especialmente ao Rafael pelas ajudas nos momentos de sufoco;

Ao Jorge pela leitura e revisão do texto;

Aos amigos de Santa Maria da Vitória:

Kynkas que abriu as portas da Casa da Cultura Antonio Lisboa de Morais, da Biblioteca Campesina e "dos gerais" para a realização da pesquisa;

Angélica pelas prosas alegres;

Cadinha e Hermes pelas informações e companhia na visita às comunidades do Mutum;

Ronaldo e ao Fred pelas informações e prosas;

Sr. Quinha pelas valiosas informações sobre os meandros dos conflitos agrários;

Sr. João Cerrano STR - Santa Maria da Vitória, pelas informações;

À equipe da CPT de Santa Maria da Vitória:

Julita, Albetânia, João Batista, Samuel e Marilene (in memoriam);

À Lúcia Lyra, Célia e João Nogueira pela providência aos livros do grande lutador e mártir na defesa dos posseiros de Santa Maria da Vitória, Eugênio Lyra; 
Aos amigos da cidade de Correntina:

Iremar pela amizade, valiosas informações, indicações dos interlocutores para entrevistas, e todo tipo de apoio que precisei;

Elizete pelo apoio;

Marquinhos sempre empenhado em me ajudar em tudo que precisei;

Paulo Oisiovici pelas valiosas informações e indicações;

Cecília pelas informações e prosas;

Tarique pela alegre receptividade e muitas ajudas;

Renilda pelo apoio;

Osmino pelas informações;

Sr. Olaíde e Gessi pelas informações e por me apresentar os fechos de gerais;

Ao Sr. Roberto pelas informações;

Aos geraizeiros das comunidades do baixo vale do rio Arrojado;

Jamilton pela companhia, amizade, indicações de interlocutores, informações e disposição de sempre ajudar;

Senhores João de Castro, João Magalhães, João de Nego, Izaurino, pelas informações;

Sr. Abidias, Sr. Lázaro, Celino, Sr. Antonio, D. Justina, Sr. Anésio, Valdivino, Carlinhos e Nice, da comunidade do Brejo Verde, pela acolhida e valiosas informações;

Sr. Deca e Fernando, da comunidade do Catolé;

Mirim, D. Anália, Sr. Antonio, Sr. Zé e D. Tereza das comunidades de Couro de Porco, Bebedouro, Passaroto e Cajueiro pelas informações;

Jorge Figueiredo do STR - São Desidério, Sr. Walmir do STR - Barreiras, Martin Mayr da Agência 10-envolvimento, Jacinta do STR - Formosa do Rio Preto, pelas valiosas informações que me forneceram.

Todos foram muito importantes nessa caminhada... 


\section{Resumo}

Desde o início da década 1970, o Oeste do Estado da Bahia destaca-se como a região de grande e intensa expansão das relações de produção capitalista. Essa expansão constitui-se de políticas estatais que favorecem ao capital, por meio de incentivos fiscais e implantação da infraestrutura exigida pelo agronegócio. Dentre as grandes mudanças provocadas por tais intervenções, destacam-se a degradação das riquezas naturais e a desterritorialização dos camponeses geraizeiros, que há muito tempo ocupam as terras de uso comum na condição de posseiros. Essas terras têm sido apropriadas pelo capital, o que provoca intensos conflitos com os camponeses. Nesta tese, são estudadas as comunidades do vale do rio Arrojado, no município de Correntina (Bahia). Pesquisou-se os processos sociais, concernentes à essa problemática, recorreu-se a trabalhos de campo e à teoria do desenvolvimento desigual e combinado, abordando não somente os processos concernentes à expulsão/expropriação dos camponeses, mas também a territorialização desses sujeitos sociais. Reporto-me, assim, às estratégias de produção e reprodução socioterritorial por eles engendradas, em uma situação conflituosa com as forças do capital e do Estado.

Palavras-Chave: Oeste da Bahia, camponeses geraizeiros, terras de uso comum, conflito de terras, reprodução socioterritorial, territorialização. 


\begin{abstract}
Since the early 1970s, the West of Bahia stands out as a region of great and intense expansion of capitalist relations of production. This expansion is made up of state policies that favor capital through tax incentives and infrastructure implementation required by agribusiness. Among the major changes caused by such interventions, we highlight the degradation of natural resources and displacement of peasants geraizeiros peasants [traditional inhabitants of the sertão - the backcountry regions of northeastern Brazilian states], which long ago occupied the lands in common use as non-title-holding residents for centuries. These lands have been appropriated by capital enterprises, which causes intense conflicts between farmers and peasant populations. In this thesis, the communities of the rio Arrojado valley, in the municipality of Correntina (Bahia), are analyzed. It was researched social processes, concerning this issue, we used the field work and the theory of combined and uneven development, addressing not only the processes concerning the expulsion/expropriation of peasants, but also the territorialization of these social subjects. I refer thus to the strategies of production and reproduction socio territorial they engendered, in a situation of conflict with the forces of capital enterprises and the state.
\end{abstract}

Keywords: Western Bahia, geraizeiro peasants, common use land, land conflict, socio-territorial reproduction, territorialization. 


\section{Lista de fotos}

Foto 1 - Bombeamento de água no rio Grande para a Fazenda Busato. 64

Foto 2 - Perfuração de poços. Barreiras. 64

Foto 3 - Presídio superlotado em Barreiras - BA.......................................... 75

Foto 4 - Oficial de justiça apresenta a liminar aos ocupantes. ................................83

Foto 5 - Oficial de justiça e a polícia militar forçam a retirada das famílias. ..............83

Fotos 6a/6f - Reintegração de posse Residencial Alphavile: Barreiras. ...................84

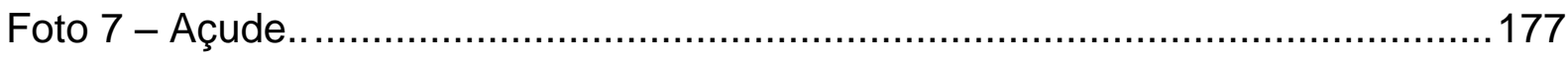

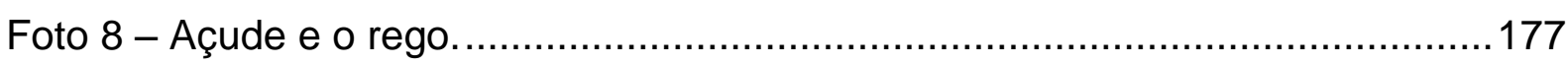

Foto 9 - Corredor (beco) que conduz o gado até o rego. ...................................181

Foto 10 - Corredor (beco) ………............................................................. 181

Foto 11 - Área de sítio: roça de feijão e a manga.................................................182

Foto 12 - O rego, a manga e a área de sítio......................................................182

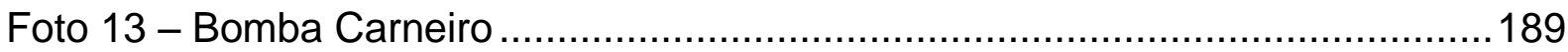

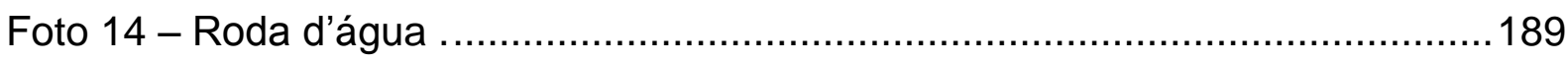

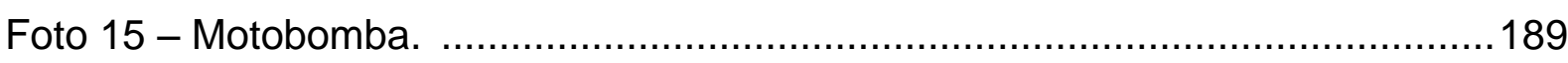

Foto 16 - Oficina: engenho de cana-de-açúcar. .............................................205

Foto 17 - Açúcar secando ao sol e a oficina de fabricação de açúcar. ..................206

Foto 18 - Utensílios da casa de farinha: o bulinete, a roda e o forno. ....................208

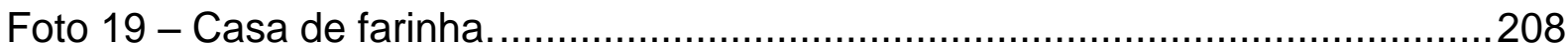

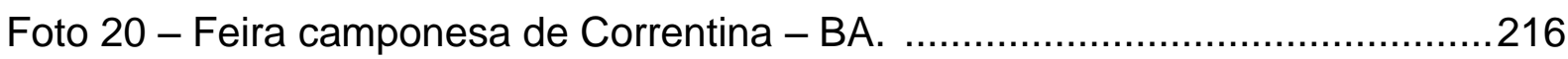

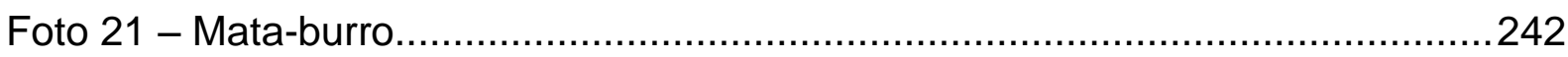

Foto 22 - Cocho e curral, fecho de gerais de Entre Morros à Morrinhos................256

Foto 23 - Rancho do fecho de gerais de Entre Morros à Morrinhos. ....................257

Foto 24 - Àrea de sítio com roça de alho e roça de feijão. .......................................323

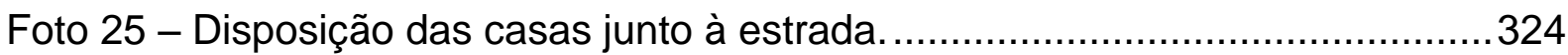

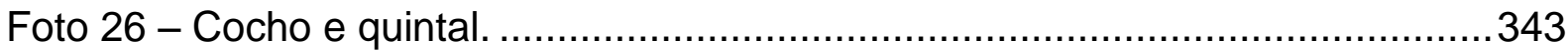

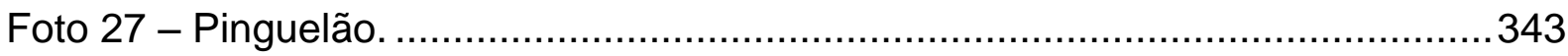

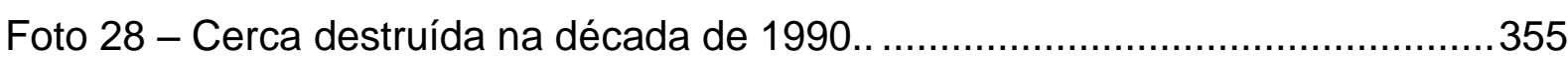




\section{Lista de figuras}

Figura 1 - Primeiro trabalho de campo, julho de 2008 ........................................

Figura 2 - Segundo trabalho de campo, janeiro de 2010 ....................................13

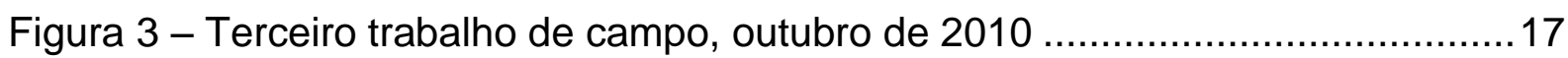

Figura 4 - Localização da área de estudo no Brasil ............................................2 25

Figura 5 - Localização da área de estudo no Estado da Bahia ..............................26

Figura 6 - Oeste da Bahia: esquema da ocupação territorial ................................51

Figura $7 \mathrm{a}$ - Imagem satélite - comunidades do baixo vale do Arrojado...................160

Figura $7 \mathrm{~b}$ - Comunidades do baixo vale do Arrojado ...........................................161

Figura 8 - Brejo Verde ............................................................................. 169

Figura 9 - Detalhe do percurso dos regos na comunidade do Brejo Verde ............171

Figura 10 - Calendário agrícola do regadio .....................................................201

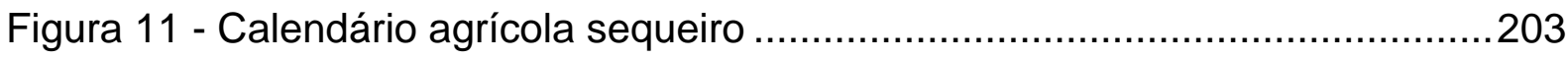

Figura 12 - Ocupação e uso da terra: comunidades do baixo vale do Arrojado .....230

Figura 12a - Ocupação e uso da terra: comunidades do baixo vale do Arrojado ...231

Figura 13 - Detalhe: usos da terra - comunidades do baixo vale do rio Arrojado ...232

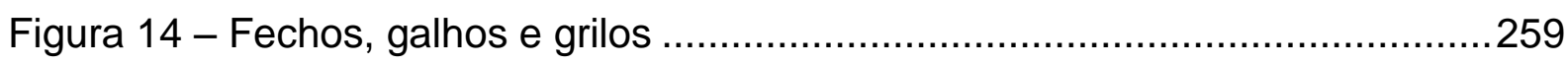

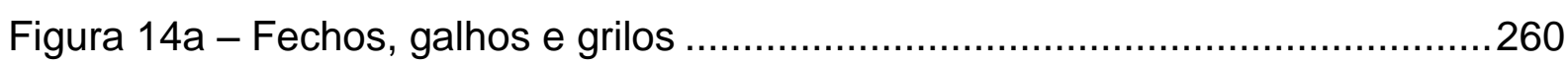

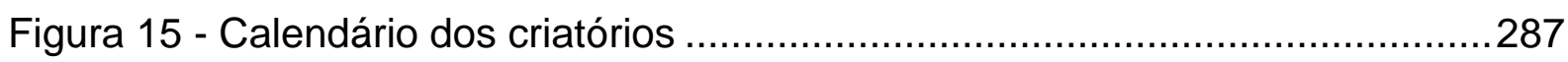

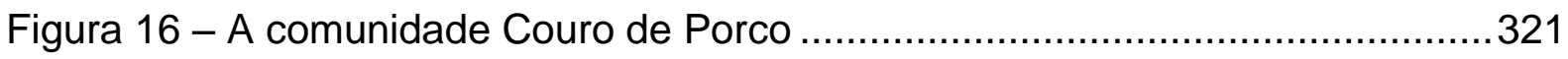

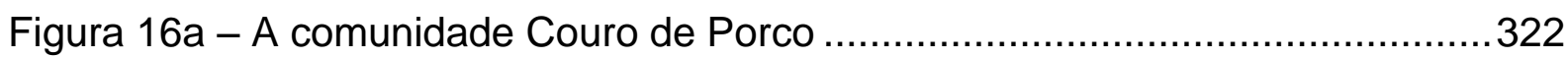

Figura 17 - Disputas territoriais na comunidade Couro de Porco ..........................356 


\section{Lista de imagens}

Imagem 1 - Certidão de Domínio, fls. 125 (frente): ação discriminatória..................360

Imagem 2 - Certidão de Domínio, fls. 125 (verso): ação discriminatória..................361

Imagem 3 - Certidão de Domínio, fls. 126 (frente): ação discriminatória..................362

Imagem 4 - Certidão de Domínio, fls. 125 (verso): ação discriminatória. .................363

Imagem 5 - Documento de penhora: ação discriminatória ....................................365

\section{Lista de tabelas}

Tabela 1 - Terras devolutas no Oeste da Bahia ................................................. 40

Tabela 2 - População e equipamentos sociais: médio vale do rio Arrojado ............320 


\section{Lista de siglas}

ABRE - Associação Baiana de Reflorestamento

ADAB - Agência Estadual de Defesa Agropecuária da Bahia

ADENE - Agência de Desenvolvimento do Nordeste

AIBA - Associação de Agricultores e Irrigantes da Bahia

ASA - Articulação do Semi-Árido

BB - Banco do Brasil

CAP - Cooperativa Agrícola de Pirapora

CAR - Companhia de Desenvolvimento e Ação Regional

CDA - Coordenação de Desenvolvimento Agrário

CEAS - Centro de Estudos e Ação Social

CEIP - Certificado Especial de Identificação e Produção

CLT - Consolidação das Leis Trabalhistas

COACERAL - Cooperativa Agrícola do Cerrado Central

CODEVASF - Companhia de Desenvolvimento do Vale do São Francisco e

Parnaíba

CONAB - Companhia Nacional de Abastecimento

CONTAG - Confederação Nacional dos Trabalhadores na Agricultura

COOPERCAMPO - Cooperativa dos Usuários dos Campos Públicos Ltda

COOPERSANTO - Cooperativa de Santo Antônio dos Anjos

COOPERTUBA - Cooperativa de Criadores Tradicionais do Campo da Pirituba

CPT - Comissão Pastoral da Terra

CRA - Conselho Regional de Administração

CUC - Canudos, Uauá e Curaçá

DIEESE - Departamento Intersindical de Estatística e Estudos Socioeconômicos

DNOCS - Departamento Nacional de Obras Contra a Seca

DRT - Delegacia Regional do Trabalho

DSR - Descanso Semanal Remunerado

EBDA - Empresa Baiana de Desenvolvimento Agrícola

EMBRAPA - Empresa Brasileira de Pesquisa Agropecuária

FETAG - Federação dos Trabalhadores na Agricultura

FUNDIFRAN - Fundação de Desenvolvimento Integrado do São Francisco 
FUNRURAL - Fundo de Assistência ao Trabalhador Rural

IBAMA - Instituto Brasileiros do Meio Ambiente e dos Recursos Naturais

Renováveis

IBGE - Instituto Brasileiro de Geografia e Estatística

INCRA - Instituto Nacional de Colonização e Reforma Agrária

INSS - Instituto Nacional do Seguro Social

IRPAA - Instituto Regional de Pequena Agricultura Apropriada

JICA - Japan International Cooperation Agency

$M A B$ - Movimento dos Atingidos por Barragens

MAPA - Ministério da Agricultura, Pecuária e Abastecimento

MP - Ministério Público

MP 432 - Medida Provisória 432

MST - Movimento dos Trabalhadores Rurais Sem Terra

MTE - Ministério do Trabalho e Emprego

OEDSV - Órgão Estadual de Defesa Sanitária Vegetal

ONG - Organização Não Governamental

PAC - Programa de Aceleração do Crescimento

PBF - Programa Bolsa Família

PC do B - Partido Comunista do Brasil

PDRI - Projetos de Desenvolvimento Rural Integrado

PFL - Partido da Frente Liberal

PGFN - Procuradoria-Geral da Fazenda Nacional

PMDB - Partido do Movimento Democrático Brasileiro

POLONORDESTE - Programa de Desenvolvimento de Áreas Integradas do

Nordeste

PROÁLCOOL - Programa Nacional do Álcool

PRODECER - Programa de Desenvolvimento do Cerrado

PRONAF - Programa Nacional de Fortalecimento da Agricultura Familiar

PRORURAL - Programa Estadual de Apoio ao Pequeno Trabalhador Rural

PT - Partido dos Trabalhadores

PVC - Policloreto de Polivinila

SEAGRI - Secretaria de Agricultura, Irrigação e Reforma Agrária

SEI-BA - Superintendência de Estudos Econômicos e Sociais - Bahia

SEPLANTEC - Secretaria de Planejamento, Ciência e Tecnologia 
SINDITEC - Sindicato dos Trabalhadores em Educação de Correntina

SIREGEO - Simpósio Regional de Geografia do Cerrado

STR - Sindicato dos Trabalhadores Rurais

SUDAM - Superintendência de Desenvolvimento da Amazônia

SUDENE - Superintendência de Desenvolvimento do Nordeste

TGI - Trabalho de Graduação Individual

UFBA - Universidade Federal da Bahia

UTM - Sistema Universal Transverso de Mercator 


\section{Glossário}

Açougueiro: comerciante de carne, integrante da comunidade ou da cidade, que compra o gado, abate-o e o vende no varejo.

Açude: construção para a captação da água do rio Arrojado ou de afluente, para o abastecimento dos regos.

Aguada: onde o gado bebe água.

Ajuda: auxílio com o sentido de reciprocidade.

Amigo: aquele com o qual se tem grande afinidade. Em geral trata-se de um parente ou membro da comunidade.

Apurado: o mesmo que necessitado.

Área de sítio: porção ribeirinha da parcela de uso exclusivo familiar onde a produção agrícola é mais intensa (geralmente dois ciclos anuais).

Arroz de prefeitura: variedade de arroz, cujo ciclo produtivo, dura seis meses.

Babuja: pequenas ervas daninhas que costumam nascer em grande quantidade nas terras por muito tempo cultivadas.

Bage: o mesmo que vagem.

Balsa: embarcação construída com um feixe de talas da palmeira buriti, a qual suporta carga de aproximadamente meia tonelada, variando conforme a quantidade de peças usadas na construção.

Barranco de rego: margem onde é depositada a lama rica em matéria orgânica, retirada do fundo no ato da limpeza.

Batida do gado: vestígio deixado pelo gado na sua locomoção, constituindo-se de pegadas ou outros sinais no caminho por onde passou.

Beca: fileira que se semeia ou na qual se planta os cultivos.

Beco: o mesmo que corredor.

Bom inverno: verão com quantidade de chuva considera satisfatória para o ciclo produtivo dos cultivos.

Botar a roça: trabalhar a terra durante o ciclo produtivo dos cultivos.

Botar sítio: o mesmo que formar sítio, ou seja, sedentarizar-se onde se pode a partir da aglomeração de outros geraizeiros, forma uma comunidade. 
Broca: na formação da roça corresponde ao corte da vegetação rasteira e de média altura com o uso de foice e em seguida a derrubada das árvores de grande porte com o uso de machados.

Broto mole: broto novo que sai após as queimadas.

Bulinete: equipamento rusticamente construído em madeira formando um cilindro com serras em volta, o qual, ao ser girado, tritura a mandioca.

Caçambinha de mão: o mesmo que carrinho de mão.

Cambão: dois pedaços de madeira, com uma corda amarrando um ao outro.

Campear: procurar o gado.

Capim de planta: o mesmo que capim forrageira, cultivado por alguns criadores e oferecido como alimento para o gado.

Capim de ração: o mesmo que capim forrageiro.

Capineira: o mesmo que capim forrageiro ou de ração.

Carreiro: homem que conduz o carro de boi.

Carros de linha: Camionetes e/ou ônibus que diariamente transportam passageiros e mercadorias do campo para a cidade e vice-versa.

Casa de farinha: pequena indústria onde se processa a mandioca, onde fabrica a farinha e demais derivados do tubérculo.

Cerca reforçada: cerca construída com varas fincadas ao chão e emparelhadas de modo a impedir o acesso de animais de médio e grande porte.

Chiqueiro: cercado onde se aprisiona os animais de pequeno e médio porte.

Chucho: vara de madeira com ponta em uma das extremidades, com a qual o lavrador abre na terra preparada um buraco onde se deposita a semente.

Cocheira: o mesmo que cocho onde se disponibiliza alimento para os animais.

Consideração: o mesmo que estima.

Cordas de terra: o mesmo que "tiras de terra".

Corredor: espécie de caminho, cercado nas laterais, o qual conduz o gado das mangas ou da solta para o rego (onde bebe água), ou para o curral.

Cuca: o mesmo que cozinheiro.

Dar a despesa: o mesmo que fornecer o alimento, a comida.

Embeiçar: o encontro da cerca com a extremidade do galho.

Encarunchar: submeter-se a ação perfurante do inseto "gorgulho" que ataca os cereais. 
Faisqueiro: atravessador que fazia e faz a compra do gado diretamente do criador e o repassa para terceiros, comerciantes da cidade.

Fazer a queimada: queimar a vegetação, após derrubada e seca;

Fazer sítio: o mesmo que se sedentarizar, instalar-se em um local que poderá formar uma comunidade.

Fechos de gerais: áreas de terras de uso comum, localizadas distantes das comunidades, na montante do vale do Arrojado, nas quais os camponeses geraizeiros soltam o gado em determinados períodos do ano, de acordo com as demandas do ciclo do capim, do regime do clima, assim como do ciclo das pastagens naturais.

Feijão catador: o mesmo que feijão de corda - colhido vagem por vagem.

Fraqueza: estado daquele camponês necessitado de víveres ou da família cuja produção da unidade familiar de produção não foi suficiente para o sustento familiar durante $o$ ano.

Gado solteiro: refere-se à rês que não se encontra com bezerros ou, de modo geral, aquele gado que se encontra forte, em condições de suportar a fadiga da longa viagem para os gerais.

Galho: pequeno afluente ou subafluente do rio Arrojado.

Gato: intermediários que aliciam os trabalhadores para o serviço nas grandes fazendas.

Gerais: ampla região constituída de terras encoberta pela vegetação de cerrados e livres de apropriação privada, da qual os camponeses geraizeiros apropriaram-se de boa parte como posseiros.

Gramalha: cerca provisória construída a partir de troncos com os galhos e folhas e que durava apenas enquanto se cultivava a roça.

Grota: na área de solta, a nascente onde o gado bebe água.

Inverno: o mesmo que estação chuvosa ou verão.

Ladrão: escavação na borda do rego para a retirada da água usada na irrigação.

Lambedor: mancha de solo de alto teor salino cujo sal é aproveitado pelo gado pé duro.

Leirinha: pequena leira de terra feita entre os plantios para conduzir a água na irrigação. 
Lote: expressão usada para se referir ao que restou àqueles que "venderam" a sua posse à frente, o que corresponde a área de solta, Ihes restando apenas a área da moradia e seu entorno imediato, da estrada ao rio.

Mal de toque: doença que atinge o estômago e o intestino do gado vacum, causada pela ingestão de grande quantidade de areia fixada nas folhas do capim.

Manga: área de pasto formado nas parcelas de uso exclusivo familiar.

Mangueiro: nos fechos de gerais denominam-se os cercados onde prendem o gado para reuni-lo e retornar às áreas das comunidades. No mangueiro também permanecem os cavalos utilizados diariamente no campear do gado.

Mata burro: consiste numa espécie de túnel construído sob a estrada. Nele o gado passa para ter acesso à água do rego e ao que é servido nas proximidades da casa, sem o risco de se dispersar na estrada.

Mata: vegetação típica da zona de transição entre os biomas dos cerrados e caatingas.

Moradia: casa de morada;

Muinha: palha seca e fragmentada.

Mutirão: trabalho em conjunto e gratuito com o sentido de ajuda, que prestam uns aos outros, os membros de uma comunidade.

Na perna: assim chamada a transação comercial em que o gado não é pesado no ato. Estima-se seu peso e a partir disto comercializa-o.

Nanuscada: o mesmo que noz-moscada.

Necessitado: aquele que se encontra carente de ajuda.

Oficina: pequena indústria doméstica em que processam os produtos oriundos da produção da unidade familiar de produção.

Paiada: o mesmo que palha seca.

Paiol: abrigo (pequeno galpão) construído para o armazenamento dos produtos colhidos (principalmente o milho).

Para a semente: separado e conservado para plantio.

Pastagem mansa: o mesmo que pastagem cultivada.

Pasto manso: o mesmo que pasto cultivado.

Perder o leite: referência ao estagio inicial da desidratação ou secagem do caule ou rama da mandioca.

Picadão: estreita e comprida abertura nas áreas dos cerrados, empregado para servir de divisa entre as posses ou propriedades. 
Pinguelão: tronco comprido de madeira que é instalado transversalmente ao rio Arrojado para a travessia de pedestres.

Piquete: fração do pasto da parcela de uso exclusivo familiar, cercada, e formada com pastagem.

Produtos da terra: o que é produzido nas comunidades ou extraído dos cerrados.

Queimada boa: quando a queimada proporciona o broto da pastagem em abundância para a alimentação do gado.

Quintal: nas comunidades do médio vale do Arrojado é assim chamada a área cercada entre a moradia e o rio na qual se encontram os cercados onde aprisionam os animais de pequeno e médio porte, cultivam alguns alimentos (principal mandioca e feijão) e formam pastagem.

Ralo: utensílio usado para ralar a mandioca. É construído a partir de uma folha de flandres perfurada e em formato retangular. Suas extremidades maiores são fixadas (com o uso de pregos) em uma grade feita em madeira.

Rama: o caule da mandioca.

Rancho: ponto de apoio nos fechos de gerais onde os criadores permanecem enquanto cuidam do gado. É aí que deixam as ferramentas de trabalho e também se encontra o curral, o mangueiro e os cochos que servem o sal para o gado.

Rebentão: rompimento do barranco do rego pela força da água.

Regadio: área onde se pratica a agricultura irrigada.

Rego: canal de irrigação que percorre uma curva de nível na vertente do vale. Do rego capta-se a água para a irrigação da área de sítio.

Relâmpago: ação rápida de construção ou destruição de benfeitorias na área de conflito.

Roça de sequeiro: roça cultivada na estação chuvosa, no verão.

Salina: referência ao recipiente (cocho), mas também, ao lugar onde é oferecido o sal para o gado.

Sequeiro: cultivos não irrigados e realizados na estação chuvosa.

Serra: a escarpa de subida para o tabuleiro.

Sítio: parcela onde se trabalha e se constitui moradia.

Soca: brotos nascidos a partir do tronco do arroz colhido, produzindo novos cachos e uma segunda colheita.

Solta: área de criatório anexa à comunidade na qual o rebanho dos criadores é solto a pastar misturado. 
Tardão: cultivo de ciclo produtivo longo.

Tempestade: o mesmo que ventania.

Terra mansa: terra desmatada, trabalhada, e que já foi cultivada.

Terras de cultura: as terras férteis localizadas nas vertentes baixas dos vales, usadas em cultivos de alimentos ou de pastagens.

Testa de ferro: assim chamados na região aqueles que tomam ou adquirirem, por meios ilícitos, determinada área dos camponeses geraizeiros, sem qualquer intenção de torná-la economicamente produtiva. Em seguida, contando com os préstimos do aparelho estatal local, estadual e até mesmo federal, "fabrica" documentação ilícita, com a qual transfere a terra para terceiros.

Tipiti: espécie de cesto para espremer a massa da mandioca usada na fabricação da farinha.

Tiras de terra: parcelas de terra estreitas e longas.

Toras de terra: partes da parcela fracionada transversalmente nas partes mais elevadas, nas terras de cultura.

Trabalho de metade: trabalho em que a colheita é dividida em partes iguais destinadas ao camponês que trabalha e ao dono da terra.

Tralha: utensílios de cozinha necessários para a preparação dos alimentos.

Traquejado: refere-se ao gado ambientado, aquele que, melhor adaptado às condições naturais, sobrevive com maior facilidade aproveitando os víveres oferecidos pelos cerrados.

Troca de serviço: o mesmo que troca de trabalho.

Tropeiro: comerciante que percorria a região transportando as mercadorias em animais de carga.

Vala: sulco cavado transversalmente ao rio, utilizado para drenar a umidade excessiva do terreno tornando possível o cultivo de produtos agrícolas.

Vazante: área submetida à inundação quando das cheias dos rios.

Ventania: ações de grupos, dos geraizeiros ou das empresas, que constroem ou destroem rapidamente alguma benfeitoria na área de conflito.

Verão: a estação seca, ou de inverno.

Vizinho: aquele que mora próximo, na comunidade. 


\section{Sumário}

À guisa da introdução: os caminhos e as caminhadas..........................................

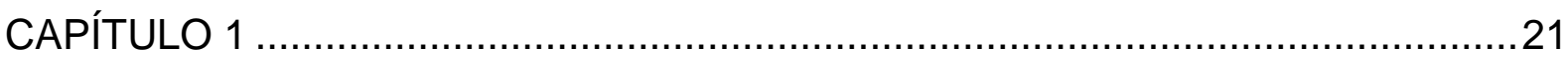

1.1 A expansão da propriedade capitalista da terra no Oeste da Bahia ................22

1.2 Caracterização do Oeste da Bahia ................................................................ 24

1.3 Abordagens sobre o conceito de território ............................................... 28

1.4 As correntes teóricas interpretativas do campo e da agricultura no Brasil ..... 43

1.5 A "ocupação" "moderna" no Oeste da Bahia ............................................... 49

1.6 As relações de trabalho e a atuação dos sindicatos no Oeste da Bahia ........ 76

CAPÍTULO 2

2.1 As investidas contra as terras de trabalho camponesas no Oeste da Bahia .. 88

2.2 A expropriação e a expulsão para a superexploração da força de trabalho ... 96

2.3 A Des-Ocupação do vale do São Francisco/Oeste da Bahia: um mergulho na

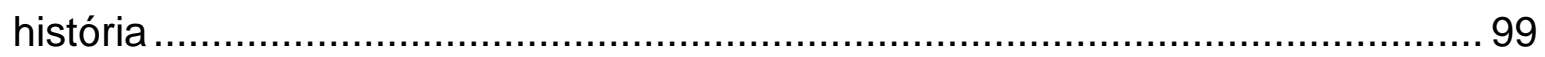

$2.4 \mathrm{O}$ uso comum da terra no Brasil ........................................................... 107

2.5 Os fundos de pastos no Estado da Bahia ................................................. 119

CAPÍTULO 3

3.1 A atuação dos mediadores junto aos movimentos sociais .......................... 140

3.2 Investida privatista da terra no Oeste da Bahia: articulação da resistência.. 144

3.3 No horizonte, ao longe, alguma luz ...................................................... 153

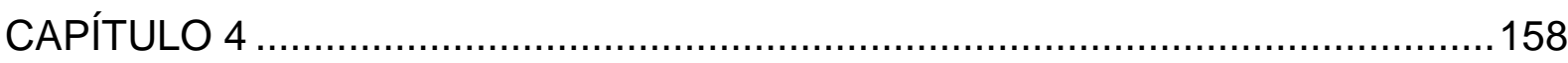

4.1 Comunidades do vale do Arrojado: caminhos percorridos para o estudo..... 159

4.2 As comunidades do baixo vale do rio Arrojado........................................... 163

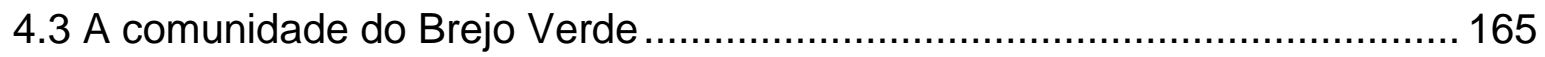

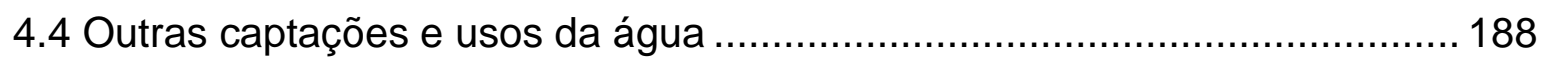

4.5 Usos da terra e da água na área de regadio ................................................ 191

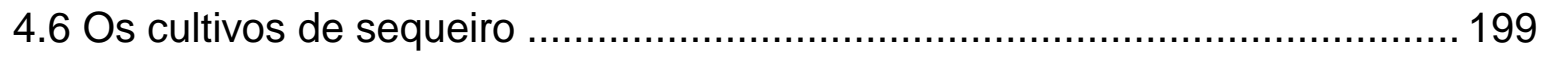

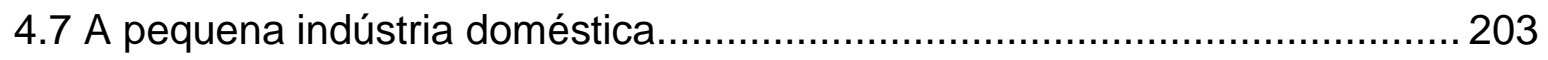


4.8 As parcerias: nos usos dos meios de trabalho, no trabalho e na terra .........218

4.9 Trabalho acessório e migração........................................................ 232

4.100 ordenamento da unidade territorial camponesa ................................ 238

4.11 A territorialização geraizeira do Oeste da Bahia .................................. 246

4.12 As investidas dos grileiros: desterritorialização dos geraizeiros ................. 266

4.13 Saberes e organização dos geraizeiros para o uso pecuário da terra........ 282

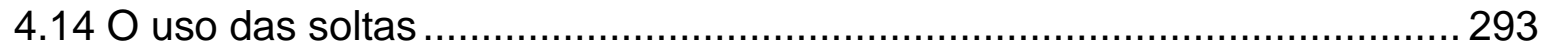

$4.15 \mathrm{O}$ uso geraizeiro da terra e a luta pela preservação ambiental .................. 312

4.16 A comercialização da produção pecuarista dos geraizeiros ..................... 314

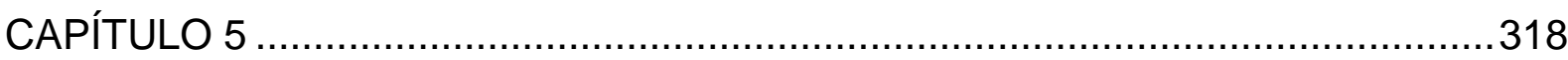

5.1 As comunidades do médio vale do rio Arrojado .................................... 319

5.2 A territorialização geraizeira do médio vale do Arrojado: o uso agrícola das

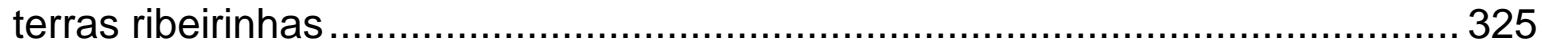

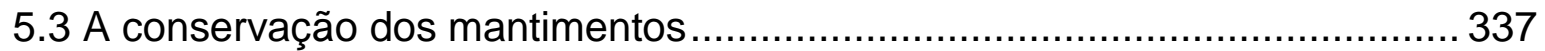

$5.4 \mathrm{O}$ uso pecuário da terra e os tratos aos animais .................................... 339

5.5 A fração territorial comunitária dos camponeses geraizeiros do médio vale do rio Arrojado em disputa............................................................ 345

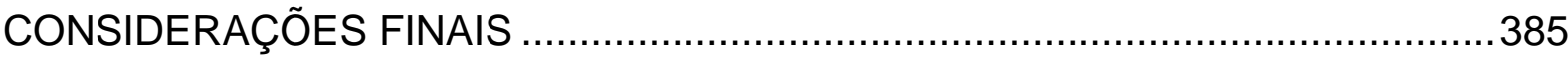

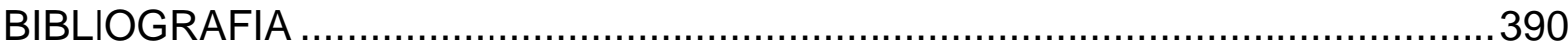

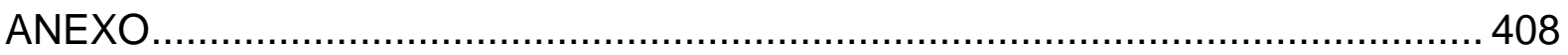


Me oculto no teu ventre

$$
\text { TERRA }
$$

Me encontro, homem, no teu grito

TERRA

Espero da justiça o último

E

C

O

E trago no meu grito o fato

TERRA

Aqueles que não tem

TERRA

Aqueles que tiveram

TERRA

Aqueles que pretendem

ter

ra

ter

Não morrerão sem

TERRA

Martelo.

O ferro funde o ferro:

Forja,

assim como...

Trabalho,

e amo,

aro a terra

Custo a acreditar.

Na posse da tua terra

semeando / plantando

não podes trabalhar

malditainjustaes ( ta ) trutura

EUGÊNIO LYRA 


\section{À guisa da introdução: os caminhos e as caminhadas}

$\mathrm{Na}$ trajetória percorrida para a realização desta pesquisa, persegui os processos constituintes da problemática de estudos, adotando o caminho indicado por Martins (1996, pp.1-2), quando afirmou que o "conceito vem no final do processo de pensamento e não no começo". Desta forma, este trabalho consiste em mais um estágio de um processo começado à 15 anos antes, quando comecei a envolver-me com os problemas relacionados ao vale do rio São Francisco. Desde o princípio dos estudos, tenho adotado, como principal fonte para as reflexões, a realidade concreta, visitada sempre que o aperto da vida permite algum escape.

Nesta trajetória, tenho evitado pré-concepções a partir de noções pouco embasadas, apriorísticas, sobre os problemas de estudo. Sempre acreditei que a principal fonte de pensamento é a realidade concreta. E, imediatamente após a alguma aproximação a esta, o pensamento começa operar e disto resulta o processo de pensamento que continua, a partir da escolha de conceitos e categorias que julgo adequados para a formulação e a reformulação constante da reflexão sobre a realidade.

Esta pesquisa significa, pois, a continuidade dos estudos sobre o vale do rio São Francisco iniciados em maio de 1996 pelo grupo de estudos "Chico Velho", quando estava no quinto semestre do curso de Geografia da Faculdade de Filosofia, Letras e Ciências Humanas da Universidade de São Paulo.

O interesse pelas questões relacionadas à região Nordeste, mais especificamente ao vale do rio São Francisco, teve início quando li, por indicação de 
um amigo de turma e depois de grupo, o livro Tradição e mudanças - a organização do espaço rural e urbano na área de irrigação do sub-médio São Francisco, de Manoel Correia de Andrade.

Decidimos fundar o grupo de estudos e realizarmos, logo em seguida, no mês de julho de 1996, uma viagem ao vale. O objetivo daquela viagem seria conhecê-lo e encontrar o objeto de estudos para a realização do Trabalho de Graduação Individual (TGl), pesquisa exigida para a conclusão do curso. Naquela viagem, tivemos contato com várias localidades do vale e decidi realizar a pretendida pesquisa sobre os projetos de irrigação da Companhia de Desenvolvimento do Vale do São Francisco e Parnaíba (CODEVASF), situados no submédio vale, com intuito, segundo a companhia, de sanar as consequências, das frequentes estiagens, sentidas pela população nordestina. E elegi, para estudos mais aprofundados, o Projeto de Irrigação de Bebedouro, situado no município de Petrolina (PE).

Aquele trabalho teve como título "Submédio São Francisco: seus projetos e seu povo" e foi desenvolvido sob orientação do Prof. Ariovaldo Umbelino de Oliveira. A análise foi realizada enfocando as políticas públicas governamentais destinadas a sanar os efeitos das constantes estiagens que assolam a região semiárida nordestina. Assim, das conclusões a que cheguei, quando verifiquei o grau de acesso das populações locais à estrutura ali instalada, destaca-se o insignificante número de pessoas beneficiadas com as intervenções estatais - comparando-se com a quantidade de empresas que se deslocam do centro-sul para a região. Estas empresas apropriam-se de imensas áreas, que antes eram ocupadas pelos beiradeiros, pelos pequenos produtores camponeses de sequeiro, e também dos incentivos fiscais e financiamentos para aquela região. Ou seja, confirmava-se a nossa hipótese inicial (naquela ocasião) de que os projetos governamentais, destinados à região, "beneficiaram muito a poucos e pouco a muitos" (SOUSA SOBRINHO, 1998).

Desde a fundação do grupo, encontramo-nos semanalmente para discutir nossas leituras, além de assistir e discutir filmes e documentários sobre a região de interesse. Consta também das nossas atividades a realização de viagens ao vale.

Em 1998, realizei a segunda viagem à região para trabalho de campo do TGI e, em julho de 2001, fiz a terceira. Nesta última, o objetivo seria também o encontro de objeto de pesquisa e de materiais que subsidiassem a elaboração de um projeto 
de pesquisa para concorrer a uma vaga no curso de pós-graduação (mestrado). procedimento para coleta de materiais foi idêntico ao da primeira viagem, embora, na última, tenha também explorado todas as bibliotecas públicas municipais, eclesiásticas e universitárias das cidades visitadas (as mineiras: Morro da Garça, Pirapora, Montes Claros, Januária e Itacarambi; as baianas: Caetité, Bom Jesus da Lapa, Serra do Ramalho, Barra e Juazeiro; e as pernambucanas: Petrolina e Exu). Foi nessa ocasião que se deu também o primeiro contato com o objeto específico de estudo da pesquisa para o mestrado: os Brejos da Barra (BA).

A realidade brejeira causou-me grandes surpresas e despertou muito interesse: a situação geográfica dos brejos "ilhados" nos imensos campos dunares; a paisagem do ambiente brejeiro: o verde aceso naquele "mar" cinzento das caatingas, as sombras e as águas frescas; e quanto ao povo: suas moradias, seus instrumentos de trabalho (engenhos e casas de farinha), suas relações, espacializações, prestatividade e seu acolhimento.

As primeiras impressões foram de muito agrado e tinha por certo uma realidade de grande interesse para estudos. No entanto, "pensava grande": queria estudar o vale por inteiro - até porque, outras áreas também interessavam muito. Queria "entender tudo" e, por isso, os anseios eram demais ambiciosos.

Elaborei o projeto, no qual constava áreas-problemas de pesquisa diferentes e afastadas uma das outras. Assim, acreditava poder abarcar ou aproximar dos problemas do vale na sua totalidade.

Elegi problemas de pesquisa no município de Pirapora (MG), envolvendo o Projeto de Irrigação Cooperativa Agrícola de Pirapora (CAP) e a população trabalhadora do povoado de Barra do Guaicuí, nas proximidades da barra do afluente do São Francisco, rio das Velhas. Além de outros problemas do entorno, tais como os desmatamentos de cerrados para transformação em carvão e em lavouras de eucalipto; problemas ambientais causados pelas atividades mineradoras e outros.

No Oeste da Bahia, pretendi pesquisar uma ampla área compreendida pelos vales dos rios Carinhanha, Corrente e Grande; incluindo-se os Brejos da Barra, assim como os problemas relacionados à expansão dos cultivos de soja, milho e algodão nos chapadões dos gerais baianos. 
No submédio São Francisco, queria estudar o vale do rio Salitre, onde se encontra o Projeto de Irrigação Salitre da CODEVASF. Ficara instigado pelo advento da massiva expropriação dos saliteiros (antigos horticultores) pelas grandes empresas agrícolas, os quais, tradicionalmente, comercializavam sua produção numa feira exclusiva na cidade de Juazeiro (BA).

Queria estudar, ainda, os problemas relacionados ao vale do rio Brígida, mais precisamente os povoados de Araripe e Sítio dos Pereiras, no sopé da Chapada do Araripe, município de Exu (PE). Questões como a concentração da propriedade fundiária e da água, a ampliação dos desmatamentos para implantação das pastagens, a mecanização agrícola e seus reflexos no solo (empobrecimento), a migração da população e outros.

Após ingresso no mestrado, segundo semestre de 2003, realizei, no mês de janeiro de 2004, uma viagem a estas localidades, quando pretendia estabelecer contato com seu povo e aproximar-me das questões que me instigavam.

Os desdobramentos relacionados a uma importante questão prática me fizeram reavaliar meus planos. Tratavam-se dos (im)previstos no encaminhamento das atividades e na disposição de tempo suficiente, o qual logo percebi que não tinha. Durante um mês chuvoso, percorri 7 mil quilômetros nas visitas às áreas de interesse. As péssimas condições das estradas percorridas e seus reflexos - os danos no veículo - logo se manifestaram.

Após o retorno e as avaliações, decidi redefinir a área de pesquisa e ater-me aos problemas relacionados aos brejos e sua população, por incluírem-se em um ecossistema bastante frágil (Campo de Paleodunas ${ }^{1}$ ). Estes brejos são semelhantes a formações recorrentes em grandes quantidades no vale (em Minas Gerais, denominam-se veredas) e são de grande importância para a formação de riachos e dos principais afluentes do São Francisco. A fúria da racionalidade econômica que motiva a exploração intensa das riquezas naturais está provocando a morte dos riachos e a expulsão das comunidades rurais para o meio urbano, cujo modo de vida, até mesmo quando permanecem em seus lugares, está sendo fortemente alterado.

\footnotetext{
1"depósitos arenosos de origem eólica, caracterizado como um paleo campo de dunas" (Diagnóstico Ambiental da APA, 2002).
} 
Por encontrarem-se, os Brejos da Barra e os brejeiros, em fase inicial de inclusão nesta outra racionalidade, procurei entender como os processos socioterritoriais realizavam-se e como adquiriam outras dinâmicas; além disso, verifiquei como as comunidades locais são inseridas nessas outras significações e sentidos atribuídos a seus lugares, às suas atividades, às suas vidas.

Outros passos constituíram também essa trajetória na pesquisa para 0 mestrado, mas, relatá-los aqui incorreria em uma delonga que pode ser evitada.

Como se pode ver, desde há muito os problemas relacionados à região Oeste da Bahia já estavam presentes em meus estudos, interesses estes que permaneceram. A região Oeste da Bahia, tal como as demais do Brasil, encobertas pela vegetação de cerrados, tem sido alvejada pela intervenção arrasadora de agentes do capital, combinada com as políticas desenvolvimentistas estatais, sem qualquer limite.

Como diferencial do Oeste da Bahia que atribuo relevância, cito a importância dessa região para formação de importantes rios responsáveis pela recarga do São Francisco. Este patrimônio e grande riqueza nacional poderiam ser muito úteis ao povo do nordeste semiárido se a ele se tornar acessível, o que, até o presente, infelizmente não tem acontecido; e as intenções conhecidas do projeto de transposição de suas águas, assim como de muitos outros usos, que há muito tempo já vêm sendo feitos, mostram isso.

Ao considerar a importância do rio São Francisco para o nordeste semiárido, não cabe desconsiderar o significado das águas em abundância na região para as populações geraizeiras. E é certo que estas só estarão acessíveis às populações se for garantido o acesso à terra de trabalho na forma que sempre existiu, o que tem garantido fartura para aqueles que trabalham. Assim, demonstro meu interesse na investigação dos processos sociais concernentes às alterações no âmbito da propriedade da terra na região.

Esta minha compreensão é antiga e, por isso, a vontade de estudá-la já estava presente em projetos passados. $\mathrm{O}$ adiamento deveu-se, pura e simplesmente, a oportunidades irrecusáveis oferecidas por sujeitos sociais de outra área (recorte espacial, no caso, os Brejos da Barra), cuja problemática se fazia e se faz também muito instigante, e, inclusive, também estava presente no projeto, 
conforme demonstrado. O fato é que a logística oferecida por agentes da Igreja Católica (da Diocese e da Paróquia) do município de Barra muito significava para a realização dos trabalhos e, noutros casos, não havia até então facilidades efetivadas como no referido caso. Devido às escolhas que venho fazendo, entretanto, outras problemáticas, presentes no referido projeto, também estão "arquivadas" para oportunidades futuras.

Confesso que na elaboração do projeto de doutorado também incorri na grande ambição quanto à amplitude da área a ser estudada. Porém, a partir do aprendizado das experiências vividas no passado, percorri caminhos com distâncias parecidas, mas, desta vez, imbuídos de intencionalidades, pois não cabe, na postura acadêmica que assumo, a escolha de problemas de realidades totalmente desconhecidas e, por isso, suscetível à inexistência de qualquer representatividade ou relação com o todo perseguido, que só não o adoto diretamente, devido às experienciadas limitações.

Ao longo do desenvolvimento da atual pesquisa decidi, portanto, investir na aproximação de possíveis casos a partir de contatos, primeiros, com a totalidade da área, a região Oeste da Bahia, e, em seguida, buscar a definição do que deveria aproximar-me mais, para estudos com maior profundidade. Nessa perspectiva, fiz cinco trabalhos de campo na região.

De antemão, entretanto, a partir do comprometimento social norteador da minha opção pela prática acadêmica, persegui o contato com sujeitos sociais ligados ao movimento do sindicalismo rural e social de luta pela terra em geral.

Optei por me aproximar da problemática geral da região Oeste da Bahia, a partir de uma primeira viagem, na qual visitei municípios pré-escolhidos que contatasse com sujeitos sociais, considerados chaves para o princípio dos desvendamentos a partir de uma visão geral da região que essa etapa da pesquisa me oferecesse. Nessa perspectiva, realizei, em julho de 2008, a primeira viagem ao Oeste da Bahia (figura 1). 
Figura 1 - Primeiro trabalho de campo, julho de 2008

\section{TRABALHO DE CAMPO: JULHO/2008}

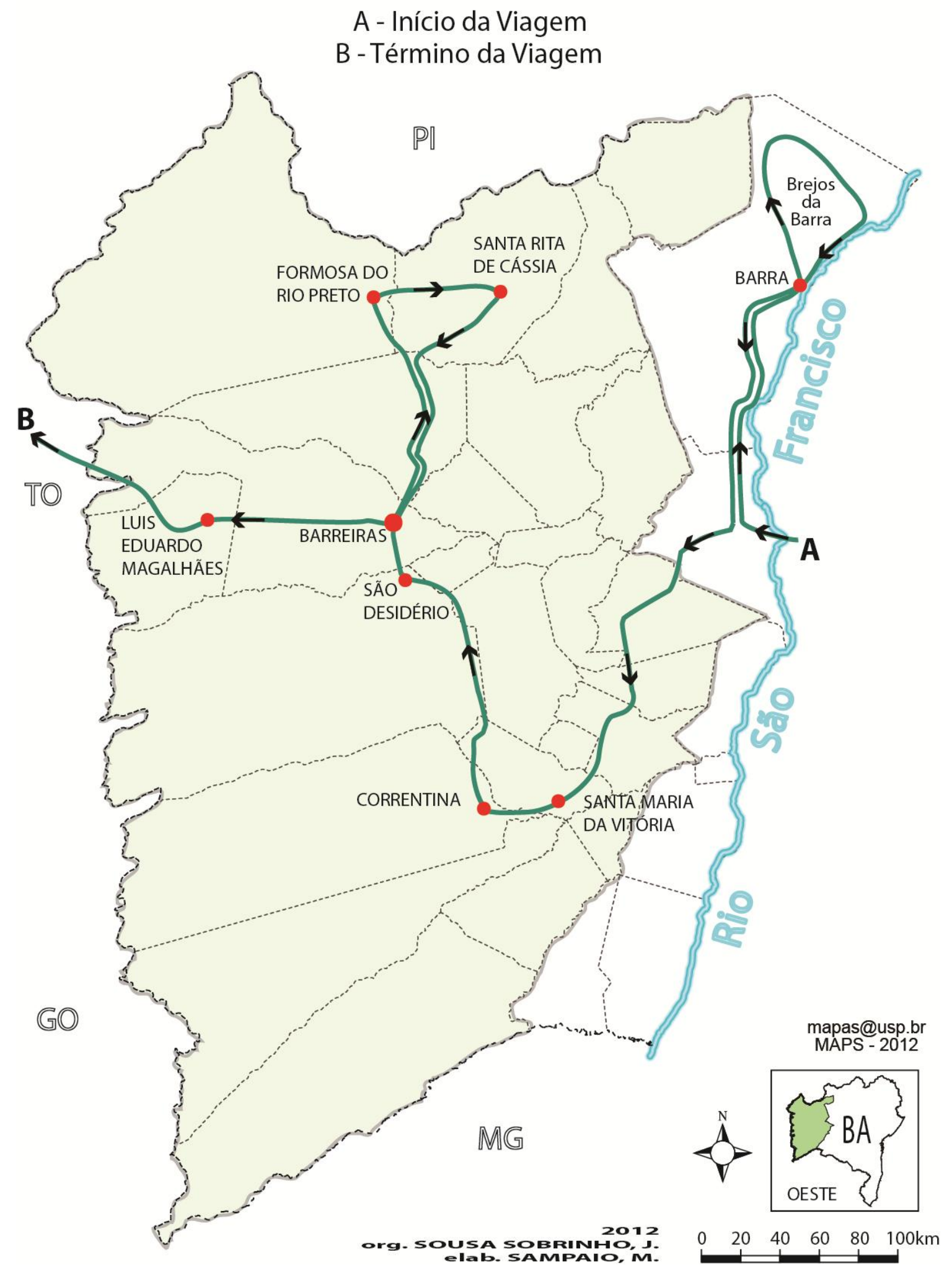


Porém, antes de visitar as localidades pretendidas para início dos estudos, fiz uma visita aos Brejos da Barra, quando pude rever os amigos dos tempos do mestrado e distribuir, a sujeitos sociais que colaboraram com a minha pesquisa, os exemplares da dissertação.

Dali, parti para a cidade de Santa Maria da Vitória, onde, por indicação da pesquisadora Ely Estrela, estabeleci o primeiro contato com o Coordenador da Casa da Cultura Antonio Lisboa de Morais e da Biblioteca Campesina, Joaquim Lisboa Neto (Kynkas), que foi muito receptivo e não mediu esforços na "abertura de muitas portas" que viabilizaram o meu transitar em muitos dos meios pretendidos, tanto no município de Santa Maria da Vitória quanto no de Correntina.

O próprio Kynkas concedeu-me entrevista e mediou o meu contato com um grupo de agentes da Comissão Pastoral da Terra (CPT) de Bom Jesus da Lapa, extensão Santa Maria da Vitória, os quais também me concederam entrevista. Pretendia também, nesta oportunidade, aproximar-me do Sindicato dos Trabalhadores Rurais (STR) de Santa Maria da Vitória, mas, afora uma breve conversa com o presidente em exercício ${ }^{2}$, outros contatos não foram possíveis naquela oportunidade e nem nas outras nas quais procurei este STR.

A entrevista realizada com Kynkas - ferrenho ativista nas lutas contra a ditadura militar, as oligarquias locais e os demais interesses privatistas da terra, que atormentam os camponeses e os pequenos proprietários camponeses desde a década de 1970 - rendeu muitas contribuições, no tocante à organização das forças de resistência, que recorreram a diversas estratégias de luta contra as investidas privatizantes; dentre as quais, cito a criação e a publicação do jornal "O Posseiro", por mais de 10 anos; a fundação da Campesina ${ }^{3}$ e da Casa da Cultura Antonio Lisboa de Morais; além disso, muitas articulações e muitos agitos foram organizados a partir dessa estrutura montada.

$\mathrm{Na}$ entrevista com o grupo da CPT, foram relatados os conflitos travados por questões de terra na região, envolvendo camponeses posseiros e pequenos proprietários de terras camponesas contra os grileiros, os quais geralmente são grandes fazendeiros da região ou de outros estados do Nordeste; são os chamados testas-de-ferro, que fazem o trabalho de expulsão dos camponeses de suas terras

\footnotetext{
${ }^{2} \mathrm{O}$ presidente titular encontrava-se afastado, candidato a vereador nas eleições municipais daquele ano.

${ }^{3}$ Nesta viagem, fiz pesquisas nos arquivos d'O Posseiro e no acervo da Campesina.
} 
e repassam a pretendentes oriundos de outras regiões; e são também agentes do capital moderno que, diretamente, fazem o trabalho fraudulento e violento da tomada das terras dos camponeses.

Neste contexto, a CPT atua junto aos atingidos por essa investida prestando assessoria jurídica e outras que se fazem necessárias para o enfrentamento.

De Santa Maria da Vitória parti para Correntina, onde, tal como em Santa Maria, não consegui, naquela viagem, contribuição junto ao STR. Como em Santa Maria, as disputas políticas estavam no centro das preocupações dos sindicalistas e, possivelmente por isso, foram infrutíferas minhas tentativas de estabelecer contato.

Por outro lado, consegui longas entrevistas com ex-sindicalistas e antigos militantes do Partido Comunista do Brasil (PC do B) que foram destacados para a região com a finalidade de auxiliar nos trabalhos do recém-fundado STR-Correntina (1980). Estes fizeram uma longa abordagem histórica sobre os conflitos agrários no município, desde os tempos da arbitrária implantação dos frustrados projetos de "reflorestamento" na região até a atualidade, no contexto de expansão da agricultura moderna. Fizeram também relatos sobre as disputas entre o Partido Comunista e a Igreja Católica e sobre o quadro sociopolítico geral no âmbito do município.

Dali, parti para São Desidério, e também por motivos eleitorais, não consegui contribuição da principal liderança sindical - o presidente -, pois estava candidato a vereador nas eleições daquele ano. Tive breve conversa com um membro da diretoria do sindicato, o qual relatou o quadro de violenta opressão sofrida pelos camponeses em um processo de impedimento generalizado à fonte do seu meio de vida - a terra. Apesar disso, tal como os demais, o sindicato dividia a sua capacidade de ação entre as tarefas governamentais e a expectativa de participar do poder municipal.

Em Barreiras, fui atendido por um sindicalista que conheci em uma passagem que fiz pela cidade em 2004, quando o entrevistei. Naquele ano, alimentava a esperança de levar à frente o grande projeto, depois repensado e reformulado. A diretoria desse sindicato não estava, pelo menos diretamente, envolvida em disputas eleitorais, embora o campo de atuação frente à extrema opressão sofrida pela população camponesa não se diferenciasse dos outros.

Cabe ressaltar que a expansão da agricultura moderna teve início a partir da região de Barreiras. Sendo assim, a fronteira se encontra tomada em maior 
expressão pelas forças privatistas da terra e, neste quadro, o movimento sindical vem se ocupando, embora carregado de absurdas contradições, com as pautas dos trabalhadores dos empreendimentos agrícolas. Dentre os problemas que afligem essa categoria está a alta incidência de trabalho escravo, tanto na região de Barreiras, quanto no Oeste da Bahia como um todo. Embora os sindicatos, contraditoriamente, nem sempre dêem a devida importância a esta questão nas suas atuações.

A entrevista com esse interlocutor em Barreiras foi muito frutífera, ao demonstrar o quanto é arrasadora e truculenta a expansão do capital autointitulada moderna, tanto nos aspectos ambientais quanto sociais na região. Foi relatado o processo de expansão da grilagem no município, os altos impactos do modelo agrícola em expansão, que provoca desmatamentos desenfreados, uso desordenado de agrotóxicos, exploração indiscriminadas das riquezas hídricas, assim como a referida superexploração da força de trabalho. Foi relatado também o quanto os desmandos vêm causando problemas, como inchaço urbano, e submetendo a população expropriada à extrema pobreza nas periferias da cidade, desprovida de quaisquer condições de suporte a essa população.

$\mathrm{Na}$ Diocese de Barreiras não há CPT. A instituição da Igreja Católica preocupada com as questões relacionadas ao campo é a Agência 10-envolvimento. Tive uma breve conversa com um membro dessa entidade, mas que não foi satisfatoriamente produtiva, por ter sido breve.

De Barreiras fui para Formosa do Rio Preto; neste município, o presidente do STR também se encontrava candidato a vereador e fui recebido pela presidente em exercício, que me concedeu uma longa entrevista, muito rica de informações sobre o quadro conflituoso do município. Demonstrou o quanto se faz massiva e violenta a investida expropriativa contra os camponeses. Foi muito enfática em seu relato sobre a atuação fraudulenta do Grupo Estrondo, que grilou uma área de centenas de milhares de hectares de terras no município e vem loteando-a para venda, onde se concentra uma grande quantidade de norte-americanos. Ressaltou que o conflito não se restringe a grileiros e camponeses: também ocorre entre os próprios grileiros, levando, inclusive, à morte de poderosos constituintes de uma das partes do conflito.

Nesses conflitos, o poder judiciário das municipalidades vem se esquivando do cumprimento do seu dever. Na maioria das vezes, deixa as demandas em litígio 
se alongarem no tempo até que a parte, no limite prejudicada, os camponeses, por questão de sobrevivência, desista de continuar lutando, resultando num desfecho favorável à parte dos poderosos, à qual o aparelho estatal tem claramente prestado serviços em várias frentes na região.

Dentre muitas contradições na atuação do movimento sindical local, uma que ressalto é a compreensão de que os agricultores modernos são pacíficos, como se a terra onde se assentam, em grande maioria, não tivesse sido grilada e não fosse produto de conflitos no passado. $E$, de alto e bom tom, afirmam que os trabalhadores dos cerrados ganham bons salários. Assim, fazem vistas grossas à absurda precariedade das condições e das relações de trabalho na região, as quais alongam em progressão geométrica a "lista suja do trabalho escravo" criada por entidades preocupadas com esse problema.

Depois de Formosa do Rio Preto, seguindo o roteiro demonstrado na figura (1), fui para Santa Rita de Cássia. Desta visita, tive como dado o fato de nada conseguir dos sujeitos sociais indicados por interlocutores de outros municípios. $\mathrm{O}$ STR local estava em uma intensa movimentação em recepção aos técnicos de agências oficiais fomentadoras da agricultura familiar, que faziam tratativas de questões relacionadas às dívidas dos produtores, como também dos trabalhos da campanha eleitoral do presidente da instituição. Após muitos descumprimentos das marcações de entrevista, desconfiei da existência de má vontade em receber-me - e na verdade senti medo, a partir de uma sensação de que também estavam amedrontados com a presença de um sujeito estranho naquela pequena e conturbada localidade na qual o conflito e a violência coronelista são cotidianas.

Não sei o quanto estas sensações correspondem à realidade, até porque daquela visita só consegui colher incógnitas, dúvidas, enigmas. Restou-me planejar uma saída inesperada, sem despedidas, e procurar distanciar-me rapidamente.

Dali, parti para a cidade de Luiz Eduardo Magalhães, onde, devido o esgotamento do tempo que dispunha para o trabalho de campo, as atividades se restringiram a observações realizadas em um tour pela cidade. Surpreendeu-me seu exotismo com alta densidade de lojas de maquinários, artefatos agrícolas, autopeças e os suntuosos prédios de apartamentos "perdidos" em um horizonte pouco povoado. Tudo aquilo me pareceu tão estranho quanto o sotaque no palavreado dos 
frequentadores da Churrascaria Gaúcha, localizada nas dependências do Posto (de combustíveis) Mimoso.

Na segunda viagem que fiz à região, o propósito seria, beneficiando-me dos auxílios de contatos estabelecidos na primeira viagem, chegar até às comunidades envolvidas em conflitos. Esta, inclusive, foi a estratégia pré-estabelecida e apresentada no projeto.

O primeiro município visitado foi Santa Maria da Vitória (figura 2). A partir do ponto mais receptivo e de sólido apoio, a Casa da Cultura Antonio Lisboa de Morais, consegui ampliar a pesquisa na Biblioteca Campesina e realizar entrevistas com outros interlocutores, que proporcionaram aprofundamento das questões já tratadas pelos primeiros e até acrescentaram pontos sobre a ocupação camponesa da região, assim como relacionados a problemas ambientais na bacia do rio Corrente. Consegui também chegar até o agrupamento comunitário da região do Mutum, constituída das comunidades de Brejinho dos Gerais, Olho d'Água do Barro, Pedra Preta, Currais Velhos, Salobro, Mutum, Morro dos Macacos, Quati, Jacurutu, Barrinha e Vieiras.

Nesta região, consegui uma longa entrevista com uma liderança comunitária, a qual abordou o histórico do conflito envolvendo as comunidades e os grileiros que há muito as atormentam; foi também elucidativa nas explicações de como os grileiros se intrometem na vida das comunidades e de quais estratégias se utilizam para isso. Dentre elas, ressalto a cooptação daqueles membros das comunidades com fortes ambições individualistas; o aproveitamento dos conflitos interfamiliares no ambiente comunitário e até mesmo a promoção da intensificação destes, provocando o enfraquecimento do grupo. E, a partir daí, a penetração nas "frestas" que se abrem e, valendo-se de todo apoio do aparelho estatal, investe-se na expulsão das comunidades de suas terras. 
Figura 2 - Segundo trabalho de campo, janeiro de 2010

\section{TRABALHO DE CAMPO: JANEIRO/2010}

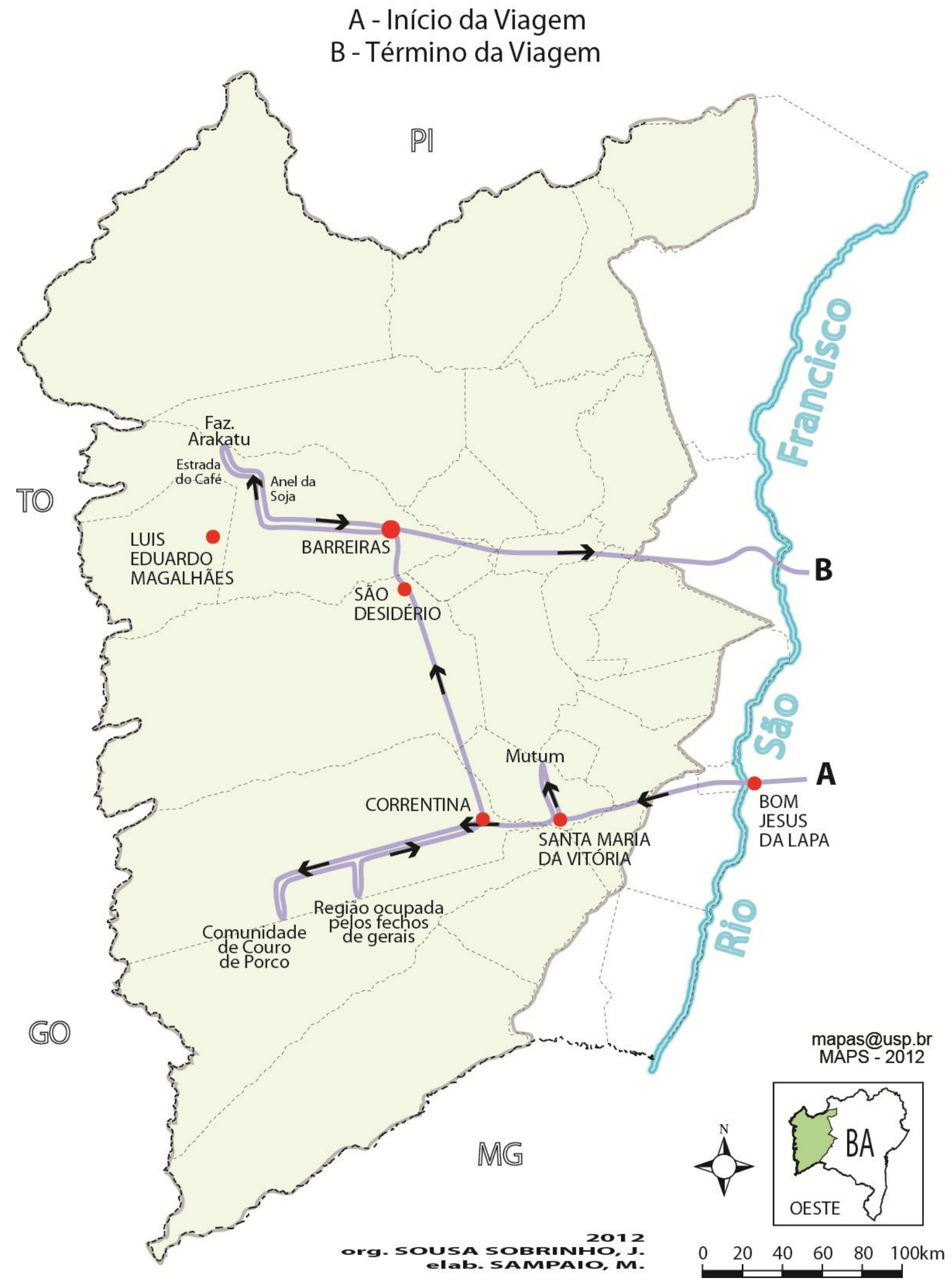


Estas comunidades vêm se organizando no âmbito de sua associação e, com o apoio do STR e da CPT, vêm conseguindo algumas conquistas; dentre elas, a promoção de uma audiência pública em 2009, a partir da qual se iniciaram os trabalhos de uma ação discriminatória administrativa, que, a depender do grau de união do grupo, para continuar pressionando o poder público, pode ter como desfecho algum resultado positivo, na opinião do entrevistado.

A partir dos interlocutores de Santa Maria da Vitória, consegui, desta vez, ser atendido por membros da atual diretoria do STR-Correntina, por ativistas do Movimento dos Atingidos por Barragens (MAB) e por lideranças dos professores da rede municipal de ensino, que me concederam entrevistas e foram importantes facilitadores da visita que fiz à área de conflito entre os usuários do fecho de gerais de Morrinhos e Entre Morros, dos fechos do entorno e o grupo inglês CFMAgropecuária e o grileiro João Branco, cujo relato com detalhes apresento em outra parte do trabalho. Proporcionaram-me também uma visita à Comunidade de Couro de Porco (atual Arrojelândia). Nesta comunidade, se encontra um dos conflitos mais expressivos da região Oeste da Bahia, que tem como principais protagonistas os membros da referida comunidade e a empresa Italiana Planta 7 Empreendimentos Rurais (mas não só ela), atuante no ramo de reflorestamento, fruticultura e mineração. Embora os entrevistados afirmem que a referida empresa quase nada planta na área grilada de 217 mil hectares de terra no município de Correntina, muito possivelmente se utilize desta área para finalidades outras e estranhas à produção.

Nesta comunidade, entrevistei um grupo de moradores, os quais fizeram longo relato do conflito e dos confrontos entre seus membros e os pistoleiros serviçais da empresa grileira.

De Correntina fui para Barreiras. Nesta cidade, fiz visitas às áreas periféricas e pesquisas nas bibliotecas da Universidade Federal da Bahia (UFBA) - Barreiras e Pública Municipal, retomando os contatos com o STR-Barreiras.

Em cumprimento ao proposto no projeto, pretendia fazer visitas a campo para aproximar-me da realidade imediata e vivida pelos sujeitos sociais mais diretamente envolvidos e atingidos pela expansão da agricultura capitalista na região, no contexto daquele município: os trabalhadores assalariados das empresas agrícolas.

Fiz uma visita à fazenda Arakatu, de um proprietário holandês, produtora de café e hortaliças, e à granja Mauricéia. 
Foi oportuno para o cumprimento da atividade pretendida, o trabalho que a diretoria do STR fazia: de eleição dos delegados sindicais nas fazendas. A forma que os sindicalistas conduziam os trabalhos pouco permitiu o contato direto com os trabalhadores, mas foram elucidativas as observações do quanto o sindicato inverte as suas funções. Ficou demonstrado o lado que o sindicato escolheu para atuar de fato, visto nas práticas, a desconstrução do que prega os discursos dos sindicalistas. Todo o aparato para a realização da eleição era organizado pela empresa; a recepção dos gerentes de produção aos sindicalistas pareceu-me demais amistosa; e, de modo algum, pareceu haver antagonismo entre as partes. Se este existe, e com certeza há, apresenta-se na realidade concreta enfrentada pelo trabalhador no processo de produção e no cotidiano vivido. $E$ isto transpareceu no descontentamento daqueles que se encorajaram a falar em uma assembleia em que fazia parte da Mesa o gerente da fazenda. Para não alongar-me, cito apenas um exemplo: após a conclusão do processo eleitoral, o conselho, ou ordem, que partia do Secretário de Assalariados do Sindicato para o delegado sindical vitorioso na eleição, era: "comporte-se. Não queremos saber de greve".

Ainda em Barreiras, realizei entrevistas com um grupo de técnicos de uma Organização Não Governamental (ONG) ambientalista, a Bioeste, que atua na região Oeste e que tem como atividade, trabalhos de educação ambiental a médios e grandes produtores.

A Bioeste se destaca como entidade "ambientalista" na região, ao promover eventos ambientais nas semanas de meio ambiente e em atividades simbólicas de plantação de mudas de árvores (em número pouco expressivo), assim como na legitimação do discurso da produção sustentável do agronegócio regional. A principal fonte mantenedora dessa ONG é a Associação dos Agricultores e Irrigantes da Bahia (AIBA), entidade dos produtores de maior peso ligada ao agronegócio.

Nesta viagem, pretendia retornar à Formosa do Rio Preto, mas a impossibilidade de comunicação com os pretendidos apoiadores/interlocutores, obrigou-me a encerrar as atividades daquela etapa da pesquisa.

Nestas viagens que realizei à área de estudo, o objetivo inicial foi concretizado: cada uma alimentou e potencializou o aproveitamento da próxima, graças ao apoio daqueles que se simpatizaram com a proposta. Posso até afirmar que as mãos construtoras do trabalho se multiplicaram a cada contato. 
$\mathrm{Na}$ terceira viagem, fui para a região a fim de participar do I Simpósio Regional de Geografia do Cerrado, ocorrido na cidade de Barreiras, entre os dias $9 \mathrm{e}$ 12 de outubro de 2010. Aproveitei essa oportunidade para conhecer, em um dos trabalhos de campo (atividade do Simpósio), o Projeto de Assentamento Angical, satisfazendo um interesse antigo, e fazer um trabalho de campo durante uma semana na área específica de estudos - que estava ganhando definição - o vale do rio Arrojado, onde se encontra grande quantidade de comunidades camponesas ribeirinhas e usuárias de soltas e fechos de gerais.

Esta viagem à área de estudos foi muito produtiva no tocante ao cumprimento dos objetivos. Pretendia visitar o agrupamento de comunidades, onde moram os usuários dos fechos de gerais de Morrinhos e Entre Morros e adjacências, e voltar à comunidade de Couro de Porco, para entrevistas com interlocutores de grande importância na história de enfrentamento travado contra as forças privatistas da terra.

O primeiro objetivo foi satisfatoriamente concretizado nas visitas que fiz a dois agrupamentos de comunidades, situados em torno dos povoados de Passagem do Grilo (atual Aparecida do Oeste) e da Praia, cito: Taboa, Catingueiro, Laje, Jatobá, Passagem Funda, Malhadinha, Brejo Verde e Catolé (figura 3).

Sobre os conteúdos das entrevistas realizadas nessas comunidades, seria repetitivo tratar aqui, porque já estão presentes na parte que reservo para tratar da configuração e dinâmica dos usos das soltas e dos fechos de gerais, bem como dos conflitos envolvendo os membros das comunidades e as empresas que se expandem sobre as áreas de uso comunitário.

Quanto ao segundo objetivo, revisitar a comunidade de Couro de Porco, não foi realizado porque fui informado da ausência dos interlocutores a ser entrevistados. Mesmo assim, considerei a viagem altamente produtiva, porque pude potencializar os trabalhos nos agrupamentos até então desconhecidos. E os resultados das atividades ali desenvolvidas foram muito positivos para os objetivos da tese. Também foram muito elucidativas as extensas entrevistas feitas com os mediadores desses contatos com as comunidades. 
Figura 3 - Terceiro trabalho de campo, outubro de 2010

\section{$3^{\circ}$ TRABALHO DE CAMPO: OUTUBRO/2010}

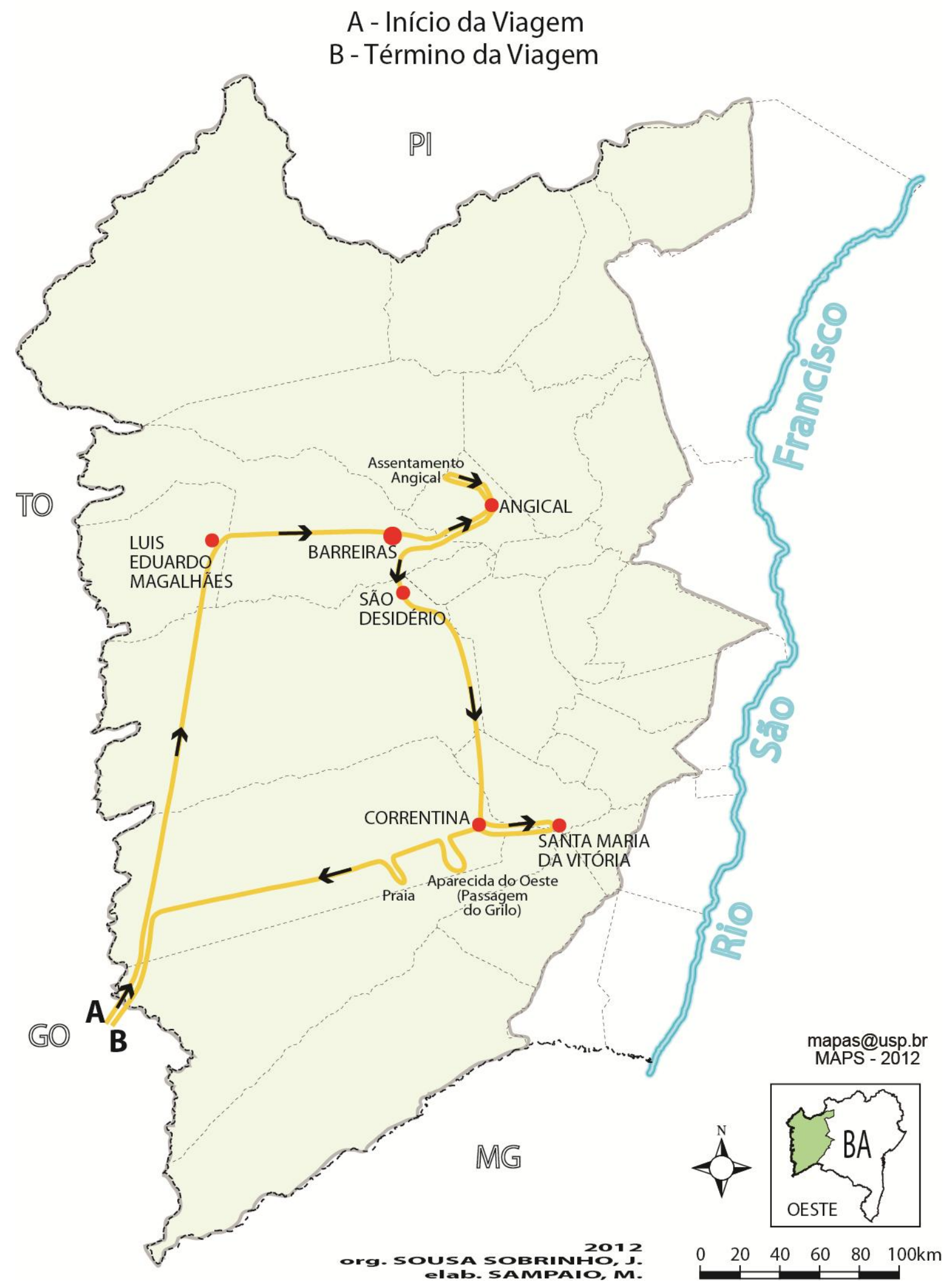


Em prosseguimento à pesquisa, realizei mais dois trabalhos de campo: julho de 2011 e janeiro de 2012. Nestes, foquei as atenções nos levantamentos junto às comunidades, na perspectiva de descobrir aquela cujos processos sociais fossem mais representativos da totalidade. A partir dos critérios que exponho em outro momento do texto, escolhi, para estudos com maior profundidade, as comunidades de Brejo Verde, localizada no baixo vale do rio Arrojado, e a comunidade de Couro de Porco, além das adjacentes Bebedouro, Passaroto e Cajueiro. As problemáticas relacionadas a estas comunidades ocuparam o centro das minhas atenções na pesquisa, cujos resultados, apresento na tese.

A trajetória percorrida e as problemáticas constatadas indicam as principais proposições constantes na tese, e, para apresentá-las, organizei-a em cinco capítulos.

No primeiro, apresento uma caracterização do Oeste da Bahia, ressaltando os elementos que se destacam como de interesse do capital em sua expansão sobre a região. Em seguida, demarco o campo teórico escolhido para o desenvolvimento da pesquisa, conferindo maior ênfase ao conceito de território no qual, dentre as várias concepções existentes, ressalto aquela que adoto para o desvendamento dos processos que se desenvolvem na região estudada. Seguindo a concepção de território escolhida, apresento as contradições do modelo de ocupação da região, o qual se denomina por agricultura moderna ou agronegócio, destacando, entre elas, os impactos socioambientais que repercutem na generalizada degradação das condições de vida em consequência dos usos das riquezas naturais e da superexploração da força de trabalho. Neste contexto, faço referência também à atuação do movimento sindical dos trabalhadores rurais, cuja elevada carga de contradições se destaca como marca principal.

No segundo capítulo, centro-me na expansão do modo de produção capitalista que ocorreu no Brasil, a partir da década de 1970, provocando fortes modificações na agricultura, sobretudo, na camponesa. Foram fortemente impactadas pela investida capitalista e privatista da terra, as terras de uso comum existentes no Brasil, geralmente devolutas e costumeiramente usadas pelos camponeses. Nesta perspectiva, discorro sobre os casos dos faxinais do Paraná, 
das terras de uso comum na liha de Santa Catarina, assim como o dos fundos de pasto espalhados na Bahia. Esta investida privatista sobre as terras de uso comum apropriadas pelos camponeses provocou a resistência das comunidades impactadas por este processo.

No terceiro capítulo, discorro sobre a organização da resistência, sobre a politização das lutas, destacando o relevante papel desempenhado pelos mediadores sociais, tais como os constituintes de setores progressistas da Igreja Católica, além de membros do Partido Comunista e dos Sindicatos de Trabalhadores Rurais. Destaco também os processos que se desenvolveram no âmbito da atuação dos referidos mediadores sociais, levando-os a exercerem um papel altamente contraditório, chegando ao ponto de pouco ou quase nada realizarem na defesa dos camponeses. Não obstante estes continuarem submetidos à violenta escalada de expulsão/expropriação das suas terras de trabalho pelo capital em combinação com as políticas de vários órgãos do Estado.

No quarto capítulo, centro o foco na pesquisa empírica voltada às comunidades do baixo vale do rio Arrojado. Discorro sobre o seu processo de territorialização, com vistas à garantia da sobrevivência e de sua reprodução socioterritorial. Deste modo, foram destacados os engendramentos concernentes aos usos da terra e da água: para a agricultura, a pecuária, a industrialização da produção e outros usos. Nesta perspectiva, territorializaram-se no vale do rio Arrojado, ocupando os diferentes compartimentos naturais e implantando nestes a infraestrutura necessária aos possíveis e diferentes usos a partir das suas relações sociais de produção e das forças produtivas que Ihes são próprias. No que diz respeito aos usos das riquezas naturais, ressaltei a situação de conflito em que estão envolvidas, sobretudo, na luta pela sua reprodução socioterritorial em defesa das terras de uso comum, quais sejam as soltas ou os fechos de gerais. Nestes conflitos/disputas, enfrentam a escalada privatista da terra, que se realiza sob a intervenção de grileiros, os quais têm se beneficiado do apoio e dos serviços do aparelho estatal. Esta investida constitui-se, no modelo brasileiro de desenvolvimento do capitalismo no campo, uma das contraditórias estratégias do capital em sua expansão à busca de sua produção e reprodução ampliada. Esta abordagem contempla também as estratégias dos camponeses geraizeiros, continuamente engendradas para enfrentar as forças que investem em sua 
desterritorialização. Isto ocorre tanto nos embates conflituosos quanto no seu dia a dia de trabalho, beneficiando-se e refazendo a sua organização com vistas a propiciar a potencialização da capacidade de enfrentamento.

No quinto e último capítulo, continuando a abordagem sobre a pesquisa empírica, discorro sobre os processos relacionados a um conjunto de comunidades instalado no médio vale do rio Arrojado. Esta parte do vale, por se encontrar nos altos gerais, os quais dominantemente são encobertos pela vegetação dos cerrados, e, portanto, mais cobiçados pelas forças privatistas da terra, apresenta um contexto consideravelmente diferenciado das comunidades do baixo vale. Referindome a estas comunidades, descrevo as estratégias por eles estabelecidas, concernentes aos usos da terra e da água, com vistas a proporcionar a sua reprodução socioterritorial, pois, assim como as comunidades do baixo vale, se submeteram a um processo de extrema minifundização das parcelas por eles apropriadas. Em função disso, muitos engendramentos foram criados para viabilizar a aquisição dos seus meios de vida.

A estes fatores se soma a extrema pressão das forças privatistas da terra que investem sobre as comunidades com vistas a expulsá-las, a desterritorializá-las totalmente, valendo-se de métodos absurdamente fraudulentos nas grilagens das terras constituintes da fração camponesa do território. Em resposta a esta investida, as comunidades têm se organizado e travado uma brava resistência na defesa dessa fração. Como resultado, já se vem colhendo alguns frutos, vistos na intervenção do Estado (embora tímida e contraditória) que, em atendimento à forte pressão dos camponeses, reconheceu a apropriação fraudulenta pelos grileiros das terras das comunidades e do seu entorno. 
CAPÍTULO 1 


\title{
1.1 A expansão da propriedade capitalista da terra no Oeste da Bahia
}

\author{
"É improvável que alguém se atreva hoje a escrever ou falar sobre \\ as características ou os acontecimentos do mundo rural brasileiro sem \\ atribuí-los à expansão do capitalismo no campo..." “... Se os camponeses \\ não são expulsos da terra, isso é por causa da expansão do capitalismo, \\ se são expulsos também é por causa da expansão do capitalismo"
} (MARTINS, 1983, p.151).

Com suas características ambientais - rica biodiversidade e grande disponibilidade de água -, uma forma camponesa de ocupação da terra muito peculiar, em uma organização social e de uso da terra altamente compatível com o ambiente local, a região Oeste da Bahia, com seus mais de $200.000 \mathrm{Km}^{2}$, destacase por seus aspectos econômicos, biogenéticos e socioculturais.

O jeito próprio de ser daquelas populações sertanejas, localmente conhecidas como geraizeiras, nas últimas décadas, vem sofrendo grandes alterações em função da expansão do modo capitalista de produção e da privatização capitalista da terra que lhes é característico e que por ali se expande.

Sob a ótica da linha teórica que concebe o desenvolvimento do capitalismo no campo de forma contraditória, desigual e combinada, preconizada por autores clássicos como Rosa Luxemburgo e Teodor Shanin - e, no Brasil, pelos professores José de Souza Martins e Ariovaldo Umbelino de Oliveira, dentre outros, busquei a compreensão dos processos sociais concernentes ao processo de privatização capitalista da terra naquela região.

Estabeleci, como recorte temporal dos processos que analisei, a década de 1970 e as que se seguiram, período no qual se iniciou, na região, a problemática escolhida para estudo. E, como recorte espacial, elegi a região Oeste da Bahia, porém com foco mais centrado, sob critérios pré-estabelecidos e em consonância com os objetivos da pesquisa, nas frações camponesas do território que constituem as comunidades de Aparecida do Oeste, Pombas, Riacho de Areia, Jatobá e adjacências, usuárias do fecho de Morrinhos à Entre Morros, Gado Bravo e outros. Estas se localizam no Sudeste do município de Correntina (BA), às margens do rio Arrojado, onde cultivam, em parcelas de uso exclusivo familiar, produtos alimentícios 
para autoconsumo e comercialização do excedente, e, no interflúvio, entre os rios Arrojado, Ribeirão e das Éguas, soltam seus criatórios nos fechos de gerais. Tratam-se de terras de uso comum, localizadas distantes das comunidades, na montante do rio Arrojado, nas quais os camponeses geraizeiros costumeiramente praticam a pecuária bovina, aproveitando-se da pastagem natural da vegetação de cerrados e das aguadas ${ }^{4}$ em períodos do ano, em uma combinação com o ciclo do capim e com o regime climático da região.

Os mediadores sociais e setores do Governo do Estado, em uma alusão aos fundos de pastos, muito comuns nas áreas sertanejas encobertas pela vegetação das caatingas, as designam de fechos de pastos. Nesta abordagem, entretanto, adotei a designação fecho de gerais, seguindo, portanto, a denominação empregada pelos criadores da região, usuários dessas unidades territoriais.

Em função de limitações ao estudo diretamente no referido conjunto de comunidades, sob critérios pré-estabelecidos e por mim considerados em sintonia com a totalidade, escolhi a comunidade de Brejo Verde para estudo com maior profundidade.

Outros casos de estudo são as comunidades de Couro de Porco, situada à margem esquerda do rio Arrojado, e suas vizinhas, Passaroto, Bebedouro e Cajueiro. Seus integrantes praticam a agricultura de gêneros alimentícios, na margem direita do mesmo rio, e os criatórios em soltas na esquerda, delimitando, com importante precisão, a terra de morada (margem esquerda), a terra de se plantar (margem direita) e a terra de criar (fundos das terras de morada). Da mesma forma, em vez da denominação, fundo de pasto, usada por setores do Governo do Estado e mediadores sociais, adotei o termo solta, usado pelos criadores, para designar as áreas de pastagens de uso comum, anexas às áreas parcelares das comunidades.

Como critérios para a escolha dessas comunidades, estabeleci o fato de praticarem o uso comum da terra com característica muito peculiares à região (combinando o uso familiar da área parcelar conjugado ao uso comum das soltas e/ou fechos de gerais), bem como o fato de se encontrarem em uma situação de disputa pela terra travada com os grileiros. A comunidade de Couro de Porco, por

\footnotetext{
${ }^{4}$ Onde o gado bebe água.
} 
exemplo, desde início dos anos 1970 vêm resistindo à ação de grileiros e, por vezes, até com confrontos físicos, na luta em defesa das terras de trabalho ${ }^{5}$.

Os integrantes das comunidades ali instaladas constituem-se de remanescentes de índios ou são egressos das precárias condições de vida enfrentadas em localidades do alto sertão semiárido, mais precisamente das imediações de Macaúbas, onde viviam sob condições de opressão, praticadas pelos donos do poder local, acrescidas às fortes estiagens que assolaram os sertões em finais do século XIX e início do século XX. Nos gerais baianos, encontraram terras e águas fartas ${ }^{6}$. Desde então, fincaram raízes ali e, atualmente, estão com o sossego interrompido pela investida privatista da terra, praticada pelas empresas situadas no Sul e no Sudeste do país, em obediência às políticas públicas do Estado, iniciadas no período autoritário e continuadas até os dias atuais.

$\mathrm{Na}$ pesquisa que desenvolvi na referida região, procurei mostrar que a propriedade capitalista da terra, tal como se expande na região, tem como finalidade maior a especulação fundiária, a extração da renda da terra quando posta ou não a produzir. É o exemplo do grupo Papaiz, com cerca de 40 mil hectares de terras nas proximidades das comunidades em estudo, onde apenas $2 \%$ da área é explorada com o cultivo de eucalipto e pastagem. O restante é alugado como pastagem natural para os criadores das comunidades do entorno, alguns deles até ex-usuários da área, através da cobrança mensal de 5 reais por cabeça de gado ${ }^{7}$.

\subsection{Caracterização do Oeste da Bahia}

A Mesorregião Oeste do Estado da Bahia é formada por 24 municípios, localizada na margem esquerda do rio São Francisco, no seu médio vale. Ao sul, limita-se com o Estado de Minas Geras; a oeste, com os Estados de Goiás e Tocantins; ao norte, com o Estado do Piauí e, a leste, com o rio São Francisco.

\footnotetext{
${ }^{5}$ Assim se refere Martins (1991) à terra de onde o camponês, por meio do trabalho retira os meios de vida, em oposição à "terra de negócio", de propriedade privada capitalista, e, por isso, apropriada para explorar trabalho alheio, auferindo lucros ao proprietário.

${ }^{5}$ Na região Oeste da Bahia, encontram-se três dos mais importantes afluentes do rio São Francisco, a saber: o rio Grande, o rio Corrente e o rio Carinhanha. Esses importantes rios são originados por umas infinidades de nascentes d'água que brotam nos gerais baianos, resultantes da importante pluviosidade da região, aumentada ainda mais conforme se avança rumo à Serra Geral, na divisa com os Estados de Goiás e Tocantins.

${ }^{7}$ Segundo informou um diretor do STR-Correntina.
} 
Conforme suas características morfoclimáticas, esta ampla área pode ser dividida em duas partes: uma porção mais baixa, situada na depressão do São Francisco, e outra mais elevada, constituída de planalto, na região também conhecida como gerais ou chapada. A porção mais baixa se estende da calha do rio São Francisco até a borda do planalto. Esta área é encoberta em grande parte pela vegetação de caatingas ${ }^{8}$ e se constitui de relevo predominantemente plano. Em direção à borda do planalto, encontra-se relevo colinado e de inclinação mais acentuada, conforme dela se aproxima. A porção mais elevada, o planalto, é constituída de amplos tabuleiros e adentra-se para o oeste até o contato com a Serra Geral de Goiás, ao sudoeste, e com o Espigão Mestre ao Norte. Esta área é encoberta pela vegetação de cerrados ${ }^{9} \mathrm{em}$ seu contato com as caatingas, que predominam na parte baixa e se estendem para a região Nordeste do país, mais precisamente ao sertão semiárido (figuras 4 e 5).

\section{Figura 4 - Localização da área de estudo no Brasil}

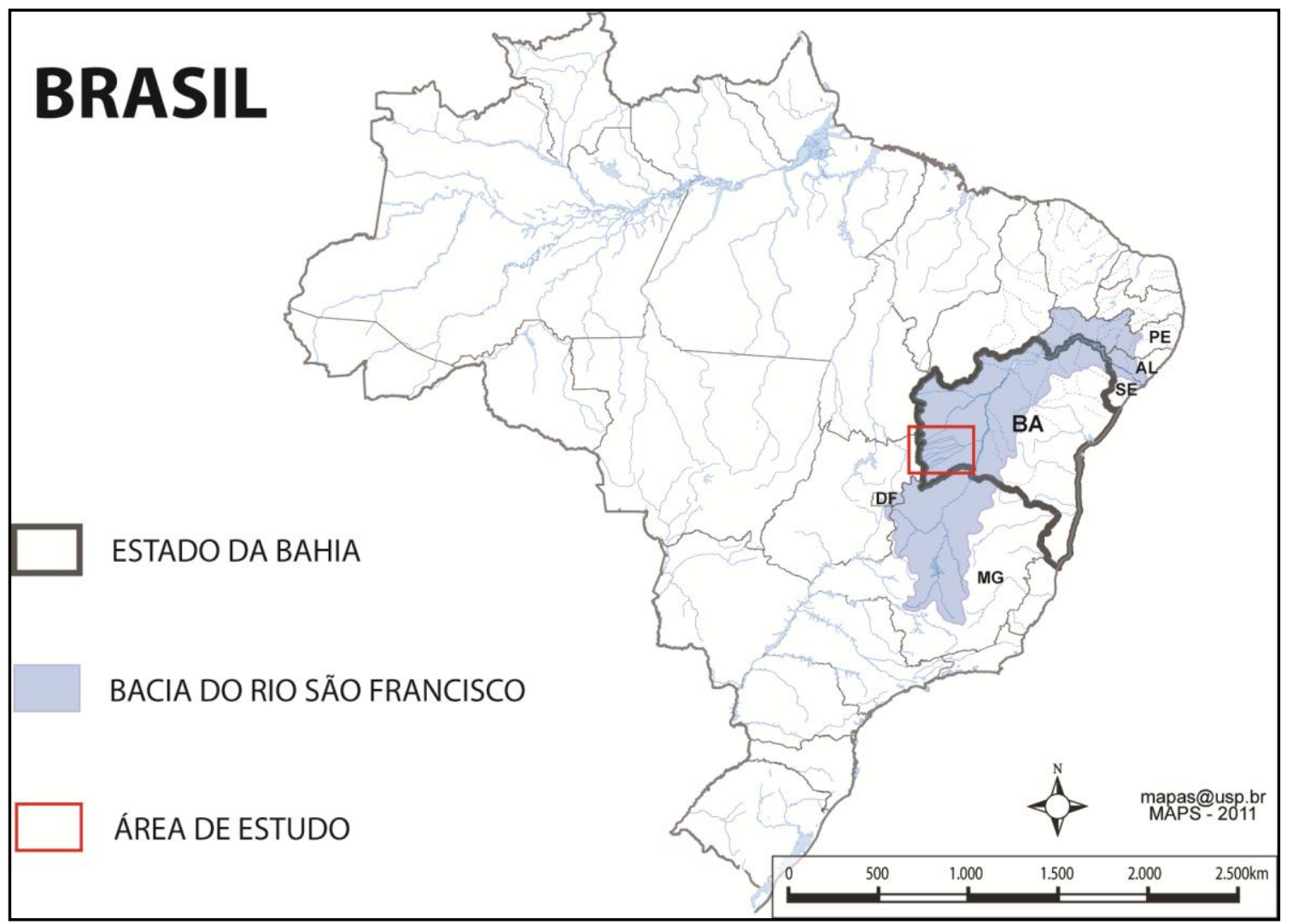

Organização Sousa Sobrinho, J. (2011). Elaborado por Sampaio, Mateus (2011).

\footnotetext{
8 Adoto o que indica Bernardes (1999, p. 69): "de tal modo é variada a paisagem vegetal característica do interior do Nordeste brasileiro que seria preferível referir-se a ela no plural".

${ }^{9}$ Adoto a indicação constante na nota 6 também para a vegetação de cerrados por perceber similaridade com as caatingas quanto à grande variação da cobertura vegetal.
} 
Figura 5 - Localização da área de estudo no Estado da Bahia

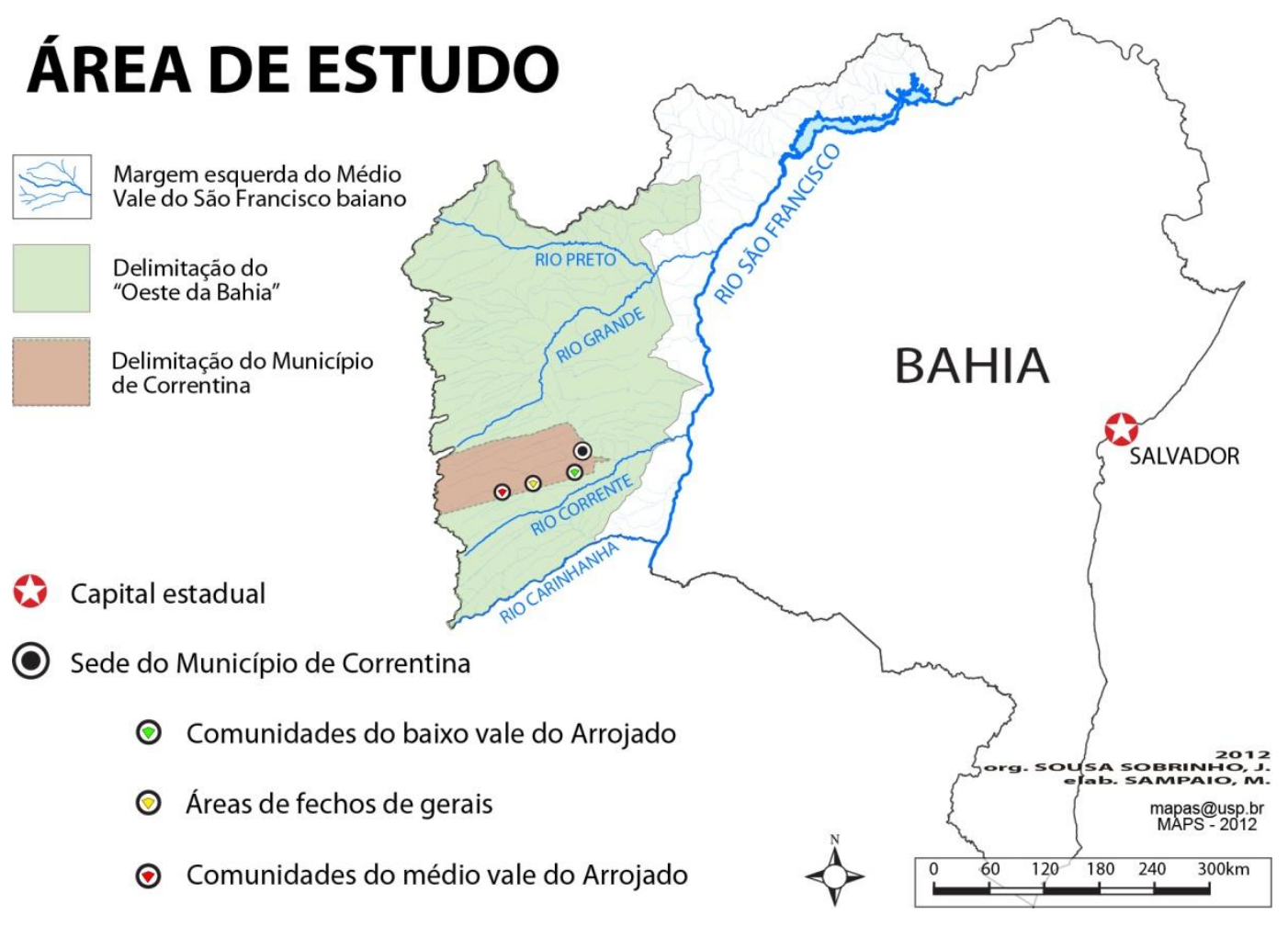

No contato imediato da vegetação de cerrados com as caatingas e, com maior freqüência, nas bordas do planalto, se encontram importantes manchas ou enclaves do que denominam localmente de $\operatorname{carrascos}^{10}$. Trata-se de vegetação densa e trançada de espécies lenhosas. Esta formação vegetal, conforme os saberes populares locais, indica o surgimento de solos localmente reconhecidos como férteis nos interflúvios, o que se torna mais comum conforme as caatingas vão se consolidando de oeste para leste.

A porção do planalto é também conhecida como gerais e é formada por amplos tabuleiros com vales de encostas suavemente inclinadas. Ali se encontra uma grande quantidade de nascentes de riachos (concentrados nas proximidades da Serra Geral do Goiás) que correm para leste em direção à calha do rio São Francisco e vão formando importantes rios da região, como o Itaguari (afluente do rio Carinhanha); rio Formoso, rio Arrojado, rio das Éguas ou Correntina, rio do Meio e rio Guará (afluentes do rio Corrente); rio dos Porcos, rio Galheiro, rio Roda Velha, rio das Fêmeas, rio de Ondas, rio das Pedras, rio de Janeiro e rio Branco, riacho do

\footnotetext{
10 "No nordeste, diferentes autores usam o termo carrasco para referir-se àquela vegetação arbustiva densa xerófila do planalto da lbiapaba e chapada do Araripe, ou a um tipo de cerrado denso na Bahia, ou a alguns tipos de caatingas arbustivas em solos pedregosos" (ARAÚJO, et al., 1999, p. 664).
} 
Camboeiro (os mais importantes tributários do rio Grande) e rio do Ouro e rio Sapão, tributários do Rio Preto, também importante afluente do rio Grande. Os mencionados afluentes de segunda ordem do São Francisco formam os rios Carinhanha, Corrente e Grande, imediatamente após a decida do planalto para a Depressão Sãofranciscana. "Todos esses rios são perenes durante o ano inteiro, mas, até cerca de trinta anos atrás, seu volume era no mínimo cinco vezes maior que o atual" (BARBOSA, 2007, p.96). Essa diminuição de volume está diretamente relacionada com os usos da terra, que vêm se realizando nas últimas décadas, pois a intervenção arrasadora da monocultura em grande escala ataca amplas áreas contínuas, justamente onde se situam as nascentes formadoras dos respectivos rios.

A partir da década de 1970, as áreas dos chapadões onde se situam as nascentes e os cursos médios desses rios vêm sofrendo uma grande transformação, com a retirada da cobertura vegetal natural para a plantação de grãos e outras plantas exóticas. Este fato tem impedido a realimentação normal dos aqüíferos, contribuindo para o desaparecimento de inúmeros afluentes menores e a diminuição drástica do volume dos cursos maiores. Em outras palavras, o sistema de capilaridade aquosa está sendo drasticamente afetado (BARBOSA, 2007, p.96).

Um programa televisivo da Rede Globo, Globo Rural, ${ }^{11}$ divulgou a lista daqueles rios e ribeirões, tributários do rio Arrojado, mortos em decorrência, principalmente, dos desmatamentos desordenados praticados na região, com o respectivo ano de interrupção de seus fluxos, a citar:

Ribeirão Bom Jesus (1980), ribeirão da Vaca Morta (1982), ribeirão do Rosário (1983), ribeirão da Salobra (1984), ribeirão do Sapé (1985), ribeirão Lençóis (1985), ribeirão Caixeiro (1986), ribeirão Baixão (1986), ribeirão dos Buritis (1987), rio Planta Cana (1988), rio Itapicuru (1989), rio do Corredor (1990), rio Cabeceira Grande (1992), rio Sucuriu (1995), rio Catingueiro (1996), rio Caititu (1998) ribeirão do Salitre (1999).

Tornaram-se, pois, intermitentes, 17 rios ou ribeirões, tributários apenas de um dos rios da região, o rio Arrojado. Tendo em consideração que do ano de 2000 em diante a prática dos desmatamentos continuou, pode-se compreender a preocupação de Barbosa (2000) - e até mesmo ter uma ideia da gravidade da situação na região - pois estas investidas predatórias às riquezas naturais, infelizmente, abarcam toda a região Oeste da Bahia.

O mesmo programa da Rede Globo fez referência a abusos praticados por fazendeiros, que, achando-se donos dos rios que passam em suas terras, os

\footnotetext{
${ }^{11}$ Rede Globo, Programa Globo Rural, exibido em 10/12/2000.
} 
represam e até fazem canais desviando seus leitos, como é o caso de um fazendeiro paulista que, por meio de um canal de $9 \mathrm{~km}$ de cumprimento por $10 \mathrm{~m}$ de largura, desviou o rio Arrojado, causando danos irreparáveis a este.

\subsection{Abordagens sobre o conceito de território}

Destaco a seguir um dos recortes teóricos que estabeleço para o desenvolvimento da pesquisa. Trata-se do conceito de território, com o qual proponho balizar as reflexões e os procedimentos na busca do desvendamento dos processos sociais concernentes à realidade estudada.

Antes, porém, discorro sobre as formas como esse conceito foi tratado por aqueles autores que se preocuparam com ele.

O conceito de território tem sido objeto de longas abordagens, realizadas por muitos estudiosos, com diferentes concepções sobre ele e, inclusive, elaborando diferentes conceituações. E, nessa ampla gama de concepções, vê-se que cada um privilegia alguma dimensão a ele relacionada.

Há, portanto, autores que se apegam às abordagens de clássicos da geopolítica, os quais conferem centralidade ao papel de domínio e controle territorial do Estado, enquanto outros contemplam, nas suas conceituações e análises, elementos da produção mais recente do conhecimento geográfico, incorporando contribuições idealistas ou da dialética materialista de Karl Marx. Dentre os primeiros, merece destaque, na produção brasileira do conhecimento geográfico, os ligados à geopolítica, tal como Antonio Carlos Robert Moraes. Para este autor, o domínio territorial se faz pelo Estado e, propondo-se a dialogar com autores que concebem o território sob o ponto de vista do uso - e sobre o caso brasileiro -, escreveu:

Para bem equacionar em termos geopolíticos a pioneira construção do poder estatal
brasileiro é necessário diferenciar os conceitos de 'território' e de 'território usado', de
modo a captar sua relação nesse processo. O território diz respeito à área de domínio
político internacionalmente reconhecido como de soberania legítima de um Estado,
principalmente pelos Estados vizinhos. O território usado, uma fração desse espaço,
compreende os lugares economicamente integrados na lógica do sistema colonial,
dotados de estruturas produtivas incorporadas pela colonização (MORAES, 2010, pp.
$61-62$ ).

Esta concepção coloca no centro, pois, o domínio do Estado. E quando se refere ao território usado - fração do território sob domínio do Estado - entende-o 
como incorporado na lógica da colonização. Assim, não concebe, no território dominado pelo Estado, frações que, contraditoriamente, possam constituir-se de racionalidades diferenciadas, de apropriações da terra sob lógicas diferentes, tais como, podemos citar, os territórios quilombolas e os indígenas. Quanto a estas partes não usadas pela economia nacional, Moraes as qualifica de "fundos territoriais" "na perspectiva de uma geopolítica estatal” (MORAES, 2010, p.62).

Nessa concepção territorial, sobressai, pois, o território enquanto espaço nacional e como área controlada por um Estado nacional (MORAES, 1985, p.91). Essa formulação remonta a Friedrich Ratzel, no Antropogeografia, e, nesta concepção, o

território define-se pela propriedade, isto é, representa uma parcela do espaço terrestre identificada pela posse. O território, para Ratzel, é uma área que alguém possui, o espaço dominado por uma comunidade ou por um Estado. A função precípua do Estado, segundo ele, seria a defesa do território. Em suas palavras: "quando a sociedade se organiza para defender o território, transforma-se em Estado" (MORAES, 1985, p.91).

Na medida em que prima a superestrutura estatal na formação territorial, esta concepção não aborda a multiplicidade de dimensões que constitui os processos sociais também relevantes na formação do território.

Nessa perspectiva, os trabalhos de Haesbaert da Costa (1995 e 2007) oferecem relevantes contribuições, quando discorre sobre as abordagens de vários autores sobre a temática do território, ressaltando a dimensão (ou dimensões) que cada um destaca em suas concepções ou conceituações.

Para Haesbaert da Costa,

Território tem sido uma expressão ambígua, que pode designar desde um espaço social qualquer, como predomina no senso comum e entre alguns geógrafos, até um espaço marcado e defendido por determinadas espécies animais, seu espaço de sobrevivência, como é definido pela etologia. Pode ter tanto um sentido totalmente abstrato, como o "território da filosofia", quanto muito concreto, o "território dos Estados-nações" (HAESBAERT DA COSTA, 1995, p.56).

O mesmo autor considera "um dos trabalhos mais consistentes que enfocam a produção/definição do território numa perspectiva jurídico política" o de Alliés (1980). A partir da formação territorial do Estado nacional francês, Alliés identifica três "escolas" "de tratamento teórico do território enquanto categoria jurídica: a do território-objeto, a do território sujeito e a do território função" (HAESBAERT DA COSTA, 1995, p. 58). 
$\mathrm{Na}$ concepção de "território como objeto do Estado", o território "é objeto de um direito especial de soberania, assimilável a um direito real do Estado sobre o solo nacional, distinto do poder deste sobre as pessoas. Assim, a territorialidade arrisca-se a tornar-se um ramo isolado e específico da potência estatal" (HAESBAERT DA COSTA, 1995, pp.58-59).

No território como sujeito do Estado ou limite da sua competência, "o território não é um objeto sob domínio do Estado, mas um de seus elementos constitutivos, o modo de excelência do Estado no espaço" (HAESBAERT DA CONSTA, 1995, p.59).

No território como função do Estado, "o território seria um meio de ação do Estado e não somente um quadro geofísico de sua competência" (HAESBAERT DA COSTA, 1995, p.59).

Continuando a sua abordagem sobre as concepções territoriais, ressalta a corrente "cultural (lista) que prioriza a dimensão simbólica e mais subjetiva, o território visto fundamentalmente como produto da apropriação feita através do imaginário e/ou da identidade social sobre o espaço" (HAESBAERT DA COSTA, 1995, p. 63). Assim, posicionam-se Guattari (1985) e, na Geografia, Tuan (1980, 1983).

$\mathrm{Na}$ perspectiva econômica, "que destaca a desterritorialização em sua perspectiva material-funcional, como produto espacial do embate entre classes sociais e da relação capital-trabalho" lembra as posições de Moreira (1987) e Storper (1994). Para Haesbaert da Costa, o mais comum são posições intermediárias "que integra[m] elementos políticos e econômicos", tal como a de Godelier (1984) por ele ressaltada:

Designa-se por território uma porção da natureza e, portanto, do espaço sobre a qual uma determinada sociedade reivindica e garante a todos ou a parte de seus membros direitos estáveis de acesso, de controle e de uso com respeito à totalidade ou parte dos recursos que aí se encontram e que ela deseja e é capaz de explorar (GODELIER, 1984, p.112, apud HAESBAERT DA COSTA, 1995, p.64).

Dentre as várias abordagens sobre o território demonstradas por Haesbaert da Costa, ele explicita a que adota nos seus estudos, inclusive na sua tese de doutorado desenvolvida na região Oeste do Estado da Bahia.

Apesar da identificação feita por autores como Raffestin entre território e malhas, redes e nós, preferimos partilhar da distinção feita por Lévy (1991), que associa o território a áreas/superfícies e limites/fronteiras, pois como afirma Freund (1977) e o próprio Raffestin (1993[1980]), é no sistema de relações com o que lhe é externo, ou seja, com a alteridade (definindo 'o que é meu do teu' ou distinguindo 'nós dos 
outros') que a territorialidade de um grupo social pode ser definida. Dessa forma, como já vimos, ela está impregnada não só de um poder que se circunscreve espacialmente, mas também de laços de identidade que tentam de alguma forma forjar uma homogeneidade para esse território, dotá-lo de uma área/superfície minimamente igualitária, seja por uma identidade territorial (da qual o Estado-nação é o exemplo moderno por excelência) e/ou por uma fronteira definidora da alteridade (HAESBAERT DA COSTA, 1995, p.65).

Apoiado nesta concepção o autor desenvolveu sua pesquisa centrando-se no recorte identitário constituído das "construções sociais" do que se conhece como "baiano" e "gaúcho", segundo ele, "identidades forjadas e/ou manipuladas pelos grupos econômicos e politicamente dominantes" (p.30). A partir desse ponto, investiu na "compreensão das violentas mudanças socioespaciais ocorridas nos cerrados nordestinos, em especial o oeste baiano, a partir da década de 1980" (HAESBAERT DA COSTA, 1995, p.30).

Milton Santos soma-se aos estudiosos que se dedicaram à reflexão sobre a questão do território. Este autor coloca no centro da sua abordagem o "território usado" e explicita sua concepção:

O território tem que ser entendido como território usado, não o território em si. O território usado é o chão mais a identidade. A identidade é o sentimento de pertencer àquilo que nos pertence. O território é o fundamento do trabalho; o lugar da residência, das trocas materiais e espirituais e do exercício da vida. O território em si não é uma categoria de análise em disciplinas históricas, como a geografia. É o território usado que é uma categoria de análise (SANTOS, 2007, p.14) (grifo do autor).

A noção de uso desenvolvida por Santos (1996) contempla domínios tanto do nível local, as chamadas "horizontalidades", quanto de pontos distantes, as "verticalidades":

As horizontalidades serão dos domínios da contiguidade, daqueles lugares vizinhos reunidos por uma continuidade territorial, enquanto as verticalidades seriam formadas por pontos distantes uns dos outros, ligados por todas as formas e processos sociais (SANTOS, 1996, p.16).

Continua, complementando essa ideia:

Afirma-se, ainda mais, a dialética no território e, ousaria dizer, a dialética do território já que usado o território é humano, podendo, desse modo, comportar uma dialética. Essa dialética se afirma mediante um controle 'local' da parcela 'técnica' da produção e um controle remoto da parcela política da produção (SANTOS, 1996, p.17).

Enfatiza ainda o papel da técnica no controle do território. Este controle estabelece-se por meio do equipamento a prepará-lo para uma funcionalidade. $E$ as ações (de instalação de equipamentos) estabelecem-se por forças internas - a 
população local que o ocupa - e as externas, as redes, verticais. Conforme Santos, a complexidade progressiva que adquire o espaço como resultante das ações realizadas por forças internas e externas culmina na maior necessidade de regulamentação. "E se levanta a necessidade de Estado. O Estado e os limites, o Estado e a produção, o Estado e a distribuição, o Estado e a garantia do trabalho, o Estado e a garantia da solidariedade e o Estado e a busca da excelência na existência" (SANTOS, 2007, p.16).

Dessa forma, ressalta também na sua abordagem a normatização como dimensão de grande relevância na sua concepção de território, conferindo destaque ao papel do Estado.

Outros autores acrescentam a noção de apropriação no processo de construção do território. Esta noção permite que se compreenda o território a partir dos processos sociais que se desenvolvem no âmbito das frações do território que formam o todo, um território do modo capitalista de produção. Este todo na atualidade está sob a territorialização contraditória do capitalismo. No próximo tópico, discorro sobre as contribuições desses autores, as quais foram adotadas nos delineamentos da pesquisa que desenvolvi no vale do rio Arrojado/Oeste da Bahia.

\subsubsection{A Territorialização do Capital}

No Oeste da Bahia/vale do rio Arrojado, constatam-se alterações consideráveis nos usos que se faz da terra nas últimas décadas. Estas alterações estão relacionadas ao processo de desenvolvimento do modo capitalista de produção, que se intensificou no país, incorporando novas áreas no campo em todas as regiões, atrelando-as ao processo de industrialização que se concentrou nas regiões metropolitanas e nas grandes cidades do país. Este processo foi impulsionado

pelos governos militares pós-1964 com a finalidade de ampliar o comércio internacional do Brasil com a Comunidade Econômica Europeia e com o Japão. Toda a expansão da agricultura de soja na região do cerrado brasileiro está relacionada com os incentivos oriundos do Prodecer (Programa Nipo-brasileiro de Cooperação para o Desenvolvimento do Cerrado), assinado em 1974 entre o governo brasileiro e o japonês (OLIVEIRA, 2003, p.469).

Dentre os produtos agrícolas priorizados nesta política de expansão da produção capitalista no campo destaca-se a soja, mas também se cultiva milho, 
algodão - produtos transformados em commodities - e que têm mercados garantidos no comércio internacional.

Esta lógica condiz com

o processo de internacionalização da economia brasileira e revela, então, que o desenvolvimento do capitalismo na agricultura está marcado, sobretudo, pela sua industrialização. Esta industrialização deve ser entendida como o processo de introdução do modo de produzir industrial no campo, que por sua vez provoca um inter-relacionamento intenso entre a indústria e a agricultura (OLIVEIRA, 2003, p.470).

Os investimentos estatais concentraram-se para o desenvolvimento desse modelo de desenvolvimento da agricultura e do capital no campo "deixando praticamente abandonadas as culturas que se têm constituído, historicamente, na alimentação básica dos trabalhadores brasileiros" (OLIVEIRA, 2003, p.70).

Para viabilizar as demandas desse modelo de desenvolvimento do capital, criou-se uma variedade de programas voltados à implementação dos novos polos de desenvolvimento espalhados pelo país:

O Polocentro, o Polonordeste e o Poloamazônia. O Polocentro esteve e está voltado para a expansão da cultura de grãos - soja e arroz principalmente - no cerrado do Brasil Central. O Polonordeste foi responsável, sobretudo, pelos investimentos na Zona da Mata nordestina e no Sertão. Na região semiárida, essas políticas governamentais privilegiaram investimentos em projetos de irrigação, quer nas áreas dos açudes, quer nos vales dos rios da região. Papel de destaque coube à área do rio São Francisco nos Estados da Bahia e Pernambuco, ao vale do rio/açude Açu no Rio Grande do Norte e ao vale do rio Jaguaribe no Ceará. O Poloamazônico foi responsável pelo estabelecimento dos polos de desenvolvimento agromineral e agropecuários na região amazônica (OLIVEIRA, 2003, p.518).

Estas políticas de estado destinam-se a atender as demandas do capital na busca de novos espaços nos quais possa territorializar-se e viabilizar sua acumulação/concentração. Neste sentido, Calabi e Endovina asseveram:

O território (na sua totalidade) não é "outro" com relação ao "processo capitalista", mas, ao contrário, ele é usado e se transforma em função daquele processo geral. Isto significa:

a) que o processo de desenvolvimento econômico tende a abarcar com as suas relações, todas as esferas da produção de mercadorias e por consequência, todo o território;

b) que na base deste processo está a tendência à concentração do capital, portanto o "uso capitalista" total do território deve ser analisado e estudado em relação ao processo de concentração do capital, com a concentração tão acentuada das massas de homens e de capitais em determinados pontos, progride a concentração destas massas de capitais em poucas mãos (CALABI \& ENDOVINA,1973, p.1). 
Os usos capitalistas do território visam, sobretudo, atender às demandas do processo do capital e, a este respeito, Calabi e Endovina destacam que estes usos se referem: "ao processo de produção propriamente dito (extração de mais-valia); à circulação e valorização do capital; à reprodução da força-de-trabalho" (CALABI \& ENDOVINA,1973, p.1).

Estes autores entendem, pois, que o capital, no seu processo de desenvolvimento/valorização/acumulação/concentração, tende a abarcar, com suas relações de produção, todo o território e assim explicam:

As relações capitalistas de produção tendem a se ampliar e a abranger toda a sociedade; são estas relações e o desenvolvimento das forças produtivas que dão a configuração especifica ao território. Deste ponto de vista, a organização do território não é um prius, mas deriva do capital e do seu processo (CALABI \& ENDOVINA,1973, p.1).

Embora afirmem, também, que não se trata de "um uso 'igual' de todo o território, mas um uso total, ainda que especificado por partes" (CALABI \& ENDOVINA, 1973, p.1), sustentam que, para se apreender esta questão, há que se ater aos processos dos quais derivam o desenvolvimento do capital em seu processo de territorialização.

Seguindo esta concepção, em sua explicação sobre o modelo brasileiro de desenvolvimento do modo capitalista de produção no campo e suas respectivas contradições, Oliveira afirma que

\begin{abstract}
a chamada modernização da agricultura não vai atuar no sentido da transformação dos latifundiários em empresários capitalistas, mas, ao contrário, transformou os capitalistas industriais e urbanos - sobretudo do Centro-Sul do país - em proprietários de terra, em latifundiários. A política de incentivos fiscais da Sudene e da Sudam foram os instrumentos de política econômica que viabilizaram esta fusão. Dessa forma, os capitalistas urbanos tornaram-se os maiores proprietários de terra no Brasil, possuindo áreas com dimensões nunca registradas na história da humanidade (OLIVEIRA, 2001, p.186).
\end{abstract}

A região estudada, conforme Oliveira mencionou, destaca-se como um polo de desenvolvimento deste modelo de intervenção/desenvolvimento do capital.

\title{
1.3.2 O Vale do rio Arrojado/Oeste da Bahia e os processos de territorialização
}

No vale do rio Arrojado, são perceptíveis variedades de territorializações, que correspondem às ações dos diferentes sujeitos que se apoderam da terra, por meio 
de suas representações, seus projetos e seus usos e que materializam nele o conjunto de relações que transparecem nas configurações territoriais específicas.

Estas configurações territoriais revelam as diferentes relações sociais, que caracterizam a modalidade de apropriação camponesa e a modalidade de apropriação capitalista. Tem-se, pois, o que observa Raffestin:

Todo projeto é sustentado por um conhecimento e uma prática, isto é, por ações e ou comportamentos que, é claro, supõe a posse de códigos, de sistemas sêmicos. É por esses sistemas sêmicos que se realizam as objetivações do espaço, que são processos sociais. É preciso, pois, compreender que o espaço representado é uma relação e que suas propriedades são reveladas por meio de códigos e de sistemas sêmicos. Os limites do espaço são os sistemas sêmicos usados para representá-los (RAFFESTIN, 1993, p.144).

As diferentes modalidades de territorialidades, visíveis a partir dos sistemas sêmicos, nem sempre estão precisamente delimitadas. Ao se aproximar do nível imediato, no qual as relações se processam, observa-se que, não raro, elas se desenvolvem entrelaçando-se e estabelecendo, muitas vezes, laços de interdependência, mas também de subordinação, de conflito, de confronto, de enfrentamento entre os sujeitos; e isto revela a tônica das relações - as contradições - pois, o desenvolvimento do modo capitalista de produção não ocorre de maneira linear e unidirecional. Ele se processa, se desenvolve

como sendo contraditório e combinado, ou seja, ao mesmo tempo que segue reproduzindo relações especificamente capitalistas mais avançadas, produz também, igual e contraditoriamente, relações não capitalistas de produção e de trabalho, como as relações camponesas de produção, a peonagem, etc. todas necessárias à sua lógica de desenvolvimento (OLIVEIRA, 2002, p.74).

É sob esta concepção de desenvolvimento do modo capitalista de produção que Oliveira, a partir de autores como Lefebvre, Calabi, Endovina, Raffestin, Gottdiner, Coraggio, Quaini, Chesnais e Lacoste, formula a sua concepção de território.

Parto da concepção de que o território deve ser apreendido como síntese contraditória, como totalidade concreta do processo/modo de produção/distribuição/circulação/consumo e suas articulações e mediações superestruturais (políticas, ideológicas, simbólicas, etc.) em que o Estado desempenha a função de regulação. O território é assim produto concreto da luta de classes travada pela sociedade no processo de produção de sua existência. Sociedade capitalista que está assentada em três classes sociais fundamentais: assalariado, burguesia e proprietários de terras.

Dessa forma, são as relações sociais de produção e 0 processo contínuo/contraditório de desenvolvimento das forças produtivas que dão a configuração histórica específica ao território. Logo o território não é um prius ou um a 
priori mas a contínua luta da sociedade pela socialização igualmente contínua da natureza.

O processo de construção do território é simultaneamente construção/destruição/manutenção/transformação. Em síntese, é a unidade dialética, portanto contraditória, da espacialidade que a sociedade tem e desenvolve. Logo, a construção do território é contraditoriamente o desenvolvimento desigual, simultâneo e combinado, o que quer dizer: valorização, produção e reprodução (OLIVEIRA, 2002, p.74).

Esta definição contempla o que considero central na explicação dos processos em desenvolvimento no vale do rio Arrojado. $O$ vale deste rio, mas também toda a região Oeste da Bahia, caracteriza-se, sobretudo, como um palco de conflito em que as diferentes classes sociais, no caso a burguesa, juntamente com os proprietários de terra, investem na expropriação/expulsão dos camponeses com vistas a transformar suas terras de trabalho em terra de negócio. Ao expropriar/expulsar os camponeses, os capitalistas pretendem transformá-los em assalariados, portadores da mercadoria "força de trabalho" da qual o capital extrairá mais-valia para viabilizar a sua acumulação. Este processo de territorialização do capital tem provocado a resistência dos camponeses e gerado conflitos e confrontos em um território que se torna sempre mais multifacetário, comportando frações territoriais diferentes, conformando, pois, uma síntese contraditória, resultante dos processos que se realizam pelas ações de sujeitos portadores de interesses antagônicos, mas também combinados, os quais constroem/destroem/mantêm/transformam simultaneamente e continuamente o território.

$\mathrm{Na}$ composição desse processo, sobressaem-se frações territoriais resultantes dos diferentes modos de apropriação/socialização da terra, coadunandose com a assertiva de Raffestin:

Toda prática espacial, mesmo embrionária, induzida por um sistema de ações ou de comportamentos se traduz por uma "produção territorial" que faz intervir tessitura, nó e rede. É interessante destacar a esse respeito que nenhuma sociedade, por mais elementar que seja, escapa à necessidade de organizar o campo operatório de sua ação (RAFFESTIN, 1993, p.150).

No caso estudado, isto se observa claramente nas diferentes apropriações/propriedades da terra, as quais imprimem no território suas infraestruturas próprias, que possibilitam a operacionalização/uso e a socialização das riquezas naturais em conformidade com o modo de produção a ela concernente. Exemplifico a ordenação territorial que se construiu nas áreas dominantemente de uso exclusivo familiar que formam as comunidades; as áreas onde predominam o 
uso comum pecuário; e, revelando outra racionalidade e sentido do uso e apropriação da terra, as de apropriação capitalista, cuja marca principal é a propriedade privada delimitada por linhas precisas, geralmente com cercas, mas quando não, cerceando o uso pela força e gerando conflitos.

No modo costumeiro de se territorializar no Oeste da Bahia/vale do rio Arrojado, a terra, tradicionalmente, é usada desprovida do valor de troca ${ }^{12}$ e isto é coerente com o que assevera Marx (1988, p.46): "o valor de uso realiza-se somente no uso ou no consumo. Os valores de uso constituem o conteúdo material da riqueza, qualquer que seja a forma social desta". Isto se evidencia claramente, no que representa a terra para os camponeses geraizeiros. Este bem natural significa um instrumento de trabalho, que eles usam para adquirir os meios necessários para a reprodução de suas vidas e, de modo geral, não o concebem como constituído de valor de troca. Isto se observa nos casos de transferências do direito de uso da terra entre os criadores dos fechos de gerais. Quando ocorrem as transferências, a quantificação do valor realiza-se em bolas de arame. Isto indica que apenas a quantidade de dinheiro gasta na construção da cerca, e de modo muito impreciso e geralmente subestimando o trabalho empregado, é computado na transação. A terra e seus elementos: vegetação, água, capacidade produtiva do solo, não são computados nas transferências e pode-se, pois, afirmar que ocorre uma transferência de direito de uso territorial.

Esta representação da natureza, é coerente com a concepção de espaço e território defendida por Raffestin. Para este autor, o território "é um espaço onde se projetou um trabalho, seja energia e informação, e que, por consequência, revela relações marcadas pelo poder. O espaço é a 'prisão original', o território é a prisão que os homens constroem para si" (RAFFESTIN, 1993, p.144). Complementa:

\begin{abstract}
é essencial compreender bem que o espaço é anterior ao território. O território se forma a partir do espaço, é o resultado de uma ação conduzida por um ator sintagmático (ator que realiza um programa) em qualquer nível. Ao se apropriar de um espaço, concreta ou abstratamente (por exemplo, pela representação) o ator "territorializa" o espaço (RAFFESTIN, 1993, p.143).
\end{abstract}

A chegada das empresas capitalistas com pretensões de apropriarem-se da terra confere a ela outro sentido, este coerente com as relações sociais de produção capitalista, cuja característica que se sobressai é a privatização da terra e, mesmo

\footnotetext{
12 "a relação quantitativa, a proporção na qual valores de uso de uma espécie se trocam contra valores de uso de outra espécie" (MARX, 1988, p.46).
} 
que nela não se tenha empregado trabalho, como é o caso de imensas áreas intactas da região estudada, transformam-na em mercadoria, com valor de troca.

Nesse processo, quando os camponeses posseiros resistem à expulsão de suas terras de trabalho, ocorre-lhes "vendê-la" ao capitalista por preços irrisórios, que muitas vezes, sequer pagam as benfeitorias executadas na terra, conforme explica Martins:

\begin{abstract}
Quando é expulso da terra e resiste, o posseiro consegue às vezes receber uma indenização pelas benfeitorias. Como geralmente não conhece o princípio da propriedade em que se baseia a sua expulsão, exige ou aceita que o pagamento se faça pelos seus serviços contidos na terra, pelo seu trabalho, pelas benfeitorias - a derrubada da mata, a casa, as plantações. Operando com uma lógica distinta da do seu inimigo, aquele que o expulsa, o posseiro não tem condições de entender a amplitude das relações e do processo em que está envolvido. É o que o torna mais facilmente vitima do fazendeiro, do grileiro, da empresa e do próprio governo (MARTINS, 1981, p.117) (grifo do autor).
\end{abstract}

O que Martins afirmou nesta citação é muito presente no vale do rio Arrojado, mas merece especial destaque os casos das comunidades do médio vale. Estas vem sendo acometidas a um processo de expulsão/expropriação/desterritorialização total e de modo extremamente violento pelas forças privatistas do capital. Sob esta forte pressão, pode-se dizer que se envolvem em um foco de conflito no território ao longo do vale. Deste modo, muitos resistem bravamente, mas outros cedem à força expansionista do capital, cuja determinação visa a desterritorialização total. Sob esta forte pressão, parte dos posseiros por ela vitimada cede suas frações territoriais, muitas vezes se coadunando com a afirmação de Martins (1991).

$\mathrm{Na}$ abordagem que desenvolvi sobre o referido vale, diferencio o grau de desterritorialização descrito com o qual se envolve as comunidades do baixo vale. Estas, por terem asseguradas as suas áreas de moradia, plantios e criatórios, sobretudo nas parcelas de uso exclusivo familiar, e por enfrentarem maior pressão desterritorializante na outra fração do território, nos fechos de gerais, têm a sua reprodução socioterritorial, em parte, garantida. Portanto, as referidas comunidades estão envolvidas em um processo que denomino de desterritorialização parcial.

Com a afirmação a seguir, Martins elucida bem o universo de representação do camponês posseiro, em relação à questão da propriedade da terra:

Eu tenho encontrado muitas pessoas nas regiões por onde ando, no sertão, que nunca havia tido notícia da propriedade privada da terra, não tinham a menor ideia do que fosse isso. E ficaram assustadas quando ali começaram a chegar os primeiros proprietários, as primeiras cercas e tudo o mais. Isso causa um grande espanto. $\mathrm{O}$ 
espanto não é pela novidade da coisa, pelo tamanho da coisa. É pela forma, pela própria essência da coisa, ou seja, pela propriedade capitalista da terra que começa a chegar ali (MARTINS, 1981, p. 129).

Há que se destacar ainda que, ao espanto provocado pela propriedade privada e seu significado, soma-se a força da violência usada nos métodos de tomadas das terras, utilizando-se das absurdas manobras fraudulentas no campo jurídico, assim como as agressões e os assassinatos praticados por pistoleiros a serviço do capital.

Estes não são casos raros. Infiro que, sem carecer muito esforço, breves levantamentos nos cartórios das regiões, por onde se expandiu e se expande o agronegócio com suas práticas "modernas", seriam suficientes para descobrir a prática mais recorrente da privatização capitalista da terra - a grilagem.

No Oeste da Bahia, isto é fato e cito exemplo: apenas de uma matrícula - a de número 2.280 -, registrada no Cartório de Registro de Imóveis e Hipotecas da Comarca de Santa Maria da Vitória, surgiu mais de 400 matrículas de imóveis, abarcando cerca de 600 mil hectares nos municípios de Santa Maria da Vitória, Correntina, Jaborandi e Coribe (anexo 1). Em outra parte do Oeste, município de Formosa do Rio Preto, da mesma forma, ampla área privatizada por empresas do agronegócio está com suas matrículas trancadas. De modo geral, pode-se afirmar que basta a resistência dos camponeses posseiros conseguir romper as barreiras impostas pelo judiciário das comarcas locais, e questionar a apropriação das terras pelas empresas capitalistas, que chega-se à conclusão dos processos com a comprovação da apropriação fraudulenta da terra; uma vez que, conforme afirmou Martins, "a expansão do capital se faz preferencialmente sobre as terras ocupadas por posseiros". Estas terras, que são tradicionalmente ocupadas como terra de trabalho, são terras devolutas (tabela 1). 
Tabela 1 - Terras devolutas no Oeste da Bahia, 2010

\begin{tabular}{l|c|c|c|c}
\hline Município & Área (ha) & $\begin{array}{c}\% \text { da área do } \\
\text { município }\end{array}$ & $\begin{array}{c}\mathbf{n}^{\mathbf{0}} \text { de } \\
\text { imóveis }\end{array}$ & $\begin{array}{c}\text { Área ocupada } \\
\text { (ha) }\end{array}$ \\
\hline Barreiras & 441.425 & $37 \%$ & 179 & 478.033 \\
\hline Luiz Eduardo & 23.204 & $17 \%$ & 65 & 82.747 \\
\hline Formosa do Rio Preto & 712.453 & $43 \%$ & 365 & 2.017 .789 \\
\hline Santa Rita de Cássia & 274.278 & $45 \%$ & 59 & 279.785 \\
\hline São Desidério & 243.138 & $56 \%$ & 495 & 1.514 .245 \\
\hline Correntina & 356.554 & $31 \%$ & 263 & 1.001 .546 \\
\hline Jaborandi & 601.634 & $60 \%$ & 126 & 665.478 \\
\hline Cocos & 206.917 & $21 \%$ & 230 & 1.435 .587 \\
\hline Bahia & $\mathbf{2 2 . 8 3 8 . 6 6 2}$ & $\mathbf{4 0 \%}$ & $\mathbf{6 . 7 2 5}$ & $\mathbf{1 7 . 6 7 7 . 5 0 7}$ \\
\hline
\end{tabular}

Fonte: INCRA. Elaborada por Oliveira, A. Umbelino e Org. por Sousa Sobrinho, J. (2010)

A tabela revela o quadro de irregularidade da ocupação da terra nos municípios listados, pois, o número de imóveis que delas se apropriaram, ocupam uma área superior à quantidade de terras devolutas existente em cada município.

Merecem destaque os casos dos municípios de São Desidério e de Cocos. No primeiro, os 495 imóveis ocupantes das terras devolutas têm documentos que abarcam uma área de 1.514.245ha, aproximadamente seis vezes maior do que a existente. No segundo município, os 230 imóveis têm documentação para uma área de 1.435.587ha, quase sete vezes maior do que a das terras devolutas existentes.

O absurdo pode ser ainda maior, pois, no município de Correntina a tabela mostra que os 263 imóveis ocupam uma área de 1.001.546ha, correspondendo a aproximadamente três vezes mais do que as existentes. No entanto, no referido município, é comum a afirmação da insuficiência da área do município para cobrir a documentação que existe; afirmam que seria necessário multiplicá-la por três para atingir o lastro territorial demandado pelos papéis das fábricas de escrituras, dos cartórios, o que formaria um beliche fundiário.

Práticas como estas contradizem o discurso que pretende justificar a modernização do campo ocorrida nas últimas décadas, levada a cabo pelo capital industrial globalizado.

Muitos estudiosos da questão agrária brasileira na atualidade omitem esses processos em suas análises, mas destacam como centrais os componentes 
modernos das relações sociais de produção em expansão, as capitalistas. Dentre estas abordagens, destaco a seguinte afirmação:

\begin{abstract}
a agricultura brasileira evoluiu basicamente daquilo que poderíamos chamar de vários complexos rurais, grandes fazendas, grandes propriedades que tinham nível de consumo interno e produção de subsistência interna na propriedade, para aquilo que hoje se chama complexos agroindustriais. É como se aquilo que era anteriormente agricultura fosse num primeiro momento se subdividindo, se repartindo, se desestruturando. Expulsando de dentro dela uma série de atividades como, por exemplo, a fabricação de insumos orgânicos que se transformaram em adubos químicos. Antes a agricultura produzia os seus próprios adubos. Hoje esses adubos são adquiridos de fora; antes a agricultura criava os seus próprios animais de tração, hoje esses animais de tração foram substituídos pelos tratores. Então, é como se da agricultura daquele grande complexo rural fossem saindo partes dele e formando ramo da indústria que depois ligam novamente esses ramos da indústria, formando os complexos rurais. Hoje a gente fala de complexo soja, do complexo álcool ou complexo canavieiro, enfim, vários complexos (GRAZIANO DA SILVA, 2004, pp.137138).
\end{abstract}

Não se trata aqui de negar a ocorrência das transformações que ocorreram na agricultura nas últimas décadas. Em muitas análises que são feitas na atualidade faltou "mergulhar" nos processos sociais, nas relações que de fato ocorrem no âmbito do imediato e associá-las à lógica de reprodução do capital em escala global. Esta postura permitiria escapar-se das explicações a priori e certamente resultaria em outras mais totalizantes. Posso afirmar que as formulações presentes nas abordagens de José Graziano, e de outros autores integrantes da mesma corrente de interpretação das transformações no campo, não são suficientes para explicar a variedade de situações que se processam no Oeste da Bahia/vale do rio Arrojado.

O desenvolvimento do modo capitalista de produção $^{13}$ no campo realiza-se incorporando relações de produção não capitalista. Martins, a partir de Marx, aponta para a necessidade de se adotar esta concepção, a qual deve refletir em procedimentos a serem seguidos em estudos desta problemática, quando afirma que o "próprio capital engendra e reproduz relações não capitalistas de produção". Esta concepção permitiu-lhe "desenvolver a análise do regime de colonato nas fazendas de café, constituído de relações de trabalho que foram historicamente criadas na própria substituição do trabalhador escravo, conforme as necessidades do capital, sem que no final viesse a se definir um regime de trabalho assalariado nos cafezais" (MARTINS, 1996, p.3).

\footnotetext{
${ }^{13}$ Entendido conforme Martins: "modo historicamente determinado de exploração da força de trabalho no processo de produção no qual são produzidas também as relações sociais de uma sociedade" (MATINS, 1996, p.2).
} 
Nesta mesma perspectiva, Oliveira afirma que

\begin{abstract}
O estudo da agricultura brasileira deve ser feito levando-se em conta que o processo de desenvolvimento do modo capitalista de produção no território brasileiro é contraditório e combinado. Isso quer dizer que, ao mesmo tempo que esse desenvolvimento avança reproduzindo relações especificamente capitalistas (implantando o trabalho assalariado pela presença no campo do boia-fria), ele (o capitalismo) produz também, igual e contraditoriamente, relações camponesas de produção (pela presença e aumento do trabalho familiar no campo) (OLIVEIRA, 2002, p.73).
\end{abstract}

No caso em estudo, observa-se que o modo capitalista de produção expandese, territorializando as relações sociais de produção. Dentre elas, destaca-se a privatização das terras de trabalho, que vem comprometendo o costumeiro uso dos amplos gerais pelos camponeses geraizeiros em suas atividades pecuaristas, extrativistas e agrícolas nas áreas ribeirinhas. Em função da redução das terras de trabalho, o trabalho assalariado vem ganhando importância, envolvendo principalmente a população jovem, que migra para outros estados ou se assalaria nos empreendimentos agropecuários da região (em menor quantidade), inclusive submetendo-se a relações de trabalho precárias, contraditórias ao que preconiza o discurso do capital moderno. No médio vale do rio Arrojado, principalmente, a ocorrência dessas relações de trabalho em grande medida é favorecida ao capital pelo acesso que o trabalhador tem à pequena parcela de terra nas áreas ribeirinhas, nas quais cultiva pequenas lavouras em períodos em que o processo produtivo das monoculturas dispensa a força de trabalho.

Essas condições favorecem a manutenção da oferta de mão de obra nas proximidades dos empreendimentos capitalistas e facilita a superexploração pelo capital ao camponês, pois, o mesmo tem como outra fonte de sustento o produto de seu trabalho ou de sua família na pequena parcela de terra que lhe é acessível, mas também, contraditoriamente, possibilita a reprodução camponesa, na medida em que os ganhos do trabalho acessório, realizado nos empreendimentos capitalistas, complementam o sustento da família.

Apesar de se perceber o aumento do assalariamento, verifica-se também a resistência de boa parte dos membros das comunidades em se submeter ao trabalho assalariado. Quando eles se referem às condições de trabalho que as empresas oferecem, afirmam que se trata de trabalho escravo e que não compensa deixar de cuidar do gado e da roça para se assalariar. Os geraizeiros que têm este entendimento investem na mobilização para a luta contra os grileiros de suas terras 
e criticam aqueles que, por qualquer mixaria, entregam suas posses e, daí em diante, não Ihes restam alternativa senão se submeter ao trabalho escravo.

\subsection{As correntes teóricas interpretativas do campo e da agricultura no Brasil}

Há três principais correntes teóricas de interpretação do campo e da agricultura brasileira. A primeira corrente tem sua origem nos partidos comunistas e sua teoria tem como base as obras dos pensadores clássicos que interpretaram a problemática do campo na Europa da segunda metade do século XIX. Esta corrente entende que a sociedade capitalista constitui-se apenas de duas classes sociais: os capitalistas e os assalariados. Quanto aos proprietários de terras (latifundiários), são vistos pelos precursores dessa corrente como permanência dos resquícios feudais e, tal como ocorreu na Europa, deverão ser extintos para que se constitua por completo a sociedade capitalista ${ }^{14}$.

A segunda corrente tem como principais contribuições a evolução do pensamento sobre a realidade do campo brasileiro e a ruptura do pensamento dos comunistas quanto ao seu eurocentrismo. O principal ícone dessa corrente no Brasil foi o historiador Caio Prado Júnior. Para ele, não cabe na realidade brasileira a existência do feudalismo. E, sendo assim, o que seriam as relações de servidão (resquícios feudais para os da primeira corrente), poderiam ser chamadas de restos escravistas ${ }^{15}$.

Também para os adeptos dessa corrente, na sociedade futura, o campesinato seria extinto. A sociedade capitalista seria composta por duas classes sociais: a dos capitalistas e a dos assalariados. E, por esta apriorística conclusão, afirmam que históricas relações de trabalho no campo brasileiro, tais como o colonato, a parceria e outras, mesmo não sendo integralmente remuneradas por dinheiro, seriam formas disfarçadas de assalariamentos. Tudo isso para não reconhecer, no modelo de desenvolvimento do capitalismo brasileiro, a existência/importância do campesinato.

Os adeptos mais recentes dessa corrente, discutem a permanência dos pequenos proprietários de terra, os designam de agricultores familiares, aqueles que

\footnotetext{
${ }^{14}$ No Brasil, são seguidores dessa corrente: Alberto Passos Guimarães, Nelson Werneck Sodré, Ignácio Rangel e Orlando Valverde.

${ }_{15}$ José Graziano da Silva é o representante mais fiel dessa corrente na atualidade. No entanto, outros intelectuais, como Ricardo Abramovay e José Eli da Veiga, também a seguem.
} 
comporiam o "agronegocinho" ao se modernizarem. E, se não, assim como as grandes propriedades, tenderão ao desaparecimento.

A interpretação do campo brasileiro por essas correntes tem realimentado o modelo neoliberal, na medida em que exalta o agronegócio e não acena com rupturas que viabilizem o combate à escandalosa desigualdade social presente no campo. Uma prova disso é o seu posicionamento sobre a reforma agrária. Por entender que esta possibilitaria a recriação do pequeno proprietário (que, para eles, são sujeitos pretéritos), quando a defendem, esta defesa limita-se à política pública compensatória, sem importância política e apenas social. Ou seja, nas palavras do prof. Ariovaldo Umbelino de Oliveira, para "tirá-los do mundo miserável e colocá-los no mundo dos pobres". Assim, não acenam com o combate à extrema concentração de terras, uma das grandes culpadas pela escandalosa precariedade das condições de vida no campo brasileiro.

Dentre as correntes teóricas de interpretação do campo, quero explicitar a que adotei para delinear a minha análise e minha reflexão sobre os processos que se desenvolvem na região Oeste da Bahia, pois entendo ser esta a que melhor explica os processos em desenvolvimento na parte que adotei como recorte - e que privilegia os conceitos e as categorias de análise mais adequadas ao exercício da produção de conhecimento que faço sobre a região em estudo ${ }^{16}$. Destaca-se, pois, no meu entendimento, pela maior eficácia a me proporcionar melhor compreensão da parte na sua intrínseca relação com a totalidade.

Tratam-se das formulações da pensadora marxista Rosa Luxemburgo e do próprio Marx nos dois últimos livros d'O Capital, assim como dos seus últimos escritos, nos quais compreende que o capitalismo é composto por três classes sociais, a saber: os capitalistas, os assalariados e os proprietários de terra, incluídos, na última, os camponeses ${ }^{17}$.

Esta corrente adota o método marxista do materialismo dialético. $\mathrm{E}$, por assim proceder, ao invés do apriorismo teórico que embasa a prática das outras correntes, tem como procedimento, na produção do conhecimento, a busca do desvendamento

\footnotetext{
16 "O método não existe como uma entidade simples e desconectada da realidade científica. Ele comporta, ao ser internalizado e utilizado pelo pesquisador, outros elementos. Esses elementos são, sem nenhuma preocupação de comparar suas importâncias, a doutrina, a teoria, as leis, os conceitos e as categorias" (SPOSITO, 2004, p. 55).

${ }^{17}$ Como representantes dessa corrente no Brasil, temos: José de Souza Martins, Ariovaldo Umbelino de Oliveira, Carlos Rodrigues Bandão, Alfredo Wagner e outros.
} 
dos processos sociais, sem perder de vista as contradições que compõem o movimento da sociedade.

São importantes pensadores dessa corrente no Brasil os professores José de Souza Martins e Ariovaldo Umbelino de Oliveira. As contribuições desses estudiosos são de grande relevância para o entendimento da realidade brasileira. Seus estudos sobre o modo capitalista de produção na história do Brasil, desenvolvendo-se e construíndo parte de seu território, demonstram que latifundiários e camponeses não são sujeitos de fora do capitalismo e sim de dentro (MARTINS, 1983, p.170). Para tanto, revelam que, no modelo brasileiro, desde os tempos do império, a classe dos proprietários de terra, as ditas oligarquias, ou assumem diretamente o poder ou fazem aliança com o Estado e seus respectivos governos. E que, sem a referida aliança, nenhuma facção política conseguiu governar (MARTINS, 1999, p.20).

Até mesmo governos autoritários, tais como o instalado com o golpe de 1964, apregoando o desenvolvimentismo, se aliaram às oligarquias; e mais, reforçou como nenhum outro, o poderio dos proprietários de terra, a partir da fusão de interesses do capital moderno e dos proprietários, unindo-os na mesma pessoa. Isto ficou muito evidente na dita política de ocupação dos "espaços vazios" (assim chamados pelos militares no poder) destinada principalmente à região amazônica, através dos escandalosos incentivos fiscais a grupos empresariais do centro-sul dispostos a se apropriarem, na maioria das vezes de forma ilícitas, das terras, na verdade, ocupadas pelas populações indígenas e de posseiros. Na mesma região e em outras do país, a prática do trabalho escravo é das mais usuais em muitas das atividades desses grandes empreendimentos com faces modernas (MARTINS, 1997, p.81). No centro-sul do país, o capital se apropria da renda da terra camponesa a partir do que Oliveira chama de "monopolização do território pelo capital", exemplificada nos cultivos de fumo no Rio Grande do Sul, dos criatórios de frango polarizados no Estado de Santa Catarina, nos cultivos de soja do sul e cultivos de laranja do Estado de São Paulo (OLIVEIRA, 1996, p.24-25), indicando, portanto, a contraditória "produção capitalista de relações não capitalistas de produção" (MARTINS, 1996, p.21).

A região Oeste da Bahia também nos oferece importantes evidências que confirmam esses pressupostos. Como exemplo, tem-se as políticas estatais, tais como o Programa Nacional de Fortalecimento da Agricultura Familiar (PRONAF), a 
compra da produção camponesa pela Companhia Nacional de Abastecimento (CONAB) estabelecendo preços mínimos, que viabilizam a reprodução do campesinato, o qual cumpre relevante papel tanto no quesito oferta de mão de obra aos empreendimentos capitalistas, quanto na abundante oferta de alimento negociados nas feiras camponesas muito recorrentes e expressivas nas cidades da região.

\subsubsection{A persistente história da questão agrária brasileira}

Apresentadas as principais correntes teóricas de interpretação do campo no Brasil, cabe agora prosseguir a abordagem, contextualizando a propriedade da terra na história brasileira. E, nesse sentido, tal como nos informa Martins, em seu livro "O poder do atraso" ${ }^{18}$, o ano de 1850, no qual foi criada a Lei de Terras, representa 0 principal marco histórico. Trata-se da Lei $n^{0}$ 601, de 18 de setembro de 1850 . Esta lei tornou a terra mercadoria, na medida em que determina o acesso somente pela via da compra. Excluindo, pois, da aquisição, os escravos posteriormente libertos e os camponeses pobres.

Em seu livro, Martins demonstra também o grande poder político conservador e conservado pelas oligarquias agrárias brasileiras ao longo dos tempos. Inclusive o referido autor complementa o título do seu livro com o subtítulo "ensaio de sociologia da história lenta". E, logo a partir da primeira linha da introdução, escreve:

É A PERSISTÊNCIA do passado que constitui o teor deste livro. O passado que se esconde, e às vezes se esconde mal, por trás da aparência do moderno, fazendo da sociedade brasileira uma sociedade em que essa peculiaridade pesa mais do que à primeira vista se vê (MARTINS, 1994, p.11).

Esse passado que persiste é o grande e o antigo poder das oligarquias locais. Estas se reproduzem às custas do controle que exercem sobre o eleitorado, no âmbito dos municípios, e pela importância do fator voto para os representantes políticos de outras instâncias do poder, seja estadual ou federal. Os sucessivos governos desses níveis da representação política não conseguiram (aqueles poucos que tentaram) levar a cabo seus mandatos sem que fizessem concessões e alianças com aqueles donos dos votos, donos dos "currais" eleitorais.

\footnotetext{
${ }^{18} \mathrm{Na}$ discussão deste tópico, utilizo-me da valiosa contribuição do referido autor nesta obra.
} 
Martins (1994) cita o caso dos governos João Goulart e Collor de Melo, que não conseguiram concluir seus mandatos por terem contrariado os interesses das referidas oligarquias. Outros governos, até autoritários, tais como o de Getúlio Vargas e o instalado com o golpe militar de 1964, tiveram que fazer importantes concessões às oligarquias para manterem-se no poder.

No caso do governo de Getúlio Vargas, limitou-se a legalização das relações de trabalho no meio urbano e, para não contrariar as oligarquias, negou-se a extensão dessa medida, reivindicada pela totalidade dos trabalhadores, aos trabalhadores rurais.

No caso dos governos militares, apoiados em seu golpe pelas ditas oligarquias, através da Superintendência de Desenvolvimento da Amazônia (SUDAM) e de outras superintendências regionais, fizeram a maior aliança entre o capital e propriedade da terra da história do Brasil, por meio da concessão de escandalosos incentivos à expansão da propriedade privada e capitalista da terra sobre as terras públicas, ditas por eles espaços vazios. Na verdade, são terras ocupadas pelas populações indígenas e pelos camponeses posseiros, aos quais a garantia de continuidade em suas terras seria um direito legítimo. Os militares criaram ainda o Estatuto da Terra que, ao contrário do avanço que parecia representar em um primeiro momento, na perspectiva de uma reforma agrária, acabou conferindo à propriedade da terra um caráter empresarial capitalista, que pôs abaixo as expectativas de avanço no processo de distribuição de terras no país.

No caso do governo desenvolvimentista de Jucelino Kubitschek, conforme Martins (1999, p.59), como política de desenvolvimento para a região Nordeste do país, criou-se a Superintendência de Desenvolvimento do Nordeste (SUDENE). No entanto, manteve o Departamento Nacional de Obras Contra a Seca (DNOCS), órgão controlado pelas ditas oligarquias, principalmente do Estado do Ceará, e portador do dito atraso que o governo Jucelino Kubitschek prometia combater. E não se pode esquecer que até mesmo a SUDENE acabou caindo no controle das oligarquias.

O passado, dito por Martins (1999, p.11), é o que vem persistindo no modelo de desenvolvimento brasileiro, representado pelo poderio influente das oligarquias proprietárias de terra. $\mathrm{O}$ que seria uma irracionalidade para o desenvolvimento capitalista, a propriedade privada da terra, no modelo brasileiro, contraditoriamente, 
é uma peça importante da sua reprodução, com a participação ativa do Estado brasileiro com seu caráter claramente classista.

Esta característica peculiar do modelo de desenvolvimento brasileiro tem suas raízes na metade do século XIX, com a Lei de Terras. Por pressões inglesas, o trabalho foi tornando-se liberto, culminando na abolição da escravatura em 1888. "Num regime de terras livres, o trabalho tinha que ser cativo; num regime de trabalho livre (a partir da referida lei) a terra tinha que ser cativa" (MARTINS, 1986, p.32), cujo acesso só era possível através da compra. À massa de escravo e camponeses pobres foi negado o acesso à terra e ao trabalho, pois iniciaram-se as campanhas de atração de mão de obra estrangeira para suprir as demandas de trabalho nas atividades econômicas, principalmente nas grandes lavouras de café da região Sudeste. A partir dos registros paroquiais - os fraudulentos "registros do vigário" (SILVA, 2008, p.190) - foi reconhecido o direito de propriedade aos antigos concessionários de sesmarias, quando a prática da grilagem de terras se tornou "generalizada"19, com a falsificação de documentos comprobatórios da existência/antiguidade das propriedades. Nestes registros, eram reconhecidas as propriedades a partir das declarações verbais, dos próprios requerentes, da localização, delimitação e extensão das áreas pretendidas.

O processo de privatização das terras teve outro impulso a partir de 1891, após a Proclamação da República, quando foi transferida para os Estados a responsabilidade de legislar sobre as terras públicas. Com esta medida, em troca de favores, autoridades estatais concediam títulos de terras seja aos integrantes das oligarquias e/ou às autoridades das instâncias estaduais ou municipais do poder. Não se pode esquecer que as terras apropriadas, sejam pelas referidas formas de concessão seja pela grilagem, já estavam ocupadas por índios ou posseiros. Por isso, a história da propriedade da terra no Brasil é uma história de conflito e/ou genocídio, "uma história de lutas e de violência" (OLIVEIRA, 2001, p.190). E estes conflitos já são antigos e relativamente frequentes. Na história do Brasil, foram vários e seguidos os períodos em que imperou a farra da grilagem, a qual gerou intensos conflitos. Martins (1981) faz uma importante descrição desses conflitos:

A maior guerra popular da história contemporânea do Brasil foi a Guerra do Contestado, uma guerra camponesa no sul do país, nas regiões do Paraná e Santa Catarina, de 1912 a 1916. Abrangeu 20 mil rebeldes, envolveu metade dos efetivos do Exército brasileiro em 1914, mais uma tropa de mil 'vaqueanos', combatentes

\footnotetext{
${ }^{19}$ Entre aspas porque praticada por aqueles mais aquinhoados.
} 
irregulares. Deixou um saldo de pelo menos três mil mortos. Pouco antes, em 189697, a Guerra de Canudos, nos sertões da Bahia, que durou cerca de um ano, também envolvera metade do Exército e milhares de camponeses, tivera uns cinco mil mortos entre estes, impondo severas derrotas às forças militares..." “... a Revolta do Formoso, que por mais de uma década, nos anos cinqüenta e sessenta, implantou um território livre dominado por camponeses no centro do país, no Estado de Goiás, permanece assunto esquecido e sem importância (MARTINS, 1981, p.26,27).

Um período da história brasileira em que os movimentos sociais de luta pela terra ganharam importante abrangência foi iniciado na década de 1950 e se prolongou até os anos recentes, com características peculiares a cada momento. Essa fase tem, como importante característica, a politização dos movimentos sociais, em função da mediação de setores políticos e do clero, assunto que abordarei com maior detalhe em outro momento.

\subsection{A "ocupação" "moderna" no Oeste da Bahia}

A problemática principal deste estudo surgiu da intervenção arrasadora, que, nas palavras de Atair Sales Barbosa (s/d), constitui-se um genocídio praticado pela expansão do modo capitalista de produção, tornando a região alvejada pela fúria dos interesses do capital nacional e internacional e entregue a estes pelo Estado.

Esta intervenção na região foi impulsionada a partir do golpe de Estado de 1964, que inaugurou um modelo de desenvolvimento a ser implantado no país, que tem como importante marca o atendimento dos interesses do capital, conferindo-Ihe, contraditoriamente, outra frente de reprodução ampliada, que se baseou em grandes e escandalosos incentivos governamentais à apropriação privada, por grandes empresas de setores da economia que se intitulam modernos, de grandes extensões de terras nas áreas de fronteiras do país. O principal foco dessa investida foi a região amazônica, mas, logo em seguida, convênios estabelecidos entre o governo militar $\mathrm{e}$ as agências fomentadoras de desenvolvimento do Japão ${ }^{20}$, Japan International Cooperation Agency (JICA), conferiram ao capital a territorialização sobre a região, intervindo nas grandes áreas de terras devolutas, ocupadas pelas

\footnotetext{
20 Como desdobramentos desse convênio, foram criados os PRODECER (Programa de Desenvolvimento do Cerrado I, II, III e IV), (Programa (s) de Cooperação Nipo-Brasileiro para o Desenvolvimento dos Cerrados), idealizado em 1974. Os anos de 1974 a 1977 foram de entendimentos, acordos e amadurecimento do projeto, para então em 1978 dar início às atividades nos cerrados, local que até então era considerado impróprio para a agricultura. Na região Oeste do Estado da Bahia, as intervenções desses programas se fizeram presentes a partir da década de 1980.
} 
populações camponesas. Territorialização, esta, praticada por métodos extremamente violentos, e ilícitos, contraditoriamente, por agentes e setores do sistema que se autointitulam como modernos.

O referido convênio baseou-se no investimento de altas cifras e em transferência de tecnologias que deram impulsos às pesquisas realizadas em agências fomentadoras dessas atividades, tais como Empresa Brasileira de Pesquisa Agropecuária (EMBRAPA), Fundação Bahia, Empresa Baiana de Desenvolvimento Agrícola S.A. (EBDA) etc. Isso repercutiu no modelo de ocupação em expansão na região mais recentemente; a saber, da década de 1980 até os dias atuais, no que se conhece como agricultura moderna de grãos voltada para os mercados internos e para exportação (figura 6).

Esta modalidade de intervenção é dotada de outros sujeitos. Seus personificadores são agências internacionais fomentadoras de desenvolvimento, o próprio Estado, com todo o seu aparato de planejamento e repressor - seus bancos e agências fomentadoras -, as grandes empresas oriundas de outras regiões da Bahia ou de outros estados, e até mesmos sujeitos coadjuvantes, mas que compõem o entramado que resulta na feição arrasada visível a todos.

O Estado desempenhou um importante papel como agente viabilizador desse processo, fornecendo o apoio financeiro, implantando uma infra-estrutura física e institucional ou mesmo fazendo 'vista grossa' às apropriações ilegais de terras e outras violências contra os camponeses. Favorecida pela atuação do Estado, a iniciativa privada passa a exercer o seu 'pioneirismo', promovendo a 'ocupação do Oeste' que conduz à moderna agricultura que se expande na região, alavancando o processo de 'privatização do Oeste' ele toma ritmo e corpo próprios, colocando novas demandas ao Estado. A intervenção estatal na região também está associada aos interesses envolvidos na ocupação nos cerrados brasileiros, onde estão presentes empresas, cooperativas e o governo japonês, que participa técnica e financeiramente do PRODECER através da JICA (Japan International Cooperation Agency) (KRAICHETE e COMERFORD, 1991, p. 131). 


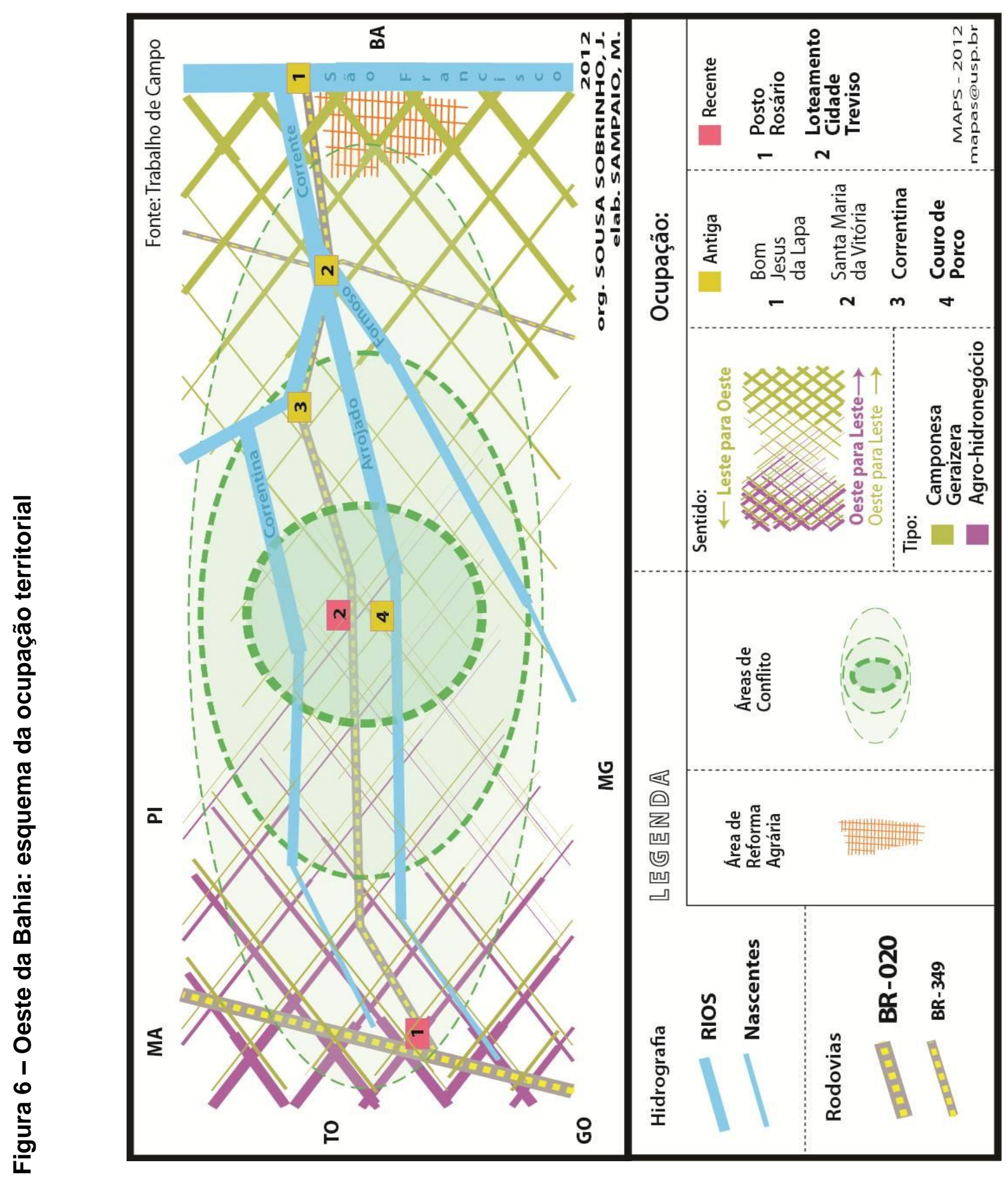


Esta intervenção é mais recente. A antiga foi capitaneada pelos predadores dos nativos (que resultou na ocupação de fato pelos camponeses) e expandiu-se de leste para oeste, causando, em um primeiro momento a desocupação, na medida em que expulsava ou exterminava as populações indígenas e deixava nos imensos latifúndios, geralmente, um casal de trabalhadores (vaqueiros) para os cuidados do rebanho a multiplicar-se no futuro. A segunda foi impulsionada a partir da década de 1970 e segue até os dias atuais. Esta última, em parte se assemelha à primeira, no que diz respeito à desocupação, na medida em que vêm "varrendo" do campo as populações camponesas, expulsando-as violentamente de suas terras. Esta se expande em direção contrária à da primeira - de oeste para leste -, aproveitando-se da abundância de água ofertada pela densa rede hidrográfica presente desde as proximidades da Serra Geral de Goiás. O contato conflituoso se faz, portanto, no encontro dessas diferentes racionalidades de uso e ocupação da terra. Tal como a primeira intervenção, esta se caracteriza pelo esvaziamento territorial, mas se diferencia pela sua alta mecanização e demais técnicas de manejo que lhes são características.

Esta investida vem se apropriando das terras até então tidas como impróprias para a agricultura situadas nos gerais. Estas terras são visadas por sujeitos mediadores diretos da reprodução do capital e, como tais, Ihes são acessíveis as técnicas recentemente desenvolvidas para manejos de solos, tais como os de cerrados, com fins de uso agrícola.

De posse das terras e de técnicas modernas de manejo, resta-lhe, como elemento fundamental para a atividade agrícola, a disponibilidade de água. Por meio desse quesito, se entende o porquê do ponto do qual parte esse modelo de ocupação - o sopé da Serra Geral de Goiás - onde os índices pluviométricos chegam a $1.800 \mathrm{mmHg}$ anuais e o relevo do terreno também se faz importante fator, por ser propício à mecanização. ${ }^{21}$

As "deficiências" dos solos, para as atividades pretendidas, são corrigidas por calcário e com o uso dos agroquímicos disponibilizados pelas "vedetes" do grande capital como Rhodia, Syngenta, Pfizer e outras. Tem-se assim, outra leva de ocupação e investidas sobre as terras do oeste baiano dirigida de oeste para leste. Abaixo, apresentamos lista de algumas das agroindústrias instaladas na região:

\footnotetext{
21 "A região possui disponibilidade de mais 1,5 milhões de hectares de terras planas e a pluviosidade chega a 1.800 mm" (SEAGRI, 2011).
} 
Bunge Alimentos S.A - Esmagadora e envasamento de óleo de soja, Galvani Fertilizantes - Fábrica de adubos, Bunge Fertilizantes - Misturadora de adubos, Cotton Placas - Descaroçadora de algodão, Cotton Max - Descaroçadora de algodão, S.I.A.L - Descaroçadora e fiação de algodão, Mauricéia - Fábrica de ração e integrado de frango, Esteves S.A - Comércio, armazenadora e exportadora de algodão e café, Casa Pronta - Fábrica de Pré-moldados. JP Pré Moldados - Fábrica de artefatos de cimento, TH Indústria e Com. Ltda - Descascagem e empacotamento de arroz, Da Silveira South América Ltda - Fabricação de equipamentos para bovinocultura, TEC Agro - Unidade de beneficiamento de sementes climatizadas, Grupo Taji - Extração de Óleo de Algodão, L Xavier Batista - Extração de Óleo de Algodão, Golmur Ind. Comercio Ltda - Descaroçadora de algodão, Esteve S.A - Comércio e beneficiamento de algodão (SEAGRI, 2001).

Soma-se a essas empresas um sem número de fazendas que se apropriam das riquezas naturais e transformam a terra em um meio de produção, ou seja, como meio para explorar trabalho alheio, quando a destina para a produção, ou, em casos muito comuns na região, como meio de extrair renda da terra da sociedade em geral.

\subsection{1 "Reflorestamento" e privatização da terra no Oeste da Bahia}

Já me referi à relação existente entre as características do quadro natural da região Oeste do Estado da Bahia e a ocupação e os usos camponeses da terra engendrados ao longo dos tempos. Essa ocupação, conforme já enfatizado, expandiu-se no sentido leste-oeste, aproveitando-se das terras de vertentes e fundos de vale (terras de cultura), para a agricultura, e das terras dos interflúvios (gerais) para os criatórios.

Entretanto, outra "ocupação" mais recente, iniciada a partir dos anos 1970, desenvolve-se em sentido oposto, de oeste para leste. Essa oposição entre os sentidos pode ser entendida a partir da história das técnicas, do desenvolvimento das forças produtivas, das relações sociais de produção e tem como protagonistas outros sujeitos sociais contemplados pelas políticas de planejamento territorial do Estado.

Vale lembrar que diferentes compartimentos naturais comportaram levas de ocupantes com distintas lógicas ao longo da história. Assim, a fração do Oeste da Bahia, situada na Depressão do São Francisco, diferentemente dos gerais, no mesmo período, foi submetida à privatização da terra, pelos supostos projetos agropecuários financiados pelo governo (por intermédio da SUDENE). Protagonizaram essa leva, fazendeiros originários, principalmente, do Estado de 
Pernambuco. Neste sentido, é digna de nota a luta travada pelo Sindicato dos Trabalhadores Rurais de Santa Maria da Vitória contra a onda privatizante das terras, que expropriou enormes contingentes de camponeses nas décadas de 1970 e 1980, culminando, inclusive, com o assassinato do advogado do Sindicato, Eugênio Lyra, em 1977. Nos gerais, entretanto, antecedeu à expansão atual da agricultura de grãos, uma investida massacrante das empresas "reflorestadoras" ou desflorestadoras, igualmente financiada escandalosamente pelo Estado, no regime autoritário, e, endossada e impulsionada pelo governo do Estado sob a justificativa de suprir a crise energética mundial ocorrida na primeira metade da década de 1970.

com a crise mundial de derivados do petróleo, vislumbrou-se a utilização da biomassa, particularmente a floresta plantada, como uma solução alternativa para o problema energético brasileiro mediante a produção de substitutivo dos óleos combustíveis derivado do petróleo (peletização da madeira), substitutivo da gasolina (álcool da madeira) e ainda com a produção do carvão vegetal (ABRE, 1980, p.3).

Neste sentido, a partir da Lei 5.106, de 2 de setembro de 1966, foram concedidos

incentivos fiscais a empreendimentos florestais, constituindo 0 abatimento ou desconto nas declarações de rendimentos das pessoas físicas ou jurídicas, das quantias aplicadas em projetos de florestamento e reflorestamento, observados os percentuais permitidos na lei (ABRE, 1980, p.4).

Nessa leva, como em outras concomitantes ou que a sucederam, foram destinatárias dos recursos públicos, concedidos pelo Estado, as empresas que se dispusessem a intervir na região, cujas características atrativas eram: grande oferta de água, terras públicas (as quais se tornaram alvo da privatização ilícita), topografia plana e abundância de mão de obra barata, que foi submetida à extrema exploração nos empreendimentos silvicultores.

O Sindicato dos Trabalhadores Rurais de Correntina forneceu a lista das empresas "reflorestadoras" e envolvidas nesse programa de apropriação das terras $^{22}$, e que dá uma noção da dimensão desses, entre tantos outros, projetos megalomaníacos do período autoritário:

AGROCAM agro Florestadora Comercial S/A, PERNAMBUCO Florestadora LTDA, VALE FLORA Florestadora Agropecuária, TECNOFLORA Florestadora LTDA; FLONOR Florestadora LTDA, D. COIMBRA Agrícola Florestadora LTDA, AGROMAN Empresa Agro Técnica LTDA, Reflorestadora BRASIL TROPICAL LTDA, ENGEAGRO Empresa Florestadora Agro-Técnica LTDA, PARCOM Comércio Part.

\footnotetext{
${ }^{22}$ Cabe a pergunta: essas terras estavam desocupadas?
} 
LTDA, Florestadora CAMPO LARGO LTDA, CIF Companhia Integrada de Florestamento LTDA, OPENFLORA Reflorestadora Agropecuária S/A, UBERFLORA Uberaba Florestadora LTDA, FLORYL Florestal Ipê S/A, BAMERINDUS Nordeste S/A, LAR Empresa Imobiliária LTDA, TECMAP Infraestrutura Agrícola, EMFIL Empresa Reflorestadora Imobiliária, REBA Reflorestadora da Bahia LTDA, PRESTEC Prestadora de Serviços Técnicos LTDA, FLORIANA Agro Reflorestadora LTDA, REFLORESTADORA Marquesa S/A, EMPROL Construções e Projetos, SOCIEDADE FLORESTADORA DO BRASIL Itda, TRIFLORA FLORESTADORA LTDA, BANDEIRANTE Reflorestadora LTDA, REBRACA Reflorestadora B. C. Indústria LTDA, SERRA VERDE Empresa Florestadora LTDA, SÃO MATEUS AgroFlorestadora LTDA, ICARAÍ Ass. Projetos Florestais LTDA, Agro Industrial LRG LTDA, SANTA MARIA Florestal LTDA, SANTA TEREZA Reflorestadora LTDA, ESTORIL Reflorestadora LTDA, CALDA E COSTA Agro Florestal LTDA, CBF Companhia Brasileira de Ferro, Reflorestadora RIO PONTAL LTDA, SM Agro Florestal LTDA, ENGECRON S/A, ENGEFLOR Engenharia Florestal LTDA, ENGEAGRO Empreendimentos, Planejamento e Ass. Técnica LTDA, EUCAFLORA Reflorestamento LTDA, CANADIAN Florestal S/C LTDA, CITRIODRA Agro Florestal do Brasil LTDA, Companhia de Expansão Agrícola BOICAJU, Companhia Agro Pastoril VALE DO MOXOTÓ, Companhia Agro Pastoril Implantação VALE FÉRTIL, CAMPO LIMPO Florestal LTDA, DINÂMICA Assessoria e Empreendimentos LTDA, DOMUS Incorporação e Construções LTDA, Agro Florestal Goiás LTDA, AGROFLOR Agro Florestal NOVA BAHIA LTDA, ABRAMEF Administração Brasileira de M. Empreendimentos florestais, BRASIL VERDE Reflorestamento e Agropecuária LTDA, BRAÚNA Florestal LTDA, BETIM Técnica Agrícola LTDA; BRASENF Brasileira de Empreendimentos Florestais, BONANÇA Agro Industrial S/A, AGROTEC Serviços Geológicos e Agrotécnicos, Agro Pecuária ZAMZAM LTDA, ASSESSO Assessoria Executiva LTDA, Agro Pecuária SANTO ANTONIO, MEIRELES Agro Pecuária LTDA, Agro Florestal CAMPINAS LTDA, AGROPEC Florestal S/C LTDA, ABRICAVA Construções e Mineração, PARTNER Assessoria e Empreendimentos LTDA, REFLOREST INVEST, RIO ARROJADO Florestal LTDA, FLOEMA Empreendimentos Florestais, RIO FORMOSO Florestal, TRIFLORA Triângulo Florestadora S/A, VALE FLORA Vale Formoso Agro Pastoril Florestal LTDA, Reflorestadora SERRA BRANCA LTDA, PRUMO Florestal e Agrícola LTDA, FLORESTAL BRASILEIRA de Reflorestamento, FLORESTAMINAS Florestamentos Minas Gerais (STRCORRENTINA, s/d.).

Esta lista indica o quanto foram atrativos para as empresas os programas estatais de "reflorestamentos", pois, só para o município de Correntina, conforme a lista, foram atraídas 79 empresas do ramo silvicultor, pecuário ou ligado a um desses ramos.

Coube investigar o quanto esses projetos se efetivaram. Observações em campo e informações de interlocutores nos deram importantes indicações. Repito o exemplo da fazenda Entre Rios, de propriedade do grupo Papaiz. Segundo um diretor do Sindicato dos Trabalhadores Rurais de Correntina, de uma área de 40 mil hectares que forma a fazenda, apenas $2 \%$ são cultivos de eucaliptos. $O$ restante permanece inexplorado e a pastagem natural é alugada para os criadores do entorno ao custo mensal de 5 reais por cabeça de gado. Outro caso emblemático é o da área apropriada pela empresa italiana Planta 7 Empreendimentos Rurais. De uma escritura adquirida referente a uma área avalida em $\operatorname{Cr} \$ 25,50$, cresceu (por 
meio de retificação) para 217.000 hectares. Lembro que estes feitos visavam a implementação do programa de reflorestamento na região, embora, nesse caso também, um interlocutor da comunidade de Couro de Porco, explicitou as finalidades da apropriação:

No meu entendimento, as terras que eles querem, é pra fazer isso. Tirar rio de dinheiro, tirar muito dinheiro, se movimentar com muito dinheiro, trazer o trabalho escravo (...) (...) e ela plantou no mínimo umas 2.500 hectares de mandioca, que a mandioca está sendo só, pode todo mundo ir lá e filmar, a mandioca está sendo, está acabano. Lá dento dos matos. Inclusive me falaram que até eles mesmo, lá estavam limpando ela lá através de veneno, de coisa. Então eu acho que isso é destruição. Eu acho que esse dinheiro aí eles estão levando ele pra outro canto. Eles estão usando isso aí como uma chantasma ali. É um foco pra eles puxarem recurso. A nível do exterior e a nível aqui do nosso Brasil, eles, esse dinheiro, uns falam pra nós aqui que esse dinheiro, que o empresário lá é italiano, né? Tem muito contato lá fora. Então esse dinheiro aí é uma lavagem de dinheiro pelo que está fazendo lá, e não tá aproveitando (Sr. Claudomiro Pereira de Jesus, morador da comunidade de Couro de Porco, trabalho de campo realizado em janeiro de 2010).

O relato desse interlocutor oferece importantes elementos que caracterizam a investida privatizante das terras sobre as áreas parcelares camponesas a partir da década de 1970, inaugurada com a onda dos projetos de "reflorestamento" ou desflorestamentos na região. Indica a finalidade especulativa da apropriação capitalista da terra; e, de fato, a valorização das terras na região tem sido, para muitos, a principal fonte de enriquecimento. Alguma atividade desenvolvida, tal como o referido plantio de mandioca, muito provavelmente sirva apenas para ser fotografada pelos técnicos dos bancos em suas visitas "fiscalizadoras" de destinos dos financiamentos concedidos.

$\mathrm{Na}$ área apropriada pela empresa Planta 7, o que se podia ver, da silvicultura pretendida com os projetos, são raras e esparsas árvores de eucaliptos e pinus dispersas nos cerrados já recompostos, indicando que, das áreas que foram desmatadas, parte foram cultivadas, porém, abandonadas tal como o plantio de mandioca referido.

Os dois exemplos citados ilustram bem o que era muito comum no município de Correntina, a contrastar de forma absurda com o que preconizava o programa de "reflorestamento" - a cobertura da quase totalidade da área do município com exceção daquelas destinadas à CODEVASF e ao Programa Nacional do Álcool (PROÁLCOOL). ${ }^{23}$ Este não tinha em conta sequer as propriedades juridicamente

\footnotetext{
23 "O Programa de Reflorestamento do Estado da Bahia e os Planos de Reflorestamento do Oeste Baiano, prevêem a ocupação de toda a área do município $\left(21.253 \mathrm{Km}^{2}-\right.$ pouco menos que a área
} 
regulares do município, e muito menos as posses e as moradias das comunidades camponesas, o que indicava pouca ou nenhuma seriedade em sua elaboração. $\mathrm{Na}$ verdade seu objetivo era transferir para o capital a renda da terra por meio da viabilização para as empresas "reflorestadoras" e agropecuárias do saque do patrimônio público, as terras públicas e devolutas, muito recorrentes na região.

Quanto à referência que o interlocutor faz à ocorrência do trabalho escravo, os flagrantes na região ainda hoje são muito frequentes, apesar de não serem muitas as blitze feitas, em função do desaparelhamento dos órgãos fiscalizadores na região.

E começaram limpar o algodão aqui de enxada. Cada fazenda tinha 300 homens, 400 homens, 500 homens, e eu tive o privilégio, que eu era quem coordenava, andava com o pessoal do Ministério do Trabalho, e pessoal do Governo Federal, a MOVE, que é o trabalho escravo é... que está atingindo. O que é o trabalho escravo? Aqui na região nós entendemos o trabalho escravo não é que o cara está amarrado, mas está num cerrado aí dormindo no chão, comendo de qualquer jeito, bebendo água de balde que é sujo de agrotóxico, dormindo em barraco de lona, isto muito, ainda hoje, hoje, nós temos trabalho escravo na nossa região. A minha colega, Jacinta, que você vai, se você chegar em Formosa, você vai perguntar para ela se tem trabalho escravo. E ela vai te dizer a mesma coisinha do que eu estou afirmando. De acordo a nossa pressão do movimento sindical, com toda a dificuldade que nós temos do governo federal, e do governo é sobre a fiscalização, aí porque aqui são os grandes e os grandes têm a bancada deles lá no congresso. Então, opa, lá é minha propriedade, você vai fiscalizar? Calma aí meu filho! Chega para o Ministro, chega para quem pode, e aí a fiscalização fica complicada para nós que somos sindicalistas, para os trabalhadores, cobra do sindicato e o sindicato não vai poder fazer muita coisa. E a MOVE mesmo está sumindo da região. A MOVE por que multou muita gente. Na verdade veio, mas agora está tendo uma freada por cima, que quando tem tudo falta a diária, que não... com diária, e assim complica as coisas (Sr. Walmir dos Santos, diretor do STR de Barreiras em janeiro de 2010).

$\mathrm{Na}$ área apropriada pela empresa Planta 7, onde se encontravam também as empresas D. Coimbra, Fazenda Arrojado, Reba e Florestaminas - empresas que cercam a comunidade Couro de Porco - em todas ocorreu o trabalho escravo, segundo relatório do Sindicato dos Trabalhadores Rurais de Correntina (STRCORRENTINA, s/d, p.1)

Os trabalhadores vitimados pelo trabalho escravo nesses empreendimentos silvicultores eram arregimentados em localidades distantes, em grande maioria em outros estados.

$80 \%$ dos que trabalham nas empresas reflorestadoras em Correntina, vem de fora. Originam-se dos Estados de Minas Gerais (maior percentual), Goiás, Ceará, Paraíba,

total do país El Salvador), com exceção da sede do município e das áreas destinada a projetos do PROÁLCOOL e CODEVASF. A área requerida ao IBDF, em 1981, foi de 308.578,76 hectares" (STRCORRENTINA, s/d, p.1). 
Pernambuco, etc. dos $20 \%$ restantes, 15 vem de outros municípios baianos e os outros $5 \%$ são de Correntina. É o que revela o levantamento feito por nós. Esses trabalhadores são trazidos dos seus Estados de origem pelos "gatos" (empreiteiros) que lhes prometem boa comida, boa empreita, carteira assinada, salário acima do mínimo, pontualidade no pagamento, crédito nas "vendas", bom transporte e outras mentiras, transportando-os em seus 'caminhões negreiros' como bem trata o presidente do sindicato, Wilson Martins Furtado, que circulam livremente pelas estradas do país, como se não houvesse polícia rodoviária (STR-CORRENTINA, s/d, p.7).

Somava-se a essas irregularidades a grande ocorrência de trabalho infantil, torturas, assassinatos e outros tipos de violências:

As maiores vítimas dos reflorestamentos no município, são os menores e crianças, que trabalhando nos viveiros, intoxicam-se na mistura de venenos com adubos e no combate às formigas, ficando desde cedo incapacitados para o trabalho. Os alojamentos em sua maioria $(90 \%)$ são de palha, povoados por barbeiros (a SUCAM recentemente encontrou 6000 deles) e outros insetos. Não existem camas'. Os bóiasfrias dormem em esteiras, ou simplesmente no chão. Há alojamentos que comportam de 30 a 40 pessoas. Os salários atrasam em até 10 meses. E na maioria das vezes quando acontece, recebem apenas parte deles. A esmagadora maioria dos bóiasfrias trabalha sem registro. Nos barracões das firmas, são roubados, pois o que compram não sabem o preço, já recebendo o desconto no salário. São transportados nos caminhões sem lona e sem bancada, em meio a bolas de arames farpado, peças e outros materiais, sendo comuns os acidentes e quedas. A comida é a pior possível. O prato mais comum é: feijão e arroz, às vezes cozidos em latas de gás, com água, óleo e sal, mexidos com qualquer pedaço de pau. Não existe talheres. Os trabalhadores comem com os dedos. Os menores representam $50 \%$ da mão-de-obra utilizada pelo reflorestamento no município. Os outros $50 \%$ dividem-se entre homens e mulheres (STR-CORRENTINA, s/d, p.8).

O STR-Correntina relata ainda outros casos de violência contra trabalhadores

nas fazendas entre os anos de 1981 e 1982, conforme lista abaixo:

\footnotetext{
- Pedreiro pernambucano é morto na beira de asfalto num trecho de estrada na disputa de um grupo por terra.

- Um cadáver é encontrado queimado na campina.

- Encontrou-se um corpo perfurado à bala, na estrada para o Goiás, acima da localidade de Piquizeiros - proximidades da REBA reflorestadora.

- Um pistoleiro profissional que trabalhava para diversas firmas, de nome Cissão é morto em Veredãozinho de Arrojado. Estava a serviço de grilagem.

- Trabalhador de nome Valter foi morto no "Pratudinho", deixando 5 filhas. Seu corpo foi mutilado. Disputa de dois grupos poderosos de Goiás e Bahia.

- Trabalhador assassinado na estrada para Posse.

- Trabalhador da FLORYL assassinado a facadas.

- Assalariado da FLORESTAMINAS sai para o banho e desaparece.

- Trabalhador da FLORESTAMINAS é amarrado e espancado. Depois desaparece.

- Morto um trabalhador na PRESTEC.

- Em setembro dois trabalhadores do reflorestamento morreram queimados. Um era de menor (STR-CORRENTINA, s/d.).
}

Embora a lista de atos violentos acima não estabeleça, em alguns casos, uma correspondência direta entre eles e a relação de produção inaugurada com a expansão das reflorestadoras no município, fica clara, mesmo nos casos não 
diretamente relacionados, a ligação com o contexto conflituoso típico das frentes de expansão do capital no país.

\title{
1.5.2 A investida da agricultura capitalista nos cerrados do oeste baiano
}

A discussão sobre as mudanças que se processam na região Oeste da Bahia nas últimas décadas, necessariamente, passa pela questão da terra e da água. 0 capital, na sua constante necessidade de desenvolver-se, carece da disponibilidade de terras apropriadas para tanto ou pelo menos que lhe garanta a remuneração compatível com os objetivos pré-determinados em projetos elaborados invariavelmente nos gabinetes empresariais e/ou estatais.

Muito se fala da relação existente entre a investida desenvolvimentista nos cerrados brasileiros a partir da década de 1970, quer seja por meio dos programas de "reflorestamentos" ou da expansão da agricultura tecnificada de grãos - voltados, em maioria, para o abastecimento do mercado externo - com alterações na política agrícola norte-americana e que, por sua vez, refletiu na necessidade do governo japonês investir no aumento da produção de alimentos em países que tivessem terras potencialmente agricultáveis, como é o caso do Brasil. ${ }^{24}$

\begin{abstract}
Serão sobretudo os personagens extra-locais que aparecerão como os portadores das transformações na região: gaúchos e japoneses em Barreiras, fazendeiros pernambucanos e de outras regiões em Santa Maria da Vitória, órgãos do governo e empresas privadas nos projetos de irrigação. Num primeiro momento, a grilagem, a expropriação camponesa, a especulação de terras, as empresas de reflorestamento, a abertura de estradas e a pecuária tangendo a pequena produção aparecem como a face visível desse processo. Num segundo momento a paisagem regional, novamente se remodela, com a expansão da moderna agricultura de grãos nos cerrados, aprofundando o processo de diferenciação social já em curso (COMERFORD e KRAICHETE, 1991, p. 58).
\end{abstract}

A partir da necessidade japonesa, sua agência fomentadora do desenvolvimento, JICA, dispôs recursos para financiar programas de desenvolvimento dos cerrados, tais como os Programa de Desenvolvimento do

\footnotetext{
24 "Em 1974, o então Presidente Geisel promovia o desenvolvimento agrícola dos cerrados. Em meio a essas circunstâncias, o Japão, que havia sofrido um grande impacto com o embargo à exportação da soja imposto pelos Estados Unidos em 1973, voltou seu interesse para o desenvolvimento agrícola dos cerrados e, em 1974, por ocasião da visita do então Primeiro-Ministro Kakuei Tanaka ao Brasil, foi acordada, com o Presidente Geisel, uma cooperação para o desenvolvimento agrícola dos cerrados" (JICA, 2009, p.4).
} 
Cerrado (PRODECER) I, II, III e IV, constituídos de financiamento à pesquisa agrícola endereçados, principalmente, à EMBRAPA e às empresas ou aos agricultores que se dispusessem a investir na região.

O fato é que, de todo modo, essa investida do capital na região está relacionada ao estágio de desenvolvimento das forças produtivas, no que se conhece como revolução verde e incentivos estatais, e à disponibilidade de terras amplas com grande oferta de água, sol e mão de obra barata, como na região Oeste da Bahia e no Nordeste do Brasil. Estas se destacaram como atrativas para atender à demanda do capital interno e externo para a sua reprodução ampliada. E o Estado, nesse processo, cumpriu seu papel de tutor na viabilização do interesse capitalista.

Não custa lembrar também do quanto atende às demandas do capital financeiro. O dinheiro para custear empreendimentos, como os implementados na região Oeste da Bahia, se origina do mercado financeiro, o qual media também a aquisição de implementos como maquinários, insumos, venenos e demais meios que constituem as técnicas de produção próprias do modelo de agricultura praticado, do agronegócio.

Assim como na década de 1970, quando o interesse japonês se voltou para o Brasil, na atualidade, chineses, norte-americanos, portugueses, italianos, ingleses, canadense e alemães, dentre outros, investem na região Oeste da Bahia, alegando favorecer ao Brasil pela transferência de tecnologias e pregando tratar-se de cooperação. Vê-se que essas tecnologias são escoadas na forma de produto e equipamentos modernos (mercadorias do grande capital - na forma de custos de produção - no processo produtivo) e, enquanto isso, vem relegando ao Brasil seu histórico papel de produtor/exportador de matérias-primas e importador de produtos com alto valor agregado. Justificam ainda, esses investimentos/agressões à geração de empregos - assim a renda da terra vem sendo apropriada diretamente pelo grande capital internacional, por meio dos grupos empresariais, ditos cooperadores, assim como por integrantes das oligarquias locais, pois seu maior investimento se dá na apropriação das terras públicas, adquiridas dos testas-de-ferro ${ }^{25}$ ou griladas por elas próprias.

\footnotetext{
${ }^{25}$ Assim chamado localmente aquele que faz o "trabalho" da grilagem das terras com o objetivo de repassá-las logo em seguida para interessados, de modo geral, oriundo de outros Estados/regiões ou países.
} 
Os grandes proprietários locais, mesmo os que não se modernizaram, foram favorecidos pela política fundiária e pela decorrente valorização de seus imóveis. Face à sua rentabilidade, a expansão da pecuária extensiva é simultânea à da agricultura moderna, apresentando-se como uma forma de ocupação de vastas extensões de terra que também desempenham o papel de reserva de valor. Desta forma, o estabelecimento de fazendas pecuárias constitui-se num atrativo tanto para as empresas modernas como para os tradicionais senhores de terra, em busca de seu espaço no novo cenário regional (KRAICHETE e COMERFORD, 1991, p. 58).

Das abordagens realizadas por diferentes autores sobre a região, os dizeres citados parecem conter a maior assertiva, pois até mesmo naqueles empreendimentos que absorvem em suas atividades tecnologias modernas, na tão propalada produção de grãos (soja, milho, etc.), é sabido, por afirmações dos próprios produtores, que, no balanço de seus anos de atividade, a maior fonte de enriquecimento se dá pela valorização das terras.

Portanto, como fator favorável a essa investida, destaca-se a grande disponibilidade de terras devolutas na região. Estas estão, passando por um processo generalizado de saque na investida privatizante, por meio da grilagem que sequer respeita as áreas das antigas fazendas regularizadas e muito menos aquelas secularmente apropriadas por um grande contingente de posseiros, que por meio do trabalho familiar, retiram o sustento de suas famílias.

No método de apropriação muito comum na região (a grilagem), usam do recurso legal da retificação de área. Porém, sob conivência do judiciário local, esta retificação é aprovada sem que os pretendentes das terras cumpram a exigência legal de oferecer ao judiciário o laudo demonstrando que a área pretendida se encontra livre de qualquer posse ou outras formas de apropriações.

A mensuração primeira da terra a ser grilada, geralmente se faz através de sobrevoos sobre imensas áreas constituídas de dezenas de milhares de hectares. A segunda etapa dessa ação se faz a partir da equipe de gabinete constituída de advogados, políticos influentes na localidade, contribuição das indústrias de escrituras falsas, assim chamados nas localidades os cartórios, e do judiciário local, o qual, quando pouco faz, "fecha os olhos" para tais desmandos. Concomitante a essa etapa, também se fazem operações em campo, por meio das equipes de "segurança", na verdade bandos de jagunços, que cometem todo tipo de violência contra os antigos ocupantes das terras, nas suas ações de "limpeza" das áreas pretendidas pelas empresas ditas modernas. E, não é raro, ou quase sempre, contam com os serviços da polícia nessas operações. 
Já aconteceu inclusive, aqui em Santa Maria da Vitória e Coribe, o comando da polícia ir pegar os coitados dos posseiros que trabalhavam para produzir, para manter o pão. Depois juntava os grileiros e os comandos para pegar, trazer peado, amarrar, prender pra não trabalhar, pra deixar pra eles produzir capim (CEAS, 1985 p.29).

Nóis têm muito rio $\operatorname{seco}^{26}$.

Após tratar do quesito terras públicas e livres como atrativas para a investida do capital, e das respectivas atrocidades no processo de privatização dessas terras, quero tratar do segundo quesito que se faz atrativo para a investida desenvolvimentista, contemplando os interesses do capital na região: a água. Tem razão a CPT na proposição da luta pela Terra e pela Água como centro das suas ações em apoio à permanência da população camponesa no campo e de posse dos seus meios de vida.

O Oeste da Bahia é uma região constituída das formações geológicas, os aquíferos Urucuia e Bambuí, e irrigada por três importantes sub-bacias do rio São Francisco, as dos rios Carinhanha, Corrente e Grande. Estas, nas suas porções altas, se constituem de uma rede hidrográfica de alta densidade, de um conjunto de milhares de nascentes localizadas nas proximidades da Serra Geral de Goiás. Dos encontros desses inúmeros pequenos corpos d'água, se formam rios como o Itaguari, da Bacia do rio Carinhanha; rios Formoso, Pratudinho, Pratudão, Arrojado, das Éguas, do Meio e Guará, da Bacia do rio Corrente; rio dos Porcos, Galheiro, Roda Velha, Fêmeas, Ondas, das Pedras, de Janeiro e Branco, da Bacia do rio Grande; e, ainda dessa mesma bacia, o importante rio Preto, formado do encontro dos rios do Ouro e Sapão no extremo noroeste do estado da Bahia, na porção conhecida como Mapitoba, constituída das divisas com os Estados do Maranhão, Piauí e Tocantins.

É justamente esta imensa riqueza hídrica, acompanhada do fator terra pública, que atrai o grande capital para o seu desenvolvimento na região, a partir das práticas predatórias do agronegócio. E essa investida começa justamente nas áreas onde se concentram a maior quantidade das nascentes dos córregos formadores dos rios que deságuam no principal da bacia: no São Francisco. A ocupação agrícola ignora a existência das nascentes, das veredas, arrasando-as com suas correntes e esteiras do maquinário pesado e, tão imponente quanto a

\footnotetext{
${ }^{26}$ Sr. Walmir dos Santos, diretor do STR-Barreiras. Trabalho de campo realizado em janeiro de 2010.
} 
violência da fúria que a tudo arrasa, transforma imensas áreas numa monótona e enfadonha paisagem monocultora.

Nos rios que ainda resistem a essas intervenções arrasadoras, são comuns os desvios dos seus leitos para a finalidade pretendida por quem pode tudo ${ }^{27}$ e também os barramentos que, em casos não raros, interrompem a totalidade do volume de água corrente do rio. Tal como diz um interlocutor:

\begin{abstract}
dá mais de $40 \mathrm{~km}$ de extensão de área (a propriedade dos americanos na região nos municípios de São Desidério e Correntina), né? Passa por 4 rios, já existem 6 barragens deles acumulando as águas, não tem fiscalização, não tem nada, a maior algodoeira da América Latina, está sendo, né? Para ser inaugurada agora no dia primeiro (Sr. Walmir dos Santos, diretor do STR-Barreiras, trabalho de campo realizado em jan/2010).
\end{abstract}

A preocupação é com as águas ${ }^{28}$.

Nos rios, instalam quantas bombas potentes necessárias para abastecer as dezenas de pivôs centrais pertencentes a uma única fazenda. Cito o exemplo do rio Branco, sugado em sua totalidade pelas bombas da Fazenda Agronol, proprietária de 38 pivôs centrais. É desnecessário dizer o que aconteceu com o "rosário" de comunidades ribeirinhas centenárias que dependiam da água de rios como esse para a tradicional irrigação de suas lavouras alimentícias.

Atualmente, aqueles que resistiram às investidas da grilagem, agora são dessedentados pela água transportada pelos caminhões-pipas ofertada pelo Estado em sua atitude de compaixão para com o sofrimento daquele povo teimoso. Sem água em suas minúsculas glebas, que heroicamente defenderam dos grileiros, não mais conseguem produzir e, outra alternativa não lhes restam, senão se assalariarem nos empreendimentos capitalistas instalados nas terras que thes pertenciam. Confirma-se, dessa forma, o que escreveu Martins: "não se trata, portanto, de encarar expropriação e exploração como dois momentos que se sucedem. No caso da nossa sociedade, são processos que estão ocorrendo simultaneamente, articulados pelo mesmo agente, que é o capital" (1991, p.17).

Com o uso de bombas potentes, sugam a água do rio quando as características topográficas possibilitam as construções para os barramentos (foto 1). Quando não é possível, ou os empreendimentos se localizam distantes, no

${ }^{27}$ A este respeito cito um criminoso desvio do rio Arrojado para um canal de $9 \mathrm{~km}$ de comprimento e $10 \mathrm{~m}$ de largura realizado por fazendeiros para a irrigação em duas fazendas.

${ }^{28} \mathrm{Sr}$. Walmir dos Santos, diretor do STR-Barreiras, trabalho de campo realizado em janeiro de 2010. 
interflúvio, perfuram poços artesianos de 200, 300 metros de profundidade para abastecer os pivôs centrais (foto 2).

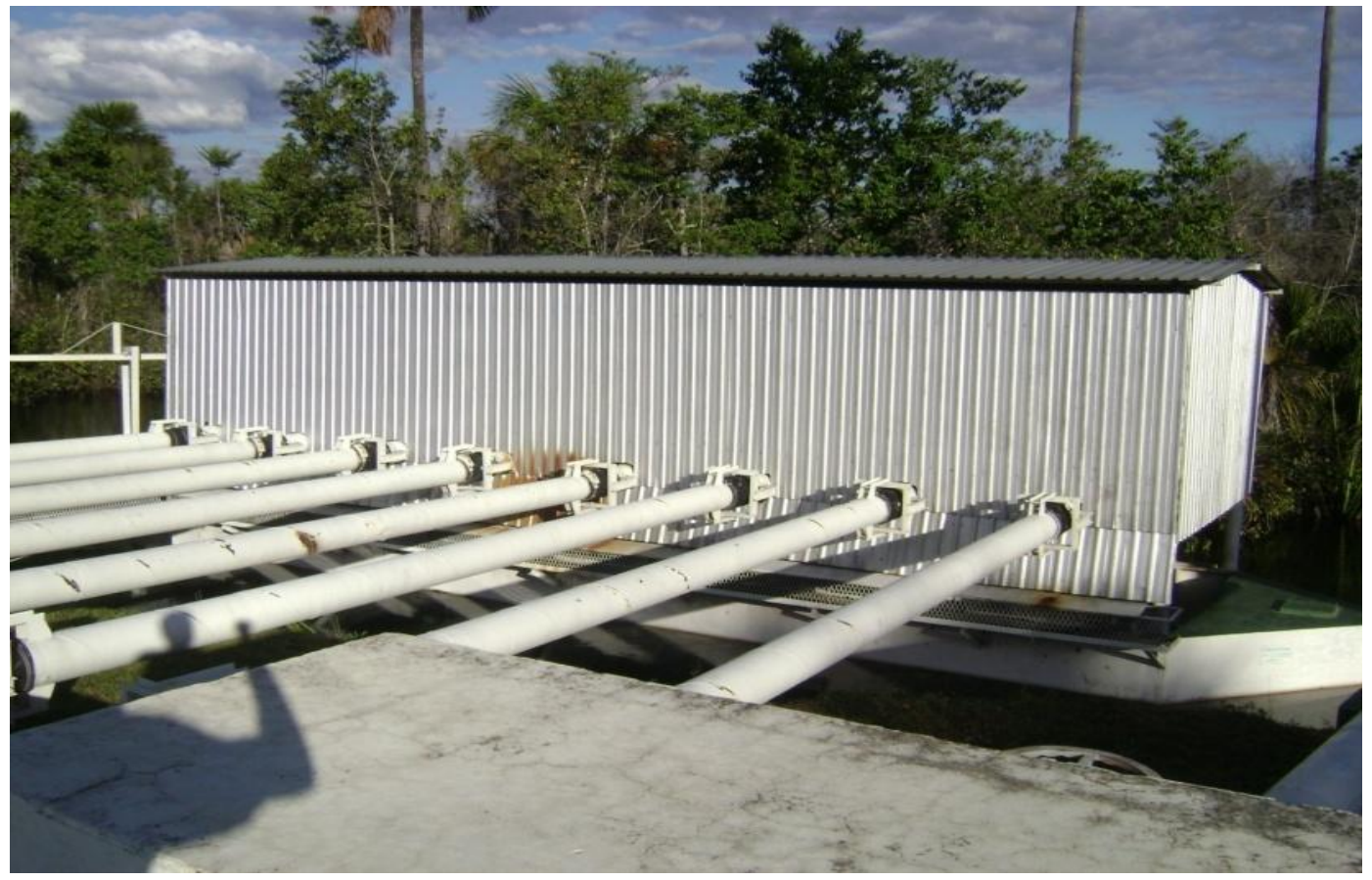

Foto 1 - Bombeamento de água no rio Grande para a Fazenda Busato. Luis Eduardo Magalhães - BA. Iremar B. Araújo, julho de 2009.

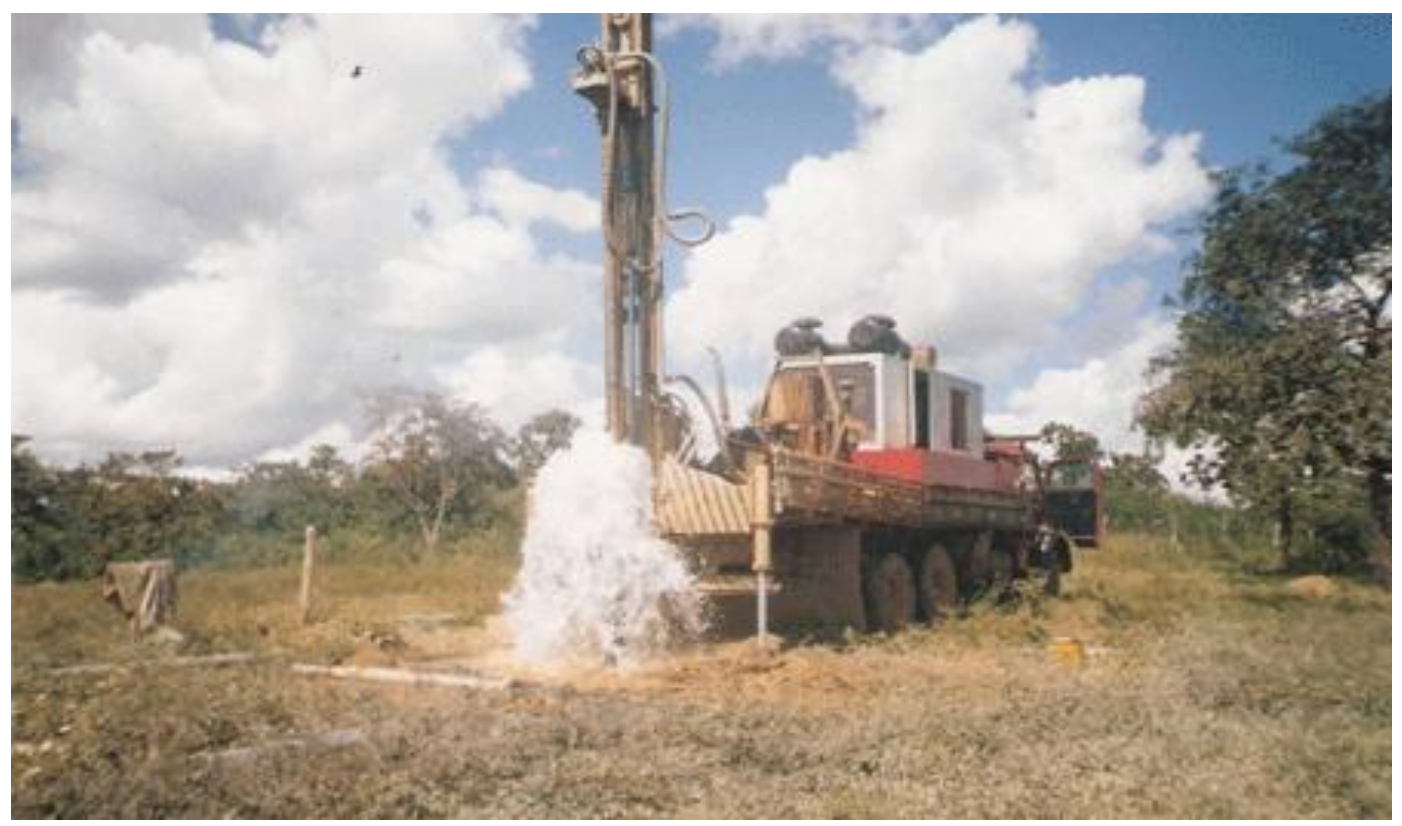

Foto 2 - Perfuração de poços artesianos. In: Jornal Nova Fronteira, Barreiras, 02/09/2009. 
Na região na qual a Cooperativa Agrícola do Cerrado Central (COACERAL) intervém, já se percebe o rebaixamento do terreno e pesquisadores estão interessados em saber as causas, mas antecipadamente suspeitam de serem provocadas pelo uso demasiado do lençol d'água subterrâneo na região. ${ }^{29}$

Na região Oeste da Bahia existem aproximadamente 850 pivôs centrais que utilizam
água para irrigação de lavouras, destes, em torno de 45 usam água de poços
artesianos, com uma vazão média por pivô de $220 \mathrm{~m}^{3} /$ hora. Além disso, em quase a
totalidade das fazendas do cerrado existem poços artesianos que retiram água do
aquífero Urucuia para abastecimento humano e dessedentação animal. ${ }^{30}$

Os órgãos do governo e a grande imprensa alardeiam demasiadamente os números dos recordes anuais do agronegócio. Porém, não levam em conta o fato desses grãos destinados aos grandes mercados conterem água e que, portanto, exporta-se na forma de grãos as nossas riquezas hídricas e consequentemente florística e faunística - a biodiversidade -, um bem que a cada dia se torna mais valioso, porém, não computado nos preços do que se exporta. Acrescenta-se a isso, a carga de agrotóxicos empregada nesses processos produtivos, que é jogada nos solos e vai parar nos rios e aquíferos, contaminando-os. O resultado disto tem sido a grande mortandade de peixes nos rios da região, transformando-os em corpos d'água estéreis. Resulta disso os reclames das populações ribeirinhas sobre a escassez do pescado tão abundante noutros tempos, e que somado à fauna em abundância, garantiam a comodidade de sobreviverem do que extraíam das riquezas que os cerrados Ihes ofereciam.

$\mathrm{Na}$ fúria da racionalidade econômica gestada pelos governos, por meio dos incentivos ao agronegócio e com o objetivo de equilibrar a balança comercial, reproduz-se a exportação de matérias-primas (atualmente grãos), dando continuidade à tradição primário-exportadora brasileira. Em troca, importa-se tecnologias "avançadas", contidas nos maquinários pesados que desmatam as florestas, compactam os solos, sugam as águas dos rios, e nos venenos que, de forma descontrolada, são jogados nos solos e nas águas.

Os jornais locais e até mesmo dos grandes centros urbanos do país noticiam a propaganda que os grandes agricultores do Oeste da Bahia fazem da posição de campeão nacional no ranking da coleta de embalagens de agrotóxicos.

\footnotetext{
${ }^{29}$ Assunto debatido no SIREGEO-Simpósio Regional de Geografia do Cerrado, Barreiras, 2010.

${ }^{30}$ Jornal Nova Fronteira, Barreiras, 02.09.2009. (da redação / Fotos: divulgação).
} 
Estado está entre os que mais destinaram no primeiro quadrimestre, com o processamento de 511 toneladas de recipientes vazios. (...) Foram retiradas do campo 511 toneladas de embalagens vazias de defensivos agrícolas no Estado da Bahia no primeiro quadrimestre de 2007 , volume $32,7 \%$ maior que o mesmo período do ano passado, quando foram devolvidas 385 toneladas. Este crescimento expressivo reflete o alto grau de comprometimento com o meio ambiente de todos os envolvidos no programa de destinação final de embalagens vazias no Estado: agricultores, canais de distribuição, a indústria fabricante de defensivos agrícolas e o poder público, representados pelo CRA/BA (Conselho Regional de Administração da Bahia), Agência Estadual de Defesa Agropecuária da Bahia (ADAB) e CODEVASF. ${ }^{31}$

Se, por um lado, merece consideração a iniciativa de recolhimento das embalagens, por outro, entende-se que não há o que comemorar, pois estão recolhendo parte das embalagens. E o conteúdo, de volume muitas vezes maior, de acordo com a lógica do modelo agrícola, continuará sendo despejado de forma indiscriminada na natureza. Merece considerar também o fato de ser noticiado o quanto se recolhe, mas não há informação do quanto não é recolhido e se é seguido algum critério nesses usos. O mesmo jornal, inclusive, noticia que parte importante desses produtos é contrabandeada e de uso ilegal. Ou seja, estão fora dos padrões exigidos pela legislação brasileira.

Durante a "Operação Arrastão" (operação dos fiscais estaduais da Agência de Defesa
Agropecuária da Bahia (Adab), órgão vinculado à Secretaria de Agricultura (Seagri))
foram gerados 21 notificações, 12 auto de interdição, de aproximadamente, duas
toneladas de agrotóxicos, sendo comercializado e/ou armazenado em desacordo com
as leis, como: comercialização de produtos com validade vencida, produtos sem
registro no MAPA (Ministério da Agricultura, Pecuária e Abastecimento) ou OEDSV
(Órgão Estadual de Defesa Sanitária Vegetal), produto sem lote ou data de
vencimento dentre outros. (...) As infrações constatadas foram: comercialização de
agrotóxicos e afins sem receituário agronômico e lavrado 12 autos de infração em
função de comercialização de agrotóxicos com validade vencida, receita agronômica
assinada em branco, ausência de cadastro junto ao OEDSV, controle de estoque em
desacordo e armazenamento inadequado. As multas aplicadas somaram
aproximadamente $\mathrm{R} \$ 200.000,00$ (duzentos mil reais).

De todo modo, os resultados dos desmandos praticados pelos agentes do atual modelo agrícola estão à vista: alto índice de intoxicação de trabalhadores, desmatamentos indiscriminados, consequentemente, morte da fauna, também pelos envenenamentos, morte dos rios e piora na qualidade dos alimentos produzidos, que certamente causam imensuráveis prejuízos à saúde dos consumidores.

\footnotetext{
${ }^{31}$ Jornal Nova Fronteira, Barreiras, 22.05.2007.

${ }^{32}$ Jornal Nova Fronteira, Barreiras, 03.09.2009.
} 


\subsubsection{O agronegócio e seu custo socioambiental}

No noticiário veiculado pela grande imprensa, quando se tratam das mudanças recentes na agricultura brasileira, frequentemente se faz uma positivação unilateral deste fenômeno. São revelados os números do sucesso nas exportações agrícolas, seus impactos positivos na balança comercial, sua importância para geração de emprego e sua relevância para o fortalecimento da economia brasileira.

Essas avaliações e propagandas do modelo de desenvolvimento brasileiro no tocante à agricultura, fundamentada no agronegócio, chegam ao povo, de modo demasiadamente parcial por intermédio dos meios de comunicação tão monopolizados quanto os benefícios que proporcionam a expansão desse modelo.

Cabe aqui tecer algumas considerações sobre essa problemática a partir de uma visão crítica valorizando os conteúdos dos processos constituintes, muitos deles ocultados nas referidas abordagens sobre o assunto.

Em outras partes desse trabalho tratei dos problemas ambientais e da investida privatista das terras, procurando apontar as contradições que estão no bojo de cada uma dessas frentes de intervenção da expansão do agronegócio na região.

Nesta oportunidade, me atenho aos custos do agronegócio, os quais me levam a questionar até mesmo a viabilidade econômica tão alardeada pelos defensores desse modelo de uso e ocupação da terra no Brasil. E um bom alicerce para os questionamentos é o sistema agrícola. Sabe-se das propriedades edafológicas dos solos dos cerrados, os quais são concebidos pelas populações de ocupação antiga da região como impróprios para a agricultura e que até mesmo os contrapõem às terras de cultura das áreas encobertas por matas. Os solos encobertos pela vegetação dos cerrados destinam-se aos criatórios extensivos, sistema de uso que tem sido favorável à preservação das condições naturais e que propicia a presente abundância de água na região.

A conversão desses solos à atividade agrícola implicou em um elevado custo socioeconômico e ambiental, pois, patrimônios da nação, como as riquezas hídricos, a biodiversidade e, até mesmo, as possibilidades de se viver em melhores condições de vida, têm sido comprometidas em função desse modelo de ocupação do país. 
Quanto aos custos econômicos, após o golpe militar de 1964 os governos brasileiros têm disponibilizado escandalosos incentivos financeiros às empresas que se dispõem aderir aos empreendimentos propostos nos programas governamentais, visando assim, no tocante à agricultura, o acesso às tecnologias recémdesenvolvidas e constituintes da chamada revolução verde.

O modelo de agricultura agroexportador em grande escala e as técnicas de cultivos que o caracteriza na atualidade representam uma intensa ruptura com a dinâmica natural dos ecossistemas onde se implanta. Exporta-se água na forma de grãos e recebe-se em troca, na forma de tecnologias avançadas: maquinário pesado que desmata e compacta os solos e alta carga de agrotóxico que envenenam os aquíferos, os solos e os rios.

A aplicação desse aparato tecnológico onera demasiadamente a sociedade, só satisfaz à ânsia do capital por condições que garantam a sua reprodução; coadunando-se, portanto, com o que afirmou um interlocutor da cidade de Correntina, referindo-se ao que caracteriza o modelo de desenvolvimento que se expande sobre o Oeste da Bahia. Segundo ele, o que dá sustentação ao modelo de desenvolvimento em implantação é a cerca de carabina, o calote, os subsídios e incentivos escandalosos, as anistias ambientais e aos grileiros, a rapinagem do grande capital às terras públicas ${ }^{33}$.

Não é raro constatar nos portões ou nas cancelas de propriedades empresariais agrícolas ditas modernas, que se encontram nessa região, a restrição ao acesso comunicada em uma placa avisando o "perigo de vida", pois se trata de uma área de "propriedade particular."

Do início da investida privatista da terra, datado da década de 1970, até recentemente, o Estado da Bahia não sinalizou interesse pela averiguação das condições das suas terras. Só recentemente, possivelmente em resposta às pressões dos movimentos sociais (com destaque para as associações de agricultores/criadores camponeses), o poder público vem demonstrando, embora de forma extremamente incipiente, algum interesse em saber da situação das terras públicas. Tem-se como exemplo as ações discriminatórias administrativas que, respondendo às pressões das associações comunitárias, vêm ocorrendo na região.

\footnotetext{
${ }^{33}$ Iremar Barbosa de Araújo, ativista do Movimento dos Atingidos por Barragens e da Rede Municipal de Ensino do Município de Correntina, entrevista em janeiro de 2010.
} 
A grande maioria das propriedades onde se pratica atualmente 0 agronegócio, assim como imensas áreas de terras desocupadas e sem qualquer uso, porém cercadas, foram adquiridas sob a mediação dos testas-de-ferro ou até mesmo diretamente pelas atuais empresas ou pelos supostos proprietários.

Mediante a situação fraudulenta dos processos de apropriação, as medidas recentemente tomadas pelo Estado têm provocado um generalizado desespero por significativa parte dos agentes do agronegócio, produtores de grãos, conforme indica a matéria no Jornal Nova Fronteira sobre a situação de supostos proprietários da COACERAL, município de Formosa do Rio Preto.

A ameaça de perder as suas propriedades teve início em dezembro de 2007, através uma portaria expedida pela corregedoria-geral de Justiça da Bahia, que determinou o cancelamento do registro de aproximadamente 200 propriedades, que totalizam uma área de 300 mil hectares, no cartório de Santa Rita de Cássia. Uma nova portaria revogou no início de março a decisão, devolvendo a titularidade das terras aos produtores.

Um proprietário, que preferiu não se identificar, diz que os produtores continuam a se preocupar, porque os requerentes das terras trabalham nos bastidores do judiciário. Os produtores podem entrar com uma ação de uso capião. "Percorremos toda a área e verificamos que eles realmente produzem. Eles também mostraram as fotos tiradas há 20 anos, e claro que a justiça precisa se manifestar pela legitimidade destes proprietários", posiciona-se. (Procurador da Coordenadoria do Desenvolvimento Agrário do Estado da Bahia, Estácio Dourado). Outra forma, segundo o procurador, é tentar desqualificar os títulos de registro, e mostrar que a documentação daqueles que requerem na justiça as terras, é falsa. Os proprietários resistem às duas alternativas. Eles gostariam de um trâmite mais rápido, para que não atrapalhasse o planejamento da próxima safra agrícola ${ }^{34}$.

Curiosamente, o próprio procurador do órgão baiano Coordenação de Desenvolvimento Agrário (CDA) encarregado da regularização e do zelo pelas terras públicas se manifesta indicando caminhos jurídicos para aqueles, em situações de litígios, iniciados por órgão do próprio Estado, a Corregedoria Geral da Justiça da Bahia.

Em uma grita geral, esses pretensos proprietários reclamam da situação em que se encontram, pois a continuidade da batalha judicial, segundo os "produtores", "atrapalharia a aquisição de créditos, a renegociação das dívidas, e a inclusão em programas dos governos destinados para a próxima safra”. É possível que sejam justamente estas as finalidades das suas investidas na apropriação das terras na região e o que mais incomoda, ao contrário do que afirmam, é a queda dos preços das suas terras, provocada pela situação litigiosa, pois os pequenos e médios

\footnotetext{
${ }^{34}$ Jornal Nova Fronteira, Barreiras, 09.05.2008. (por: Hebert Regis).
} 
produtores da região apontam como fonte de enriquecimento muito superior à principal atividade que muitos praticam a mais de uma década, a agricultura, a exorbitante alta nos preços de suas terras. Se isso ocorre com os pequenos, com os grandes, certamente não é diferente.

E quanto aos compromissos firmados com os bancos públicos, assim se comportam, conforme a matéria do Jornal Nova Fronteira:

\begin{abstract}
Terça-feira, 30, é o último dia para a renegociação das dívidas rurais. Apesar das inúmeras vantagens concedidas, muitos agricultores da região Oeste ainda não compareceram as agências do Banco do Brasil (BB) para fazer a adesão. (...) Segundo o superintendente do Banco do Brasil (BB) de Barreiras, José Maria Araújo, menos de $40 \%$ dos produtores procuraram suas agências para aderirem à renegociação. Ele falou também que o prazo para adesão a renegociação prevista na MP 432 é até o dia 30/09, sendo que o pagamento da parcela da repactuação, dependendo da linha de crédito, será até o dia. (...) Araújo informou ainda que quem não aderir até lá, perderá direito a benefícios como ampliação de prazos de pagamento até 2025, descontos para liquidação e rolagem, eliminação de multas, extensão de bônus de adimplência e troca de indexadores dos débitos. Vale ressaltar que a adesão também é valida para as condições:

-redução de juros inicialmente contratados;

-abonos/rebates para liquidação da operação (integralmente);

-prorrogação com alongamento do prazo final.

Mas é bom ficar atento, pois restam apenas mais dois dias úteis para que o agricultor rural procure renegociar suas dívidas. Dessa forma ele ficará apto a pegar novos empréstimos rurais para investir em suas terras ${ }^{35}$.
\end{abstract}

Cabe destacar que nem os incentivos, que parecem indicar um pedido de favor da parte do banco, são capazes de atrair os devedores a darem satisfação ao credor sobre seus débitos.

Mas também não é difícil encontrar explicação para a postura dos devedores do setor agrícola. Estes integrantes das oligarquias rurais estão muito seguros da eficiência da bancada ruralista (bancada de deputados proprietários e/ou que representam os interesses desses) e do quanto os governos historicamente cedem às suas reivindicações.

A Deputada Jusmari Oliveira foi recebida em audiência nesta terça-feira (17/04), pelo
Ministro da Agricultura, Reinhold Stephanes, juntamente com o presidente e vice-
presidente da subcomissão para tratar de endividamento rural da Comissão de
Agricultura da Câmara dos Deputados, os deputados Ronaldo Caiado e Luiz Carlos
Heinze, apresentando ao Ministro, algumas propostas emergenciais que precisam ser
implementadas para aliviar as pressões existentes sobre o setor rural em relação ao
vencimento de dívidas previstas para o ano de 2007 .
Dentro das questões levadas ao Ministro, está o pedido de prorrogação de prazo de
vencimento para liquidação das parcelas de pesa, securitização e recoop, fixado para
$30 / 04$, tendo em vista que ainda não foi autorizado o recebimento da parcela de
securitização com desconto, em operações contratadas fora do Banco do Brasil, a

${ }^{35}$ Jornal Nova Fronteira, Barreiras, 26.09.2008. (por: Elisângela Rosa). 
prorrogação do prazo de adesão para renegociação de dívidas contratadas na região da Agência de Desenvolvimento do Nordeste (ADENE), vencida no último dia 31/03, a suspensão do vencimento de todas as parcelas vencidas e vincendas em 2007 pelo prazo de até 180 dias, para que Governo e Comissão de Agricultura possam fazer um diagnóstico do endividamento dos produtores rurais e por último, a suspensão das cobranças por parte da Procuradoria Geral da Fazenda Nacional, de dívidas rurais transferidas para a sua responsabilidade.

Jusmari pediu ao Ministro "urgência" na adoção das medidas solicitadas e acrescentou: "na região nordeste, muitos produtores deixaram de fazer a opção de renegociação de suas dívidas, por falta de informação por parte dos bancos, e também por conta do atraso na edição das normas, fato que tem ocorrido também em relação às parcelas de securitização e pesa vencidas em 2005 e 2006, que até o momento, não estão sendo financiadas pelo BNB, mesmo com a autorização contida nos artigos 15 e 15-A da lei no 11.322, de 2006".

A deputada comentou também os procedimentos de cobranças realizados pela PGFN, acrescentando: "o governo não pode permitir "este tipo de ação por parte da PGNF, bloqueando contas bancárias de pequenos produtores rurais que muitas vezes sobrevivem com a aposentadoria e ameaçando de tomar suas terras através de execução fiscal". O Ministro se sensibilizou com os problemas e prometeu que levaria o assunto ao presidente Lula na próxima semana e também trataria do assunto com o Ministro da Fazenda, Guido Mantega ${ }^{36}$.

Qualquer associação dessa matéria com a anterior não parece tratar-se de mera coincidência. Em levantamento feito nas publicações desse jornal, nos anos de 2007, 2008 e 2009, é muito marcante a repetição do ciclo: liberação de créditos pelo governo; cobrança pelos bancos com os respectivos incentivos aos possíveis pagantes; o não comparecimento dos devedores para pagarem ou renegociarem; e, finalmente, a organização da caravana de parlamentares (no caso só Jusmari, mas costumeiramente vão em maior quantidade) a exercerem pressões ao Executivo pela anistia dos débitos dos seus representados. Interessante ainda a menção que faz aos devedores, incluindo-os no grupo dos "pequenos produtores". Esta estratégia tem sido utilizada pelos ruralistas para usurpar recursos públicos do Estado, obter todo tipo de benefícios - e o discurso que tem embasado a pressão pela mudança no Código Florestal é um exemplo disso. O que se observa, é que os pequenos estão à margem do modelo agrícola brasileiro e as referidas reivindicações destinam-se aos grandes que, na região estudada, investem sobre os pequenos com vistas a expropriá-los.

Nos aspectos concernentes às relações de trabalho, verifica-se que as condições oferecidas aos trabalhadores, são, de modo geral, desumanas, e mesmo assim, entendem que os órgãos públicos de fiscalização, quando aparecem, incomodam muito e, portanto, escolhem a substituição da mão de obra braçal pelo

\footnotetext{
${ }^{36}$ Jornal Nova Fronteira, Barreiras, 18.04.2007. (por: Creudson Cruz).
} 
trabalho mecanizado na maioria das atividades do processo produtivo, como medida mais viável.

No que diz respeito aos impactos ambientais do agronegócio na região, notase um quadro de extrema gravidade. Fruto do total descaso do Estado para com a fúria arrasadora do agronegócio, presencia-se uma situação de degradação generalizada do meio ambiente na região. Nem mesmo o que determina a lei, a questionável reserva legal para as áreas de cerrados ${ }^{37}$, é cumprido pelas empresas do agronegócio. Nas áreas onde se concentra as atividades agrícolas, causa fadiga a monótona e homogênea paisagem, desprovida de qualquer cobertura vegetal natural. Os desmatamentos foram generalizados, assim como os aterramentos de nascentes de riachos e veredas e os despejos de venenos nos solos são da mesma forma indiscriminados, culminando num conjunto de agressões às riquezas naturais rumo à arenização e à morte geral. ${ }^{38}$

Recentemente, o Ministério Público Estadual iniciou algumas providências, investigando 104 empresas agrícolas detentora de áreas acima de dez mil hectares, quanto ao cumprimento da legislação ambiental. Isso tem provocado um apavoramento dos empresários, os quais afirmam que medidas como essas vão inviabilizar a geração de empregos, as atividades produtivas, "causar pane na produção de commodities, ou seja, comprometerão o modelo por eles posto em prática.

$\mathrm{Na}$ contramão dessa investida do Ministério Público, as empresas vêm exercendo pressões ao Governo Federal para o melhor aparelhamento do Instituto Brasileiro do Meio Ambiente e dos Recursos Naturais Renováveis (IBAMA). Não se trata, pois, de tornar esse órgão mais eficiente na sua missão fiscalizadora, e sim, de torná-lo mais ágil na concessão de licenças para os desmatamentos. Haja vista, só recentemente, buscarem o cumprimento dessa exigência legal. Historicamente (e muito recorrente nos dias atuais), os desmatamentos se faziam sem qualquer controle do poder público.

\footnotetext{
${ }^{37} \mathrm{~A}$ legislação ambiental vigente, Código Florestal (Lei Federal $\mathrm{n}^{0} 4.771$, de 1965), estabelece um percentual mínimo de $20 \%$ e $35 \%$ de reserva legal em propriedades rurais localizadas no bioma Cerrado e áreas de Cerrados inseridas na Amazônia Legal, respectivamente.

38 "O termo arenização foi proposto por Suertegaray (1987) para caracterizar o fenômeno de degradação e perda da produtividade que ocorre nestes solos, definindo-o como o processo de retrabalhamento de depósitos areníticos não consolidados, conferindo mobilidade aos sedimentos não protegidos pela vegetação e distinguindo-o do fenômeno da desertificação" (ROVEDDER et. al, 2005, p.501).
} 
Com o recente aumento das exigências legais, o descompasso tem surgido entre a fúria das empresas pela continuidade dos desmatamentos e a falta de aparelhamento dos órgãos ambientais.

Temendo o que já se chama de uma possível pane na produção da commodity na região, os produtores, através da Associação de Agricultores e Irrigantes da Bahia (Aiba), percorrem os gabinetes de Brasília em busca de uma solução para o problema, cujo cerne está na falta de agilidade dos órgãos públicos competentes para fazer os licenciamentos ambientais. Ontem (27) pela manhã, o presidente da Aiba, Humberto Santa Cruz, o vice Sérgio Pitt e a deputada federal Jusmari Oliveira reuniram-se em Brasília com o ministro das Relações Institucionais, José Mucio Monteiro, para expor o problema. Em seguida, participaram de reunião com o ministro interino da Agricultura, Silas Brasileiro, e com o assessor especial do ministro, Gerardo Fontelles.

Os encontros são parte de uma verdadeira cruzada que vem sendo empreendida pela entidade de classe dos produtores desde 2000, alertando os governos Federal e Estadual para o passivo gerado pela falta de equipamentos e recursos humanos de órgãos como o IBAMA para agir com celeridade em processos como os de averbação de reserva legal. Essa demora deixa o produtor que já cumpre a lei, preservando a reserva legal, vulnerável às penalidades por não possuir a autorização para supressão vegetal e licenciamento ambiental, o que, na maioria dos casos, pode levar anos para acontecer.

O ministro José Mucio Monteiro entregará ao presidente Lula, na próxima segunda feira (01), uma carta assinada pela Aiba e pela Deputada Jusmari Oliveira, dando ciência da situação na região e da "inoperância do IBAMA". Os produtores pedem a interveniência do presidente na formalização de um Termo de Compromisso Tripartite (Aiba, Governo Federal/IBAMA e Governo do Estado da Bahia/Sema) que estabeleça metas e condições para a regularização das áreas da região. Além disso, a suspensão imediata do embargo a fim de garantir o plantio nesta safra.

Em Formosa do Rio Preto, a 1,1 mil quilômetros de Salvador, a Operação Veredas teve a participação pessoal do Ministro do Meio Ambiente, Carlos Minc, em uma das blitze, no dia 06 de novembro. $O$ saldo da operação na região, divulgado pelo Ministério do Meio Ambiente, foi de 57 mil hectares de terras embargadas, $R \$ 33,6$ milhões de reais em multas, apreensão de 27 máquinas agrícolas, quatro caminhões, oito motosserras, dois silos, dois geradores e 124 toneladas de soja. ${ }^{39}$

Ressalta-se que medidas como essa só têm sido tomadas recentemente e não representam efetividade significativa frente à grande frequência dos descumprimentos da legislação ambiental, enfatizadas por interlocutores que apontam como regra a desobediência das determinações legais. Isto fica demonstrado, no que consta da citação acima, na movimentação da classe dos grandes proprietários de terra para garantir a continuidade das investidas que historicamente praticaram sem empecilhos.

Como desfecho dos embates entre empresas e órgãos do poder público, temse o seguinte:

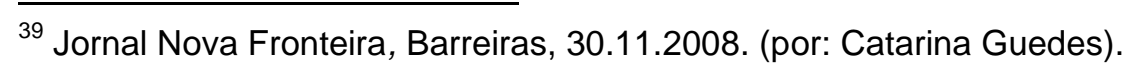


Como fruto da parceria entre Governo e Aiba, no dia 29.05.2009, foi anunciado e publicado pelo Governo da Bahia o Decreto $n^{\circ} 11.558 / 2009$, aprovando o Plano Estadual de Adequação Ambiental dos Imóveis Rurais.

Para segurança e balizamento dos trabalhos a serem implementados pelo Plano em todos os níveis dos órgãos ambientais, no último dia 05.06.2009, em Caravelas, no Sul da Bahia, foi assinado um Protocolo de Intenções entre Governo do Estado, IBAMA e Ministério do Meio Ambiente, na presença do Presidente Lula, para, no prazo de 60 dias, ser transformado em Convênio de Cooperação Técnica, ratificando o modelo de Adequação e Regularização Ambiental dos Imóveis Rurais instituído pelo Governo da Bahia através do decreto ${ }^{40}$.

Fica demonstrada, portanto, a grande receptividade do Estado classista às demandas das oligarquias rurais, ou até mesmo, pode-se afirmar, da convergência de projetos para o país, visível no modelo de desenvolvimento em prática de forma combinada por ambas as forças.

Neste sentido, são visíveis as vultosas cifras que sangram dos cofres públicos para a instalação da infraestrutura que viabilize as atividades e atendam as expectativas empresariais; os investimentos diretos na forma de subsídios e anistias às dívidas do empresariado agrícola e a alta renda absoluta da terra ${ }^{41}$, que a sociedade paga à classe detentora das propriedades do solo. Tem-se, como exemplo localizado, o alto impacto negativo da concentração fundiária, e em decorrência, a grande diminuição da produção de alimentos e a respectiva alta dos preços após a investida privatizante das terras,

\begin{abstract}
Quem não se lembra do tempo que Santa Maria da Vitória produzia gêneros de $1^{\text {a }}$ necessidade; e do cais tomado por sacos e sacos de feijão, mamona, milho, algodão, farinha e fardos de rapadura; e das feiras onde abundavam os maxixes, quiabos, alface e abóbora?

Depois que nossa cidade foi invadida pelos novos 'cowboys americanos' - se dizem pioneiros que vieram ocupar estas terras 'sem dono' (para eles) - tudo isso sumiu, restando apenas no cais uns poucos montes de areia lavada e uns poucos casalzinhos de namorados, de carro, à noite. Porque isso aconteceu?

Nos anos 70, surgiu um plano econômico do governo para exploração da região nos moldes da economia capitalista avançada, cujos 'cowboys' são seus representantes. O capital precisava expandir-se e assim o fez.

Vejamos os 'benefícios' que isso nos trouxe: em $1967,87,6 \%$ dos estabelecimentos eram de minifúndios ou pequenos produtores e ocupavam $44,28 \%$ da área do município. Em 1980, o número de estabelecimentos minifundistas cai para $73,58 \%$ enquanto a área que estes detinham baixou para 33,45\% da área total em 1980.

Os posseiros, por sua vez, que eram $31,8 \%$ do número de estabelecimentos e ocupavam $7 \%$ da área total em 1967, caiu em $20,7 \%$ de estabelecimentos e em $2,5 \%$ da área ocupada em 1980. Por outro lado, a área ocupada com lavoura decresceu em $27,75 \%$ de 1975 para 1980. Com esse número de concentração da terra e sabendo que os produtores (posseiros, arrendatários, pequenos proprietários, etc.)
\end{abstract}

\footnotetext{
40 Jornal Nova Fronteira, Barreiras, 09.06.2009.

${ }^{41}$ "É a renda obtida pelo "exercício do monopólio de uma classe ou fração de classe sobre a terra". (...) Esta classe só a coloca para "produzir mediante a cobrança de um tributo, permitindo assim que mesmo o 'pior solo' (que não paga renda) possa também auferir renda” (OLIVEIRA, 1986, p.77).
} 
produzem $70 \%$ dos alimentos da Bahia, fica claro porque caíram os índices dos gêneros de primeira necessidade.

Com o fechamento das áreas 'livres' dos gerais, os pequenos produtores foram obrigados a reduzir a área utilizada para a lavoura como forma de 'racionalização' de suas terras para o criatório..."

"...Sendo nossa área uma área agrícola é interessante ver que o número de pessoas economicamente ativas ocupadas na agricultura caiu de 17.128 pessoas em 1975 para $11.325 \mathrm{em} 1980$. E espero que não me venham falar que aumentou o número de empregos agrícolas na região (Por: Gal, Fernando e Cezar, in O Posseiro, no 40, p.4, julho/1983). ${ }^{42}$.

O texto acima faz referência ao caso específico do município de Santa Maria da Vitória, mas pode ser projetado também para os demais municípios do oeste baiano atingidos pela investida privatizante da terra. $E$, dentre os problemas surgidos há o desordenado aumento da população de cidades regionais, a enfrentarem o desenfreado aumento de problemas típicos das grandes cidades brasileiras, dentre eles a violência que atinge principalmente a juventude nessas cidades e o elevado índice de indigência da população. Uma importante noção do referido quadro social pode ser observada a partir das notícias do Jornal Nova Fronteira (foto 3). ${ }^{43}$

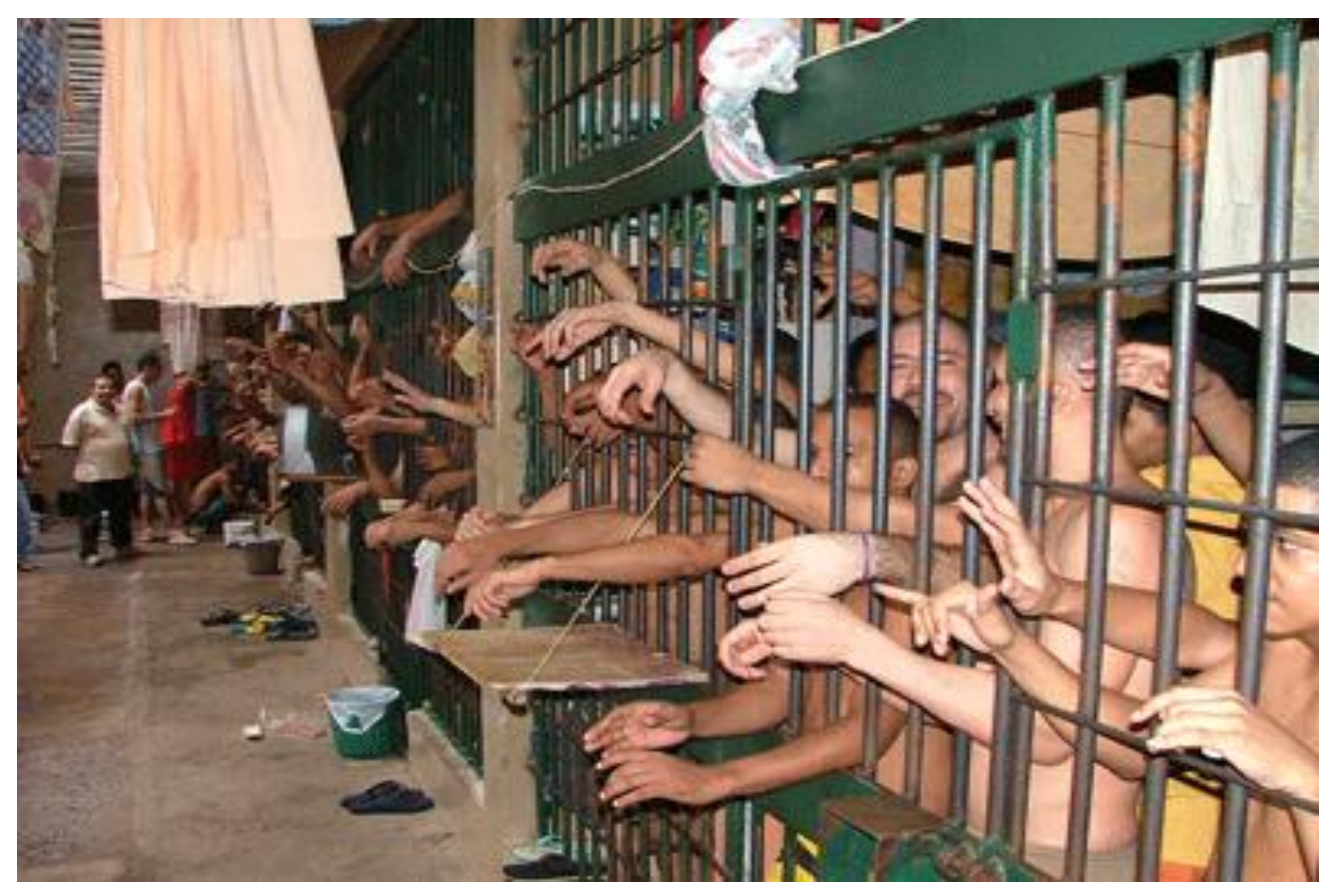

Foto 3 - Presídio superlotado em Barreiras - BA. In: Jornal Nova Fronteira, Barreiras, 05.06.2007. (por: Leila Ribeiro).

Os jornais locais, com muita frequência, noticiam as ocorrências e os aumentos de roubos de veículos, de consumo e tráfico de droga, de assaltos às

\footnotetext{
${ }^{42}$ Observação: os dados aludidos são do Instituto Brasileiro de Geografia e Estatística (IBGE).

${ }^{43}$ Trinta presos fogem do Complexo Policial de Barreiras. O presídio foi construído para abrigar 28 presos, mas na época estava com aproximadamente 150. In: Jornal Nova Fronteira, Barreiras, 05.06.2007. (por: Eduardo Lena, fotos: Leila Ribeiro).
} 
pessoas e aos estabelecimentos comerciais, e muitas outras. É muito frequente, na cidade de Barreiras, a população em gigantescas passeatas em protestos pedindo paz. Porém, como solução para estes problemas, as elites locais apontam a construção de presídios maiores e o aumento do contingente policial, motivo de insistentes reivindicações ao poder público. O que não há é o uso dessa mesma união de forças para reivindicar melhor estrutura e serviços públicos para as cidades que possam garantir melhoria na qualidade de vida da população que mora nas periferias, assim como para a realização da reforma agrária que possa garantir a fixação dos camponeses na terra.

\subsection{As relações de trabalho e a atuação dos sindicatos no Oeste da Bahia}

Dentre outros fatores atrativos para a expansão do agronegócio na região, cabe destaque a abundância de mão de obra. Inclusive a região Nordeste tem desempenhado histórico papel de atender as demandas de força de trabalho nas mais diferentes regiões do país.

No caso estudado, para lá se expande o modo capitalista de produção, com a promessa, segundo os programas governamentais e agentes dos governos de outras esferas do poder público, de gerar empregos para a grande massa carente. $\mathrm{Na}$ verdade, isso coincide muito com a lógica do sistema capitalista. Neste, os investimentos do Estado, visando ao bom desempenho da economia, têm como finalidade a geração de empregos, pelo menos no discurso, e nessa situação "o trabalhador é apropriado pelo capital" (MARTINS, 1983, p. 153). No caso da região Oeste da Bahia, cabe ressaltar que a geração de emprego, quando ocorre, tem como premissa a expropriação ou expulsão de um numeroso contingente populacional das suas terras. ${ }^{44}$ É sabido que do ponto de vista do capital esse trabalho familiar camponês em sua parcela não é considerado produtivo, porque não contribui diretamente para a produção do capital. No entanto, de forma contraditória, esses camponeses estão inseridos no capitalismo, na medida em que produzem em abundância e a baixos preços os alimentos que viabilizam a superexploração da força de trabalho nos empreendimentos capitalistas, por exemplo. Prova disso é a

\footnotetext{
${ }^{44}$ A dita geração de emprego precisa, portanto, ser relativizada.
} 
importância das feiras camponesas em cidades como Barreiras, Santa Maria da Vitória, São Desidério e Correntina.

Apesar da relevância da produção camponesa para a produção do capital, sabe-se também que, noutra contradição, o capital almeja essas terras (dos camponeses), quer seja para a exploração do trabalho alheio, e desta forma viabilizar a sua reprodução, quer seja para dela extrair alta renda, conforme é notória a absurda elevação dos preços das terras na região. Isso tem provocado uma grande diminuição na produção de alimento, devido a outra destinação à terra conferida pelos capitalistas pós-privatização, resultando, inclusive, na exorbitante alta dos preços e, desta forma, em tese, comprometida a reprodução do capital na sua ânsia pela superexploração da força de trabalho.

A região Nordeste, porém, se faz muito propícia à reprodução do capital, mesmo a partir dessas considerações, pois as relações sociais historicamente engendradas com sua estrutura social arcaica, pautada pelo coronelismo e tudo que Ihe é característico, contribuíram para a criação de um imenso exército de reserva de mão de obra; e a Bahia não se diferencia do quadro regional - muito pelo contrário. Nesse sentido, há que considerar a particularidade da região Oeste, onde a recente investida do capital se faz mais perversa, pois, até a década de 1970, nas comunidades, todos tinham terra e nestas tudo que se planta dá bom e em abundância. Mas é justamente os processos expropriatórios levados a cabo após esta década que contribuíram para o despejo de um contingente populacional enorme a sobreviver do nada nas periferias das cidades regionais ${ }^{45}$, quando não se dispersaram para Brasília, Goiânia, São Paulo e outras cidades. Nas cidades locais, frases como esta, resumem suas ocupações e condições de moradia: Vão trabalhar temporariamente no cerrado. Outros fazem bico. Muitos moram em casa de papelão... ... e aqueles que resistem no campo são mão de obra das fazendas. ${ }^{46}$ Esta última afirmação refere-se àquelas frentes de investidas mais intensas da privatização capitalista da terra, onde o agronegócio se faz mais presente.

\footnotetext{
${ }^{45}$ Cidades da região, como Luiz Eduardo Magalhães e Barreiras, têm aumentado tremendamente a população. As periferias dessas cidades são desprovidas de qualquer infraestrutura urbana para a população. Inclusive o próprio nome de um Bairro de Barreiras é sugestivo neste aspecto. O mesmo é chamado de Vila Papelão. Numa entrevista com o tesoureiro do STR-Barreiras em 2004, o mesmo se referia à cidade como um "grande favelão", onde as pessoas (em maioria, residentes nas periferias) tinham como importante meio de sustento a sopa distribuída pela prefeitura e Organizações Sociais de cunho assistencialista.

${ }^{46}$ Sr. Walmir dos Santos, diretor do STR-Barreiras, trabalho de campo realizado em julho de 2008.
} 
Estes expropriados ou expulsos de suas terras se incluíram no conjunto daqueles a se submetem à fúria exploradora do modo capitalista de produção - e as denúncias envolvendo grande parte das empresas agrícolas da região da prática do trabalho escravo confirmam isso.

No entanto, os empresários do agronegócio se autorreconhecem como generosos ao oferecer "empregos" àquela "legião de indigentes", pois, nas periferias das cidades, sem quaisquer condições de sobrevivência - haja vista nos meios urbanos, nada há que se fazer e, mesmo que houvesse, provavelmente a grandiosidade de seus saberes e sabedorias, tão relevantes na ambiência camponesa da qual são egressos, de nada ou de quase nada serviria para os tipos de ocupações nessa outra realidade.

O capitalista e, muitas vezes, o "gato" ${ }^{47}$, se veem como misericordiosos, ao dar o que fazer àquele, do mundo, desencantado. $E$ assim são justificadas as intervenções capitalistas dos empresários e do seu tutor, o Estado, nas frações territoriais e na vida dos camponeses do Oeste da Bahia.

Mas, contrariando os interesses dos capitalistas, contraditoriamente, por vezes aparecem os grupos de Combate ao Trabalho Escravo que comprometem a ânsia de exploração da força de trabalho até a exaustão. Ou, nas convenções coletivas, contrariando as pretensões dos empresários do agronegócio e também dos STR, intervém, de forma contraditória, os agentes do Ministério do Trabalho e Emprego (MTE) e do Ministério Público. Estes, dão uma cacetada ${ }^{48}$ nos planos dos empresários e dos sindicatos da região, não mais permitindo que os assalariados trabalhem trinta dias sem descanso semanal, para que possam desfrutar de seis dias de folga, tempo considerado suficiente para as visitas familiares em longínquas localidades até noutros estados como, por exemplo, Alagoas.

Com essas exigências, os empreendedores capitalistas afirmam que não mais compensa o emprego da força de trabalho humana em atividades como colheita do café e limpa do algodão. Como solução viável para o capital, inculcada

\footnotetext{
47 "Conhecido em amplas regiões, opera como um agenciador de trabalhadores. Geralmente, possui ou aluga um caminhão para transportar os peões, recrutando-os sob promessas de salário e regalias que não serão cumpridas. Como não há fiscalização, o trabalhador, quanto mais se aproxima do local de trabalho, mais longe fica de qualquer proteção ou garantia quanto aos seus direitos trabalhistas" (MARTINS, 1991, p.49).

${ }^{48}$ Expressão de sindicalista do STR-Barreiras, Sr. Walmir dos Santos, trabalho de campo em julho de 2008, referindo-se ao impedimento, pelos referidos órgãos, das intenções dos sindicatos de trabalhadores e patronais na convenção coletiva de 2008.
} 
de maneira incansável por empresas do grande capital, como John Dery, Pfizer, Rhodia e outras, os empresários vêm optando pela compra de máquinas inteligentes para a colheita do café, as quais trabalham por 100,150 trabalhadores, e na limpeza do algodão, tal como afirmou o Sr. Walmir: No início, na limpa de algodão, fazendas empregavam 300, 400, 500 homens... Atualmente, um litro de Produzolino faz por 200 trabalhadores. ${ }^{49}$ Faz-se desnecessário dizer o quanto essa última "solução" contribui para o "sucesso" da região Oeste da Bahia, no ranking das coletoras de embalagens de agrotóxicos no país. Mas, por outro lado, estas soluções também dão importantes contribuições para a desmistificação do discurso dos defensores do agronegócio, pois não mais a geração de "empregos" servirá como justificativa para a investida que a tudo arrasa no Oeste da Bahia.

Mesmo assim, o emprego de mão de obra humana persiste no "rastelamento" ou na cata de raiz após os desmatamentos da vegetação. E, curiosamente, é nesta atividade que concentra o maior número de ocorrência de trabalho escravo na região - conforme frequentes flagrantes das equipes de combate ao trabalho escravo - um dos feitos da grande monocultura e que tem como protagonistas as grandes empresas do capital nacional, internacional e o Estado "modernos".

\subsubsection{As contradições do movimento sindical nas mediações das relações capital trabalho}

O salário do cerrado é muito bom, é alto..$^{50}$

O agronegócio se expande empregando sempre menos mão de obra e oferecendo condições de trabalho precárias; concomitante a isso, absorve mercadorias do capital, que se traduzem como tecnologias modernas - maquinários, insumos, agrotóxicos em geral - na verdade, desempregadoras de mão de obra na essência.

O patronato do agronegócio justifica a absorção crescente de tecnologias no processo produtivo devido às exigências crescentes dos técnicos do MTE. Abaixo,

\footnotetext{
${ }^{49}$ Sr.Walmir dos Santos diretor do STR-Barreiras, trabalho de campo em julho de 2008.

${ }^{50}$ Frase pronunciada pelo Sr. Walmir dos Santos, diretor do STR-Barreiras, trabalho de campo realizado em julho de 2008.
} 
cito trechos de uma reportagem na qual constam manifestações de empresários e de um sindicalista do setor do agronegócio sobre a questão:

As normas da NR31, do Ministério do Trabalho segundo ele, está fazendo com que os agricultores busquem tecnologias que requer cada vez menos trabalhadores no campo. "Infelizmente essa é a realidade. Tanta gente precisando de emprego para sustentar suas famílias e nós agricultores somos obrigados a diminuir as contratações, mesmo tendo, em alguns casos, um custo maior", afirma Faedo.

"Deveria existir um bom senso por parte dos fiscais na hora da fiscalização. Os produtores não deveriam ser tratados como bandidos, pois estão gerando emprego e riqueza para nosso país", argumenta Faedo, e diz ainda que seria necessário rever as leis e as normas trabalhistas, pois a forma como estão impostas, vão na contramão da história. Ele disse ainda que enquanto os países desenvolvidos estão flexibilizando a questão do trabalho e produção, nossas autoridades estão fazendo exatamente o contrário.

De acordo com o empresário de revenda de máquinas agrícolas e produtor rural, João Antônio Franciosi, a lei trabalhista deveria ter mais flexibilidade em todos os setores, e, principalmente, na área rural. Para ele, o Ministério do Trabalho deveria deixar mais nas mãos dos empregadores e dos empregados e seus representantes de classe, a formalização destes acordos. Lógico, resguardando os direitos trabalhistas previstos na $\mathrm{CF} / 88$. "Nosso principal obstáculo hoje, é sem dúvida a questão das horas trabalhadas, a proibição de formalizar um Banco de Horas na área rural e da possibilidade do nosso colaborador estar acumulando as folgas semanais (DSR) para que sejam usadas de uma só vez, como vinham sendo feitas até a última Convenção Coletiva de Trabalho", relata Franciosi.

"Acredito que os órgãos encarregados desta fiscalização, deveriam ter uma vivência maior sobre o que é o trabalho em uma fazenda. Deveriam perguntar aos trabalhadores o que eles acham sobre o assunto, viver o dia-a-dia de uma empresa rural. Certas leis e normas como esta que acaba de proibir a livre negociação entre os sindicatos representantes da classe com relação ao acúmulo de folgas, está prejudicando e muito não só os agricultores, mas principalmente os trabalhadores. Se as leis trabalhistas visam na sua maioria das vezes resguardar os direitos das partes menos favorecidas na relação (empregado), neste caso, estão prejudicando e muito aos mesmos".

Contrariado com a situação, o empresário finaliza dizendo que trabalhadores de várias regiões buscam no Oeste da Bahia uma oportunidade de emprego, mas em decorrência do excesso de exigências trabalhistas não conseguem colocação, aumentando a miséria e a criminalidade regional.

O secretário do Sindicato dos Produtores Rurais de Barreiras, Leonardo Soares, foi enfático ao afirmar que hoje é mais viável para o agricultor investir em máquinas do que em pessoas. A mão-de-obra é bem mais lenta do que as máquinas e as exigências do Ministério do Trabalho são bastante penosa. "As consequências disso para a sociedade é lastimável, pois cresce o desemprego e aumenta o índice de marginalidade", conclui. ${ }^{51}$

Nesta matéria, os empresários tentam justificar o emprego de tecnologias em detrimento do uso de força de trabalho humana. Curioso que isto ocorra mesmo que o uso de máquina torne o processo produtivo mais encarecido. Defendem a flexibilização da legislação trabalhista, propondo que a formalização dos acordos na relação capital e trabalho seja estabelecida entre o patrão e o empregado ou com o seu representante de classe. Quanto a essa proposição, o entendimento do

\footnotetext{
${ }^{51}$ Jornal Nova Fronteira, Barreiras, 16.09.2008. (por: Elisângela Rosa, foto: Eduardo Lena).
} 
sindicalista citado (diretor do STR-Barreiras), oferece uma boa noção do quanto esses colaboradores ${ }^{52}$ serão explorados e o quanto terão que esperar a defesa do seu representante de classe.

Nas convenções coletivas anuais, os empresários do agronegócio assumem postura coordenada e intransigente para não permitir aumentos de salários. Como exemplo, citamos a convenção coletiva de 2008, quando, em uma das rodadas de negociações, os sindicatos dos trabalhadores rurais reivindicavam um salário de 460 reais mensais para aquele ano e os patrões tinham chegado a 445 - e relutavam em atender o que reivindicavam os sindicatos. Nós colocamos é, um valor de 460, mais eu acredito que deve fechar em 450 porque já ficou em 445 . É...? Em 445, acredito que vai ficar por uns 450. O piso salarial. Mas nós tamos querendo fechar com $450^{53}$

Nesta convenção, participavam das negociações, além dos sindicatos dos trabalhadores da região Oeste da Bahia e dos sindicatos patronais, o Ministério Público, a Delegacia Regional do Trabalho (DRT), o Ministério do Trabalho e Emprego, a Federação dos Trabalhadores na Agricultura (FETAG), a Confederação Nacional dos Trabalhadores na Agricultura (CONTAG) e o Departamento Intersindical de Estatística e Estudos Socioeconômicos (DIEESE) e ocorria um grande impasse causado pela interferência do Ministério Público, que exigia o cumprimento, pelos patrões, e, por incrível que pareça, pelos sindicatos do que preconiza a Consolidação das Leis Trabalhistas (CLT).

Cabe lembrar que grande parte dos trabalhadores é oriunda de localidades distantes, muitos, até de outros estados, tais como Alagoas, Piauí, Goiás, Tocantins, Minas Gerais, etc. No caso de Correntina, estima-se que 95\% dos trabalhadores são procedentes de fora do município ${ }^{54}$. Costumeiramente, trabalhavam 30 dias ininterruptos no mês para usufruírem seis dias de folga e visitar a família. No entanto, a intervenção do Ministério Público, ao exigir o cumprimento do que

\footnotetext{
${ }^{52}$ Cabe referir-se ao que ocorre na cidade de Luis Eduardo Magalhães, mas isso não se reduz a ela. Aos colaboradores nas atividades desenvolvidas pelo empresariado capitalista da região são dadas como única opção morar numa favela, sem qualquer estrutura, localizada distante da cidade, onde a degradação das condições de vida é extrema.

${ }^{53} \mathrm{Sr}$. Walmir dos Santos, diretor do STR-Barreiras, trabalho de campo realizado em julho de 2008.

${ }^{54}$ Segundo o Sr. Roberto Getúlio de Oliveira, diretor do STR-Correntina, trabalho de campo realizado em janeiro de 2010.
} 
determina a legislação trabalhista, deu uma cacetada na Federação e no Sindicato ${ }^{55}$, ao não permitir que os trabalhadores permanecessem tantos dias sem folgas.

Como "solução" para o referido impasse, concordaram de os assalariados trabalharem as tardes dos sábados ${ }^{56}$ e mais duas horas diárias para serem acumuladas em banco de horas. Ao fim do mês, estas poderiam ser convertidas em folgas para visitarem a família. ${ }^{57}$

Um problema surgido para os trabalhadores em função desse acordo está relacionado à distância de onde muitos são originários. Nesse caso, segundo afirmação do próprio Secretário de Assalariados do STR-Barreiras, os trabalhadores gastam nas viagens de ida e volta às suas casas, seis dias, restando apenas dois (2) para ficar com a mulher e com os filhos. Outro problema que enfrentam é o custo dessa viagem, o qual gira em torno de 500 reais. Disto, presume-se que, em função desse custo e do salário mensal que percebem, fica inviabilizada a visita à família uma vez por mês.

Das condições que estão dadas, muitos trabalhadores decidem trazer suas famílias para morar em Barreiras, Luiz Eduardo Magalhães, principalmente. E, a partir desse fato, se explica o imenso crescimento da mancha urbana dessas cidades, porém, sem qualquer infraestrutura a oferecer para os que chegam. Em função desse grande contingente atraído nas últimas décadas, a especulação imobiliária provocou um tremendo aumento dos preços dos imóveis ${ }^{58}$ e outra opção não lhes resta senão a ocupação irregular das áreas periféricas dessas cidades.

Outro produto da des-retorialização recente foi a intensa periferização da população como efeito direto do processo de valorização dos imóveis em consequência da mercantilização desenfreada trazida no bojo da modernização. Muitos foram os moradores entrevistados que, ignorando a natureza mais ampla da reprodução capitalista, associavam a "inflação imobiliária" que tornou Barreiras uma das cidades de moradia mais cara da Bahia simplesmente "aos sulistas ricos" e sua "ostentação",

\footnotetext{
55 Frase pronunciada pelo Sr. Walmir dos Santos, diretor do STR-Barreiras, referindo-se ao impedimento do Ministério Público.

${ }^{56}$ A manhã do sábado é considerada horário de trabalho normal.

${ }^{57}$ Esta informação foi obtida no mês de janeiro de 2010, o que indica o atendimento dos reclames do empresariado pelos agentes do Ministério do Trabalho e Emprego.

58 "Segundo uma professora sulista, "o pessoal daqui até conseguia morar em casas boas, com aluguel barato; com a entrada desse tipo de empresa extrapolou (...) Ouve-se comentar que 'os gaúchos inflacionaram os preços' (...) e que temos aqui uma inflação ainda mais alta do que no resto do Brasil'. Para o Bispo de Barreiras, 'aumentou da noite para o dia os preços dos imóveis. Isso faz com que a população que não tem imóvel seja empurrada para fora da cidade, aí cresceram os cinturões de miséria e favelas (...). Nesses últimos dez anos, aumentou enormemente a pobreza da cidade (...) isso é visível (...), de uma maneira assustadora. Aconteceu em certa época que o aluguel em Barreiras era mais alto que em Feira de Santana ou Goiânia"' (HAESBAERT DA COSTA, 1995, p.183).
} 
propondo preços mais elevados pelos aluguéis. Como para uma moradora do centro antigo que afirmou: "Eles davam o preço - minha mãe alugou uma casa que a gaúcha ofereceu o triplo (...) para ela desfazer outro contrato" (HAESBAERT DA COSTA, 1995, p.183).

Disto resulta a convivência com a falta de quaisquer serviços e equipamentos públicos nos bairros periféricos, somando-se ainda os desassossegos provocados pelos violentos cumprimentos, pela polícia, de liminares de reintegração de posse das áreas que ocupam (foto 4 e 5 ).

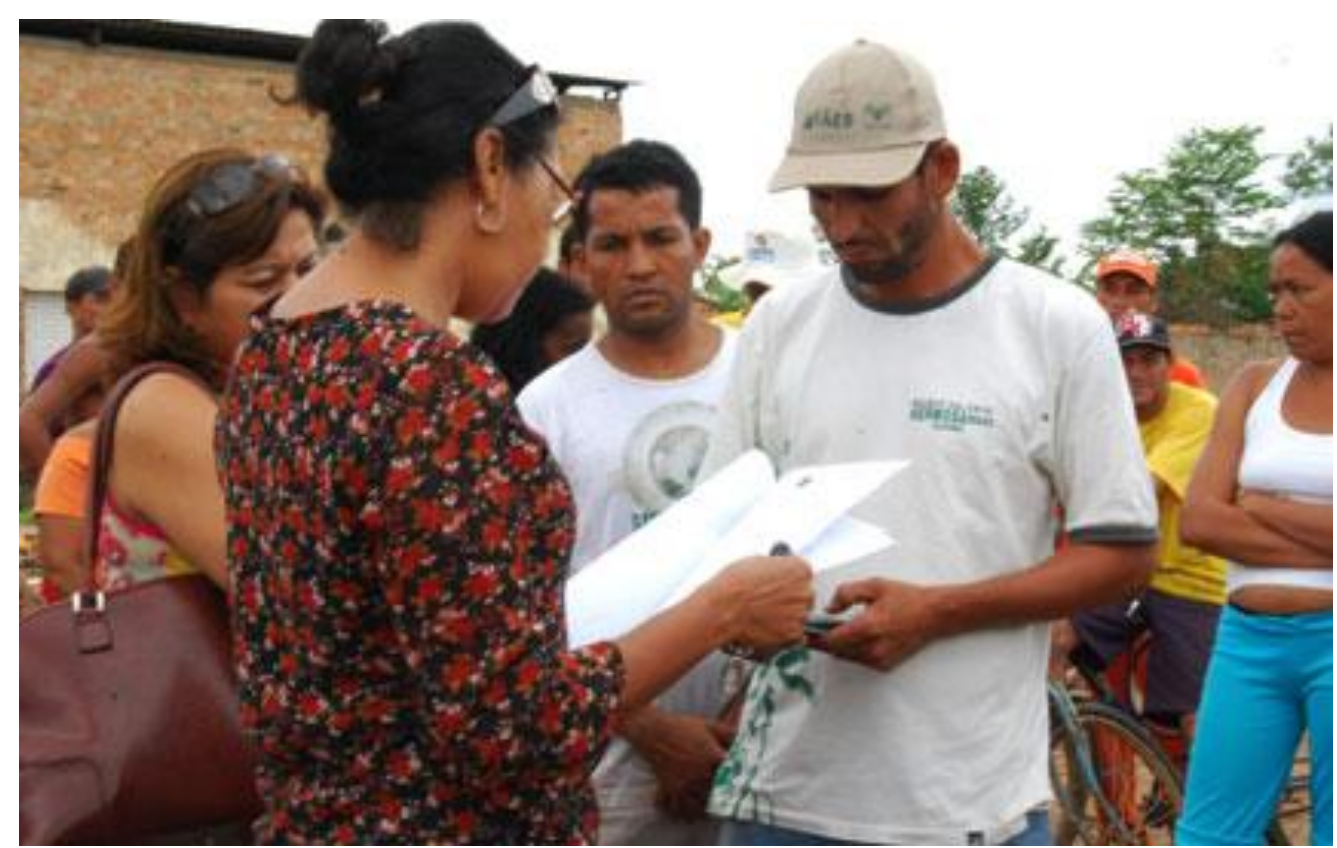

Foto 4 - Oficial de justiça Bartira da Silva apresenta a liminar aos ocupantes. In: Jornal Nova Fronteira, Barreiras, 21.11.2008. (por: Marília Fidelis).

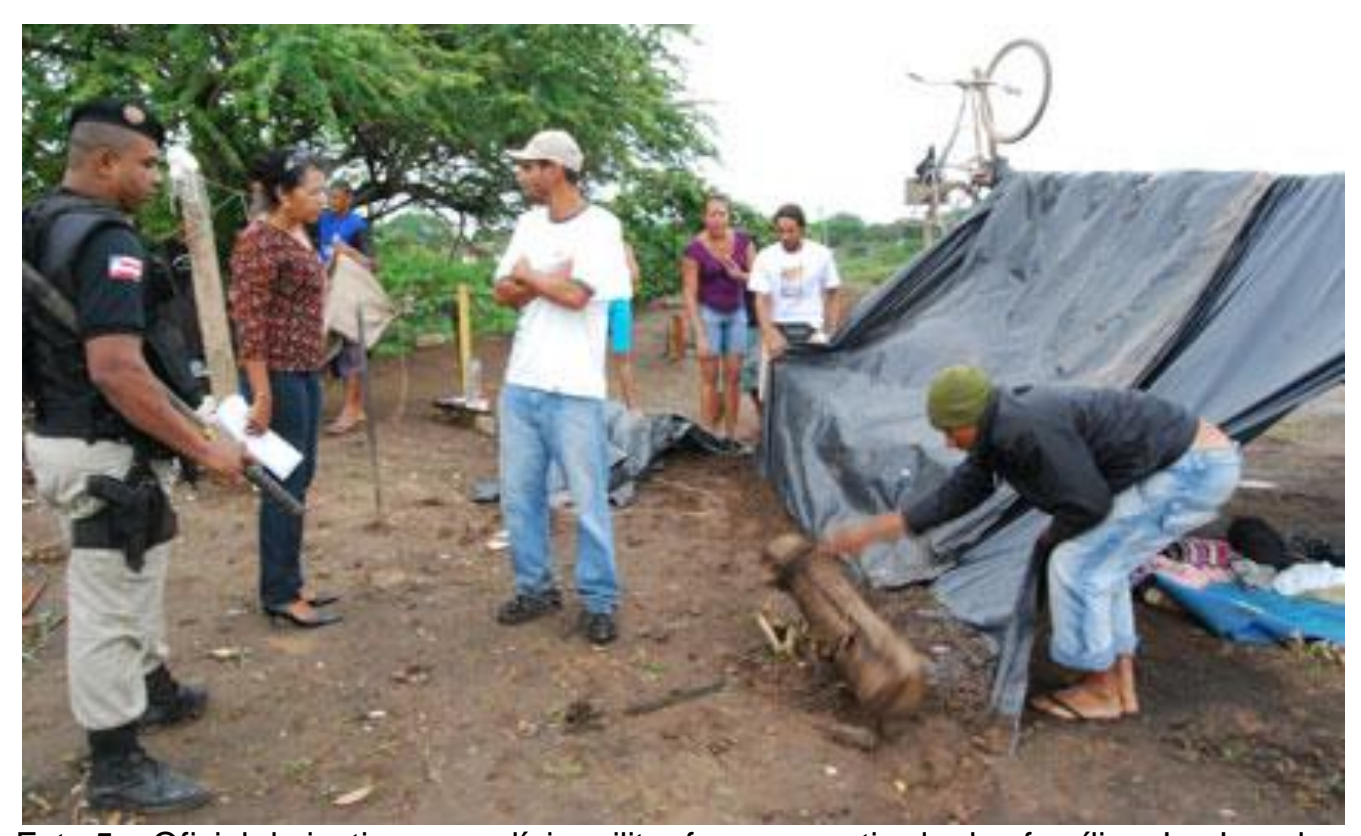

Foto 5 - Oficial de justiça e a polícia militar forçam a retirada das famílias. In: Jornal Nova Fronteira, Barreiras, 21.11.2008. (por: Marília Fidelis). 
"Nós só queremos um lugar para morar. Nada mais. Até plantamos algumas mudas aqui. Se sairmos, para onde iremos?", questiona um dos componentes do grupo às oficias de justiça.

Os ocupantes disseram que não vão desistir da área e que no primeiro momento irão abandonar o local, mas pretendem retornar (fotos 6a,6b,6c,6d,6e,6f). Vamos fazer manifestos, o que for preciso, mas queremos um lugar pra morar, desabafa Tonis Mário. ${ }^{59}$
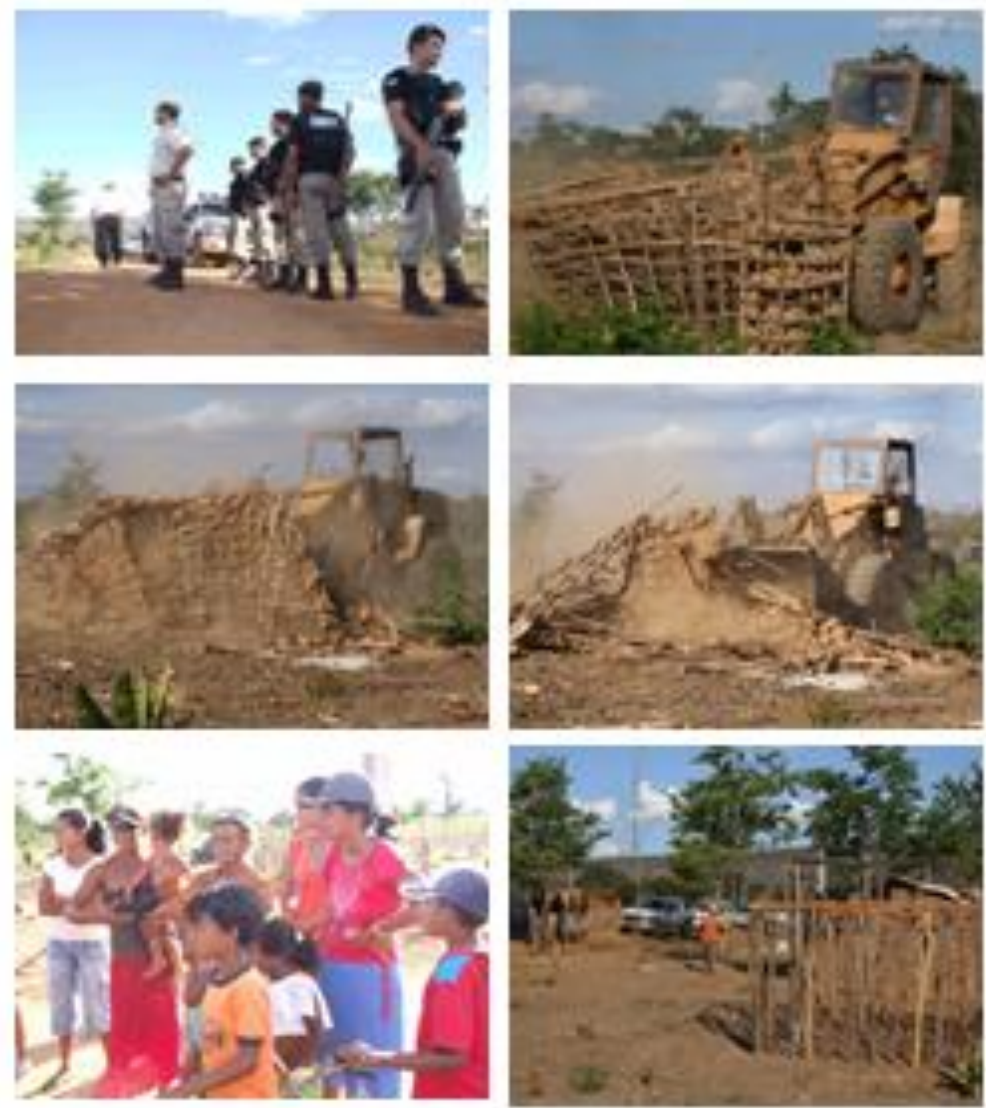

Fotos $6 a$,6b,6c,6d,6e,6f, - Reintegração de posse no Residencial Alphavile. In: Jornal Nova Fronteira, Barreiras, 09.06.2007. (por: Eduardo Lena).

A situação de penúria vivida pela população trabalhadora do campo e da cidade contrasta com os recordes de produção e faturamento tão exaltados nos meios de comunicação e defendido pelos agentes do Estado. A invisibilidade das condições de vida enfrentadas pela população trabalhadora inserida nesse modelo de desenvolvimento demonstra a naturalização da perversidade praticada pelos agentes do grande capital.

Nesse quadro, chama muita a atenção a defesa do agronegócio que os sindicatos de trabalhadores da região fazem. $\mathrm{Na}$ atualidade, a atuação sindical,

\footnotetext{
${ }^{59}$ Ambas as citações são da mesma matéria do Jornal Nova Fronteira.
} 
principalmente nos municípios onde a presença do agronegócio se faz mais intensa - Barreiras, São Desidério e Luis Eduardo Magalhães - está voltada para os assalariados.

Isto contraria os princípios que nortearam a criação dos sindicatos de trabalhadores rurais na região: o combate à expansão e à violência da grilagem de terras.

\begin{abstract}
...temos pai de família ainda enterrado debaixo dos pés de pau por aí, né? Porque a grilagem veio para matar; quem não desocupasse tinha que morrer. ...tinha um deputado federal na época chamado Domingo Leoneli, que mantia, dava força, outro rapaz aqui, que era revolucionário, chamava Jorge Figueiredo. Então quem eles trouxeram a comissão da terra naquelas épocas, e mantinha esse povo no lugar. Mais o coronel Aroldo, resistindo, atirando, querendo matar muitas pessoas. Nós ocupamos, tomamos o sindicato de outro grupo que não fazia nada, em defesa dos trabalhadores e caminhamos pra cima. Nós tinha feito, fizemos uma parceria imediata com a CPT, e aí tinha um pessoal que hoje, nós tem a companheira Nilsa, que é do $P T$, candidata a prefeita hoje, por incrível que pareça, e tinha um advogado. E caminhamos pra cima. Fomos cadastrar o pessoal. E nós conseguimos na época (Diretor do STR-Barreiras, trabalho de campo realizado em julho de 2008).
\end{abstract}

No entanto, o que se percebe, nos dias atuais, é uma grande mudança, e, sob um ponto de vista crítico, até de inversão de objetivos dos sindicatos, pois muitos diretores de sindicatos, com os quais conversei, elogiaram o agronegócio e afirmaram que os produtores de soja são pacíficos, como se a maioria das terras onde hoje se assenta o agronegócio não fosse apropriada pela via da grilagem, que veio para matar ${ }^{60}$, e mesmo assim entendem que o salário do cerrado é muito bom, é alto, e que no cerrado não se ganha mal... ...ninguém ganha salário-mínimo.

Cabe perguntar o quanto há que trabalhar nas horas extras para ganhar mais que o salário-mínimo e, com a criação do banco de horas, sequer essa possibilidade existe mais.

Muitos diretores de sindicato subestimam a existência da grilagem de terra na atualidade e a concebe como prática do passado.

então a gente luta tanto, e nós continua hoje lutando pelos direitos dos trabalhadores. Hoje não tem mais esse problema de terra, de grilagem, hoje não existe. O nosso hoje, alvo hoje, é... nós, é... com os assalariados, é o pessoal é, coisa de diplomata, porque não tem mais esse problema de terra com o pessoal (Sr. Walmir dos Santos, diretor do STR-Barreiras, trabalho de campo realizado em julho de 2008).

Ao contrário, a grilagem está muito presente, porém, de forma mais intensa naquelas áreas de frentes da expansão privatista da terra. $E$ muitos dos interlocutores afirmam isso. O que se vê com grande frequência é a partidarização e

\footnotetext{
${ }^{60} \mathrm{Sr}$. Walmir dos Santos, diretor do STR-Barreiras, trabalho de campo realizado em julho de 2008.
} 
o agenciamento estatal generalizados dos sindicatos e uma mudança de foco de atuação, também contraditória, conforme já explicitado.

Os conflitos também permanecem, tanto nas relações de trabalho quanto no processo de privatização das terras. É visível, entretanto, que as vítimas não podem mais contar com os supostos defensores, seus representantes. Isto é mais evidente nos casos da grilagem e da expulsão dos camponeses das suas terras, motivo maior que resultou na organização dos camponeses em sindicatos. Por isso, cabe afirmar que os camponeses perderam para os mediadores sociais distanciados da base seu instrumento de luta contra a perversidade do capital, contra a superexploração por eles sofrida e isto está bem claro na concepção de diretores de sindicato entrevistados.

Por outro lado, enfatizo que é muito comum a partidarização das lideranças sindicais junto a partidos políticos que vêm alimentando o modelo opressor e, na medida em que se partidarizam, concordando com a ideologia dos governos que optaram pelo modelo de desenvolvimento pautado pelo agronegócio não têm mais ao que se contrapor, sem que não caiam em grandes contradições. Os governos, com seu modelo de desenvolvimento e a prática sindical afirmando-lhes pela via da partidarização, coincidem-se. Até porque muitos sindicatos se tornaram agências estatais de assistência social. Ou seja, se tornaram parceiros do Estado que financia e dá toda a condição de implantação do modelo que oprime representados dos sindicatos, os seus sócios, integrantes da legião de oprimidos. 
CAPÍTULO 2 


\subsection{As investidas contra as terras de trabalho camponesas no Oeste da Bahia}

Para as pessoas que vivem no conforto da cidade, essa questão pode parecer absurda. No campo, porém, é a questão do dia-a-dia, uma questão bastante complicada. Para entendê-la temos que compreender que a terra é um instrumento de trabalho, pois sem o trabalho ela não oferecerá os seus frutos, não alimentará a sociedade. Qualquer fazendeiro, qualquer camponês, qualquer trabalhador do campo sabe disso, muito bem. Por esse motivo, uma preocupação com a propriedade da terra é, também, necessariamente, preocupação com o principal instrumento de trabalho que há no campo. É, consequentemente, preocupação com quem trabalha e com quem não trabalha, com quem colhe os frutos do trabalho na terra (MARTINS, 1981, p.138).

$\mathrm{Na}$ perspectiva de desvendar os processos sociais relativos ao desenvolvimento do modo capitalista de produção na região Oeste da Bahia, discorro sobre as modificações na propriedade da terra na região, por considerar de grande relevância essa problemática nas relações sociais de produção.

Assim como outras regiões do Brasil, desde a década de 1970, o Oeste da Bahia vem passando por um processo de investida contra a apropriação camponesa da terra. Nesse processo, o Estado se destaca como o principal agente impulsionador dessa investida, fazendo a propaganda para atrair interessados na apropriação das terras da região, implantando a infraestrutura necessária ao desenvolvimento do capital e criando políticas de incentivos fiscais às grandes empresas.

Embora esse processo tenha sido mais intenso nas amplas áreas de terras da região amazônica, na região Nordeste também se fez presente de forma considerável. Nela, em especial no vale do São Francisco e oeste da Bahia, a primeira investida foi desferida contra as populações indígenas, logo a partir do século XVI, pelos grandes latifundiários criadores de gado e, mais recentemente, principalmente a partir da década de 1970, o capital nacional e internacional, tutorado pelo Estado, investe sobre os camponeses posseiros e pequenos proprietários de terra. Estes camponeses há muito tempo exploravam a terra como 
terra de trabalho e fonte dos meios de vida que assegurava o sustento familiar, constituindo, pois, uma forma de uso da terra fundada no trabalho. É essa modalidade de constituição da fração camponesa do território que se converterá no principal alvo à expansão da propriedade capitalista da terra, na investida sobre novas áreas visando, sobretudo, à acumulação do capital. Esta segunda forma de propriedade da terra Martins assim a define:

\begin{abstract}
Quando o capital se apropria da terra, esta se transforma em terra de negócio, em terra de exploração do trabalho alheio..." “... são regimes distintos de propriedade em aberto conflito um com o outro. Quando o capitalista se apropria da terra, ele o faz com o intuito do lucro, direto ou indireto. Ou a terra serve para explorar o trabalho de quem não tem terra; ou a terra serve para ser vendida por alto preço a quem dela precisa para trabalhar e não a tem. Por isso, nem sempre a apropriação da terra pelo capital se deve à vontade do capitalista de se dedicar à agricultura (1980, p.42).
\end{abstract}

A função da terra sofre, pois, um processo de inversão. Da condição de garantir a reprodução da vida daquele que nela trabalha à função de proporcionar (pela via da apropriação capitalista) a exploração do trabalhador quando posta a produzir; ou auferir renda ao proprietário para garantir a produção do capital quando este converte a renda em capital.

Faz-se necessário ao capital, para viabilizar a sua acumulação, ter à sua disposição quantidade sempre maior de trabalhadores despidos dos meios de produção à procura do capitalista que Ihe ofereça a oportunidade de trabalho.

a expropriação constitui uma característica essencial do processo de crescimento do
capitalismo, é um componente da lógica de reprodução do capital. O capital só pode
crescer, só pode se reproduzir, à custa do trabalho, porque só o trabalho é capaz de
criar riqueza. Por isso, uma lei básica do capital é a de subjugar o trabalho. Não há
capitalismo sem a subjugação do trabalho. Assim, na medida em que o trabalhador
vende a sua força de trabalho ao capitalista, mediante o salário, os frutos do seu
trabalho aparecerão necessariamente como frutos do capital que o comprou, como
propriedade do capitalista. Para que isso ocorra é necessário separar o trabalhador
dos seus instrumentos de trabalho; para evitar que o trabalhador trabalhe para si
mesmo, isto é, para evitar que deixe de trabalhar para o capitalista (MARTINS, 1980,
p.39).

Há, portanto, que intensificar a investida por novas áreas, provocando a expropriação dos camponeses e, no caso brasileiro, muitas vezes por métodos ilícitos e violentos. Ações estas aparentemente contraditórias à lógica do capital são executadas muitas vezes em favor e diretamente pelos grupos empresariais ditos modernos, através de jagunços, pistoleiros, polícia, cartórios e agentes do judiciário subservientes aos interesses do capital e até mesmo diretamente em seu próprio 
benefício, como são os exemplos concentrados no Pontal do Paranapanema, Estado de São Paulo, e em outras localidades do país.

No caso do Oeste da Bahia, há séculos os camponeses ali se instalaram nas terras devolutas, praticando a pequena agricultura. De modo geral, nos fundos de vale se apropriavam de parcelas para uso familiar onde cultivavam alimentos para o sustento da família e excedentes para comércio. Nas áreas mais elevadas, onde praticam a pecuária, a apropriação, de modo geral, se faz pelo uso comum da terra, nas soltas, concentradas mais próximas às comunidades e nos fechos de gerais, quando localizadas ou nos interflúvios dos afluentes ou nos chapadões, onde se localiza a maioria das nascentes que formam os rios da região.

Estas áreas de apropriação comum desempenham importante papel na reprodução camponesa, particularmente dos posseiros da região estudada. Nas comunidades, de modo geral, são reduzidas as áreas das terras que costumeiramente se apropriam, por meio do trabalho familiar na agricultura, e das quais extraem os meios de vida necessários ao sustento da família, como feijão, milho, mandioca, arroz e cana-de-açúcar. Dada a pouca especialização na produção, ou até mesmo sua inexistência, torna-se indispensável para a sua reprodução a disposição das áreas maiores de terras que costumeiramente se apropriam pelo uso comum. Nestas, desenvolvem as atividades complementares à agricultura, tais como a caça, a pesca, a coleta de frutos, de plantas medicinais, de madeira e praticam a pecuária (geralmente soltos e misturados), pois nelas, muitas vezes, estão as aguadas.

São justamente nessas frações do território camponês geraizeiro, pautadas pelo uso comum da terra, os fechos de gerais, que em geral inicia-se a tomada das terras de trabalho, pela propriedade capitalista caracterizada essencialmente pela privatização. Esta tem como marca mais significativa a cerca impedindo os acessos às riquezas naturais nelas existentes e que tradicionalmente eram acessíveis a todos aqueles reconhecidos como integrantes da comunidade.

Pelo fato de serem essenciais para a reprodução do campesinato, não concebo a forma de apropriação camponesa da terra típica da região em estudo como uma negação ao modo capitalista de produção e sim, contraditoriamente, como uma peça-chave na produção do capital. 
São comuns, nas cidades do Oeste da Bahia, as feiras camponesas. Para estas, os camponeses trazem os produtos da sua produção à venda e, com o dinheiro adquirido, compram outros produtos no comércio, ativando a economia local.

As antigas feiras costumeiramente ocorriam nos mercados municipais, geralmente situados na região central das cidades. Estes estabelecimentos tornaram-se insuficientes para as feiras crescentes e, por iniciativa dos administradores municipais, estas vêm ganhando instalações mais amplas e estruturadas para a sua realização, geralmente em localidades mais afastadas do centro, com galpões cobertos, "stands" e bancadas construídas em alvenaria. Isso parece demonstrar uma contradição, pois os administradores municipais, de modo geral, são integrantes das oligarquias locais e promotores diretos e/ou indiretos do modelo de desenvolvimento pautado na expansão da propriedade privada que expulsa o campesinato de suas terras de trabalho.

O que considero relevante é que as terras de uso exclusivo familiar, conjugadas às de uso comum, possibilitaram a reprodução do campesinato inserido no mercado. Este tem sido um fator de grande relevância para preservar uma importante autonomia dos camponeses praticamente sem a subordinação direta ao capital, pois, vendem o produto do seu trabalho, em geral a baixo preço, e compram as mercadorias no mercado, seja para o sustento da família e/ou para a realização do seu trabalho.

Outro aspecto a ter em conta é a possibilidade desse regime de apropriação permitir o assentamento das novas famílias camponesas, na medida em que podem expandir as áreas de cultivos sob aquelas costumeiramente destinadas a criatórios quando cultiváveis.

É importante ainda considerar o elevado grau de preservação das riquezas naturais que possibilita o regime de apropriação costumeira dos camponeses da região. Enquanto inseridos dessa forma no mercado, suas expectativas de consumo tendem a serem menores em relação àqueles inseridos em um grau mais elevado. Isso se evidencia na preservação por muito tempo da vegetação e consequentemente da abundância de água. Contraditoriamente, a expansão da agricultura dita moderna traz a morte de grande quantidade das nascentes dos cursos d'água da região, decorrentes dos desmatamentos que se expandem, ao 
represamento da água dos rios a serem bombeadas para abastecer os pivôs centrais, provocando a morte de córregos, ribeirões e rios. Quando estes morrem, passam a investir na exploração dos lençóis freáticos, perfurando profundos poços artesianos. Tem sido comum na região, às populações camponesas situadas à jusante, nas margens de rios, a falta de água até mesmo para o consumo doméstico. Mesmo sendo uma região que se destaca pela grande densidade hidrográfica, muitas comunidades localizadas principalmente nos municípios de Barreiras e Luiz Eduardo Magalhães, atualmente são abastecidas por caminhõespipas.

No outro lado, está o regime de apropriação camponesa que caracteriza-se por atividades que desmatam pequenas áreas de terra, o suficiente apenas para 0 cultivo dos produtos alimentícios. A área de criatórios, e de onde extraem madeira para construção, combustível, cercas e fabrico dos instrumentos de trabalho, costuma permanecer relativamente preservada, o que é muito positivo para a preservação da biodiversidade e para a proteção das nascentes dos riachos que formam importantes rios da região, que deságuam no rio São Francisco.

A expansão da propriedade capitalista da terra, ao contrário, abre no campo imensos vazios demográficos, pois, visam a extração de renda e lucro; a modalidade de apropriação camponesa geraizeira da terra, combinando a apropriação de parcelas de uso exclusivo familiar associada às de uso comum (as soltas e os fechos de gerais) sobressaem-se favoravelmente à reprodução socioterritorial camponesa quando comparadas com as apropriações exclusivamente parcelares, tal como se efetiva o modelo de assentamentos do Instituto Nacional de Colonização e Reforma Agrária (INCRA).

Como consequência da expulsão dos camponeses de suas terras, nas cidades da região é visível o crescimento da mancha urbana nas áreas periféricas, onde a ausência de equipamentos públicos de primeira necessidade é quase total. Em Barreiras, por exemplo, muitos de seus moradores foram expulsos do meio rural, em muitos casos de forma violenta, pela privatização capitalista da terra, e não raro, de forma ilícita pelos grileiros. Atualmente, quando encontram trabalho é na condição de bóias-frias nas terras que foram suas ou que deveriam lhes pertencer e não mais as são, porque se tornaram terras de exploração do trabalho alheio, de propriedade dos capitalistas. Na região, é grande a ocorrência de mão de obra 
oriunda de outras regiões dos Estados da Bahia, do Piauí, do Tocantins e outros. Os trabalhadores são atraídos para se submeterem às condições de trabalho precário nas lavouras ditas modernas. Nesta parte aí é onde está a situação. O pessoal não tem documento para trabalhar fichado, alojamento das piores qualidades, era lona preta parecendo assentamento de acampamento. ${ }^{61}$

Contraditoriamente, a burguesia local ostenta poder econômico, desfilando em luxuosas picapes pelos sertões, morando em condomínios fechados e de luxo assim como nos suntuosos prédios de apartamentos na cidade de Luiz Eduardo Magalhães, que simboliza o sucesso do agronegócio na região.

Assim, esta expansão da propriedade capitalista da terra, vem exaurindo tanto as possibilidades de sobrevivência das comunidades camponesas, quanto das riquezas naturais, que poderiam, se responsavelmente utilizadas, possibilitarem condições de vida dignas e promissoras tanto para a atual quanto para as futuras gerações.

\begin{abstract}
Quem contribui para a destruição desse cerrado está cometendo um crime, o maior crime que existe especificado nos nossos dicionários, que é o genocídio. O genocídio é o crime cometido contra a humanidade. O crime que se está cometendo no momento, destruindo todo o cerrado, é um crime maior do que isso, mas não tem qualificação para ele. E ele é classificado por enquanto como genocídio. Porque ele é um crime contra a humanidade. Porque se continuar da forma que está, essas crianças de 11 anos, de 12 , de 10 que estão na frente terão uma vida muito difícil pela frente. Isto é se conseguirem sobreviver (Professor Altair Sales Barbosa, da Universidade Católica de Goiás, em palestra no Primeiro Seminário do Bioma Cerrado da Bacia do rio Corrente, realizado pela Associação Ambientalista Corrente Verde de Santa Maria da Vitória-BA).
\end{abstract}

Este quadro exposto levou-me a ter como relevante para a análise da tese a questão da propriedade da terra decorrente da metamorfose da terra de trabalho à terra de exploração do trabalho ou de negócio. Adoto como direcionamento para a pesquisa a noção marxista, de que as condições originais de organização social do ser humano é condição para a realização do trabalho:

\begin{abstract}
uma relação do sujeito atuante (produtor) (ou um sujeito que reproduz a si mesmo) com as condições de sua produção ou reprodução como suas, próprias. Portanto, conforme as condições de produção, a propriedade terá formas diferentes. O objeto da produção, em si, é reproduzir o produtor em e simultaneamente com aquelas condições objetivas de sua existência. Seu comportamento como proprietário - que não é o resultado mas a condição prévia do trabalho, ou seja, da produção - toma a existência específica do indivíduo como parte de uma entidade tribal ou comunal (da qual ele próprio é, até certo ponto, propriedade) (MARX, 1991, p. 90).
\end{abstract}

\footnotetext{
${ }^{61}$ Sr. Walmir dos Santos, diretor do STR-Barreiras, entrevista concedida em janeiro de 2004.
} 
Assim, cabe àquele que trabalha, a decisão sobre os elementos da natureza nos quais lançou a sua capacidade de trabalho. Refiro-me, portanto, à autonomia de quem trabalha sobre o processo de trabalho. A partir da apropriação das suas condições objetivas de existência, poderá o trabalhador determinar o formato, o destino da sua obra e poderá ter a livre decisão de aplicar seus conhecimentos, patrimônio do grupo social, na transformação dos elementos da natureza para a reprodução de si e dos seus, podendo conferir a este o sentido que considerar importante na elaboração da obra no processo de trabalho (HOBSBAWM, 1991, p. 16).

A apropriação das terras pelas empresas atua contra o tradicional acesso direto das populações camponesas ao seu meio de trabalho. $O$ objetivo é extrair a renda da terra tanto pela produção que justifique o reconhecimento da propriedade ${ }^{62}$ ou pela via da especulação direta quando ocorre de não destiná-la à produção.

\begin{abstract}
O monopólio de classe sobre a terra assegura ao capitalista o direito de cobrar da sociedade inteira um tributo pelo uso da terra. É a chamada renda fundiária ou renda da terra. A renda não existe apenas quando a terra é alugada; ela existe também quando a terra é vendida. Alugar ou vender significa cobrar uma renda para que a terra seja utilizada. É o que se está observando agora nos chamados projetos de colonização particular. Posseiro não pode ter acesso a terra e dela é expulso porque não pode pagar por ela. Embora o Estado ceda essas terras a preços simbólicos a empresários capitalistas para que as revendam, para que negociem com elas. Fica com a terra quem pode pagar (MARTINS, 1980, p.42).
\end{abstract}

Assim, os capitalistas apropriam-se de imensas áreas de terras devolutas, há muito tempo ocupadas pelos camponeses posseiros, através do recurso da grilagem, expulsando-os violentamente.

Dentre os principais usos da terra, pelos expropriadores, destaca-se a pecuária:

e por que a insistência na pecuária? O gado não exige a presença física constante do empresário e, ao mesmo tempo, garante com facilidade a posse da terra. Há quem estranhe, ainda, a escolha da pecuária em função de sua conhecida baixa taxa de lucratividade, mas isso não pode ser aplicado de modo simplista à região, principalmente se observarmos os objetivos especulativos que orientavam a maioria dos que conseguiram terras no São Francisco. Sabe-se que a valorização, de modo geral, da terra, entre os anos $70 / 75$, girou em torno de $28 \%$ ao ano e, em algumas áreas de fronteira agrícola, em cerca de 38\%. Levando-se em conta que o governo investia em infraestrutura, que não havia praticamente risco nenhum em apostar na pecuária e que não havia qualquer exigência em se gastar consideravelmente com

62 "Entre 1967 e 1982, por exemplo, foram aprovados 37 projetos agropecuários de grupos empresariais na região, todos eles investimentos dirigidos prioritariamente à pecuária e, destaque-se, apropriados em sua totalidade por grupos sediados fora do espaço regional" (OLIVEIRA, 1983, p.22). 
insumos, é fácil perceber por que o empresário preferiu esse setor (JOSÉ, 1981, p.13).

São muito comuns nas localidades espalhadas pelo vale do São Francisco os reclames, das oligarquias detentoras do poder local, à atenção do Estado para investimentos em equipamentos no território, de modo a torná-lo propício à operacionalização das atividades mais favoráveis à reprodução do capital. $\mathrm{Na}$ medida em que este processo se desenvolve, tem-se, como consequência, a alta valorização das terras, o que torna compensador colocá-las a produzir ou vendê-las por preços exorbitantes a quem se interessar.

Enquanto executam o processo especulativo, recorrem a estratégias que camuflam essa contradição, incorporando um discurso que alardeia o inverso do que praticam: o retorno das práticas arcaicas travestidas de modernas ${ }^{63}$. Dessa forma, na expansão do capitalismo em busca da sua reprodução ampliada, "o que não poderá ser removido, será por ele apropriado e até mesmo recriado" Martins (1997).

O Estado coloca-se como o principal agente promotor desse modelo de desenvolvimento pautado pelas demandas de reprodução ampliada do capital. No Oeste da Bahia, esta intervenção desenvolvimentista representa, em parte, as demandas do capital internacional, concretizada por meio do convênio do Governo Federal com o Governo Japonês, conforme Kraychete \& Comerford,

a intervenção estatal na região também está associada aos interesses envolvidos na ocupação dos cerrados brasileiros, onde estão presentes empresas, cooperativas e o governo japonês, que participa técnica e financeiramente do PRODECER através da JICA (Japan International Cooperation Agency) (1991, p. 58).

Outros agentes passam a constituir o cenário no contexto das mudanças que se processam no território, "sobretudo personagens extra locais que aparecerão como os portadores das transformações da região: 'gaúchos' e japoneses em Barreiras, fazendeiros pernambucanos e de outras regiões em Santa Maria da

\footnotetext{
${ }^{63} \mathrm{~A}$ apropriação de grandes áreas para implantação de pastagens demonstra claramente o contrário do que pretendem justificar nos projetos: a expansão da propriedade privada da terra. Esta intenção é camuflada nos discursos de defesa dos empreendimentos empresariais para a geração de emprego. O contrário do que propagam nesse discurso demonstra Martins: "O estímulo à expansão das pastagens também causa amplo desemprego, mesmo que não haja modernização. Estudo do Núcleo de Altos Estudos Amazônicos, da Universidade Federal do Pará, mostrou que, nas novas fazendas de gado, cada 788 ha ocupam um único trabalhador. Segundo os critérios do próprio Instituto de Colonização e Reforma Agrária, que a região adota um módulo de 100 ha como área mínima para o trabalho do lavrador, aquela área teria condições de dar trabalho para 8 famílias" (1980, p.40). No caso do Oeste da Bahia em que o módulo rural é de 60 ha, a perversidade desse modelo expande sua marca de forma ainda mais aguda.
} 
Vitória, órgãos do governo e empresas privadas nos projetos de irrigação" (KRAYCHETE \& COMERFORD 1991, p.58).

Tais sujeitos sociais são portadores de uma mentalidade e uma concepção utilitarista das riquezas naturais e no âmbito do imediato têm suas práticas pautadas pelas forças que emanam de outra racionalidade econômica de mercado, que destroem as frações do território historicamente apropriadas pelas populações camponesas. Tradicionalmente, os latifundiários dominavam grandes áreas, com vista ao impedimento da liberdade dos camponeses, os quais podiam cultivar alimentos em "suas" terras, mas eram impedidos (se tentassem) de regularizar a propriedade em terras devolutas, as quais os coronéis se diziam donos (FREITAS, 1997). Assim, era interessante aos coronéis manter a massa de camponeses por perto, assegurando a oferta de mão de obra para a exploração ${ }^{64}$.

\subsection{A expropriação e a expulsão para a superexploração da força de trabalho}

O desenvolvimento do modo capitalista de produção é constituído de um par combinado. Isso quer dizer que é indispensável, para a acumulação capitalista, o exercício da dupla pressão do capital, visando à apropriação privada dos meios de produção (sendo a terra um deles), ou seja, expropriar o trabalhador das condições de produção dos seus meios de vida e, logo em seguida, explorar a sua força de trabalho, pois, nessas condições, ao trabalhador outra opção não restará, já que a única propriedade que lhe resta é a propriedade da sua força de trabalho.

$O$ relato a seguir destaca as consequências sofridas pelos camponeses posseiros:

Existia antigamente, mas depois da grilagem sumiu, foram empurrando, tão tudo na cidade, aí que tá o problema: o êxodo rural chegou, quem tava na zona rural teve que vir para as periferias. E hoje volta a trabalhar de boia-fria. A soja, o milho e até o algodão, para cada mil hectares eles usam um ou dois funcionários. Porque tudo é através da máquina: pra plantar, para colher, a colheita do algodão, a colheita da soja, a colheita do milho, é uma máquina sozinha com o operador e é colhendo e jogando em cima do caminhão, do basculante... ... onde é que tá a situação do trabalhador: os trabalhadores eles apanham gente no Piauí, pega em Tocantins, pega na Bahia em Irecê, quanto mais aquelas localidades que tem o êxodo da pobreza muito grande aí é que vem para Barreiras, para trabalhar aqui no Cerrado (Sr. Walmir dos Santos, diretor do STR-Barreiras, entrevista concedida em janeiro 2004).

${ }_{64}$ Vide casos relatados em "Porto Calendário", por Castro (1961), sobre o impedimento pelos coronéis da saída dos jovens para os centros urbanos até mesmo com o uso da força. 
Martins (1997) também indica importantes elementos para se entender o processo de degradação das condições de vida daqueles trabalhadores vitimados pela onda opressora do capital moderno, culminando na intensa exploração da sua força de trabalho, que o autor designa como peonagem ou escravidão por dívida (MARTINS, 1997, p.81). Afirma também, que este regime de trabalho atualmente está presente, sobretudo, naquelas regiões de fronteira ou de desenvolvimento, enfatizando a contradição embutida nesta relação de trabalho.

\begin{abstract}
Não estamos, portanto, apenas diante de um fenômeno de persistência de relações arcaicas de trabalho que, à primeira vista, têm sido muitas vezes definidas, impropriamente, como pré-capitalistas. Pois o que constatamos é que modernas empresas capitalistas que investem em empreendimentos agropecuários na vasta região da Amazônia brasileira (mais da metade do território de um país com cerca de oito milhões e meio de quilômetros quadrados) rotineiramente têm recorrido à escravidão por dívida em algumas de suas atividades (MARTINS, 1997, pp. 81-82).
\end{abstract}

O Oeste da Bahia, tal como a região amazônica estudada por Martins, é uma área de expansão do capital nos dias atuais e, por isso, não foge à regra. $O$ processo de expropriação desde a década de 1970 continua gerando a degradação das condições de vida e trabalho, e tal como afirmou o Sr. Walmir, esta é a tônica que atinge os trabalhadores expropriados.

A expropriação do trabalhador das suas condições objetivas de sobrevivência e as consequências por ele sofridas, em função disso, são importantes questões nesta pesquisa. E Marx nos indica a sua pertinência:

O que exige explicação não é a unidade natural de seres humanos vivos e ativos com as condições naturais e inorgânicas de seu metabolismo com a natureza e, portanto, sua apropriação da natureza; nem isto é o resultado de um processo histórico. O que tem de ser explicado é a separação entre essas condições inorgânicas da existência humana e a existência ativa, uma separação somente completada, plenamente, na relação entre o trabalho-assalariado e o capital (MARX, 1974, p.82).

Outro componente simultâneo à degradação das condições de vida e de trabalho é o processo de urbanização da população que vem se desenvolvendo na região. Dentre os principais centros, cabe destacar a cidade de Barreiras. Esta cidade apresentava taxas de crescimento médio anual de 8,11\%, de 1980 a 1991, e de $4,30 \%$, de 1991 a 1996. A população urbana desse município em 1980 era de 30.055, em 1991, 70.870, em 1996 de 87.455 habitantes e em 2010, 137.428. ${ }^{65}$

${ }^{65}$ IBGE, Censo 2010. 
Outro importante município da região é Santa Maria da Vitória, o segundo mais populoso do Oeste da Bahia com 40.316 em 201066. Nesse município, os camponeses travaram uma resistência, por meio do seu Sindicato Rural, contra a expropriação de suas terras pelos grandes fazendeiros grileiros; da mesma forma, os moradores da cidade, por meio da Associação dos Moradores de Santa Maria da Vitória, organizaram-se para reivindicar junto às autoridades municipais e estaduais equipamentos sociais e condições de vida dignas no meio urbano, pois a grande maioria era originária da zona rural, expulsos pela onda privatista de suas terras. Os camponeses expulsos da terra, em grande maioria, estão povoando as periferias das cidades da região.

\begin{abstract}
Você quer contar quantas (favelas)? Têm vários (casos). Os bairros periféricos aqui são denominados favelas e de outras cidades também. São Desidério é primeiro lugar. O nível de renda das pessoas é baixíssimo, pobreza mesmo. É o segundo município mais rico do oeste e o primeiro em pobreza. Mas o problema é que são rico para $15 \%$ da população, $15 \%$ escolhe o que come e $85 \%$ caça o que comer e não acha. O Brasil nosso é desse jeito (Sr. Walmir dos Santos, diretor do STR-Barreiras, entrevista concedida em janeiro de 2004).
\end{abstract}

Esses camponeses expulsos/expropriados, quando residem nas periferias das cidades locais, tornam-se trabalhadores nos empreendimentos modernos, em regime de bóias-frias, quando encontram trabalho, e não raro ficam desempregados, em uma constante procura de ocupações ou subocupações, pois não mais dispõem do pedaço de terra que garantia o trabalho e o sustento de sua família. Outros se deslocam à procura de trabalho sob as condições convenientes ao capital, como é o caso dos bóias-frias nos cortes de cana em vários pontos do país. Ou, ainda migram para os centros dinâmicos da economia capitalista, como é o caso da região Sudeste.

Contra esse processo expropriador se fez a resistência dos camponeses através do enfrentamento direto à ação violenta dos grandes fazendeiros, cujos casos foram os enfrentamentos organizados pelos Sindicatos dos Trabalhadores Rurais de Santa Maria da Vitória e de Correntina, como nos indica Kraychete \& Comerford,

a organização do Sindicato dos Trabalhadores Rurais de Santa Maria da Vitória, em 1974, seus momentos mais importantes e suas principais vitórias realizaram-se no âmbito da luta contra a grilagem. O assassinato de Eugênio Lyra, advogado do sindicato, em setembro de 1977, em pleno centro de Santa Maria da Vitória, e a

${ }^{66}$ IBGE, Censo 2010. 
morte de vários outros trabalhadores na resistência pela posse da terra expressavam um novo tipo de violência que envolveria a região. O Oeste baiano já não mais se configurava pleno de vastas terras "desdoadas de donos" (1991, p.69).

Porém como a investida contra a apropriação camponesa das terras continua em execução pelos grileiros, na atualidade os camponeses pouco esperam do papel a cumprir pelos sindicatos e até mesmo da pastoral da Igreja Católica (parceira histórica) nas suas batalhas. Por isso, as próprias comunidades têm se organizado em associações de Fundo e Fechos de Pastos e são estas que têm protagonizado a luta pela defesa de suas terras. Estas lutas são travadas tanto no campo jurídico, a enfrentar as muralhas do judiciário local e de outras instâncias, como, quando necessário, nas manifestações de rua, nas chamadas ventanias que derrubam e constroem cercas, pontes, casas de grileiros, muitas vezes, em revide à queima das casas de posseiros. As comunidades escolhidas para análise com maior profundidade compõem esse quadro conflituoso que vêm travando-se nos dias atuais em todo Oeste da Bahia.

\subsection{A Des-Ocupação do vale do São Francisco/Oeste da Bahia: um mergulho na história}

Opará, Rio-mar, rio tão grande quanto o mar. Este foi o nome primeiro dado ao Rio. As nações indígenas, habitantes de origem, viram o rio como espaço sagrado de vida, presente e presença do Criador. No dia

4 de outubro de 1501, encontrada a sua foz pelos conquistadores portugueses, o rio recebeu outro nome. Rio São Francisco, santo rio, mar

de vida. Utilizado como estrada pelos conquistadores em busca de riquezas, o rio facilitou a penetração nos interiores da nova terra. Assim, o espaço sagrado de vida foi usado como caminho para a morte, o saqueamento, a escravidão. Esta foi a primeira invasão. Passados quase quinhentos anos deste encontro, o rio continua sendo a fonte essencial de vida para seus filhos de todas as origens (CAPPIO et al, 1995, p.76).

No compartimento da Depressão do São Francisco, na margem esquerda do rio, a ocupação de origem europeia data dos primórdios da ocupação territorial portuguesa da colônia. Nesta área, predominou a formação de grandes latifúndios, concedidos pela Coroa Portuguesa à família Garcia D'Ávila da Casa da Torre, 
"tornando-se senhores de uma extensão territorial maior do que muitos reinos europeus, pois possuíam, em 1710, em nossos sertões mais de 340 léguas de terra nas margens do rio São Francisco e de seus afluentes" (ANDRADE, 1998, p.168), assim como à família Mestre de-Campo Antônio Guedes de Brito da Casa da Ponte "que possuía propriedades que se estendiam desde o Morro do Chapéu até às nascentes do rio das Velhas, compreendendo mais de 160 léguas de terras" (ANDRADE, idem), com a pretensão da prática pecuarista, sobretudo, "bois e cavalos aos engenhos $\mathrm{e}$ ao abastecimento dos centros urbanos em desenvolvimento" (ANDRADE, idem, p.167).

Não eram, porém, apenas esses latifúndios. Outros menores, embora de extensões importantes, também se formaram e foram acrescidos após a fragmentação dos maiores, provocada pela crise da atividade canavieira na Zona da Mata, formando-se, portanto,

\begin{abstract}
uma região dominada pela grande propriedade, mas onde os seus próprios donos não sabiam precisar o seu real tamanho, delimitá-la, construir cercas que marcassem os seus domínios. A relação entre custo e valor da terra inibia qualquer iniciativa nesse sentido. Essa atitude, entretanto, não deve ser entendida como ausência ou desinteresse. A terra, apesar de livre tinha dono, e todos sabiam e respeitavam. Os seus senhores, contemporaneamente indicados como coronéis, construíram e demarcaram um conjunto de relações que os tornaram proprietários do público e do privado, encarados como um conjunto, administrados como se assim fosse (GUERREIRO FREITAS, 1999, pp.60-61).
\end{abstract}

A vasta literatura histórica, entretanto, demonstra uma realidade historicamente conflituosa no campo desde os primórdios da Colônia, intensificada no início da República, e que vem se alongando até a atualidade. E esses conflitos, em boa parte, são motivados por questões de terras, levando à compreensão de que, aquele que mais podia ou pode estendia ou estende em maiores extensões as suas propriedades, pois, conforme Silva (2008, p.69), o poder público, apesar das incansáveis tentativas, jamais conseguiu controlar o território e impedir as irregularidades generalizadas, tanto no âmbito das sesmarias concedidas quanto das grandes posses que se generalizaram, constituindo-se imensos latifúndios usurpadores das terras públicas.

O respeito que se tinha aos limites das propriedades, portanto, não condiz com ausência de conflitos e confrontos, até porque a investida dos sesmeiros e grileiros sobre as posses camponesas eram constantes. E a não demarcação e/ou o não cercamento das terras, possivelmente, se explique pela possibilidade de 
expansão destas conforme o contexto na correlação de forças com os proprietários limítrofes. Este assunto é tema da obra do jornalista e romancista Wilson Lins, que foca os encarniçados confrontos belicosos entre esses verdadeiros potentados, que muito em função do papel que desempenhavam - como representantes do Estado naqueles tempos e em certa medida também hoje - os chefes políticos locais detentores de grande poder político disputavam entre si imensas áreas e 0 respectivo eleitorado, valendo-se do grande arsenal bélico em seu poder e do numeroso contingente de "cabras" dispostos ou coagidos a lutar pela preservação da honra do poderoso mandante.

Até bem pouco tempo as propriedades da região foram cenários de sangrentas lutas entre famílias locais, por questões de terra, gado e política. O vale do São Francisco foi o domínio dos "coronéis", em sua maioria grandes fazendeiros e chefes políticos. Carinhanha, Xique-Xique, Pilão Arcado e Remanso são municípios famosos pela violência que aí imperava no tempo das grandes lutas (IBGE, 1994, p.16).

Tem-se assim, a questão das terras como causa de conflito e, por meio do pacto coronelista (a troca de favores entre políticos estaduais e chefes municipais, geralmente grandes proprietários de terras), o poder dos coronéis era aumentado, tornando-se mais violentos e sangrentos os confrontos. Guerreiro Freitas (1999) também faz importantes menções ao grande poder desses mandantes e como ele era exercido, tratando-se do caso específico do oeste baiano.

\begin{abstract}
Naqueles dutos tempos, as pequenas vilas e cidades do vale do São Francisco, isoladas do resto do país, viviam entregues ao arbítrio dos coronéis, que eram os senhores da vida e da morte, especialmente da morte, de quantos ali habitassem. Os governos estaduais não tinham como fazer chegar as suas populações os efeitos da autoridade pública e dos mandamentos da lei. A justiça era distribuída pelos chefes locais, que dominavam os juízes e promotores, que, só em um ou outro caso isolado, reagiam à prepotência dos rudes senhores, e os poucos magistrados que ensaiavam reagir eram quase sempre transferidos, uma vez que os governadores dos Estados procuram de todo modo evitar choques com os governantes virtuais do Sertão, cujos aguerridos exércitos mantinham aqueles ermos inteiramente fora de controle de outra autoridade que não fosse a deles (GUERREIRO FREITAS, 1999, pp.62-62, apud. LINS, 1965, p.184).
\end{abstract}

Essa estrutura social, apesar dos tempos passados, ainda perdura, pois todos sabem da violência dos latifundiários nos dias de hoje, que varre o campo, expulsando a população camponesa de sua fração do território sob a conivência do poder público. O propalado Estado de Direito parece ficção. Os arranjos entre poderes executivos, legislativo, judiciário e muitas das instituições sociais em uma convergência para o atendimento dos interesses das classes dominantes, os 
coronéis de hoje, lembra o sistema colonial dos primórdios da história nacional, o pacto coronelista da República Velha e nos dias de hoje, a convergência de interesses das elites locais, para alavancar o modelo de desenvolvimento em execução pelo Estado. Gerentes de banco (do Brasil) que negarem empréstimo a fazendeiro com propriedades ilegais amanhecem comendo formiga ${ }^{67}$, assim como juíz que contrariar os interesses de poderosos também não ficam ${ }^{68}$.

Em meu entendimento, os fatos elencados não revelam uma ausência do Estado, como afirmou Lins e Guerreiro de Freitas, e sim uma forma deste se apresentar, embora carregada de contradições, se levado em conta o que promete ser o Estado na sociedade moderna. Trata-se, pois, não da ausência, mas da presença deste coadunando com o respectivo tempo histórico daquelas paragens. $O$ Estado moderno, assim se pretende, como Estado de direitos. Mas, conforme nos indicam os autores, o aparelho estatal é apropriado para o atendimento de interesses particulares, de classes ou grupos, a potencializar a opressão sobre a maioria desprovida de qualquer direito. Inclusive, é bom que se diga que essa contradição na ação do Estado não se restringe à área estudada. Essas relações sociopolíticas, conforme já demonstrado, são sustentadas pelos laços estabelecidos entre esses mandantes locais e outros atuantes em escala mais ampla do poder, em âmbitos estaduais e federais, que da mesma forma se reproduzem às custas das relações que estabelecem com os mandantes de escala local.

A configuração territorial e sociopolítica descrita, conforme indica Martins $(1994)^{69}$, persiste na história do Brasil. O vale do São Francisco é locus privilegiado dessas relações, porém em processo de mudanças consideráveis, resultantes de intervenções desenvolvimentistas estatais, que se realizam em benefício de setores privados da economia. Entretanto, esse processo vem carregado de contradições, pois, a complexidade da realidade em construção, é composta de um movimento constituído de persistências, alterações e recriações em uma coexistência não raro conflituosa.

$\mathrm{Na}$ atualidade, ainda se encontram casarões rodeados por antigos e imensos currais, tanto no oeste baiano quanto em outras localidades do vale do São

\footnotetext{
${ }^{67}$ Expressão muito comum nas falas dos interlocutores quando se referem às arbitrariedades praticadas pelos chefes / coronéis de hoje, muitos deles grandes empresários do agronegócio.

${ }^{68}$ Idem.

${ }^{69}$ Martins, José de Souza. O Poder do Atraso: ensaios de sociologia da história lenta. $2^{\underline{a}}$ edição, São Paulo, Hucitec, 1999, especialmente capítulo II.
} 
Francisco, os quais indicam a expressão dos empreendimentos dos chefes locais, que deram ao rio São Francisco a denominação de "rio dos currais". Mas, no povoamento de fato do vale, constituiu-se dezenas de aglomerados comunitários, em uma forma de "rosário", ocupando as margens dos rios, ribeirões e riachos. Daqueles nativos anciões ouve-se a história da chegada dos ancestrais, em grande maioria posseiros, e da constituição da extensa família, ramificando-se ao longo das beiras dos cursos d'água tanto a montante quanto a jusante, espalhando-se pelas terras livres.

A majoritária literatura histórica oculta o fato de que aqueles que se tornaram senhores das terras eram absenteístas habitantes das cidades mais expressivas da região ou até mesmo das capitais dos Estados. A ocupação de fato se realizou pelos escravos ou pequenos posseiros subordinados aos latifundiários concessionários de sesmarias ou grandes grileiros. No caso dos pequenos posseiros, estes

\begin{abstract}
eram obrigados a colocar-se sob proteção dos grão-senhores, não por temer 0 ataque dos índios, mas para não serem perseguidos pelos poderosos de Salvador. Reconhecendo o domínio da terra aos mesmos e tornando-se seus foreiros, estabeleciam-se com o curral e as reses no que chamavam de "sítio", pagando anualmente um foro que atingia em 1710, 10 mil-réis na Bahia. Estes sítios não tinham aquelas dimensões de principado das sesmarias, mas eram formados quase sempre por um lote de uma légua em quadro (ANDRADE, 1998, p.168).
\end{abstract}

É oportuno observar a relação de sujeição que se realizava no âmbito da propriedade da terra oriunda das exigências da Coroa Portuguesa para a concessão de sesmarias, excluindo desse direito aquela população que deveria tornar-se subordinada aos cidadãos de bem, os fidalgos, pois aquele trabalhador da terra, camponês, seria obrigado a sujeitar-se ao senhor, seja como agregado direto da fazenda ou como foreiro de fragmentos (geralmente de uma légua quadrada de área) arrendado do sesmeiro ou grande grileiro.

Esta intervenção no vale como já afirmado, representou ainda um verdadeiro genocídio aos nativos da região, praticado por bandeirantes oriundos do Sudeste, São Paulo, e do Nordeste, Pernambuco e Bahia, como também pelos agentes dos empreendimentos pecuaristas instalados, sob pretexto de ocupação econômica. Lins (1983) informou seu objetivo maior:

ao tempo em que davam a penetração do grande vale, os colonizadores, em vez de povoarem-no, promoviam o seu despovoamento, matando o gentio que o ocupava. Plantando currais pelo ermo adentro, o explorador branco substituía por boiadas as tribos que encontrava no seu caminho. Matando ou escravizando o índio, o colonizador português, a princípio realizou uma obra de escravização e extermínio de 
toda uma nação, e não de civilização de um povo. Por causa da tão propalada falta de braços para a lavoura, que em várias oportunidades iria determinar a paralisação dos engenhos do litoral, generalizou-se a caça ao silvícola, comandada quase sempre pelos próprios governadores, como é o caso do governador Luiz de Brito e Almeida, que venceu e escravizou os nativos do rio Real (LINS, 1983, p.21).

Vê-se, portanto, a importância assumida pela escravidão colonial. Isso inclusive é também lembrado por Martins (1996, p.15), quando aborda a importância assumida pela quantidade de braços em posse dos fazendeiros a Ihes conferir acesso a créditos sob a penhora da quantidade de escravos em sua posse.

O escravo tinha dupla função na economia da fazenda. De um lado, sendo fonte de trabalho, era o fator privilegiado da produção. Por esse motivo era, também, de outro lado, a condição para que o fazendeiro obtivesse dos capitalistas (emprestadores de dinheiro), dos comissários (intermediários na comercialização do café) ou dos bancos o capital necessário seja ao custeio, seja à expansão de suas fazendas. O escravo era o penhor de pagamento dos empréstimos. Por isso, praticamente todo capital de custeio provinha de hipotecas lançadas sobre a escravaria das fazendas. Tendo o fazendeiro imobilizado nas pessoas dos cativos os seus capitais, transfigurados em renda capitalizada, subordinava-se uma segunda vez ao capital comercial, mediante empréstimos, para poder por em movimento os seus empreendimentos econômicos, inclusive para promover a abertura de novas fazendas e adquirir equipamentos de benefício (MARTINS, 1996, p. 26).

Os objetivos das atividades econômicas desenvolvidas na colônia não eram apenas o cultivo de produtos tropicais para o abastecimento do mercado europeu, sob comando da Coroa Portuguesa. Uma das grandes motivações do sistema colonial, era também o comércio de escravos africanos escoados na colônia, a servir ao trabalho agrícola nas lavouras de cana-de-açúcar, no primeiro momento, e, em seguida, na mineração e no café.

Continuando esse raciocínio, pode-se apontar, a partir do que nos indica Lins, um importante objetivo da distribuição das terras sertanejas, compreendendo o vale do São Francisco e a sua porção do Oeste da Bahia, convertidos nos imensos latifúndios das famílias Guedes de Brito e Garcia D’Ávila. Áreas tão extensas de terras que abarcariam uma imensa quantidade de nativos a serem aprisionados e comercializados para a escravização na Zona da Mata, cumprindo, assim, dentro do próprio território colonial, uma função congênere àquela desempenhada pelo sistema colonial, no caso do comércio de escravo. Martins assim se referiu:

A sujeição da produção ao comércio impunha a extração de lucro antes que o trabalhador começasse a produzir, representando, pois, um adiantamento de capital, ele não entrava no processo de trabalho como vendedor da mercadoria força-detrabalho e sim diretamente como mercadoria; mas, não entrava também como capital, no sentido estrito, e sim como equivalente de capital, como renda capitalizada. A exploração da força de trabalho se determinava, pois, pela taxa de juros no mercado 
de dinheiro, pelo emprego alternativo do capital nele investido antecipadamente, isto é, o cálculo capitalista da produção era mediado por fatores e relações estranhos à produção (MARTINS, 1996, p. 15).

Haveria, pois, para a viabilização do pretendido, de impedir o acesso à terra aos escravos e aos camponeses pobres, os quais deveriam se inserir em condições de sujeição no referido sistema. E, ao indígena, restou como alternativa a sujeição, no trabalho forçado, ou o extermínio - o que aconteceu por completo com alguns povos.

Evidencia-se a contradição na ação do Estado; pois, "como os padres se opunham a caça aos índios, os empreiteiros das expedições procuravam fazer crer que as tribos que povoavam as margens do São Francisco eram ferocíssimas" (LINS, idem) e, sob esses argumentos, os invasores e o próprio Estado buscavam justificar a violência desferida sobre os nativos agindo

como horda inimiga, arrasando o silvícola desprevenido. Alegando tratar-se de seres muito ferozes, procuravam obter a tolerância dos padres para as suas entradas, cujo objetivo era mais o apresamento de escravos (que eram vendidos a dois cruzados por cabeças), do que o desbravamento da terra desconhecida (LINS, 1983, p.21-22).

Nos currais espalhados vale afora, deixavam alguns agregados (vaqueiros e/ou escravos) e algumas cabeças de gado para futuro rendimento sob cuidados do vaqueiro, quando era o caso, sob recompensa no regime de quarteação ${ }^{70}$. Vê-se, pois, que, "com todos os seus defeitos e erros, é a tais caçadores de índios que se deve a penetração nas terras do vale são-franciscano" (LINS, 1983, p.22). E, apesar do pouco emprego de mão de obra, que é característico da atividade pecuarista extensiva praticada na região, esta contribuiu, ao longo dos tempos, para o povoamento, constituindo um campesinato que compreendia os trabalhadores desses empreendimentos.

Esta ocupação latifundista da terra assentava-se nas terras devolutas que, conforme já assinalando, eram mantidas sob domínio dos mandantes locais quase que exclusivamente pelo seu poder de mando, respaldado na força bélica e na ligação com os chefes dos poderes de outras instâncias. Estas extensas terras eram de pouco valor monetário, tanto que os autodenominados donos alegavam não compensar medir e muito menos cercá-las. No entanto, todas tinham "dono". O

\footnotetext{
70"O termo quarteação origina-se da prática de, a cada cinco anos, o fazendeiro repassar ao vaqueiro um quarto das crias acumuladas durante o período, como forma de remunerar o trabalho do empregado" (MENEZES, 2010, nota de rodapé, p.4).
} 
domínio sobre os imensos latifúndios visava, pois, manter o controle das terras e da massa de camponeses sujeitas a esses mandantes, pois até mesmo a migração para outros lugares ou regiões era impedida pelos ditos senhores, conforme mostrou Castro (1961, p.58), no depoimento de um coronel (no caso, Major Queirós) sobre a preocupação dos coronéis de Santa Maria da Vitória com a grande migração:

vai deixar o Corrente (vale) no casco. Irá tudo para São Paulo e quem haverá de pensar? De um tempo para cá, até as mulheres tão se indo. Assim, Santa Maria da Vitória, sem gente para trabalhar, vai ficar como a Igreja de Sítio do Mato. Restará santo, rico e morcego.

Clodomir Morais também mostrou que a crise de 1929 atingiu sobremaneira a economia sertaneja da região e "na falta de emprego, mesmo para os filhos de famílias de alguns recursos, muitos jovens tiveram que arribar, gerais afora, rumo a Goiás, Mato Grosso e São Paulo" (MORAIS. In: O Posseiro, 1987).

E os mandantes locais lançaram mão de medidas imperativas como as que seguem:

\begin{abstract}
Santa Maria da Vitória que, no meio século de seu aparecimento e 20 anos de seu 'status' de cidade, apresentava um razoável desenvolvimento, na década de 30 entraria em plena decadência econômica e cultural. O esvaziamento demográfico era tão visível que, em 1938, mais de 40 casas (10\% do total de prédios urbanos) estavam vazias e metade destes se arruinando a olhos vistos dado o abandono total. O intendente, ou prefeito municipal, coronel Clemente, com o propósito de conter a fuga de 'braços', do município emitia editais proibindo a transumância. Não obstante fossem injustas as medidas desses editais bem como as de outros editais combatendo a vadiagem, elas se circunscreviam no entanto, dentro da lógica da única grande empresa capitalista do município ('Araújo Castro e Cia') consumidora de 'plus-valia' de centenas e centenas de assalariados nas colheitas de algodão, sobretudo nas fazendas Mazangá e Lagoa da Tábua (MORAIS. In: O Posseiro, 1987).
\end{abstract}

Cabe destacar que a dita empresa Araújo Castro e Cia pertencia ao intendente municipal, coronel Clemente de Araújo Castro.

E os desmandos prosseguiam:

Para um maior controle do fisco municipal a cidade foi toda cercada com 12 fios de arame farpado em grossos mourões de muçambé e aroeira. Cinco cancelões com tramelas e o Rio Corrente constituíam as únicas vias de acesso ou de saída da 'urbs' (MORAIS. In: O Posseiro,1987).

A estrutura social e política engendrada e imposta pelos mandantes locais, como não podia ser diferente, provocava repulsa da população oprimida. Disto resultou o deslocamento populacional dos camponeses locais e dos oriundos de outras regiões do Estado da Bahia, submetidos à mesma estrutura social, para a 
montante dos afluentes do rio São Francisco e de seus subafluentes localizados nos gerais. É comum encontrar moradores nas margens dos médios e altos cursos desses rios originários principalmente de Macaúbas e de outras localidades do vale do Paramirim, afluente da margem direita do São Francisco, na altura do Oeste da Bahia, os quais afirmam terem fugido das rigorosas estiagens ocorridas nas últimas décadas do século XIX e da falta de terras para plantar.

\subsection{0 uso comum da terra no Brasil}

No Brasil, são muitas as ocorrências de uso comum da terra. Elas contêm muitas especificidades, as quais guardam relação com os aspectos históricos, econômico-sociais e com o quadro natural. Assim, apresento a seguir as ocorrências na região sul do Brasil, localizadas no Estado de Santa Catarina, objeto de estudos de Campos, em sua dissertação de mestrado (1991) e na tese de Doutorado (2000), e a ocorrência dos Faxinais localizados no Estado do Paraná, estudados por Chang (1985), Campos (1991 e 2000), Tavares (2005 e 2008).

Para as ocorrências de uso comum da terra no Estado da Bahia, dedico especial atenção em um tópico exclusivo, para, em seguida, ater-me às que constituem a preocupação central deste trabalho, as da região Oeste do mesmo Estado.

Pode-se afirmar que o uso comum da terra é muito característico das modalidades de apropriações camponesas da terra. E, sendo assim, a relevante ocorrência deste tipo de apropriação da terra na região sul do Brasil, muito provavelmente, guarde estreitas relações com o modelo de ocupação territorial daquela parte do país. Aquela região, neste aspecto, é bastante peculiar em relação às demais do Brasil; pois, enquanto outras tiveram sua ocupação pautada pela concessão de grandes glebas de terras (sesmarias) pela Coroa Portuguesa àqueles que se dispusessem explorá-las, a ocupação da região Sul se deu com o intuito de povoá-la, protegendo-a da pretensão de invasão pelos espanhóis.

Ali, desde 1748 , foram concedidas parcelas de terras relativamente pequenas aos colonos europeus e, no caso da llha de Santa Catarina, onde o estudo de Campos (1991) se atém com maior profundidade, foi ocupada preponderantemente pelos colonos originários dos Açores e da llha da Madeira. 
No contexto da economia açoriana, havia também a utilização de terras comunais, também conhecidas por logradouros públicos ou outras designações regionais. Eram de grande importância para o pequeno produtor, pois complementavam sua economia (quando não, sua própria sobrevivência) principalmente daqueles mais pobres (CAMPOS, 1991, p.38).

Trouxeram consigo para a nova terra o uso costumeiro que praticavam em sua terra de origem.

Quanto à afirmação da ligação do uso comum da terra com a forma de apropriação camponesa da terra, assim compreendo por ser muito comum a limitação das terras que os camponeses tradicionalmente apropriam-se para dela, pelo trabalho familiar, extrair os meios necessários ao sustento da família. Nestas, desenvolvem as atividades complementares à agricultura (e não raro esta atividade é praticada até mesmo na terra de uso comum), à pecuária (geralmente com o gado solto e misturado). Ao contrário do que afirma Engels (1987), e com ele corrobora Campos (2000, p.20), não reconheço estas terras como "excesso de solos ou sobrantes". As terras de uso comum, em meu entendimento, são indispensáveis para a reprodução do camponês com relevante autonomia - e estudos comprovam que não raro a permanência da produção camponesa em suas parcelas de uso exclusivo familiar interdepende das atividades praticadas nas terras de uso comum $^{71}$. As pequenas parcelas camponesas são insuficientes para fornecer-lhes o material para a construção de suas moradias, a madeira para a construção de cercas, instrumentos de trabalho, combustível (lenha) para o preparo dos alimentos e mesmo para os criatórios tão significativos na economia do núcleo familiar e comunidade camponesa. Esses criatórios têm funções variadas. Eles podem ser empregados como força motriz nos engenhos, no transporte, no abastecimento alimentar da família e ainda como "poupança" para eventos como casamentos de filhos, momentos de crise na produção do roçado, podendo ser vendidos também para possibilitar a ampliação da terra apropriada e assentar a família crescente. Da terra de uso comum, também coletam frutos, plantas medicinais, caçam e nelas às vezes também estão as aguadas.

\footnotetext{
${ }^{71}$ Isto foi constatado em pesquisa para a minha dissertação de mestrado realizada nos Brejos da Barra, município de Barra (BA), conforme SOUSA SOBRINHO, José de. Brejos da Barra-BA: comunidades camponesas no processo de des-envolvimento no Vale do São Francisco, Dissertação de Mestrado - Departamento de Geografia da Faculdade de Filosofia, Letras e Ciências Humanas da Universidade de São Paulo, 2006. Especialmente capítulo III.
} 
Pelos motivos apresentados, não as concebo como terras sobrantes e sim como parte inerente ao sistema que compõe a apropriação camponesa da terra. Como poder-se-á ver mais adiante, são justamente por essas terras de uso comum que geralmente iniciam-se as investidas contra à apropriação camponesa da terra, pela propriedade capitalista. Sua marca mais significativa é a cerca impedindo os acessos às riquezas naturais nelas existentes e que tradicionalmente eram acessíveis a todos aqueles reconhecidos como integrantes do grupo comunitário.

O acesso livre às riquezas naturais contraria a lógica capitalista e a história mostra evidências disto no Código Civil português de 1867, o qual, como nos informa Campos (1991, p.52), entregava os pastos comuns à municipalidade, com a possibilidade de serem distribuídos, pois considerava, em seus "artigos 2.262 e 2.266 que os baldios eram uma espécie de propriedade comum altamente inconveniente para o progresso e desenvolvimento da agricultura" (CAMPOS, 1991, p.52).

Tal como aconteceu no Brasil, principalmente na década de 1970, em Portugal, na década de 1960, o governo salazarista "em seu programa de florestação, requereu grandes áreas de baldios para a plantação de pinheiros no norte de Portugal" (CAMPOS, 1991, p.52).

Quanto à situação jurídico-espacial e à representação das terras de uso comum para as comunidades, Campos assim se referiu:

\footnotetext{
Margeando as propriedades individuais encontram-se as áreas abertas, 'livres', terras 'sem dono'. Por isso a comunidade acha-se no direito de utilizá-las coletivamente, sem restrições e preocupações com qualquer regime jurídico de propriedade. Esse direito é predominantemente baseado na tradição, cujos usuários consideram que tais áreas eram coletivamente utilizadas 'desde tempos antigos, já da época de nossos bisavós...'. Deixam assim entender a antiguidade do instituto. Os documentos muitas vezes reconhecem tal antiguidade, considerando o uso comum 'desde os tempos imemoriais' (2000, p.81).
}

Este autor definiu-as ainda como de "interesses da comunidade" (CAMPOS, 2000, p.81) e "conjugando interesses internos e externos à comunidade" (CAMPOS, 2000, p.119). Como exemplo do primeiro caso, cita as localizadas na fachada litorânea do Estado de Santa Catarina, onde ocorre a prática agrícola em terras comuns pelos caiçaras, os campos de altitude ou Estivais (Campos dos Padres, Serra do Tabuleiro e da Boa Vista). Estes são utilizados pelas comunidades dos municípios de Santo Amaro da Imperatriz, Águas Mornas, São Bonifácio, Palhoça e Paulo Lopes. Neste grupo, se incluem ainda os campos de uso comum cooperativo, 
como o Campo da Eira ou o Campo de Madre (entre os municípios de Tubarão e Laguna, Sul de Santa Catarina), Campo da Eira e Campo de Baixo (município de Laguna), Campo da Pirituba (município de Gravatal).

Quanto ao segundo caso, Campos citou ocorrências no município de Lages (SC), definindo-as como de interesse dos latifundiários. Estes casos são por eles permitidos para garantir, próximas às suas propriedades, a presença dos camponeses que lhes ofereçam mão de obra em suas fazendas. Ainda no mesmo caso, Campos faz referência às terras de uso comum junto aos caminhos de tropas, para engorda e descanso do gado, ao Campo de Araçatuba (imensa área do município de Palhoça (SC)). Na Ilha de Santa Catarina, fez referência ao Campo da Barra, Campo da Carniça, Campo Magalhães, Campo D’Una. E, no Estado do Paraná, citou os Faxinais.

Quanto aos casos de uso comum presentes na llha de Santa Catarina, Campos (1991) afirmou que, até as décadas de 1940 e 1960, a quase totalidade da ilha tinha seu uso e sua ocupação sob o regime de uso comum da terra. Ali se instalavam as comunidades que, nas proximidades de suas terras, dispunham de imensos campos, cujos limites constituíam-se de barreiras naturais, tais como: rios, riachos, morros, banhados, dunas e matas. Nessas áreas, praticavam fundamentalmente os criatórios soltos e misturados, porém, nos terrenos rebaixados, onde se encontravam solos agricultáveis, principalmente aqueles camponeses menos abastados, os aproveitavam no cultivo da mandioca (principalmente), milho, feijão, melancia, batata-doce, mamona e algodão.

Outro uso também muito significativo destes campos consiste na retirada de madeira para construção das cercas, mobiliários domésticos e instrumentos de trabalho (prensas, engenhos, etc.), para uso geral.

Esses usos indicam a importância das terras de uso comum, principalmente nos tempos em que a circulação do dinheiro no interior das comunidades tradicionais era inexpressiva. E, sendo assim, pode-se deduzir o quanto dependente eram essas comunidades das áreas florestadas em que pudessem retirar os materiais para a construção de moradias, equipamentos de trabalho, para alimentar os animais tão indispensáveis no processo de trabalho e em sua economia, bem como a lenha para a preparação dos alimentos nos tempos em que o fogão a gás não era acessível para muitos em função do baixo poder aquisitivo. 
Quanto à organização comunitária, relativa aos usos dos campos comuns, muitas normas eram estabelecidas por leis municipais, as quais puniam com multa os casos de desobediência. Mas parte importante do funcionamento também era regida pelo espírito da vivência em comunidade. Sendo assim, "a relação no interior das áreas comunitárias era a extensão das que mantinham no interior da comunidade, no dia-a-dia: uns olhavam os gados dos outros - havia uma confiança recíproca" (CAMPOS, 1991, p.115).

Até mesmo a Lei de Terras, de 18 de setembro de 1850, garantia a reserva nas proximidades das povoações e freguesias dos terrenos necessários para os logradouros públicos. Essas terras eram administradas pelas Câmaras Municipais, que cobravam aforamento conforme garantia os Artigos 27 e 30 da Lei Provincial №. 347, de $1^{\circ}$ de maio de 1852 (CAMPOS, 1991, p.128).

Porém, a Constituição republicana de 1891 transferiu a administração dessas terras para a responsabilidade dos Estados. A partir desta data, intensifica-se o processo de intromissão dos interesses privados sobre as terras de uso comum, tradicionalmente utilizadas pelas comunidades. Intensificou-se a prática das autoridades da instância provincial em conceder, aos interessados das localidades, essas áreas em troca de favores.

Entre muitos, constam políticos de renome, militares, intendentes, comerciantes da capital, etc. Nem sempre cercavam as áreas comunais de imediato, permitindo, assim, sua utilização por algum tempo ainda. Boa parte, contudo, não só cercava, como impedia o trânsito por servidões antigas (CAMPOS, 1991, p.131).

A década de 1960 é marcada pelo intenso crescimento de Florianópolis. Isto culmina com a transformação dessas áreas em campos de monta para o abastecimento da população urbana. E, posteriormente, com a intensificação do processo de privatização, transformam-se em loteamentos e chácaras privados.

O regime autoritário instalado em 1964 muito contribuiu para o processo de privatização, através das concessões indiscriminadas aos interesses privados. Estas concessões foram interrompidas em 1982, sob interferência da Procuradoria Geral do Estado, que as considerou ilícitas.

No entanto, a investida continua com o aumento da classe burguesa em Florianópolis e com a integração de Santa Catarina ao turismo brasileiro. Isto resultou na expansão e na especulação imobiliária e no desenvolvimento da infraestrutura turística nos mais variados pontos da ilha, instalando os balneários, os 
bairros e os hotéis de luxo nas áreas antes ocupadas pelas comunidades camponesas, nas antigas terras de uso comum.

Uma importante experiência de cooperação apresentada por Campos (2000) são os campos de uso comum cooperativos. São três as experiências apresentadas e uma delas é a Cooperativa dos Usuários dos Campos Públicos Ltda (COOPERCAMPO). Esta cooperativa foi fundada em 1976, após o grande aumento das pressões privatizantes da terra, depois da década de 1950. O terreno apropriado pela cooperativa abrange a área de 1.200 ha, pertencentes ao Estado, o qual permite o usufruto pelos cooperativados (CAMPOS, 2000, p.111).

São campos de uso comum para criatórios de gados bovinos e de equinos. "Para uso do campo, cada associado paga uma taxa equivalente a um saláriomínimo e $R \$ 0,70$ mensal por cabeça de gado mantida no campo. Este dinheiro destina-se à manutenção e à limpeza do campo, à construção de valas e drenagens, de banheiros carrapaticidas, de mangueiros, à compra de remédios, entre outros benefícios" (CAMPOS, 2000, p.111).

Cada usuário pode criar no campo, no máximo, 30 cabeças de gado. Acima deste número, considera-se em condições de criar o gado em sua parcela.

A Cooperativa começou com 100 associados e aproximadamente 2.000 reses. Nos finais da década de 1980, contava com 482 associados e mais de 7.000 animais. Este número é considerado o limite máximo para o campo. Na década de 1990 atingiu 526 sócios, mas sem ultrapassar o número máximo de animais permitidos (CAMPOS, 2000, p.111).

O gado bovino é destinado ao corte e à produção de leite e cada criador administra a venda do seu gado. O criatório para alguns é suplemento ao autoconsumo e outros o direciona ao mercado.

Campos (2000) apresentou ainda mais duas experiências de campos de uso comum cooperativo. Uma delas é a Cooperativa de Santo Antônio dos Anjos, dos criadores dos campos públicos de Laguna Ltda (COOPERSANTO), no município de Laguna (SC). Esta cooperativa foi oficializada em 1980 e é formada pelos moradores das comunidades da Madre, Ribeirão Grande, Ribeirão Pequeno, Parobé, Figueira, Morro Grande, Bananal, Laranjeiras, Km 37 e Cabeçudas (CAMPOS, 2000, p.114). No ano 2000, esta cooperativa contava com 305 sócios e continha de 2.000 a 2.500 cabeças de gado. Neste campo, é permitido criar no mínimo 5 e no máximo 30 
cabeças de gado, sendo que cada sócio paga a taxa de 30 reais para cada 5 cabeças e $\mathrm{R} \$ 0,30$ mensais por cabeça.

A outra experiência é a Cooperativa de Criadores Tradicionais do Campo da Pirituba (COOPERTUBA) que surgiu em 1996, nos mesmos moldes da COOPERCAMPO e da COOPERSANTO. Esta ocupa uma pequena área do antigo e imenso Campo da Pirituba (CAMPOS, 2000, p.115).

Entendo que essas experiências representam resistências às investidas privatizantes das terras utilizadas comunalmente pelos camponeses. Ao sofrerem as ameaças da impossibilidade da sua reprodução, por meio da usurpação das suas terras de criatórios tão indispensáveis para o sustento da unidade familiar, estes engendram meios de ter garantida a apropriação das suas terras de trabalho.

\subsubsection{Os Faxinais do Estado do Paraná}

Outra modalidade de uso comum da terra que apresento, a partir de Chang (1985), Campos (1991 e 2000) e Tavares (2005 e 2008), são os Faxinais. Trata-se de "uma forma particular de aproveitamento da mata conjugada às áreas circunvizinhas, cuja peculiaridade se assenta sobre o uso comum das terras de faxinal para a criação extensiva e para o extrativismo da erva-mate" (CHANG, 1985, p.86).

Os faxinais têm mais de um século de existência e o costume de criar os animais soltos é praticado pelos moradores locais desde o século XVIII. Esta modalidade de uso comum da terra ocorre na região Sul do país e esta abordagem refere-se à região centro-sul do Paraná (onde se concentra grande parte dos faxinais), incorporando 18 municípios da região, conforme Tavares (2005, p.4) ou “aproximadamente 1/6 da superfície do Estado" (CHANG, 1985, p. 87).

Grande parte dos faxinais assenta-se em propriedade privada, mas parte deles está em terras devolutas. Em ambos os casos, apenas o uso da terra é comum. A apropriação do trabalho é individual.

No Paraná, a origem dos faxinais, conforme Chang (1985, p.88), está relacionada com os ciclos econômicos do Estado. O primeiro ciclo foi o da mineração, o segundo da pecuária (importante na fixação do homem e nos desenvolvimentos iniciais da província), o terceiro, do café, e o quarto, da soja. 
Os latifúndios na região dos faxinais eram doados pela Coroa aos coronéis que pouco exploravam as terras. Com a decadência da pecuária e a ascensão do mate, a população interiorizou-se nas matas mistas, onde se encontram os ervais nativos. Devido ao costume tanto da parte dos caboclos quanto dos fazendeiros, da prática dos criatórios soltos, ambos migraram para o interior da mata. Ali, durante todo o ano, praticavam a pecuária e, no tempo da colheita do mate, o proprietário da terra tinha à sua disposição a mão de obra cabocla (agregado) para a colheita da erva-mate (CHANG, 1985, p.89).

De modo mais detalhado e enfatizando o viés costumeiro dos iniciadores dos faxinais, e em uma visão menos econômica que a adotada por Chang (1985), Tavares (2008) atribuiu a gênese dos faxinais às práticas de uso comum dos indígenas fugitivos do sistema de peonagem, conjugada à prática de criatórios de animais soltos pelos escravos africanos não aquilombados (mais a prática de extração da erva-mate por ambos os sujeitos sociais). Desta combinação, "constituíram os elementos fundantes na construção dos faxinais que no início do século XX" e, em seguida, "recebeu a contribuição significativa dos imigrantes europeus, principalmente dos camponeses do leste europeu (Ucrânia e Polônia); e da fração dos camponeses que participaram da Guerra do Contestado" (TAVARES, 2008, p.383).

Após apresentar várias definições dos faxinais, elaboradas pelos sucessivos pesquisadores que os estudaram, assim como as definições dos próprios faxinalenses coletadas em entrevistas, Tavares assim os definiu:

É preciso ter claro que o faxinal encerra muitos elementos histórico-geográficos, sociocultural, econômico-político, e especialmente humano-natural. Portanto, inicialmente, na contemporaneidade, compreendo como uma formação social tipicamente camponesa, silvo-agro-pastoril, com tradição secular de terra de uso comum, independente de a propriedade ser privada ou não, que constrói, mantém e reconstrói a fração do território comunitário camponês faxinalense em uma combinação de três elementos inseparáveis que conformaram a tríade de sua sustentação:

1. Terras de uso comum no criadouro comunitário ou comum - terras de criar e viver formadas por várias parcelas de terras contíguas de uso comum, assim como os recursos naturais - biodiversidade - nelas contidos. As terras e os recursos naturais são apropriados de forma total ou parcial, dependendo da interação interna de seus membros em que o elemento principal é a posse e não a propriedade;

2. Cercas das terras de uso comum no criadouro comunitário ou comum delimitam os criadouros das terras agrícolas - planta ou plantar - independente das terras pertencerem à fração do território comunitário camponês faxinalense, pois, na maioria das vezes a distribuição geográfica das terras que compõem a fração do território comunitário camponês faxinalense, não é contígua ao criadouro comunitário ou comum; 
3. Terras agrícolas - majoritariamente de propriedades privadas e posses individuais; mas podendo existir outros tipos de posses, como a posse em terras devolutas e terras públicas patrimoniais ou próprias (TAVARES, 2008, p.574).

Nesta definição, pode-se notar que Tavares realça fatores primordiais à realização da comunidade camponesa, tal como a não especialização de suas atividades, explicitada em seu caráter silvo-agro-pastoril, bem como o sentido típico que Ihes conferem a terra, que, apesar de dominantemente tratar-se de propriedade privada, o acesso a esta na fração do criadouro comum ou comunitário é permitido a todos aqueles reconhecidos integrantes da comunidade, formadores da fração do território comunitário camponês faxinalense. A própria composição dos sujeitos sociais que integram os faxinais, quanto à situação jurídica de acesso à terra, já indica esta característica marcante, na medida em que se encontra aqueles detentores da matrícula definitiva da terra (a maioria), parte que tem apenas o documento de herança, arrendatários, posseiros e sem terras. Todos estes integrantes da comunidade têm garantido o acesso ao criadouro comunitário.

Esta característica da organização socioterritorial camponesa faxinalense, quanto à socialização do acesso à terra, em muito se assemelha à que se percebe na organização comunitária camponesa geraizeira do Oeste do Estado da Bahia. Nesta, do mesmo modo, os usos das soltas e dos fechos de gerais são livres àqueles componentes do grupo de criadores, na medida em que participam das comunidades geraizeiras e contribuem com o seu trabalho nas tarefas demandas na viabilização dos usos das referidas áreas. Um importante diferencial que merece destaque no caso dos geraizeiros é a ausência de propriedade privada (titulada) nas áreas de criatórios soltos e misturados. Estas são terras públicas, as quais os geraizeiros as ocupam na condição de posseiros, a partir de uma organização consuetudinária desde tempos antigos. Ali o gado se alimenta da pastagem natural.

Nas áreas de uso exclusivo familiar, onde praticam a agricultura e a pecuária nas pastagens cultivadas, o quadro de situação jurídica das terras é bem variado. Tem-se escritura pública, tem-se título de terra, mas a maioria é irregular, pois eram escrituras antigas, viraram espólios e não se tratou mais da regularização. Ao longo dos tempos, não se preocuparam com a situação jurídica de suas terras. Os documentos antigos, por sua vez, são de pouca validade jurídica, na medida em que se referem a áreas de terras com delimitações pouco precisas, cujos marcos não foram georreferenciados (embora geralmente respeitados pelos confrontantes), 
tratando-se, de modo geral, de elementos móveis como uma pedra situada em certo lugar, um curso d'água, o topo de um morro, ou de relativa efemeridade, como uma árvore, uma estrada ou um caminho, etc. Além disso, a mensuração costumeira fazia-se em réis de terra, elemento este de importante validade nos moldes costumeiros de relações no âmbito das comunidades, mas que, nos dias de hoje, confrontam-se com a ordem jurídica do direito positivo que se expande, favorecendo a interesses de grupos dominantes em uma correlação de forças por vezes imensamente desigual em prejuízo da consuetudinária organização comunitária com seu respectivo código costumeiro aplicado à sua fração de território.

Iremar: ...tem alguns títulos de terra nesse trecho. Tem escritura pública, tem título de terra, mas é um negócio muito acanhado.

José: a maioria...

Iremar: não. A maioria não. A maioria é irregular. Inclusive das heranças, por que é assim, eram escrituras antigas, viraram espólios e não se tratou mais disso, vendeu para terceiro, então a situação é irregular. Muita gente aqui não pode fazer empréstimo, inclusive porque a situação do documento... ele é morador na propriedade. Mas a propriedade é um espólio, é herança lá de 11 herdeiros. Ele tá sozinho em cima da terra, não tem nada regular, não foi feito arrolamentos, não foi feito nada. Então a absoluta maioria do município de Correntina é irregular. Inclusive desses antigos moradores daqui de baixo. Não é só os de lá dos gerais... a imensa maioria é irregular... eles estão em situação irregular em função de não haver essa preocupação de regularizar o documento dele. Tem muita gente que tá com a escritura do avô, do bisavô, lá numa pasta lá. Só que mora vinte na área ou então venderam aquilo ali, sem fazer nada. Quer dizer, com um recibo de compra e venda, e mora um terceiro lá que tá com um documento lá na mão. Mas tá irregular. E mesmo assim tem gente que nem documento tem. De compra e venda e de nada. Comprou lá de boca, pagou, o cara foi embora, tá lá. ...esses documentos, em maioria são daquele tempo que se comprava terra em contos de réis. Mil réis de terra e o limite é na aroeira tal, na pedra tal, e depois derruba a pedra, corta a aroeira, acabou. Sem georreferenciamento, a imensa maioria das propriedades daqui não tem georreferenciamento. A imensa maioria. ...essas partes de criatório é pior ainda. É do Estado e ponto. Aí não tem nada (Iremar Barbosa de Araújo, professor da rede municipal de ensino de Correntina lotado na escola da comunidade de Couro de Porco e ativista dos movimentos sociais de sua categoria, do MAB e de luta pela terra no município. Trabalho de campo realizado em janeiro de 2012).

Outra importante diferença dos faxinais, em relação às terras de uso, das comunidades geraizeiras é o fato de as terras de viver (moradias, nos faxinais) se situarem no interior das terras de criar ou criadouro comum. Nas comunidades geraizeiras do baixo vale do rio arrojado, as moradias situam-se imediatamente próximas às áreas de sítio $^{72}$, onde predominantemente se praticam os cultivos de regadio. Dali, em direção ao interflúvio, os cultivos de sequeiro dividem as terras ou intercalam-se com as pastagens formadas ou mangas e nas áreas mais

\footnotetext{
${ }^{72}$ Porção ribeirinha da parcela de uso exclusivo familiar onde a produção agrícola é mais intensa (geralmente dois ciclos anuais).
} 
elevadas, conforme se aproxima dos cerrados, torna-se dominante a prática dos criatórios, nas soltas. Nas comunidades do médio vale do rio Arrojado, diferentemente, conforme descrevo com maior detalhe em outra oportunidade, estão precisamente separadas as áreas de sítio, na margem direita do rio Arrojado. As moradias e os respectivos quintais situam-se na margem esquerda, seguida da área de domínio dos criatórios em pastagens formadas ou mangas, no caso da comunidade de Couro de Porco. No caso das outras comunidades - Bebedouro, Passaroto e Cajueiro - após os quintais, na direção do interflúvio, logo se encontram as soltas, pois não formaram pastagens ou mangas. Outra área de criatório usada pelas comunidades são os fechos de gerais, estes, porém, localizados distantes das moradias das comunidades.

As relações que se estabelecem entre os elementos da tríade (terras de uso comum no criadouro comunitário ou comum, cercas das terras de uso comum no criadouro comunitário ou comum, terras agrícolas) conforme Tavares (2008, p.574), Chang designa de sistema faxinal e define como "uma forma particular de aproveitamento desta mata conjugada às áreas circunvizinhas, cuja peculiaridade se assenta sobre o uso comum das terras de faxinal para a criação extensiva e para o extrativismo da erva mate" (CHANG, 1985, p.86).

Para a funcionalidade do sistema faxinal, merece destaque o conjunto de normas, chamado por Chang de sociologia das cercas.

\footnotetext{
Essas normas têm como origem leis consuetudinárias surgidas a partir do próprio exercício do coletivo. A filosofia central dessas leis se baseia sobre o princípio comunitário de direitos contra obrigações - todos têm o mesmo direito desde que participem de alguma forma das obrigações. Estas obrigações são flexíveis e é enfatizado o espírito solidário, pois as contribuições são flexíveis e são medidas conforme as possibilidades de cada usuário (CHANG, 1985, pp.90-91).
}

O fator preservação das cercas assume grande relevância na medida em que as áreas de criatórios são densamente povoadas de animais de pequeno porte, predominantemente suínos, mas também caprinos e aves, e as cercas visam proteger os plantios, localizados muitas vezes nas proximidades dos criadouros, da entrada desses animais.

Nas comunidades geraizeiras, embora se tenha que manter presos os animais em certos períodos, o rigor no fator preservação das cercas torna-se menor, pois os animais de grande porte são criados em compartimentos específicos: nas mangas, nas soltas ou nos fechos de gerais. Mesmo havendo de se garantir o 
bom estado das cercas, o fato de se tratar de animais de grande porte, bovinos e equinos, o ônus é menor na preservação de cercas (geralmente de cinco fios de arame farpado).

Este fator, entretanto, ganhou maior relevância nas áreas de fechos de gerais, quando em situações de conflitos com grileiros que expandiam suas investidas nas áreas anexas. Eles próprios e muitas vezes pistoleiros abatiam os animais que ultrapassassem para as áreas das quais se pretendiam ou se pretendem proprietários. Nesta situação, a preservação da cerca é fundamental e, por vezes, há cobranças e descontentamentos do grupo de criadores àquele que descuida dos cuidados com a sua parte de cerca, geralmente o menos dependente do fecho, o qual geralmente dispõe de área maior de pastagem que possa dar suporte ao seu rebanho.

Quanto às áreas de plantios, os regadios, a preservação das cercas não costuma gerar problemas entre os moradores, pois, muitas vezes, nem existem na divisa das parcelas, predominando, pois, a cerca de respeito, conforme Oliveira (1991). Isto se deve ao fato do calendário agrícola ser comum a todos os parceleiros e, por isso, nos períodos que necessário se faça, os animais de pequeno porte são aprisionados em sua totalidade nos chiqueiros ou pequenos cercados situados nos arredores das moradias.

A principal base da organização comunitária, conforme Chang (1985, p.91), constitui-se a partir do significado das cercas para a funcionalidade do sistema faxinal. É a partir das cercas que se estabelecem os direitos e as obrigações dos integrantes do grupo comunitário. As cercas são divididas proporcionalmente à área de terra que cada proprietário possui e são construídas no perímetro das terras de criar, abarcando o conjunto de propriedades. Cada proprietário se responsabiliza pela construção e pela manutenção da cerca contida em sua propriedade e conta com o auxílio daqueles não proprietários que participam dos mutirões de construção e/ou manutenção.

A capacidade de vedação das cercas é pré-requisito fundamental para o bom funcionamento do sistema faxinal, pois um, e apenas um, que não zele de sua cerca é o suficiente para abrir passagem para as criações às lavouras, o que poderá comprometer o funcionamento do sistema, gerando discórdia entre os integrantes do grupo. 


\subsection{Os fundos de pastos no Estado da Bahia}

No Estado da Bahia, assim como na porção semiárida da região Nordeste do Brasil, pode-se destacar, como elementos de relevante importância para a territorialização do campesinato, aqueles concernentes à história da colonização do país, desde os tempos coloniais em consonância com os relacionados ao quadro natural da região.

No primeiro aspecto, fez-se relevante o fato de se ter estabelecido, desde o princípio da colonização, a divisão territorial do trabalho, conferindo à Zona da Mata a incumbência da produção agrícola canavieira e, atrelada a esta, a pecuária que se expandiu pela zona semiárida sertaneja. Conforme já referido, esta última atividade expandiu-se por meio da concessão de imensos latifúndios a indivíduos cristãos que usufruíam de certos privilégios junto à Coroa Portuguesa. Merece destaque, a "Casa da Torre", dos Garcia D’Ávila, e a "Casa da Ponte", de Antonio Guedes de Brito, os quais atingiram, em 1710, 370 e 160 léguas, respectivamente. Cabe ressaltar, contudo, que o povoamento, de fato, ocorreu através dos vaqueiros, os quais cuidavam "das reses deixadas nos currais como verdadeiros marcos da expansão do movimento povoador" (ANDRADE, 1998, p. 168), e por posseiros que, sendo considerados mestiços, de sangue impuro, tal como os vaqueiros, era-lhes vedado 0 direito de receber terras em concessão (sesmarias).

A massa dos excluídos constituída durante o período colonial não era, pois, massa indiferençada. Isso permitia a um branco deserdado do morgadio abrir a sua própria posse, onde pudesse, e obter assim a sua sesmaria. Já um mestiço pobre podia abrir a sua posse, mas, devido aos mecanismos tradicionais de exclusão que alcançavam o impuro de sangue, dificilmente podia tornar-se um sesmeiro (MARTINS, 1981, p.34).

Nos três primeiros séculos da Colônia, a ocupação pecuarista sertaneja esteve atrelada à atividade desenvolvida na Zona da Mata, a canavieira, na medida em que a esta fornecia o gado para o trabalho nos engenhos, o couro e a carne para o abastecimento da região. A crise da atividade canavieira, ocorrida a partir do século XVIII, e a respectiva descoberta das minas de ouro na Chapada Diamantina e em Minas Gerais redirecionaram o motivo/destino da atividade pecuarista para a área mineradora. Na virada do século XVIII para o XIX, as minas foram exaurindo-se e, concomitante a isso, a atividade pecuarista sertaneja também entrou em crise. 
Disto resultou a fragmentação de muitos dos grandes latifúndios, inclusive das referidas Casas, e muitos sesmeiros até mesmo abandonaram suas glebas.

Evolui-se, a partir disso, para um processo de campesinização sertaneja que se desenvolveu ao longo dos tempos, em uma elevada combinação com a localização dos antigos currais, tal como afirmou Ferraro (2010, p.397), "há uma coincidência geográfica, a mesma associação com as aguadas, a antiguidade das comunidades e os formais de partilha que datam da primeira metade do século XIX, período de desmembramento das sesmarias".

Os trabalhadores dos empreendimentos pecuaristas ali permaneceram e engendram uma modalidade de uso da terra muito própria daquelas paragens sertanejas. Esta se baseia na apropriação de terras de uso comum por meio da criação, sobretudo de caprinos e ovinos, mas também de bovinos (em menor proporção), muares, suínos e aves, misturados e pertencentes a diferentes donos; no extrativismo vegetal, para o fabrico de utensílios domésticos, madeiras como combustível (lenha) para o preparo dos alimentos e para as oficinas da pequena indústria doméstica, como também para a confecção de instrumentos de trabalho, além de frutos destinados à alimentação da família; na atividade agrícola, principalmente de autoconsumo, mas também, em menor proporção, destinada ao comércio em áreas cercadas, para proteger os plantios da entrada dos animais.

De modo mais detalhado, Carvalho afirmou:

Embora existam diferenças entre regiões e entre comunidades, é possível afirmar que nas áreas individuais encontramos a casa de moradia, o quintal com jardim de flores, algumas árvores frutíferas e plantas medicinais mais usadas. São encontrados, também, uma horta, geralmente na beira de um pequeno local de armazenamento de água de enxurrada (barreiro), e os roçados. Hoje, é recorrente encontrar-se um tanque, ao lado da casa, chamado de cisterna, que armazena a água da chuva que escorre pelo telhado. Os roçados e os pequenos barreiros são cercados cuidadosamente para evitar a entrada de animas, uma vez que nas áreas individuais abertas é permitido o pastejo, uma vez que elas fazem parte das terras de uso comum. Além das áreas individuais não cercadas, há terras cuja posse não pertencia a ninguém especificamente, que complementam as terras de uso comum. Nestas terras, além dos pastejos dos animais, são compartilhadas as aguadas, as madeiras para lenha e para construção de casas, cercas, móveis e utensílios domésticos. Uma série de outros extrativismos são realizados, como materiais para confecção de remédios caseiros e oferendas religiosas, coletas de frutas e como locais de caça (CARVALHO, 2008, pp.57-58).

Pode-se inferir a relação desse ordenamento territorial constituído pelas populações camponesas sertanejas com o quadro natural da região semiárida nordestina, na qual as riquezas naturais, notadamente a água, encontram-se em 
escassez considerável. Deste modo, a apropriação comum de boa parte das terras comunitárias isentas de cercas permite a socialização das aguadas existentes, da vegetação natural para diversos usos, destacando-se, entre eles, o pastejo das espécies vegetais relativamente escassas pelos animais, sobretudo, nos períodos de estiagens prolongadas.

Isto ganha maior importância se considerado que estas comunidades sertanejas submeteram-se ao crescimento e ao adensamento populacional e não raro estão confinadas/circundadas por latifúndios que se expandiram, sobretudo, nas últimas décadas. Assim, suas terras tornar-se-iam demais insuficientes para garantir o sustento das famílias, numa condição de apropriação individual da terra como se configura na propriedade privada, nos moldes capitalistas da atualidade.

Merece destacar, ainda, o uso racional que fazem de riquezas naturais, inclusive potencializado nos últimos anos, sob orientação de entidades como a Articulação do Semi-Árido (ASA), que as assessoram, destacando-se o caso dos sistemas de coleta e armazenamentos de água, tal como as cisternas, mas também uma série de outros que convergem para o melhor uso do potencial que possa ser aproveitado no regime irregular de oferta, como o constituinte da região de clima semiárido nordestino.

Conforme descrito por Carvalho na citação anterior, os camponeses estabeleceram, como atividades produtivas que viabilizem a obtenção dos meios de vida, a ovinocaprinocultura extensiva (principalmente), o extrativismo e a agricultura voltada para o autoconsumo. As duas primeiras atividades são realizadas em áreas não cercadas e de uso comum, geralmente localizada nos fundos da área onde se localiza as moradias.

As roças são formadas nas áreas rebaixadas (baixios), onde os solos são mais úmidos e mais profundos. Nestas roças, são cultivados regularmente mandioca, milho, feijão catador (feijão de corda), feijão andu, abóbora, melancia, maxixe e batata-doce, sendo constituídas de talhões geralmente não muito extensos, inclusos no interior da área de uso comum, porém, sendo áreas cuidadosamente cercadas, utilizando-se de estacas/varas de madeiras coletadas nas caatingas, as quais são fincadas ao chão de maneira emparelhada a impedir o acesso dos animais de grande, médio e pequeno portes. 
A este compartimento da apropriação camponesa soma-se uma pequena parcela cercada. Ali, encontram-se a casa de morada e o quintal, em seu entorno. Neste, encontram-se os pequenos cercados ou chiqueiros, onde se aprisionam os animais, geralmente os porcos e as galinhas, conforme a necessidade, principalmente em função da procriação e/ou engorda; cultivam-se frutos, como ciriguelas, umbus e também a palma, que se destina à alimentação do gado, sobretudo, na estação seca; jardins com variedades de flores e uma importante diversidade de plantas medicinais. Outro compartimento cercado é a aguada ou barreiro, à beira do qual, conforme afirmou Carvalho, encontra-se a horta, constituída de plantios como cebolinha, coentro, alface, couve, etc.

O conjunto de apropriações familiares que forma a fração da comunidade camponesa do território, nos dias de hoje conhecido como fundo de pasto, é constituído de compartimentos. Alguns são apropriados exclusivamente pela unidade familiar e, dentre eles, cito o quintal no entorno da casa e o(s) cercado(s) onde se encontra(m) o(s) cultivo(s) de palma. A parcela reconhecida como de apropriação da família, de modo geral, projeta-se para os fundos da fração camponesa do território da comunidade e se adentra pelas caatingas por longas distâncias, compreendendo, geralmente, quilômetros. Esta parte dos fundos, quando usada para a atividade agrícola, do mesmo modo é de uso exclusivo familiar, separada da área comum por meio de uma cerca que protege os cultivos da entrada dos animais, conforme já afirmado. O seu entorno, porém, compõe a área de uso comum da comunidade, incluindo-se no conjunto de parcelas projetadas para os fundos, porém livres de cercas. Nesta área, os camponeses praticam os criatórios, predominantemente de caprinos e de ovinos, mas também bovinos e suínos soltos e misturados, cuja marca de seu dono encontra-se na orelha através de um pequeno corte, no caso dos primeiros.

A expansão do modo capitalista de produção no campo, impulsionada a partir da década de 1970, deu prioridade aos grandes empreendimentos agropecuários e foram justamente as áreas de criatórios, há muito usadas pelos camponeses, as incorporadas pelos projetos de desenvolvimento estatais e privados.

Destacaram-se, nesse processo de investidas sobre as frações camponesas do território, programas tais o de Desenvolvimento de Áreas Integradas do Nordeste (POLONORDESTE), o qual, aliado a outros órgãos de fomento ao desenvolvimento 
capitalista, tal como a SUDENE e os bancos estatais, ofereceram escandalosos incentivos fiscais ao grande capital que se dispusesse a investir (ou intervir) no campo.

Em muitas frentes de intervenção, os projetos governamentais e privados intensificaram as investidas sobre as terras até então livres - onde os camponeses praticavam e praticam os criatórios soltos. Esses projetos representaram e representam uma ação conjunta do capital que, contando com a mediação do Estado classista, investe na privatização das terras, retirando-as das mãos dos camponeses. Em função disso, acirrou-se a disputa entre as diferentes formas de constituição do território: a fração camponesa, engendrada ao longo da história de ocupação interiorana do território brasileiro e fundamentada na organização familiar e comunitária para, por meio do trabalho, se autossustentarem, e a fração capitalista, marcada pela propriedade privada capitalista da terra, da água e das demais riquezas naturais.

De várias maneiras, os capitalistas se beneficiam dessas terras para viabilizar a acumulação do capital: pela especulação; como reserva de valor; como penhora nos vultosos empréstimos em instituições financeiras, principalmente públicas; e, quando as põem a produzir, extraem a mais valia do trabalhador e renda capitalista da terra da sociedade. Sobre o último quesito Paulino explica:

\begin{abstract}
os proprietários fundiários desfrutam de uma condição de enriquecimento singular, proporcionada pelo status de mercadoria que a terra possui, à qual denominamos renda absoluta. Face ao preceito da propriedade privada, combinado com a dinâmica socioeconômica da sociedade, há uma valorização progressiva das terras, sem que para isso concorra qualquer intervenção desses proprietários sobre seu patrimônio fundiário (PAULINO, 2006, p. 55) (grifo da autora).
\end{abstract}

Estes ganhos para o capital ocorrem às custas de ônus que recai sobre a sociedade, conforme acrescenta Paulino:

Trata-se de reconhecer, então, que a propriedade privada da terra envolve uma contradição, já que o reconhecimento desse direito interfere em um dos princípios basilares do modo capitalista de produção: a acumulação, à medida que pesa sobre todos um encargo que necessariamente é pago quando do desfrute de quaisquer bens provenientes do substrato terra, a base de toda existência e de toda ação humana.

Por conseguinte, a renda da terra constitui-se em tributo que atinge diretamente os trabalhadores que, ao morar, ao consumir alimentos ou qualquer bem de consumo, têm parte de seus rendimentos monetários transferidos aos proprietários fundiários, os depositários últimos dessa modalidade de renda (PAULINO, 2006, p.55). 
A apropriação capitalista da terra confere a ela o status de mercadoria e, assume relevante papel na acumulação do capital nas mãos dos capitalistas, pelo simples fato de adquiri-la pela compra ou, como é muito recorrente no Brasil, por meio da grilagem e de uso da violência, tomando-a das mãos dos camponeses, conforme explicita Alcântara e Germani:

\begin{abstract}
Um livro publicado pelo Grupo de Estudos Agrários/Salvador apresenta uma pesquisa realizada sobre a grilagem de terra na Bahia nos anos de 1979 e 1980. O estudo mostra que em apenas dois anos na Bahia ocorreu grilagem de terra em 25 municípios do estado, sendo que as terras disputadas somavam cerca de 86.881 ha, afetando 10.500 pessoas. O estudo apresenta como grileiro grupos de japoneses instalados em São Paulo e a Tratocar, empresas privadas como os grupos Agros industriais Camurugipe e Indústria Cabrália. A ação dos grileiros é violenta ameaçando a integridade física dos moradores destruindo casas e plantações usando o trator, impedido o livre acesso obstruindo o caminhar, matando a criação, falsificando documentos, e o uso coercitivo da policia e/ou o setor judiciário (ALCÂNTARA e GERMANI, 2005, p.343).
\end{abstract}

Esta prática até os dias atuais é muito recorrente, como será demonstrado, posteriormente, no caso da região Oeste do referido Estado. O coordenador da CDA, Nilo Ramos, em entrevista concedida ao programa de rádio "Viva Bem no Sertão ${ }^{73}$ ", assevera que a grilagem de terra é

um grande entrave no desenvolvimento desse modelo de produção (o chamado fundo de pasto) tão importante para a agricultura familiar: Nilo Ramos é categórico em afirmar que muitas vezes, os latifúndios existem na região somente para fins de especulação imobiliária, ou para a garantia de recursos oficiais e, em alguns casos para a lavagem de dinheiro (IRPAA, 2009).

A escalada privatista da terra investiu e investe em várias frentes. Em localidades, tais como os municípios de Abaré, Curaçá, Chorrochó, Macururé, Euclides da Cunha, Uauá, Jeremoabo, Santa Brígida, Senhor do Bonfim, Juazeiro, Rodelas, Monte Santo, Glória, Paulo Afonso, Jaguarari, conforme Alcântara e Germani (2010, p.47), a intervenção violenta é feita pela implantação de infraestrutura, tais como as hidrelétricas de Paulo Afonso e Sobradinho e os projetos agropecuários incentivados por agências estatais de desenvolvimentos, maioria destes concentrada na região do submédio São Francisco.

Em outra frente, a escalada privatista da terra investe contra as comunidades da região de Oliveira dos Brejinhos e Brotas de Macaúbas.

\footnotetext{
${ }^{73}$ Programa de rádio produzido pelo Instituto Regional de Pequena Agricultura Apropriada (IRPAA) semanalmente e apresentado na Emissora Rural da Diocese de Petrolina (PE) e nas rádios comunitárias de Curaçá, Uauá, Remanso e Pilão Arcado, todas na Bahia.
} 
o agrupamento denominado Serra Geral, que abrange os Fundos de Pasto dos municípios de Oliveira dos Brejinhos, Brotas de Macaúbas e lbititá foi marcado pelo processo de interligação do Estado através da construção de rodovias, no caso a BR 242. Esta intervenção estatal tem como saldo concreto a divisão da comunidade de Várzea Alegre e Várzea Grande, a agudização dos conflitos e o cercamento do perímetro externo desses Fundos de Pasto como estratégia de defesa de suas áreas (ALCÂNTARA e GERMANI, 2010, p.50).

Uma terceira frente de investida privatista da terra que atinge as comunidades camponesas, neste caso, de fechos de gerais, intervém na região Oeste do Estado da Bahia e sobre esta Germani e Alcântara (2010) citam apenas quatro municípios: Santa Maria da Vitória, Correntina, Coribe e Canápolis. Neste último, inclusive, foi realizada uma ação discriminatória administrativa atendendo ao que determina a Constituição do Estado da Bahia, de 1989. Como resultado desta ação, segundo informação de interlocutores, em pesquisa de campo, descobriu-se que toda área do município, incluindo a sua sede, fora grilado. Após esta constatação, misteriosamente, desapareceu toda a documentação de terras do município constante do levantamento feito na ação. Nesta pesquisa, constatei que, diferente do que afirmam Alcântara e Germani, toda a região está sob intervenção da investida privatista da terra, desde o município de Formosa do Rio Preto, no extremo norte, até o município de Cocos, no extremo sul.

$\mathrm{Na}$ costumeira relação com a terra, engendrada pelas comunidades centenárias que se territorializam nos sertões, seus criatórios pastavam e pastam livremente na fração comunitária do território, mas, também, aproveitando-se da ausência de cercas, por vezes se dispersavam para as áreas de outras comunidades, as quais, reconhecendo a marca do dono, tratavam de avisá-lo para que viesse buscar. Esta modalidade de apropriação da terra concebe a terra como instrumento de trabalho, por meio do qual se consegue os meios de vida para a família e para a comunidade, formada, em grande maioria, por parentes, compadres, vizinhos, amigos.

A outra modalidade de apropriação da terra, a capitalista, diverge daquela engendrada pelas comunidades e é impulsionada pelos projetos desenvolvimentistas estatais, a partir da instalação dos empreendimentos agropecuários, conforme já referi.

Esta modalidade de propriedade instalou-se amparada em leis que foram criadas em muitos municípios, as quais determinavam o cercamento das terras privatizadas com apenas 4 fios de arame, por isso, chamada de "Lei dos 4 fios" ou 
"Lei do Pé Alto", aludindo-se ao criatório bovino, do pé alto, diferentemente dos criatórios costumeiros das comunidades (caprinos, ovinos, suínos e outros), cujas cercas para contê-los eram construídas de madeira fincadas ao chão emparelhadas ou, quando de arame, com nove (9) ou dez (10) fios.

A partir do final da década de 1970, as comunidades pastoris estavam sendo impedidas de criar ovinos e caprinos, base de sua atividade econômica e de subsistência, em virtude da crescente apropriação privada da terra, apoiada por leis municipais da mesma época, denominadas popularmente de "lei do pé alto" ou "lei dos quatro fios". Elas favoreciam a ocupação de terras por grandes pecuaristas de gado de corte, criado em regime extensivo, em detrimento da ocupação vigente, no regime de "bode solto", característico dos Fundos de Pasto (FERRARO, 2010, p. 395).

Esta Lei foi amparada na Lei $\mathrm{n}^{\circ} 3.071$, de $1^{\circ}$ de janeiro de $1916^{74}$, a qual versa o seguinte:

Art. 588. O proprietário tem direito a cercar, murar, valar, ou tapar de qualquer modo o seu prédio, urbano ou rural, conformando-se com estas disposições:

$\S 20$ Por "tapumes" entendem-se as sebes vivas, as cercas de arame ou de madeira, as valas ou banquetas, ou quaisquer outros meios de separação dos terrenos, observadas as dimensões estabelecidas em posturas municipais, de acordo com os costumes de cada localidade, contanto que impeçam a passagem de animais de grande porte, como sejam gado vacum, cavalar e muar.

§ 30 A obrigação de cercar as propriedades para deter nos seus limites aves domésticas e animais, tais como cabritos, porcos e carneiros, que exigem tapumes especiais, cabe exclusivamente aos proprietários e detentores (Redação dada pelo Decreto do Poder Legislativo no 3.725, de 15.1.1919).

A partir destes preceitos, municípios legislaram:

Art. 1 ${ }^{\circ} \mathrm{A}$ criação de caprinos e ovinos no município deverá ser em áreas cercadas e os rebanhos guardados e vigiados com cuidado preciso a fim de evitar prejuízo a propriedade alheias.

Art. $2^{\circ}$ Aos agricultores e pecuaristas fica assegurado o direito de construírem cercas para proteção de suas lavouras e para o criatório do gado vacum com apenas 3 ou 4 fios de arame farpado.

Art. $3^{\circ}$ Pela não observância do art. $1^{0}$ desta lei, os infratores ficam obrigados ao pagamento dos danos causados pelos seus animais, de acordo com as leis vigentes no país.

Art. $4^{0}$ Esta lei entrará em vigor no prazo de 90 dias, depois de sua aprovação.

Paulo Afonso, sala das Sessões em 23 de maio de 1980.

Estas cercas não impediam a entrada dos animais de pequeno e médio portes nos latifúndios próximos às comunidades; assim, quando estes animais ultrapassavam as cercas, muitas vezes, eram abatidos pelos poderosos latifundiários.

\footnotetext{
${ }^{74}$ Código Civil; Capítulo II; Da propriedade imóvel; Seção V; Dos direitos de vizinhança do uso nocivo da propriedade; Do direito de tapagem.
} 
Nos meios comunitários, do mesmo modo, os conflitos foram impulsionados pelas políticas desenvolvimentistas estatais, na medida em que os empréstimos para projetos também se destinavam a alguns integrantes das comunidades, geralmente aqueles mais abastados. E, como condição para ser beneficiário dos empréstimos, havia que se adotar o pacote do projeto desenvolvimentista, do qual continha, quando voltado para a agricultura, o que preconiza a revolução verde: sementes selecionadas, agrotóxicos e procedimentos padrões no cultivo. Quando voltados à pecuária, destinava-se à formação de pastagens, aquisição de gado bovino e construção de cercas de quatro 4 fios, incompatíveis com as normas costumeiras de ordenamento territorial comunitário. Isto pode ser visto como uma intervenção estatal na tradicional organização da comunidade, com vistas a desarticular as suas bases de sustentação, provocando muitas discórdias em seu meio, como de fato ocorreu.

\begin{abstract}
Muito importante ressaltar que estas leis são criadas simultaneamente com o oferecimento dos pacotes tecnológicos, pelas agências bancárias, para o plantio de determinados cultivos, como o feijão ou cebola, na região de Irecê, e algodão, na região de Guanambi. Os técnicos, do banco ou da empresa de assistência técnica, responsáveis pela liberação dos créditos e pela fiscalização da instalação dos empreendimentos, vetavam a criação de pequenos animais e do consórcio dos cultivos que estavam sendo financiados com os demais cultivos, tais como abóbora, mandioca, milhos, melancia, maxixe. Visava-se, assim, a implantação de monocultivos (CARVALHO, 2008, p.69).
\end{abstract}

O que Carvalho afirmou pode ser exemplificado no que constatei em 2005, na comunidade de Riachão, situada imediatamente após a travessia do rio Verde Grande, nas proximidades de sua confluência com o rio São Francisco, município de Malhada (BA). Nesta comunidade, moram 90 famílias e parte de suas parcelas foi desmatada para implantação de lavouras de algodão. Em conversa com o Sr. Abel, morador da comunidade, este informou que, há alguns anos, parte dos moradores aderiu aos projetos do governo do Estado.

Ao destinar a sua terra e a força de trabalho familiar para o objetivo do projeto, a monocultura de algodão, o agricultor recebia o financiamento e obrigatoriamente deveria adotar o pacote tecnológico que proporcionava e ditava os procedimentos de todo o processo produtivo, conforme preconizavam e exigiam os técnicos. Entretanto, o descontentamento generalizava-se, pois, no ano anterior (2004), o preço da arroba do algodão oscilou entre 18 e 22 reais e, naquele ano (2005), estava cotado em apenas 9 reais. Além deste agravante, o Sr. Abel 
reclamava da grande quantidade de pragas que atacavam os cultivos (possivelmente em função da monocultura) e que o veneno que aplicava no plantio não produzia efeito. Nestas condições, muitos agricultores estavam inadimplentes e pretendiam desistir. Porém, muito provavelmente, as tradicionais bases de sustentação da comunidade haviam sido sensivelmente abaladas em função dos conflitos entre os adeptos da lógica da agricultura moderna e os contrários a ela, tal como se refere Carvalho.

O processo de intervenção externa na costumeira produção camponesa em suas posses desencadeou uma escalada de conflitos em todo Estado da Bahia. A resistência, entretanto, foi mais eficaz nos conjuntos de municípios onde, na atualidade, organizam-se as comunidades de fundos de pasto e suas respectivas associações comunitárias, formando as Centrais de Associações de Fundo de Pasto, em respostas à intensa intervenção.

Para a organização da resistência, desempenharam importante papel na mediação dos camponeses em suas lutas, as entidades ligadas à Igreja Católica, tais como a CPT e a Fundação de Desenvolvimento Integrado do São Francisco (FUNDIFRAN), esta última ligada à Diocese de Barra, com atuação voltada para a região do baixo-médio vale do rio São Francisco. Mas também somaram forças os Sindicatos de Trabalhadores Rurais de cada município e várias ONG que atuam na região, assessorando as comunidades tanto nos aspectos produtivos quanto políticos e jurídicos.

Apoiados pelos agentes sociais de mediação de suas lutas, os camponeses desencadearam a resistência à expansão dos latifúndios, culminando no que se denominou de "Luta pelo Bode Solto", com o foco centrado no impedimento da implantação da Lei dos 4 fios. Carvalho, em sua dissertação de mestrado, na qual estudou mais detidamente os processos de formação e consolidação dos fundos de pasto nos municípios de Oliveira dos Brejinhos e Brotas de Macaúbas, cita importante episódio, que bem demonstra o grau de mobilização para o enfrentamento às forças privatistas da terra, constituídas de interesses privados em consonância com o aparelho estatal. Trata-se de um confronto ocorrido no dia marcado pelo juiz como ultimato à criação solta no município de Oliveira dos Brejinhos, em cumprimento à Lei dos 4 fios. Os camponeses organizaram-se e a 
força da união impediu a concretização do que pretendiam as autoridades municipais.

a estrada deu acesso aos fazendeiros, aí começou a vir pessoas daqui, pessoas dali, pessoas de outras regiões e teve gente daqui da região que fez parceria com os caras... Teve umas épocas que nós enfrentamos os poderes públicos, tivemos de enfrentar a prefeitura, tivemos de enfrentar a delegacia, tivemos que enfrentar os companheiros peito a peito, tivemos que jogar pesado... Tinha um monte de esquema para cima da gente... só conseguimos porque jogamos duro, se a gente não joga apertado de verdade, a gente não conseguia não. Fizemos uma reunião lá no arroz, e conseguimos reunir a base de umas mil e duzentas pessoas, e veio o juiz, prefeito... tinha um edital do juiz dizendo que era o último dia dos animais soltos, naquela data, se não me engano dia vinte e três de novembro de oitenta e três... organizamos os companheiros, articulamos quando foi no dia, na hora que eles chegaram lá... por volta das dez horas da manhã, chegaram as autoridades ali... consultaram... na hora que eles pararam o carro, subiram umas trinta, quarenta pessoas na carroceria do carro, era uma D10. A bicha levantou aqui... não deixamos os caras sair não, fechamos eles ali, não deixamos sair ninguém... e diante disso... como foi no mato e era um lugar que se fosse para, dizer assim, jogar cacete, tinha madeira batendo lá que estava quebrando até hoje... Lá era um lugar fechado, não saía não, só se chegasse de avião ou chegasse por ali mesmo. Fechamos a estrada em dois lugares... o povo reunido lá no meio... mas não se mexeram também para sair... ficaram ali... o que nós tínhamos para dizer aos companheiros era bastante coisa... e o juiz naquela hora ali colocou se nós estávamos manifestando de alegria... aí nós falamos que infelizmente... um fato de sentimento que vocês sendo uma autoridade e tem a ousadia de dizer que hoje é o último dia do bode solto na região e aqui nós queremos dizer para você que quem manda aqui somos nós e a precisão das nossas casas quem conhece somos nós e nós viemos dar um recado para o senhor que aqui nós vamos criar, nós vamos mostrar para o senhor se nós vamos criar ou não vamos... vamos trabalhar... e daquela ação fomos a Salvador, falamos com o secretário, colocou um monte de dificuldade, mas conseguimos entregar um documento e para encurtar a história depois de uns 26 dias apareceu alguém na minha casa para tomar providência, iniciar a documentação das terras... hoje estamos atuando aí, a gente agradece a Deus, as forças que a gente tinha, o esforço que a gente fez, e os apoios que a gente teve, as entidades tipo a FUNDIFRAN, ajudou a gente, o sindicato, a igreja, a paróquia deu uma força muito grande... ${ }^{75}$

A Luta Pelo Bode Solto foi que na década de 80 saiu um empréstimo pelo Bando do Brasil para o plantio de mandioca, mas sabemos que no semiárido há diferenças grandes, de uma região para outra, dentro de um mesmo município, e nós sabíamos que aqui não ia dar certo não. Veio junto uma lei, chamada dos quatro fios, que queria acabar com a criação solta, pois cercar a mandioca com apenas quatro fios não ia deixar a gente criar, pois o bode não entende que a cerca, mesmo tendo apenas quatro fios, ele não poderia passar... a minha mãe, Virgilina Nogueira de Sales, juntamente com dois companheiros, um já falecido, Manoel Gregório da Silva, e seu irmão e José Gregório da Silva, foram três pessoas citadas pela justiça no final do conflito pelo bode, pois não poderiam citar todas as pessoas e estas foram citadas... O escrivão da justiça nos procurou em intimidade, que devíamos guardar sigilo, e nos avisou que seria marcada uma reunião para o dia vinte e três de novembro de mil novecentos e oitenta e três, onde a criação de pequeno porte desapareceria da nossa região. Só uma organização bem forte poderia barrar esta decisão da justiça. No dia dessa reunião estavam presentes mais de mil pessoas. Não paramos por aí, fomos a Salvador buscar a forma que poderíamos criar, pois nós éramos considerados posseiros, não tínhamos título de domínio das terras. Em 1985 tivemos com o secretário da agricultura, que nos prometeu mandar o pessoal, na época era a INTERBA o órgão que cuidava da questão das terras, e veio uma equipe.

\footnotetext{
${ }^{75}$ Entrevista concedida por João Nogueira, em 2006, comunidade de fundo de pasto do município de Oliveira dos Brejinhos a Carvalho (2008, p.76).
} 
Nós tínhamos levado um documento reivindicatório que explicava toda a situação. Eles comprovaram tudo que estava no documento e a partir daí eles fizeram a regularização fundiária, pois disseram que já tinham uma pequena experiência, na região de Uauá, onde a criação era criada num sistema chamado Fundo de Pasto. Então estes Fundos de Pasto nossos surgiram a partir de 1985, até aí não conhecíamos este sistema chamado Fundo de Pasto onde as áreas são coletivas. Temos as áreas individuais, com títulos individuais de cada um e um título coletivo daquela área onde a criação é criada solta, mas assim solta dentro daquela área que é chamada de área coletiva. Para nós é uma grande conquista, pois é um reconhecimento até para o Estado, que servirá como modelo para outras regiões do nosso estado, quem sabe do Brasil. O nosso sistema não era tão diferente de agora, mas tinha um pouco de diferença pois não tinha limite, as criações circulavam por todas as áreas, por todas as comunidades. Hoje em cada associação tem um limite da cerca onde passa a área coletiva, no perímetro da área coletiva, daí as criações já ficam separadas em seus fundos de pasto. A vantagem é que se tinha um manejo muito melhor das criações. Da forma que criamos hoje temos um grande prejuízo, e precisa de um manejo do rebanho com mais produtividade que depende da organização, que se não tiver organização a gente não consegue chegar em lugar nenhum.

Do ponto de vista da produção, há trinta, quarenta anos atrás existia grandes reservas de mata virgem, de caatinga virgem por este sertão a fora, coisa que hoje na não existe mais. A questão Fundo de Pasto é muito positiva, mas ela foi criada não assim exatamente um Fundo de Pasto, ela teve todo um processo de degradação da nossa caatinga desse nosso sertão que nos levou a conclusão de que para continuarmos criando os bodes nós precisávamos dos Fundos de Pasto, de um lugar reservado para que essa criação ficasse solta. Esse é um fator. Um outro fator foi a questão da grilagem, os fazendeiros chegaram num determinado momento que vinham fechando o cerco e nós que somos produtores, pequenos produtores vínhamos nos sentindo sufocados. Então as organizações, igrejas, sindicatos de trabalhadores rurais, as ONGs daqui da região se reuniram, fizemos documentos de reivindicações para o governo do estado até chegarmos hoje nesta coisa que chamamos de Fundo de Pasto. E por incrível que pareça ainda tem pessoas que necessitam, que dependem destes Fundos de Pasto que não compreenderam o valor que ele tem, a necessidade da gente manter estes Fundos de Pastos ativos e organizados, para garantirmos o sustento de nossas famílias através da produção de frutas, de ovinos, de todas as atividades econômicas que a gente exerce dentro destas áreas ${ }^{77}$.

\section{Estes depoimentos explicitam avaliações do projeto fundo de pasto pelos} camponeses; o grau de radicalidade a que chegaram na luta pelo acesso à terra como meio de trabalho, na qual tradicionalmente criaram seu gado solto. Estes enfretamentos significam, pois, uma ferrenha resistência contra a expropriação/expulsão das terras de trabalho a impedir que se tornasse terra de negócio pela propriedade privada capitalista.

Enfrentaram, nestas lutas, interesses do capital e o aparelho estatal declaradamente a seu serviço, mas, também, "companheiros" integrantes das comunidades que aderiram aos projetos desenvolvimentistas, conforme já referido.

\footnotetext{
${ }^{76}$ Entrevista concedida por Ivanilda Nogueira de Sales, liderança da comunidade de fundo de pasto de Várzea Grande, em 2006, a Carvalho (2008, p.78).

${ }^{77}$ Entrevista concedida por Gilson Paula Moreira, morador da comunidade de Jatobá, em 2006, a Carvalho (2008, P.79).
} 
Serviram de referência para o engendramento da resistência, o foco de intervenção que primeiro ganhou notabilidade, os casos de resistência à escalada privatista da terra ocorridos nos municípios de Uauá, Jaguarari, Monte Santo e outros vizinhos, na região de Canudos, durante a década de 1970.

Após 1978, como reflexo das pressões do movimento social de luta pela terra $^{78}$, em sua versão "Luta pelo Bode Solto", foram realizados estudos pelos órgãos do Estado sobre as comunidades camponesas. Esses estudos tinham como objetivos conhecer a realidade dos camponeses - suas formas de organização -, de modo a subsidiar intervenções futuras que fossem ao encontro das reivindicações de regularização das terras, amenizando, assim, os conflitos. Cito os estudos realizados pelo Instituto de Terra da Bahia (INTERBA) ${ }^{79}$ (1981), pela Companhia de Desenvolvimento e Ação Regional (CAR) (1982), pelos Projetos de Desenvolvimento Rural Integrado (PDRI-Nordeste) (1982), pela Secretaria de Planejamento, Ciência e Tecnologia do Estado da Bahia (SEPLANTEC/CAR) (1983) e pela INTERBA - Secretaria de Agricultura do Estado da Bahia (SEAGRI) (1985).

Foram muitas as dificuldades alegadas pelo órgão de terras do Estado, por não encontrar, segundo seus técnicos, brechas na legislação do Estado que favorecessem a regularização das terras apropriadas, conforme a organização tradicionalmente engendrada pelos camponeses, ou seja, que permitissem a concessão de áreas consideráveis de terras. Sobre esta questão, Santos afirmou:

Inicialmente buscou-se jurisprudência em outros estados da federação, porém nada
foi encontrado. Tratava-se, naquele momento, de uma situação sui generis. A
proposta, executada pelo Interba, de acordo com o PDRI, de regularização fundiária
com a titulação individual foi rejeitada pelos grupos. Essa proposta surgiu do plano de
regularização fundiária para a região Nordeste do estado, de acordo com a Lei $n^{0}$
$3038,10 / 1972$ - Lei de Terras da Bahia -, que não previa a titulação coletiva. O
Interba resistia e apresentava muitos impedimentos, alegando, na época, que não
havia arcabouço jurídico, pois, a Lei impedia a regularização e titulação das terras de

78 "O conflito que dera origem à necessidade de construção do Projeto de Fundo de Pasto acontecera em Uauá no ano de 1981 e levou os técnicos do INTERBA-Instituto de Terras da Bahia e da CAR a elaborarem conjuntamente um projeto que pudesse diminuir as tensões sociais crescente, no tocante a questão agrária, no semiárido baiano e garantir para as comunidades de Fundo de Pasto o direito a se manterem na terra" (ALCÂNTARA e GERMANI, 2005, p.344).

79 "Este instituto foi criado em 15 de maio de 1974, pela Lei $n^{\circ} 3635$. Em 1978 no dia 4 de janeiro tornou-se Autarquia e foi reorganizado pela Lei Delegada no $36 / 83$. Tinha como função executar a política agrária estadual. As ações/processos executadas pelo INTERBA eram: a) ação discriminatória que tem como objetivo separar as terras públicas das particulares; b) cadastramento onde se identifica, registra os imóveis rurais, através do qual se atualiza este registro, com base nas alterações verificadas na malha fundiárias; c) regularização fundiária que consiste na organização jurídica da situação do indivíduo sobre a terra que são de origem pública, podendo esta ser feita através de doação, alienação, concessão de uso ou venda e d)reestruturação que acontece através da formação de assentamentos dirigidos pelo Estado" (ALCÂNTARA e GERMANI, 2005, p.344). 
uso comum e o órgão não contemplava, no âmbito de suas ações, as questões jurídicas envolvidas, o que o impedia de envolver-se nos litígios existentes nos fundos de pasto (SANTOS, 2010, p.93).

No calor das mobilizações do movimento social, visando imprimir seus interesses na Constituição Baiana de 1989, os camponeses organizaram-se em polos ou Centrais de Fundo de Pasto, a partir de uma regionalização própria, divergindo, inclusive, da estabelecida pelos órgãos estatais, a partir dos citados estudos, à qual não correspondia à existência real das comunidades (ALCÂNTARA e GERMANI, 2010, p.51). Inviabilizada a regularização das terras de uso camponês, a partir da intervenção do INTERBA, transferiu-se a tarefa para os técnicos da CAR, os quais "direcionaram suas ações, nos primeiros momentos, para a efetivação da regularização através das associações das terras de fundo de pasto. O que era uma experiência nova de intervenção do Estado no que se refere à questão fundiária" (SANTOS, 2010, p.93).

Evidenciado o fato de que a titulação individual impossibilitava o uso costumeiro do pastoreio em terras de uso comum, optou-se "pela Sociedade Civil, disciplinada nos Arts. 1.363 a 1.409 do Código Civil Brasileiro, como alternativa jurídica de propriedade comum, aquela considerada, naquele momento, como a mais ajustada à necessidade dos grupos" (SANTOS, 2010, p.93).

Santos complementa:

Esse conjunto de artigos regulamenta a organização da Sociedade Civil. O art. 1.363 ,
por exemplo, versa: "celebram contrato de sociedade as pessoas que mutuamente se
obrigam a combinar seus esforços ou recursos, para lograr fins comuns". Feita a
Sociedade entre os membros do fundo de pasto, organizados em associação,
ampare-se a titulação da terra de uso comum em nome da mesma, em consonância
com o art. $3^{0}$, da Lei 4.504 de $30 / 11 / 1964$, o Estatuto da Terra. Este artigo profere que
"o Poder Público reconhece às entidades privadas, nacionais ou estrangeiras, o
direito à propriedade da terra em condomínio, quer sob a forma de cooperativas quer
como sociedades abertas constituídas na forma da legislação em vigor. E em seu
parágrafo único afirma que "os estatutos das cooperativas e demais sociedades, que
se organizarem na forma previstas neste artigo, deverão ser aprovados pelo INCRA
que estabelecerá condições mínimas para a democratização dessas sociedades"
(SANTOS, 2010, pp. 93-94).

Abertas essas possibilidades no campo jurídico, tratou-se de sintonizar esses preceitos ao que preconiza a Lei de Terras do Estado da Bahia, referente à alienação de terras públicas, conforme Santos demonstra:

Esta Lei, em seu art. 12 traz as seguintes inscrições: "a disposição de terras públicas atenderá ao interesse público e objetivará o desenvolvimento econômico e social do Estado", no art. 15: "é vedada a alienação à mesma pessoa, natural ou jurídica, de 
terras públicas de área superior a 500 ha, exceto em caso de empreendimento considerado de interesse para o desenvolvimento econômico do Estado"; e no $\S 1^{0}$ : "considera-se interesse para o desenvolvimento econômico do Estado o empreendimento destinado a reflorestamento, colonização particular, ou exploração agropecuária racional e intensiva com projeto aprovado pelo órgão executor da política agrária, ouvida a Secretaria do Planejamento".

Havia outros limites no que se refere à doação de terras devolutas incorporadas ao patrimônio público, a alienação de terras públicas ocorre em relação às possibilidades, a saber:

Para área de até 100 ha - doação de 1 título individual a partir da comprovação de posse.

Para área de até 500 ha - alienação simples, a partir da apresentação de projeto agropecuário, que deveria regular certa racionalidade econômica, segundo os critérios de seleção da instituição encarregada de fazê-lo.

Para área de até 3.000 ha - alienação excepcional, para se requerer do estado essas áreas, é preciso que seja apresentado um projeto agropecuário, cuja viabilidade deverá se fazer dentro da lógica de modernização compatível com os investimentos de capital no campo.

Para área com tamanho acima de 3.000 ha - necessita de aprovação do Senado Nacional (SANTOS, 2010, p.94).

Todas essas buscas de compatibilizações das demandas dos camponeses ao arcabouço jurídico fizeram-se em um contexto de intensa pressão do movimento social, de intenso conflito no campo, em período pré-constituinte do Estado da Bahia - ano de 1988 -, em que o movimento camponês, apoiado pelas referidas entidades mediadoras ${ }^{80,81}$, organizou-se em torno de uma emenda popular que legitimasse e reconhecesse a organização territorial do fundo de pasto a constar na Constituição do Estado, promulgada em 5 de outubro de 1989, a qual foi aprovada com o seguinte texto, no Artigo 178:

Art. 178 - sempre que o estado considerar conveniente, poderá utilizar-se do direito real de concessão de uso, dispondo sobre a destinação de gleba, o prazo de concessão e outras condições.

Parágrafo Único

No caso de uso e cultivo da terra sob forma comunitária, o Estado, se considerar conveniente, poderá conceder o direito real de concessão de uso, gravado de cláusula de inalienabilidade à associação legalmente constituída, especialmente nas áreas denominadas de Fundos de Pasto ou Fecho e nas ilhas de propriedades do

\footnotetext{
${ }^{80}$ Conforme nos indica Alcântara e Germani, (2010, p. 52) no Pólo Bonfim a CPT assessora a organização da Central de Fundo de Pasto das comunidades localizadas nos municípios de Senhor do Bonfim, Jaguarari, Andorinha, Monte Santo, Itiúba, Campo Formoso, Antonio Gonçalves, Pindobaçu, Mirangaba e Umburanas; O Pólo de Juazeiro assessora as comunidades dos municípios de Juazeiro Sobradinho, Casa Nova, Sento Sé, Remanso, Campo Alegre de Lourdes e Pilão Arcado; E no Pólo CUC - situado no Nordeste do estado, assessora as comunidades dos municípios de Canudos, Uauá e Curaçá. A FUNDIFRAN investiu na organização das comunidades de Fundo de Pasto localizadas nos municípios de, Brotas de Macaúbas e Oliveira dos Brejinhos.

${ }^{81} \mathrm{Tal}$ como afirma Ferraro (2008, p.396) "Um importante passo na resistência das comunidades pastoris e consolidação da categoria dos Fundos de Pastos foi o artigo 178 da Constituição baiana de 1989, que reconhecia a existência de formas de uso comunitário da terra. Várias instituições, como a Comissão Pastoral da Terra (CPT), declaram que as suas ações em defesa dos Fundos de Pastos se fortaleceram a partir desse artigo da Constituição."
} 
Estado, vedada a este transferência de domínio (Constituição da Bahia, promulgada em 5 de outubro de 1989).

Criaram-se, pois, as condições legais para a regularização das terras das comunidades sertanejas, doravante designadas comunidades de fundo de pasto. Foram concedidos títulos individuais à parte de apropriação exclusiva familiar. E quanto à terra de uso comum, estabeleceu-se como condição, para que se efetivasse a regularização, a formação e o registro de uma associação comunitária de fundo de pasto, à qual se emite o título de concessão de uso.

O termo fundo de pasto surgiu nos primórdios das investidas dos órgãos governamentais designados a intervir nos conflitos em seu epicentro, município de Uauá e vizinhos, nos finais da década de 1970.

Carvalho discorre sobre a dinâmica da assimilação do termo fundo de pasto, ganhando significados ao longo dos processos que constituem a luta, favorecidos pelo reconhecimento da territorialidade específica por parte dos órgãos estatais, possibilitando, com isto, a unificação da luta pela terra no Estado da Bahia.

\begin{abstract}
Observação importante é o uso dos termos "Luta pelo Bode Solto" e "Fundos de Pasto". No primeiro caso, a designação refere-se ao significado literal, ou seja, a luta pela criação solta e um local de reserva de pasto para que essa criação permaneça solta. Ela se refere ao espaço e ao animal. O segundo significado remete a um sistema econômico, que inclui as várias atividades agroextrativistas além do pastejo extensivo, como a caça, as aguadas, as plantas, a técnica de utilização dos recursos ambientais (...)

Apesar da aproximação entre seus significados, há diferenças importantes entre os dois termos. A "Luta pelo Bode Solto" significava a luta pela lei do costume que valorizava 0 modo de vida existente e recusava o cercamento dos animais, a fragmentação do território intercomunidades, a grilagem de terras. A "Luta pelo Bode Solto" é um termo nativo forjado na luta diante de forças que queriam expropriar os territórios das comunidades, queriam impedir a criação de pequenos animais, queriam eliminar um modo de vida.

Já "Fundos de Pasto" representa o ajuste necessário, a saída legal encontrada, a sintonia com uma luta maior, o reconhecimento dos próprios limites e forças. "Fundos de Pasto" é um termo externo que, aos poucos, vai sendo incorporado, até o momento em que representa o modo de vida atual. O termo "Comunidades de Fundo de Pasto" da região de Oliveira dos Brejinhos identifica o atual modo de viver, que tem como referência a Luta pelo Bode Solto, mas mesmo que tenha se transformado em algo diferente do que era, respeita a lógica da subsistência da família, das relações de parentesco e compadrio. Respeita as formas organizativas préexistentes, ao mesmo tempo que implanta novas formas, como a associação. Muda constantemente para tentar ser o mesmo, assegurando a vida digna na região (CARVALHO, 2008, p.80-81).
\end{abstract}

$\mathrm{Na}$ medida em que o Estado reconhece a territorialidade camponesa, os termos nativos, luta pelo bode solto, foram ganhando outros significados, e estes transparecem no que hoje entende-se como fundo de pasto, o qual, doravante, tornou-se instrumento de luta mais eficaz, a partir dos reforços conseguidos, por 
meio dele, na unificação das pautas pela regularização das terras ocupadas pelas comunidades em nível estadual.

Fundo de pasto representa ainda "o ajuste necessário, a saída legal encontrada, a sintonia com uma luta maior", formando redes a partir de outros grupos, cujas pautas eram comuns, porque todos vitimados pela grilagem de suas terras. Isto resultou na unificação da luta camponesa em escala estadual, representada no que se formou - a "Articulação Estadual de Fundo de Pasto". Ou seja, assumiram o fundo de pasto, externo, mas necessário ao tornar-se instrumentalizado para reforçar a luta contra a expulsão da terra, mesmo havendo diferenças em relação à forma costumeira de constituir o processo de territorialização comunitária.

Esta expressão, processo de territorialização, tenta propiciar instrumentos para compreender como os territórios de pertencimento foram sendo construídos politicamente através das mobilizações por livre acesso aos recursos básicos em diferentes regiões e em diferentes tempos históricos. O processo de territorialização é resultante de uma conjunção de fatores, que envolvem a capacidade mobilizatória, em torno de uma política de identidade, e um certo jogo de forças em que os agentes sociais, através de suas expressões organizadas, travam lutas e reivindicam direitos face ao Estado (ALMEIDA, 2008, p.118).

É na luta que foi travada com os interesses antagônicos que investiam sobre as frações comunitárias camponesas do território, que se forjou o fundo de pasto. Santos apontou a sua origem:

A partir de 1983, da observação in loco dos técnicos é que surge a expressão FUNDO DE PASTO. Assim, a denominação passou a existir quando da intervenção do Governo da Bahia dirigida ao reconhecimento jurídico dessa forma de organização social e da relação que esses grupos estabeleciam com a terra, ou seja, a sua territorialidade, o seu modo de vida, este espalhado em diferentes municípios do semiárido baiano. Naquele momento, em seus estudos preliminares na região Nordeste do estado, os técnicos observaram as casas dos camponeses com seus quintais/terrenos, tendo suas criações ao fundo, pastando no bioma da Caatinga; assim, surgiu, então o termo Fundo de Pasto (SANTOS, 2010, p.69).

\section{E, quanto à identificação dos grupos camponeses com a nova}

categoria/instrumento da luta, a mesma autora afirmou:

Atualmente essa denominação está assimilada e difundida entre os grupos que compartilham desse modo de vida, ganhou uma dimensão política e enquanto categoria do presente, vem sendo valorizada e visibilizada a partir da sua identidade peculiar, que está retratada no seu modo de vida - "Fundo de Pasto: nosso jeito de viver no sertão". A afirmação dessa categoria busca ainda a diferenciação em relação a outros movimentos que lutam pela terra, constituindo uma "articulação" que os congrega e representa na Bahia, levantando "bandeiras de luta" específicas para esse segmento camponês junto ao Estado. Inclusive, os grupos organizados apenas consideram como Fundo de Pasto os grupos cadastrados ou em fase de 
reconhecimento pelo estado através dos órgãos responsáveis em implementar essa política, resguardando, também, a observação da historicidade ancestral do grupo, considerando essa característica fundamental para a definição: a de "ser ou não ser" um fundo de pasto tradicional, ou de representar apenas um grupo forjado em um outro processo para garantir a titulação de suas terras. Assim, alguns grupos, embora cadastrados e mesmo reconhecidos pelo estado como de fundo de pasto, não o são pelos grupos que têm ancestralidade comprovada e resguardada por suas tradições (SANTOS, 2010, p.69-70).

Embora a adoção do conceito fundo de pasto tenha representado avanços, na medida em que os camponeses o assumiram como instrumento de luta política, os limites também devem ser destacados, pois, ao conceder um título, as terras que a ele se refere são medidas. E, no contexto de expansão do latifúndio, da propriedade privada da terra, a extensão da área de uso comum foi limitada a partir da construção de cercas. Inclusive, como exemplos de impasses criados em função dessa imposição, há vários casos no município de Oliveira dos Brejnhos. Concedidos os títulos e demarcadas as áreas de fundo de pasto, os camponeses não dispunham de condições para cercá-las, na medida em que as cercas para garantir a contenção dos animais predominantes nos fundos de pastos demandam altos custos, ao serem construídas com nove a dez fios de arame. A solução foi facilitada pelo Estado, o qual forneceu o material (arame e estacas), de modo que as comunidades, organizadas em mutirões, as construissem.

Desta maneira, as comunidades se encontram em limitadas condições de reprodução socioterritorial, na medida em que as áreas de apropriação comunitária apresentam limites de usos e não mais é permitida aos animais a dispersão, como antes, pelas terras livres que as circundavam, além de uma série de outros impedimentos elencados por Carvalho:

A titulação, na forma como foi estabelecida, vem ameaçando o modo de vida tradicional (Germani \& Oliveira 2006:18). Em casos como o de Várzea Alegre, cujo processo de regularização foi concluído, tanto no tocante às áreas individuais quanto às áreas coletivas, novos problemas surgem. As comunidades passam a ser submetidas à legislação sobre a propriedade da terra, e a partilha por herança tem a obrigatoriedade de passar pelo cartório. A presidente da associação, Maria, que recebeu as terras de herança do seu pai, sob a forma tradicional, após o processo de regularização fundiária, não teria direitos aos benefícios de crédito agrícola, por não ser reconhecida como proprietária. Até sua legitimidade como presidente da associação foi questionada por um técnico do INCRA. Já seu irmão, que mora atualmente em São Paulo, e tinha recebido as terras de herança antes da regularização fundiária, pois já era casado, tinha direito aos benefícios que eram negados a Maria, por não ser considerada proprietária. Da mesma forma outros casos são questionados e a comunidade se coloca em defesa de todos que estejam usufruindo da terra, legitimados pela posse. O próprio irmão de Maria não se acha no direito de receber os créditos. Este fato, que encontra paralelo em outras 
comunidades, demonstra, eloquentemente, que tradicionalmente a posse da terra era tida como mais legítima do que a propriedade.

A regularização também legitimou a usurpação de parte do território tradicionalmente ocupado para agentes externos à comunidade, o que incidiu diretamente no suporte de pastejo, na perda de aguadas, diminuição dos animais de caça e maior vulnerabilidade ambiental com a derrubada da caatinga para a implantação de empreendimentos, desde plantio de capim, formação de monocultura, e exploração de carvão ou de minérios. Outro problema foi a fragmentação do território, impedindo a ampla movimenta dos animais. Em todos os casos, a pressão sobre os recursos ambientais aumenta, acelerando a degradação da mata, o que exige redução do rebanho ou adaptações tecnológicas (CARVALHO, 2008, p.61).

São, pois, problemas concernentes à lógica da propriedade privada que se impõem nas frações camponesas do território pela combinação da ação do Estado capitalista e o interesse dos capitalistas pela acumulação via privatização da terra, a qual, no modelo brasileiro de desenvolvimento do capital no campo proporciona a acumulação capitalista em favor dos grupos econômicos. Esta lógica e este sentido da apropriação da terra se efetivam pela expropriação/expulsão dos camponeses de suas frações territoriais, privatizando-a, e, no caso dos fundos de pastos, assim, como nos fechos de gerais do Oeste da Bahia, estudados nesta tese, provocam repulsa/resistência dos camponeses, os quais se apropriaram da terra como posseiros. "No centro das lutas tem estado a luta contra a apropriação privada da terra. O fim da propriedade privada da terra coloca em questão o fim da propriedade dos meios de produção" (OLIVEIRA, 1996, p.14).

No que diz respeito aos fundos de pasto, a partir das avaliações realizadas por seus interlocutores e coletadas em entrevistas, Carvalho asseverou:

Ter um Fundo de Pasto não era o que se pleiteava inicialmente na Luta pelo Bode
Solto. O objetivo era a manutenção do seu modo de vida e isso significava a
possibilidade de manter a terra tradicionalmente ocupada, o acesso às terras de uso
comum. A idéia do Fundo de Pasto veio a ser um remendo, pois significava manter
cercadas, numa mesma área, várias famílias que queriam continuar criando à forma
antiga. Infelizmente não só a estrada (BR-242) fragmentou as áreas. Algumas
famílias, que não queriam criar mais cabras e ovelhas, não queriam compartilhar suas
áreas de pastejo (CARVALHO, 2008, p.117).

Vê-se, pois, que no contexto de expansão do modo capitalista de produção regido pelo Estado capitalista, a reprodução socioterritorial camponesa efetiva-se no limite, sob condição de intenso conflito e contínuo enfrentamento aos interesses privados e ao aparelho repressor estatal. O capital, territorializa-se por meio das normas impostas, não raro com o uso da violência sobre aqueles que resistem a abrir mão da liberdade que se materializa no acesso direto aos meios de reprodução de suas vidas. As relações sociais de produção capitalistas se expandem, 
territorializando-se, sendo que as faces mais visíveis são a propriedade privada e a opressão nas relações de trabalho àqueles que perderam suas terras de trabalho, as quais se metamorfosearam em terras de exploração ou de negócio.

os posseiros têm travado lutas sangrentas contra o capital e seus asseclas. $O$ objetivo dessa luta é livrar-se do destino de alguns de seus companheiros: se tornar assalariado; ser "boia-fria". Primeiramente, o capital sujeita a renda da terra e em seguida subjuga o trabalho nela praticado (OLIVEIRA, 1996, p.13).

Como muito bem disseram os camponeses participantes da oficina da "Nova Cartografia Social dos Povos e Comunidades Tradicionais do Brasil: Fundos de Pasto nosso Jeito de Viver no Sertão", o fundo de pasto "é uma forma de defesa", pois "já se vivia na terra há muito tempo, mas por ameaça de grupos (fazendeiros, mineração) que grilavam a terra, buscamos documentos para garantir a terra para gente" (Grupo de Sento Sé e Sobradinho). É também "uma forma de defender-se da grilagem pelos fazendeiros, carvoeiros, empresas agrícolas, e preservar a área para criar mais tranquilo" (Grupo de Pilão Arcado, Remanso e Campo Alegre de Lourdes). Entendem que "Esse é um jeito de garantir (...) a permanência na terra e também um jeito de enfrentar os grandes projetos de irrigação, como o Cruz das Almas e os grandes fazendeiros que são os famosos grileiros dos Fundos de Pasto" (Grupo de Casa Nova). É também "uma forma de preservar a caatinga". Na medida em que "Fundo de Pasto é uma área preservada pelos moradores da comunidade que dali tiram o meio de sobrevivência das famílias que ali residem, como criação de abelhas, caprinos e ovinos, e outros animais que existem na área. Assim tem-se como trabalhar e dar continuidade para os filhos" (Grupo de Casa Nova) (Projeto nova cartografia social dos povos e comunidades tradicionais do brasil, 2006, p.4). 
CAPÍTULO 3 


\subsection{A atuação dos mediadores junto aos movimentos sociais ${ }^{82}$}

Em meados do século XX, mais precisamente da década de 1950 à primeira metade dos anos 1960, os movimentos sociais e sindicais, tanto das cidades quanto do campo, viveram momentos de grande efervescência, demonstrando descontentamentos. Este período histórico inaugurou uma onda de grandes manifestações, as quais respondem às situações construídas ao longo da história de subordinação e marginalização de grande parcela da sociedade no modelo de desenvolvimento protagonizado pelas elites econômicas e pelo Estado brasileiro de caráter classista.

Martins (1994) associa esse quadro ao desenvolvimentismo impulsionado pelos sucessivos governos da década de 1950 até a implantação do regime militar. Segundo o autor, desde a abolição da escravatura as relações de trabalho permaneceram instáveis. A grande exploração monocultora, tanto no Nordeste quanto no Sudeste do país, aproveitava-se dessa situação para superexplorar livremente a mão de obra e o auge desse fenômeno ocorreu na década de 1950 quando, em função da elevação do preço do açúcar, os fazendeiros da Zona da Mata nordestina aumentaram o foro e/ou expandiram as áreas de cultivos de canade-açúcar sobre as terras onde os trabalhadores da lavoura cultivavam seus alimentos.

A situação limite em que os trabalhadores encontravam-se resultou no aumento da migração para outras regiões do país, principalmente para os grandes centros urbanos da região Sudeste. Aqueles que permaneceram na região Nordeste organizaram-se em ligas de associações posteriormente chamadas de Ligas Camponesas, que depois se proliferaram por todo Nordeste e até por Estados de outras regiões do país.

Na região Sudeste, o uso de técnicas modernas nas lavouras de café e a sua substituição por cultivos mecanizáveis expulsaram das fazendas muitos trabalhadores, que foram deslocados para os centros urbanos, os quais não dispunham de condições de suporte a este contingente populacional, e as

\footnotetext{
${ }^{82}$ A discussão que apresento neste tópico se baseia, em grande parte, nas contribuições de Martins (1981), especialmente capítulo I, e Martins (1994), especialmente capítulo III.
} 
consequências não foram outras, senão a precarização das condições de vida dos trabalhadores.

Nesse quadro, assumem importante papel, como mediadores dos movimentos sociais do campo e da cidade, a Igreja Católica e o Partido Comunista do Brasil.

O Partido Comunista sai na defesa dos trabalhadores, apoiando as Ligas Camponesas e suas reivindicações pela reforma agrária. Na verdade, como indica Martins (1994, p.103 e 112), por questões doutrinárias, defendia, de fato, a extensão da legislação trabalhista e a sindicalização dos trabalhadores do campo. Quanto à reforma agrária, a colocava, na prática, num segundo plano, pois entendiam que os pequenos proprietários, se bem sucedidos, se tornariam burgueses. E a classe verdadeiramente revolucionária seria a do proletariado.

A partir deste posicionamento dos comunistas, pode-se entender que sua atuação junto às Ligas Camponesas representava, por um lado, a viabilização do enfrentamento ao latifúndio, por eles entendido como resquícios feudais, e, por outro lado, o atendimento do interesse político de atuação junto às massas para a construção do socialismo.

Os comunistas prosseguiram, portanto, até o desferimento do golpe militar de 1964, atuando de forma ambígua junto aos movimentos sociais, principalmente, junto às Ligas Camponesas.

Quanto ao outro mediador atuante junto aos movimentos sociais, a Igreja Católica, sua postura foi assumindo diferentes posicionamentos, conforme a conjuntura política e social evoluía e Ihes oferecia elementos que aos poucos foram redirecionando a sua histórica postura conservadora. Até a Proclamação da República, a Igreja Católica mantinha grande proximidade com o Estado. Devido a sua natureza conservadora e monárquica, com a Proclamação da República, a Igreja se afastou dos governos que se sucederam pelo menos até a revolução de 1930. Doravante, a Igreja reaproximou-se do Estado e, nos sucessivos governos, se aliou ao poder central. Esta aliança se fazia com maior solidez junto aos ditos governos fortes e centralizadores, tais como os instalados com a revolução de 1930 e com o golpe de 1964. O governo de Getúlio Vargas selou sua aproximação com a Igreja implantando no sistema educacional o ensino religioso. 
Até os primeiros anos do golpe militar de 1964, como solução para a situação de penúria enfrentada pelos trabalhadores, a Igreja Católica acreditava na modernização das forças produtivas e no desenvolvimento do capitalismo. Para tanto, atuava junto aos trabalhadores do campo, competindo com o Partido Comunista na organização sindical. Se, por um lado, o Partido Comunista atuava nesta frente à busca de canais legítimos de atuação política (o Partido era ilegal), por outro, a Igreja também atuava para barrar a marcha do seu adversário, do "perigo vermelho". Se o PC defendia a reforma agrária radical para usufruir da projeção política junto às Ligas Camponesas, a Igreja Católica defendia a reforma agrária para viabilizar a permanência da população no campo e impedir a migração para os centros urbanos, onde se tornaria "presa fácil" dos comunistas ateus.

A reforma agrária defendida pela Igreja tinha caráter de política pública compensatória e, ao contrário da pretendida pelas Ligas Camponesas, tinha que respeitar a propriedade privada da terra; assim, deveria haver indenização para as propriedades destinadas para a reforma agrária.

Por defender as bandeiras do desenvolvimentismo e combater os comunistas o governo militar teve o apoio da lgreja que historicamente se identificava com governos centralizadores, tal como o instalado com o golpe de 1964.

No entanto, passaram as décadas de 1950, 1960 e 1970, o desenvolvimentismo e a modernização almejados avançaram e as condições de vida dos trabalhadores não melhoraram, pelo contrário, até pioraram, apesar de em grande medida satisfeitas as doutrinas leninistas do Partido Comunista com a criação do Estatuto do Trabalhador Rural em 1963.

De princípio, as concepções de reforma agrária desenvolvimentista da Igreja Católica e do regime autoritário eram bastante coincidentes. Só no decorrer da sua implantação, na medida em que incorporou as terras amazônicas com as brutalidades praticadas aos povos indígenas e posseiros - a base de expansão das missões católicas - é que as divergências se afloraram.

A reforma agrária do regime autoritário foi concretizada a partir de forte aliança com o grande capital desenvolvido dos centros do sistema, particularmente da região Sudeste, tida como desenvolvida e grande parceira do regime em sua ação nos massacres aos povos da floresta na ânsia privatista da terra nos moldes capitalistas. 
Esta aliança do capital e da propriedade da terra ressoldada pelos militares, culminando em alterações negativas nas condições de vida e sobrevivência dos índios e camponeses na Amazônia e na concomitante repressão aos missionários e, posteriormente agentes de pastorais da Igreja, colocou importantes setores da instituição religiosa na linha de frente contra o regime e em constante pressão às alas conservadoras da Igreja, para reorientar a histórica concepção que sustentava sua atuação junto aos ditos pobres do campo.

A forte repressão do regime militar aos comunistas havia tirado a "pedra do caminho" da Igreja e, como resultante das divergências com o regime, muitos manifestos foram elaborados e tornados públicos pelos bispos de diversas regiões do país a partir do início da década de 1970. Deste marco em diante, foi criado o Conselho Indigenista Missionário (CIMI) em 1972 e a CPT em 1975, que passaram a dar assessoria aos índios e aos camponeses, respectivamente.

O movimento indígena se fortaleceu na luta contra o saque às suas terras e, como reflexo da ação da Pastoral da Terra e outras, surgiram milhares de sindicatos de trabalhadores pelas regiões focos de massacres praticados pelos grileiros de terra e seus jagunços em parceria com o aparelho repressivo do regime.

Como resultante da ação da Igreja Católica, principalmente após a década de 1970, pode-se ver a amplitude que ganhou o movimento social politizado, culminando na sindicalização massiva dos trabalhadores do campo ${ }^{83}$ e da cidade e a importância que representa o Movimento dos Trabalhadores Rurais Sem Terra (MST) nas décadas que se sucederam.

No entanto, esta relevante força que ganhou os movimentos sociais de luta pela terra, com atuação marcada pelas ocupações de terras, prédios públicos e grandes marchas visando mostrar à opinião pública a relevância da sua causa, que é de todos, inflamou a ira das elites agrárias, de governos e de setores conservadores da sociedade. E, como resposta, pode-se ver a nova face expansiva da privatização capitalista da terra travestida de moderna no que vem aos nossos olhos no formato do que se conhece como agronegócio. A região do Oeste da Bahia destaca-se como foco dessa investida.

\footnotetext{
${ }^{83} \mathrm{Da}$ atuação de agentes da Igreja Católica e quadros do Partido na região Oeste da Bahia, tal como em grande parte do país, foi criado nesta época Sindicatos de Trabalhadores Rurais em cada município com o objetivo de combater a onda de privatização das terras, invariavelmente por meio da grilagem.
} 


\subsection{Investida privatista da terra no Oeste da Bahia e a articulação da resistência}

No Oeste da Bahia, a investida do regime autoritário está relacionada, conforme já referi, com a doutrina da ocupação dos ditos "espaços vazios", diga-se, daqueles onde o Estado e o seu modelo de desenvolvimento não se faziam satisfatoriamente presente e capazes de barrar ou mesmo impedir a influência da ameaça comunista. Investiu-se, portanto, como em outras regiões do país, numa contraditória aliança com o grande capital, constituída em transferência das terras públicas para as mãos das grandes empresas modernas capitalistas (MARTINS, 1999, pp.78-79). Esse processo se expandiu de forma demais truculenta e os clamores das populações rurais vitimadas abrem maiores campos para a atuação daqueles destacados pelo Partido Comunista para atuarem na região.

No contexto conflituoso, destacaram-se, de um lado, o Estado autoritário, apresentando-se em escala local como as oligarquias e, no caso da baiana bem exemplificada no que conhecemos do carlismo, e o Partido Comunista.

Em outra frente, atuou a Igreja Católica, que inicialmente apoiava o regime autoritário, quando da sua implantação, e, por divergências de princípios, com os comunistas, diverge e se opõe radicalmente à ampliação da influência comunista por essas regiões de fronteiras.

No entanto, para que ampliasse a sua influência, a Igreja não podia calar-se frente a tanta opressão e violência sofridas pelos "pobres" do campo, em um primeiro momento, e depois até mesmo por aqueles enviados para atuarem na defesa dos pobres, os leigos, maioria, pertencentes à Teologia da Libertação.

Neste clima de enfrentamento ao inimigo comum - o Estado autoritário e as oligarquias locais e regionais - abriram-se condições de alianças, não sem conflitos, no caso do oeste baiano, entre comunistas e católicos.

Esta coalizão de forças possibilitou uma significativa organização dos camponeses em sindicatos fundados sob a atuação direta desses mediadores sociais, sejam religiosos ou comunistas.

É muito lembrada pelos interlocutores a atuação de padres nos municípios de Santa Maria da Vitória e Correntina. No quadro de penúria generalizada 
enfrentada pela população vitimada pelas injustiças intensificada pela onda privatizante das terras, os padres interviam nessa realidade, tanto na assistência social quanto, em alguma medida, na organização dos camponeses em parceria com agentes do Partido Comunista.

Dessa parceria, conforme assinalado, fundou-se 0 Sindicato de Trabalhadores Rurais nos municípios e, no caso de Correntina, teve muito destaque o trabalho realizado pelo quadro do PC, tão lembrado pelos interlocutores, o paulista e sindicalista ferroviário, natural de Queluz, Wilson Martins Furtado, que se instalou nos gerais, mais precisamente na comunidade rural de Couro de Porco, e, juntamente com Pe. André, fundaram o Sindicato dos Trabalhadores Rurais de Correntina (em 1980), com o objetivo de combater a massiva onda de grilagem das terras.

Além da atuação no tocante à organização dos camponeses junto ao sindicato, Wilson era comerciante tropeiro que transportava mercadorias da região de Correntina para Goiás. Desta atividade, interlocutores informaram da ligação de Wilson com a Guerrilha do Araguaia, no abastecimento de alimentos e outros suprimentos demandados pela guerrilha.

No Município de Santa Maria da Vitória, o Sindicato dos Trabalhadores Rurais foi fundado em 1974. A intervenção privatista da terra neste município chegou primeiro, protagonizada pelos interessados na implantação de projetos pecuaristas incentivados por escandalosos incentivos governamentais fornecidos pelo Banco do Nordeste/SUDENE. A investida contra a apropriação camponesa da terra foi ferrenha e a resistência foi organizada tendo à frente o Partido Comunista. O relato de Joaquim Lisboa dá uma importante indicação disso: na imprensa brasileira de resistência à ditadura, O Opinião é um dos principais. Do
começo dos anos setenta. Num levantamento que o próprio jornal fez, no seu
cadastro de assinantes... maior parte dos assinantes se encontra em São Paulo,
depois Rio, Minas, Rio Grande, Bahia e Distrito Federal. Aí vem em relação ao
número de habitantes, as cidades que tem maior número de assinantes, no Brasil,
são: Santa Maria da Vitória, na Bahia, ${ }^{84}$ (risos). E eu vendia essas assinaturas......E
tá aqui, Santa Maria, em todo país, primeiríssimo lugar em relação... tinha um amigo
meu de Brasília, que morava em Brasília nesse período, ele, chegou aos ouvidos
dele, que Santa Maria ficou na mira do SNI por causa disso aqui. Porra como é que
uma cidade dessa vende essa quantidade de assinaturas desse jornal contra a
ditadura? Tem alguma coisa lá diferente nesse lugar. Logo os caras ficaram de olho...
... no Opinião escrevia pessoas de várias tendências, né? PC do B, PCB, MR 8, tudo,

${ }^{84}$ Este relato indica a grande concentração no município de Santa Maria da Vitória de opositores ao regime. E outros relatos informam a grande movimentação de protestos em passeatas, prisões de militantes e enfrentamento por estes à ordem do regime. 
né? Nesse Opinião saía normalmente, tinha uma página que era do Le Monde, Le Monde Diplomatique, tava lá... ${ }^{85}$ (Joaquim Lisboa Neto, Coordenador da Casa da Cultura Antonio Lisboa de Morais e da Biblioteca Campesina de Santa Maria da Vitória, trabalho de campo realizado em jullho de 2008)

No município de Santa Maria da Vitória, a resistência à grilagem caminhou junto com a resistência à ditadura militar. Não é difícil entender esse casamento, pois o processo de privatização das terras posto em prática pelas oligarquias locais combinada com interesses de grupos empresariais, correspondia a uma política estatal que visava justamente viabilizar a produção do capital naqueles "espaços vazios", e, por este meio, impedir a investidas dos comunistas que, na ilegalidade, direcionavam seu foco de atuação para os campos longínquos interioranos, na organização dos camponeses para o enfrentamento ao regime e à privatização da terra pelos interesses capitalistas. Por esta via, pode-se compreender o porquê das "vistas grossas" do aparelho estatal a tantas atrocidades praticadas pelos privatistas e até mesmo ação direta a serviço de grileiros, da parte de juízes, polícia, cartórios e todo aparelho estatal.

Até a primeira metade da década de 1970, apesar das brutalidades das forças privatistas da terra, a organização dos camponeses praticamente inexistia. Só entre 1975 e 1976 a CPT destacou, para a região da Bacia do rio Corrente, uma equipe de voluntários, a fim de atuar no trabalho religioso e pastoral. E, após a criação da CPT- Bom Jesus da Lapa, em 1980, foram encaminhados três agentes (dois leigos e um advogado) para o trabalho na região.

Da mesma forma, o Partido Comunista enviou quadros para a região, tal como Wilson Martins Furtado em finais da década de 1960 (designado por Ângelo Arroyo) e Paulo Oisiovici em 1982 (por decisão do Comitê Regional do Partido Comunista em Salvador, para auxiliar Wilson nos trabalhos do Sindicato). O trabalho conjunto de religiosos e militantes do partido resultou na fundação de sindicatos na região e consequentemente no fortalecimento da resistência às forças privatizantes.

Fatos marcantes nesses anos sombrios foram os assassinatos de muitos trabalhadores camponeses e do advogado do Sindicato dos Trabalhadores Rurais de Santa Maria da Vitória, Eugênio Alberto Lyra, no dia 22 de setembro de 1977, um dia antes da viagem desse advogado para Salvador, a fim de prestar depoimento à

\footnotetext{
${ }^{85}$ Falhas na gravação truncaram as frases e por vezes comprometeu o conteúdo da entrevista. Mas, mesmo assim a apresento, por considerar a importância desse conjunto de iniciativas no engendramento da resistência ao regime autoritário à investida dos grileiros às terras camponesas.
} 
CPI (Comissão Parlamentar de Inquérito) da grilagem na Assembleia Legislativa do Estado da Bahia, na qual prometia apresentar farta documentação sobre os processos fraudulentos de privatização das terras na região.

Além da fundação dos sindicatos para a organização dos camponeses, por iniciativa de um grupo de ativistas, dois anos após o assassinato do advogado do sindicato, criou-se os jornais "O Posseiro" (em 1979) ${ }^{86}$ e "A Foice", ligados ao Sindicato dos Trabalhadores Rurais do município de Correntina. Em seguida, por iniciativa do mesmo grupo, foi fundada a Biblioteca Campesina ${ }^{87}$ e a Casa da Cultura Antonio Lisboa de Morais ${ }^{88}$, onde, após o crescimento da biblioteca, Ihe deu abrigo.

bem, aqui em Santa Maria eu tenho uma crença muito forte de que essa luta que a
gente trava aqui... difícil você encontrar em outras cidades: Correntina, Lapa,...
outras... Pelo menos uma vez por semana me aparece um jovem dizendo, ó eu quero
me aprofundar... aí, o que é que acontece? Quando nós criamos essa biblioteca
aqui... O Posseiro, O Posseiro foi o embrião, né? O Posseiro foi o embrião. Quando
nós criamos O Posseiro, nós começamos já a disseminar as idéias dos nossos
camponeses, né? Na questão política como também artística, né? Guarani, na
questão literária, Osório Alves de Castro... E Osório aí já juntava a literária com a
política, pelo fato de Osório ter sido... São Paulo, etc. criar o PC, politicamente mais...
Guarani, que é o carranqueiro maior nosso, né? E depois na luta pela terra, além de
Clodomir de Morais ter, lá no Pernambuco, criado as Ligas Camponesas, organizado,
as ligas que se espalharam... nós tivemos, vamos dizer assim, o privilégio de receber
Eugênio Lyra, que chegou, né? O advogado tratando dos posseiros, né? E juntando
todas essas forças..., esses ícones, Guarani com as carrancas, isso deu pra gente,
naquele período... uma força... esses seriam os nomes que Santa Maria deu ao
mundo sem nenhum exagero... que.... começar com O Posseiro, o jornal, que foi
criado dois anos depois da morte de Eugênio Lyra,... mais precisamente, que Eugênio
morreu em setembro e através d'O Posseiro nós começamos a demonstrar para a
sociedade, uma coletividade santamariense, que existia pessoas que não se
conformava em só ver as coisas acontecendo e, ficarem calados... as coisas
acontecendo e a gente digamos só contemplando, ou só se queixando, né?
Começamos realmente... tal... combate... nesse período, nos anos setenta foi que foi
que... capitalismo no campo... praticamente não existia assim, o latifúndio. Eram ou

${ }^{86}$ A publicação d'“O Posseiro" se encerrou em 1996, em seu número 91. Este jornal tem com principal característica a divulgação dos conflitos criados pela expansão da propriedade capitalista da terra sobre as terras apossadas pelos camponeses. Os fatos são abordados a partir da fala de quem vivenciou os enfrentamentos (os posseiros e outros sujeitos sociais que saíram na sua defesa, tais como os sindicatos, advogados, igreja (CPT)).

Estes jornais inteiramente voltados para as questões agrárias da região desempenharam importante papel na organização da resistência camponesa, bem como na publicidade da situação conflituosa na região, no país e até no exterior. Cabe nota também sua importância como fonte de pesquisa para o trabalho em desenvolvimento.

${ }^{87}$ Com um acervo de mais de 30 mil volumes selecionados sob o rigor de um excelente gosto, esta Biblioteca e Casa da Cultura representa um "oásis" de cultura letrada em longínquos sertões do Estado da Bahia. Este "achado" representa uma anormalidade naqueles sertões que historicamente amargam a opressão das oligarquias arcaicas que sempre oprimiram e oprimem as massas com seu impiedoso braço de ferro.

${ }^{88}$ No histórico de atividades dessa entidade, constam importantes exposições das artes plásticas, palestras com poetas/escritores, apresentações musicais nas edições anuais da Semana da Cultura de Santa Maria da Vitória, com o que conhecemos de mais fino da música brasileira, dentre outras. 
minifúndios ou médias propriedades. Era realmente a produção agrícola. Algodão... etc,... produtor de feijão da Bahia. Só com pequenos produtores... aqui essa produção tremenda de alimentos aqui. E aí o que é que acontece? Com a entrada desses capitalistas protegidos pelos bancos oficiais e tal, aí começou a expulsão e a produção agrícola baixou, não é, diminuiu muito, muito mesmo... pecuária, né? Foram ficando na mão desses... já acompanhados dos seus respectivos pistoleiros. E esse clima forçou a gente a lutar, com nosso arco e flecha, né? Nós resolvemos criar uma biblioteca... importante, interessante... a biblioteca iria exercer um papel interessante que gera a questão da leitura, né?... O povo quanto mais for... doutor... não,... o cara que tem consciência da sua realidade, né?... ... despertou perante a classe dominante uma espécie de um.... né? Porque os que constrói a biblioteca eram os mesmos que vinham fazendo $O$ Posseiro. Então... perceberam que a coisa ia ficando mais, mais grave. E até exemplificando, tinha um prefeito da época, ele deu ordem aos funcionários públicos municipais de não freqüentarem a biblioteca. Aquele que freqüentasse seria punido... e um outro que não era prefeito, vereador nem nada, mais politiqueiro... coronelismo, né? Comentava: se eu fosse o prefeito eu mandava tocar fogo nessa biblioteca. De fato a biblioteca, cujo seu primeiro espaço, media dois metros por um. Eu e você, essa mesa nem cabia. Espaço pequeno, uma mesinha, três caixotes de maçã servindo de estante, causou todo esse alvoroço, né? Perante a classe dominante. ...pistoleiros, etc. E enfim, tivemos dificuldade para romper o bloqueio. Porque, o povo, digamos, dominado, né? Por essa classe dominante tinha medo de freqüentar a biblioteca... Tinha dinheiro nem sequer para atravessar o rio aqui para ir para São Félix. Aí foi, divulguei logo o trabalho d'O Posseiro, da biblioteca, aí consegui apoios, né? Lá fora, aqui dentro difícil,... vir de lá da América Central, do Peru, fui adquirindo um pouco mais de experiência para saber como... Aí gradativamente a biblioteca foi avançando. Depois criamos a Casa da Cultura, mantendo o nome: Biblioteca Campesina, mas Casa da Cultura Antonio Lisboa para ir buscar como entidade, e não clandestina, né? Porque mesmo estando aí ostensivamente, mas sem a tal da... A Semana de Arte e Cultura foi... os nossos mesmos. Já na segunda... cada semana, trouxemos aqui alguns nomes da política... de forma tal que a Semana de Arte e Cultura em Santa Maria, durante toda uma semana, de segunda feira... a cidade só respirava isso, praticamente. As escolas liberavam seus alunos, entendeu... todas as escolas... os climas quentes, né? Do momento, sobre socialismo... até hoje também me cobram a volta da Semana de Arte e Cultura, isso porque toda a juventude vibrava (Joaquim Lisboa Neto, Coordenador da Casa da Cultura Antonio Lisboa de Morais e da Biblioteca Campesina de Santa Maria da Vitória, trabalho de campo realizado em julho de 2008).

Este depoimento dá indicações de como foi engendrada a resistência em âmbito local. Estas iniciativas, conforme assinalado, se somaram a outras frentes constituídas da atuação de comunistas que chegaram à região, bem como a influência de religiosos progressistas da Igreja Católica, resultando em uma articulação da resistência ao regime autoritário e às investidas privatistas da terra na região.

\subsubsection{A Atuação dos sindicatos frente à intervenção privatista da terra}

Esse conjunto de iniciativas teve, como importante resultado, o aumento da visibilidade para a sociedade abrangente da situação de extrema opressão e 
violência sofrida pela população trabalhadora da região. Possibilitou também o reforço da resistência, levando os conflitos para a seara jurídica. Como consequencia ocorreu com a intensificação da violência da parte das oligarquias locais que se encarregaram de, em um primeiro momento, mais diretamente, fazer a "limpeza" da área expulsando com a violência os camponeses.

Esse contexto intensificou o conflito e abriu maior campo de atuação, tanto para quadros do Partido Comunista, apesar da clandestinidade, quanto para agentes da Igreja Católica. Isto resultou na fundação da CPT- Bom Jesus da Lapa, em início da década de 1980, e, após abertura política, em uma ampliação da influência comunista na região. Um saldo bastante positivo dessa fase foi a politização do movimento camponês na região. O Sindicato dos Trabalhadores Rurais de Santa Maria da Vitória, no período do auge do conflito, segunda metade da década de 1970 e primeira metade da década de 1980, representou um bom exemplo disso, conforme Kraichete e Comerford:

Nas condições da época, os êxitos do trabalho realizado refletiam-se no aumento do
número de associados ao sindicato e de sócios quites. No $1^{0}$ de maio de 1985 , o
sindicato promovia, em Santa Maria da Vitória, uma manifestação com 5.000
trabalhadores. Além disso, em alguns casos, conseguiu-se garantir a permanência de
pequenos produtores em áreas sob a mira dos grileiros: "se não fosse o STR ter
chamado a união dos trabalhadores, hoje várias regiões vizinhas só teriam
fazendeiros, currais, pastagens e amalhador de gado. Hoje, graças a Deus, ainda tem
centenas e dezenas de trabalhadores chegando e a luta continua". "Teve muitas
vitórias. Tanto aqui como em outras regiões era uma briga pela terra que não era
fácil. Morreu muito trabalhador" (depoimentos de trabalhadores rurais a (KRAICHETE
e COMERFORD, 1991, p. 70)). Esta citação faz referência a um período em que a organização dos camponeses se destacou, pois, em um contexto de forte investida da grilagem e de pouca disposição da antiga diretoria do STR em organizar a base para o enfrentamento, esta se levantou e, nas eleições sindicais de 1983, tomou a direção da entidade e estabeleceu novas estratégias de luta, conforme Kraichete e Comerford (1991, p. 70):

A renovação da diretoria do sindicato em 1983, ocorreu simultaneamente a um processo de resistência à grilagem. Montou-se uma estrutura sindical baseada em delegacias e num rodízio de diretores que permitia aos membros da direção do sindicato permanecerem trabalhando em suas roças. A atividade da diretoria incluía visitas constantes às áreas, num trabalho conjunto com as delegacias sindicais. Nestas visitas, além das questões imediatas, discutiam-se também temas como a reforma agrária. "No fim de 1984, fizemos um encontro central para avaliar o trabalho. A diretoria ajudava muito as delegacias. Os delegados, por sua vez, sempre iam à sede para levar e receber informações e sugestões para as assembléias enfrentarem. Com isso, cresceu o prestígio e a delegacia aumentou o número de delegados. As 
pessoas que não sabiam o que era reforma agrária ficaram sabendo (KRAICHETE e COMERFORD, 1991, p.70).

O período em que a capacidade de organização ganha maior poder de enfrentamento coincide com o marco oficial da abertura política e, no Estado da Bahia, com as campanhas que garantiram a vitória do governo progressista de Waldir Pires, em 1986.

Dessa maior capacidade organizativa surgiram algumas vitórias frente à truculência dos latifundiários, diminuindo a prática da grilagem - e até mesmo algumas desapropriações de terras griladas aconteceram na região. Uma das grandes vitórias apontadas pelas lideranças sindicais, resultante desse processo, foi o primeiro assentamento de reforma agrária da Bahia, instalado no município de Angical, que, com muito ânimo, foi comemorado pelas lideranças do movimento sindical da região.

Com a Reforma Agrária na Fazenda Sertaneja, quebrou-se a espinha dorsal do latifúndio na região, como afirma certeiramente Wilson Martins Furtado, secretário da FETAG-BA. Wilson, ex-presidente do Sindicato dos Trabalhadores Rurais de Correntina, considera que essa vitória dos trabalhadores deve-se a atuação de diversas entidades como o Sindicato dos Trabalhadores Rurais de Barreiras, Igreja, FETAG, CONTAG e PMDB. Vale lembrar que quem deu início à luta pela reforma a ser feita na Fazenda Sertaneja foi o ex-ministro da Reforma Agrária, Nelson Ribeiro, o qual enfrentou fortes pressões principalmente por parte de Marco Maciel, pois o chefe da Casa Civil como bom defensor dos oligarcas, não concordava com a medida. ${ }^{89}$

Nos anos que se seguiram, concomitante a algumas vitórias dos camponeses nos embates com os grileiros, e político-eleitorais de setores da esquerda da época, a combatividade das lideranças que assumira destaque nos anos de 1980 foi se arrefecendo. As divergências entre as partes constituintes da resistência (CPT e PCdoB) foram se aflorando e se acirraram, polarizando, muitas vezes no interior das próprias diretorias de sindicatos, os sindicalistas ligados ao Partido Comunista e os ligados à igreja. Estes últimos foram se ligando ao Partido dos Trabalhadores (PT) o qual passou a atuar em momentos como aliado do PCdoB e em outros até como adversário dos comunistas. Isto é evidenciado no caso do município de Correntina em que, recentemente (eleições de 2008), o PCdoB acolheu em sua legenda um egresso do antigo Partido da Frente Liberal (PFL), atual

\footnotetext{
${ }^{89} \mathrm{O}$ Posseiro, ano VII, n. 62, set-1986, p.6. (por Joaquim Lisboa Neto)
} 
Democrata $^{90}$, o prefeito do município, e o PT disputou a eleição municipal em outra chapa (a derrotada). Postura parecida com a do PCdoB, no que diz respeito às alianças, também é visível no PT, como é o caso do governo Jaques Wagner acolher políticos ligados ao carlismo, os secretários de seu primeiro mandato, da agricultura (Roberto Muniz) e da infraestrutura (João Leão).

\subsubsection{A partidarização e o agenciamento estatal das entidades representativas dos camponeses geraizeiros}

São frequentes as críticas à atuação das tradicionais entidades representativas dos camponeses nos dias atuais (Sindicatos de Trabalhadores Rurais e Comissão Pastoral da Terra). Muitos afirmam que as entidades se distanciaram das lutas e que suas sedes foram transformadas em agências do Instituto Nacional de Seguro Social (INSS), do governo ${ }^{91}$.

Segundo interlocutores, após o governo Collor de Mello, com a extinção do Fundo de Assistência ao Trabalhador Rural (FUNRURAL), este delegou aos sindicatos filiados à FETAG, a distribuição de benefícios sociais, como aposentadoria do trabalhador rural, e, mais recentemente, auxílio-gestante e outros serviços/benefícios. Esta incumbência assumida pelos sindicatos acabou por sobrecarregar a sua estrutura com trabalhos burocráticos ${ }^{92}$, em detrimento da sua devida atuação em apoio às lutas necessárias e até desesperadamente clamada pelos posseiros em situação de conflitos causados pela violência do massivo processo expropriatório em contínua expansão na região.

Hoje a gente tá envolvido com essa questão do INSS. O governo jogou esse pacote em cima do movimento sindical e tem deixado muito a preocupação. Porque sem a

\footnotetext{
${ }^{90}$ Com a eleição de Jaques Wagner ao Governo da Bahia, o chefe político de Correntina (atual prefeito) transferiu-se do Democrata para o PCdoB, tornando-se integrante da base de apoio (do governo) no âmbito do Estado, porém, adversário do PT em âmbito municipal nas eleições de 2008.

${ }^{91}$ Isto se deve ao grande empenho das entidades em serviços de competência do governo/Estado, sugerindo o entendimento de cooptação das entidades sindicais pelo governo.

92 Desde a década de 1970 o Estado implementa medidas de intervenção na organização dos camponeses. "Com o lançamento do PRORURAL, em 1971, e sua posterior implementação, ficou evidente 0 interesse do Estado em cooptar os sindicatos de trabalhadores rurais, através de convênios estabelecidos com eles para a administração da assistência médica, com vistas à legitimação de uma determinada estrutura social estratificada e contraditória (Coradini, 1996, p.185). Como resultado, esses sindicatos transformaram-se em agências de prestação de serviço antes de entidades representativas de interesses de classe (Delgado e Schwarzer, 2000, p.190; Schmitt, 1996) e se tornaram dependentes dos organismos governamentais (Coradini, 1989, p.59). (BRUMER, 2002, p.66).
} 
gente não consegue e é uma pancada muito dura. Eles vão inventando lei e jogando aí para o sindicato ter que definir, o pessoal acha que o sindicato é quem tem que fazer... isso também é uma questão muito complicada no movimento sindical. A questão de aposentadoria, salário maternidade, auxílio doença, fica tudo a nosso respeito e isso é complicado. Mas a gente vai seguindo assim mesmo, empurrando com a barriga, tudo levando. Mas complica muito os movimentos das ações. É que pertence a grilagem, que pertence à agricultura... fica muito tempo empalhado nisso, né? É 24 horas por dia se você ficar ligado no telefone só atendendo questões do INSS. É complicado (Sr. Roberto Getúlio de Oliveira, diretor do Sindicato dos Trabalhadores Rurais de Correntina, trabalho de campo realizado em janeiro de 2010).

Apesar do refluxo do movimento sindical, as demandas para o trabalho desse instrumento de luta dos camponeses continuam e, em resposta à postura assumida pelas lideranças, muitos dizem que os sindicatos se apelegaram e que não mais querem se envolver na luta, agora são agências do governo.

O próprio presidente do Sindicato dos Trabalhadores Rurais de Santa Maria da Vitória e Coribe, assume que atualmente cerca de $70 \%$ da sua atuação (sindical) está voltada para a assistência social e os 30\% restantes para a luta, para a mobilização dos camponeses na região.

Da mesma forma, são feitas críticas à CPT, que tem se empenhado em atribuições que são próprias ou são dever do Estado, tal como viabilizar a aquisição de documentos, como certidões de nascimento, alegando tratar-se de uma atuação importante para a conquista da cidadania das pessoas.

Um campo de atuação que tem ocupado as entidades é a assessoria/assistência jurídica aos camponeses em situação de conflito, embora nesse aspecto também sejam criticadas sobre a precariedade dos serviços que prestam. É muito comum, conforme um interlocutor, advogados contratados pelo sindicato defenderem posseiro, em uma causa, e, concomitantemente, a grileiros/latifundiários, em outra. Isto tem sido caro aos camponeses cedentes da procuração, pois ocorre do advogado faltar às audiências marcadas em momentos chaves da demanda judicial, o que reverte em grandes prejuízos e, às vezes, decisivos, para o camponês posseiro.

As entidades representativas dos camponeses da região passam também por um intenso processo de partidarização. Isto ficou muito claro quando do meu trabalho de campo realizado em julho de 2008, no qual visitei os municípios de Santa Maria da Vitória, Correntina, São Desidério, Barreiras, Formosa do Rio Preto e Santa Rita de Cássia. Desses municípios visitados, somente o Sindicato dos Trabalhadores Rurais de Barreiras não tinha seu presidente candidato a vereador 
nas eleições municipais daquele ano. ${ }^{93}$ Considero a partidarização das lideranças e entidades do movimento social um fato muito significativo e preocupante, pois, conforme afirmei em outro momento, os atuais governos ${ }^{94}$, mesmo sendo de partidos que historicamente fizeram oposição às oligarquias de extrema direita, nas esferas municipal, estadual e federal, ao chegarem ao poder, não adotaram um modelo de desenvolvimento diferenciado ${ }^{95}$ daquele que, inclusive pelas críticas e oposição que historicamente fizeram, Ihes proporcionaram, com o empenho das massas populares, a chegada ao poder.

Tal postura adotada pelas diretorias de entidades que deveriam lutar pelos interesses dos camponeses e de fato representá-los nas instâncias e nos foros de classe ou do poder público, tem provocado o descrédito destas junto às suas bases, o que torna o futuro ainda mais ofuscado e preocupante. ${ }^{96}$

\subsection{No horizonte, ao longe, alguma luz}

A postura adotada pelas entidades representativas dos movimentos sindical e social na região tem deixado um vácuo a ser preenchido - e é nesse contexto que vem surgindo outras formas de organização dos camponeses posseiros. Tratam-se das Associações Comunitárias, que têm sua atuação pautada na organização comunitária para a reivindicação de melhorias estruturais e no processo produtivo na comunidade, e das Associações Comunitárias de Fundo de Pasto e das Associações Comunitárias de Fechos de Pasto. ${ }^{97}$

\footnotetext{
${ }^{93}$ Isto coaduna com o que nos adverte José de Souza Martins em O Poder do atraso: Ensaios de Sociologia da História Lenta. $2^{\mathrm{a}}$ edição, São Paulo, Hucitec, 1999, pp. 160-161.

${ }^{94} \mathrm{O}$ atual prefeito de Santa Maria da Vitória, é do Partido dos Trabalhadores; do município de Correntina, é do PCdoB; e o governo do Estado da Bahia é do Partido dos Trabalhadores.

${ }_{95}$ Muito pelo contrário até impulsionaram esse modelo e as vultosas cifras de investimentos, incentivos, anistias (jurídicas e ambientais), linhas de créditos disponibilizadas às grandes empresas do agronegócio mostram isso. No âmbito do governo estadual, como podemos ver na Bahia, é muito especial a atenção do Governo Jaques Wagner ao empresariado do agronegócio, vista na sua assiduidade às Farmshows, anualmente realizadas no município de Luiz Eduardo Magalhães, evidenciada ainda mais nos conteúdos dos seus discursos elogiosos e de exaltação àqueles personagens "bandeirantes" do desenvolvimento, tal como seu par em âmbito Federal, Luiz Inácio da Silva, conferindo aos empresários sucroalcooleiros o título de heróis.

${ }_{96}$ Embora as entidades tenham adotado tais posturas é fato notório que as gritantes demandas dos posseiros continuam e até vem se intensificando em alguns casos. Pois as investidas da propriedade capitalista da terra sobre as terras de trabalho camponesas não cessaram.

${ }_{97}$ Estas associações vêm organizando os interessados no âmbito da comunidade para a sua defesa até mesmo em confrontos diretos como já se evidenciou em alguns casos na região.
} 
As circunstâncias levaram as comunidades, a partir da sua organização, a se disporem ao enfrentamento direto quando necessário. São vários os casos de derrubadas de cercas pelas empresas e reconstrução imediata pela comunidade ou 0 contrário. ${ }^{98} \mathrm{O}$ mesmo acontece com pontes que garantem acesso à comunidade e/ou às empresas.

Essas situações conflituosas permaneceriam enclausuradas nos bloqueios engendrados pelas elites dominantes que, tradicionalmente, contando com a conivência e o apoio direto do poder público local e estadual, continuariam com a invisibilidade forjada por esses poderes ${ }^{99}$.

Nos últimos anos, esses confrontos têm chegado ao conhecimento das instâncias extralocais dos poderes e alguns foros têm sido criados, nos quais os camponeses podem externar as denúncias há muito tempo abafadas pelas oligarquias locais. Refiro-me às audiências públicas que, como resultado da árdua luta dos camponeses, vêm ocorrendo na região. Nestas, suas vozes ecoam para instâncias extralocais do poder público e, como fruto, algumas ações discriminatórias administrativas de terras vêm ocorrendo na região, embora o poder dos grileiros seja tanto, que vem oferecendo impedimentos à atuação dos órgãos competentes, como CDA, órgão baiano encarregado da regularização das terras públicas.

\begin{abstract}
...não tem sido suficiente (apoios da CPT e sindicato). Sabe por quê? Nem o governo! Que o governo mandou medir aí, uma pessoa representante do Estado aí e ele foi barrado por eles. Foi barrado! E até hoje e até hoje a liminar nunca saiu, a discriminatória nunca saiu. Quer dizer, concluíram a medição porque quando o pistoleiro foi barrar e tinha duas pessoas medindo do lado, dois agrimensores, quando eles barraram um (...) (...) o Paulo, o grileiro Paulo. Medindo essa própria área que tá devoluta. Tem algumas posse aí no meio, tudo bem, que é dele, mas medir para fazer a discriminação, o que é dele e o que não é dele... aí ele foi barrado. Quer dizer, ele mandou barrar. Dizendo que tavam invadindo terra dele, terras escrituradas, e ameaçou uma das pessoas que tavam medindo com o grupo de pessoas do lugar, daqui do lugar nosso, acompanhando, e o cara desistiu, saiu com medo. Só que quando um desistiu, o outro já vinha na outra linha bem próximo, o outro cabou de chegar no ponto aonde ele tinha parado. Só que saíram, a marca que eles colocavam, numerações, eles saíram tirando tudo de facão, machado, não respeitou o governo! (Morador da comunidade de Olhos D'água dos Neres, município de Santa Maria da Vitória, janeiro de 2010).
\end{abstract}

\footnotetext{
98 É muito emblemático nesse sentido, o caso das comunidades de Couro de Porco e do agrupamento comunitário usuário dos fechos de gerais, contidos na área visada pela empresa CFMAgropecuária, na região de Morrinhos e Entre Morros.

99 Jornais criados com a finalidade de tirar da invisibilidade as injustiças praticadas pelos poderosos sobre os camponeses locais, tal como "O Posseiro" e "A Foice" não mais circulam. Cabe às comunidades se valerem de outras estratégias forjadas na organização interna.
} 
Em um episódio como esse, em que o Estado é desafiado, o uso da força não foi feito tal como corriqueiramente se faz em combinação com os interesses privatistas na região, a benefício dos grileiros e contra os camponeses posseiros.

Nessa investida, os grileiros pretendem expropriar/expulsar os camponeses tanto dos gerais quanto das parcelas de uso familiar pelos membros da comunidade. Porém, para expulsar o posseiro da sua parcela de uso exclusivo, carece de maiores artifícios e manobras jurídicas, o que não é muito raro praticar na região. Mas, nesse caso, a resistência tem sido maior e, onde a privatização das terras livres está mais consolidada, presencia-se a situação da comunidade estar quase ou totalmente expropriada, desprovida de terras que possa trabalhar e garantir o seu sustento.

$\mathrm{Na}$ prática privatista da terra, as empresas geralmente se apropriam, no primeiro momento, das áreas de tabuleiros (os gerais). Imediatamente, constroem cercas, picadas e contratam pistoleiros (por elas chamados de seguranças) para a garantia do domínio. Utilizando-se dos serviços desses comparsas investem incansavelmente na expulsão da comunidade instalada no fundo de vale, desassossegando-a, tanto nas áreas de criatórios nos gerais (fecho de gerais), quanto naqueles de morada e da prática agrícola.

O grileiro intervém nas propriedades camponesas, geralmente por meio da "compra" de pequenos talhões de terras (quando se trata das áreas de fecho de gerais, "compram" "bola de arame" de terra (transação que será explicada oportunamente). A partir do recibo concedido pelo posseiro, servem-se dos cartórios para a elaboração de uma escritura de área invariavelmente superior à de todo o fecho) que os posseiros tradicionalmente se apropriaram. Por meio dessa via, o grileiro forja, contando com os serviços dos cartórios do município, uma escritura de área muito maior, abarcando muitas outras posses e até mesmo propriedades registradas com escrituras públicas. A partir dessa intervenção, o desassossego se instala nos ambientes comunitários, tanto devido aos serviços que alguns de seus integrantes prestam a esse forasteiro oportunista, quanto à ameaça e à ação constante dos jagunços que se valem da violência para fazer valer a investida do grileiro, garantir a sua propriedade. São várias as reações dos posseiros a essa investida expropriatória. Uns se desgostam e abandonam suas posses centenárias em busca de uma vida de paz. Outros resistem. E, há posseiros que "vendem" sua 
posse a troco de qualquer coisa para o próprio grileiro ou a quem se disponha a enfrentar a situação de instabilidade e conflito instalado. O fato é que qualquer que seja a decisão, não é vantajosa, pois, no caso da venda da posse, dada a instabilidade, esta fica extremamente desvalorizada. A resistência implica expor-se a situações de riscos constantes no enfrentamento a um inimigo cujo poder de ataque é imensurável, pois tem o apoio direto do Estado ou omissão deste para com a garantia dos direitos dos camponeses posseiros. Sabe-se também que essa situação inaugura a chegada dos interesses do capital nacional e/ou internacional, o qual conta com o incondicional apoio do Estado com todo o seu aparelhamento dos poderes que o constitui. Ou seja, com toda a sua máquina repressora a serviço/defesa da classe dominante a oprimir os camponeses na investida expropriatória que satisfaz aos seus interesses.

Nos altos chapadões, a oeste, a intervenção é mais antiga e tem sido mais intensa. Os camponeses resistem nas parcelas de fundo de vale, onde há muito tempo residem e trabalham, defendendo a sua terra de trabalho. Temos como exemplos de situação de ferrenho conflito, as comunidades de Couro de Porco, Bebedouro, Passaroto e Cajueiro situadas na margem esquerda do rio Arrojado. Estas travam disputas com as empresas Planta 7, D. Coimbra, Brasil Verde, Reba e outras. Quando das primeiras investidas das empresas grileiras do ramo madeireiro/silvicultor ${ }^{100}$, as comunidades procuraram se defender, demarcando para si a parte do fundo de vale (que constitui as terras de trabalho das comunidades), traçando um "picadão", delimitando-as. Porém, as pretensões das empresas grileiras eram e são muito mais ambiciosas e as disputas/confrontos se tornaram constantes a partir de então.

À investida privatista dos grileiros soma-se a diminuição da produtividade dos solos nas parcelas das comunidades. Essa deficiência é atribuída à antiguidade da exploração ininterrupta, combinada com o adensamento populacional no interior das comunidades.

Entre as providências tomadas pelas famílias para a garantia da sobrevivência, estão as seguintes:

a) migrar para as cidades locais (cidades como Barreiras e Luiz Eduardo Magalhães têm se destacado como atrativas para essas populações);

\footnotetext{
${ }^{100} \mathrm{Na}$ região Oeste da Bahia, a investida privatista da terra se iniciou pelas empresas desse ramo, cuja lista de muitas delas já apresentei.
} 
b) assalariarem-se nas empresas que perseguem as terras de sua comunidade, visando privatizá-las. Essa opção abre campo para a "adoção" de postura contraditória por alguns sujeitos, que resulta em uma forma de intromissão da empresa na vida da comunidade, dificultando a luta daqueles que resistem a qualquer lógica imposta pelos interesses privatistas na organização comunitária.

c) aumentar a atividade pecuária com maior uso dos fechos ou pastagens naturais em geral. Essa se destaca como uma das alternativas mais corajosas, pois significa resistir às investidas de grileiros e conviver com ameaças e práticas violentas, como a própria grilagem e a pistolagem; enfrentar as represálias diretas que impedem ou limitam o uso das soltas, dos gerais, com obstrução dos acessos às aguadas, interrupção de estradas, aprisionamento e abates do gado e outras, e as indiretas, que são os processos impetrados no judiciário local, instância historicamente desfavorável aos camponeses devido ao casamento selado entre as oligarquias locais e regionais, com os interesses do capital seja nacional ou internacional. Nesta situação, buscam potencializar sua organização fortalecendo as Associações de Fundo e Fecho de Pasto, as quais, apesar das contradições nas práticas de algumas lideranças, têm se destacado como alternativa na luta pela permanência na terra de trabalho. 
CAPÍTULO 4 


\subsection{Comunidades do vale do rio Arrojado: caminhos percorridos para o estudo}

$\mathrm{Na}$ busca do desvendamento dos processos sociais em desenvolvimento no Oeste da Bahia, percorri os caminhos aos quais me referi na parte introdutória do trabalho. O objetivo foi levantar as problemáticas da região e, a partir do contato com elas, escolher a que melhor representasse os processos concernentes à totalidade do Oeste da Bahia. Estas descobertas dar-se-iam concomitante à escolha da área de estudo nas quais as problemáticas se manifestassem de modo mais completo e, da mesma forma, mais representativo da região em estudos.

Das localidades visitadas nos primeiros trabalhos de campo, Correntina destacou-se, apresentando alguns fatores atrativos para a minha investida no prosseguimento da pesquisa. Dentre eles, cito a importante ocupação camponesa do território, principalmente nas margens do rio Arrojado. Esta ocupação, como se pode ver abrange uma área expressiva no vale, destacando-se entre as frações camponesas do território efetivamente ocupadas em outras localidades (figuras 7 a e 7b). No princípio, inferi, e depois ficou comprovado, que o uso camponês dos gerais, nas áreas a montante do vale, também se fazia expressivo, o que me proporcionou maior segurança na escolha da área.

Outro fator que influenciou na escolha do vale do Arrojado para a realização da pesquisa foi a receptividade maior à minha proposta de estudos pelos sujeitos sociais envolvidos com o movimento social camponês. Isto foi demonstrado em suas inteiras disposições a me atender nos pedidos de entrevistas e no empenho para facilitar as minhas visitas e minha aproximação às comunidades, indicando os interlocutores com os quais eu pudesse dialogar, bem como a todo tipo de apoio que eu necessitasse e estivesse a seu alcance.

Foram indispensáveis os auxílios prestados por ativistas de movimentos políticos de esquerda, agentes da CPT, alguns diretores do Sindicato dos Trabalhadores Rurais de Correntina, Diretores do Sindicato dos Trabalhadores em Educação de Correntina (SINDITEC), militantes do MAB, militantes do Movimento Negro e Ambientalista de Correntina. 


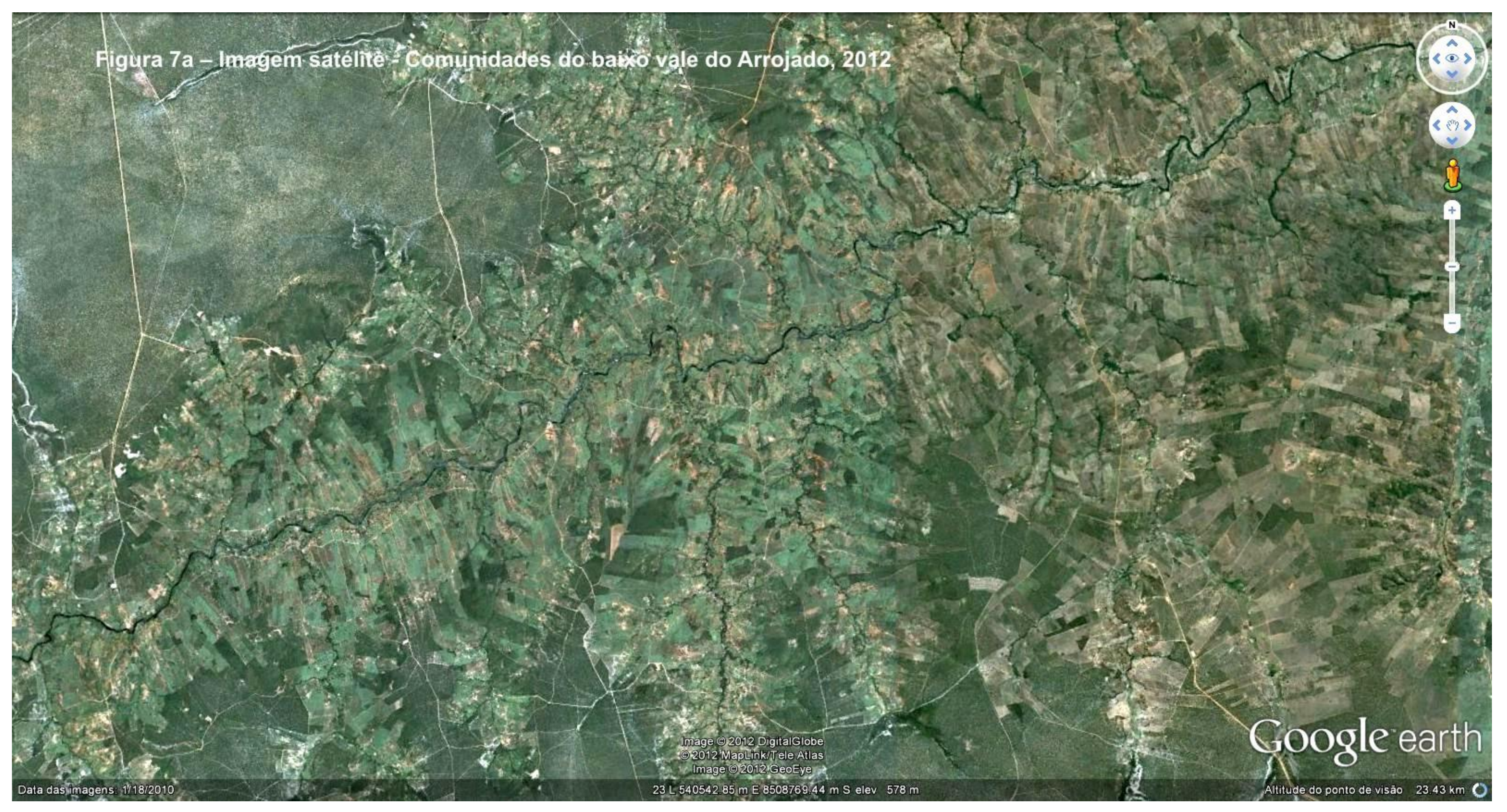


Figura 7b - Comunidades do baixo vale do Arrojado, 2012

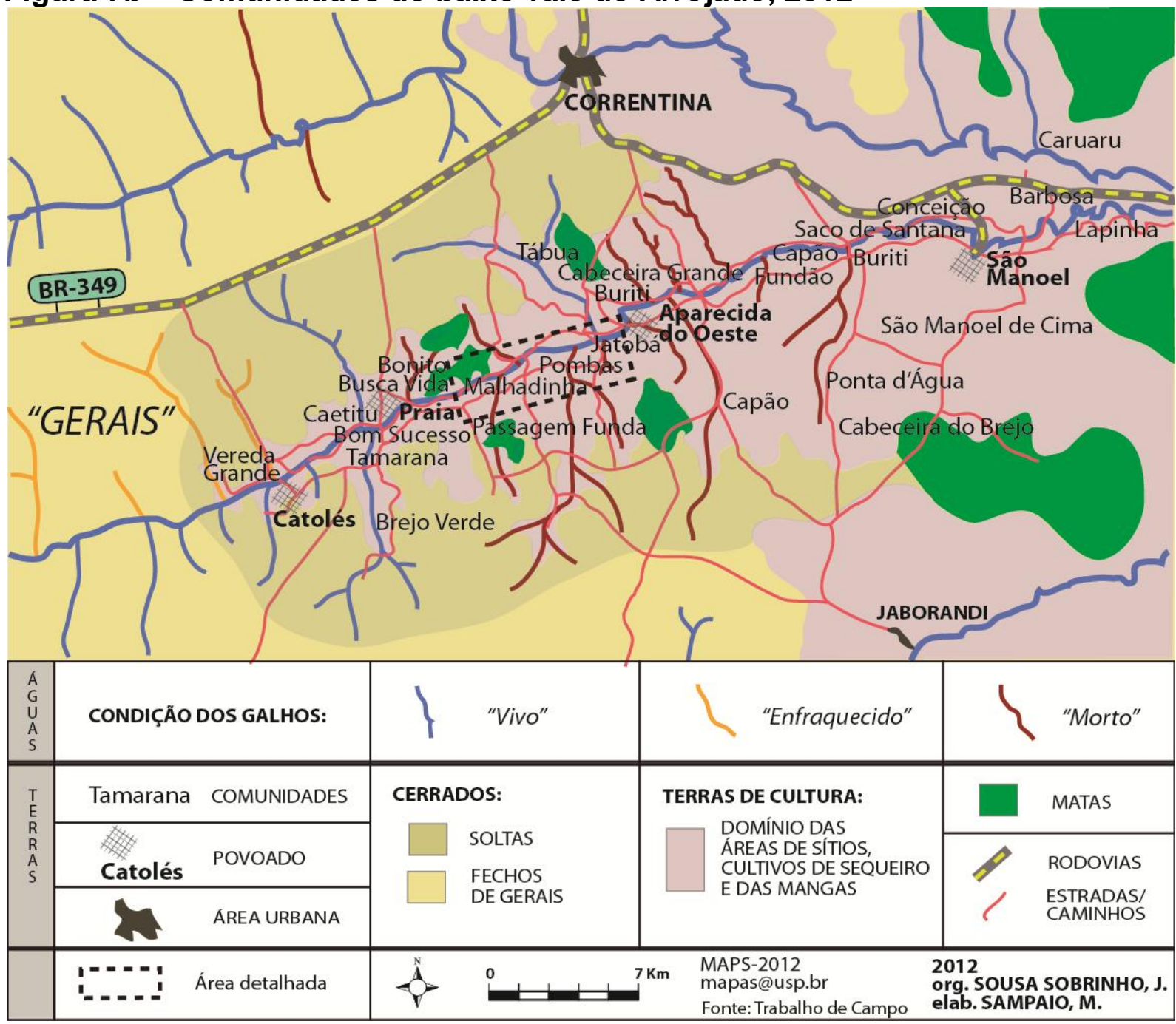

Dentre as problemáticas, compreendo como central, para o desvendamento dos processos sociais na região em estudo, a secular constituição da fração camponesa geraizeira do território e o conflito que se estabelece entre a sua territorialização e a expansão do modo capitalista de produção, levando a cabo, dentre outros fatores, a privatização das terras secularmente por eles apropriadas. Muitos interlocutores, inclusive, reforçam enfaticamente a importância dessa problemática, colocando-se no centro das questões concernentes ao Oeste da Bahia na atualidade, quando afirmam, frequentemente, que o modelo de ocupação recente 
da região sustenta-se às custas das cercas de carabinas, do financiamento público e do respectivo calote ${ }^{101}$.

Instigado por esta problemática, percorri trechos do vale do rio Arrojado em visita a várias comunidades camponesas. E, nas conversas com os integrantes destas, confirmou-se o que os primeiros informantes e as leituras previamente realizadas informavam: tal como a totalidade do Oeste da Bahia, as comunidades centenárias residentes no vale do Arrojado engendraram, ao longo dos tempos vividos ali, um modo de vida peculiar e uma territorialidade própria. Esta, extrapola as áreas de "ocupação de fato, contínua no tempo e no espaço" ${ }^{102}$, territorializandose por áreas longínquas, onde o conflito com as forças expropriatórias do modo capitalista de produção expande-se e, em alguns casos, vem provocando a expropriação, tomando-Ihes as áreas nas quais têm o costume de praticar os criatórios soltos, nas terras devolutas e de uso comum.

Essa tradicional abundância de terras devolutas e livres constituiu a base da territorialidade camponesa geraizeira na região - e as recentes investidas do modo capitalista de produção, marcado pela privatização da propriedade da terra, têm provocado conflitos acirrados, envolvendo a totalidade da população no campo.

No vale do Arrojado, entretanto, cabe ressaltar os diferentes graus de envolvimento das comunidades nos conflitos. Como se poderá ver, um conjunto maior de comunidades situadas no baixo vale do rio Arrojado, cerca de 90, nele se envolve parcialmente. Estas têm asseguradas as terras de morar, plantar e criar (de cultura e soltas, respectivamente) nas parcelas por elas apropriadas há séculos. O conflito em que se envolvem é pela disputa das terras devolutas e historicamente livres, situadas tanto em volta das áreas parceladas, quanto em localidades afastadas, a montante do vale.

Entretanto, outras comunidades, localizadas no médio vale, como as de Couro de Porco, Bebedouro, Passaroto e Cajueiro, enfrentam uma situação de risco de perda total de suas frações territoriais. E, por isso, há cerca de trinta anos, resistem bravamente às escaladas de violência praticada por grileiros, que, se utilizando de pistoleiros, ameaçam e muitas vezes põem em prática os atentados

\footnotetext{
${ }^{101}$ Em depoimento de Iremar Barbosa de Araújo, ativista do movimento social no município. Trabalho de Campo realizado em outubro de 2010.

${ }^{102}$ Entendendo por isto as áreas onde moram e trabalham continuamente e cuja indispensável complementariedade do sustento advém da pecuária, principalmente, praticada em áreas afastadas, nos fechos de gerais.
} 
contra a vida dos posseiros, os abates de seus animais, derrubadas de cercas, queimas de casas e outras. Este caso, que também será estudado, caracteriza-se como de envolvimento total no conflito.

\subsection{As comunidades do baixo vale do rio Arrojado}

Nas páginas seguintes, dedico-me à discussão sobre o primeiro caso, o do baixo vale do rio Arrojado. Nesta região, entretanto, o elevado número de comunidades impôs-se como fator limitante à realização da pesquisa, abarcando diretamente a totalidade da área onde se situam.

A partir deste quadro, tornou-se forçosa a escolha de um caso no universo de comunidades - e que o mesmo se revelasse o mais representativo possível da realidade comum a todas as comunidades.

A opção pela centralidade do conceito de território na análise, todavia, já aponta os elementos considerados nela relevantes e, nestes termos, foram adotados como critérios para a escolha da comunidade a estudar com maior profundidade as questões relacionadas ao uso da terra e da água, bem como o ordenamento territorial que viabilize os usos dessas riquezas naturais.

Esta escolha se fundamentou na prévia noção dos usos costumeiros da terra e da água típicos da região Oeste da Bahia pelos camponeses, baseados na prática agrícola nos fundos de vale e criatórios soltos nos interflúvios. Sabia-se também das variações nesses usos conforme a comunidade, geralmente relacionados aos processos sociais em desenvolvimento.

Quanto às variações consideradas, cito o uso da água na irrigação por meio de longos canais ou regos, relativamente paralelos aos rios e córregos, entre os quais praticam a agricultura irrigada nas partes baixas, na área de sítio. Em uma faixa um pouco mais elevada, imediatamente após o rego, predomina os cultivos em regime de sequeiro, constituídos de produtos alimentícios e/ou pastagens, sendo que as pastagens ganham maior importância na medida em que se distanciam do fundo de vale e os solos vão se tornando menos úmidos e mais fracos. Porém, pouco ou raramente se cultivam pastagens nos fundos das tiras de terra, onde a terra de cultura cede lugar aos solos arenosos de cerrados. Nas áreas com essas características, o uso predominante é o pecuário, solto, nas soltas, usufruindo da vegetação natural como alimento. 
Outra variação considerada na escolha da comunidade diz respeito à prática dos criatórios usando três áreas. Cito a área de pasto formado nas parcelas de uso exclusivo familiar, a manga, a área de solta, localizada nas proximidades da comunidade, geralmente anexa a esta, e a área de fecho de gerais, localizada distante da comunidade, na montante do vale do Arrojado.

Considerou-se também, para a escolha da comunidade, o número da população, pois, assim, aquela escolhida (com maior número) tornar-se-ia mais representativa da totalidade em estudo.

Com relação aos usos da terra, é válido mencionar que, nas últimas décadas, importantes alterações vêm se processando. Muitas comunidades não mais praticam a agricultura irrigada e isto se deve ao fato de muitos córregos estarem perdendo volume de água de modo acelerado ou mesmo já estarem mortos. Em outro momento, citei uma considerável quantidade deles, inclusive veiculada no Programa Globo Repórter, da Rede Globo de Televisão. Porém, levantamento in loco e relatos de moradores da região, revelam que o número é muitas vezes maior.

Outra importante mudança no uso da terra está relacionada às áreas de criatórios. Costumeiramente, os camponeses geraizeiros usufruíam de terras amplas e livres, onde podiam, inclusive, escolher as áreas nas quais as aguadas fossem boas e a alimentação para o gado fosse farta. Podiam encontrar estas áreas nas proximidades das comunidades, nas soltas, ou nos gerais mais afastados, nos fechos de gerais, complementando a alimentação do gado durante o ano, com as pastagens cultivadas (isto nos anos mais recentes) nas parcelas de uso exclusivo familiar, conforme já assinalado.

Nas últimas décadas, entretanto, as comunidades vêm passando por um processo importante de aumento da pecuária entre suas atividades e, concomitante a isto, em proporção inversa, as áreas de criatórios, tanto as próximas quanto as afastadas, vêm sendo tomadas por grileiros que, em seguida, as vendem por preços altos a empresas oriundas geralmente de outros estados ou regiões. Ou então são as próprias empresas que praticam diretamente a grilagem.

Desta situação constata-se que muitas das comunidades não mais dispõem das áreas de criatórios próximas às comunidades, as soltas, e têm como opções de pastagens para seu gado apenas as mangas (pastagens cultivadas nas parcelas) e os gerais. 
Adotando como critérios os usos costumeiros das três áreas de terras para a prática da pecuária (as pastagens da parcela - as mangas, a solta e os fechos de gerais), o uso da água para a irrigação agrícola e a prática da agricultura de sequeiro, das comunidades, a que melhor atende a estas condições e que apresenta maior população é a do Brejo Verde, sobre a qual discorro no próximo tópico.

\subsection{A comunidade do Brejo Verde}

A comunidade do Brejo Verde ocupa as margens do córrego Santana, afluente da margem direita do rio Arrojado e antepenúltimo riacho da extensa área onde se concentram as comunidades do baixo vale do rio Arrojado. Além das margens do córrego Santana, parte da população da comunidade instala-se nas margens de galhos do mesmo córrego, tais como Galho da Vereda Seca, Galho do Pichico, Galho do Vira Saia e Galho do Bota Bunda. Para alguns moradores, a comunidade é dividida em Brejo Verde, Brejo Verde do Meio, Brejo Verde de Cima e Vereda Seca. Inclusive a Secretaria Municipal de Saúde reconhece essa divisão. Mas no meio comunitário ela não é consensual.

$\mathrm{Na}$ comunidade, esta divisão é aceita apenas por parte dos integrantes, geralmente aqueles que residem no baixo vale do córrego, onde as áreas úmidas são mais extensas, os solos são mais férteis e propiciam melhores condições de vida. Estes, quando se referem às localidades a montante (Brejo Verde de Cima e Vereda Seca), as generalizam e as denominam de Vereda Seca - vereda morta que, em função da exiguidade e da fraqueza das terras, exige maior afinco de seus moradores no trabalho para a obtenção dos meios de vida. Os moradores destas localidades (Vereda Seca, Pichico e Vira Saia), acham-se discriminados por esta qualificação pejorativa e não concordam com a divisão. Por isso, afirmam: aqui tudo é Brejo Verde. Realmente, pude constatar que as referidas divisões não estão bem delimitadas e que, se eu optasse pelo estudo a partir de uma das parcelas, eu poderia encontrar dificuldades em função disso, pois importantes questões concernentes à totalidade do Brejo Verde estão relacionadas a elementos presentes a montante ou a jusante do vale ${ }^{103}$. Somado a isto, pude perceber também que a

\footnotetext{
103 Refiro-me a questões como: mobilização da comunidade para a proteção da vereda contra incêndios (mobilizam-se mais os moradores da montante), disponibilidade de áreas mais amplas e solos mais férteis para a prática da agricultura (mais presente na jusante).
} 
maioria dos moradores não se identifica como integrante de uma ou outra localidade, e sim, do Brejo Verde. Este último motivo já seria o bastante para não correr o risco de comprometer a aceitação dos resultados da pesquisa pela comunidade, em razão de uma questão que considero de pouca relevância, tendo em vista o foco central.

Portanto, tendo por base os motivos elencados, referir-me-ei ao Brejo Verde, conforme a aceitação da maioria, à totalidade do vale do córrego Santana.

A comunidade de Brejo Verde, assim como as demais do entorno, formaramse a partir da antiga e efetiva ocupação das terras que se encontram nas proximidades dos leitos dos rios e riachos, onde são mais extensas as manchas de solos agricultáveis - as terras de cultura. É difícil precisar-se o princípio, quando chegaram nas localidades os primeiros ocupantes. Os anciões dos dias de hoje invariavelmente fazem referências a seus avós nascidos na terra que hoje ocupam, ou, quando não, ali chegaram por meio da compra de parcelas que, ao longo dos tempos, foram subdividindo-se. Deste processo, resultou o que hoje pode-se observar, não somente no Brejo Verde, mas também nas comunidades ao longo do vale do Arrojado: os agrupamentos de casas, constituídos de gerações que se sucederam aos antigos e primeiros ocupantes.

Deste modo, a comunidade se formou de modo semelhante ao caso estudado por Marques:

Pelo grupo de vizinhança, que em geral é formado por membros de uma mesma família, descendentes de um mesmo patriarca. Além dos laços de parentesco, o grupo é ligado por laços de territorialidade, de vizinhança, que se fundam na residência, propriedade (MARQUES, 1994, p.96).

O grupo de vizinhança, segundo Antonio Cândido (2003) corresponde a um tipo de povoamento disperso. Na comunidade de Brejo Verde, há poucos equipamentos sociais que viabilizam a sociabilidade dos seus integrantes na fração territarial da comunidade. Contam apenas com uma escola, a qual se encontrava fechada ${ }^{104}$, e um campo de futebol. Servem-se da infraestrutura de serviços

\footnotetext{
${ }^{104}$ Isto ocorre sob a alegação da falta de alunos suficientes para a formação de classes com as séries correspondentes. Achou-se mais conveniente transportá-los para o povoado de Praia. Neste, é oferecido até o ensino fundamental. Para cursar o ensino médio, deslocam-se em ônibus fretados pela Prefeitura Municipal para a cidade de Correntina. Há uma forte cobrança das comunidades do entorno do povoado pelo oferecimento do ensino médio. Porém, a Prefeitura não assume este compromisso, alegando que é responsabilidade do Estado e este, por sua vez, alega a inviabilidade em função do considerado baixo número de alunos.
} 
religiosos, saúde, comércio, lazer e outros existentes no povoado de Praia, caracterizando-se, pois, como um território subordinado a uma povoação (CÂNDIDO, 2003, p. 82), no caso, o referido povoado o qual dista entre 3 (baixo vale) e 8 quilômetros (alto vale) dos agrupamentos familiares da comunidade de Brejo Verde.

Embora não se encontrem na área da comunidade os equipamentos que the proporcione uma razoável vivência cultural, verifica-se nela o exercício de uma importante sociabilidade, viabilizada pela organização da coletividade, afim de melhor apropriarem-se das riquezas naturais, principalmente a terra (por meio das apropriações individuais e comuns), a água, conforme se verá adiante no caso da feitura e uso dos regos, bem como dos encanamentos, que viabilizam a utilização da água potável. A partir destas características, a referida comunidade pode ser definida a partir de Lefebvre, como

uma forma de agrupamento social, que organiza, segundo modalidade historicamente determinada, um conjunto de famílias fixadas ao solo. Estes grupos elementares possuem, por um lado, bens coletivos e indivisos, e, por outro, bens privados, conforme relações variáveis, mas, sempre, historicamente determinadas (LEFEBVRE, 1981, p. 156).

A comunidade de Brejo Verde está localizada a cerca de $30 \mathrm{~km}$ da cidade de Correntina e é habitada por 80 famílias, o que corresponde a 313 habitantes ${ }^{105}$. Limita-se, a norte, com o rio Arrojado (a comunidade de Busca Vida na outra margem), ao sul, com o fecho do Povo de Jaborandi, a sudeste, com o fecho do Lobilino e o fecho de Nezinho, a leste, com o fecho do Vira Saia, usado principalmente pelo povo da comunidade de Passagem Funda, a oeste, com o fecho da própria comunidade e, a este, com o fecho do povo dos Catolés (figura $8)^{106}$.

Interessante notar a referência às áreas de criatórios - fecho do Vira Saia e fecho dos Catolés - como "fechos". Estas áreas situam-se anexas às comunidades de Passagem Funda e de Catolés, respectivamente. Até recentemente, apesar de serem usadas pelas comunidades de Catolés e Passagem Funda como soltas, eram usadas também como fecho pelos criadores de outras comunidades, tais como os da Praia, que traziam seus animais para soltarem ali.

\footnotetext{
${ }^{105}$ Conforme dados do ano de 2012 da Secretaria Municipal de Saúde de Correntina.

${ }^{106}$ A área detalhada em destaque na figura 8 se refere ao recorte apresentado na figura 9, a qual mostra o percurso dos regos.
} 
Em função do uso por outras comunidades como fecho, assim ficou sendo chamada também pelos moradores das comunidades anexas, apesar de usarem como solta ${ }^{107}$.

Chamo a atenção a este fato porque a comunidade de Brejo Verde inclui-se no mesmo caso. Inclusive sua área de solta não era cercada e até recentemente o gado da referida comunidade, da comunidade de Catolés e Praia era solto nela. Mas, alegando a pressão privatista dos grileiros, as comunidades de Catolés e Brejo Verde decidiram cercá-la. Isto provocou intenso conflito entre as duas comunidades na disputa pelos limites e também com a comunidade de Praia, a qual ficou excluída do direito de uso. Segundo os moradores de Brejo Verde e Catolés, os criadores da Praia não têm direito à continuidade do uso por dois motivos: primeiro, eles não moram anexo à área que usavam; segundo, quando a usavam, "venderam" parte para gente de fora (a parte "deles").

${ }^{107}$ Este também é o caso da comunidade de Brejo Verde, que usa a área anexa como solta, mas a ela se refere como fecho. 
Figura 8 - Brejo Verde, 2012

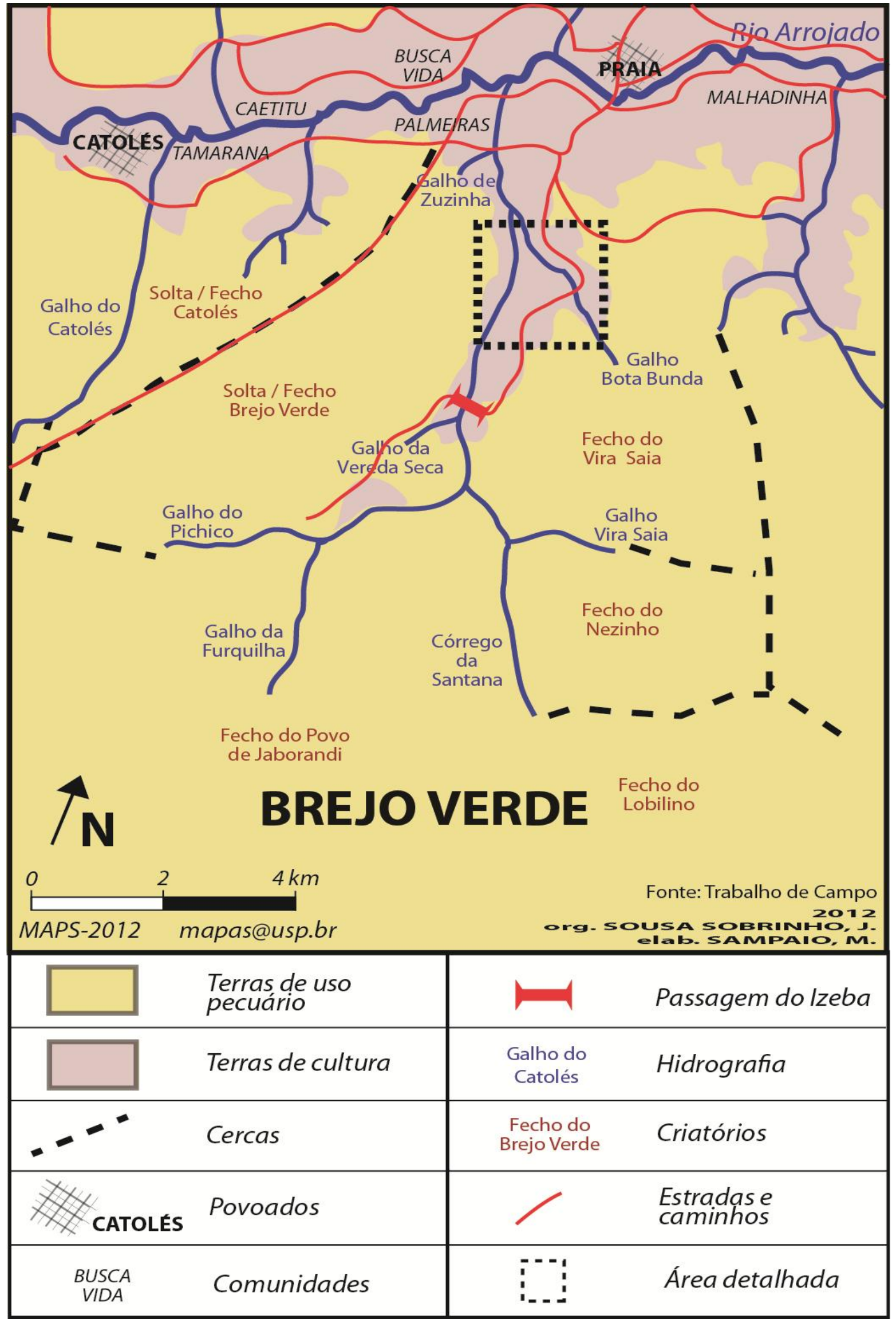


Pode-se ver na figura (8) que no entorno dessa comunidade são extensas as áreas de gerais. Isto se deve à sua situação, no contato das áreas da comunidade com a vegetação de cerrados propriamente dita, com os gerais. Ali já são menos extensas as áreas de terras de cultura, restringindo-se basicamente à beira do rio e dos córregos. Nas margens do córrego Santana, as terras de cultura apresentam maior extensão na margem direita, onde o uso agrícola é mais intenso. Ao contrário, na margem esquerda do córrego, os solos arenosos de cerrados estendem-se até à beira, não favorecendo a prática agrícola e isto explica a pequena quantidade de casas nesta vertente do vale. Inclusive esta configuração se apresenta também em outros riachos da região de contato das terras de cultura com os cerrados. Nesta região, nota-se que a mancha de terras agricultáveis, com os recursos disponíveis aos camponeses, vai cedendo lugar aos solos arenosos dos cerrados e, em outros córregos a montante, já não se nota mais terras de cultura nas margens dos galhos, e, por isso, não fizeram sítio ${ }^{108}$.

\section{a) $O$ percurso dos regos}

A comunidade de Brejo Verde foi escolhido para a realização da pesquisa com maior profundidade por apresentar a diversidade de usos da terra e da água costumeiramente praticados pelos geraizeiros ao longo de sua história e também por apresentar as alterações nestes usos em função dos processos sociais em desenvolvimento na atualidade.

Dentre os vários usos, agora me atenho ao da água com foco mais voltado para o percurso dos canais de irrigação, os regos (figura 9).

Diferentemente de grande parte das comunidades concentradas no baixo vale do rio Arrojado, a comunidade do Brejo Verde usufrui do bom estado dos canais de irrigação ou regos e, inclusive, em grande quantidade, um total de cinco, percorrendo e servindo toda extensão povoada do vale do córrego Santana. Isto possibilita a esta comunidade uma expressiva produção agrícola ao longo do ano, apesar da pouca extensão das áreas de terras de cultura. $O$ rendimento agrícola ganha maior expressividade porque são colhidas duas safras, a de sequeiro, na estação chuvosa, e a do regadio ${ }^{109}$, na estação seca.

\footnotetext{
108 Não povoaram ou construíram moradias.

109 Assim chamados os cultivos da área irrigável, localizada entre o rego e o leito do córrego Santana.
} 
Figura 9 - Detalhe do percurso dos regos na comunidade do Brejo Verde, 2012

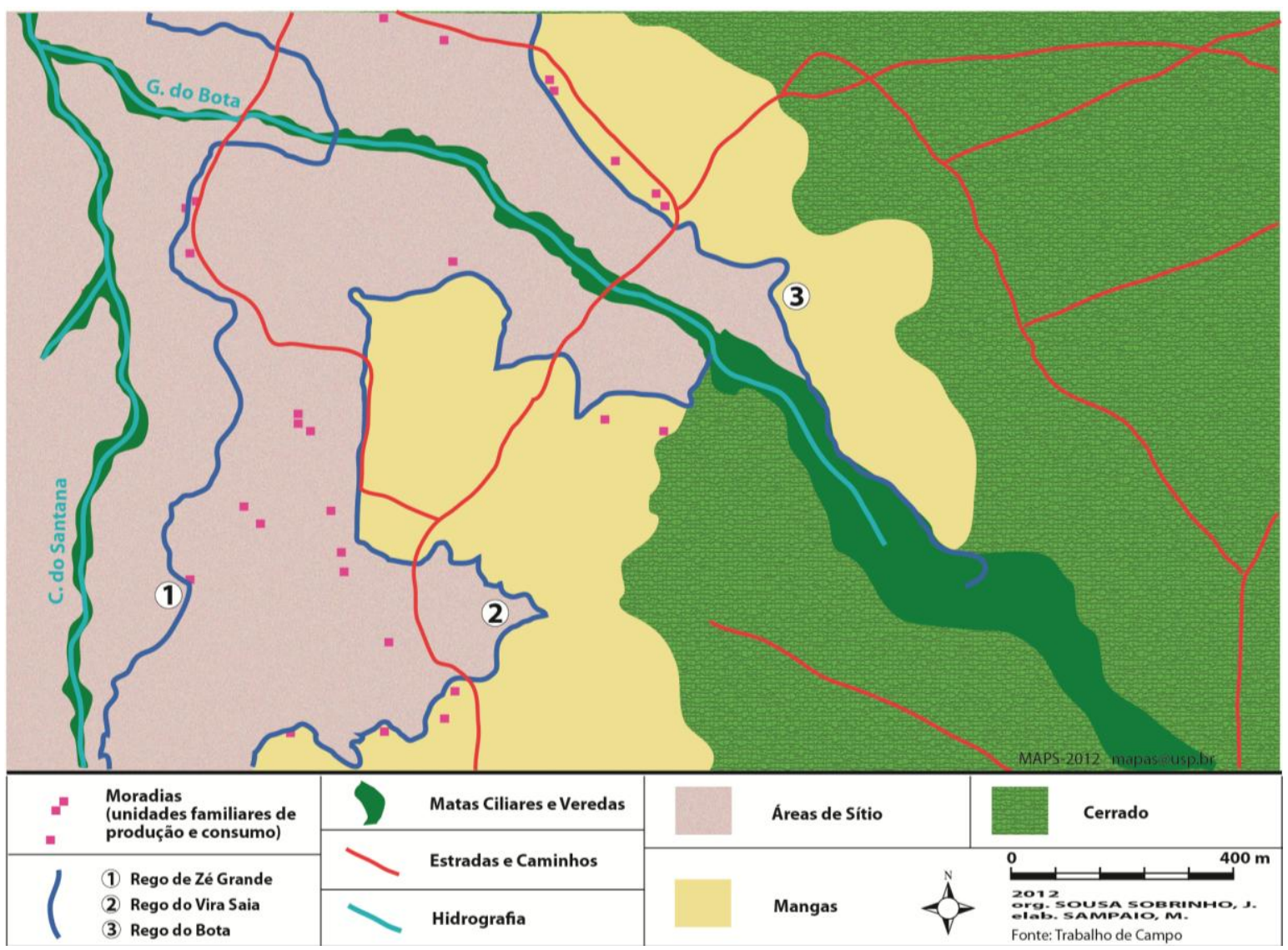

Nesta estação, entretanto, o potencial produtivo de cada parcela pode variar em função da área irrigável, como também da oferta hídrica que é proporcionada pelo percurso dos regos.

$\mathrm{Na}$ comunidade de Brejo Verde, os regos mais longos são os do Vira Saia, assim chamados porque as captações das águas, seus açudes ${ }^{110}$, localizam-se no galho Vira Saia, na região das nascentes do córrego principal, o do Santana (cerca de $10 \mathrm{~km}$ de comprimento). Um deles, o que irriga as áreas mais baixas, percorre toda a extensão da área da comunidade, da extremidade da montante à da jusante, indo até a comunidade da Praia. O outro, que irriga as áreas mais elevadas, interrompe seu fluxo um pouco antes do galho Bota Bunda. Ambos trilham a vertente da direita do córrego, sendo que um percorre a direita da estrada, às vezes serpenteando-a em alguns trechos, e o outro à esquerda, na margem mais próxima ao córrego e onde se concentra a maior quantidade de moradias da comunidade. Estes abarcam a totalidade das terras agricultáveis. A grande parte das áreas

${ }^{110}$ Construção geralmente em pedras, para a captação da água do rio Arrojado ou de afluente, para o abastecimento dos regos. 
trabalhadas (desmatadas) estão abaixo das linhas por onde passam os regos. Alguns talhões desmatados, que ultrapassam para o lado direito do rego que percorre as terras mais altas, são desmates da vegetação de cerrados visando o cultivo de pastagens nos solos arenosos que dificilmente são bem sucedidas.

Esta área, à esquerda do rego Vira Saia, é de domínio das pastagens, embora plantem também milho, mandioca e feijão, na estação seca (irrigados) e na chuvosa, em regime de sequeiro, pois nessa época o fluxo de água do rego é interrompido.

É importante observar, nas áreas das comunidades do vale do Arrojado, que as estradas, em maior parte dos seus percursos, acompanham o traçado dos regos. $E$, consequentemente, esta linha quase sempre corresponde à transição de domínio das lavouras de regadio para as de sequeiro. Na linha traçada pelos regos também se concentram as moradias (geralmente no lado alto). Nos arredores das casas é comum encontrar-se uma variedade de pequenos cercados, nos quais ficam aprisionados animais de pequeno porte, a se beneficiarem da água dos regos. A faixa entre o rego e o rio ou o córrego geralmente é poupada de construções e destina-se exclusivamente aos cultivos de regadio.

A comunidade de Brejo Verde, como já se viu, é beneficiária de mais de um rego nas áreas de cultivos e, por isso, as casas de morada estão situadas nas proximidades de um ou de outro rego, distanciando-se, conforme o caso, da linha da estrada.

Outro rego que percorre a vertente à direita do córrego Santana é o chamado rego de Zé Grande ${ }^{111}$. Este tem seu açude localizado a $700 \mathrm{~m}$, na jusante da localidade chamada Passagem do Izeba ${ }^{112}$. Por um percurso de $1.200 \mathrm{~m}$, percorre a margem imediata do córrego em área quase totalmente imprópria e demais exígua para a prática da agricultura. A partir deste percurso, começa a servir à irrigação dos cultivos até o galho do Bota, onde se encerra.

Conforme descrito anteriormente, no lado esquerdo do córrego Santana, na maioria do seu percurso, os solos arenosos dos cerrados avançam até à sua margem imediata. Entretanto, no alto vale residem alguns moradores, que potencializam o aproveitamento das exíguas áreas agricultáveis disponíveis com a irrigação a partir de dois outros regos. Um deles capta água nas proximidades da

\footnotetext{
111 O rego ganhou o nome do empreiteiro que o construiu.

112 Travessia da Estrada sobre o córrego Santana.
} 
nascente do galho do Pichico e percorre $3.700 \mathrm{~m}$, possibilitando a irrigação de pequenas áreas da beira do córrego. Inclusive atravessa cerca de $700 \mathrm{~m}$ em meio aos cerrados para, em seguida, ofertar água a algumas manchas de solos de uma área na qual alguns moradores da chamada Vereda Seca residem e cultivam alimentos.

O último rego, e menor, também capta água do galho do Pichico e percorre $2.500 \mathrm{~m}$, possibilitando a irrigação de estreitas áreas nas margens do mesmo galho e beneficia principalmente a comunidade chamada Vereda Seca.

O rego do Vira Saia, que irriga as áreas mais elevadas, percorre seu longo trecho com distância média de $600 \mathrm{~m}$ do leito do córrego Santana. As partes mais próximas estão a cerca de $450 \mathrm{~m}$ e as mais distantes a $800 \mathrm{~m}$ do córrego Santana.

O rego Vira Saia, que irriga as áreas mais próximas ao córrego Santana, dista deste à média de 400 m, variando sua distância entre 250 e 550 m.

Já o rego de Zé Grande, conforme assinalado, percorre grande parte de seu curso nas proximidades do córrego Santana, a cerca de $70 \mathrm{~m}$. Quando se afasta e se torna mais importante para a irrigação, sua distância do córrego atinge a média de 190 m, variando entre 160, a distância menor, e 210 a maior.

Quanto aos regos que irrigam a margem esquerda do córrego Santana, o que percorre as áreas mais elevadas afasta-se do galho do Pichico ou do córrego Santana, distância média de 370 m, variando de 210, a menor distância, a 550, a maior. No mesmo lado do córrego, o que irriga as áreas mais baixas dista a média de 250 m, variando entre 200 m, a menor distância, e 350 m, a maior.

Estes são, portanto, os percursos dos regos que irrigam a maior parte das áreas nas quais os moradores da comunidade do Brejo Verde praticam a agricultura. Estes regos abarcam a quase totalidade das áreas agricultáveis.

\section{b) A organização comunitária para a construção dos regos}

No tópico anterior, ative-me ao caso do Brejo Verde na descrição do percurso dos regos na área da comunidade, no entanto, há que se salientar que esse modo de uso da água constitui a tradição de todas as comunidades do baixo vale do Arrojado, embora, conforme já assinalado, muitas delas não disponham mais de água para a irrigação, porque seus riachos diminuíram o volume ou até já morreram.

O que é fundamental ressaltar é a grande importância dessa forma de aproveitamento da água para as comunidades; pois, ao longo dos anos, em função 
dos processos socioambientais que se desenvolveram, os usos da água e da terra passaram por importantes modificações. Entre elas está, por exemplo: o aumento populacional e a respectiva minifundização das parcelas de uso exclusivo familiar; a proibição, pelos órgãos ambientais, dos cultivos nas veredas (terras livres) a montante e a tomada das terras de criatórios por grileiros; e o aumento significativo da demanda por alimentos e, inversamente, das dificuldades para consegui-los. Uma das alternativas que as comunidades adotaram para garantir a sua reprodução socioterritorial foi ampliar as áreas agricultáveis em suas parcelas e aumentar a produtividade por meio da irrigação, garantido, assim, dupla safra de produtos alimentícios durante o ano.

Nas glebas bastante numerosas irrigadas, conhecidas como "terrenos de regadio", são plantadas duas lavouras anuais, de modo que o uso da terra sob cultivo, em comparação com a área de pastagens, é consideravelmente maior aqui do que seria em outra circunstância. Afirma-se que o valor da produção agrícola aproxima-se quatro vezes mais do que o de animais e produtos dessa origem (PIERSON, 1972, p.447).

Conforme salientado em outro momento, a captação de água dos regos para uso na agricultura faz parte da tradição das comunidades, mas, no passado remoto, esta prática era exercida em pequena escala, muitas vezes por iniciativas individuais ou de pequenos grupos de camponeses, tornando-se mais corrente, a partir dos referidos processos sociais.

O Brejo Verde, todavia, se destaca como um caso um tanto diferenciado; pois, seus moradores afirmam que a tradição de irrigação a partir dos regos é do tempo dos antigos, de tempos remotos, e que regos importantes, como os do Vira Saia, são muito antigos. Contanto, cabe lembrar que outros também importantes foram construídos há não muito tempo, indicando que a comunidade, tal como as outras, foi impactada pelos referidos processos socioambientais.

Porém, o que se evidencia como particular no Brejo Verde pode ser entendido a partir da seguinte colocação: esta comunidade localiza-se no contato mais imediato das terras de cultura com os contínuos solos arenosos dos cerrados. Portanto, a carência de condições para a produção agrícola, nessa comunidade, possivelmente seja anterior às demais, cujas terras de cultura são mais extensas e muito mais férteis, tal como informaram os interlocutores da referida comunidade: 
a gente trabalha mais... só dá para comer, para vender não dá, porque a terra é pouca e a produção não é muita. ${ }^{113}$ Quando a terra é muita, a pessoa planta e colhe, vende um saco de feijão, vende um saco de farinha... ${ }^{114}$ agora aqui pra baixo, na região do Arrojado, do Grilo, Jatobá, eles plantam e colhem e deixam para a despesa e vendem, né?... Que as terras são boas... ${ }^{15}$ é de cultura, moço! ${ }^{116}$ As terras são maiores e produzem mais, né? Que dá para a despesa e que dá para eles venderem na feira. ${ }^{17}$

Esta situação de exiguidade dos solos agricultáveis foi agravada pelo aumento populacional e pelos impedimentos dos tradicionais cultivos que se faziam ao longo do vale dos rios da região. Foi visando compensar esta perda de terra de trabalho, que os regos foram construídos, permitindo a expansão e a potencialização do aproveitamento da terra para a agricultura.

Encontra-se precedente histórico de situação como esta, no uso da terra e da água feitos pelos ameríndios, notadamente os Incas, os quais empreenderam grandiosas obras de engenharia, da mesma forma, com vista a possibilitar a potencialização do uso agrícola das exíguas terras agricultáveis.

Conquistado o Inca qualquer reino ou província, estabelecido o governo das aldeias e das casas dos moradores, conforme sua idolatria e leis, mandava que se aumentassem as terras para a agricultura (que se entende as terras para cultivar o milho) para o que mandava trazer os engenheiros de acéquias de água, que os houve famosíssimos, como mostram hoje suas obras, bem como aquelas que foram destruídas, cujas marcas se vêem ainda, como as que existem. Os mestres construíram as acéquias necessárias, conforme as terras que havia de proveito; porque é de se saber que a maior parte de toda aquela terra é pobre de terras de pão. E por isso procuram aumentá-las tanto quanto lhes era possível; e porque, por estar sob a zona tórrida, tem necessidade de irrigação, o faziam com grandes cuidados e não semeavam grão de milho sem água de irrigação (VEGA, in BELLOTO \& CORRÊA, 1991, p.13).

Nesta organização produtiva Inca, o uso da terra se destinava à produção de alimento para a população e isto se constituía uma decisão de governo. Para viabilizar esta concepção, todas as condições eram oferecidas aos índios para que na terra pudessem trabalhar e produzir alimentos. Como mostra Garcilaso de La Vega, o governo mobilizava as avançadas técnicas de engenharia para a construção de acéquias (açudes), terraços e canais, para tornar produtiva as escassas terras que possibilitassem, a partir das obras de engenharia, a produção agrícola.

Construídas as acéquias, aplainavam os campos e os quadriculavam para que aproveitassem bem da irrigação; nos montes e encostas de boa terra faziam terraços

\footnotetext{
${ }^{113}$ Sr. Antonio José de Araújo - trabalho de campo realizado em janeiro de 2012.

${ }_{114}^{114}$ Esposa do Sr. Antonio José de Araújo - trabalho de campo realizado em janeiro de 2012.

${ }^{115}$ Sr. Antonio José de Araújo - trabalho de campo realizado em janeiro de 2012.

${ }^{116}$ Edinho - trabalho de campo realizado em janeiro de 2012.

117 Sr. Antonio José de Araújo - trabalho de campo realizado em janeiro de 2012.
} 
para aplainá-los, como hoje se vê em Cuzco e em todo o Peru. Para fazer esses terraços, levantavam três muros de cantaria forte, um a frente e dois dos lados, um pouco inclinados para dentro, como são todas as paredes que constroem, para que possam suportar o peso da terra que sustentam até emparelhar com 0 alto das paredes. Passando o primeiro terraço, faziam logo outro menor, e adiante daquele, outro menor. E assim iam ganhando todo o cerro pouco a pouco, aplainando-o com seus terraços à maneira de escada, aproveitando toda a terra que estava boa para semear e que se podia regar. Onde havia rochedos, tiravam as pedras e traziam terras de outra parte para fazer terraços e aproveitar aquele lugar que não se perdesse. Os primeiros terraços eram grandes, conforme a disposição do local, largos e longos de cem, de duzentos e de trezentos mais ou menos fânegas de semeadura, e os segundos eram menores; e assim iam diminuindo conforme iam subindo até os últimos que vinham a ser de duas ou três fileiras de milho. Muito habilidosos foram os Incas no que se refere ao aumento de terras para semear o milho. Em muitas partes percorriam de quinze a vinte léguas com uma acéquia para regar muito poucas fânegas de terra de pão para que não se perdessem (VEGA, in BELLOTO\& CORRÊA, 1991, pp.13-14).

Do mesmo modo, os índios se lançavam na penosidade extrema do trabalho na construção das referidas obras e no amanho da terra para dela extrair o necessário alimento. Por serem exíguas, aplicavam todas as possíveis técnicas no processo de produção, com vista a atingir a máxima produtividade. Assim, as terras de milho se semeavam a cada ano, porque, como as beneficiavam com água $e$ esterco, como uma horta, produziam sempre frutos (VEGA, in BELLOTO \& CORRÊA, 1991, p.14). E os consórcios também eram práticas correntes, produzindo simultaneamente o milho e, em mesma terra, a quinua.

Diferentemente da organização produtiva dos Incas - na qual a irrigação possibilitada a partir de grandes obras constituía-se de política de governo - no caso das comunidades dos gerais do Oeste da Bahia, com vistas a viabilizar o maior aproveitamento das exíguas terras e também permitir a necessária produção de alimentos, as construções são realizadas por iniciativa (e utilização do trabalho comunitário) da comunidade. Só em casos raros o poder público participa, ofertando os serviços que empregam técnicas pouco dominadas pelos integrantes das comunidades, tais como a da topografia, em marcações de curvas de nível por onde passarão os regos, e, do mesmo modo, em alguma manutenção nas situações em que a grande quantidade de trabalho humano pode ser reduzida com o emprego de maquinário pesado, como é o caso das reversões de rebentões ${ }^{118}$ nos canais.

Os regos iniciam-se em um açude, primitiva construção a partir da qual se faz a captação de água de um rio ou riacho (fotos 7 e 8).

\footnotetext{
${ }^{118}$ Rompimento do barranco do rego, implicando no desvio indesejado do destino da água.
} 


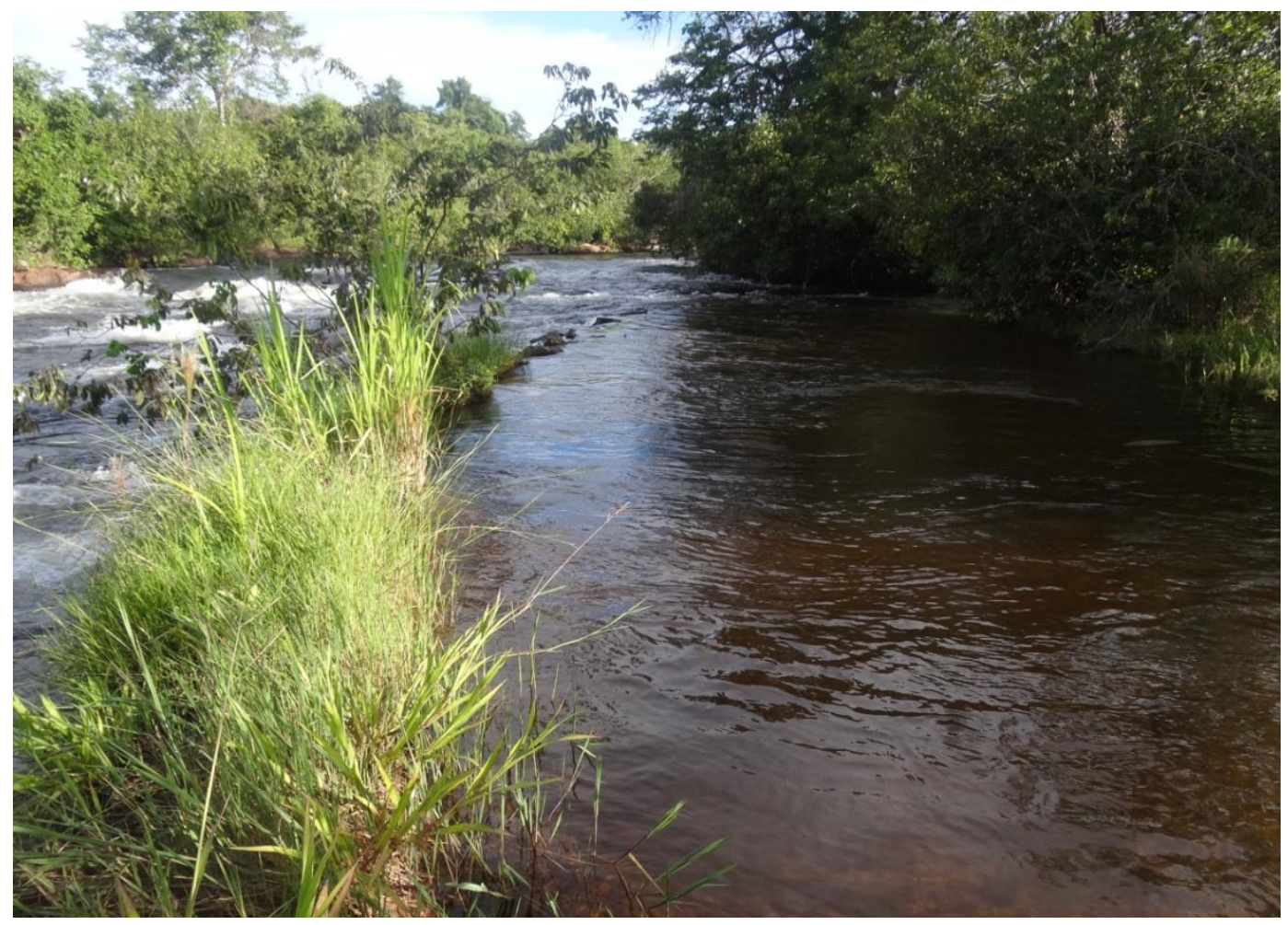

Foto 7 - Açude. À esquerda, rio Arrojado; ao centro, o enfileirado de pedras que capta a água para o rego (à direita). Comunidade Aparecida do Oeste; Correntina BA. Sousa Sobrinho, J. (jan. 2012).

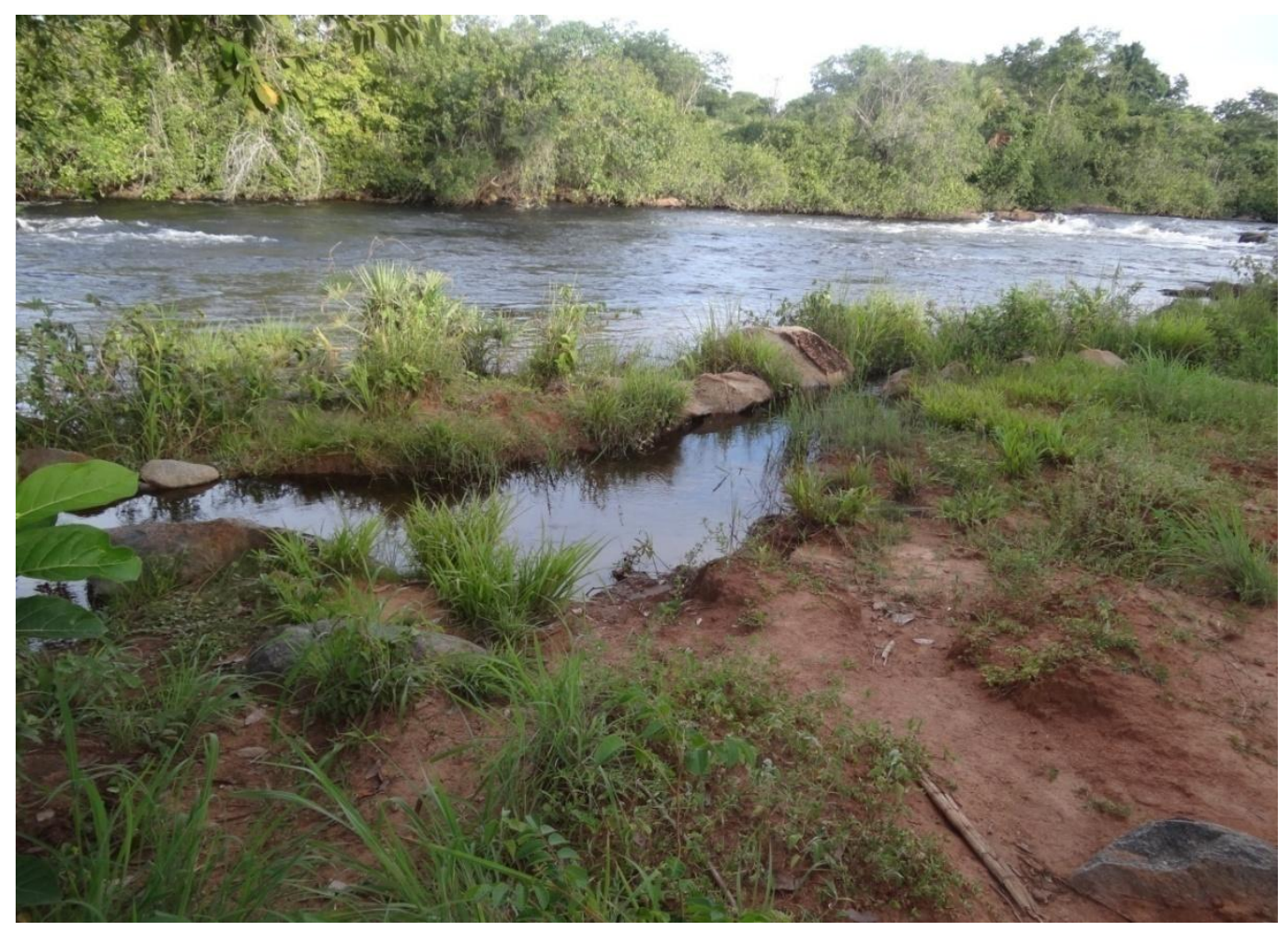

Foto 8 - Açude. Ao fundo o rio Arrojado; à frente, o rego, nas proximidades do açude. Comunidade Aparecida do Oeste; Correntina - BA. Sousa Sobrinho, J. (jan. 2012). 
No local onde a água deve ser captada, paus são fincados verticalmente no curso de água, prendendo-se a eles outros paus e ramos em ângulo reto de maneira a formar um paredão que ofereça resistência à corrente, diminuindo-Ihe a força e desviando um pouco de água para um canal, conhecido aqui e nos Gerais como "rego". Pedras soltas são dispostas na outra extremidade da barragem, a uns quatro metros da margem, de onde o rego propriamente dito conduz a água para seu destino final (PIERSON, 1972, p.487).

Pude conhecer um açude menos complexo do que o acima descrito. Este se constituía de um amontoado de pedras enfileiradas no leito do rio Arrojado, em um trecho de correnteza. Mais largo na parte mais funda, o açude estreita-se conforme se aproximava da margem do rio (no caso, à direita), conduzindo a água do desvio para o rego de aproximadamente $80 \mathrm{~cm}$ de largura por $70 \mathrm{~cm}$ de profundidade, porém, em forte correnteza.

Para a construção dos regos, as comunidades assim se organizam:

A) a própria comunidade reúne-se em mutirões e os constroem utilizando-se do conhecimento intuitivo de alguns dos seus membros;

B) a comunidade associa-se e empreita o serviço de construção do rego para algum de seus membros, portador de expertise; e

C) a prefeitura municipal oferece os serviços de medições topográficas, a comunidade reúne-se em mutirão e realiza os serviços de escavação.

O Sr. Lázaro de Souza Brito, morador do Brejo Verde, relata a segunda situação:

Bom, esse daqui foi empreitado. O empreiteiro foi um Sr. de Zé Grande ${ }^{119}$, que morava aqui no Catolé, um homem muito trabalhador, um homem carapina, fazedor de carro-de-boi, fazedor de engenho, animado, inteligente, né? Ele foi e empreitou esse rego. Daqui na Prainha ${ }^{120}$, baratim moço! Naquele tempo, não sei se foi, não sei se foi por quatro contos, ou foi [por] cinco contos naquele tempo. Conto, o Sr. entende de conto? (risos). Ele chegou mais ou menos aqui em baixo, numa propriedade aqui em baixo, o dinheiro não deu para sair o serviço. Ele foi e falou com o cara que é um senhor Fulgêncio ${ }^{121}$, que é casado com a filha desse compadre Abdias ali. Ele falou para o empreiteiro ${ }^{122}$ que o dinheiro não ia dar para sair o serviço. Ele falou, então vamos fazer isso: daqui pra baixo, cada dono vai entrar Ihe ajudando. Quer dizer, que a empreita foi feita só até ali. Pra baixo, os donos entraram ajudando ele, e ele ganhando a dia, até sair lá na Prainha. Mas ó meu Deus quem é que hoje tem quem pega um serviço desse por pouco dinheiro? Enxadão, comprava um enxadão, com 8 dias tinha acabado na pedra, e cortava esse mundão, multidão de companheiro trabalhano, matava um gado não dava para comer uma semana. Turma! Vinha cavacano aqui aquele trecho até aquele quadro. Quando chegava lá, todo mundo parava, tirava a água daqui, encanalizava que a água tchaaa... chegava lá. Fazia um

\footnotetext{
${ }^{119} \mathrm{O}$ nome do empreiteiro foi emprestado ao rego.

120 Trata-se do povoado da Praia.

${ }^{121} \mathrm{O}$ membro da comunidade que tomou a iniciativa e se encarregou de administrar o serviço.

122 Diga-se o integrante da comunidade que o empreitou.
} 
ladrão. Aí ia fazer daí pra lá... ... Onde tivesse uma baixa, ele aterrava ali, onde tivesse um alto, ele tirava (Trabalho de campo realizado em janeiro de 2012).

Estas palavras mostram um misto de situações. A comunidade, no primeiro momento, se associou para arcar com os custos de construção do rego, contratando um empreiteiro, no caso, um sujeito dotado de múltiplos saberes. Mas, possivelmente em função do tamanho sem precedente da obra, o preço cobrado não foi suficiente para concluir o serviço. Na outra situação, a comunidade organiza-se em mutirão e, usufruindo dos serviços e dos conhecimentos do mestre, ela mesma executa os serviços para o término do rego.

Ocorreu também exemplo de outra situação. Nesta, a prefeitura realizou os serviços de medições topográficas e a comunidade entrou com o trabalho de escavação do rego, conforme nos esclarece o Sr. João Castro e Silva:

\begin{abstract}
olha esse rego ele era só de uma metade aí pra cima. Depois, a necessidade do povo aqui, foi irriba foi em baixo, o prefeito deu uma ajuda. Tá vendo aquela fazenda ali que era do finado Liozão? Dali pra cá, o prefeito judou trabaiá nele né? Fez mutirão, depois foi animando o povo, depois os proprietários foi tirando... ...ela só entrou com o mutirão um dia só, né? Mas o mais foi os proprietários que tirou. Só que o nivelamento foi os que trabalha na prefeitura que mediu (Sr. João Castro e Silva, morador da comunidade do Jatobá, trabalho de campo, julho de 2011).
\end{abstract}

Esse aumento da necessidade do povo, certamente está relacionado aos motivos já mencionados, pois a comunidade do Jatobá, assim como as vizinhas, figura com grande densidade populacional e, como consequência disto, tem alto fracionamento das parcelas de uso exclusivo familiar na agricultura e pecuária.

\title{
c) A organização comunitária para o uso dos regos
}

um rego desse é uma riqueza! Moço, olhe as lavouras que têm nos barrancos desse rego! Não tem governo para comprar! Rã! Bom, e a servidão de casa? O córrego ta lá embaixo! A servidão para galinha, um porco e tudo... mulher que lava um trem e coisa, é uma riqueza um canal desse! $!^{123}$

A unidade territorial camponesa no vale do Arrojado, bem como de outras regiões do Oeste da Bahia, tem como importantes elementos que a constitui os usos que fazem da terra e da água ao longo de sua história, interagindo com os

\footnotetext{
${ }^{123}$ Sr. Lázaro Souza Brito, comunidade do Brejo Verde, entrevista em trabalho de campo, janeiro de 2012.
} 
processos sociais internos e/ou externos, os quais agem no sentido de reforçá-la, recriá-la ou abalar de modo negativo as suas estruturas, tal como se percebe, nas últimas décadas, as fortes investidas da produção capitalista com o propósito de expropriar os camponeses das condições de reprodução, quer seja social e/ou territorial.

A construção dos regos pode ser entendida como uma das medidas engendradas pelos camponeses geraizeiros com vistas a garantir a sua reprodução socioterritorial, embasadas em um uso da água com características muito peculiares, frente às situações e aos processos que a impactam ou a limitam.

Os regos proporcionam às comunidades geraizeiras a ampliação das terras agricultáveis, pois é conhecido que, na estação chuvosa, quando formam as roças de sequeiro, muitas das áreas de vazante são submetidas a inundações. E, na longa estação seca da região, com o recuo das águas, estas áreas tornaram-se cultiváveis graças aos regos que proporcionam a grande vantagem do incremento de uma colheita a mais.

Se não bastasse isto, a irrigação permitiu também, às comunidades, grande diversificação na produção agrícola. Nas áreas irrigáveis, nos sítios ${ }^{124}$ ou regadios, além dos produtos alimentícios cultivados tradicionalmente, plantam também hortas com grande diversidade de verduras e legumes. No pomar, é admirável a diversidade de frutos cultivados. No terreiro, irrigam o jardim e uma infinidade de plantas medicinais e ainda dessedentam a grande variedade de animais de terreiro $^{125}$ ou que permanecem presos nos pequenos cercados do entorno da casa. E o gado que pasta nas mangas, cultivadas geralmente nas vertentes altas, para beber água, é conduzido por um beco (fotos 9 e 10) até o rego que o atravessa.

Portanto, o Sr. Lázaro não exagera quando atribui tamanha relevância a essa riqueza, os regos (fotos 11 e 12), que possibilita a socialização e a potencialização dos usos desses bens fundamentais da comunidade, a água e a terra.

Com a intensificação do uso da água por meio dos regos, todas as terras agricultáveis no vale do córrego Santana tornaram-se potencialmente cultiváveis. Nestas, plantam produtos alimentícios e pastagens durante todo o ano, nas roças de sequeiro e nas de regadio.

\footnotetext{
${ }_{124}^{124}$ Parcela onde se trabalha e se constitui moradia.

${ }^{125}$ Animais de pequeno e médio portes, como galinhas, galinhas de angola, patos, porcos, caprinos e outros.
} 


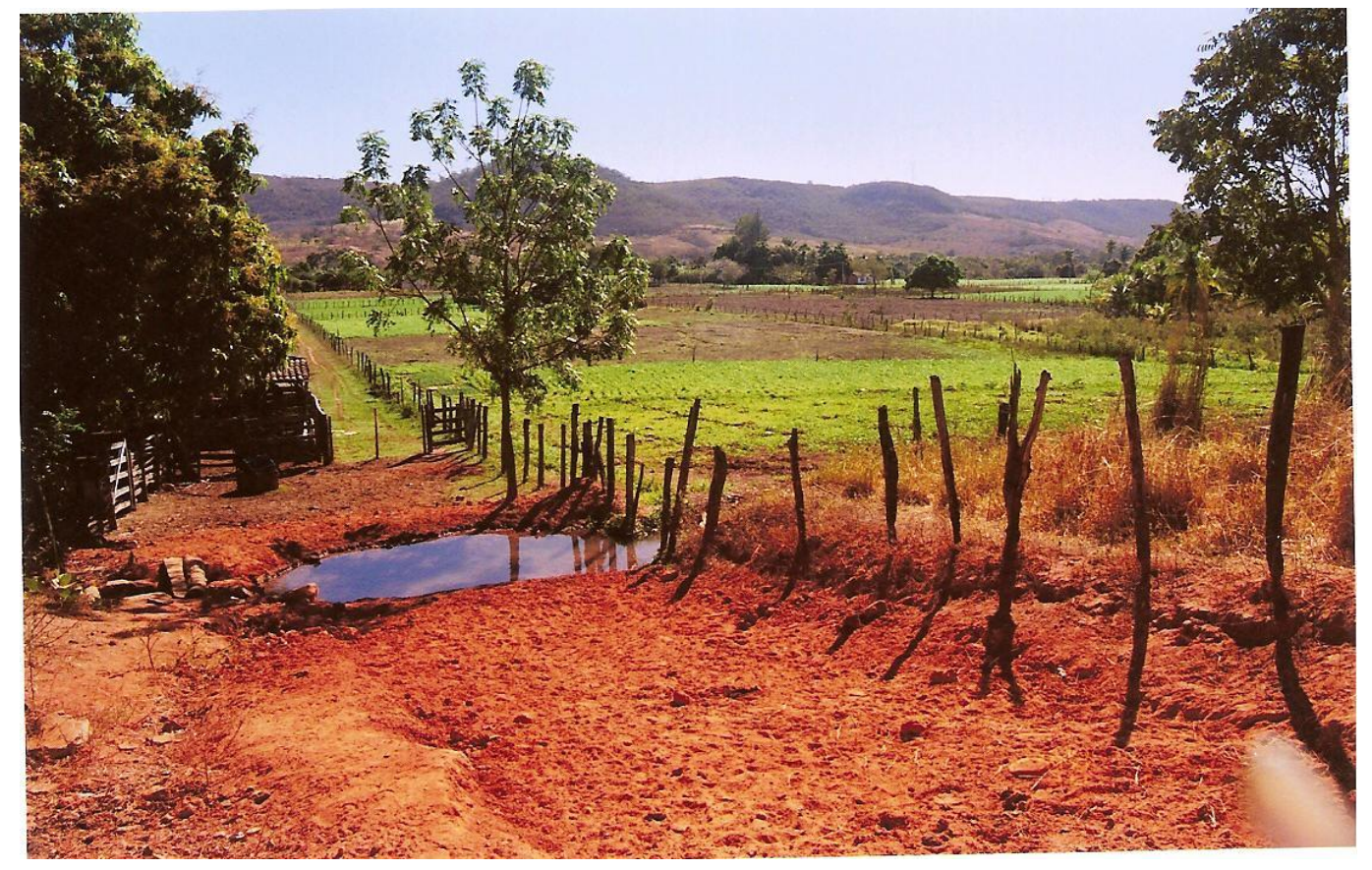

Foto 9 - Corredor (beco) que conduz o gado até o rego. Comunidade Muçambé, Correntina - BA. Sousa Sobrinho, J. (jul. 2011).

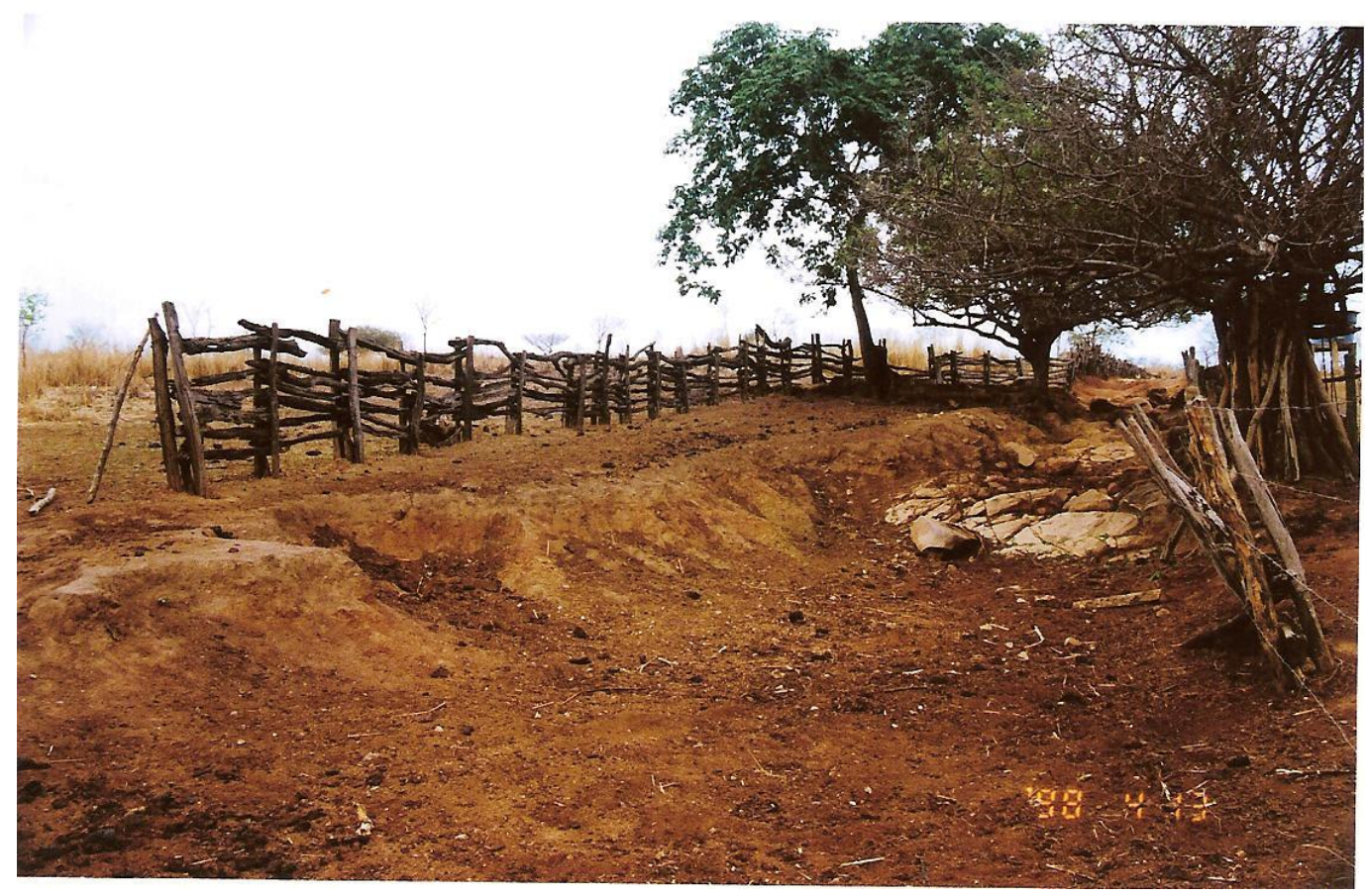

Foto 10 - Corredor (beco) que conduz o gado até o rego. Comunidade Jatobá, Correntina - BA. Sousa Sobrinho, J. (out. 2010). 


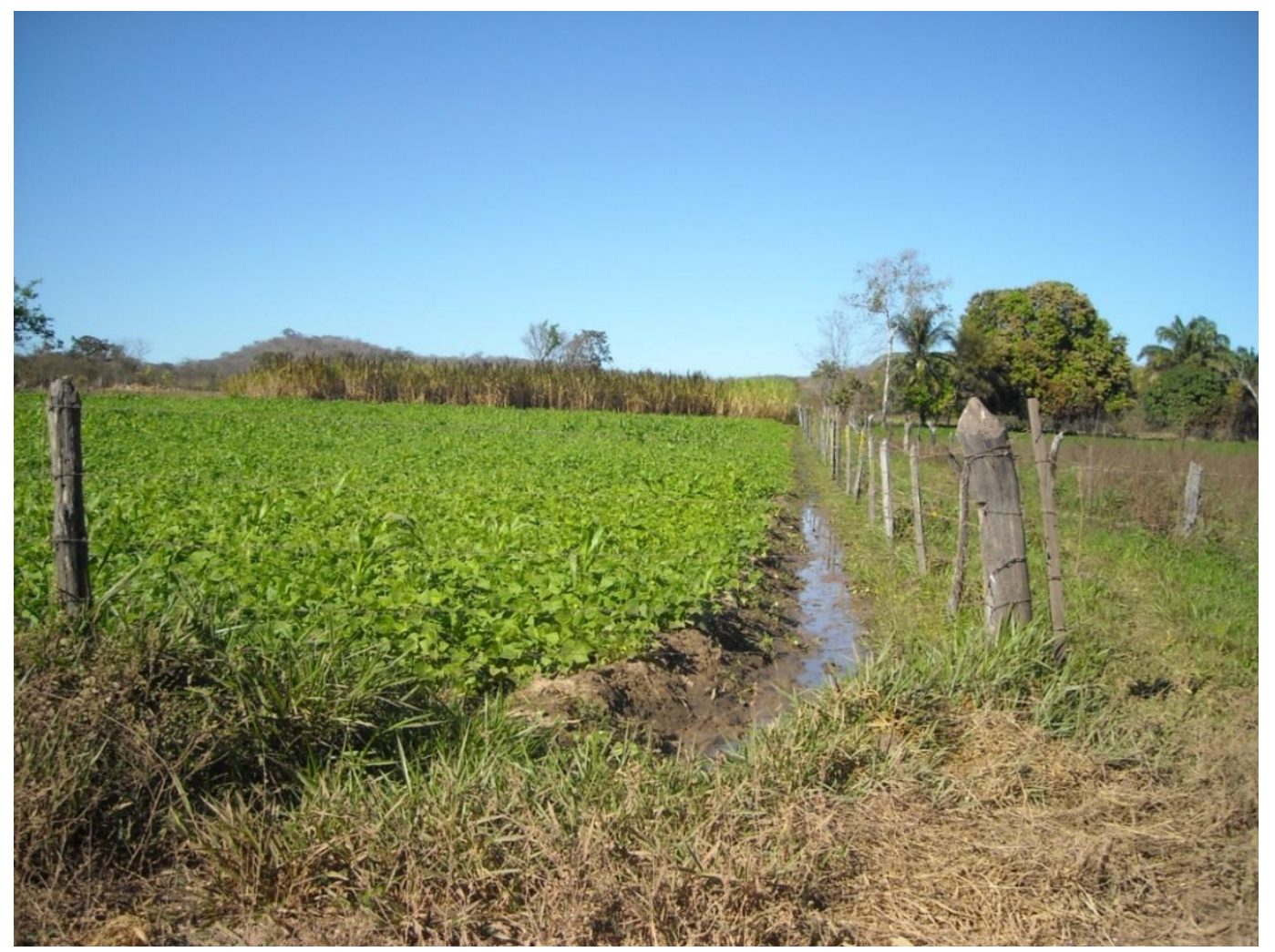

Foto 11 - Área de sítio. À esquerda, roça de feijão; ao centro, o rego; e, à direita, a manga. Comunidade do Muçambé, Correntina - BA. Oliveira, Ariovaldo U. (jul. 2011).

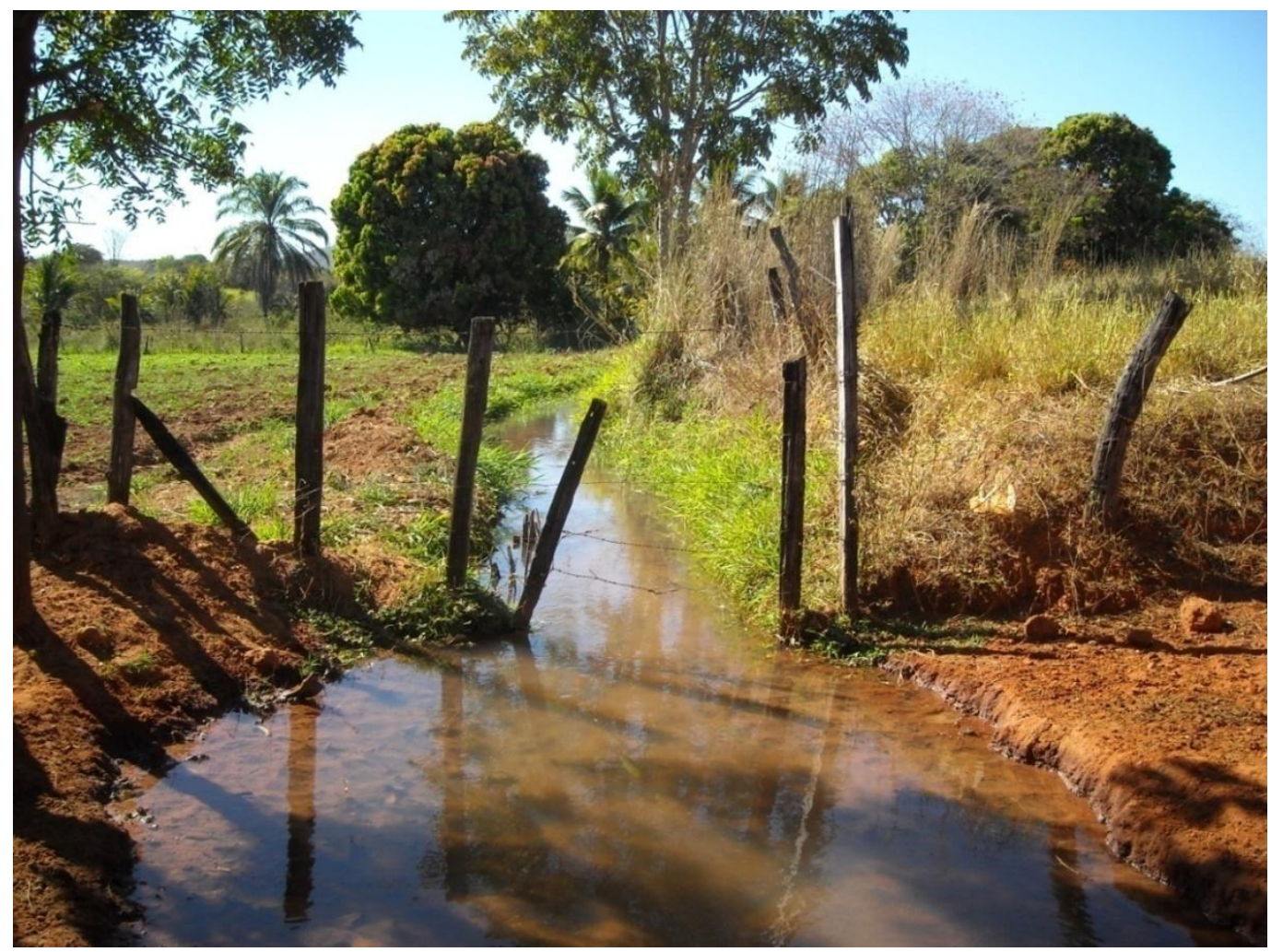

Foto 12 - O rego ao centro; à direita, a manga; e à esquerda, a área de sítio. Comunidade do Muçambé, Correntina - BA. Oliveira, Ariovaldo U. (jul. 2011). 
O mesmo se verifica no vale do rio Arrojado, onde se encontram as terras de cultura ao longo de aproximadamente $100 \mathrm{~km}$ de extensão em ambas as margens do rio, dos seus afluentes (aqueles que ainda não secaram) e das respectivas vertentes. Os regos proporcionaram, portanto, a potencialização do uso da água e da terra e, consequentemente, o que tanto significa para as comunidades ribeirinhas geraizeiras: a fartura dos seus meios de vida.

A ampliação dos regos, inclusive, foi a solução adotada pelas comunidades para compensar a diminuição das áreas tradicionalmente cultivadas, em decorrência das proibições impostas pelos órgãos ambientais, que não mais permitem a formação de roças nas veredas a montante nos gerais.

Daqui ao Couro de Porco, é 130 quilômetro. O cara arriava um burro aqui, era dois dia de animal, pra chegar lá. Comprava sua farinha, fazia os cargueiro, arroz, e vinha, porque, às vezes, era o seguinte: aqui tinha as terras de plantar, mas acontece que a maioria trabalhava lá, aqui não tinha um rego tirado pra molhar, depois foi que os mais velho inventou de tirar um rego, um canal de rego aqui, para dar suporte. Tirou bem na verdade. Mas você ver, com o desmate que tem em cima, seca, cadê a água do rego? Você passa aí ó, tá o rego aí, a água acabou! A água, botar um pé tapa! Então é desse jeito... (Sr. Joaquim Francisco Dourado, morador da comunidade dos Catolés, trabalho de campo realizado em julho de 2011).

Antes da construção dos regos, conforme os interlocutores, grande parte do abastecimento das comunidades vinha dos gerais, das roças que plantavam nas veredas. Uns plantavam suas próprias roças e outros, na falta de alimento, para lá se dirigiam a fim de comprá-lo. Após a proibição do cultivo nessas áreas, construíram os regos nas áreas das próprias comunidades. Porém, os desmatamentos desenfreados dos gerais, praticados pelos usos capitalistas da terra, têm provocado a diminuição do volume das águas dos rios e córregos e, consequentemente, a interrupção do fluxo d'água de muitos regos.

Mas, naquelas comunidades onde os regos continuam canalizando a água para as áreas cultiváveis, a organização da comunidade para possibilitar a operação e o bom aproveitamento é de fundamental importância. E, neste tópico, pretendo discorrer sobre ela.

A organização da comunidade para ampliar o aproveitamento da água e da terra teve início no ato de construir os regos, conforme já demonstrado. Realizada esta etapa, a operação dos regos continuou exigindo a organização do grupo visando o uso comum. 
Neste sentido, em todo início de período de formação das roças, os donos das parcelas banhadas pelos regos encarregam-se de fazer a limpeza do trecho que passa pela sua parcela. Trata-se de um trabalho muito penoso. Mas, em cumprimento ao que a comunidade convencionou, todos, independentemente de usarem ou não a água, são obrigados a executar o serviço de limpeza do rego ${ }^{126}$. Um possível descumprimento por algum usuário implicaria na falta de água para aqueles que se encontram à jusante.

No tempo de fazer a limpeza é difícil. É uma lama, é uma grama, é preciso homem de força para arrastar aquilo para jogar para fora. É um baque esquisito. Teve um cara aí que mudou para não limpar a parte dele. Mudou. Vendeu a fazenda e mudou (Sr. Lázaro de Souza Brito, morador da comunidade do Brejo Verde, trabalho de campo realizado em janeiro de 2012).

Outro morador da comunidade de Jatobá explica:

Então no correr das águas quase que esse canal aqui é sem água. Tem dia que tem e tem dia que não tem. E as lamas dos enxorros que vem de fora vai caindo dentro, tem lugar aí que nego bate é semana pa tirar, devido o enxorro. Que se a água tiver aí, a enxurrada cai dentro, e ela vai levando a terra. Se tiver um lugarzinho fundo ela pára, e se não tiver, ela vai embora, né? (Sr. João Castro e Silva, morador da comunidade do Jatobá, trabalho de campo realizado em Julho de 2011).

Segundo interlocutores, os eventuais descumpridores do que foi estabelecido poderão ser denunciados à prefeitura, que poderá puni-los com multa e, se por acaso, mesmo assim, não façam o serviço, o caso poderá ser entregue ao juiz para encaminhar as providências.

Mas, no ambiente comunitário, o que se percebe é que a possibilidade destas providências coloca-se apenas no âmbito das ameaças e a consideração, valor predominante e que norteia as relações entre os vizinhos, tem impedido a intromissão da ordem jurídica na mediação de conflitos relacionados a essa questão, pois não se teve notícia de um caso sequer, em que se recorreu ao recurso da lei e, inclusive, o caso de uma reincidente por quatro anos, muito reclamado na comunidade do Jatobá, não levou a comunidade a tomar as referidas providências.

Cada qual limpa em sua propriedade. Só que tá com quatro anos que nóis daqui de baixo vamos limpar o direito de uma mulher ali. Que ela não quer limpar que disse que não planta, né? Ela mesmo tá em São Paulo. Nós é contra isso. Porque, só porque a gente precisa da água é obrigado limpar o quintal dos outros, não tem isso não! (Sr. João Castro e Silva, morador da comunidade do Jatobá, trabalho de campo realizado em julho de 2011).

\footnotetext{
${ }^{126}$ Este trabalho consiste na remoção do barro acumulado no leito do rego em função do trabalho dos enxorros (enxurradas), assim como da capina do mato que cresce em suas margens.
} 
A tarefa de limpeza do rego é executada no término da estação chuvosa e a comunidade mobiliza-se para isto no decorrer dos 10 dias iniciais do mês de maio.

Além da limpeza dos regos, imprevistos podem demandar grande quantidade de trabalho do grupo de usuários. Trata-se dos chamados rebentões que, quando ocorrem, a depender da situação, obrigam a mobilização de um grupo numeroso de pessoas para providências nos reparos. O Sr. Lázaro cita um caso em que foi necessário recorrer à ajuda do poder público para realizar o reparo em um rebentão de grandes proporções.

esse rego, moço, se facilitar, com uma noite forma um rebentão aí que nem a prefeitura tampa. Numa terra fraca. Porque o rego é forte de água! Como formou um rebentão aqui no ano trasado, eu fui quem fui lá no prefeito pra ele vim, trouxe as máquinas tudo, trator, e pá mecânica e tudo, caçamba pra tampar esse buraco aí desse rego (Sr. Lázaro de Souza Brito, morador da comunidade do Brejo Verde, trabalho de campo realizado em janeiro de 2012).

Assim há as vezes a intervenção do poder público em um serviço que a comunidade encontraria dificuldade para realizar. Porém, o mesmo interlocutor revela os meandros da influência política no atendimento do aparelho estatal ao seu pedido. Informa que a depender da maioria dos usuários, o pedido à prefeitura não seria atendido, porque votaram contra o prefeito na eleição passada. Portanto, a referida intervenção não deve ser entendida como uma postura de pronto atendimento com vistas a impulsionar a rentável agricultura camponesa geraizeira, mas sim, como uma prática de favoritismo, por assim dizer, mediada pela conveniência entre as partes.

Quanto à distribuição da água para cada parcela, isto também é decidido em comum acordo a partir de uma reunião com os futuros usuários antes do início da formação das roças. O propósito é atender a todos e, desta maneira, dividem os tempos de água proporcionalmente à necessidade de cada agricultor.

A necessidade de cada usuário varia conforme a amplitude da área a ser irrigada e o grau de umidade do terreno. No caso do Brejo Verde, boa parte dos regos tem seu açude na parte alta, nas proximidades das nascentes do córrego Santana. Assim, os regos possibilitam a irrigação de uma extensa área da vertente e o grau de umidade dos terrenos a serem irrigados varia muito. Deste modo, ocorre que roças menores situadas na parte alta demandarem maior quantidade de água do que aquelas maiores, porém situadas nas áreas de vazantes, bastante úmidas. 
a minha aqui, porque já pegou muito embaixo essas beiras de brejo, né? Só tocou pra mim meio dia e meia noite de água. É um dia e uma noite para mim e outro vizinho aqui mais embaixo. Que ficou muito perto do córrego, né? Não cobriu esses terrenão, agora tem cara aí que tem dois dias com duas noite, tem um dia com uma noite, outros têm só uma noite, outros têm meio dia, é assim, é de acordo a área... (Sr. Lázaro de Souza Brito, morador da comunidade do Brejo Verde, trabalho de campo realizado em janeiro de 2012).

A partir destas situações, estabelecem o fracionamento dos tempos de água para atender as próximas roças e é assim, olhe, vai... num ano tem uma organização, no outro já eles desmancha e faz outra ${ }^{127}$.

No caso do Sr. Lázaro, para o ano de 2011, Ihe tocou 12 horas de água a cada 18 dias. Apesar da quantidade de água do rego ser suficiente e até sobrar da irrigação na sua roça, o intervalo de 18 dias era demais longo e seus plantios começavam sentir a falta de água, a amarelar a folha. Seu vizinho da jusante também dispunha do mesmo tempo de água e como solução para o problema do longo intervalo fez um acordo com seu vizinho. A cada 9 dias o Sr. Lázaro usava a metade da água do rego deixando a outra para o vizinho que também ficou usando metade da água a cada 9 dias e o problema ficou resolvido.

Os usuários do rego nunca desviam a totalidade da água para a sua roça. Sempre deixa uma teinha d'água. Qualquer um, igual nóis aqui, não tira não, né? Que tem criação que bebe aí então ela tem que descer seje que tanto for para o bicho servir, né? ${ }^{128}$

A solidariedade costuma estar muito presente nas relações de partilha da água. E a sua destinação prioritária é para a irrigação do que consideram essencial e diretamente voltado ao sustento da família. Como exemplo, o Sr. Lázaro cita: eu não vou molhar cana sem maior precisão, que o pessoal ta com os feijão lá em baixo, caindo a flor. Eu vou botar em cana? Fico com dó! A água desce no rego! É deles! Só que eles também não me abusa não. ${ }^{129}$

Porém, fica perceptível no relato que o Sr. Lázaro espera um tratamento recíproco: não me abusa não. Assim, as relações de reciprocidade vão sendo tecidas.

\footnotetext{
${ }^{127}$ Sr. Lázaro de Souza Brito morador da comunidade do Brejo Verde, trabalho de campo realizado em janeiro de 2012.

${ }^{128}$ Sr. João Castro e Silva, morador da comunidade do Jatobá, trabalho de campo realizado em julho de 2011.

${ }_{129}$ Sr. Lázaro de Souza Brito, morador da comunidade do Brejo Verde, trabalho de campo realizado em janeiro de 2012.
} 
Os acordos, as solidariedades nas relações, são muito comuns nas comunidades, embora também haja muitas desavenças provocadas pelas "espertezas" de alguns, conforme relata o Sr. João de Castro e Silva:

olha, isso aí acontece é demais, demais. Porque tem uns, tá vendo aqui, a minha propriedade é miudinha ${ }^{130}$, né? É no instantinho tiro aí meu ladrãozinho d'água molho aí e solto. Chega ali em baixo, ou ali em cima aí tem um que planta é saco de mantimento aí ele segura a água ou um dia, ou um dia e pouco. Tem hora que quando ela falta, assim um dia, dois, aí o povo aqui de baixo revolta, que diabo é isso, bota a enxada nas costa e vai atrás, né? Quando chegar lá tapa. Se o cabra não cabou ele vai dando as costa, ele vai lá abre traveiz. Mais enquanto não molhar não solta. É desse jeito. Mas graças a Deus nunca teve assim nem pancada, nem arrelia assim para ocupar a justiça por causa da água, não (João de Castro e Silva, morador da comunidade do Jatobá, trabalho de campo realizado em julho de 2011).

Donald Pierson também registrou a organização que se estabelece para os usos da água, assim como os possíveis encaminhamentos que possam se dar em função dos descumprimentos do combinado em comum:

Geralmente, o uso em comum de um rego continua sem incidentes imprevistos. A propósito, disse um homem que conhecia o rego acima mencionado desde seus tempos de menino: "Nunca houve o menor problema. Todo mundo sabe que nas segundas feiras a água vai para fulano e na terça e quarta para sicrano, e assim por diante. E ninguém tirou jamais água quando era dia de outro homem usá-la". Não obstante, surgem às vezes conflitos. O lavrador que mora na extremidade do rego mais distante da corrente pode sentir-se prejudicado porque um ou mais moradores mais próximos da fonte usaram tanta água que somente um volume insuficiente ou mesmo nenhum chegou às suas terras. Se os implicados não chegam a um acordo satisfatório, o prejudicado pode fazer queixa ao prefeito e pedir-lhe uma "partilha de água" (PIERSON, 1972, p.487).

O que se pode perceber como dominante, apesar dos desentendimentos, dos conflitos internos, dos desvios daqueles que se diferenciam, é a concretização do sentimento de comunidade. De modo geral está presente a compreensão de que as riquezas naturais, os meios de vida, deverão ser partilhados para que todos, horizontalmente relacionando, possam reproduzirem-se. E a união de todos sempre se faz necessária para, na situação de quase total desamparo do poder público, enfrentarem as dificuldades, sanarem-as e garantir o sustento da família. Evitar o máximo as desavenças é positivo para todos, pois necessitam estar unidos para o enfrentamento às forças das classes dominantes nas suas investidas que visam subordiná-los e/ou expropriá-los/expulsá-los da terra de trabalho.

\footnotetext{
${ }^{130}$ A parcela do Sr. João Castro mede 13 ha e nela trabalham ele e mais três filhos casados.
} 


\subsection{Outras captações e usos da água}

Os gerais do Oeste da Bahia destacam-se como região de importante disponibilidade hídrica e o campesinato local, com grande maestria, tem criado formas de aproveitamento das riquezas naturais, no caso, a água, para propiciar melhorias nas condições de reprodução.

No tópico anterior, já discorri sobre os açudes/regos. Porém, há que me referir também a outras técnicas adotadas pelos camponeses geraizeiros para se beneficiarem da importante riqueza hídrica da região.

Para o uso na agricultura, a forma mais importante de canalização da água são os regos, que partem dos açudes e, por gravidade, canalizam a água para distâncias que podem ultrapassar $10 \mathrm{Km}$. No percurso, sua água irriga por sulcos de gravidade os cultivos de regadios praticados na longa faixa entre o rego e o leito do córrego ou rio, conforme o caso.

Porém, é comum a água do rego servir também como já indicado à dessedentação do gado, que geralmente é conduzido das mangas e das soltas por um beco ao encontro do rego que o atravessa (foto 7). Este uso da água do rio, do córrego e dos regos pelos animais a torna imprópria para o consumo doméstico. Por isso, os camponeses geraizeiros, sempre que possível, fazem captação da água nas cabeceiras dos córregos e galhos ${ }^{131}$, lugares que costumeiramente protegem contra desmatamentos, queimadas e outros usos que possam comprometer a perenidade dos cursos d'água e a sua potabilidade. Sabem, muito bem, que a preservação da vegetação na montante, nos arredores das nascentes, resulta na disponibilidade de água com boa qualidade nas áreas das jusantes, conforme nos diz o Sr. Lázaro, sobre a qualidade e os usos:

Uma água boa moço! Que é da cabeceira do córrego irriba. Uma água limpa. O uso é somente para beber. Outros é para beber, banheiro, outros até que lava roupa, nesses tanquim, né? Dessa água, mas ela foi instalada mesmo para usar para beber. Porque é uma água sadia, né? É uma água que não tem bebedor de gado nela, é água tratada, pode dizer, né? (Sr. Lázaro de Souza Brito, morador da comunidade do Brejo Verde, trabalho de campo realizado em janeiro de 2012).

Ao longo do Arrojado, é comum encontrar moradias dispersas no seu vale. Nesses casos, por iniciativa individual, o morador toma as providências para o

\footnotetext{
${ }^{131}$ Afluentes ou subafluentes de pouca expressão dos rios da região quanto ao volume de água, também chamados de córregos ou riachos.
} 
acesso à água potável e se utiliza de várias técnicas, tais como as bombas carneiro (foto 13), as rodas d'água (foto 14) e motobombas (foto 15). ${ }^{132}$
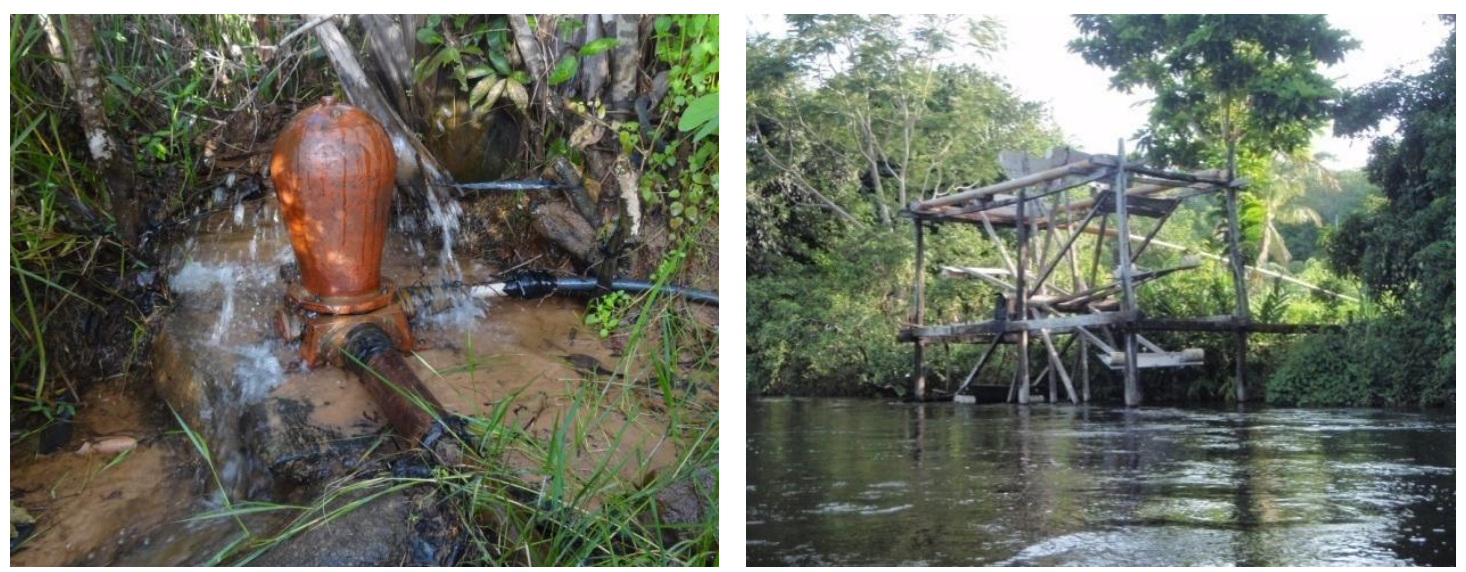

Foto 13 - Bomba Carneiro (esquerda). Foto: Sousa Sobrinho, J. (jan. 2012).

Foto 14 - Roda d' água (direita). Comunidade do baixo vale do rio Arrojado, Correntina - BA. Beltrão, Marcos R. (jan. 2010).

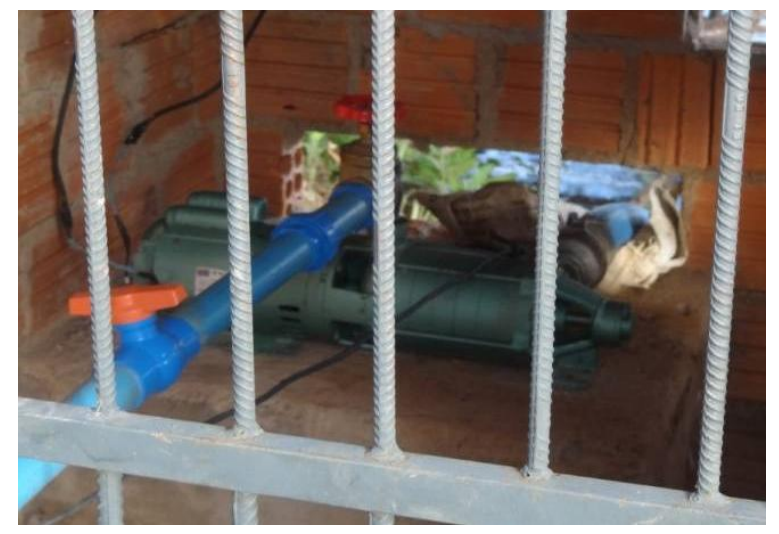

Foto 15 - Motobomba. Comunidade do baixo vale do rio Arrojado, Correntina - BA. Sousa Sobrinho, J. (jan. 2012).

Quando se trata de aglomerações populacionais mais densas ou de condições que favoreçam a implantação de um sistema de abastecimento de água que atenda à totalidade da comunidade, esta se organiza para tal finalidade. O Brejo Verde é bem ilustrativo deste caso. Com o aumento dos cultivos nas margens do córrego Santana e outros usos de sua água, esta se tornou imprópria para o consumo humano. Assim, com o auxílio da prefeitura municipal, fizeram a canalização da água da seguinte forma:

\footnotetext{
${ }^{132}$ Este meio geralmente é utilizado por aqueles mais apossados, e a captação da água para consumo humano, quando não é possível das cabeceiras, faz-se do próprio rio, no caso do Arrojado. E neste caso, pode servir também para outros usos, tais como dessedentação animal e irrigação.
} 
entremos com o trabalho. Os equipamentos de puxar os gai pra casa, aqueles canos finos, torneira, essas coisas, foi tudo por conta de cada dono. O prefeito só entrou com a canaiada grande. E os outros foi por conta de cada um (Sr. Lázaro de Souza Brito, morador da comunidade do Brejo Verde, trabalho de campo realizado em janeiro de 2012).

Esta obra, objetivando atender à totalidade da comunidade, foi construída em 2006. Para tanto, por meio da associação de moradores, compraram motor e bomba e conseguiram da prefeitura os tubos. ${ }^{133} \mathrm{~A}$ comunidade organizou-se em mutirões e construiu uma rede mestra abrangendo todo o vale do córrego Santana. Após a conclusão da rede mestra, a cada morador coube arcar apenas com os custos de construção do ramal que canaliza a água até sua moradia, conforme nos diz o Sr. Lázaro. Para o funcionamento do sistema de abastecimento, são duas as fontes de recursos: da parte da comunidade, cada morador contribui mensalmente com $\mathrm{R} \$$ 10,00. Do total arrecadado, paga-se o operador do motor e uma parte do diesel gasto, a outra parte fica a cargo da prefeitura.

A rede mestra foi construída na vertente direita do vale, onde se concentra a maior quantidade de moradores, mas atende também aos poucos moradores da margem esquerda, que, devido à maior distância, arcam com maiores despesas na construção dos ramais.

Dessa forma as iniciativas dos camponeses geraizeiros, relativas aos usos da água, muito contribuem para a melhoria das suas condições de vida. Como se viu, os regos canalizam as águas para as proximidades das moradias. Com esta água, irrigam os pomares, os jardins e as hortas constituídas de grande variedade de verduras, frutas e plantas medicinais. Estas águas também servem para a dessedentação dos animais presos e soltos, nas imediações do terreiro, e potencializam o aproveitamento dos melhores solos, os margeantes aos cursos d'água, irrigando-os. Isto Ihes acresce mais uma importante safra no decorrer do ano.

\footnotetext{
${ }^{133}$ Este sistema de abastecimento consta do bombeamento da água do córrego Santana, por meio de motor a diesel e bomba. A água é armazenada em um tanque e, dali, por gravidade, alimenta a rede de distribuição ao longo de todo o vale do córrego.
} 


\title{
4.5 Usos da terra e da água na área de regadio
}

\author{
Debulhar o trigo \\ Recolher cada bago do trigo \\ Forjar no trigo o milagre do pão \\ E se fartar de pão \\ Decepar a cana \\ Recolher a garapa da cana \\ Roubar da cana a doçura do mel \\ Se lambuzar de mel \\ Afagar a terra \\ Conhecer os desejos da terra \\ Cio da terra, a propícia estação \\ E fecundar o chão \\ O Cio da Terra \\ Composição: Chico Buarque / \\ Milton Nascimento
}

Após discorrer sobre a infraestrutura construída pelos camponeses geraizeiros para viabilizar os usos da água, agora, complementando a abordagem em curso, cabe centrar nos usos agrícolas da terra, muitos deles favorecidos pelas águas disponíveis.

Os usos agrícolas da terra, realizados pelas comunidades do baixo vale do rio Arrojado, mantêm importante relação com as características dos solos. Nas áreas onde os camponeses geraizeiros moram, praticam a agricultura e os criatórios, ou seja, nos fundos de vale e vertentes, está bem definido onde cada atividade é exercida. As manchas de terras de cultura são utilizadas para cultivos, quais sejam agrícolas ou de pastos. Nas proximidades do rio ou dos córregos, o domínio é dos cultivos. Conforme se afasta, adentrando-se para o interflúvio, o uso agrícola da terra perde importância e o uso pela pecuária vai se tornando dominante. Mas, nas proximidades do rio, abaixo da linha onde se situam a estrada, as casas de moradas e o conjunto do entorno - pomar, cercados, oficinas - as terras de cultura são aproveitadas de modo intensivo. Ali praticam os cultivos de regadio na estação seca e os cultivos de sequeiro na estação chuvosa. Estes últimos também são cultivados nas áreas acima do rego, muitas vezes se intercalando com os cultivos de pastagens

Antes das intervenções arrasadoras da agricultura moderna, o rio Arrojado, e seus afluentes, tinham maior volume de água e a agricultura que usufruía da irrigação podia realizar-se em áreas mais extensas. Isto porque havia casos de, na 
mesma vertente, captações alimentarem mais de um rego que, relativamente paralelos, percorriam grandes distâncias ao longo do vale, tal como foi demonstrado no caso do Brejo Verde.

$\mathrm{Na}$ atualidade, entretanto, em função da significativa diminuição do volume de água do rio Arrojado e córregos, isto não é mais possível e o Sr. João de Castro e Silva lamenta: estou com 71 anos e vejo o rio que não ta com a metade da água do rio que conheci. ${ }^{134}$

$\mathrm{Na}$ área de regadio, além dos cultivos já mencionados, predominantemente se cultivam produtos alimentares, tais como arroz, feijão, milho e mandioca. Mas também naqueles sítios maiores cultiva-se a cana-de-açúcar para a fabricação de rapadura, açúcar e/ou cachaça. A cana-de-açúcar pode servir também de ração para o gado. Ainda nos sítios, quando são mais amplos, se cultivam também pequenos talhões de pastos ou mangas para socorrer o gado fraco na época da seca.

Vê-se, pois, a relevância das áreas de sítios ou regadios para a unidade econômica camponesa. Dali os camponeses retiram os suprimentos para o sustento direto da família - e parte da alimentação dos animais na estação seca quando estão precisados.

As atividades agrícolas intensivas na referida área são possíveis graças ao uso da água na irrigação. Porém, em algumas comunidades, a minifundização chegou ao limite e, nesses casos, as estreitas tiras de terra são divididas em toras nas áreas mais elevadas, acima do rego; e abaixo do rego, no sítio, a extensão da tira de frente para o rio ou córrego, para permitir o acesso à área irrigada àqueles donos das toras, é dividida em pequenos talhões em sentido longitudinal ao da tira, conforme demonstra o esquema a seguir.

Rego

Rio/córrego

\begin{tabular}{|l|l|l|l|}
\hline \multirow{2}{*}{ Tora 3 } & Tora 2 & Tora 1 & Tora 1 \\
\cline { 3 - 4 } & & & Tora 2 \\
\cline { 3 - 4 } & & & Tora 3 \\
\hline
\end{tabular}

Aqui nessa propriedade que era do velho meu pai sozinho, hoje tu vê, olhe, tem Beto, compadre Sabino, eu, Olavo meu irmão, Gregório, Joaquim, olhe, numa propriedade

\footnotetext{
${ }^{134}$ Sr. João de Castro e Silva, morador da comunidade de Jatobá, trabalho de campo realizado emoutubro de 2010.
} 
só já tá dividida para esse tanto de gente. Tudo é de uma família só (João de Castro e Silva, morador da comunidade do Jatobá, trabalho de campo realizado em julho de 2011).

E, até mesmo a parte que o Sr. João herdou já está dividida: Olha, só nessa arinha minha é 13 ha de terra que eu labuto aqui, já tem dois filho morando em cima, junto comigo.

Nestas condições de extrema minifundização, os camponeses geraizeiros se utilizam de todos os recursos possíveis no manejo da terra para conseguir a máxima produtividade.

O aperto resultante de processos sociais, como a grilagem das terras, a proibição de cultivos nas veredas a montante e o aumento populacional, obrigou os camponeses geraizeiros a engendrarem suas próprias técnicas de uso da terra. No que se referem à prática agrícola, as inovações se fazem mais presentes e diversas, justamente nas áreas de regadio, onde a agricultura é praticada com maior intensidade. Conforme já mencionado, nesta área, cultiva-se em dois períodos do ano: na estação seca e na chuvosa. Todos os cultivos da unidade de produção são praticados na área de regadio e dali são retirados os suprimentos alimentícios para o sustento da família, para o comércio e para a alimentação animal, principalmente em períodos de escassez de pastagens, tal como assevera Shanin (1976, p. 20) el cutivo (tanto la labranza como la cría de ganado) es lo esencial de la economía campesina. La agricultura ha sido definida como proveedora de alimentos y materias primas de origen animal o vegetal (SHANIN, 1976, p.20).

Justamente por isso, esta área se destaca com maior importância na parcela; assim, para extrair maior produtividade dos cultivos, desenvolvem-se e se aplicam os aprimoramentos técnicos engendrados.

No passado, praticavam a técnica da coivara, que consiste na derrubada da vegetação nativa seguida da queima, conforme relata o Sr. João:

toda vida do tempo de meu pai nóis queimava, né? Nóis fazia roça no mato alto aí era nesse tempo. Depois quando era ali, vizinhano outubro nóis tocava fogo, queimava aquele resto de garrancho que ficava, nóis ia ajuntar na mão, porque a madeira todinha era serrada para fazer cerca contra porco e bode (João de Castro e Silva, comunidade do Jatobá, trabalho de campo realizado em julho de 2011).

O uso desta técnica, entretanto, se remete aos tempos em que a oferta de terras disponíveis para a agricultura nas parcelas de uso exclusivo familiar era maior. No decorrer dos anos, a população cresceu, adensou-se, e, consequentemente, as 
áreas agricultáveis se tornaram fracionadas, impossibilitando a prática das queimadas/coivaras nas parcelas. Seu uso, todavia, ainda perdurou por algum tempo nas roças que se formavam nas veredas, a montante do vale. Com muita frequência, os camponeses referiam-se às vantagem desta prática, pois derrubavam a vegetação da vereda, queimavam-na, plantavam o arroz e outros cultivos, e não precisavam limpar porque não nascia mato para competir com o cultivo. $O$ motivo mencionado nas parcelas de uso exclusivo familiar, o progressivo aumento da competição das ervas daninhas ${ }^{135}$ com os cultivos e a proibição da exploração agrícola das veredas, resultou na drástica diminuição das plantações de arroz, já que, devido à exigência de três limpas no cultivo, este é lembrado como trabalhoso demais para se cultivar, não compensa. Principalmente nos dias atuais, em que o aumento dos criatórios ocupa grande parte do tempo dos camponeses, os quais não mais dispõem do tempo que exige o cultivo de arroz, enfrentando as condições anteriormente descritas. Frequentemente, afirmavam que não tinham tempo suficiente para dedicar-se tanto à agricultura e pagar a um companheiro não dá. Quando colhe, põe na ponta do lápis o que gastou, e se vê que o prejuízo é grande. Deste modo, concluem que é mais vantajoso abdicar do plantio do arroz e dedicarse aos criatórios. Quando o geraizeiro necessita comprar algo que não produz na parcela, tal como o arroz, vende um garrote e faz a feira para uma boa temporada.

Como heranças do antigo costume, ainda hoje praticam a queima de parte da biomassa, porém somente daquela cujo tempo de decomposição tornaria inviável seu aproveitamento. Conforme relata o Sr. João de Castro e Silva, de vez em quando, palha de coco, essas caçambas assim, eu tiro daqui, montoo ai, tiro na mão e queimo ${ }^{136}$. O produto da combustão, as cinzas, é depositado nas covas dos plantios.

Todavia, a partir dos processos mencionados anteriormente, os camponeses passaram a adotar outras técnicas de cultivos. Revolvem a terra com 0 arado manual, puxado por uma junta de boi, e toda biomassa (matéria orgânica) que consideram aproveitável acrescentam aos solos, enriquecendo-os. Ellen Woortmann demonstra a concepção camponesa que norteia a sua relação com a terra:

O trabalho do homem é o de preparar a terra e quando necessário alimentá-la com a "vitamina" do adubo. O trabalho da terra é o de fazer nascer e crescer a planta,

\footnotetext{
${ }^{135}$ Uma planta indesejada que nasce espontaneamente.

136 João de Castro e Silva, comunidade do Jatobá, julho de 2011.
} 
alimentado-a com a sua "vitamina". A terra, agradecida, retribui o trabalho do homem com uma colheita abundante. Quando ela "recebe a vitamina dada pelo homem e a chuva de Deus, ela fica alegre e agradece, dando muito alimento" e trazendo "fartura". Mas, se a terra trabalha, tal como o homem, ela fica "cansada" e é preciso respeitar seu tempo de "descanso" (pousio) (WOORTMANN, 2004, p.134).

Como exemplo desta relação "respeitosa" com a terra, cito a adubação no cultivo do milho. Esta é feita usando-se o esterco de gado ${ }^{137}$, que é depositado nas covas e complementado pela matéria orgânica produzida na própria roça. Assim, após a colheita do milho, soltam o gado na roça para comerem a paiada. $O$ gado come uma parte, cerca de $50 \%$, e a outra, no pisoteio dos animais forma uma muinha que acrescenta matéria orgânica na terra e a enriquece para o cultivo do ano seguinte, realizado novamente com o acréscimo do esterco (misturado com restolhos de plantas) depositado na cova. Esta técnica é utilizada também em outros plantios que geralmente são cultivados juntos, em consórcio entre si, potencializando assim, o aproveitamento da terra nas exíguas parcelas de uso exclusivo familiar.

rapaz é o seguinte: o esterco do gado a gente usa ele para várias opções: a gente usa ele na planta do feijão, a gente usa ele na planta do milho, na planta da mandioca, na planta de arroz, um adubo muito beleza, né? Onde você esterca com esterco de gado de curral é outra produção, tem outro rendimento... ...quando a gente colhe o milho, aí a gente põe o gado na paiada, se trata paiada, né? E depois o gado come um pouco e fica $50 \%$ na terra, o gado quebra tudo, aquele negócio... e depois, e depois fica aquela muinha na terra, a gente ara, e aquela muinha serve de adubo, né?... (Sr. Antonio José de Araújo, morador da comunidade do Brejo Verde, trabalho de campo realizado em janeiro de 2012).

No ano seguinte, ao arar a terra, a referida muinha já decomposta é misturada ao solo, adubando-o.

Do milho, aproveita-se a espiga para a alimentação humana e dos animais de pequeno porte e a palha para a alimentação do gado e adubação da terra.

Semelhante ao milho, o feijão também é adubado com esterco de gado misturado com outras matérias orgânicas. Este é arrancado (quando é o caso) ${ }^{138}$, bate-se com o cambão - dois pedaços de madeira, com uma corda amarrando um ao outro - a palha é destinada à alimentação do gado e os restos, misturados com esterco, servem para a adubação colocada nas covas dos plantios no ano seguinte.

\footnotetext{
${ }^{137}$ Este, porém, não é puro. É misturado com um conglomerado de biomassa produzido na parcela durante o ano e amontoado para submeter-se à decomposição na estação chuvosa.

${ }^{138}$ Cultivam o feijão de arranca e o feijão catador ou de corda.
} 
O cultivo da mandioca também se utiliza do esterco animal misturado com a matéria orgânica oriunda dos cultivos do ano anterior. Uma parte das suas ramas é separada para a semente e a outra, após a exposição ao sol por alguns dias, para murchar e sair o leite, é destinada à alimentação do gado. Os restos, tal como nos outros casos, após decomposição, é destinado para a adubação da terra no ano seguinte.

Outra fonte de matéria orgânica explorada pelos camponeses geraizeiros são os regos. Estes, nos trechos das parcelas que atravessam, são sombreados pelas plantas dos pomares, dos plantios das roças ou das pastagens, geralmente vedadas em suas margens. No fundo, são depositadas quantidades significativas de folhas secas que caem das referidas plantas. Estas são retiradas juntas com o barro quando das limpezas dos regos ${ }^{139}$ e, quase sempre já decompostas, formam uma rica mistura que também é aproveitada na adubação dos plantios, conforme nos explica o Sr. João de Castro:

...agora esse barranco de rego aqui, quando acontece que eu tiro a terra de dentro, eu jogo aqui, depois eu ponho numa caçambinha de mão e vou botando aí pra dentro, né?... ...olha essa que eu tiro daqui de dentro, porque essa aí vai juntando essa folha podre aí, e olhe, vai podrecendo aí e vai virando. Depois eu tiro, eu ajunto ela com a enxada, pego com a pá e boto aqui, e daqui eu vou botando aí os montinho daqui pra culá, a hora que eu vou trabalhando eu vou esparramando, né? (Sr. João de Castro e Silva, morador da comunidade do Jatobá, trabalho de campo realizado em julho de 2011).

A cana-de-açúcar também é muito cultivada e ocupa principalmente as áreas de regadio. Porém, os talhões são mais extensos naquelas parcelas maiores. Nestas, a cana-de-açúcar pode destinar-se ao fabrico da rapadura, da cachaça, do açúcar e também à alimentação do gado, principalmente, na estação seca, quando acode o gado mais fraco. Nas parcelas menores, quando é cultivada, visa ao fabrico apenas da rapadura e à alimentação animal.

Visando à alimentação animal, também cultivam, nas áreas de regadio, pequenos talhões de pastos ou mangas, assim como o capim de planta ${ }^{140}$ (plantado por poucos criadores). Ambos são irrigados e desempenham o importante papel de salvar aquelas reses que se enfraquecem na estação seca. Quanto ao

\footnotetext{
139 Estas limpezas, diferentemente daquelas que obedecem à organização da comunidade, são realizadas com o intuito de aproveitar o adubo depositado no fundo do rego. Esta mistura (barro mais folhas decompostas) é transportada utilizando-se de uma caçambinha de mão e disposta em montinhos na roça. Quando da limpa (ou carpina), os montinhos são espalhados e a terra ganha este acréscimo de fertilidade.

${ }^{140}$ Capim forrageiro.
} 
capim de planta, quando cultivado pelos menos apossados é servido ao gado na palha (ou inteiro) e, se plantado nas parcelas maiores, onde se cria rebanho mais numeroso, tritura-se no triturador para servi-lo em cochos aos animais.

Como se pode observar, engendram-se uma variedade de estratégias visando à provisão do gado na estação seca. Isto se deve às características do clima da região, marcadas regularmente por longa estiagem e ocorrências de prolongamento em alguns anos, como neste em que redijo o presente trabalho. Nesta situação, é comum as pastagens das parcelas chegarem à total exaustão, obrigando ao deslocamento da maioria do rebanho para as áreas de soltas e/ou de fechos de gerais. A parte do rebanho que não se encontra em condições para o deslocamento permanece nas parcelas e há que providenciar para ela os alimentos; destacandose, como principal fonte, tudo que é possível cultivar nas áreas de regadio.

Outro cultivo que ocupa principalmente a área de regadio é o arroz. Ao contrário dos outros, que são praticados na estação seca e irrigados, o arroz é cultivado na estação chuvosa, na vazante.

Um tipo de atividade que contribui significativamente para a melhoria da dieta dos geraizeiros é a horticultura, que é dominantemente praticada na área de regadio e constitui-se de uma importante variedade de cultivos, tais como: alface, tomate, pepino, pimenta, pimentão, cebola, cebolinha (em folha), coentro, salsa, chuchu, beterraba, cenoura, rabanete, mostarda e abóbora. Esta lista foi constatada apenas em uma pequena horta cultivada ao redor de uma casa, na comunidade de Jatobá. Visitas a outras, provavelmente, ofereceriam elementos para considerável prolongamento. Os produtos dessas lavouras e/ou hortas, conforme assinalado, são cultivados utilizando-se predominantemente de adubação orgânica e não tive conhecimento do emprego de produtos químicos.

É digna de nota também a variedade de plantas medicinais cultivadas no entorno das casas nas comunidades. Ali se encontra losna, alecrim, erva cidreira, capim santo, hortelã grosso, hortelã miúdo, manjericão, canela, carquejo, arruda, confrei, cordão-de-são-francisco, cordão-de-frade, nanuscada (ou noz-moscada) e dendê.

No pomar, a variedade também é expressiva, onde se encontra cacau, coco, banana, cana-de-açúcar, laranja, laranja lima, tamarindo, goiaba, umburana, umbu, manga e café. 
A riqueza de variedade dos alimentos e plantas medicinais que os geraizeiros têm acesso é acrescida ainda por aquelas que coletam no campo.

Quanto ao preparo da terra para a formação das roças, conforme já mencionado, este é realizado com o uso do arado manual, puxado por uma junta de boi. Na aragem, deixam as leirinhas que serão usadas para a irrigação dos cultivos, conforme nos explica o Sr. Antonio José de Araújo: deixa as lerinhas e vai espalhando (a água), puxa daqui, pra li, vai esgalhando nas plantas.

O método de irrigação predominante na região é o de escoamento por sulcos de gravidade. Enquanto a água do rego lhe pertence, o agricultor abre no rego um ladrão $^{141}$ e retira a água necessária para irrigar as carreiras do cultivo abaixo, aproveitando-se das leirinhas $^{142}$ ou dos pequenos sulcos intencionalmente deixados quando da aração da terra.

\begin{abstract}
nós pega, tira um galho de água do rego e leva até a roça lá, até a lavoura. Aí nós esparrama a aguinha, vai molhando os trechinho, né? Vai molhano aquelas lerinhas, sabe? Quer dizer, a gente já faz a roça, já ara, e quando planta, prepara a terra, já deixa aquelas leirinhas, né? Faz duas, três, quatro leirinha, aí a água vai molhano, termina uma lera, aí você passa pa ota (Sr. Antonio José de Araújo, morador da comunidade do Brejo Verde, trabalho de campo realizado em janeiro de 2012).
\end{abstract}

Este método de irrigação tem o inconveniente de comprometer a fertilização do solo com o acúmulo de sal proveniente da água em sua superfície. E a reclamação na região é muito comum: se essas terras aí não dão nada ${ }^{143}$ é porque a água acaba com a terra. Umedece e o sal fica. ${ }^{144}$

Cabe lembrar que o Sr. Anésio refere-se a áreas da extrema montante do Brejo Verde, onde os solos já podem ser caracterizados como de cerrados e, por isso, a fertilidade natural é bem menor. Nesta mesma região, pude ver formidáveis lavouras de milho, embora cultivadas com o emprego das técnicas descritas anteriormente. Não se quer afirmar, entretanto, que o fenômeno da salinização não se apresente na região; portanto, os reclames de enfraquecimento dos solos, possivelmente, em parte, devem-se a isto. Entretanto, quando se cuida bem da terra, o resultado positivo é visível, causa admiração do visitante e os próprios

\footnotetext{
141 Escavação no barranco do rego para o desvio da água.

142 Pequenas leiras de terra que conduzem a água para as plantas.

143 O dizer "não dá nada" pode ser entendido como força de expressão, pois, mesmo afetados pela salinização, os solos ainda são bastante produtivos, embora menos que no passado.

${ }^{144} \mathrm{Sr}$. Anésio, comunidade do Brejo Verde, trabalho de campo realizado em janeiro de 2012.
} 
agricultores se orgulham da sua terra pelo que dela conseguem e repetidamente afirmam: aqui, tudo que planta, dá bom.

\subsection{Os cultivos de sequeiro}

No tópico anterior, foquei com maior ênfase os cultivos realizados na área de regadio. Nesta área, embora ocorra a prática do cultivo de pastagem e cana-deaçúcar, caracteriza-se pelo domínio dos cultivos alimentícios.

Entretanto, noutras áreas mais elevadas, acima do rego, também são formadas roças de produtos destinados diretamente ao sustento das famílias. Podese mesmo afirmar que todos os cultivos, com exceção do arroz - que é cultivado predominantemente na área de regadio - são praticados nas áreas onde se encontrem terras de cultura, quer seja no regadio ou nas áreas de sequeiro. $E$ a mandioca e o feijão catador, diferentemente dos demais, podem ser cultivados também nas áreas de solos arenosos, embora dependam, para um bom rendimento, do bom inverno. ${ }^{145}$

Mas é possível também identificar, na parcela, as localidades de domínio de cada cultivo.

$\mathrm{Na}$ área de regadio, pode-se afirmar que os cultivos dominantes são os das hortaliças, cana-de-açúcar e arroz (na estação chuvosa). Nas áreas elevadas, acima do rego, o cultivo dominante é o do milho e da mandioca, que se misturam com as pastagens, principalmente nas áreas mais próximas às moradias, imediatamente após o rego. Geralmente, é ocupada a totalidade de um piquete, ou, quando apenas uma parte, os camponeses fazem um cercado para proteger os cultivos dos animais.

Em comunidades como a do Brejo Verde e as do entorno, que dispõem de regos em bom funcionamento - às vezes, mais de um na vertente - e poucas terras de cultura, os cultivos de sequeiro são praticados abaixo do rego, porque entre este e o córrego se encontra uma larga faixa de terra. Isto não quer dizer, entretanto, que toda a faixa abaixo do rego seja irrigável, pois constitui-se de solos arenosos, os quais consumiriam grande quantidade de água na irrigação. Nesses casos, até mesmo as pastagens cultivadas geralmente localizam-se na referida faixa e o rego, muitas vezes, divisa as pastagens com as áreas de vegetação de cerrados. Estas

\footnotetext{
${ }^{145}$ Considerado assim, o verão, com quantidade de chuvas satisfatórias para os ciclos produtivos.
} 
áreas comumente são cercadas (pequenos talhões) e representam um prolongamento da parcela de uso exclusivo familiar que avançou sobre as terras de uso comum, as soltas (figura 9).

A área de regadio propriamente dita, nesse caso, localiza-se abaixo do rego que percorre as áreas mais baixas (figura 9). Ali estão concentradas as terras de cultura, onde se pratica a maioria dos cultivos. Nas áreas imediatamente mais elevadas, entre a estrada e as casas de moradas, as pastagens se intercalam com cultivos de sequeiro até se tornarem dominantes e, em seguida, devido à dificuldade de formá-las, não mais são cultivadas e cedem lugar para a vegetação natural de cerrados.

\subsubsection{O calendário agrícola}

Nos tópicos anteriores foi mostrado que os camponeses geraizeiros dispõem de duas áreas nas quais praticam a agricultura: a área de regadio e a de sequeiro. A disposição e o uso dessas duas áreas os envolvem em dois ciclos agrícolas durante o ano. Na área de regadio, as roças irrigadas são formadas no mês de junho (exceto a cana-de-açúcar) e, daí em diante, se ocupam em cada cultivo pelo tempo que durar o seu ciclo. Na realidade, este uso da terra é realizado de um modo relativamente complexo, pois, visando maior aproveitamento da terra, os cultivos geralmente são realizados em consórcios. Inclusive, há casos de se cultivar, concomitantemente, a mandioca, o milho e o feijão. Para possibilitar a irrigação desses cultivos, a terra é previamente preparada, conforme já descrito.

A cana-de-açúcar costumeiramente é plantada no mês de novembro e colhida a partir de 18 meses, geralmente de maio a outubro.

O feijão é plantado em junho e colhido em finais de agosto ou início de setembro. O milho é plantado em junho e colhido no mês de setembro. A mandioca é plantada em junho e colhida após um ano e meio - porém, quando cultivada nas áreas baixas, que podem embrejarem-se, é colhida antes da maturação, após cerca de 8 meses (figura 10).

Nas áreas de sequeiros, o início dos cultivos tem como fenômeno balizador o começo das chuvas. A primeira chuva amolece a terra e já torna possível a aração. Porém, apesar da primeira chuva ser normalmente esperada no mês de outubro, ela pode atrasar e só vir em novembro ou até mesmo dezembro. Quando isto ocorre, os 
cultivos também são retardados. Todos os cultivos são formados na mesma época: outubro, novembro ou dezembro.

Figura 10 - Calendário agrícola do regadio

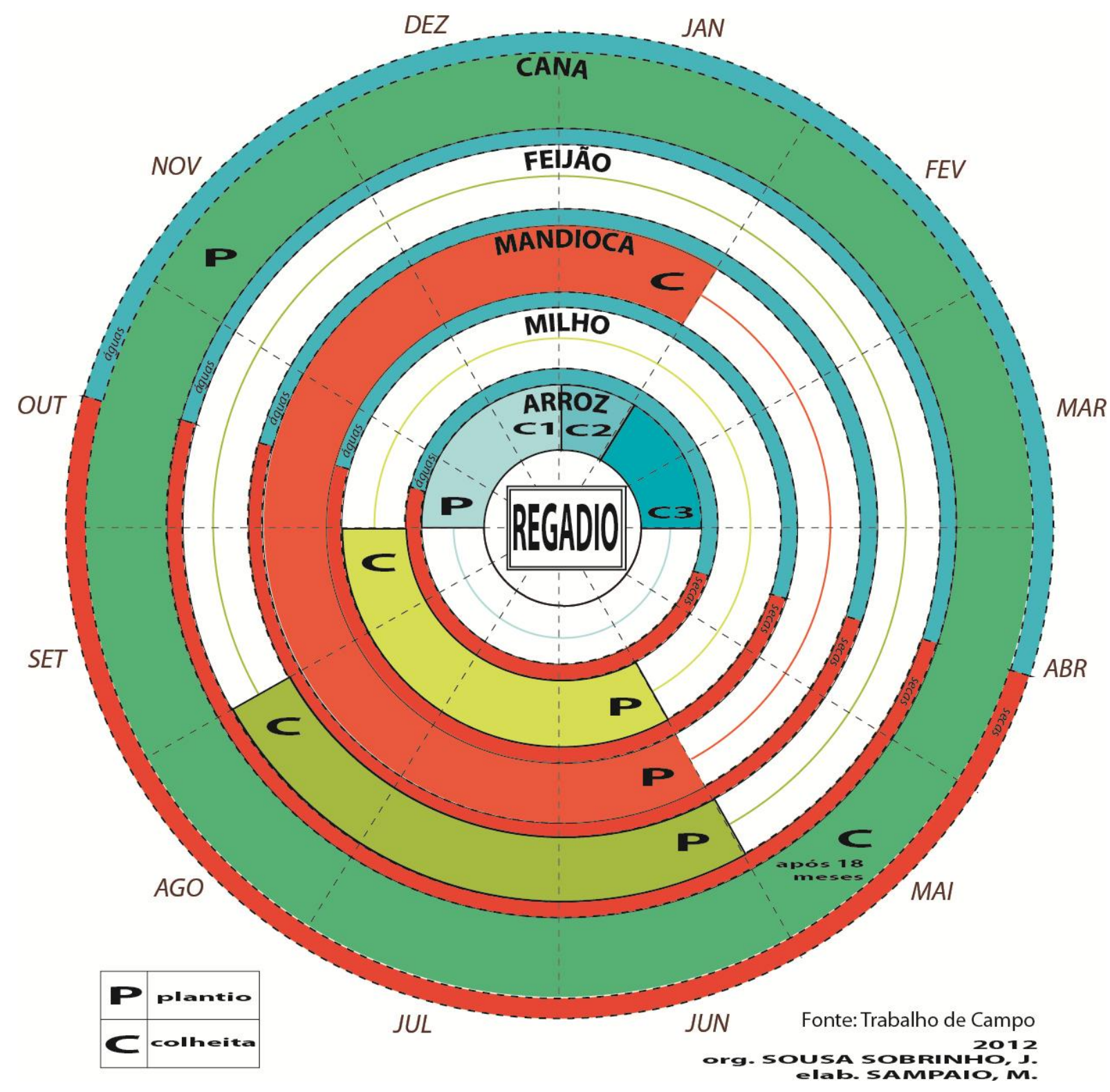


Assim, o feijão pode ser plantado em outubro e colhido dois meses depois. $O$ milho pode ser plantado em outubro e colhido cinco ou seis meses depois, nos mês de fevereiro ou março. Porém, quando necessitam retardar sua colheita, os agricultores dobram seu pé ao meio. Deste modo a espiga, já seca, fica de ponta para baixo, seu tronco, por ser impermeável, a mantém seca e a colheita pode ser adiada para algum tempo.

$O$ arroz, sendo o de prefeitura ${ }^{146}$, pode ser plantado em outubro e colhido no mês de março; porém, sendo o de três ou de quatro meses, é colhido no tempo que se finaliza o seu ciclo produtivo.

A mandioca, tal como os outros cultivos, é plantada no mês de outubro e colhida um ano e meio depois. Porém, com oito meses após o plantio, os camponeses já começam a colhê-la para o consumo in natura, geralmente cozida. Os camponeses podem também retardar a sua colheita, pois a mandioca se conserva na terra por tempo adicional ao considerado próprio para a colheita (figura, $11)$.

Os produtos acima mencionados são considerados os principais cultivados na unidade de produção dos camponeses geraizeiros. Entretanto, uma grande variedade de outros plantios, conforme já assinalado, constitui as roças ou hortas dos camponeses geraizeiros. Mas estes, apesar de serem cultivados em maioria na estação seca e dependerem da irrigação, são de ciclos curtos e, por isso, geralmente plantados mais de uma vez, quer seja no verão ou no inverno, conforme o caso.

\footnotetext{
${ }^{146}$ Variedade de arroz de ciclo produtivo longo: cerca de 6 (seis) meses.
} 
Figura 11 - Calendário agrícola sequeiro

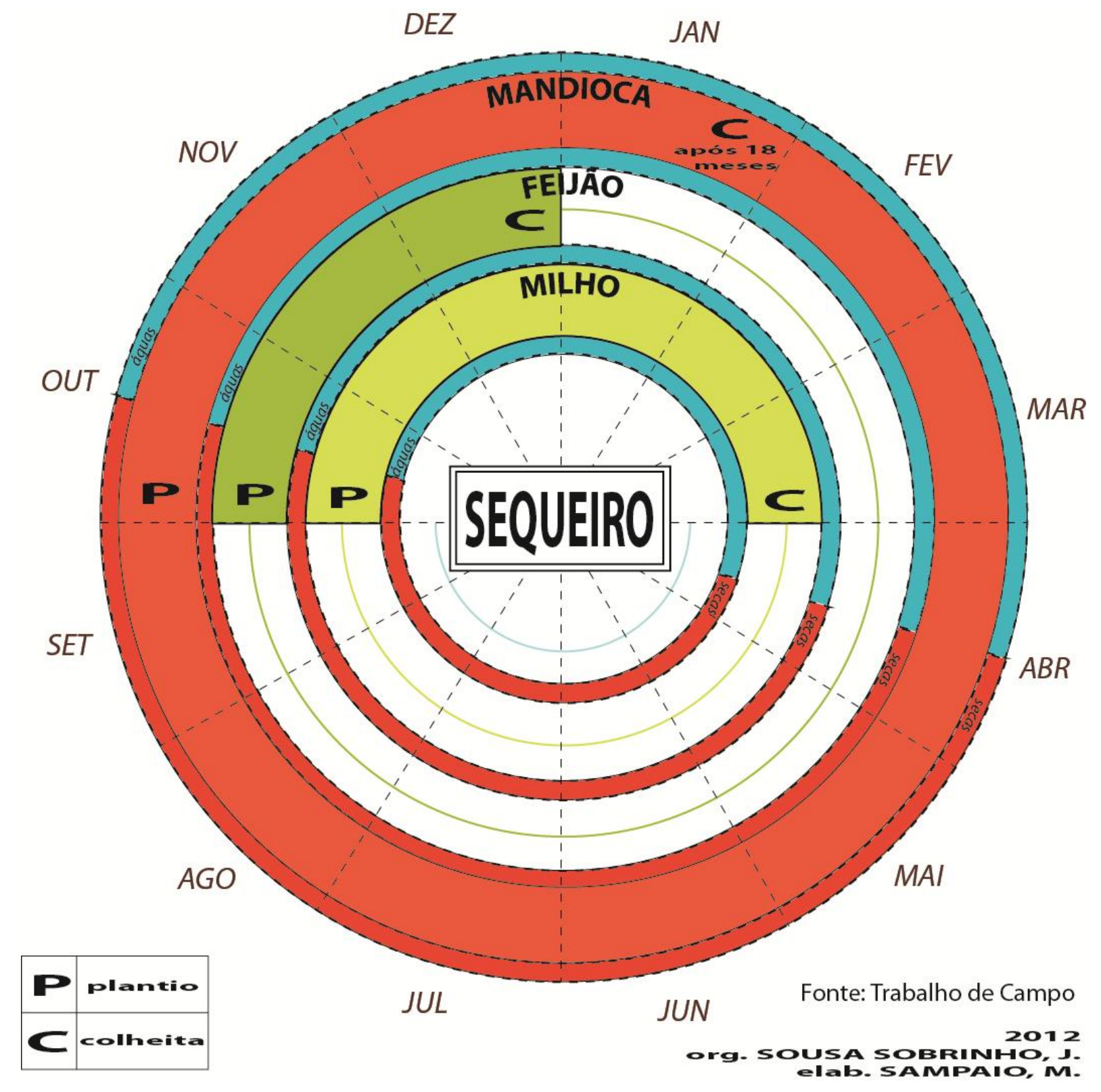

4.7 A pequena indústria doméstica 
A pequena indústria camponesa dos gerais do Oeste da Bahia vem passando por importantes alterações nas últimas décadas. Pude constatar a persistência da indústria doméstica, porém, de modo geral, voltada ao processamento de produtos oriundos da parcela e para o fabrico de boa parte dos instrumentos de trabalho, tais como arreios para os animais e artefatos de couro em geral, carros-de-boi e acessórios, engenhos e acessórios, casa de farinha e acessórios.

Além dos instrumentos fabricados e processados nas pequenas indústrias, os camponeses afirmam que, no passado, eram muito presentes nas unidades familiares as rodas de fiar e os teares empregados no fabrico de tecidos rústicos; era significativo o número de seleiros e carpinteiros, assim como daqueles moradores dos povoados dotados dos saberes na confecção dos derivados das palmeiras de buritis, como chapéus, esteiras, capas de chuva e outros.

Porém, nas últimas décadas, apesar de persistir o mal estado das estradas, o contato com a cidade aumentou. Assim, muitos dos produtos da indústria urbana tomaram o lugar daqueles tradicionalmente produzidos nas próprias unidades familiares. Estas mudanças devem-se muito a processos que se desenvolvem no meio comunitário, tais como aumento da produção de mercadorias (principalmente da pecuária, notadamente o gado vacum) e do consequente aumento da monetarização, da migração e da intervenção dos programas sociais dos últimos governos.

Forte impulso a estes fenômenos deve ser atribuído também ao fato das comunidades terem sido contempladas com o programa governamental "Luz para Todos", a partir do qual, tornou-se possível o uso da televisão, veículo de comunicação que atua dentro dos lares, desempenhando relevante papel na reorientação dos hábitos de consumo, bem como na gama de valores dos sujeitos sociais. Vê-se, em grande parte das moradias geraizeiras, o reflexo de tudo isto no padrão das casas, do mobiliário doméstico, no modo de se vestir e até mesmo nos hábitos alimentares. Deste modo, os produtos oriundos da indústria urbana, em grande parte proveniente de centros industriais distantes, fazem-se muito presente nas comunidades, mediando a reprodução do camponês geraizeiro. Todo este processo coaduna-se com o que escreveu Kautsky: 
Não é, pois, de admirar que cedo a indústria urbana superasse a profissão agrícola e fabricasse ferramentas agrícolas de qualidade que esta não tinha condições de produzir. O desenvolvimento da indústria e do comércio, no entanto, geraram a demanda de novos produtos na cidade, demanda que a indústria agrícola era incapaz de satisfazer; esses produtos, a exemplo das ferramentas novas e mais perfeitas, também começaram a invadir o campo em ritmo crescente, na medida em que crescia o intercâmbio entre a cidade e o campo. As túnicas e as peles de animais foram substituídas por roupas de pano, os sapatos de palha pelas botas de couro e assim por diante. O serviço militar, que traz os filhos dos camponeses para as cidades e os familiariza com as necessidades urbanas, favoreceu enormemente esse tipo de desenvolvimento. A ele se deve atribuir principalmente a difusão do consumo do tabaco e de bebidas alcoólicas. Enfim, a superioridade da indústria urbana tornouse tão grande que acabou por transformar os produtos da indústria agrícola em artigos de luxo, em artigos que o econômico camponês não podia dar-se ao luxo de utilizar e cuja produção acabou por abandonar. Dessa maneira, o desenvolvimento da tecelagem de algodão, que fabricava chita barata, acabou por reduzir, no geral, o plantio de cânhamo ao necessário para o uso particular do camponês. Quando não chegou a acabar com ele por completo (KAUTSKY, 1986, pp.18-19).

Nos dias de hoje, do que se produz nas parcelas de uso exclusivo familiar, alguns produtos são consumidos ou vendidos in natura e outros são processados pelos geraizeiros nas suas oficinas. Dentre os que são processados, destacam-se a mandioca, que é transformada em farinha e polvilho, e a cana-de-açúcar, da qual se faz a rapadura, a cachaça e o açúcar (foto 16 e 17).

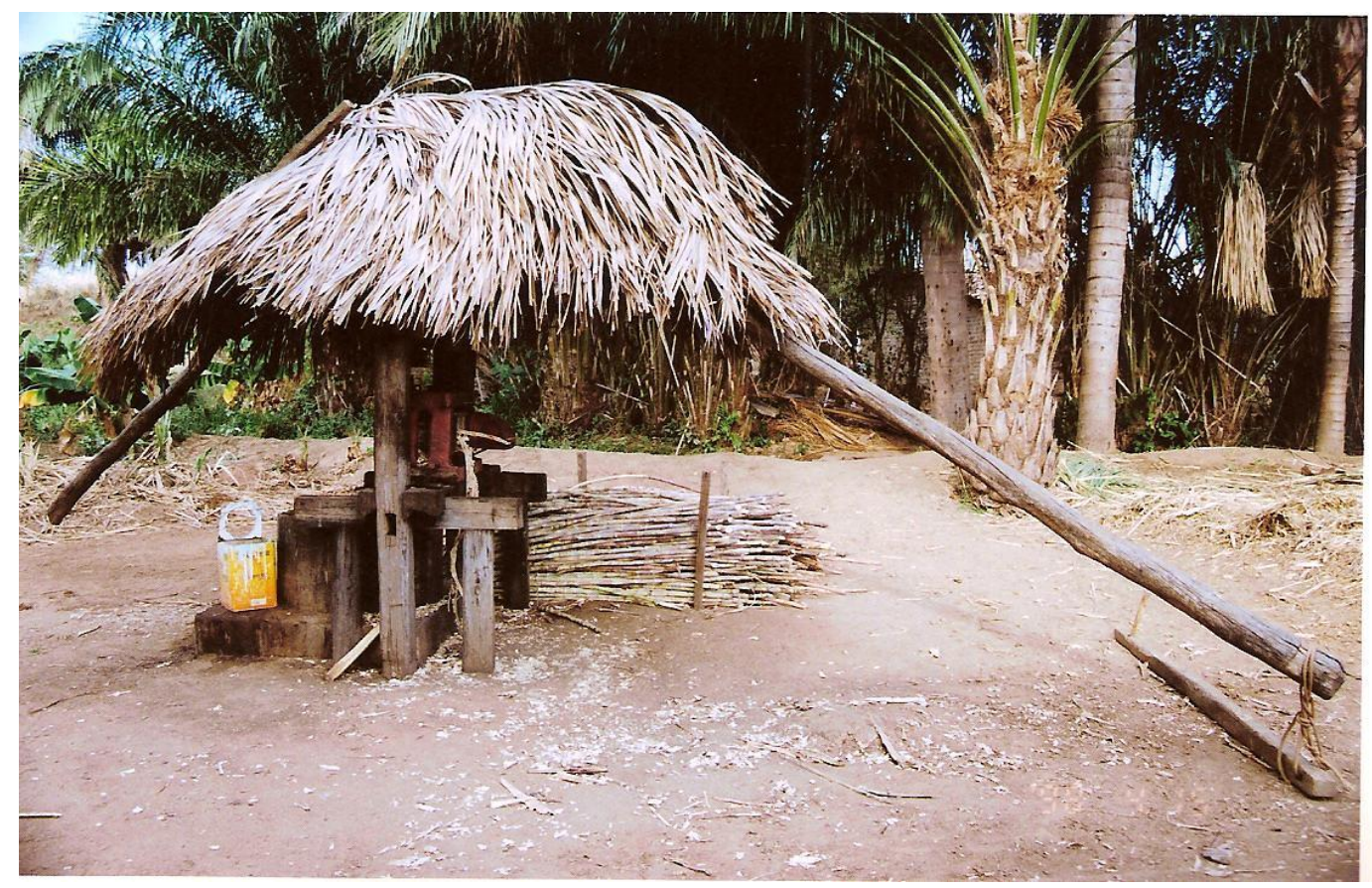

Foto 16 - Oficina: engenho de cana-de-açúcar. Brejo Verde, Correntina - BA, Sousa Sobrinho, J. (out. 2010) 


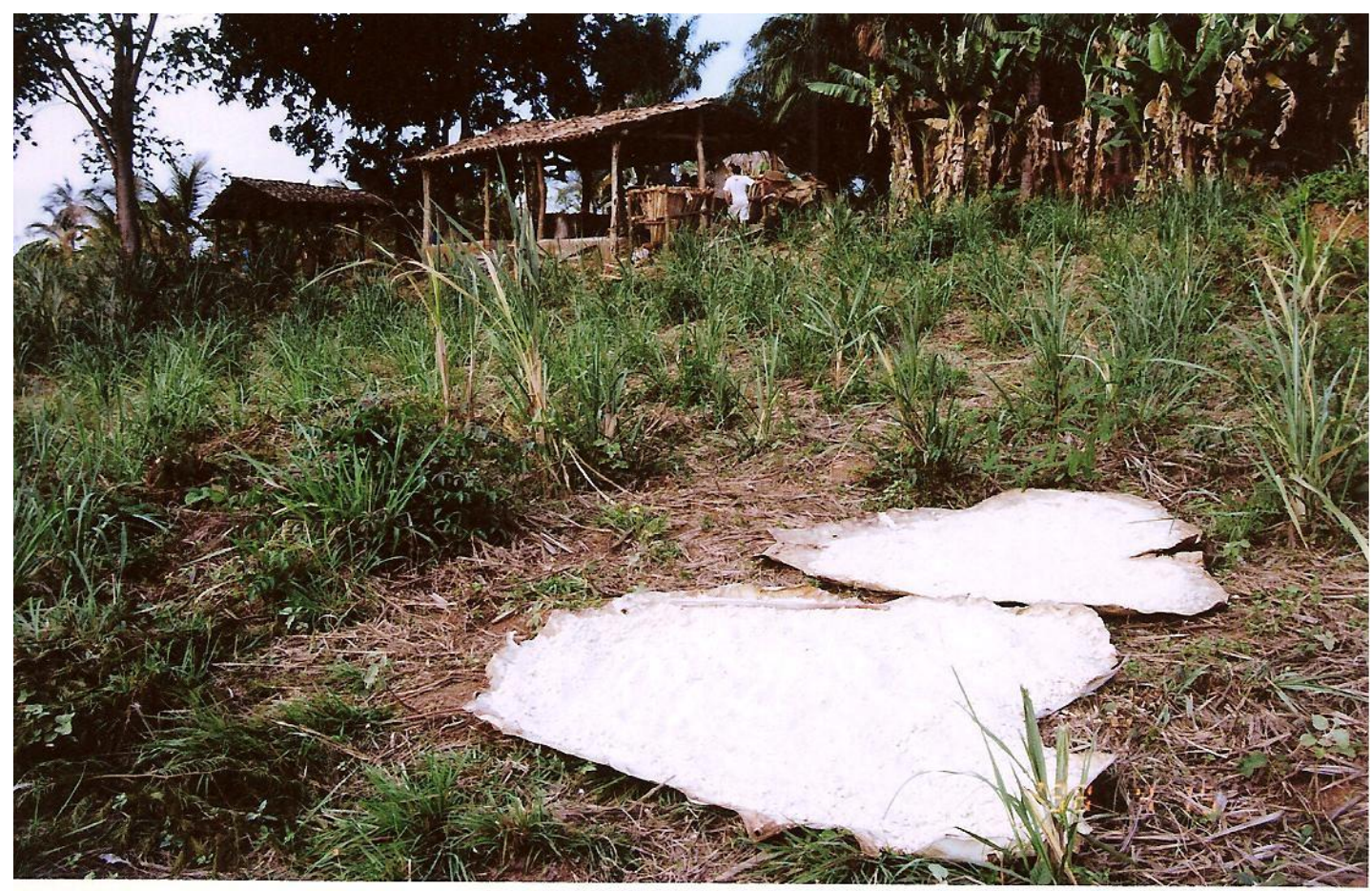

Foto 17 - No primeiro plano, açúcar secando ao sol. No segundo, oficina de fabricação de açúcar, cachaça e rapadura. Brejo Verde, Correntina - BA, Sousa Sobrinho, J. (out. 2010).

As oficinas são abrigadas em pequenos galpões anexos ou bem próximos às casas de morada, geralmente no terreiro. Situam-se, pois, nas proximidades da área de sítio, onde a produção agrícola é mais intensa (dois ciclos anuais), e da casa de morada, onde os produtos são armazenados e consumidos; embora, em alguns casos, encontre-se uma casinha, separada da casa de morada, onde os produtos alimentícios são armazenados. Ao compor esse conjunto estrategicamente situado nas proximidades do rego, o processamento dos produtos é facilitado pela proximidade da água.

São equipamentos que constituem a casa de farinha: o motor atrelado ao triturador, a prensa (geralmente instalada na parte externa ao galpão), o jirau, onde a massa é exposta ao sol para a secagem, e o forno onde a farinha é torrada. Encontra-se também uma variedade de outros utensílios, tais como cochos, gamelas e/ou bacias, geralmente usados para deixar em repouso a suspensão, após a lavagem da massa, para o fabrico do polvilho.

Há que ressaltar, entretanto, que nem todo geraizeiro tem motor na sua casa de farinha. Nesse caso, a trituração da mandioca é feita utilizando-se do antigo método da roda (geralmente construída em madeira), girada manualmente e ligada por uma correia a um bulinete, o qual tritura a mandioca. Inclusive, naquelas 
comunidades mais afastadas, onde praticamente inexiste qualquer modernização tecnológica, ainda se tritura a mandioca utilizando-se de ralo $^{147}$ e a prensagem da massa faz-se com o uso do tipiti ${ }^{148}$.

Uma casa de farinha equipada com motor a diesel geralmente atrai agricultores das proximidades, que para lá transportam sua produção a fim de processá-la. Neste processo de trabalho, costumam ocorrer relações solidárias e/ou parcerias entre as partes, destacando-se como um dos importantes promotores de laços nos quais se tecem as relações comunitárias geraizeiras. Mas, sobre este componente constituinte das comunidades pretendo tratar em outro momento.

Outra oficina que merece atenção é na qual se processa a cana-de-açúcar. Esta oficina geralmente ocupa um galpão exclusivo e é dotada dos seguintes equipamentos, empregados na fabricação de rapadura, cachaça e açúcar: o engenho (localizado na área externa ao galpão); os tachos de cobre e o forno no qual a garapa é fervida até o ponto da rapadura ou do açúcar; o alambique; os cochos, nos quais é depositada a garapa para a fermentação (fabrico da cachaça) ou o melado (fabrico do açúcar); as gamelas, nas quais o melado é mexido antes de ser colocado nas formas de rapadura; as formas, nas quais o melado cristalizado é depositado para a desidratação (fabrico do açúcar); os couros de bovinos nos quais o açúcar é exposto ao sol para secagem; espátulas e colheres-de-pau, além de uma variedade de pequenos utensílios.

Da cana-de-açúcar pode derivar três produtos: a cachaça, a rapadura e o açúcar. No entanto, várias situações se apresentam neste aspecto. Primeiro, o cultivo da cana-de-açúcar não ocorre em todas as parcelas, pois depende da extensão da área de sítio, e, se for suficiente, o agricultor pode cultivar ou não a cana. Nem todos que cultivam têm oficina, e, não tendo, geralmente estabelecem parcerias com aqueles que a tem, tal como ocorre no caso do processamento da farinha de mandioca (fotos 18 e 19).

\footnotetext{
${ }^{147}$ Utensílio usado para ralar a mandioca. É construído a partir de uma folha de flandres perfurada e em formato retangular. Suas extremidades maiores são fixadas (com o uso de pregos) em uma grade retangular (de maior comprimento) feita em madeira.

148 Tipiti: Do Tupi tipi, espremer, e ti, sumo. Espécie de cesto para espremer a massa da mandioca usada na fabricação da farinha, muito usados nos engenhos de farinha de mandioca na ilha de Santa Catarina. MINIDICIONÁRIO TUPI-GUARANI (http://povodearuanda.wordpress.com/2007/12/03/minidicionario-tupi-guarani/), acessado em 12/04/2012.
} 


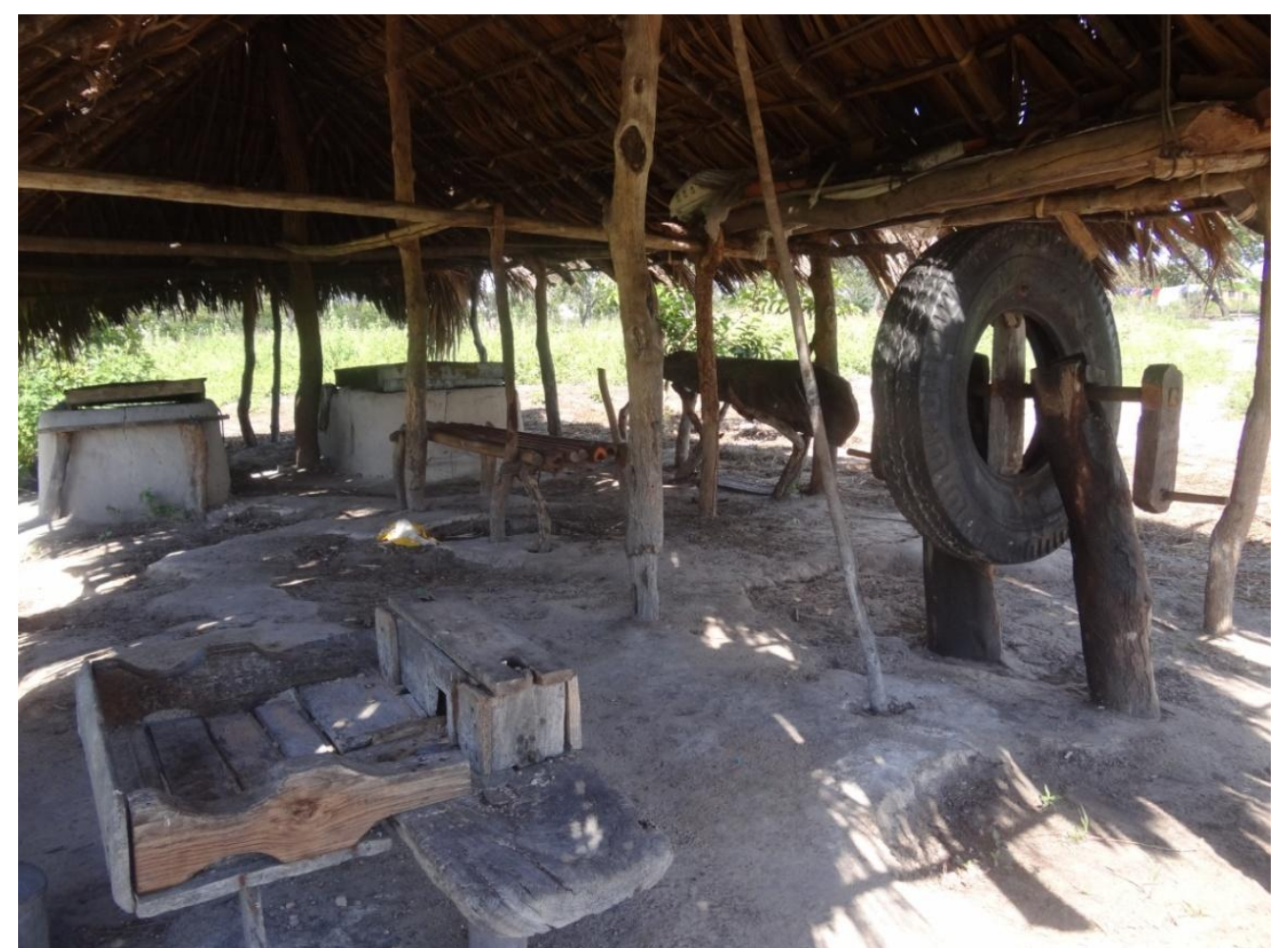

Foto 18 - Utensílios da casa de farinha: à esquerda o bulinete; à direita a roda; ao fundo, o forno. Comunidade do Cajueiro, Correntina - BA. Sousa Sobrinho, J. (jan. 2012).

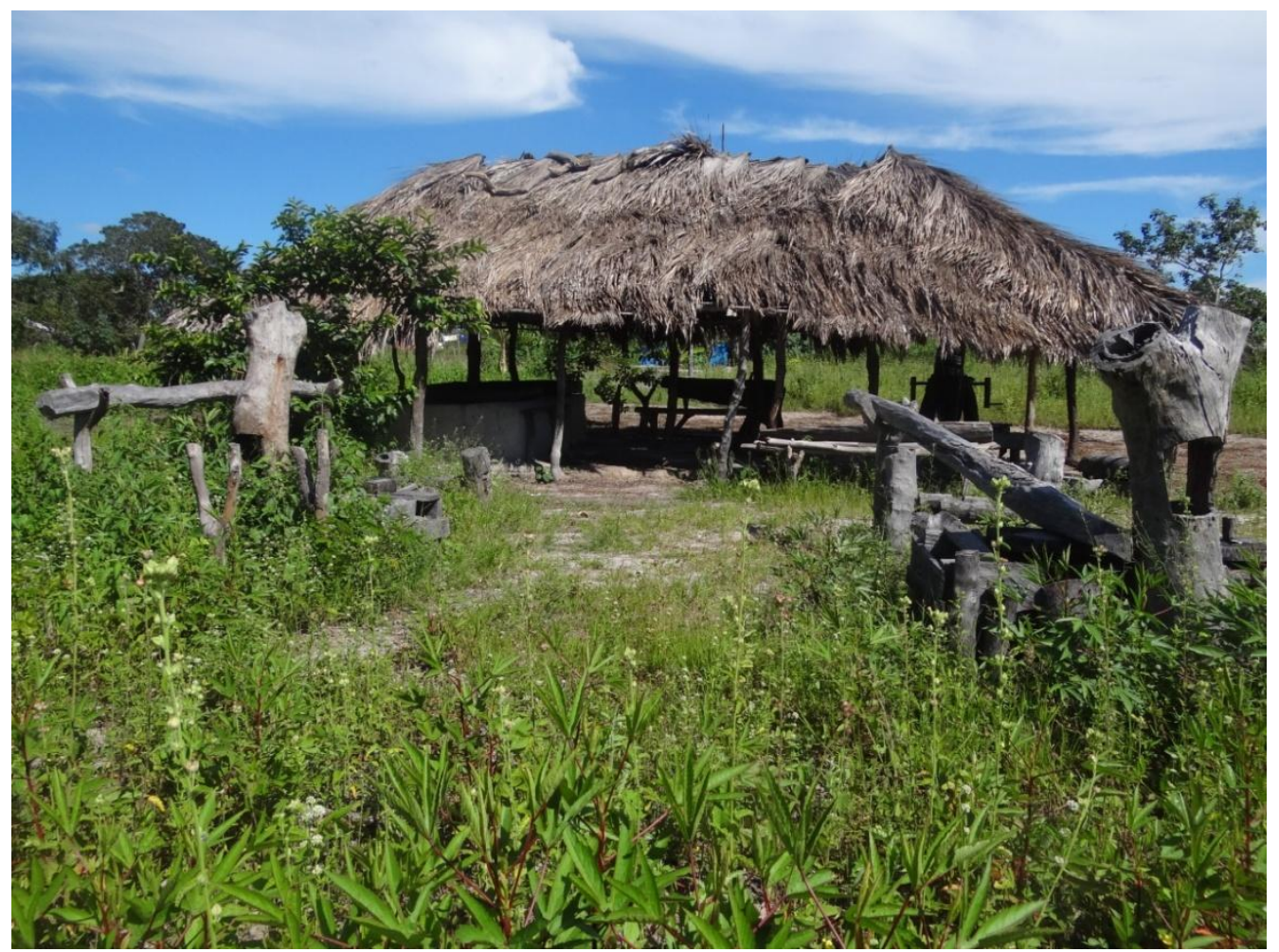

Foto 19 - Casa de farinha. Comunidade do Cajueiro, Correntina - BA. Sousa Sobrinho, J. (jan. 2012). 
Há ainda os casos daqueles que cultivam a cana, têm a oficina, mas optam pela produção de um ou de alguns dos produtos. Assim sendo, a estrutura da oficina pode variar conforme as situações.

Muitos outros produtos são processados na unidade familiar de produção camponesa. Como exemplo, cito o milho, que pode ser moído em moinhos manuais ou ralado (quando verde), sendo transformado em farinha, fubá e pamonha; o leite, que pode ser transformado em queijos e requeijões, assim como em doces; o buriti, do qual se faz a farinha ou o doce - muito consumido e apreciado na região; e uma série de outros. Mas o destaque maior deve ser dado ao processamento da canade-açúcar e da mandioca, devido a estrutura criada para tanto, o volume de processamento, a importância no abastecimento familiar direto e na obtenção da renda monetária, abarcando os dois casos, com maior intensidade, a farinha e, o segundo (a renda monetária), os derivados da cana-de-açúcar.

Usa-se no processo de trabalho realizado nas oficinas, a força de trabalho dos animais, tais como os bois-de-carro, os jumentos e os cavalos. O carro-de-bois se destaca como o principal meio de transporte de carga nas tarefas realizadas pelos geraizeiros. São usados para o transporte de materiais de construção de cercas e casas, mas também para transportar a produção da roça até a oficina. Aliás, pode-se afirmar que o carro-de-boi é o meio de transporte de carga dominante nas áreas das comunidades. E, segundo Macedo,

o carro-de-bois será ainda por muito tempo o principal veículo das fazendas
sertanejas. Moroso, é não obstante econômico e eficiente, pois carrega regular
quantidade de carga, e, em qualquer estrada, com qualquer tempo, chega sempre ao
destino da viagem...... a presença do carro-de-bois numa fazenda do São Francisco
é sinal de progresso e de atividades agrícolas. Construído, muitas vezes, nas próprias
fazendas, por carpinteiros da região, e que servem, ora numa ora noutra propriedade,
o bom carro e as boas juntas de bois constituem orgulho, não só do fazendeiro, como
do próprio carreiro (MACEDO, 1952, pp.54-55).

De fato, até os dias de hoje, o carro-de-bois tem lugar assegurado na região, pois, como os correntinenses costumar afirmar, em Correntina não tem estradas. $\mathrm{E}$ não exageram com essa afirmação. O trabalho erosivo das águas nas estradas é intenso e passam sucessivos anos sem qualquer providência do poder público. Os raros automóveis, que por lá aparecem, se aventuram na arriscada e generalizada buraqueira. Nestas condições, os carros-de-boi se encarregam do transporte de cargas, os jumentos que ainda não foram substituídos por motocicletas, das pequenas cargas, os cavalos, do transporte de pessoas gerais adentro, geralmente 
nos trabalhos de campeio do gado, e as motocicletas, em grande quantidade, nos transportes de pessoas e pequenas cargas por onde quer que seja possível circular, mesmo com imensos sacrifícios nas estradas esburacadas e espessamente arenosas.

\subsubsection{A comercialização dos produtos agrícolas}

Os principais produtos cultivados pelas comunidades geraizeiras são milho, arroz, feijão, mandioca e cana-de-açúcar. Os quatro primeiros constituem a base alimentar, mas uma infinidade de outros produtos é cultivada e compõe a rica e diversificada dieta dos geraizeiros.

A cana-de-açúcar, por ser menos relevante na dieta familiar, visa, sobretudo, conferir renda monetária ao agricultor, mas, a partir da década de 1970, a importância deste cultivo vem diminuindo em função da prioridade que se dá a outros cultivos alimentares e da ocupação de grandes áreas das parcelas com pastagens. Antes, porém, este cultivo ocupava importante área das parcelas, por meio do qual os camponeses, ao transformá-lo em rapadura, cachaça e açúcar, o comercializavam e conseguiam boa parte da renda monetária.

O Sr. Abdias, da comunidade de Brejo Verde, recorda:

Do córrego Bota Bunda até onde Badeco mora, mais ou menos $2 \mathrm{~km}$, havia 9 engenhos, era um canavial só. Quando era de noite, pegava madrugada, e era um tuá desses engenhos a moer, né? E todo mundo fazendo açúcar para vender, né? (Sr. Abdias de Souza Brito, morador da comunidade do Brejo Verde, trabalho de campo em janeiro de 2012).

O relato enfatiza a importância do cultivo da cana-de-açúcar na comunidade do Brejo Verde ${ }^{149}$ e se refere aos tempos de inícios da segunda metade do século XX. Naquela época, entretanto, além da cana-de-açúcar, os geraizeiros comercializavam outros produtos. Para o escoamento da produção, constantemente os tropeiros passavam pela comunidade do Brejo Verde e demais do entorno. Estes comerciantes compravam os produtos e transportavam para a comercialização no

\footnotetext{
${ }^{149} \mathrm{Na}$ atualidade, entretanto, a cana-de-açúcar, de modo geral, é cultivada apenas naquelas parcelas de áreas mais extensas e que dispõem de sítios maiores. Nas parcelas menores, quando cultivada, visa apenas ao fabrico da rapadura, geralmente destinada ao sustento familiar, e cuja palha destinase à alimentação do gado.
} 
Porto de São José. ${ }^{150}$. Dali em diante, os produtos eram embarcados nos navios gaiolas que trafegavam no rio São Francisco e afluentes, distribuindo-os ao longo do vale e até mesmo para outros estados ou regiões, conforme esclarece Miranda:

O fluxo comercial, antes da abertura das rodovias, nas décadas de 1940/1950, articulava exportação e importação de mercadoria, transporte de pessoas entre as áreas interioranas do Vale do São Francisco, Goiás e Mato Grosso, por via fluvial, sempre precariamente socorrida por caminhos antigos, trilhados por tropeiros, boiadeiros, viajantes e por outros personagens da época, que palmeavam o sertão. $\mathrm{O}$ comércio e as viagens, na Bacia do Rio Corrente, tiveram como grandes referenciais geográficos os portos de Pirapora e Juazeiro, interligados ao porto de Santa Maria da vitória e, por extensão, ao Porto de São José (MIRANDA, 2002, p.29).

Sobre os meios de transportes desta época, Pierson se refere:

Enquanto o autor e seus companheiros se encontravam em Correntina, no Planalto Ocidental da Bahia durante a primeira visita ao Vale, chegou de Goiás, transportando arroz, uma tropa de 15 animais. Para uma viagem de 25 dias pelos Gerais durante nosso período de pesquisa em Rio Rico (nome que antecedeu ao de Correntina), foram alugados 5 animais, um para cada um dos dois pesquisadores, outro para 0 guia, outro para o vaqueiro que conhecia bem a região, e dois de carga. Na primeira noite, passada na vereda de Furquia, o guia não dormiu com receio de que os animais pudessem se extraviar ou se perdessem. Disse ele: "o primeiro cuidado ao tomá quando se viaja num lugá como este é a tropa. Se fica com a gente, não tem problema" (PIERSON, 1972, p.582).

Macedo também faz referências aos meios de transporte geraizeiros:

A ausência de caminhões é naturalmente uma consequência da inexistência de "rodagens" (estradas). Curioso, porém, é o fato de que a falta de ambos não tem impedido que os produtores das fazendas cheguem às feiras semanais dos centros consumidores. Levados até à margem do rio no lombo de animais ou no carro-debois, dali em diante os gêneros seguem pela via fluvial, em barcos à vela, canoas e "paquetes" (MACEDO, 1952, pp.53-54).

Interlocutores do Brejo Verde, entretanto, afirmaram que a partir da decadência da navegação no rio São Francisco, diminuiu-se a prática comercial dos tropeiros nas comunidades e o escoamento da produção passou a ser feito dominantemente pelos próprios produtores, utilizando-se de carros-de-boi para levar seus produtos até às feiras das cidades próximas, como Correntina, Jaborandi, Santa Maria da Vitória e Santana. Quanto ao estado das estradas, referido por Macedo, as péssimas condições persistem até hoje e motivam protestos de motoristas dos carros de linha e dos que transportam estudantes. Estes, teimosamente circulam nas "estradas" esburacadas, as quais dificultam

150 Porto localizado no término do trecho navegável do rio Corrente, na divisa do município de Correntina com o de Santa Maria da Vitória. Dali em diante, os navios gaiolas transportavam a produção para comercialização noutras paragens ao longo do rio São Francisco e até mesmo nas grandes cidades do país. 
sobremaneira as trocas que se estabelecem com a cidade e que têm tornado-se mais intensa nas últimas décadas.

Todavia, a partir dos anos de 1950, período no qual os autores citados fazem referência, o aumento populacional nas comunidades impulsionou a expansão do uso agrícola de outras áreas, principalmente as ribeirinhas do Arrojado e de seus afluentes a montante. Nestas, os geraizeiros beneficiavam-se das terras virgens que Ihes eram vantajosas no trato aos cultivos ${ }^{151}$. Ali plantavam em maior quantidade o arroz, mas também, naquelas áreas em que formavam sítio, cultivavam outros produtos, como o milho, a mandioca e o feijão.

Esta produção era transportada por meio de tropas de muares ou em carrosde-boi até as casas de residência dos agricultores situadas nas comunidades à jusante. Também muitos tropeiros, em um primeiro momento, e depois carreiros percorriam a beira do rio, comprando a produção local e vendendo produtos oriundos de outras praças, conforme o relato abaixo:

Do Couro de Porco comprava arroz, feijão, farinha, rapadura, capado gordo, e levava para Jaborandi, Correntina, São Manoel... De Correntina levava sal, café, querosene, pinga... as cargas iam carregadas e voltavam carregadas. Gastava 3 dias de Correntina para Couro de Porco em carro de boi.

Nós saía daqui com um carro-de-boi pro Couro do Porco. Nós ia arrumar arroz no Couro de Porco! No carro-de-boi. Eu tinha uma boiada aí, seis boi carreiro, carrão! Meu carro ainda tá aí em Carlim de baixo daqueles pés de manga. Carro de viagem! Carro de arroz vinha de Couro de Porco, desse mundão aí. Não tinha quem atrapalhava a gente!... Hoje pro senhor ir no Couro de Porco por aqui é difícil, tá suscetível até morrer! Porque a estrada tá aí, a estradona de cavaleiro e de carro-deboi tá aí, mas tudo cercada de arame e naqueles lugar da estrada é colchete e trancado tudo de cadeado... ...é, cabou a regalia da gente nessa coisa aí. E antigamente nós toquemos uma roça num lugar por nome Brejão, eu mais compadre Abdias. Paulo meu irmão morava nesse Brejão. Tinha alambique, dois engenho, criava 50 vacas dentro dos brejos (Sr. Lázaro de Souza Brito, morador da comunidade do Brejo Verde, trabalho de campo realizado em janeiro de 2012).

A intensificação da grilagem de terras, entretanto, impediu os usos que os geraizeiros faziam dessas áreas na montante. Acabou a regalia, tanto daqueles que se utilizavam das terras férteis das veredas, quanto dos comerciantes, tropeiros e carreiros que circulavam livremente pelos gerais, abastecendo aquelas comunidades, que ali haviam feito sítio, e delas comprando a sua produção. Os grileiros destinaram as áreas de fundo de vale à reserva ambiental das áreas de terras que se apropriaram de modo fraudulento e apoiaram-se nos órgãos

${ }^{151}$ Nos relatos, os camponeses geraizeiros enfatizam a vantagem do cultivo nas áreas ribeirinhas. Nestas, derrubavam a mata e queimavam-na, diminuindo, assim, a proliferação de ervas competitivas com os plantios, nos primeiros anos em que formavam suas roças. 
ambientais do Estado para proibir os usos que os geraizeiros faziam ao longo de tempos remotos.

As proibições aos usos geraizeiros que se realizava ao longo das áreas ribeirinhas do rio Arrojado são impostas obedecendo ao que reza o Código Municipal do Meio Ambiente, nos artigos 37, 38, 39 e 40, no Decreto ํㅜ 085/2001, de 10 de setembro de 2001, que dispõe sobre a fixação das sanções aplicáveis às condutas e atividades lesivas ao meio ambiente,

Art. 37 - Destruir ou danificar florestas nativas ou plantadas ou vegetação fixadora de encostas, protetora de mananciais, objeto de especial preservação:

Multa de R\$1.500,00 (um mil e quinhentos reais), por hectare ou fração.

Art. 38 - Explorar área de reserva legal, florestas e formação sucessoras de origem nativa, tanto de domínio público, quanto de domínio privado, sem aprovação prévia do órgão ambiental competente, bem como da adoção de técnicas de condução, exploração, manejo e reposição florestal:

Multa de $\mathrm{R} \$ 100,00$ (cem reais) a $\mathrm{R} \$ 300,00$ (trezentos reais), por hectare ou fração, ou por unidade, estéreo, quilo ou metro cúbico.

Art. 39 - Desmatar, a corte raso, área de reserva legal ou de preservação permanente:

Multa de $R \$ 1.000,00$ (um mil reais), por hectare ou fração.

Art. 40 - Fazer uso de fogo em áreas agropastoris sem autorização do órgão competente ou em desacordo com a obtida:

Multa de $\mathrm{R} \$ 1.000,00$ (um mil reais), por hectare ou fração. ${ }^{152}$

O Sr. Abdias comenta a seguir os reflexos dessas imposições legais nos usos tradicionais que os camponeses sempre fizeram das áreas agricultáveis tornadas reserva legal pelos grileiros e pelo poder público.

Logo chegou a proibição de derrubar brejo, né? Porque antigamente era livre, né? Mas depois chegou a proibição para derrubar os brejos, né? Agora quem tem o sítio já feito, tem o sítio. Mas para aumentar mais para derrubar os matos não tá mais derrubando não. Porque foi proibido. Naquele tempo não tinha proibição nenhuma. Hoje até um pau para se derrubar é preciso pedir licença. Um pequizeiro, se derrubar e for no conhecimento, a multa pesa (Sr. Abdias de Souza Brito, morador da comunidade do Brejo Verde, trabalho de campo em janeiro de 2012).

Estas determinações legais vêm dificultando a sobrevivência nos gerais até mesmo àqueles que fizeram sítio, pois, são frequentes a visitas de agentes dos órgãos ambientais municipais e do Estado nas comunidades ameaçando a aplicação de multas pelos usos tradicionais que os geraizeiros fazem do território.

Se for considerar o grau de monetarização das famílias geraizeiras, concluiremos que estas multas, se aplicadas, serão impagáveis, e, sendo assim, a ameaça torna demais intimidatórias àqueles que historicamente zelaram pela

\footnotetext{
${ }^{152}$ http://www.correntina.ba.gov.br/admin/app_index.php?chave=065516d055102af3faeb0719d737f7e 4e4b9956a\&acao=exibir_composicao (acessado em 06.05.2012).
} 
preservação dos gerais. Ao contrário, não se verifica a mesma repressão ao arraso que as grandes empresas do agronegócio fazem, justamente nas áreas de recargas dos aquíferos, nos chapadões.

Iremar Barbosa de Araújo, ativista do MAB, com muita propriedade afirma que, nas localidades ribeirinhas usadas tradicionalmente pelos geraizeiros, se 0 interflúvio (chapada) está preservado, o riacho, ou rio, conforme o caso, estão vivos. O contrário ocorre quando o agronegócio arrasou os cerrados da chapada, mesmo não tendo uso geraizeiro das áreas ribeirinhas, o rio ou riacho estão mortos.

O uso com impactos ambientais desordenados e irreparáveis foi acelerado a partir da década de 1970, com a expansão do agronegócio na região. Não cabe atribuir a culpa ao uso tradicional geraizeiro da terra e da água, pois, secularmente as comunidades se utilizaram e se utilizam das riquezas naturais conforme o seu jeito de ser geraizeiro e até a referida década não se observava impactos tão drásticos como o que se observa na atualidade.

como eu dizia, olha, meus avós eram de lá, meus pais nasceram e criou lá, depois deles já grande, coisa, aí casou, meu pai tinha parte de terra de herança, no tempo que pai casou, mudou pra qui. Aí nós já nascemos aqui. Mas nós nunca faiemos de lá como Jamilton aqui sabe. Quando o pai de Jamilton já tava lá com nós, Jamilton, não sei se era nascido. Acho que não era não, era eles trabalhavam lá, ele e seu avô. Então eu já tenho lutado muito por causa daquilo ali. Ali é uma raiz que eu tenho ali com o meu pessoal, nasceram com o tempo aqui, que eu trabalho aqui, mas nunca falhasse de lá. E lá naquilo... trabalhava lá, naquela época trabalhava lá, e hoje, plantava mandioca, plantava arroz, plantava feijão, e dentro daqueles brejos era milho pa cair mesmo, né? Tudo era bom (Sr. José Francisco Dourado, 81 anos, morador da comunidade do Catolés e antigo morador da comunidade de Lodo, na montante do vale do rio Arrojado, trabalho de campo realizado em julho de 2010).

Este relato destaca a antiguidade da ocupação da área onde está assentada a comunidade do Lodo, margem direita do rio Arrojado, onde se encontra também o fecho de gerais do Gado Bravo, no qual os moradores da comunidade sempre criaram seus animais soltos.

No entanto, em função de limitações impostas pelos grileiros ${ }^{153}$, tais como interdição de acessos pelas cercas e pressão violenta com vistas à expulsão dos moradores, boa parte destes, apesar da resistência, vem perdendo suas terras para

\footnotetext{
${ }^{153}$ Adoto o termo grileiro porque não seria correto denominar de fazendas estas áreas, porque, a não ser a cerca, que tem como única finalidade impor o domínio sobre as áreas, em muitos casos outra benfeitoria não há. Até porque, todas as ações discriminatórias que vêm sendo feitas na região têm, como conclusão final, o fato de serem públicas essas terras. E demonstram ainda escandalosas fraudes ou grilos na geração dos documentos. Inclusive sobre a referida área, recentemente ação discriminatória administrativa realizada pela CDA, atendendo à pressão dos criadores geraizeiros concluiu que se trata de terras públicas e griladas pelo grileiro João Branco.
} 
aqueles e mudando-se. Na comunidade do Lodo, por exemplo, das 60 famílias que ali residiam antes da década de 1970 atualmente restam apenas onze (11).

Nesta comunidade, assim como em outras, a produção agrícola era grande e os excedentes abasteciam tanto as comunidades da jusante quanto outras localidades com os produtos dali transportados e/ou comercializados pelos

\section{tropeiros e carreiros.}

Os impedimentos do uso agrícola das áreas ribeirinhas da montante impulsionaram os geraizeiros a engendrarem outras estratégias que compensassem o déficit alimentar gerado em função disso, pois as terras de cultura, das parcelas de uso exclusivo familiar, eram insuficientes para suprir o abastecimento da família com as técnicas agrícolas tradicionais e dominantes.

Para possibilitar as condições de reprodução social, os geraizeiros construíram e ampliaram os usos dos regos. A partir disto, intensificaram os usos agrícolas das áreas de sítio, por meio da irrigação, o que possibilitou a colheita de duas safras por ano das lavouras de novas áreas. Esta medida favoreceu sobremaneira o maior aproveitamento agrícola nas parcelas de uso exclusivo familiar, mas, de modo geral, não se fez suficiente para garantir o abastecimento das famílias e, ao mesmo tempo, produzir o volume de excedentes que suprisse a demanda de renda monetária da unidade familiar para a aquisição de mercadorias não produzidas nas parcelas. De acordo com Shanin (1976, p.20), "La artesanía y el comercio campesinos representan el aspecto de la 'producción' en términos de Malita, mediante la adquisición de mercancías en forma independiente de la naturaleza".

Ao contrário de épocas anteriores, em que a significativa produção agrícola, favorecida pela possível territorialidade camponesa geraizeira, se destinava a mercados relativamente amplos, em função dos processos sociais descritos, os excedentes menores passaram a ser comercializados diretamente ao consumidor na feira de Correntina, bem como a comerciantes atacadistas que compram principalmente farinha, rapadura e cachaça para revenderem em outras praças.

é o seguinte, tem muitos aí que da cana vendem muito a rapadura. Eles fazem para vender, né? Vende, exporta pra fora, açúcar, farinha, menos arroz que a plantação de arroz é mais pouca. Mas rapadura e farinha eles exporta muito, cachaça... ...Por exemplo, rapadura eles levam para Correntina lá e exportam para outro Estado, né... ...contrata com os comerciantes lá e eles pegam e vendem. Vendem para os comerciantes e eles exportam para fora (Sr. Antonio José de Araújo, comunidade do Brejo Verde, trabalho de campo realizado em janeiro de 2012). 
Ao receber a produção mais diversificada dos cultivos praticados nas áreas de sítios, tais como os tradicionais cereais (foto 20), acrescidos das verduras e dos legumes das hortas, a feira camponesa de Correntina ganhou maior dinâmica. Com isso, sua antiga instalação, situada no centro da cidade, tornou-se insuficiente e o antigo casarão se encontra fechado.

Miranda (2000) faz referência ao funcionamento da antiga feira:

A economia é, pois, derivada do trabalho do pequeno produtor. Não há melhor mostruário desse mundo que a feira de Correntina. O dia oficial da feira é sábado, embora ocorra também nos outros dias. Apesar das mudanças que pudemos captar de 1980 a 1993, quer pela introdução de produtos industriais oriundos do centro-sul, inclusive uma variedade de mercadorias adquiridas no Paraguai; quer pelo grande números de caminhonetes e de outros veículos que hoje transportam os produtores rurais e suas mercadorias do campo para a cidade e, de volta para o campo, ainda é numeroso o transpor desses produtos por meio de jumentos, cavalos e carros-de-boi. Os animais e os carros-de-boi, hoje, ficam normalmente postados à margem esquerda do rio Correntina, próximo à ponte. São várias dezenas de carros, bois, cavalos e jumentos que são expressão material da pequena produção agropastoril e do artesanato local. Do lado oposto, instala-se a feira (MIRANDA, 2000, p.77).

Visando atender à nova demanda, o poder público construiu outra instalação, afastada do centro da cidade. Trata-se de um grande galpão onde é comercializada a produção agropecuária camponesa, bem como a procedente de outras praças comerciais, tais como frutas, utensílios domésticos e vestuários.

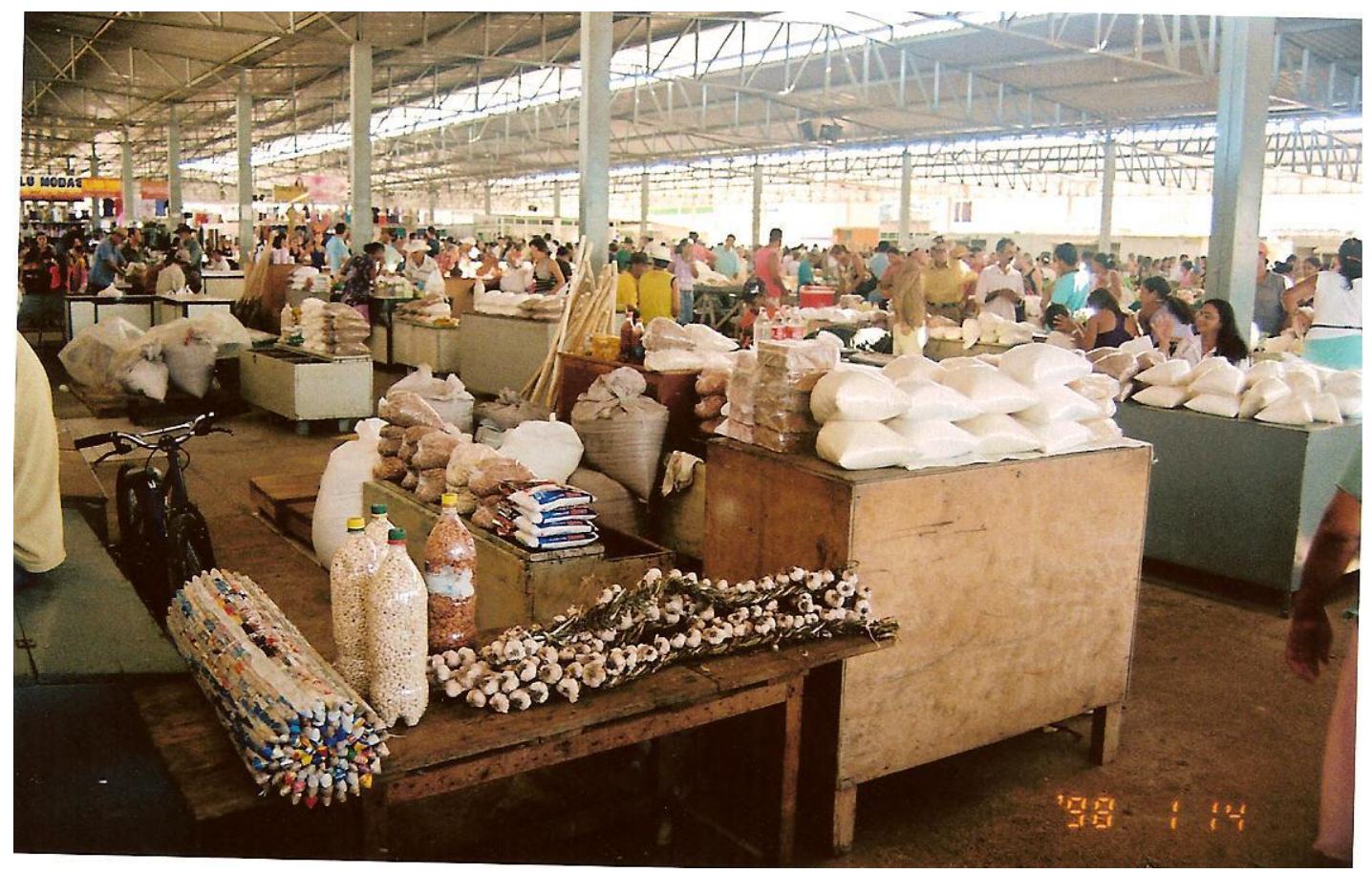

Foto 20 - Feira camponesa de Correntina - BA. Sousa Sobrinho, J. (jan. 2010) 
O antigo centro comercial da cidade continua movimentado, porém, o foco são os estabelecimentos atacadistas (que comercializam cereais), os supermercados, as lojas de vestuários e outros, que circundam o antigo casarão e a extensa área onde antigamente acontecia a feira.

Nos carros de linha que diariamente vão à cidade, muitos camponeses transportam seus produtos e comercializam diretamente ao consumidor. Vende tudo que leva. É uma feira muito rica, vende barato, mas não passa fome. ${ }^{154}$ Estas frases apontam alguns elementos que merecem ressaltar. $O$ mesmo interlocutor também afirmou que vende barato os produtos que leva para a feira porque vai à cidade a fim de resolver negócios e precisa voltar logo para continuar a lida nos trabalhos da roça. Isto sugere que confere maior prioridade à produção do roçado, de onde obtém os meios de vida para o sustento da família. O comércio que realiza the confere, pois, uma renda, e, com vista a ganhar tempo no trabalho da roça, vende o produto mesmo barato, mas não passa fome. Porém, presume-se, no valor suficiente para adquirir a mercadoria que necessita, caracterizando, pois, a feira camponesa, em certa medida, como um espaço/momento de "trocas de mercadorias" e do mesmo modo onde se concretiza a lógica da circulação simples, do vender para comprar.

é mister a distinção entre a produção camponesa e a produção capitalista. $\mathrm{Na}$ produção capitalista, ocorre o movimento de circulação do capital expresso nas fórmulas: $D-M-D$ na sua versão simples, e $D-M-D$ ' na sua versão ampliada. Já na produção camponesa, se está diante da seguinte fórmula $M-D-M$, ou seja, a forma simples de circulação das mercadorias, onde a conversão de mercadorias em dinheiro se faz com a finalidade de se poder obter os meios para adquirir outras mercadorias igualmente necessárias à satisfação de necessidades. É, pois, um movimento do vender para comprar (OLIVERIA, 2007, p.40).

Além dos produtos da agricultura geraizeira, na feira camponesa de Correntina são comercializados também os chamados produtos da terra, tais como os processados nas pequenas indústrias domésticas: queijos, requeijões, rapaduras, farinha, doces de várias espécies e cachaça; e os produtos do extrativismo geraizeiro, como mel de abelha, pequi, umbu, puçá, caju e plantas medicinais.

Lá também encontra-se ainda lanchonetes, restaurantes e churrascarias e, no seu entorno, concentram-se grande quantidade de estabelecimentos comerciais, como: supermercados, lojas de materiais de construção, de utensílios e artefatos agrícolas, de confecções e vestuários, de móveis e eletrodomésticos, açougues.

\footnotetext{
${ }^{154}$ Sr. Lázaro, comunidade do Brejo Verde, trabalho de campo em outubro de 2010.
} 
Esta nova centralidade que surgiu em função do deslocamento da feira camponesa possivelmente tenha relação também com outros processos que recentemente se desenvolvem no município de Correntina. Refiro-me à importante monetarização porque passam as comunidades rurais, tanto em decorrência da importante aumento da pecuária ${ }^{155}$ de suas atividades, quanto das intervenções do vários programas sociais, com destaque para as aposentadorias dos idosos, que alteram, de modo significativo, as formas de obtenção dos meios de vida dos camponeses geraizeiros.

Inclusive, em função de programas sociais, como aposentadorias, auxílios doença e bolsa-família ${ }^{156}$, parte importante do que se produz pode ser comercializada até mesmo no ambiente comunitário. Famílias que contam com idosos aposentados dispõem de importante rendimento monetário e disto resulta um poder de compra considerável para os padrões da região, modificando, portanto, consideravelmente, as relações de trocas no próprio ambiente comunitário.

\subsection{As parcerias: nos usos dos meios de trabalho, no trabalho e na terra}

A teoria vale apenas para ilustrar a importância que o alimento pode assumir teoricamente como elemento explicativo da vida social. Sabemos, no entanto, que a obtenção, definição e elaboração de uma dieta dependem estreitamente de organização correspondente, e que os ritos agrários se encontram na base dos desenvolvimentos culturais mais surpreendentes. Vida, meio e grupo, se integram e unificam muitas vezes em função dela (CÂNDIDO, 2003, p. 37).

\footnotetext{
${ }^{155}$ A partir deste fenômeno, não se pode afirmar que passam por um processo de especialização de suas atividades. O que se verifica possivelmente se explique pela extrema minifundização das parcelas de uso exclusivo familiar, concomitante ao enfraquecimento do solo e à menor disponibilidade de água para as atividades agrícolas nas áreas de sítio. Nestas condições, aos camponeses geraizeiros resta a alternativa de aumentar a exploração das terras livres dos gerais por meio da prática pecuarista. Por esta via, compreende-se o grau de radicalidade que estão dispostos a atingir na defesa dos seus territórios de criação de animais. Os acontecimentos recentes, descritos noutra oportunidade, servem como exemplo dessa hipótese.

${ }^{156}$ O Programa Bolsa Família (PBF) "é um programa de transferência direta de renda que beneficia famílias em situação de pobreza e de extrema pobreza em todo o País" (http://www.mds.gov.br/bolsafamilia acessado em 11/10/2012).
} 
A distribuição não equitativa da terra, das oficinas e dos animais de tração e/ou transporte, bem como as relações comunitárias de parentesco, compadrio e vizinhança, contribuem para o estabelecimento de uma variedade de relações de parcerias entre os membros das comunidades geraizeiras, geralmente pautadas pela solidariedade intersujeitos.

\subsubsection{As parcerias nos usos dos meios de trabalho}

Uma das características da comunidade camponesa é a não especialização das atividades que são praticadas no dia a dia para a obtenção dos seus meios de vida. A atividade agrícola mantém estreita relação com a pecuária - e ambas com a extrativista animal (caça e pesca) e a vegetal. No que diz respeito aos povos que vivem nos e dos cerrados, Porto Gonçalves afirmou:

os povos que vivem pelos cerrados desenvolvem sistemas de uso da terra que combinam a agricultura, geralmente nos fundos de vales, nos brejos, nos brejões, nos "pantamos", nos varjões; nas encostas e nas chapadas, áreas onde a água é mais difícil de ser captada sem tecnologias de captação em profundidade, deixam o gado à solta, fazem a coleta do pequi, da fava-d'anta, do baru, e outros frutos e resinas, recolhem madeira e lenha, geralmente fazendo uso compartilhado, sobretudo dessas terras das chapadas (PORTO GONÇALVES, 2004, p. 221).

Esta afirmação não se constitui como regra na caracterização das comunidades camponesas dos gerais. Sabe-se que muitas comunidades na atualidade não mais dispõem dos meios que possibilitem o exercício das múltiplas atividades interdependentes. Mas, nem por isso se descaracterizaram totalmente e também não é raro encontrar-se comunidades com as características descritas acima e, nestas condições, a industrialização da produção em escala doméstica pode-se somar às demais atividades.

No caso das comunidades camponesas geraizeiras do Oeste da Bahia, o traço mais característico, e que se pode dizer que Ihes fazem peculiar, são as formas de organização social engendradas por seus membros para possibilitar o uso comum das riquezas naturais. Sobre esse quesito já foi demonstrada a organização que se processa com vista ao uso comum da água. Em momento oportuno, será demonstrada a organização relativa ao uso comum da terra, principalmente no que diz respeito à atividade pecuária. 
O que mais interessa para o momento, entretanto, são as relações estabelecidas para se realizar os processos de trabalho que garantam a obtenção do sustento das famílias quais sejam quanto aos meios ou às relações em si. Com vistas a isto, fazem uso comum ou socializam por meio de diversas relações os meios de trabalho: a terra, os equipamentos, as oficinas, os animais, e, em situações de extrema necessidade, até mesmo os alimentos.

Já foi informado que na atualidade não são todos que dispõem da oficina de processamento da cana-de-açúcar, embora seja um tanto frequente o cultivo desta nas parcelas. Daquelas oficinas que existem, todavia, nem todas estão equipadas para o fabrico de todos os derivados: da rapadura, da cachaça e do açúcar. Nestas condições, o vizinho, geralmente parente ou compadre, busca a parceria com o outro para o processamento da cana. O caso de um interlocutor, o Sr. Abdias de Souza Brito, da comunidade de Brejo Verde, ilustra bem esta situação. O genro dele, que mora na sua terra, faz rapadura e açúcar na oficina da família. Todavia, na mesma não tem alambique e o mel que escorre enquanto se fabrica o açúcar é encaminhado para a oficina do Sr. Lázaro de Souza Brito, irmão do Sr. Abdias e vizinho na mesma comunidade, para o aproveitamento no fabrico da cachaça onde tem alambique. O uso da oficina do vizinho, neste caso, se dá em uma relação de solidariedade, sem, portanto, haver qualquer cobrança. Este tipo de socialização é muito comum envolvendo diversos tipos de meios utilizados no trabalho, tal como a situação relatada pelo Sr. Antonio José de Araújo, da comunidade de Brejo Verde: Às vezes a pessoa não tem o engenho, mas tem a pareia de boi. Se tem uma quantidade de cana para moer e fazer uma rapadura, ele corta a caninha dele e leva lá no engenho do amigo para moer com seus bois. E pode ocorrer até de o dono do engenho ajudar nos trabalhos. Nesse caso, é de costume o dono da cana ajudar na despesa. $^{157}$ Emprega seus bois na moagem da cana, utilizando-se do engenho do vizinho e o mesmo pode até ajudar nos trabalhos.

No que diz respeito ao processamento da mandioca, também os usos das oficinas são compartilhados entre os vizinhos. Por exemplo, eu tenho uma oficina de mandioca, e às vezes o vizim não tem. Aí eles vêm aqui eles vai fazer sua mandioca aqui, sua farinha, o quanto eles quiserem. ${ }^{158}$

\footnotetext{
${ }^{157}$ Refere-se às despesas com a alimentação enquanto se realiza os trabalhos na oficina. 158 Idem.
} 
De modo semelhante aos engenhos, os diferentes graus de equipamentos das casas de farinha, ou a presença deles mais modernos, como é o caso do motor a diesel que já se encontra em algumas oficinas, atrai a procura de vizinhos com o intuito de se beneficiar do seu uso. Entretanto, nesse caso, a depender do grau de parentesco ou de proximidade relacional entre as partes, pode-se cobrar ou não um aluguel pelo uso. A cobrança, quando ocorre, possivelmente deva-se à inclusão de um custo de produção no processo produtivo, pois, diferentemente da maioria dos equipamentos das oficinas, que são construídos pelos próprios donos ou por integrantes da comunidade, a aquisição do motor implica na mobilização de uma quantidade considerável de dinheiro para tanto, assim como sua manutenção envolve prestação de serviços de profissionais geralmente oriundos de fora da comunidade e que cobram caro pelo serviço. Mas, a depender dos laços, quais sejam de parentesco, compadrio ou vizinhança entre as partes, cobra-se apenas o combustível gasto no uso do motor.

De modo geral, a infraestrutura constituinte das oficinas é disponibilizada àqueles que dela necessitem e estes compartilhamentos de usos geralmente são extrapolados para outras situações, tal como informa o relato a seguir:

\begin{abstract}
Sr. Antonio: arado, tenho um arado aqui, tenho uma pareia de boi muito boa para o arado, aí aparece pessoas que não tem, e eu vou oferecer, tenho uma pareia de boi aí, tenho um arado... vou oferecer... funciona assim.

José: e quando o outro precisa...

Antonio: da mesma forma.

José: aqui é... maior parte aqui são parentes, como é que é?

Antonio: É, a maioria são parente. Por exemplo, eu moro nessa comunidade aqui, né? Eu tenho um irmão que mora ali, sobrinha que mora ali, tenho uma irmã que mora aqui bem vizim nos fundos, vamos dizer assim, comunidade da Vereda Seca, todos que moram lá são vizim. É pai, é mãe, é filho, é neto, e assim por diante. É primo e assim por diante. Do lado de lá, Brejo Verde, ali é da mesma forma. Sempre é parente, é primo sobrinho, são parente e assim por diante (Antonio José de Araújo, comunidade Brejo Verde, trabalho de campo realizado em janeiro de 2012).
\end{abstract}

São estas as relações engendradas pelos membros da comunidade de Brejo Verde com vistas a socializarem os meios de trabalho, haja vista a existência de integrantes no interior do grupo mais apossados e outros menos, ou um ter determinado instrumento e outro não. Embora este fator não implique em relações verticais típicas da exploração capitalista entre os integrantes da comunidade, pois a maioria, conforme visto, é constituída por parentes e compadres e, quando não, mantêm estreitas relações de vizinhança, fato este que imprime às relações um forte sentido de solidariedade. 
Notei, entretanto, nos relatos de alguns interlocutores, uma possível fragilidade nos laços que os unem, principalmente no que tange às lutas que travam contra os grileiros de suas terras. Nesta situação de conflito, houve declarações de que, para as ações diretas de resistência, não podiam contar com alguns membros do grupo e a preocupação era muito grande, pois haviam de organizar com muito disfarce as ações, excluindo aqueles não confiáveis e, inclusive, sob sigilo para não incorrerem no risco do insucesso do pretendido. E, mais grave, no interior das comunidades, alguns destes desmerecedores da confiança dos seus pares favoreceram a intromissão de grileiros nas terras de uso comum das comunidades.

Tem muita gente aqui que vendeu, enriqueceu com dinheiro de gerais aí, né? Aqui mesmo em Jaborandi tem um rico, não sabe o que possui. Ele morava aqui, vendeu um bocado de gerais aí sem ser dono. E tá rico! Não sabe o que possui. Mora aí em Jaborandi (entrevista na comunidade do Brejo Verde, trabalho de campo realizado em janeiro de 2012).

No momento reservado para tratar da situação conflituosa enfrentada pelas comunidades na defesa de suas posses, discorrerei melhor sobre esses casos. No presente, cabe afirmar que não foi observada a alteração nas relações descritas entre os membros da comunidade, em função dos desvios de conduta de alguns dos seus membros. Caberia uma investigação mais aprofundada, mas até onde se pôde levantar nas comunidades estudadas, as relações são mantidas com aqueles que atentam contra os interesses da comunidade, embora sem tê-lo como merecedor da confiança para participar das ações estratégicas ou diretas com vista à defesa dos maiores e mais nobres interesses: a garantia de sua fração territorial para sua reprodução social.

\subsubsection{Parcerias no âmbito do trabalho}

Além das relações que se realizam com vistas à socialização dos meios de trabalho, outras se estabelecem também no âmbito do trabalho envolvendo membros da família - constituída da casa tronco e demais que derivaram em função dos matrimônios entre membros das gerações sucessoras -, ou mesmo da totalidade da comunidade.

A unidade de produção camponesa tem a terra como seu principal instrumento de trabalho e é desta que retira os seus meios de vida, por meio do 
trabalho da família. ${ }^{159}$ Nas suas parcelas, durante o ano agrícola, cultivam a maior variedade possível de produtos; e as demandas de trabalho nos cultivos, concomitante às de outras atividades igualmente necessárias, exigem dos camponeses esforços que, por vezes, a quantidade de braços na família não é suficiente. Portanto, no que diz respeito aos cultivos, destacam-se como picos de demandas de trabalho as limpas e a colheita. Nestas atividades, as famílias carecem de ajuda ${ }^{160}$ dos demais parentes ou vizinhos e, neste sentido, são providenciais as tradicionais trocas de dias de serviço ${ }^{161}$ e/ou mutirões, tal como esclarece o diálogo a seguir:

José: eu queria saber de vocês o seguinte: quais são os tipos de ajudas existentes entre os vizinhos?

Sr. Antonio: bom é o seguinte: os vizinhos é assim, eu tenho um serviço para eu fazer, ou que seja de enxada, ou que seja de foice, aí a gente vai na comunidade, convida os amigos lá e troca serviço. A ajuda é essa, né? Troca serviço. Por exemplo, tá ele aqui que é vizinho, eu digo, eu preciso de dois ou três companheiros, eu preciso de tanto... eu preciso de quatro companheiro, aí eu saio na comunidade, eu arranjo quatro companheiro ou cinco, troca serviço. Aí se eles me ajudar fazer o serviço depois eu vou lá ajudar eles.

José: e aquela prática do mutirão, do ajutório...

Sr. Antonio: ainda existe ainda. Mas ta enfraquecendo, não tá querendo mais assim não, né?...

José: quando existia como é que era, ou quando existe como é que funciona?

Sr. Antonio: funciona mais rápido né?...

José: o Senhor tem um serviço aqui e está precisando fazer ele rápido...

Sr. Antonio: precisasse 10 pessoas, vinha as 10 pessoas, aí funcionava melhor né?

José: e como funcionava?

Sr. Antonio: funcionava aí o seguinte, por exemplo: o senhor precisava de vizinho aqui, quinze pessoas, aí dava a despesa, dava almoço de manhã cedo, meio dia dava o almoço, e aí funcionava assim. Se eu fosse fazer também, eu tinha que fazer do mesmo jeito. Café da manhã mais reforçado e aí quando era meio dia tinha que dar o almoço. Era assim que funcionava.

Edinho: hoje mesmo teve o mutirão de Raimundinho, ficou d'eu ir lá, só que não deu de eu ir..

José: quer dizer que se chamar o pessoal hoje já não quer...

Edinho: uns vai e outros não.

$\mathrm{Na}$ resposta do Sr. Antonio à primeira pergunta fica enfatizada a troca de dias de trabalho sob a concepção de troca de serviço e isto pressupõe a previsão de desequilíbrios entre as necessidades de serviços e as respectivas capacidades de execução por ambas as partes envolvidas na transação. Ou seja, quando um vizinho pede a ajuda do outro já está ciente de que o cedente da ajuda necessitará da sua futuramente. Outra característica desta espécie de ajuda, conforme sugere o

\footnotetext{
${ }^{159} \mathrm{CHAYANOV}$, V.A. Sobre a teoria dos sistemas econômicos não capitalistas. In GRAZIANO da SILVA, J. \& STOLCKE, V. A questão agrária. São Paulo: Brasiliense, 1981, p.138.

${ }_{160}$ Auxílio com sentido de reciprocidade.

${ }^{161} \mathrm{O}$ mesmo que troca de tempo de trabalho.
} 
interlocutor, é o fato de estar o beneficiário, a partir de então, na condição de "devedor" do serviço àquele que o ajudou. Deste modo, a relação se faz solidária na medida em que o cedente, de pronto, atende ao pedido de quem dele necessite. Uma vez que todos os participantes da rede, assim o são, pela disposição em atender aos chamados e contar com a recíproca disposição de seus pares em lhe atender quando também deles necessitar. Quem desta rede participar será considerado vizinho, amigo ${ }^{162}$, pela disposição em ajudar e, por assim proceder, beneficia-se da ajuda dos demais amigos e vizinhos que formam a comunidade. Situação similar a esta, Santos (1978, p.36) constatou no estudo sobre o bairro rural de São Pedro, em Bento Gonçalves, no Rio Grande do Sul:

Quando não é capaz de dar conta do serviço somente com sua família, o camponês pede auxílio ao vizinho, havendo expectativa de que retribua com um tempo de trabalho equivalente. Essa retribuição é feita de modo particularizado, diretamente do camponês que recebeu ajuda àquele que a favoreceu, seguindo um critério comum, o tempo de trabalho medido em jornadas... ...todas as práticas de ajuda mútua... ...cobre uma necessidade de força de trabalho que o camponês não pode suprir apenas com o trabalho familiar, e tampouco com o assalariado, pois seus rendimentos monetários não permitem pagar trabalhadores continuadamente. Desta forma, as práticas de ajuda mútua são fundamentais para reproduzir o processo de trabalho na unidade produtiva camponesa.

$\mathrm{Na}$ relação exposta evidencia-se um tanto as condições de "credor" e "devedor" das partes envolvidas enquanto a troca de serviço se realiza - e alguns indicadores sugerem que é mais presente nas comunidades geraizeiras na atualidade. Entretanto, os depoimentos dos interlocutores também revelam a existência de relações de trocas de trabalho em que o sentido de solidariedade se faz mais presente. Se alguém necessita da ajuda dos vizinhos, chama-os para a realização do trabalho e dá a despesa, constituída de um café da manhã reforçado e meio-dia o almoço. Este tipo de relação se aproxima mais do que se conhece como mutirão, que, segundo Antonio Cândido

consiste essencialmente na reunião de vizinhos, convocados por um deles, a fim de ajudá-lo a efetuar determinado trabalho: derrubada, roçada, plantio, limpa, colheita, malhação, construção de casa, fiação etc. Geralmente os vizinhos são convocados e o beneficiário lhe oferece alimento e uma festa, que encerra o trabalho. Mas não há remuneração direta de espécie alguma, a não ser a obrigação moral em que fica 0 beneficiário de corresponder aos chamados eventuais dos que o auxiliaram. Este chamado não falta, porque é praticamente impossível a um lavrador, que só dispõe de mão-de-obra doméstica, dar conta do ano agrícola sem cooperação vicinal (CÂNDIDO, 2003, p.88).

\footnotetext{
${ }^{162}$ Aquele com o qual se tem grande afinidade. Em geral trata-se de um parente ou membro da
} comunidade. 
Do que pude constatar nas comunidades do vale do rio Arrojado, possivelmente devido à fraqueza de grande parte dos integrantes, a ressalva que se faz é com respeito ao oferecimento da festa pelo beneficiário. Nestas situações, comumente o favorecido com a ajuda dos vizinhos costuma oferecer apenas o alimento, a despesa para os companheiros enquanto trabalham.

Fez-se presente também nas comunidades, e mais enfaticamente lembrado na comunidade geraizeira de Couro de Porco, uma modalidade de mutirão que se diferencia em alguns aspectos da demonstrada anteriormente. Trata-se da modalidade que Cândido (2003, p.89) chama de terno ou traição, embora os geraizeiros a denomine de mutirão apenas. Nesta, sempre que se tem notícia de que alguém se encontra doente ou, por algum motivo, impossibilitado de botar a roça, limpá-la, ou fazer a colheita, um grupo de vizinhos, membros da comunidade, mobiliza-se para socorrer, ajudar o necessitado.

Na comunidade de Couro de Porco, inclusive, ao descobrirem as vantagens desta forma de organização para o trabalho, por algum tempo, as roças de boa parte dos membros da comunidade foram tocadas utilizando-se do mutirão no formato que Cândido chama de terno ou traição, que assim comenta e define:

A necessidade de ajuda, imposta pela técnica agrícola e a sua retribuição automática,
determinava a formação duma rede ampla de relações, ligando uns aos outros os
habitantes do grupo de vizinhança e contribuindo para a sua unidade estrutural e
funcional. Este caráter por assim dizer inevitável da solidariedade aparece talvez
ainda mais claramente nas formas espontâneas de auxílio vicinal coletivo, que
constituíam modalidade particular do mutirão propriamente dito e, por vezes,
recebiam designação especial: na área que estudei, terno. Era o caso dos vizinhos,
percebendo que um deles estava apurado de serviço, combinarem entre si ajudá-lo,
sem aviso prévio. Às vezes o beneficiado ficava sabendo e preparava comida para
recebê-los; outras vezes, era realmente surpreendido e improvisava a refeição. A
diferença estava não apenas na motivação (espontânea, não convocada), mas
também no fato do beneficiado não dar festa; e muitas vezes a falta de recursos para
promovê-la é que o havia impedido de fazer a convocação (CÂNDIDO, 2003, p.89)
(grifo do autor).

Esta modalidade de mutirão, o terno, representa uma relação de ajuda, cuja solidariedade para com o apurado $^{163}$ é a motivação maior. $E$, nos meios comunitários camponeses, os períodos de apuros, de altas demandas de trabalho, em função das técnicas utilizadas, não raro geram um balanço negativo na demanda e no abastecimento da unidade familiar, provocado pelo desequilíbrio na capacidade

${ }^{163}$ O mesmo que necessitado. 
de trabalho e a quantidade de braços disponíveis para suprir as demandas nas situações de picos, principalmente nos momentos de planta, limpa e colheita; além daquelas em que o chefe ou membros das famílias encontrem-se doentes.

Os mutirões desempenham o importante papel social com vista a minimizar os desequilíbrios e ainda é muito vantajoso para o grupo, porque funciona mais rápido. Nas comunidades estudadas, em épocas anteriores, quando a prática agrícola se destacava com maior importância no abastecimento das famílias, esta prática fazia-se mais corriqueira. Entretanto, processos sociais por elas vivenciados, tal como o aumento da pecuária e da respectiva monetarização mediando a aquisição dos meios de vida, têm contribuído para a diminuição destas práticas, que ainda existe, mas está enfraquecendo.

\subsubsection{Parcerias no uso da terra}

Da mesma forma que os meios de trabalho já descritos, os acessos à terra também não ocorre de maneira suficiente a atender à totalidade das necessidades das unidades familiares, embora se costume afirmar nas comunidades que todos têm, nem que seja uma tirinha de terra. É frequente a ocorrência de relações com vistas a permitir as condições de se garantir o sustento da família, estabelecendo a parceria entre a parte que necessita da terra para trabalhar e a maior exploração da parcela por parte do cedente da terra.

Estas relações ocorrem com diferentes intensidades nas comunidades, pois depende da sua história no tocante às transferências sucessórias relacionadas às famílias e ao tamanho da sua terra. Se, por exemplo, em uma determinada área, várias famílias a ocuparam e estas se tornaram numerosas no decorrer do tempo e não dispuseram de condições para se expandir territorialmente, um processo de superfracionamento da terra ou de minifundização pode ter-se dado.

José: As parcelas daqui, qual costuma ser o tamanho delas?

Sr. Antonio: sempre é pequena. Porque é muita gente, né? Mas a maioria tem seu pedacinho de terra, mais vareia, né? Às vezes tem pessoas que têm 4 hectares, uns têm 10, umas têm 2, 3, outros têm 20 , outros têm 50 , aqui pra baixo tem gente que tem 50, tem 100 hectares, tem gente que tem $100 \ldots$

José: a maior propriedade aqui, daqui até lá no rio Arrojado, quantos hectares são?

Sr. Antonio: olha a maior propriedade é 100. 100, 150. Agora aqui pra baixo ${ }^{164}$ tem mais. Aqui pra baixo tem pessoas que tem 200, né?...

\footnotetext{
${ }^{164}$ Refere-se às áreas seguindo o rio Arrojado para jusante.
} 
José: aqui pra baixo que o senhor fala é no Arrojado...

Edinho: é no rio Arrojado.

O interlocutor refere-se ao caso da comunidade de Brejo Verde, onde a ocorrência de propriedades maiores é mais frequente. Embora afirme que para baixo encontre-se propriedades maiores, estas não devem ser muito frequentes. Pelo menos entre a comunidade de Catolés e o povoado de Aparecida do Oeste, onde conversei com quantidade maior de pessoas, que informaram que as propriedades maiores geralmente atingiam cerca de 50 ha.

De todo modo, os depoimentos demonstram a variedade de áreas das parcelas que compõem a estrutura fundiária nas comunidades e isto é o que, em meu entendimento, se destaca como um importante fator influente na incidência de parcerias envolvendo o trabalho na terra.

Comunidades como as de Bom Sucesso, Busca Vida e Caetitu, são especialmente notáveis no que diz respeito à superminifundização. E, por esta razão, são feitas constantes referências a elas como fornecedora de mão-de-obra às parcelas de outras comunidades que dispõem de condições favoráveis à prática agrícola em maior quantidade. O diálogo a seguir, com um interlocutor da comunidade de Brejo Verde, esclarece bem o que venho afirmando sobre o assunto:

José: e é comum também as parcerias, ou seja, trabalhos... como é que vocês chamam aqui? Quem por exemplo, vem trabalhar na terra do senhor, vem plantar na terra do senhor, como é que vocês chamam?

Sr. Antonio: meeiro.

José: tem muito aqui ${ }^{165}$ ?

Sr. Antonio: não. São poucos. Que cada um tem seu pedacinho de terra, né? Às vezes, quem tem um pedacinho não vai precisar trabalhar nas terras dos outros, né? José: pois é, mas esses que tem 2 hectares, eles saem, eles podem trabalhar a meia também, ou não?

Sr. Antonio: é as vezes aqueles 2 hectares que ele tem é uma terra fraca ele vai arranjar outro pedacinho de terra, de meeiro. Agora aqui na região do Bom Sucesso, são pessoas mais sofredores, né? Porque eles trabalha assim para manter a despesa e a maioria trabalha tudo de meia. Trabalha para as pessoas que têm uma terra melhor...

José: e no trabalho de meeiro, o trabalhador entra com o que e o dono da terra entra com o que?

Sr. Antonio: o dono da terra só entra com a terra mesmo.

José: e o outro?

Sr. Antonio: com a terra e as ferramentas. E a semente. Quer dizer o dono da terra, só dá a terra e a semente, né? E o meeiro, entra com as ferramentas dele e as despesas. Depois de colher é rachado no meio. E lá muitas pessoas que vivem sofrendo, né? Trabalhar de meia, sabe que não é boa coisa né?... só tem a metade, né?...

${ }^{165}$ Refiro-me à comunidade de Brejo Verde. 
Conforme indica o interlocutor, no universo de representação das comunidades em geral, o trabalho de metade, nos dias atuais, supõe se estar passando por dificuldades. Isto indica que o trabalho na própria terra não tem sido suficiente para suprir as necessidades. São casos mais frequentes nas comunidades de Bom Sucesso, Busca Vida e outras do entorno, que, devido à grande população e à pouca disponibilidade de terra e sua baixa fertilidade, enfrentam o problema da minifundização, do alto índice da população jovem e da quantidade relativamente baixa de idosos aposentados por famílias.

Importante ressaltar, no depoimento do interlocutor, o funcionamento da relação de parceria: o dono da terra fornece a semente e o meeiro entra com o trabalho, as despesas com alimentação, as ferramentas e dá a metade da produção para o propietário. Depois da colheita, ele chega com os sacos para encher ${ }^{166}$. Ou seja, as embalagens, para a parte que é destinada ao patrão, ficam a cargo dele. Todo o processo de trabalho na terra, do seu preparo à colheita do plantio é feito pelo meeiro. Um interlocutor, morador da comunidade de Buriti, disse que essa relação era muito frequente no passado e que agora está diminuindo consideravelmente. Relata particularmente o caso de um grande proprietário de terra que tinha uma ampla área de sítio e que muito se beneficiou do grande número de geraizeiro que se sujeitava às condições dessa relação na região. O mesmo só oferecia a terra e mais nada. ${ }^{167}$ Com a grande diminuição dos interessados, passou a oferecer a terra preparada para o plantio e a semente, mas ninguém quis mais e a terrona ta lá, só no mato ${ }^{168}$.

No entanto, no conjunto das comunidades, em função do seu histórico específico de apropriação da terra, podem também ocorrer, em quantidade maior ou menor, as parcerias com vistas à sua socialização. Ve-se, portanto, parcerias que se estabelecem entre sujeitos locais, do próprio meio comunitário, envolvendo sujeitos da comunidade com os de outras, destacando-se como cedentes da terra, de modo geral, aquelas em que a densidade populacional é menor, logicamente em relação à quantidade de terras agricultáveis à sua disposição, e aquela em que a densidade populacional é maior e que geralmente dispõe de menos terras agricultáveis, ou de

\footnotetext{
${ }_{167}^{166}$ Jamilton Magalhães, comunidade do Buriti, trabalho de campo realizado em janeiro de 2012 167 Idem. 168 lbidem.
} 
sítio $^{169}$. As segundas se apresentam em maior quantidade nas áreas de ocupação mais a montante, onde geralmente as terras de sítio são mais estreitas, assim como onde a presença de terras de cultura e a forte densidade populacional provocaram a formação de um retalhamento da terra em estreitíssimas tiras, como se pode ver, na área onde se localiza as referidas comunidades (figuras 12 e 13).

$\mathrm{Na}$, comunidade de Jatobá e demais do entorno, também há esse processo de forte adensamento populacional e de ocupação da terra e, por isto, se destacam como fornecedoras de mão de obra; porém, com menor intensidade em relação às outras, e isto porque dispõem de áreas de sítio mais extensas e de terras de cultura mais amplas e com maior fertilidade.

Em função do quadro exposto, as parcerias estabelecem-se entre os donos da terra e aqueles que trabalham na meia ou de metade, como falam na região. Há que ressaltar, entretanto, que a ocorrência destas relações, muito presente no passado, nas últimas décadas vem tornando-se menos presente nas comunidades, possivelmente em função dos programas sociais dos governos e do aumento das migrações. Inclusive, é também nas comunidades nas quais o adensamento populacional é maior que a migração e a prestação de trabalho acessório são mais presentes.

No que diz respeito à organização social camponesa, a comunidade, conforme afirma Martins (1973, p.29): "constitui (...) o elemento central da realidade do camponês, pois ela exprime o modo possível de conceber a sua existência".

Ou seja:

A comunidade aparece como dimensão da consciência camponesa, cuja gênese ocorre pela específica reconstrução da realidade social feita por esse personagem histórico singular: "(...) desse modo, as relações sociais preconizadas no projeto de sociedade alternativa são relações diretas de pessoa a pessoa, sem nenhuma mediação interveniente. $O$ que o projeto preconiza é a preservação da comunidade camponesa no seu sentido pré-capitalista. Ou seja, o movimento social se norteia pela comunidade utópica. No entanto, a expressividade do movimento social reside na dupla dimensão dessa utopia, duplicada que advém da ausência de domínio sobre o desenrolar da história: intersubjetivamente a comunidade utópica constitui uma forma de resistência passiva ou não, às rupturas estruturais da sociedade, objetivamente, porém, a utopia comunitária se insere dinamicamente nas relações sociais como resistência aos efeitos estruturais dessas rupturas (MARTINS, 1973, pp.27-28).

\footnotetext{
${ }^{169}$ As parcerias ocorrem preponderantemente envolvendo as áreas de sítio.
} 


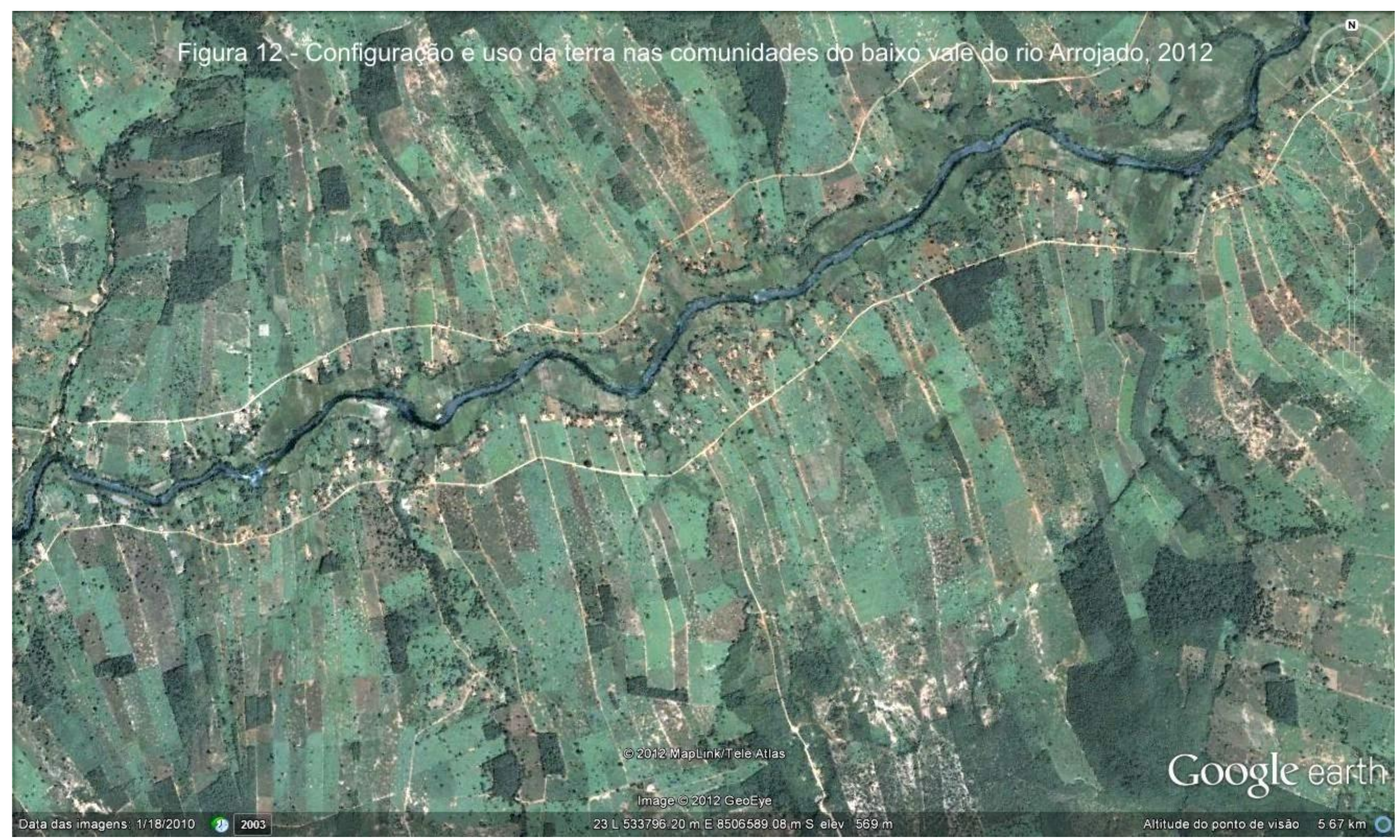




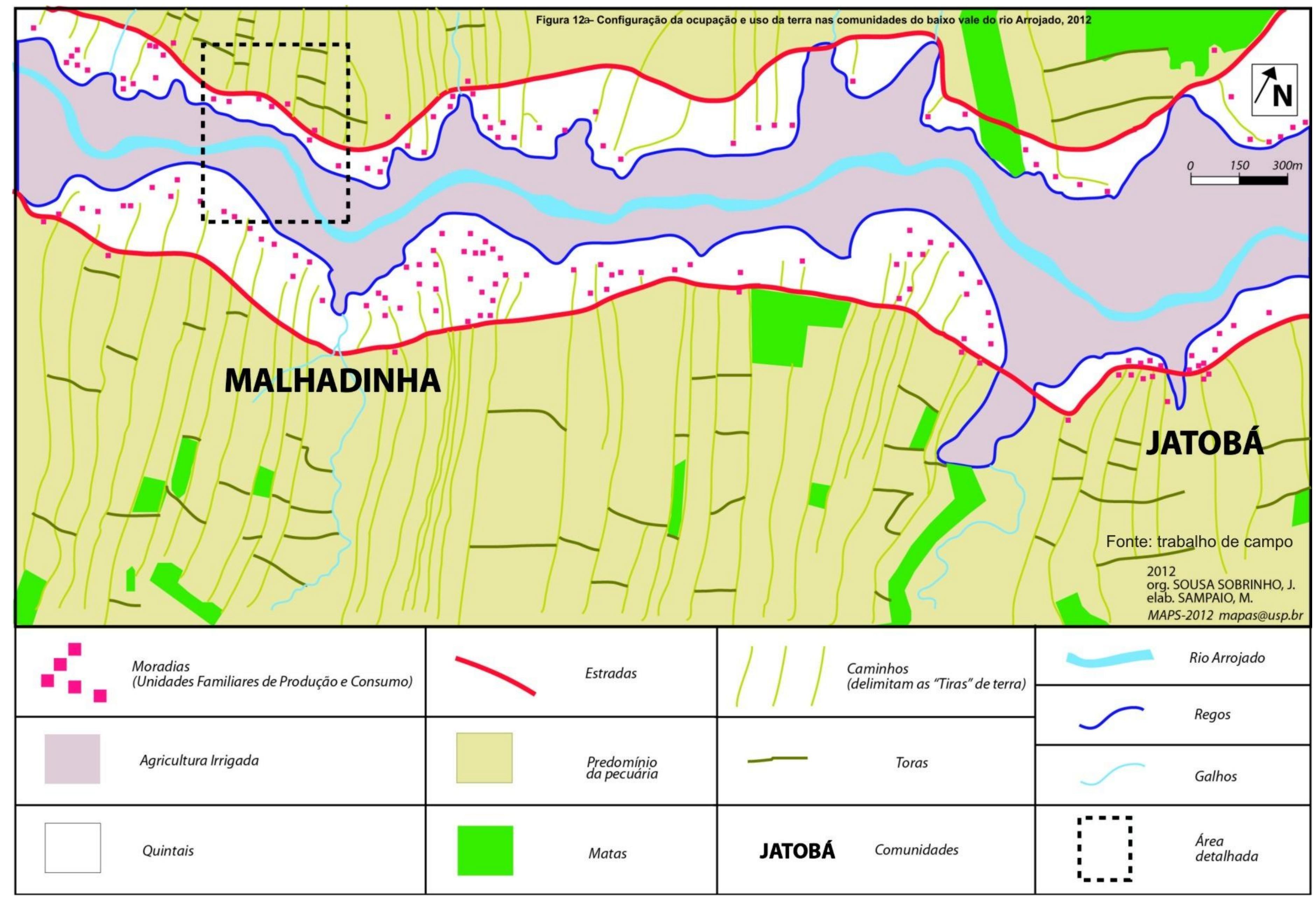


Figura 13 - Detalhe da configuração dos usos da terra nas comunidades do baixo vale do rio Arrojado, 2012

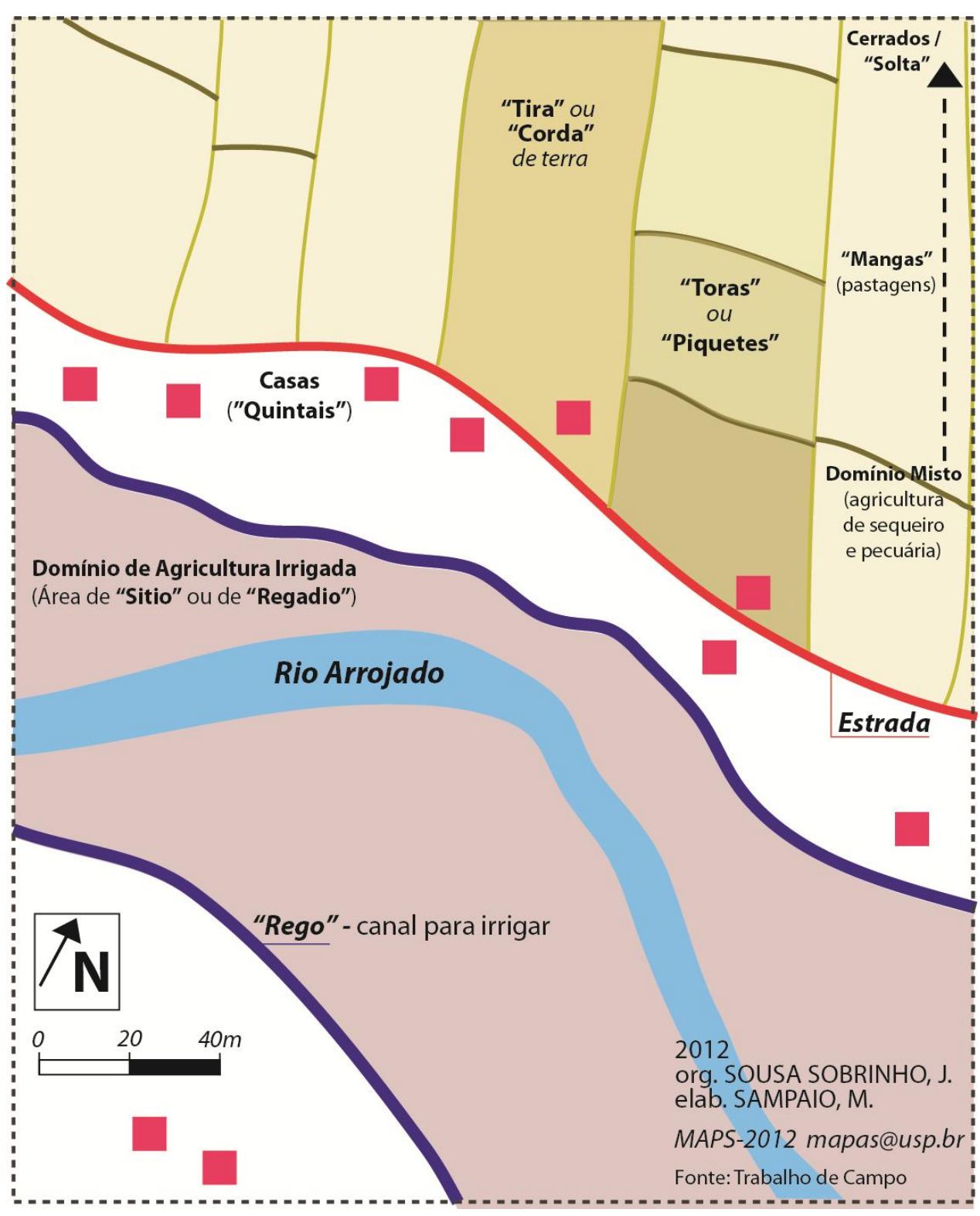

\subsection{Trabalho acessório e migração}

As atividades principais em que se envolvem os camponeses geraizeiros durante $\mathrm{o}$ ano são as relativas à agricultura e à pecuária. Porém, conforme já referi, o acesso à terra varia muito entre os integrantes das comunidades. Aquelas parcelas de terra maiores e providas de sítio ocupam grande parte ou a totalidade do tempo de seu dono no trato dos plantios, pois permitem formar duas roças durante o ano, uma na estação chuvosa, nas áreas de sequeiro, e outra na estação seca, nas áreas de sítio. Os trabalhos com a segunda atividade, a pecuária - que 
consiste nos cultivos de pasto, no transporte e nos cuidados com o gado nas soltas e/ou nos gerais, assim como na parcela, conforme a época do ano - se somam ao da agricultura, de forma que o camponês geraizeiro e sua família podem até enfrentar dificuldades, ou não conseguir realizar todas as tarefas, sendo obrigado a recorrer a auxílios de outros, pois os períodos de ciclo agrícola não raro representam o resultado do montante de trabalho aplicado durante o ano nos cultivos e, deste modo, há que garantir a realização da colheita sob pena de incorrer em grandes perdas. De modo geral, o trabalho assalariado na unidade de produção camponesa assim se justifica:

O pai de família contrata assalariados durante o pico do ciclo agrícola, pois é o volume de trabalho realizado neste momento que irá determinar o trabalho realizado durante todo o ciclo. Por isso, os trabalhadores temporários irão viabilizar a atividade dos membros da família e não a ela se opor (WOORTMANN, 1990, p.26).

Por outro lado, aqueles geraizeiros possuidores de menos terra, e/ou que sejam de baixa fertilidade, geralmente plantam pouca roça e dificilmente possuem criatório numeroso, pois, na estação em que o gado deverá permanecer na parcela, não terão pasto suficiente para alimentá-lo. No que diz respeito à atividade agrícola, estes podem se envolver nas seguintes situações: a) buscam a complementação do sustento da sua família, tocando roça de metade, conforme já apontado; b) oferecem seus serviços como diarista nas parcelas dos vizinhos possuidores de roças maiores; c) trabalham como diaristas nas fazendas da região; d) migram sazonalmente para outros Estados, destacando-se Goiás e Mato Grosso, como os mais atrativos.

Entre estas alternativas vem destacando-se a última, pois, segundo informam os interlocutores, se ganha mais. E, em função disso, é frequente aparecer na região os gatos aliciando, em maioria, os jovens, mas também os pais de família, para trabalhar fora.

Os períodos de maior incidência do trabalho acessório no interior das comunidades são os de preparo da terra e os das colheitas. Nestes, em função da grande necessidade de complementar o sustento familiar, o pequeno agricultor não raro delega seus a fazeres para a mulher e/ou filhos (quando sua idade já os permite) e vai trabalhar como diarista para os vizinhos que necessitam de 
complementação de trabalho em suas roças ${ }^{170}$ ou se submete às outras situações já descritas.

Cabe frisar, entretanto, que entre os donos de pequenas parcelas, a frequência do trabalho acessório pode variar conforme a capacidade produtiva de sua terra. Aqueles pequenos parceleiros que dispõem de boa área de sítio podem até não incorrerem ao trabalho acessório, porque conseguem da sua terra maior rendimento agrícola, a partir do qual se adquire também maior quantidade de biomassa, que utilizam na alimentação do rebanho e, além disso, podem cultivar pequenas mangas nas áreas de sítio, com as quais alimentam alguma cabeça de gado na estação seca. Nesses casos, conforme já me referi, o fator mais influente na busca de trabalho fora é o extremo fracionamento da terra, resultando em estreitas tiras ou cordas, havendo casos de ser ocupadas por mais de uma família.

Quando a parcela é pequena, mas não foi submetida ao extremo fracionamento, o camponês mantém-se numa relativa condição de autonomia e, quando presta serviços acessórios, geralmente não é por obrigação ou necessidade econômica e sim para ajudar a quem está precisando de trabalhador, situação que se aproxima das condições de integrantes do grupo estudado por Santos (1978, p.39), na qual um camponês enfatiza sua liberdade de decisão: se quero, vô.

No conjunto das comunidades situadas no baixo vale do Arrojado, aquelas que se encontram mais a montante, dispõem de menor oferta de terras de cultura e, mais, em função do enfraquecimento ou da morte de grande parte dos riachos, os regos geralmente estão enfraquecidos; ou seja, neles corre água insuficiente para as demandas e por curtos períodos do ano. Nestas, as terras de cultura se encontram apenas em estreitas faixas ribeirinhas ao Arrojado e a seus afluentes, contribuindo ainda, para intensificar as dificuldades para a sua reprodução, o intenso processo de fracionamento da terra a que se submeteram (figura 13). São exemplares desta situação as comunidades de Bom Sucesso I e II, Caetitu, Busca Vida e demais do entorno. Isto, em grande parte, explica o porquê de seus ocupantes estarem mais disponíveis ou obrigados a recorrerem ao trabalho acessório.

Há que ressaltar que os pais de família podem se submeter ao trabalho acessório, mas o público majoritário, e crescente nessas modalidades de trabalho,

\footnotetext{
${ }^{170}$ Situação similar a esta se encontra em Kautsky (1986, p.159).
} 
são os jovens, cuja afeição aos rendimentos monetários é também crescente - e seus ganhos geralmente assumem peso importante no suprimento das despesas do grupo familiar, conforme o relato de um pai de família:

\begin{abstract}
José: vocês saem para trabalhar nas fazendas?
Sr. Joaquim: não nessas aqui de perto só nas firmas. Essas firmas como a Planta 7 , vem aqui, pega pra trabalhar, mais é jovem. Os jovem vai mais, porque tem uns que não quer estudar, aquele que não quer estudar, ou então quando pega umas férias ó...

José: porque a maioria dos jovens vai para lá e os adultos não?

Sr. Joaquim: é porque aqui não corre dinheiro como a gente tamos falando, e lá é o seguinte: lá você ganha o salário, as vezes vão por causa disso. As vezes precisam comprar uma mota, uma bicicleta, e não têm como comprar. Tem que sair para ganhar um dinheiro pra comprar pelo menos aquele transporte da família e também pra ele poder ir para o serviço.

José: e os jovens quando saem para ganhar dinheiro, eles ajudam?

Sr. Joaquim: ajudam!

José: ajudam ao pai...

Sr. Joaquim: chega, chegou ali o que ele ganhou, se ele ganha lá, se ele ficou 2 meses ele traga aqui, 900, 1000 reais, ele vai tirar de comprar uma roupa, um sapato, ele vai tirar 500 contos, dá ao pai para o pai comprar a despesa, ele sabe o que precisa, logo ele tá voltano traveiz, é assim, é trabai de formiguinha, é trazeno e botano dentro da sede né? Porque a hora que precisar ta ali (Sr. Joaquim Francisco Dourado, comunidade de Catolés, trabalho de campo realizado em julho de 2011).
\end{abstract}

Além das necessidades básicas, que muitas vezes obrigam às saídas para trabalhar fora, o relato do interlocutor, revela in loco, um processo de monetarização das relações de troca em desenvolvimento e, consequentemente, um acréscimo da afeição pelas mercadorias modernas: as motocicletas, assim como os eletrodomésticos, assumem considerável destaque.

Conforme já referi, um dos destinos são as fazendas da região, embora sejam muito corrente as afirmações de que há uma rejeição da população do município em trabalhar nas fazendas, pois as mesmas têm histórica fama de submeter seus trabalhadores ao trabalho escravo, sendo que as frequentes notícias dos flagrantes que a fiscalização consegue abordar comprovam o fato, inclusive cometidos pela empresa que o interlocutor cita, a Planta 7, também envolvida, comprovadamente, em grilagem de terra e, por isso, em acirrado conflito com a comunidade de Couro de Porco.

Concomitante ao processo de minifundização, o trabalho acessório envolvendo os membros das famílias vem aumentando. Mas, também, em função dos programas sociais dos governos, principalmente das aposentadorias dos idosos, ocorre de muitos não saírem para trabalhar e também não se submeterem à baixa remuneração do trabalho ofertado nas comunidades. Isto vem causando 
descontentamentos entre aqueles que têm serviços excedentes. Afirmam que ninguém mais quer trabalhar. Inclusive, insatisfeito com isso, o Sr. Abdias de Souza Brito, idoso aposentado e poeta da comunidade de Brejo Verde, numa poesia, externa o seu descontentamento:

Se Deus aborrece na mentira Vamos amar a verdade O Homem que mente Não tem dignidade

A preguiça é um pecado mortal Amai o trabalho Que foi escrito por Deus

O trabalho é um dever

É uma necessidade

Do trabalho faz nascer

Honra e prosperidade

O homem que não trabalha

Atrasa a humanidade

Quem não ama o trabalho

Não ama a honestidade

Ele sendo desonesto

Habita a perversidade

O homem que não trabalha

Vive desocupado

Todo mundo trabalhando

E ele de braços cruzados

O fim dele vai ser triste

Vamos ver o resultado

O homem que não trabalha

Leva a vida numa boa

Desse jeito ele não cresce

Ele não alcança uma proa

Além disso ele desrespeita

A sua própria pessoa

O homem que não trabalha

Não pode ter alegria

Ele tem uma mania

Ele não planta, ele não cria

Só vive com a mão no bolso

E a algibeira vazia

Cuidado com o preguiçoso

Ele quer te derrubar

Ele compra o que é seu

Sem ter a intenção de pagar

Se um dia você procura

Ele quer te sonegar
Ele tem uma mania

De querer comprar fiado

O que é meu eu não vendo

Pra isso eu estou acordado

Se é a mulher ou um filho

Eu pego um pouco e dou dado

A mulher do preguiçoso

De sofrer não tem nem graça

Ela sofre no trabalho

E o marido na devassa

Quando ele chega em casa

Chega fazendo arruaça

Ela fala para o marido

Vou mostrar a minha raça

Vou tirar o meu vestido

E vou vestir a tua calça

$E$ se eu estiver de vestido

Na minha frente não passa

Um dia pelo menos

Na propriedade alheia

Com a sua sorte mesquinha

$A$ situação é feia

Ele nem pensava de apanhar

Foi apanhar na cadeia

É coisa que eu detesto

$E$ acho muito esquisito

É de ver um homem pobre

Andando querendo ser rico

Sendo da classe grosseira

E querendo ser muito bonito

O defeito de certos homens

Assim ficou escrito

Abaixo deixo meu nome

Abdias de Brito 
A concepção expressa nas estrofes demonstra o que representa no meio comunitário o indivíduo não afeito ao trabalho, pois o trabalho representa, na concepção expressa no poema, perspectiva de prosperidade, de ascensão material ou de tornar-se rico. Aquele que não trabalha torna-se objeto de uma série de adjetivos, tais como preguiçoso, desonesto, mal pagador e, socialmente, é desprestigiado. Conforme Bourdieu, para o camponês

O preguiçoso não realiza a função que the cabe no seio do grupo: por isso, ele se coloca à margem e se expõe a ser rejeitado. Permanecer ocioso, especialmente para quem pertence a uma grande família, significa atraiçoar próprios empenhos com relação ao grupo, significa esquivar-se aos deveres, às tarefas e aos encargos que são inseparáveis ao fato de pertencer ao grupo (BOURDIEU, 1979, p.43).

No meio comunitário, é comum àqueles possuidores de áreas maiores de terra - e, mais recentemente, os aposentados - requisitarem dias de serviço, geralmente daqueles cujas parcelas e as atividades nelas desenvolvidas não consomem todo o tempo de trabalho.

Historicamente, e até nos dias atuais, entretanto, os pagamentos aos prestadores de serviços são irrisórios e os mesmos, por falta de alternativas, obrigatoriamente se submetiam às condições oferecidas para não serem penalizados a ver a família passando por necessidades.

Os programas sociais dos últimos governos, no entanto, têm impactado sensivelmente na costumeira predisposição dos possíveis trabalhadores a serviços como diaristas pela remuneração que é oferecida criando situações nas quais os geraizeiros necessitados de força de trabalho em suas parcelas sintam-se inconformados. Neste sentido, o Sr. Abdias afirmou:

Eu paguei muita gente aqui. Um dia de serviço, um prato de feijão ${ }^{171}$. Hoje eles querem é três, quatro pratos. Eu matava um gado, era um quilo de carne ${ }^{172}$. Hoje eles não quer só dois quilos, quer é mais disso. E o pessoal não quer mais trabalhar como trabalhava antigamente não... ...naquele tempo o pessoal era mais trabalhador, hoje não. O pessoal não quer mais trabalhar não... ...o aposento, bolsa família, o pessoal mais novo não quer mais trabalhar (Sr. Abdias Souza Brito, comunidade do Brejo Verde, trabalho de campo realizado em janeiro de 2012).

Os pagamentos, pois, eram feitos em produtos e o inflacionamento destes não foi suficiente para pagar os mesmos serviços na atualidade. Ou seja, a remuneração dos serviços sofreu altas maiores e afirmam que nem assim o pessoal quer trabalhar.

\footnotetext{
${ }^{171}$ Unidade de medida ainda hoje muito usual entre os camponeses e equivale a três litros do cereal. 172 Um quilo de carne era o pagamento àquele que matava o gado, tirava o couro e entregava a carne desossada.
} 
Atualmente, as comunidades passam por um processo de aumento da monetarização nas relações de trocas, impulsionado, em boa parte, pelos referidos programas sociais dos governos. Estes também têm contribuído para a diminuição da sujeição dos menos apossados às relações desfavoráveis para si, que costumavam submeterem-se, no meio comunitário, entre os "iguais" (as horizontais), assim como nas relações verticais que se estabelecem geralmente com os de fora, com as grandes fazendas.

Isto tem provocado a indignação daqueles que necessitam de incremento de trabalho em suas parcelas, tal como o caso anteriormente exposto.

\subsection{O ordenamento da unidade territorial camponesa}

Nas páginas anteriores, já venho discorrendo sobre os elementos que os camponeses geraizeiros, desde o início da ocupação das áreas em que estão assentados, constituíram para viabilizar a sua reprodução social naquelas paragens, a partir de suas relações com a natureza.

Nas páginas seguintes, não pretendo fazer recuos à história longa sobre a ocupação do vale do rio Arrojado pelas comunidades. Para o momento, quero destacar alguns elementos relacionados à história da ocupação, a relação desta com a natureza própria da região e os elementos engendrados pelos camponeses geraizeiros para propiciar a sua reprodução socioterritorial.

Nas entrevistas realizadas com os integrantes das comunidades, sempre fiz perguntas com vista à elucidação dos antecedentes históricos, pretendendo obter evidências sobre o início da ocupação do vale. Estas perguntas, de modo geral, se dirigiam aos anciões, portadores de boa oralidade e da memória coletiva. Assim, pretendi, também, levantar informações sobre os primeiros ocupantes da região. A certeza que se pôde ter foi da antiguidade da ocupação, remetendo-se aos tempos dos primeiros exploradores da região, atraídos pela mineração do ouro, nos idos do século XVIII, cujo centro era justamente a localidade onde se constituiu a povoação de Rio Rico ${ }^{173}$, hoje cidade de Correntina, sede do município.

Quanto à ocupação das áreas das comunidades onde fiz estudos, tais como Jatobá, Catolés, Brejo Verde, Couro de Porco, Bebedouro, Passaroto e Cajueiro, em

\footnotetext{
${ }^{173}$ Nome que faz alusão às grandes jazidas de ouro de aluvião existentes na região central da cidade de Correntina.
} 
conversas com idosos de 70, 80 e 90 anos de idade, a maioria afirmou que seus avós são da própria comunidade ou são oriundos de outras do entorno. Informaram, entretanto, que estes eram possuidores de áreas de terras bem maiores e que o fracionamento que se evidencia atualmente é resultante das sucessivas divisões por heranças às gerações que se sucederam.

Até recorri aos cemitérios das comunidades e povoações, a fim de obter informações seguras a partir das datas de nascimentos dos sepultados, escritas nos túmulos, mas não fui bem sucedido na busca. Os geraizeiros não têm o costume ou mais provavelmente não têm as condições materiais para o zelo dos túmulos, de modo a permitir a obtenção das pretendidas informações a partir destes.

$\mathrm{Da}$ ocupação que se processou ao longo do tempo, atualmente se evidenciam, nas margens do rio Arrojado, cinco núcleos de povoamento mais importantes, da jusante para a montante, a saber: o Distrito de São Manuel, o povoado do Grilo (atual Aparecida do Oeste), o povoado de Praia, o povoado de Catolés e o povoado de Couro de Porco.

Dos cinco povoados, quatro se encontram no baixo vale do rio Arrojado e somente o povoado de Couro de Porco situa-se no médio vale do mesmo rio. Há, pois, maior concentração populacional na região do baixo vale do rio, atraída pelas condições naturais favoráveis: a maior oferta hídrica e as chamadas terras de cultura.

A ocupação iniciou-se a partir do baixo vale do rio Arrojado, nas suas margens e de seus afluentes, expandindo-se sobre as manchas de solos agricultáveis e, na medida em que a população se adensava, levas populacionais deslocavam-se para a montante, em direção a oeste no vale, ou para as extremidades a montante dos afluentes, onde as manchas de terras de cultura estreitam-se até não mais existirem (imagem 1). Além da escassez de terras agricultáveis nas referidas áreas, seus riachos têm diminuído muito o volume de água nas últimas décadas, o que, por vezes, impossibilita a prática da irrigação, resultando no escasseamento dos meios de vida às comunidades ali situadas.

Ao longo do baixo vale do rio Arrojado, a ocupação se estabeleceu nas duas margens do rio e, entre os povoados citados, encontram-se as comunidades originárias de troncos familiares correspondentes aos primeiros povoadores. Conforme a evolução a partir desses povoados, surgiram aglomerações mais ou 
menos adensadas entre eles e, consequentemente, diferentes estruturas fundiárias se configuraram em função disso, resultando, como se pode ver, em um formato de "espinhas de peixe" constituídas de parcelas relativamente largas concentradas em algumas localidades e de presença mais raras noutras em que predominam o que se chama localmente de tiras ou cordas de terra.

O fator que confere maior capacidade produtiva à parcela é a sua largura na testada de frente para o rio ou afluente, conforme o caso, pois, assim, geralmente abarca maior área de sítio nas margens do rio, o que possibilita duas safras agrícolas anuais e, nas porções da vertente, do mesmo modo, incorpora maiores extensões de terras de cultura, conferindo maior capacidade de produção agrícola e/ou cultivos de maiores áreas de pastagens para a alimentação do gado nos períodos em que este se encontra na parcela.

A área da comunidade de Brejo Verde, a qual me detive com maior atenção, foi ocupada de fato pelos moradores na margem direita do córrego Santana. Em função da quase inexistência de terras de cultura, a margem esquerda não foi ocupada por moradias, exceto um pequeno trecho no alto vale do córrego, no qual cerca de 15 famílias ali residem e plantam roças nas terras férteis. Esta configuração de ocupação, apesar de algumas exceções, é comum aos afluentes do rio Arrojado e, de modo geral, a ordenação territorial não se diferencia muito da maioria das comunidades, quais sejam ribeirinhas ao Arrojado ou aos seus afluentes.

Assim, a configuração dominante é a seguinte: há o rio Arrojado e, relativamente paralelas a este, de um lado e de outro, as estradas que fazem ligações entre as comunidades e os povoados, sendo uma do lado direito e a outra do lado esquerdo. Entre a estrada e o leito do rio se encontra o rego, a partir do qual se capta água para a irrigação da área de sítio, faixa de terra localizada entre o rego e o rio (figuras 9,12 e 13).

Ao longo do rio Arrojado, as casas de morada situam-se entremeando a estrada e o rego, embora, de modo geral, mais próximas ao rego do qual se utiliza da água para muitos afazeres domésticos e das oficinas. Estas, assim como os instrumentos de trabalho - ferramentas, carros-de-boi e seus acessórios, arreios quase sempre se encontram nas proximidades da casa, nas bordas do terreiro, 
abrigadas em pequenos galpões. Nos arredores da casa se encontram os cercados - chiqueiros e currais - onde ficam os animais.

\begin{abstract}
tipo de criação que nós cria... é o seguinte: como a gente não pode criar muita coisa, porque as áreas são pequenas, nós não temos muitos espaços para criar muito gado, cria um pouco de gado, cria a vaca leiteira, né? Tem os bois de puxar arado, né? O animalzinho para andar muntado, né? Para a gente campear lá no campo, né? E cria um porco, cria galinha, né? É isso que nós cria (Sr. Antonio José de Araújo, comunidade do Brejo Verde, trabalho de campo realizado em janeiro de 2012).
\end{abstract}

Nos currais $^{174}$, fica o gado para a ordenha ou para a execução de alguns serviços/cuidados ou tratamentos, como marcação, vacinação e outras medicações. Nos chiqueiros, estão os porcos (criados sempre fechados), pois não tem mais como criar solto porque ficam atentando o vizinho ${ }^{175}$; as galinhas, patos e galinhas de angola, principalmente nas épocas de planta nos meses de outubro, sequeiro, e de junho, nas áreas de sítio, também ficam presos.

Tem que prender, até que ele nasça e fica mais grandim, né?... ...tem que prender. Se não dá prejuízo. Tá tudo muito perto... ...mas também é um espaço pouco. É quinze dias. O milho cresce um pouco, já começa endurecer as palha, as galinhas já não come mais (Sr. Antonio José de Araújo, comunidade do Brejo Verde, trabalho de campo realizado em janeiro de 2012).

No entorno da casa de morada também se encontra o pomar, constituído de uma ampla diversidade de frutas, tais aqueles nos arredores da casa do Sr. João de Castro e Silva, da comunidade de Jatobá; banana, laranja, laranja lima, cacau, tamarindo, goiaba, umbu, manga e coco. Neste conjunto, geralmente mais próximo ao curral, pode-se encontrar também uma roça de palma que, juntamente com o capim de ração (forrageira, plantado na área de sítio), serve de complemento à alimentação do gado na estação seca.

O conjunto formado pela casa de morada da família camponesa e demais componentes do entorno, conforme descrito, constitui-se como unidade de processamento e consumo que absorve a produção agropecuária oriunda da área de sítio e da de sequeiro, embora, nas imediações, também se produzam, conforme visto, frutas, hortaliças (verduras e legumes) e plantas medicinais e se criem também animais de pequeno porte, os de terreiro.

Em alguns trechos, a estrada passa afastada deste conjunto, embora ocorram também casos de a casa de morada encontrar-se do outro lado da estrada,

\footnotetext{
${ }^{174}$ Os currais se encontram no entorno da casa, porém, geralmente mais próximos da estrada.

${ }^{175} \mathrm{Sr}$. Antonio José de Araújo, comunidade do Brejo Verde, trabalho de campo realizado em janeiro de 2012.
} 
conforme se pode ver na (figura 12). Dominantemente, entretanto, na porção entre a estrada e a casa de morada, assim como nas demais da tira de terra em direção ao interflúvio, a estreita parcela é dividida em toras ou piquetes. Nas áreas destes piquetes planta-se capim, do qual o gado pasta enquanto permanece na parcela, mas também cultivam milho feijão e mandioca. Os cultivos de pasto alongam-se em direção ao interflúvio, até atingir os solos arenosos, onde não prosperam. Dali em diante, nas comunidades que dispõem de soltas, começa a área de criatório em comum. E naquelas comunidades onde as antigas áreas de soltas já foram cercadas, ficam de reservas privativas àquele que cercou e de onde se retira madeiras, plantas medicinais, frutos e outras riquezas dos cerrados.

$\mathrm{O}$ acesso do gado à água do rego e aos alimentos que são oferecidos nas proximidades da casa, tais como a palha do milho, do feijão e da cana, se dá por meio de um corredor formado por cercas de arame construídas nas divisas laterais das parcelas. Neste corredor, o gado segue até encontrar a água do rego. Este pode atravessar o corredor antes ou depois da travessia da estrada. Quando depois, atravessa-se a estrada por meio de um mata-burro (foto 21) que consiste numa espécie de "túnel" construído por baixo da estrada. Nele, o gado passa para ter acesso à água do rego e ao que lhe possa ser servido nas proximidades da casa, sem o risco de se dispersar estrada afora.

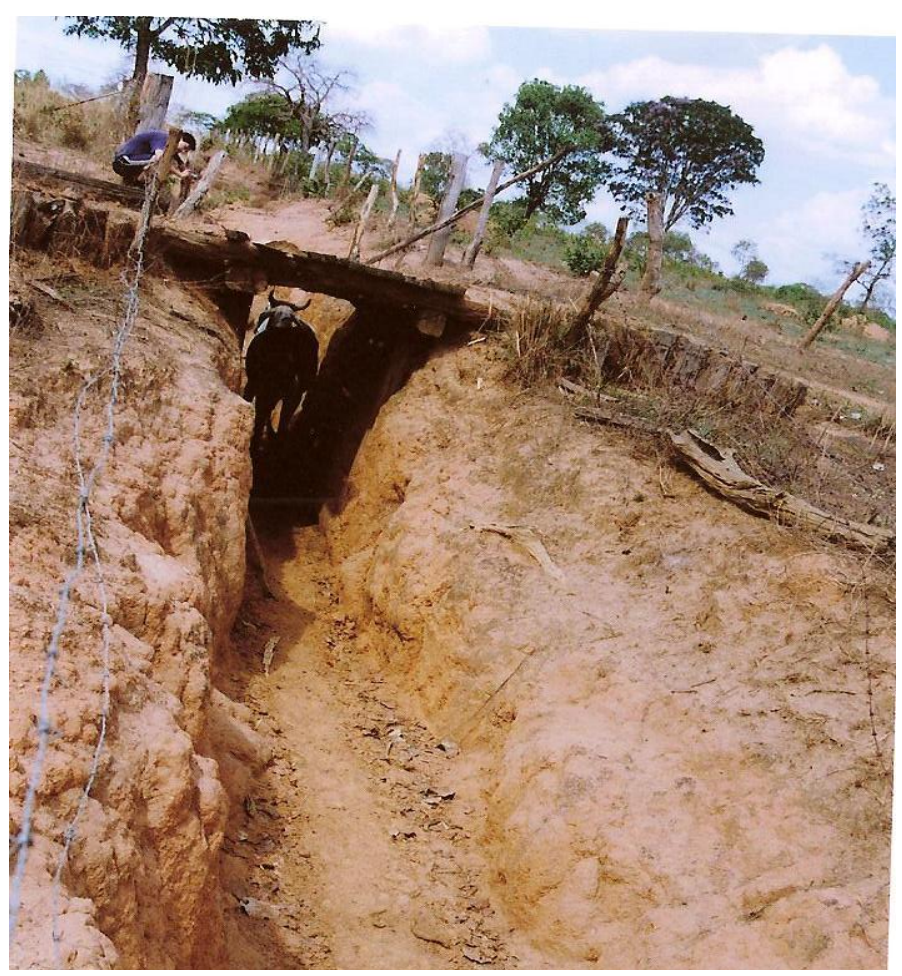

Foto 21 - Mata-burro. Brejo Verde, Correntina - BA.

Sousa Sobrinho, J. (out. 2010). 


\subsubsection{As cercas, o que cercam?}

Atualmente, as parcelas são delimitadas por meio de cercas, geralmente de arame farpado. E, no seu interior, por menor que sejam, são compartimentadas em talhões ou piquetes, nos quais o gado faz rodízio de pastejo durante 0 ano. As estradas que margeiam nos dois lados do rio, interligando as comunidades, fazem a ligação entre as comunidades de um lado e de outro do rio Arrojado e também são cercadas de ambos os lados, de modo a facilitar os deslocamentos do rebanho entre as comunidades ou o transporte das boiadas para os gerais.

No passado, até por volta da década de 1970, entretanto, praticamente não existiam cercas nas áreas das comunidades. Segundo afirmam os interlocutores, os criatórios eram menos numerosos e permaneciam soltos a pastar das matas e das gramíneas naturais dos cerrados, nas chamadas soltas. Os cercados se restringiam às áreas de sítio, nas beiras do rio, para a proteção das pequenas roças contra o ataque dos animais e para fora era tudo aberto ${ }^{176}$, era só capoeira. ${ }^{177}$

Outro interlocutor complementa, ressaltando as mudanças na ordenação territorial, que se estabeleceram em função dos processos sociais em desenvolvimento e, dentre eles, cito o aumento populacional e a grilagem de terras na região:

Hoje ocupam mais a terra com os pastos. Antigamente não existia cerca, não existia arame, as cercas eram de gramalha. Era pouca gente que tinha cerca de madeira, reforçada. Não tinha pasto nenhum. Para criar um gado antigamente, fazia ali um cercadozinho somente para tirar o leite do gado, amarrava os bezerros, as vacas ficavam no campo, quando era de manhã cedo elas vinham, tirava o leite e tornava ir para o campo. Hoje, o lugar de fazer as roças é ocupado com pastos, né? (Sr. Abdias Souza Brito, comunidade do Brejo Verde, trabalho de campo realizado em janeiro de 2012).

Conforme a afirmação dos interlocutores, as cercas eram raras e as que existiam eram precárias e provisórias, como no caso das gramalhas, que duravam apenas enquanto se cultivava a roça, ou eram demais dificultosas para se construir, como as de madeira reforçada, construídas com paus a piques, pareados e fincados no chão.

\footnotetext{
${ }^{176}$ Sr. João Magalhães, morador da comunidade de Pombas, trabalho de campo realizado em julho de 2011.

${ }_{177}$ Jamilton Magalhães, morador da comunidade do Buriti, trabalho de campo realizado em julho de 2011.
} 
Só a partir da chegada do arame e do surgimento de condições financeiras para comprá-lo, pode-se formar as pastagens cercadas, as quais ocuparam grande parte das terras onde tradicionalmente se plantavam roças que garantiam uma produção agrícola muito mais significativa que atualmente, conforme informou o Sr. Abdias.

O surgimento e a ampliação das pastagens nas áreas das parcelas possibilitaram a ampliação dos rebanhos, os quais puderam contar com outro suprimento de alimento em períodos intercalados com os que permanecem nos gerais.

Essas mudanças nas terras desenvolveram-se concomitante a um significativo aumento da pecuária, que será abordado no próximo tópico.

\subsubsection{O aumento da pecuária nas atividades das comunidades}

Como é costume das populações camponesas, os geraizeiros tradicionalmente praticam criatórios. Antes da década de 1970, porém, o rebanho das famílias era constituído de um pequeno número de cabeças de gado, os quais, na falta de pastagens cultivadas, permaneciam durante 0 ano todo soltos, revezando-se períodos de permanência nas matas e nos cerrados próximos às comunidades, nas chamadas soltas, com períodos de permanência nos gerais, mais afastados à montante do vale do rio Arrojado, nos atuais fechos de gerais.

Nesta época, a prática da agricultura se realizava predominantemente nas chamadas áreas de sítio, que nem sempre eram irrigadas, pois, os canais ou regos, quando havia, tratavam-se de simples construções de iniciativa de camponeses que abarcavam apenas estreita faixa margeante ao rio ou afluentes. Estas áreas, entretanto, eram cercadas geralmente com as cercas reforçadas (perenes), reservando-se predominantemente ao uso agrícola.

As áreas mais elevadas das encostas, acima do rego, eram abertas e as poucas cercas visavam apenas a proteger dos animais os pequenos talhões onde se realizava cultivos de sequeiro, porém, com cercas um tanto provisórias, as chamadas gramalhas, conforme assinalado anteriormente.

A década de 1970 representa um importante marco, no qual se inaugura uma série de processos que se desenvolvem nas décadas seguintes. Alguns desses 
processos estão relacionados à evolução própria das comunidades, outros a fatores externos, que interferem nas suas dinâmicas, e outros à interação entre ambos, modificando consideravelmente os usos das terras na ambiência da comunidade, nas áreas próximas, onde tradicionalmente puderam se apropriar, modificando, assim, a sua configuração socioterritorial.

Dentre os fatores, cito o intenso aumento e o adensamento da população, o que tem provocado um forte processo de fracionamento das antigas fazendas, resultando, assim, em uma extrema minifundização das parcelas apropriadas pelos geraizeiros. Concomitante a isto, e até por consequência ${ }^{178}$, os solos têm enfraquecido progressivamente e, muito em função das intervenções arrasadoras que se processam nos chapadões (nas áreas de interflúvios), o nível dos cursos d'água tem abaixado muito, afetando negativamente a tradicional prática da agricultura irrigada nas áreas de sítio.

Cabe ressaltar ainda a proibição da tradicional prática agrícola que se realizava nas áreas ribeirinhas a montante do rio Arrojado e afluentes, provocando impacto nas possibilidades de obtenção dos meios de vida. Estas áreas, assim como as de cerrados próximos a elas, onde costumeiramente se praticam os criatórios soltos e misturados, nos ditos fechos de gerais, em grande maioria transformaram-se em áreas de reservas das fazendas que por ali surgiram por meio da "farra da grilagem" que afetou a região, inclusive abalando intensamente a secular configuração territorial camponesa geraizeira.

Com vista a sanar os impactos negativos desses processos, sabiamente as comunidades engendraram uma série de medidas, entre elas:

a) Investiram na ampliação dos rebanhos, o que resultou na potencialização dos usos pecuários, tanto das áreas das parcelas, quanto daquelas onde costumeiramente soltavam o gado, quais sejam nas áreas de soltas, próximas às comunidades, ou nas de fechos de gerais, mais distantes, pois a permanência do gado, por longo período, nos gerais acarreta o mal de toque e, por isto, o aumento do rebanho obrigou a formação de pastagens nas parcelas e o respectivo cercamento destas, para dar suporte ao gado nos períodos em que se retirasse dos gerais.

\footnotetext{
178 Uma relação um tanto direta pode-se estabelecer entre o forte adensamento populacional e o sobreuso dos solos, provocando, assim, o enfraquecimento destes.
} 
b) Potencializaram os usos agrícolas nas áreas das parcelas. Isto foi possível a partir da ampliação das áreas de sítios, possibilitada com a construção de maior número de canais ou de prolongamento dos que já existiam, favorecendo, assim, maior aproveitamento das áreas irrigáveis. Esta medida, inclusive, tem alcance decrescente nos dias atuais, em função do citado rebaixamento dos níveis dos cursos d'água. Nas áreas de sequeiro, também o uso agrícola foi potencializado, ao empregarem o arame farpado cercando e piqueteando as partes elevadas da parcela. Isto favoreceu a prática agrícola - em porções ou piquetes - com os cultivos de sequeiro, tais como milho, feijão e mandioca, intercalando-se com o uso pecuário.

\subsection{A territorialização geraizeira do Oeste da Bahia}

A ocupação do Oeste da Bahia pelos camponeses geraizeiros tem por base elementos peculiares, os quais dizem respeito aos aspectos históricos, geográficos e, além desses, à situação jurídica das terras.

Os fatores atrativos para a ocupação da porção do Oeste da Bahia, onde se localiza o município de Correntina, foram os seguintes: a exploração aurífera nas áreas ribeirinhas dos rios da região, a prática pecuarista de bovinos, a agricultura comercial do algodão e os cultivos de grande diversidade de produtos alimentícios, que se aproveitavam e se aproveitam das terras férteis - as terras de cultura localizadas nas vertentes baixas dos rios e riachos. Estas terras agricultáveis eram encobertas por matas que, em função da intensa ocupação e usos das terras, reduziram-se a pequenas manchas dispersas em meio a imensa quantidade de pequenos talhões de roças e pastagens. Ainda no baixo vale do rio Arrojado, esse denso povoamento, que se beneficiou dos usos das terras de cultura, perde importância na medida em que elas se tornam escassas e cedem lugar aos solos arenosos dos amplos tabuleiros, os gerais, encobertos pela vegetação de cerrados que se expande até os fundos de vale. Este domínio estende-se de oeste para leste, em direção às caatingas que já se fazem presentes nas bordas da Depressão Sãofranciscana, constituindo-se as áreas de densa ocupação das comunidades - a zona mais efetiva de transição entre os dois biomas. As manchas das chamadas 
terras de culturas, como se pode ver na (imagem 1), se estreitam ao se adentrarem nos cerrados, de leste para oeste, ganhando maior extensão e penetração nas proximidades dos rios e afluentes da região.

Nas áreas ribeirinhas dos principais rios da região e de seus afluentes, onde se encontram as terras de cultura, está concentrada a maior parte da população ocupante da região. Suas moradias se concentram nos fundos de vale, onde também praticam a agricultura e os criatórios em pastagens cultivadas e cercadas nas parcelas de uso exclusivo familiar. Ao longo do tempo, a população foi tornandose numerosa e a atividade agrícola ocupou áreas mais a montante dos rios, inclusive em seus trechos de gerais. Ali, faziam roças, principalmente de arroz, na margem imediata do rio, onde encontrassem terras agricultáveis em extensão viável e que permitisse a drenagem. Das condições favoráveis a esses usos, inclusive resultou de alguns grupos de agricultores fazerem sítio, formando comunidades numericamente expressivas, como as geraizeiras situadas no médio vale do rio Arrojado: Lodo, Arrojadinho, Couro de Porco, Bebedouro, Passaroto, Cajueiro, Pimenteiras e Puçazeiro. Os usos da maior parte das áreas geraizeiras, dos tabuleiros que se encontram nos interflúvios, se constituem essencialmente por criatórios realizados pelas populações centenárias, situadas na borda oeste da Depressão do São Francisco. Esta configuração dos usos das terras que se apresenta no município de Correntina/Vale do rio Arrojado, projeta-se para a maioria dos municípios formadores da região Oeste da Bahia, tais como Cocos, Coribe, Jaborandi, São Desidério, Barreiras, Riachão das Neves e Formosa do Rio Preto.

Há assim, a leste dos gerais baianos, um conjunto de sedes municipais em posições relativamente alinhadas no sentido norte-sul. As áreas desses municípios, de modo geral, estendem-se das proximidades da borda da Depressão do São Francisco, onde estão as suas sedes, para oeste, em maioria indo ao encontro à divisa com os Estados de Goiás e Tocantins.

Entre a Depressão do São Francisco e a Serra Geral no limite oeste da Bahia, encontram-se os gerais, região de antiga ocupação, com o domínio da pecuária praticada pelos moradores destes municípios. Até décadas recentes, estas áreas de gerais ou chapadões, apesar dos antigos usos pelos camponeses, eram livres de apropriação privada, constituindo-se de terras públicas devolutas. 
Nos altos gerais, as centenárias comunidades que residem nas margens imediatas dos rios (Lodo, Couro de Porco, etc.), tais como os citados grupos de leste, sempre exploraram os fundos de vale com a prática agrícola e os cerrados dos amplos interflúvios para a soltura dos criatórios.

Esta configuração da distribuição populacional, aproveitando-se das potencialidades de uso das riquezas naturais como meio de vida, repete-se em todos os rios, ribeirões e córregos da região Oeste da Bahia, caracterizando, a partir disto, um modo de uso e ocupação da terra tipicamente da referida região, o geraizeiro.

\subsubsection{A ocupação geraizeira do vale do rio arrojado: os fechos de gerais}

Continuando a discussão sobre o uso e a ocupação camponesa da terra nos gerais do Oeste da Bahia, atenho-me ao vale do rio Arrojado, onde as problemáticas estudadas processam-se de modo bastante representativo da totalidade da região.

Até a década de 1970, as terras públicas dessa região mantinham-se praticamente livres de cercas e, por conseguinte, de qualquer apropriação particular a não serem as pequenas parcelas de uso exclusivo familiar, situadas nas margens dos rios onde as populações camponesas, antigas ocupantes, praticavam e praticam a agricultura num modo de uso da terra bem peculiar, conforme demonstrado anteriormente.

Segundo os relatos de antigos moradores do vale do rio Arrojado, à procura de pastagem boa para seus animais, os camponeses geraizeiros baianos situados nas proximidades do distrito correntinense de São Manuel, no baixo vale do referido rio, assim como nas comunidades mais a jusante, soltavam seus animais a uma distância de até mais de $100 \mathrm{~km}$ a oeste, o que corresponde às proximidades da comunidade de Couro de Porco. E toda a população do vale do rio Arrojado, desde que ali se instalou, usam as terras livres, os gerais, para a soltura do gado.

Das proximidades da comunidade de Couro de Porco, a oeste, predominava o uso pelos criadores dos Estados de Minas Gerais e Goiás, mas também pelos moradores baianos das margens do rio Arrojado nos gerais, a saber, das 
comunidades de Arrojadinho, Couro de Porco, Bebedouro, Passaroto, Cajueiro, Puçazeiro e Pimenteiras.

As imediações da comunidade de Couro de Porco, próximas ao ponto médio entre a cidade de Correntina (BA) e a de Posse (GO), na divisa com o Estado de Goiás, segundo relata os interlocutores, eram a "divisa" - embora sem qualquer delimitação precisa - da fração territorial de uso pecuarista majoritário dos criadores baianos e dos criadores goianos (figura 6).

Tratavam-se, pois, de terras públicas devolutas, as quais os camponeses, moradores nelas ou nas proximidades, usavam livremente para a soltura do gado, onde lhes conviessem, assim como para a agricultura, para a coleta de frutos e plantas dos cerrados, para a caça, a pesca, a coleta de madeira para uso como combustível (lenha) ou fabrico de cercas, construção das moradias e instrumentos de trabalho. Ou seja, para a reprodução da vida, livremente, aproveitavam-se de tudo que as terras livres Ihes ofertavam.

Como já informado, nas entrevistas com os anciões buscou-se recuperar os primórdios da ocupação e do uso das terras geraizeiras.

O Sr. João de Castro e Silva, usuário do fecho de gerais de Entre Morros e Morrinhos e morador da comunidade de Jatobá, com idade de 73 anos, afirmou que desde a idade de 10 anos caminha para os fechos de gerais, e que seu uso vem passando de geração em geração. E falou da procedência dos seus ancestrais:

\footnotetext{
José: o Sr. Estava falando dos avós do senhor que o senhor nem conheceu e... o senhor sabe se eles nasceram aqui, ou não?

Sr. João de Castro: moço eu credito que nasceu por aí né? Que meu avô, Manezinho, esse que eu não conheci, dois avô, não conheci. Quando eu nasci, eles já tinha... meu avô Manezinho foi pro Paraná, fazer um tratamento e de lá não voltou, né? E outro quando eu nasci ele já tinha morrido...

José: ele nasceu nessa região aqui?

Sr. João de Castro: foi ali na Baixa Grande.

José: é comunidade próxima?

Sr. João de Castro: é. Ali na Baixa Grande, né? Próximo ao Fundão, né?

José: e os pais do Sr. quando nasceram?

Sr. João de Castro: eles todos dois é de 1901, né?

José: os pais ou seus avós?

Sr. João de Castro: os pais, né?

José: nasceram aqui nas proximidades?

Sr. João de Castro: é. Ela também nasceu lá e meu pai nasceu no Catulé. Justamente onde meu avô e minha avó da parte do véi morava lá, né? José: eles estão enterrados aqui nesse cemitério?

Sr. João de Castro: minha avó é lá no cemitério do Catulé e os de lá, todos os dois é no cemitério do Tatu (Sr. João de Castro, comunidade do Brejo Verde, trabalho de campo realizado em janeiro de 2012).
} 
O Sr. João Magalhães, 82 anos de idade, usuário do fecho de gerais de Gado Bravo, Galho da Cruz e Lodo e morador da comunidade Pombas, também não conseguiu precisar o início dos usos dos fechos de gerais.

José: o Sr. se lembra quando começaram soltar gado para aqueles lados? (nos gerais).

Sr. João Magalhães: não. Eu não lembro. Porque meu pai soltava gado direto. Aí quando eu entendi por gente, já meu pai soltava o gado... ...aí depois fui ficando grandim, tal, fui até pros gerais também. Montava no meio da carga. Que sempre levava uma carga, né? Aí eu ia no meio da carga. Aí foi, foi, inté eu montei num cavalo sozinho, que eu ia. Aí agora eu tomei conta. Aí eu trabalhei mesmo (Sr. João Magalhães, morador da comunidade de Pombas, trabalho de campo realizado em julho de 2011).

O Sr. Abdias de Souza Brito, 90 anos de idade, morador da comunidade de Brejo Verde e usuário do fecho do Brejo Verde indicou a antiguidade da ocupação:

José: Quando chegaram aqui, o senhor tem essa lembrança, essa informação?

Sr. Abdias: Quando eu entendi por gente isso aqui era de um avô meu aqui. Eram três irmãos sócios que comprou isso aqui. E o sítio pra lá, era o sítio de dois irmão. Irmão do meu avô. Era meu avô mais dois irmão, né? Depois quando eu entendi por gente, já meu pai era que manobrava a terra do meu avô.

José: e o Sr. tem informação de quando começou chegar gente aqui nesse lugar? Quando mais ou menos? O senhor falou do seu avô, mas quando ele chegou já morava gente aqui...

Sr. Abdias: não foi do meu tempo.

José: o senhor andou para os gerais muito tempo soltando gado?

Sr. Abdias: antigamente era eu quem ia.

(Sr. Abdias Souza Brito, comunidade do Brejo Verde, trabalho de campo realizado em janeiro de 2012).

A ocupação das áreas onde se situam as comunidades é, portanto, de tempos remotos e os interlocutores, de idades entre 70 e 90 anos, fazem referência aos avós, muitos deles, naturais da região. E, como se sabe, a tradicional prática da pecuária é transmitida de geração em geração, e os fechos de gerais sempre se constituíram como áreas de criatórios desde que aquelas localidades foram ocupadas.

Outro interlocutor, o Sr. José Francisco Dourado (Sr. Deca), de 83 anos de idade, morador da comunidade de Catolés e usuário do fecho de Gado Bravo, Galho da Cruz e Lodo, refere-se à procedência dos seus ancestrais:

Jamilton ${ }^{179}$ : então, a gente fazendo o estudo aqui, percebemos que nesse vale, desde ha duzentos anos, há cem anos atrás, pessoas habitavam por aqui, né? Como próprio seu Deca mesmo, a família do seu Deca, é da família Catoléteo mesmo. De

\footnotetext{
179 Jamilton Magalhães, comunidade de Buriti, trabalho de campo realizado em janeiro de 2010.

${ }^{180}$ A "família Catolé" é remanescente de populações indígenas que habitam na região.
} 
família que morou aqui há muito tempo. O senhor sabe mais ou menos a quanto tempo, a quantos anos seu pai morreu?

Sr. Deca: parece que morreu com 84?

Jamilton: foi sepultado aonde?

Sr. Deca: foi sepultado lá em Brasília, que ele mudou pra lá. Ele e mãe. Ele mudou pra lá em 57.

José: 84 anos e ele nasceu aqui?

Sr. Deca: é ele nasceu aqui.

José: e o seu avô também era daqui?

Sr. Deca: era daqui. Era também.

José: o senhor lembra o ano de nascimento dessas pessoas?

Sr. Deca: do meu avô, não lembro não. Lembro nem da era do meu avô, não alembro não.

Jamilton: ele foi sepultado aonde?

Sr. Deca: aqui mesmo. Nasceu, criou, morreu aqui.

José: seu avô nasceu aqui?

Sr. Deca: é nasceu aqui. Nasceu, criou e morreu, a mãe dele... eu não sei como é que chamava o pai dele. Sei que a mãe se chamava Fortunata, velhinha, essa eu ainda era menino mais conheci. Já a minha avó, mulher do meu avô eu não cheguei a conhecer.

Esposa do Sr. Deca: ela morreu com quase uns cem anos... quase uns cem anos, tava meio banguelinha.

José: e eles vieram de onde? Quem chegou aqui primeiro veio de onde?

Sr. Deca: não sei. Essa parte aí eu não sei explicar para o senhor, quem chegou por aqui primeiro eu não sei da onde veio.

Esposa do Sr. Deca: que já nasceram aqui... nasceram a 120 anos já era daqui.

Jamilton: e todo esse povo tinha o costume, né? De levar, usar os gerais...

Sr. Deca: é de usar os gerais. Usar os gerais. Eu mostro todo lugar que pai trabalhava nos gerais, mostro tudo, o finado meu avô, mostro tudo. Minha vó é sepultada lá, o outro avô que era marido da avó é sepultado ali no Lodo (nos gerais), mostro tudo.

José: seu Deca cria na mesma área que você (Jamilton) cria...

Jamilton: é na mesma área.

José: porque o senhor escolheu aquela área para criar?

Sr. Joaquim Francisco Dourado ${ }^{181}$ (filho do Sr. Deca): porque já era a área de posse.

Sr. Deca: a área de posse antiga.

Sr. Joaquim: era área de posse dos avôs dele.

Sr. Deca: dos meus avô.

Sr. Joaquim: ...aí através deles, a gente como não dava conta de fechar tudo, aí foi chamando um amigo, um ali chama um outro, ali foi botano um pedaço de cerca, até fechou. Ficou esses 12 donos, esses 12 dessa qualidade. Mais muitos desses 12 que ta lá dentro, eles tem título de campeão de avô deles. E já deu título de campeão dos avôs deles, que nasceu, criou trabalhando lá dentro.

José: agora nós estamos contando a história do fecho que você cria... e aqueles outros fechos, todos têm essas histórias?

Sr. Joaquim: já daí os outro é assim: desses daí, quando não era posseiro, mas saía daqui naquela época, botava as roças lá, trabalhava como posseiro também. Cada posse que ele botava era dele. E dali por diante eles iam criando a comunidade deles e levando o gado pra lá também. Para localizar o gado, quem não tinha o gado, botava roça. O arroz, o feijão, essas coisa assim, de brejo. Naquela época, né? Porque, aí pronto, aí cada vez vai ter filho, vai crescendo, compra um gado, compra outro, quando você pensa que não a comunidade ta maior e vai apoderando daquilo. Então mais todo mundo tem título de campeão de dentro da área.

181 Joaquim Francisco Dourado, comunidade de Catolés, trabalho de campo realizado em janeiro de 2010. 
José de Souza Martins explica o aspecto particular da apropriação da terra pelo posseiro. Segundo ele,

a noção de posse é uma noção que privilegia não a terra, mas o trabalho: a terra entra como o instrumento do trabalho, como mediador do trabalho. Esta é uma mudança muito significativa, uma diferença muito significativa em relação às concepções e procedimentos dos proprietários de terra que aparece por lá, os "paulistas", devastando, expulsando, etc. Trata-se, portanto, como já foi dito, de um problema de uso da terra, esta forma de usar a terra, esta forma livre de ocupar a terra. Mas se trata também de uma outra coisa, uma coisa que é essencial na vida do migrante, do migrante posseiro. Ele luta radicalmente pela sua liberdade, a terra e a liberdade. Eu não vejo como falar só na terra. Frequentemente, tenho ouvido pessoas discutindo a problemática das novas regiões em termos estritamente da terra porque, de fato, a pedra de toque está na terra, mas há este outro elemento, ideológico, que marca muito a existência e os movimentos dos posseiros que é o problema da sua liberdade, a sua liberdade de trabalho familiar, a sua liberdade de trabalho autônomo, a sua liberdade de locomoção, a sua liberdade de decisão (MARTINS, 1981, 131).

A terra para o posseiro assume a função de instrumento de trabalho, por meio do qual, com o trabalho familiar, extrai-se os meios de vida para a família, e, assumindo esta função na reprodução da vida, luta-se pela apropriação (tornar-se dono) a fim de garantir a sua reprodução em situação de liberdade das formas opressoras de submissão do trabalho.

Aproveitavam das terras livres para a reprodução socioterritorial. Deslocavamse para a montante, para os altos gerais, a fim de formarem roças. Se a localidade era favorável, ali iniciavam botar sítio ${ }^{182}$, e, a partir de então, aqueles que tinham gado, criavam soltos nos cerrados e plantavam, no fundo de vale, na vereda, formando inclusive comunidades. É o exemplo da comunidade do Lodo e de outras que, mesmo com a proibição de uso agrícola das veredas, resistiram e permanecem, tais como as comunidades dos altos gerais de Arrojadinho, Couro de Porco, Bebedouro, Passaroto, Cajueiro, Puçazeiro e Pimenteiras.

José: e ainda plantam nessas localidades dos gerais?

Sr. Joaquim: não. Plantar eles não planta mais porque o IBAMA, o meio ambiente recusou para eles não trabalhar mais em brejo. Não pode mais eles ficou, não trabalha mais em brejo, mais eles ficou com a área coletiva deles tudo para criar gado. Dos animais (Sr. Joaquim Francisco Dourado, comunidade de Catolés, trabalho de campo realizado em janeiro de 2010).

Os relatos do Sr. José Francisco Dourado, sua esposa, Sr Joaquim Francisco Dourado e Jamilton Magalhães acrescentam importantes elementos: além de criadores nas áreas de imediações da comunidade do Lodo, onde seus ancestrais

\footnotetext{
${ }^{182}$ O mesmo que formar sítio, ou seja, sedentarizar-se onde se pode a partir da aglomeração de outros geraizeiros, forma uma comunidade.
} 
moravam, também plantavam grande variedade de produtos alimentícios na área ribeirinha do Arrojado, na vereda, prática esta proibida na atualidade pelos órgãos ambientais, pois, foram destinadas para reserva ambiental das áreas tomadas dos geraizeiros.

O mesmo processo de ocupação se deu nos fechos de gerais do entorno e, porque não dizer, ao longo de todo o curso do rio Arrojado e de alguns afluentes em suas áreas ribeirinhas. Cabe destaque neste aspecto à afirmação de que as famílias deslocavam-se para estas localidades a fim de plantarem roças e, ao mesmo tempo, aqueles que possuíam gado, o levavam para permanecer nos gerais, onde eram criados soltos e misturados aos dos demais companheiros, amigos, tal como o grupo de 12 usuários do atual fecho de Gado Bravo, Galho da Cruz e Lodo. O vale do Arrojado, por ser constituído de terras públicas, livres, gerais, permitia, por conseguinte, na medida em que a população aumentava nas áreas de ocupação mais antigas, a reprodução socioterritorial do camponês geraizeiro, devido aos usos que tradicionalmente fizeram e fazem dos gerais. Esses 12 criadores do referido fecho, conforme reltou o Sr. Joaquim Francisco Dourado, são posseiros das terras nas quais atualmente criam, mas no passado também plantavam. Através das relações de amizade, compadrio e parentesco com integrantes de outras comunidades, formavam grupos de criadores, que futuramente favorecem a associação para as providências nos cercamentos das áreas de criatórios com vistas a se defenderem das investidas dos grileiros. Inclusive, na atualidade, este grupo de criadores encontra-se em uma situação de conflito acirrado com o grupo inglês CFM-Agropecuária, que investe na tomada de suas posses.

Estas relações conflituosas e as proibições dos usos agrícolas da terra, impostas pelos órgãos governamentais de meio ambiente - apesar dos engendramentos que se realizam, tais como a ampliação dos regos, com vistas a compensar as perdas territoriais da montante - são importantes causadoras do aumento da migração que se verifica nas comunidades geraizeiras da jusante, assim como nas próprias ribeirinhas da montante. O caso da comunidade do Lodo é exemplar neste aspecto: das 60 famílias que ali residiam, atualmente restam apenas 12. Em grande parte, seus membros se tornaram trabalhadores nas terras que antes Ihes pertenciam, embora submetidos e submissos às precárias relações de trabalho que os tomadores de suas terras oferecem. 
Um elemento que considero bastante explicativo e significativo da ocupação geraizeira, particularmente exemplificada na família do Sr. José Francisco Dourado, diz respeito à sua ascendência dos índios Catolés. Isto é convidativo a uma investigação de maior vulto, pois a condição de remanescente indígena, por si só, conforme a Constituição Brasileira de $1988^{183}$, Ihes confere o inquestionável direito à terra. E este povo, conforme o Sr. José Francisco Dourado e o Sr. Joaquim Francisco Dourado apontam, apesar da dispersão a que se submeteram, são frequentemente encontrados como integrantes das comunidades ao longo do vale do rio Arrojado.

Nos trabalhos de campo, foi coletada grande quantidade de depoimentos e todos convergem no sentido da comprovação da antiguidade dos usos dos gerais, quais sejam pelas comunidades moradoras das áreas do baixo vale do Arrojado, ou daquelas que fizeram sítio nas áreas ribeirinhas, embora mais dispersas, ao longo de todo o curso do rio. Não obtive, entretanto, por meio desses depoimentos, qualquer noção da época em que se iniciaram a formação dessas comunidades. Isto, muito provavelmente, se deve à anterior ocupação dos gerais pelos nativos, os quais, quando da chegada das frentes expansionistas relacionadas à ocupação

\footnotetext{
${ }^{183}$ Art. 231. São reconhecidos aos índios sua organização social, costumes, línguas, crenças e tradições, e os direitos originários sobre as terras que tradicionalmente ocupam, competindo à União demarcá-las, proteger e fazer respeitar todos os seus bens.

$\S 1^{\circ}$ - São terras tradicionalmente ocupadas pelos índios as terras por eles habitadas em caráter permanente, as utilizadas para suas atividades produtivas, as imprescindíveis à preservação dos recursos ambientais necessários a seu bem-estar e as necessárias a sua reprodução física e cultural, segundo seus usos, costumes e tradições.

$\S 2^{\circ}$ - As terras tradicionalmente ocupadas pelos índios destinam-se a sua posse permanente, cabendo-lhes o usufruto exclusivo das riquezas do solo, dos rios e dos lagos nelas existentes.

$\S 3^{\circ}$ - O aproveitamento dos recursos hídricos, incluídos os potenciais energéticos, a pesquisa e a lavra das riquezas minerais em terras indígenas só podem ser efetivados com autorização do Congresso Nacional, ouvidas as comunidades afetadas, ficando-lhes assegurada participação nos resultados da lavra, na forma da lei.

$\S 4^{\circ}$ - As terras de que trata este artigo são inalienáveis e indisponíveis, e os direitos sobre elas, imprescritíveis.

$\S 5^{0}$ - É vedada a remoção dos grupos indígenas de suas terras, salvo, "ad referendum" do Congresso Nacional, em caso de catástrofe ou epidemia que ponha em risco sua população, ou no interesse da soberania do País, após deliberação do Congresso Nacional, garantido, em qualquer hipótese, o retorno imediato logo que cesse o risco.

$\S 6$ - São nulos e extintos, não produzindo efeitos jurídicos, os atos que tenham por objeto a ocupação, o domínio e a posse das terras a que se refere este artigo, ou a exploração das riquezas naturais do solo, dos rios e dos lagos nelas existentes, ressalvado relevante interesse público da União, segundo o que dispuser lei complementar, não gerando a nulidade e a extinção direito a indenização ou a ações contra a União, salvo, na forma da lei, quanto às benfeitorias derivadas da ocupação de boa fé.
} 
portuguesa no país, já se encontravam ali, e a miscigenação se processou a partir de então.

\title{
4.11.2 O processo de constituição dos fechos de gerais
}

Conforme me referi antes, em função da ausência de cercas nas imensas áreas geraizeiras do Oeste da Bahia, os camponeses tinham plena liberdade para circularem e se apropriarem das diversas riquezas naturais dos amplos gerais. Assim, praticavam o extrativismo animal (caça e pesca) e vegetal, formavam suas roças e soltavam seu gado nos gerais, na localidade que thes conviessem. Mas cabe agora focar no grau de liberdade de apropriação dos gerais que os geraizeiros usufruíam em condições de terras livres de apropriação privada. Quanto ao uso pecuário, os grupos de criadores pretendentes à determinada área formavam-se a partir de laços de afinidades, os amigos, como gostam de falar - na verdade parentes, compadres, vizinhos.

\begin{abstract}
para criar o fecho, digamos, assim, já sabe, né? Através da velha amizade, tal, até mesmo do pastoril do gado. Aí eles criam aquele fecho ali, isso é muita gente... também a questão parentesco. Tanto é que hoje já quebrou muito esse protocolo de parentesco, né? Agora seu fulano vendeu para seu beltrano. Aí outro... já não é mais parente, é comunitário, tal, é de várias comunidades (Jamilton Magalhães, morador da comunidade de Buriti e criador do Fecho de Gado Bravo, trabalho de campo realizado em janeiro de 2012).
\end{abstract}

Inclusive, o gado também influía nesta escolha, pois, ao ser levado para determinada área, ou mesmo saindo antecipadamente das áreas de sítio das comunidades, já se dirigiam para aquela localidade onde encontrava pasto bom $e$ aguada boa. Fator aparentemente prosaico, mas merece consideração, pois, se fazem relevantes para a alimentação do gado as amplas áreas de veredas, com grande oferta de gramíneas e em terra firme, onde não se arrisque a atolamentos, permitindo também, sem que se corra o mesmo risco, o bom acesso às aguadas.

Atendidos esses requisitos, o grupo de criadores providenciava a instalação da infraestrutura que atendesse às suas necessidades enquanto estivesse nos gerais, bem como a necessária para os cuidados com os animais. Para tanto, construía-se o abrigo, o rancho, onde se deixam as ferramentas de trabalho nos cuidados com as cercas, preparam os alimentos e repousam. Também construíam, 
nos arredores ou em áreas próximas, o mangueiro ${ }^{184}$, de onde vem no primeiro momento o termo fecho de gerais. Vem do fechar ${ }^{185}$. Neste mangueiro, prendem o gado para a realização de alguns cuidados ou para reuni-lo e retornar às áreas de sítio das comunidades, e nele também permanecem os cavalos utilizados diariamente no campear do gado. Ainda nos arredores de alguns ranchos encontram-se os cochos, nos quais servem o sal para o gado, e os currais que facilitam os trabalhos de cura, vacinação e ordenha, quando se faz necessário permanecer por longos períodos nos fechos (fotos 22 e 23).

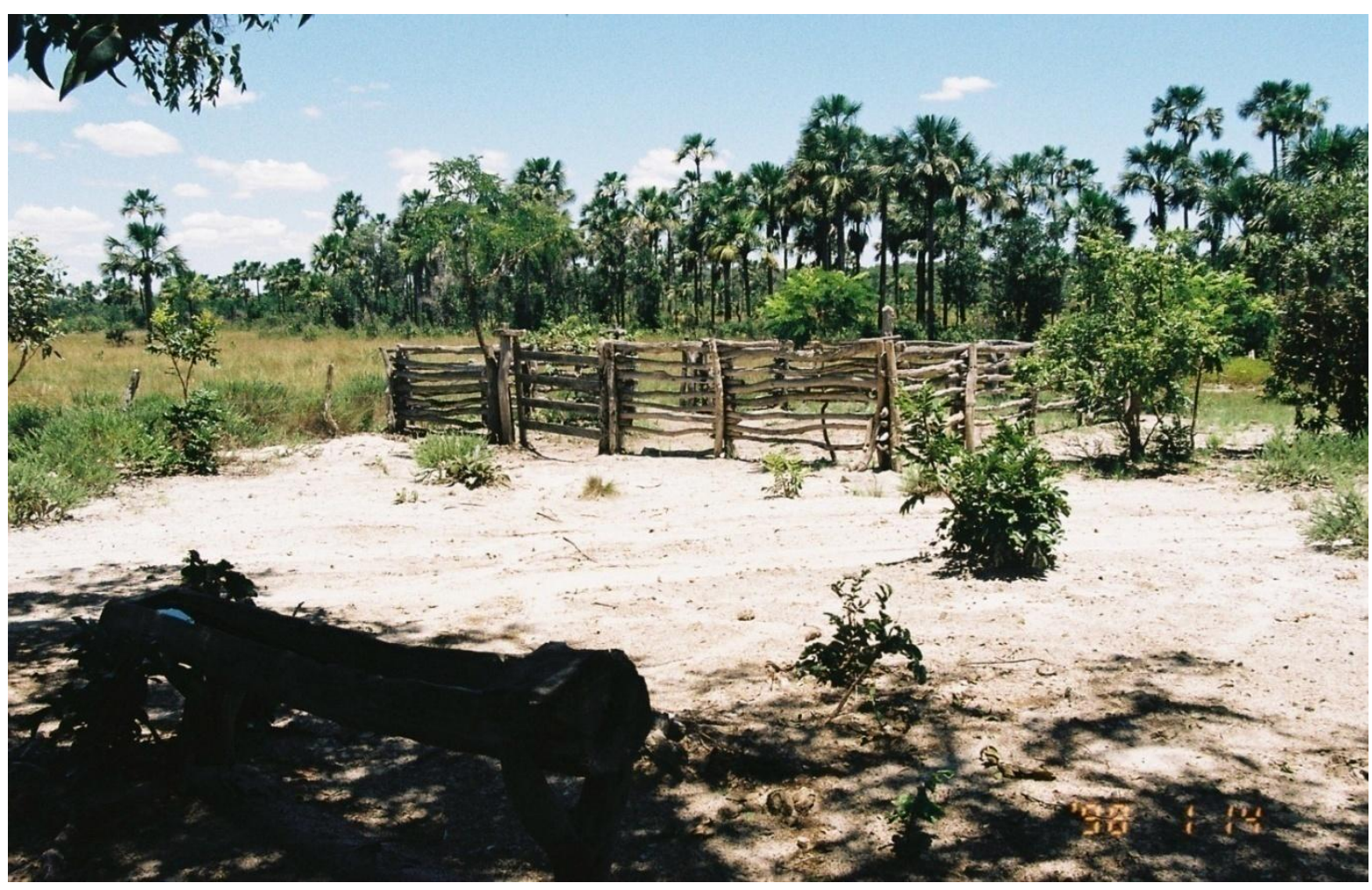

Foto 22 - Cocho e curral, fecho de gerais de Entre Morros à Morrinhos. Correntina - BA. Sousa Sobrinho, J. (jan. 2010).

\footnotetext{
${ }^{184}$ Pequeno cercado construído com estacas de madeira e arame farpado.

185 Do depoimento de Jamilton Magalhães.
} 


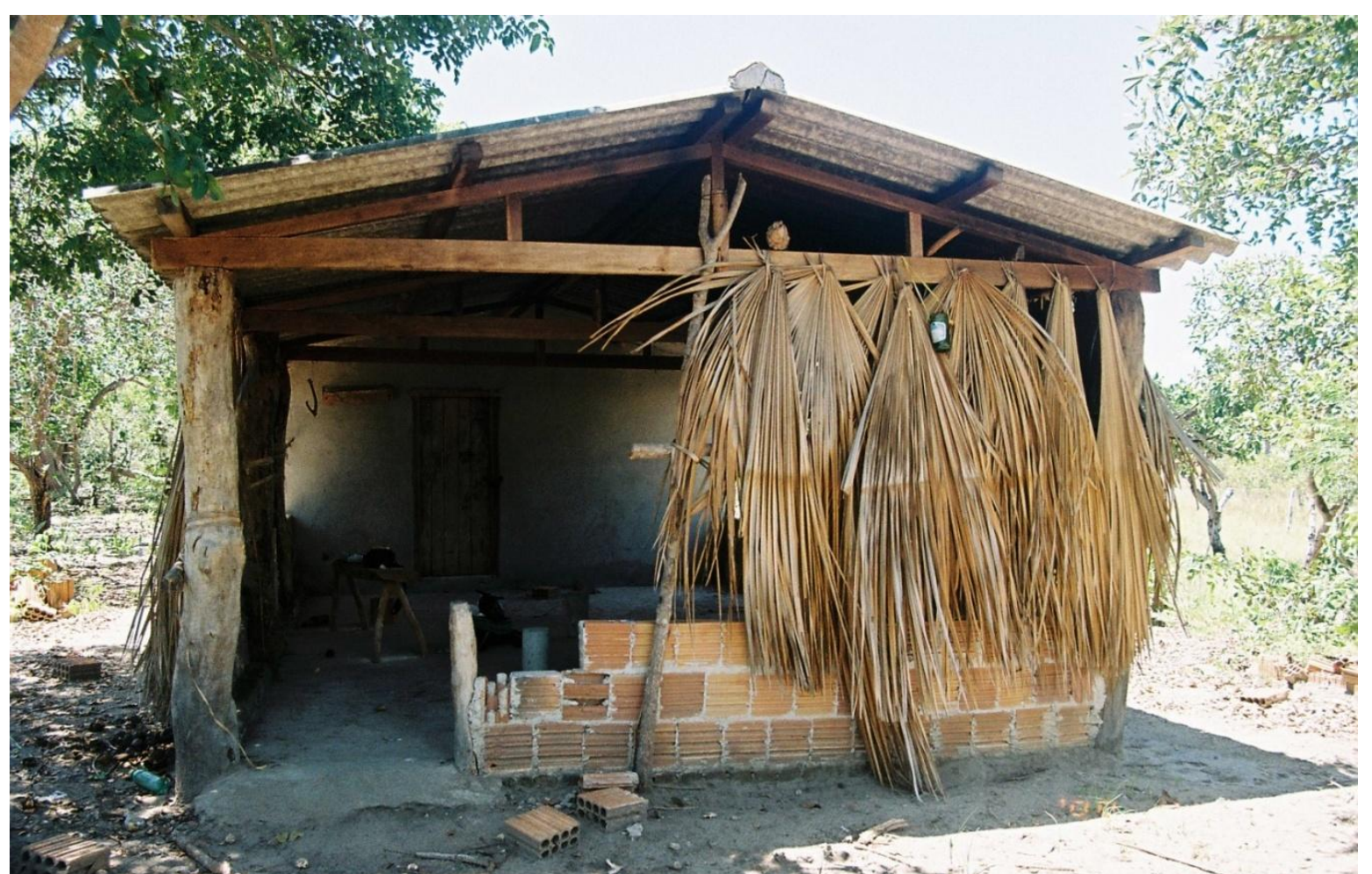

Foto 23 - Rancho do fecho de gerais de Entre Morros à Morrinhos. Correntina - BA. Sousa Sobrinho, J. (jan. 2010).

Se, tradicionalmente, o termo fecho de gerais fazia alusão apenas aos mangueiros, únicos cercados que se pudesse encontrar nos amplos gerais, a partir dos processos sociais que vêm ganhando vulto nas últimas décadas, principalmente a presença da grilagem das terras geraizeiras, os fechos de gerais atualmente se referem também a uma área muito maior, a apropriada pelo grupo e que foi cercada com vista, sobretudo, a se defender dos grileiros que investem violentamente sobre elas com a pretensão de tomá-las.

Dentro de uma mesma área de fecho é comum encontrarem-se mais de um rancho. Isto se deve aos processos internos ao grupo. Como nos relatou Jamilton, as áreas de fecho inicialmente foram apropriadas por grupos de amigos e, com o passar do tempo, foi-se quebrando o protocolo e algumas transferências ocorreram para outros, não mais integrantes da família ${ }^{186}$, embora das comunidades. Este fator soma-se ao natural crescimento das famílias e aos grupos que se polinuclearam, desenvolvendo, com isto, grupos constituídos de integrantes com maiores

\footnotetext{
${ }^{186}$ Aqui me refiro à família que pode corresponder ao grupo pouco mais extenso do que a família de procriação ou família conjugal conforme Martins (1975, p.106) ou na acepção utilizada por Chayanov (1925, p. 54 apud SHANIN 1979, p. 25): como decían los campesinos rusos, el hecho de 'comer de la olla común', mas também pode constituir-se de dos o três generaciones (SHANIN, 1979, p.25) ou mais, a base formadora das sociedades camponesas, no caso estudado, vivendo em comunidade.
} 
afinidades, geralmente pais, filhos, genros. Em função disso, houve casos de separação de ranchos e surgiram vários outros dentro de um mesmo fecho, construídos por iniciativas daqueles que pretendiam usufruir de maior privacidade frente ao grupo que se tornou demais numeroso como o exemplo do fecho da Associação de Morrinhos a Entre Morros, Gado Bravo a Ribeirão. Na margem direita do rio Arrojado, a figura nos mostra os seguintes fechos e os seus respectivos ranchos (figura 14).

A tradicional delimitação das áreas se notabiliza pela precariedade e pela pouca precisão. E, neste aspecto, faz-se relevante a configuração natural das áreas de cerrados, dos gerais. Pode-se ver o traçado do rio Arrojado e dos seus respectivos afluentes, pelos geraizeiros chamados de galhos (figura 14). Estes, em princípios, eram as únicas barreiras interfechos de gerais, limitando, até certo ponto, a possibilidade de mistura dos rebanhos dos diferentes grupos.

Este fator, inclusive, merece nota, dadas as tradicionais relações dos geraizeiros com a natureza em nível do imediato - desprovidas de mediação de técnicas modernas - muitas das barreiras constituíam-se limitantes aos acessos ou à transposição no contato direto com o corpo ou, quando mediadas, se utilizavam de técnicas pouco evoluídas.

Nesse sentido, os aspectos físico-geográficos do ambiente local exerceram e exercem importante influência na configuração da ocupação que se apresenta nos gerais, tanto no que diz respeito aos sítios das comunidades geraizeiras do baixo vale do rio Arrojado quanto às áreas usadas pelos grupos de criadores a montante. Em função disso, são muito comuns os nomes das comunidades remeterem-se ao nome do galho ${ }^{187}$, riacho ou forma do relevo. Como exemplo, cito o riacho do Jatobá, nominando a comunidade do Jatobá, o galho Barra das Lages, nominando a comunidade de Barra das Lages, riacho do Bonito, nominando a comunidade do Bonito, entre outros. Nas áreas de criatórios, nos gerais, da mesma forma vemos o galho de Entre Morros, nominando o Fecho de Entre Morros, o galho do Gado Bravo, nominando o Fecho do Gado Bravo, o galho do Catolés, nominando tanto a comunidade quanto o Fecho do Catolés e assim segue o uso da toponímia.

\footnotetext{
${ }^{187}$ Uso as expressões galho ou riacho tal como os interlocutores empregaram ao referirem-se às citadas localidades. Porém, pude observar que galho ou riacho são sinônimos e uma ou outra se refere à mesma coisa, ao pequeno afluente do rio Arrojado.
} 


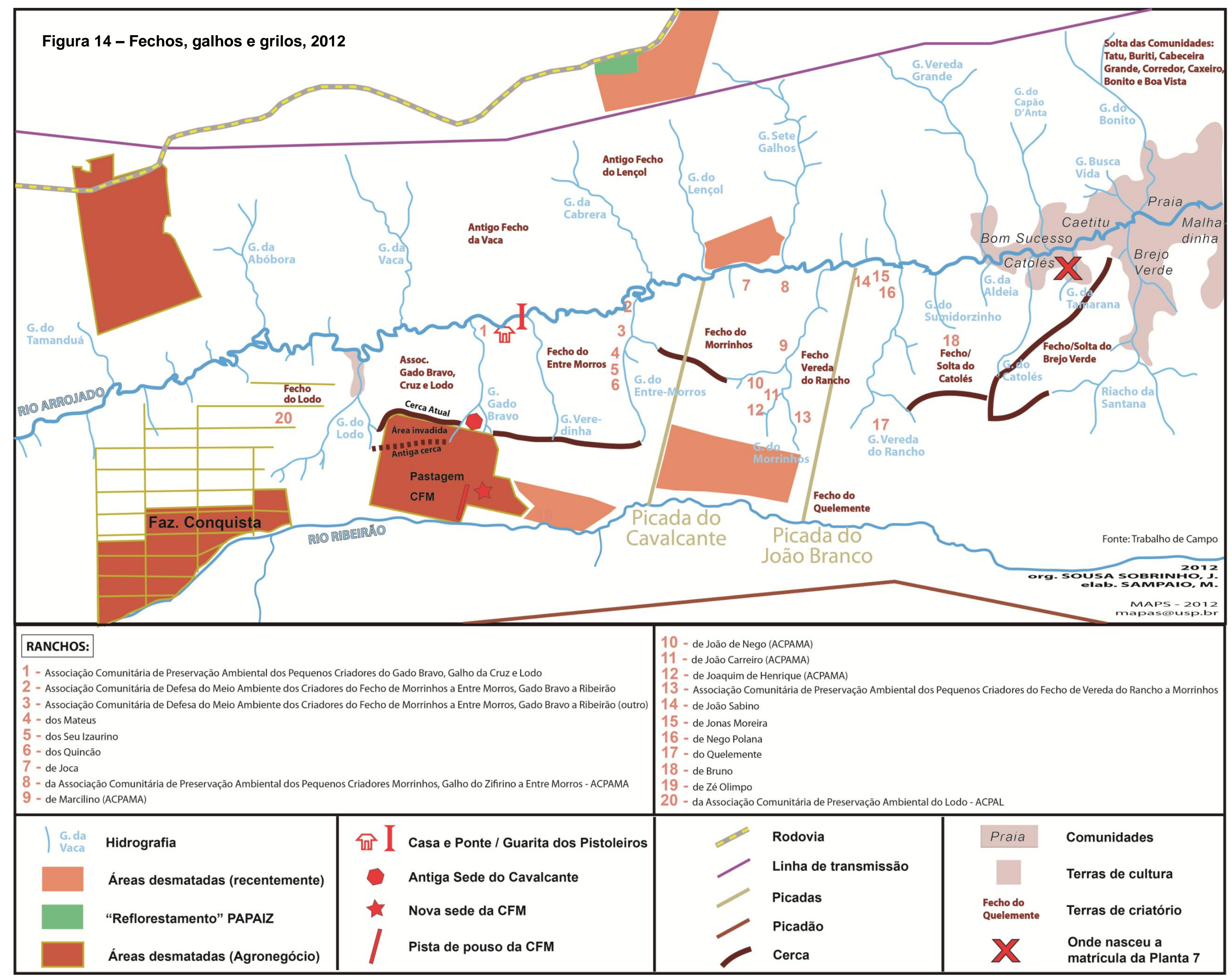




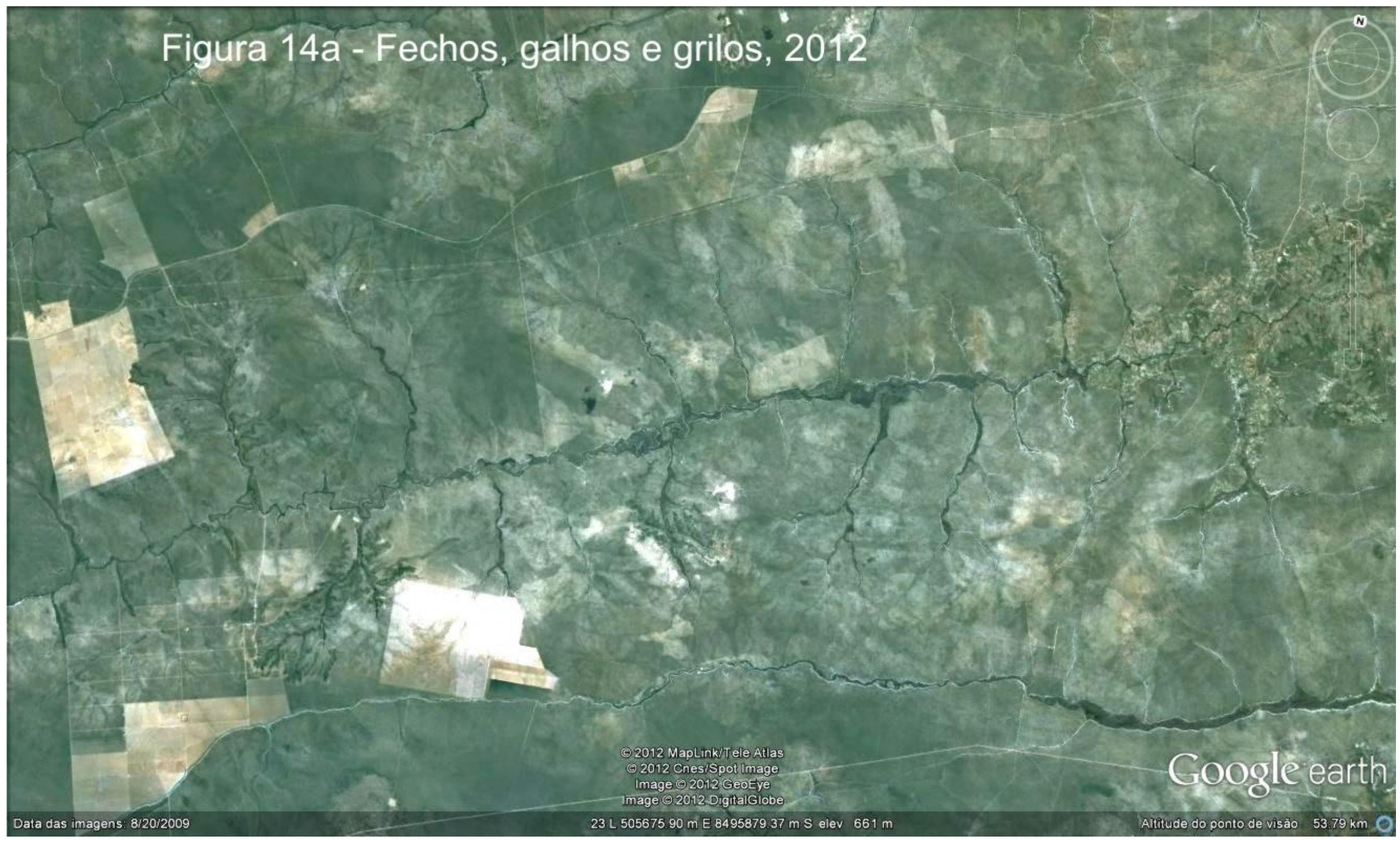


Essas observações revelam o grau de liberdade de uso das terras geraizeiras pelos criadores e as respectivas relações sociais que se estabeleciam com vista à concretização do objetivo que se processa, a territorialização camponesa nos gerais. Nos primórdios da ocupação, se alguma limitação houvesse nos acessos às diferentes áreas de criatórios, ou delimitação destas, eram os pequenos riachos e o rio que cortam os gerais. Mas cabe também relativizar essas barreiras, pois, até mesmo o rio Arrojado, em alguns pontos, poderia ser atravessado pelo gado se fosse percebida uma alimentação mais atrativa do outro lado, tal como nos relatou um usuário de fecho:

acontece muito do gado atravessar o rio (Arrojado) de um lado para o outro... o gado comia de cá, se o gado achasse por bem atravessar para o outro lado, se tinha mais queimadas boas que é uma coisa que chama, atrai o gado muito bem, chama a atenção é a queimada e o gado vai no cheiro (Jamilton Magalhães, criador do fecho de Gado Bravo, trabalho de campo realizado em julho de 2011).

Quanto à alimentação do gado nos gerais, nota-se uma relação com o tipo de cobertura vegetal e com as condições climáticas durante o ano - e enquanto o gado permanece no fecho. Neste sentido, se fazem relevantes as partes rebaixadas dos cerrados compreendidas pelas veredas (com abundante oferta de gramíneas) e as mais elevadas, encobertas pelos cerrados propriamente ditos. Cito o exemplo da permanência de outubro a meados de dezembro. Se o ano foi bom de chuva, o gado prefere alimentar-se da vegetação dos cerrados, nas áreas mais elevadas, Ihe atraindo mais as gramíneas (extrato rasteiro) um tanto rarefeitas, as pequenas palmeiras, como o tucum, bages e folhas de arbusto e árvores ${ }^{188}$. No entanto, se $o$ ano não foi bom de chuva, os cerrados são em grande parte submetidos às queimadas e a alimentação é escassa ou até inexistente porque os brotos não saíram. Nessas condições, o rebanho permanece nas áreas baixas, nas veredas, áreas mais úmidas, a se alimentar das gramíneas, do broto mole, que sai após as queimadas. Do mesmo modo, interlocutores afirmam que nas proximidades das parcelas (na jusante) nos anos de seca, a mata (muito presente e pastada pelo gado no passado) assim como o capim agropolo nos dias atuais, secam e se torna

\footnotetext{
${ }^{188}$ Alguns interlocutores ressaltaram a habilidade do gado da raça zebu no pastejo das folhas das árvores, até mesmo quando relativamente altas, rebaixando-as com o peito para comerem as folhas. Macedo (1952, p.30) também enfatiza o grau de adaptação do gado que tem como única fonte provedora de víveres enquanto permanece nos gerais, o que os cerrados lhe oferta: "a capacidade que tem o zebu de erguer-se sôbre os membros posteriores para agarrar e puxar com a bôca os ramos mais altos é, sem dúvida, uma qualidade positiva para sobrevivência ao meio. Não obstante, o curraleiro resiste mais aos efeitos da sede".
} 
escassa a alimentação e pouco atrativa para o gado. ${ }^{189}$ Quando isso ocorre, o gado sente o cheiro (do broto mole) e berra pedindo para ir para os gerais, ou, se possível, ia embora sozinho. Ou, conforme Macedo (1952, p.9), "os animais que se habituam a subir para os "gerais", se não conduzidos na época, tomam a iniciativa da viagem, nada havendo que os impeça de fazê-lo. Migram, seguindo os imperativos da natureza, que os ensina a se defender da seca". Nos dias atuais, entretanto, a privatização das terras e as respectivas cercas, os impedem dessa autotransumância e seu João Magalhães reforça: hoje não, porque tem cerca pra todo lado. ${ }^{190}$

Se o gado pasta mais nas áreas elevadas ou nas baixadas, isto implica em diferença qualitativa e quantitativa de trabalho dos criadores.

No ano bom de chuva, a vegetação dos cerrados nas partes elevadas, logo cedo, finais de setembro ou início de outubro, mesmo tendo sido queimada ${ }^{191}$, já brotou e está verde. Ali o gado pasta, porém, disperso nos amplos cerrados e demandando andanças do vaqueiro a campear ${ }^{192}$.

\footnotetext{
189 Os criadores evitam deixar o capim agropolo crescer demasiadamente, pois, no início da estação seca, os talos compridos do capim secam e se tornam pouco atrativo para o gado. Para evitar que isto ocorra, mesmo em períodos que o gado encontra-se nas áreas das comunidades (mangas e/ou soltas) faz-se necessário controlar o crescimento do capim intercalando estadas do rebanho na solta e na manga para efetuar a apara do pasto, evitando assim, o desperdício de biomassa.

${ }^{190}$ Depoimento do Sr. João Magalhães usuário do fecho de gerais de Gado Bravo, Galho da Cruz e Lodo, e morador da comunidade de Pomba. Trabalho de campo realizado em julho de 2010.

${ }^{191}$ As queimadas anuais da vegetação de cerrados, geralmente no mês de setembro, constituem-se prática tradicional no manejo dessa fonte de víveres para o gado. Com o advento das primeiras chuvas, geralmente no mês de outubro, sai o broto das gramíneas da qual o gado se alimenta ao ser retirado das áreas parcelares, ou das soltas próximas, quais sejam das matas ou das mangas, cuja alimentação, em função da seca foi exaurida. Entretanto essa prática costumeira das queimadas tem sido proibida pelos órgãos ambientais do Estado, e, embora isto tenha significado uma piora significativa na qualidade e oferta da alimentação, os geraizeiros, por não terem alternativas, persistem na prática de soltura do gado nos fechos de gerais.

${ }_{192}$ As áreas dos fechos de gerais, de modo geral, são amplas. No caso estudado, variam entre 2 mil e 11 mil hectares. Para o trabalho do campeio, o vaqueiro desenvolveu grande perspicácia e recursos dentre os quais o uso do chocalho a ser portado pela rês conforme Macedo (1952, p. 32) descreve: "aparentemente os chocalhos são todos iguais, mas para o ouvido atilado do vaqueiro os sons emitidos têm matizes próprias, possibilitando-lhe reconhecer e identificar as reses portadoras. Sua perspicácia chega ao ponto de saber pelo som, se o animal está deitado ou em pé, imóvel ou andando e, por incrível que possa parecer, conhece-lhe até o próprio estado de ânimo, se calmo, alegre ou assustado.

A escolha do animal para receber o chocalho demanda longas observações e conhecimentos sobre os hábitos do mesmo. Como há tendência do rebanho separar-se e dividir-se em pequenos grupos, a escolha recairia no animal de cada lote que demonstrasse maior docilidade. Os vaqueiros chamam de 'pasteiras' as vacas assim dóceis [...] [...] verifica-se em torno da 'pasteira' de chocalho um fenômeno muito curioso: o grupo passa a obedecê-la e a segui-la, inclusive todas as vezes que ela se dirige ao bebedouro. Tal é esta influência - diríamos melhor - tal é a influência do som que, retirandose o chocalho, o lote se dispersa, indo os animais que o compunham para outros grupos onde possam ouvir o chocalho."
} 
Nestas condições, entretanto, aqueles cuja área de pasto formada na parcela aproxima ao atendimento à demanda do rebanho, muitas vezes nem precisam levar o gado para os gerais, porque a necessária brota do capim na manga realiza-se enquanto o gado permanece nas soltas próximas (quando existem) e/ou usufrui de rodízio nos piquetes.

Mas, para os criadores cujo tamanho do rebanho é significativamente desproporcional à área formada com pasto ocorre o contrário: há que levar seu gado para os gerais, mesmo sendo ano bom de chuva, porque as pastagens das mangas se exaurem e as soltas (quando existem) muitas vezes superlotam-se.

Porém, enquanto o gado está nas áreas de cerrados, as mais elevadas, não dá tanto trabalho, não é necessário vigiá-lo com muita frequência, e há criadores que não ficam lá. Apenas de 15 em 15 dias ou mais fazem uma vistoria e, nos intervalos, pedem notícia aos companheiros, se perceberam algo que necessite cuidados, pois, nessas áreas, os riscos a que se submetem são "apenas" as picadas de cobras, bicheiras e ataques de onças, se bezerros.

Nos anos considerados ruim de chuva, é diferente a dinâmica dos trabalhos nos cuidados com o rebanho. Após as queimadas - que, apesar das proibições, ainda ocorrem (com menor frequência), quais sejam por motivações naturais ou provocadas geralmente por caçadores, coletores de mel de abelha, ou por outros que infringem as determinações dos órgãos estatais de meio ambiente - a grande maioria dos criadores desloca a totalidade do seu rebanho para os fechos de gerais.

Em situação de seca, após as queimadas, os cerrados tardam a brotar e o gado concentra-se nas baixadas, onde o capim também é submetido às queimadas, mas, devido à maior umidade, brota logo em seguida. Assim, o gado permanece mais junto, o que diminui as andanças no campeio. Mas, além dos riscos mencionados, são submetidos a frequentes e graves atolamentos nas áreas antes inundadas e que se tornaram embrejadas com o recuo das águas. Esta situação de risco demanda a vigilância constante dos vaqueiros, que percorrem as áreas de veredas em grupos de dois ou três, porque o resgate do gado atolado demanda muito trabalho e força.

Nos últimos anos, as áreas de riscos de atolamentos têm aumentado em função das intervenções dos grileiros, que, a fim de tomarem as áreas de fechos, 
desmatam indiscriminadamente, inclusive as cabeceiras dos galhos alterando sobremaneira a amplitude no regime hídrico, o que aumenta a extensão das áreas inundáveis e que se tornam encharcadas após o recuo das águas. Estas condições demandam um grande número de criadores, que, apesar dos revezamentos que estabelecem com os companheiros, amigos, fazem-se necessário na vigilância do rebanho e tem aumentado as dificuldades, sobretudo, para os criadores que têm grande dependência dos gerais. Estes permanecem lá por até três meses ininterruptos, o que gera um grande descompasso com as atividades agrícolas a desempenhar na parcela, pois, nesta época do ano (mês de outubro) tem que preparar a terra para o plantio, tão logo caia a primeira chuva.

Há criadores que têm familiares que suprem esta necessidade de sobretrabalho, mas, em função da migração, principalmente de jovens na atualidade, muitos não conseguem formar suas roças.

Contudo, alguns insistem e pagam diárias para os trabalhos da roça, mas afirmam que fazem isso só para não perder o costume, pois, após a colheita, fazem as contas do quanto se gastou e descobrem que ficaram no prejuízo.

\subsubsection{A transumância do rebanho para os gerais}

A partir da década de 1970, as comunidades geraizeiras submeteram-se a uma série de processos sociais. Alguns deles são dominantemente impulsionados pela sua dinâmica interna e outros se constituem da aceleração das intervenções externas, marcadamente do desenvolvimento e da expansão da produção capitalista no campo, alterando sobremaneira as relações sociais de produção. ${ }^{193}$ Pode-se afirmar que os processos concernentes à dinâmica interna própria poder-se-iam se

\footnotetext{
${ }^{193}$ Isto se coaduna com o que afirma Raffestin (1993, p.161) acerca da territorialidade do siciliano: "a territorialidade de um siciliano, por exemplo, é bem constituída pelo conjunto daquilo que ele vive cotidianamente: relações com o trabalho, com o não trabalho, com a família, a mulher, a autoridade política etc. Entretanto não é possível compreender essa territorialidade se não se considerar aquilo que a construiu, os lugares em que ela se desenvolve e os ritmos que ela implica. Há a parte interna da territorialidade, o núcleo denso, em certo sentido, e a parte externa, aquela imposta pelos atores não sicilianos. A territorialidade siciliana é uma longa luta para preservar uma identidade, uma diferença, mas é uma luta esgotante contra o norte da Itália. O poder piemontês não obliterou a identidade siciliana, também não modificou sensivelmente as relações ancestrais mas, ao contrário, bloqueou a evolução da territorialidade e, ao mesmo tempo, foi modificado por essa relação exaustiva. Se o norte impôs à Sicília uma relação dissimétrica no plano econômico, a Sicília, em contraposição, impôs ao norte uma relação conflitual no plano político. A relação Itália-Sicília é a história do choque de duas territorialidades contraditórias, caracterizadas, respectivamente, por uma racionalidades econômica capitalista e uma racionalidade 'feudal'.
} 
desenvolver sem grandes transtornos, não fossem as intervenções externas limitando as possibilidades de expansão territorial e até mesmo expulsando-lhes de frações territoriais consolidadas de onde tradicionalmente, por meio do trabalho familiar, extraíam os meios necessários à sobrevivência.

Tradicionalmente, a prática da agricultura realizava-se nas áreas ribeirinhas, tanto nos sítios, nas parcelas, quanto em outras localidades apropriadas para esse fim ao longo do rio Arrojado. Os impedimentos à prática da segunda alternativa, aliados ao crescimento populacional nas comunidades, Ihes obrigaram a acelerar o desenvolvimento das forças produtivas, potencializando o uso da terra nas áreas de sítio bem como o das águas a partir da ampliação dos regos e do maior uso da técnica da irrigação agrícola.

No que diz respeito à pecuária, os geraizeiros tradicionalmente intercalavam os usos das áreas de soltas - nas matas ou nos gerais próximos às comunidades - com o uso dos gerais mais afastados, onde se encontram os fechos de gerais. Nesta dinâmica dos usos pecuários das terras, os deslocamentos do gado eram influenciados pelo regime climático e pelas respectivas condições da vegetação, conforme a estação do ano. Desta forma, logo no mês de maio, em função da diminuição das chuvas, a vegetação de matas secava, assim como as grotas onde o gado bebia esgotavam-se, e ele era levado para os gerais ou até, por se encontrar solto, ia sozinho. Nos meses de novembro ou dezembro, quando o broto dos cerrados, após as queimadas realizadas geralmente em agosto ou setembro, já se encontrava endurecido, e as matas das áreas da jusante já estavam verdes e as grotas cheias, os criadores buscavam o gado nos gerais, ou, na total ausência de cercas no percurso, o rebanho podia até voltar por conta própria, conforme o Sr. João Magalhães afirma: voltava quando chovia. Quando chovia bastante aí ele vinha embora. Se não fosse buscar ele vinha embora.

José: e porque ele vinha?

Sr. João: porque ele sabia que cá tava bom, né? (risos).

José: e noutro momento do ano ele ia para lá também?

Sr. João: não. Só no mês de maio.

José: e quando ele voltava?

Sr. João: no mês de novembro, dezembro que chovesse dereitinho, criava água nas grotas, que eles bebiam nas grotas sabe? Aí ele vinha. Quando dava no mês de maio, no lugar que secava água nas grotas, ele ia embora. Se a gente não pegasse para levar eles iam embora (Sr. João Magalhães, morador da comunidade de Pombas, trabalho de campo realizado em janeiro de 2010). 
$\mathrm{Na}$ entrevista do Sr. João Magalhães, nota-se que, nas condições de terras livres de apropriação privada e, por conseguinte, de cercas, o gado tinha liberdade de escolha da localidade que the oferecesse melhor condição de pastejo. Nesta escolha, incluíam as áreas próximas às comunidades, matas e gerais, assim como os gerais afastados, nas áreas de fechos.

Da mesma forma que o gado usufruía de condições favoráveis à ampla mobilidade e de escolha, aos criadores também era permitido deslocar seu rebanho para localidades que oferecessem ao gado melhores condições de pastejo. Nestas condições, os criadores das comunidades da jusante, do baixo vale do rio Arrojado, usavam os gerais até amplas áreas do médio vale, deslocando seu rebanho a distâncias de até $100 \mathrm{~km}$ a montante nas áreas próximas a Couro de Porco.

\subsection{As investidas dos grileiros com vistas à desterritorialização dos geraizeiros}

A dinâmica costumeira dos geraizeiros, entretanto, foi alterada em função de fatores como a tomada de boa parte das áreas de criatórios por grileiros e o aumento populacional nas comunidades, o qual provocou o aumento da demanda de maiores áreas para a exploração agrícola e pecuária. Esta demanda inicialmente foi atendida com a derrubada da quase totalidade das matas para destinação aos cultivos agrícolas ou de pastagens e potencialização dos usos das áreas de sítio.

Porém, continuou o adensamento populacional, provocando uma extrema minifundização das parcelas e como resultado teve-se também a diminuição da capacidade produtiva dos solos. A alternativa encontrada pelas comunidades para compensar essas perdas foi aumentar a atividade pecuária, contraditoriamente, numa situação de crescente investidas dos grileiros sobre as áreas de criatórios.

A maioria dos fechos tomados localizava-se no lado esquerdo do rio Arrojado: o fecho dos Sete Galhos, o fecho do Lençol, o fecho da Vaca e muitas outras áreas usadas pelos criadores, mas não nomeadas como fecho. ${ }^{194} \mathrm{~A}$ área do antigo Fecho da Vaca, atualmente, está sob o domínio da Fazenda Brasil Verde. E os antigos fechos de Sete Galhos e do Lençol situam-se na área dominada

\footnotetext{
${ }^{194}$ Na figura 14, me refiro a essas áreas de criatórios como "antigos fechos".
} 
atualmente pela Fazenda Entre Rios, pertencente ao grupo Papaiz, do ramo de metalurgia (figura 14)

Esta última empresa exibe em seu site na internet, no quadro de responsabilidade social e ambiental, este "empreendimento" como um feito de caráter positivo. A ele assim se refere:

\begin{abstract}
A Papaiz mantém um Projeto de Reflorestamento de Eucaliptos, na Fazenda Entre Rios, de 24.400 hectares, no município de Correntina, Bahia, possui área de Reserva Legal equivalente a 4.880 hectares, previstos em lei. Além disso, se preocupa com a manutenção de 2.700 hectares de Área de Preservação. Hoje, 14.820 hectares se encontram preservados com a cobertura vegetal nativa (PAPAIZ, 2012).
\end{abstract}

Além da cifra que caracteriza esta fazenda como um grande latifúndio, podese notar o caráter da destinação dos referidos compartimentos. Dois deles, o de 4.880 ha e o de 2.700 ha, se destinam, a fazer propaganda do zelo da empresa pelo cumprimento da lei e da sua preocupação com a preservação ambiental. Outra parte, 14.820 ha, se encontra preservada. Somando-se as áreas desses compartimentos, e subtraindo-as da área total da fazenda, 24.400 ha, descobriremos a área em que empreendeu atividade econômica, a saber, 2.000 ha, com o projeto de reflorestamento de eucaliptos, diga-se, desflorestamento e ocupado por silvicultura de eucaliptos.

Demonstra-se, pois, de modo explícito, nestas falácias, o caráter especulativo da investida da propriedade capitalista da terra sobre as áreas secularmente apropriadas pelos criadores geraizeiros.

Sob certo ponto de vista, o fato de não haver desmatado os cerrados na área de 22.400 ha pode ser entendido como positivo. Porém, isto ainda não ocorreu porque não chegou o momento que consideram viável fazê-lo (ou de transferir para que terceiros o faça), de modo a satisfazer suas expectativas de ganho. Implícito no discurso da preservação dos cerrados, está a intenção de destruí-lo tão logo julgue oportuno e, em atendimento aos preceitos de responsabilidade ambiental, deixaram preservada a área de Reserva Legal, os 4.880 ha.

A totalidade das áreas tomadas permanece praticamente inexplorada e a fazenda tem como principal rendimento da área o aluguel da pastagem natural para os criadores que soltam gado, prosseguindo o uso segundo o costume geraizeiro.

Entre os chamados grileiros que atuaram e atuam na ampla área dos antigos fechos, fala-se na região, está Mário Zinato Santos. Falam que a ele se deve a 
tomada de toda a área que compreende atualmente a fazenda Brasil Verde, a qual permanece sob "sua propriedade", e toda a área da Fazenda Entre Rios. Fala-se também dos feitos fraudulentos nas grilagens de terras do catarinense Caetano Bernardini (a quem se atribui o empreendimento do loteamento "Cidade Treviso"), os pretensos proprietários das fazendas Triflora - Triângulo Florestadora S/A, Reba Reflorestamento da Bahia Ltda., Florestaminas - Florestamento de Minas Gerais S/A, Planta 7 - Empreendimentos Rurais Ltda. e Vale do Rio Grande Reflorestamento S/A.

Segundo informam os entrevistados, antigos criadores dos fechos tomados, um tal de Mario Zinato teria adquirido toda a área de terra "comprando", a preços irrisórios, recibos de alguns dos criadores. ${ }^{195} \mathrm{Zeca}$ vendeu, Paizinho vendeu, Nego da velha Idalina vendeu, Zé Pereira vendeu ${ }^{196,197}$. Informam também que, depois da suposta compra, o tal Mario Zinato permitia por alguns anos a continuidade dos usos tradicionais da terra pelos criadores.

A Brasil Verde comprou. Depois eles desmataram uns pedaços lá, num produziu
nada. Ela abandonou. Aí nós resolveu fazer o fecho outra vez que tava lá, nos Sete
Galhos, aí... mas nós nem parou de botar gado lá não. A Brasil Verde comprou mas
não proibiu de botar gado. Levava, trazia... depois a Brasil Verde vendeu para a
Papaiz. Aí foi aonde eles correu com o gado nosso que tava lá nos gerais, pinicou
tudo (o arame das cercas). Cabou com a cerca. Aí nós fastemos de lá. Deu pra alugar
o fecho, botamo o gado, até me venderam esta parte de lá. 198 E a gente vai correr de
lá traveiz (Morador da comunidade de Pombas, trabalho de campo realizado em
janeiro de 2010).

Quando este morador afirmou que a gente vai correr de lá traveiz, se refere à área onde solta seus criatórios atualmente, na margem direita do rio Arrojado, no fecho de Gado Bravo. Mas outro criador do mesmo fecho rebate: corre não! Tem que passar por cima de mim! $!^{199}$

\footnotetext{
${ }^{195} \mathrm{O}$ conflito se instala devido a apenas um ou alguns integrantes do grupo de criadores assinar ou assinarem o recibo de "venda" da terra. Mesmo sem contar com a assinatura de todos os criadores, o adquirente ou testa de ferro apropria-se da totalidade da área. O descontentamento daqueles que não assinaram o recibo e a insistência na continuidade dos usos, causam acirrados conflitos entre estes e o testa de ferro o qual passa a recorrer aos serviços de milícias composta de bandos de pistoleiros para expulsar a totalidade dos criadores da área em disputa.

${ }^{196}$ Antigo criador do Fecho de Sete Galhos foi expulso e atualmente solta o gado no Fecho de Gado Bravo.

${ }^{197}$ Estas transações entre criadores e testas-de-ferro tem resultado em graves consequências para os primeiros, que nos dias de hoje, boa parte já idosos, não conseguem aposentarem-se em função de problemas com suas documentações pessoais.

${ }^{198}$ Se refere à outra área que atualmente solta seu gado, no Fecho de Gado Bravo.

${ }^{199}$ Morador da comunidade de Buriti e criador no Fecho de Gado Bravo, trabalho de campo realizado em julho de 2011.
} 
Parece que este tal de Mario Zinato atua na região como testa de ferro, assim chamados na região aqueles que tomam ou adquirirem, por meios ilícitos, determinada área dos camponeses geraizeiros, sem qualquer intenção de torná-la economicamente produtiva. Em seguida, informam que eles, contando com os préstimos do aparelho estatal local, estadual e até mesmo federal, com destaque para o judiciário, "fabricam" documentação ilícita, com a qual a transferem para terceiros, de modo geral oriundos de outros Estados ou regiões do país. O segundo adquirente, concebe a propriedade como consolidada e, como muitos testas-deferro, não mais permitem o exercício de qualquer uso pelos geraizeiros, qual seja pecuário, extrativo ou outros. São muito frequentes as placas informando, algumas até de forma ameaçadora, o total interdito sobre a área privativa.

Inicialmente, o grileiro ou testa-de-ferro, primeiro agente da privatização capitalista da terra interessado em determinada área de terra, se aproxima dos posseiros, assediando-os, geralmente se beneficiando da mediação de algum conhecido no meio comunitário dos criadores. Este conhecedor do grupo de criadores o conduz até aqueles detentores de algum tipo de documento (como, por exemplo, "de compra e venda") e mais propensos a aceitar a proposta de venda deste documento, sabendo ou não do quanto poderá prejudicar seus companheiros. Nesta investida, os grileiros fazem uso de uma variedade de estratégias de convencimentos ou coerção, utilizando-se, como se sabe, em alguns casos, até de violência para conseguir o que pretendem.

Cito o exemplo informado de um famoso grileiro e dono de um escritório de advocacia prestador de serviços fraudulentos em Santa Maria da Vitória. Os posseiros vitimados pela investida desse grileiro relatam que ele se apresentou à comunidade como "boa gente", mostrando fotos de quando era padre celebrando missas. Depois de muitas prosas, soube explorar muito bem a confiança que geralmente os camponeses conferem àqueles que thes aparecem como importantes, e neste caso, ainda mais, como religioso, e assim não foi difícil "botar a mão" nas escrituras mais antigas das áreas da comunidade, a partir da qual, se utilizando da sua maestria nos ofícios fraudulentos, elaborou documento da área de toda a comunidade, tanto de onde mora quando de onde cria - dos gerais. A seguir, um morador relata uma das situações ocorridas: 
você ver o caso de um rapaz lá que ele chamou para fazer uma reunião e chegou lá disse que ele experimentava com rifle, atirando nos pau, quando caía as cascas do pau, medrontando o cara, e dizia assim: tá bom aqui já dá para, né? E o cara quase mijando nas pernas. E ele com os jagunços atirando de rifle nos pau assim para cair as folhas em riba do cara, porque o cara chamou para fazer um acordo. Em vez da pessoa dizer não, lugar de acordo é no cartório, é na delegacia... não, o cara foi lá para o conflito, fazer acordo. Zé do Prequito contou essa história lá. O pai e o irmão dele está traumatizado até hoje! Né? Mudou para Correntina e quase atacou derrame, traumatizado! O verdadeiro dono da terra, perdeu tudo! (Morador da comunidade de Olhos D'Água dos Neri, trabalho de campo realizado em janeiro de 2010).

Concomitante a essas práticas de generalização do terror, realizam os serviços fraudulentos nos cartórios, utilizando-se dos préstimos de tabeliões e funcionários, de advogados especializados nesses ofícios. Neste sentido, eu já vi a história, até não falta, porque não tenho prova, que até terra ele dá pra elas! O rapaz que descobriu isso, ficou de pesquisar para descobrir pra nós. Que ela falou que tem 200 hectares de gerais aí que recebeu em troca de documento. Isso é o maior absurdo do mundo, moço! Santa Maria da Vitória, é palco, é patrimônio aonde esse povo se sente à vontade (Morador da comunidade de Olhos D'Água dos Neri, trabalho de campo realizado em janeiro de 2010).

E quanto aos advogados: em Santa Maria, para nós encontrar advogada lá, agora que nós temos dois advogados em Santa Maria! Mas não ranja não! Um é compadre, outro é amigo, mas, amigo de um... $?^{200}$. Em outro momento, quando me refiro aos conflitos envolvendo grileiros das posses da comunidade de Couro de Porco, cito as denúncias feitas pelo Assessor Jurídico da Procuradoria Geral da Justiça do Estado da Bahia, advogado Vilobaldo Bastos de Magalhães, o qual fez minuciosa investigação acerca das escandalosas grilagens de terras nos municípios de Carinhanha, Cocos, Coribe, Santa Maria da Vitória e Correntina. Nestas, ele faz referência ao papel que desempenham, nessas fraudes, o juiz da comarca, o promotor da comarca e o representante do órgão de terra da Bahia (INTERBA). Entrevistados, informam também o empenho dos quadros dos poderes executivo e legislativo nestas fraudes e, pode-se resumir, de toda a oligarquia regional que age em seu próprio interesse e favorece de todas as formas os fraudadores que chegam das diferentes regiões do país, para a eles se unirem no sentido de consumarem o saque das terras públicas há muito apossadas pelos camponeses geraizeiros, nas quais trabalham para conseguir o sustento de suas famílias.

\footnotetext{
${ }^{200}$ Morador da comunidade de Olhos D’Água dos Neri, trabalho de campo realizado em janeiro de 2010.
} 
Concluída a lavratura do documento ou até mesmo concomitante, os grileiros realizam os serviços de campo: instalam placas, abrem picadas, derrubam cercas dos criadores, desmatam e, se utilizando dos serviços de pistoleiros e da polícia, executam prisões, matam animais, queimam casas, e fazem ameaças, etc. Ou seja, instalam o terror, desassossegando a centenária organização da vivência em comunidade camponesa. No capítulo seguinte, quando discorro sobre o conflito envolvendo as comunidades de Couro de Porco e vizinhas, serão melhor detalhadas estas práticas tão comuns na expansão da propriedade capitalista da terra pelos agentes "modernos" das elites.

Em função dessas políticas dos sucessivos governos de apoio ao "agrobanditismo"201, é que a "Longa Marcha do campesinato brasileiro está escrita nas lutas muitas vezes (ou quase sempre) sangrentas desta classe social" (OLIVEIRA, 2001, p.185).

Parte significativa dos criadores dos fechos tomados, transferiu-se para outras áreas, em maioria do lado direito do vale, e passaram a compor outros grupos de criadores $^{202}$. Porém, relatos informam que as áreas desses fechos também se encontravam em disputas com o grileiro um tal de José Cavalcanti que em 2005 vendeu para o grupo inglês CFM-Agropecuária que lá instalou a fazenda Mombin; com a empresa Floriana Agroflorestal Ltda, a qual se pretende proprietária da fazenda $\mathrm{Neli}^{203}$, e além desta travam conflitos também com a fazenda Conquista, com o grileiro um tal de João Branco, e outros. Não sendo exagerada a afirmação de que a propriedade privada no Oeste da Bahia se instalou ou se instala provocando conflito e violência onde quer que busque estabelecer-se, pois não se trata de um vazio demográfico, mas de uma região há muito ocupada por posseiros.

Pergunta: foi a própria Papaiz que chegou e tomou conta das terras, ou...

Resposta: não. Primeiro, existe, porque eles não vêm diretão, né? Tem alguém, porque as negociações de terras aqui é fácil. Até hoje tem alguém que vive disso. Você tem aquele documento de terra lá, ele compra, eles usam para formar outro documento. Vai ficando assim: era 20ha, né? Aquela propriedade antiga, 100 anos, aquele documento todo bonitinho. Alí eles vai, como é que é, retífica, né? Faz alteração e em baixo ele diga, em baixo, onde se ler 20 ha, se lê 27 mil hectares. Mais ou menos igual procedeu aquele processo lá de Couro de Porco. Era 217ha e foi para

\footnotetext{
${ }^{201}$ Oliveira, 2008. Acessado em 02.09.2012.

${ }^{202}$ Muitos dos criadores expulsos continuam usando as áreas dos antigos fechos, porém, pagando alugueis aos que tomaram suas terras.

${ }^{203}$ No mês de julho de 2012 concluiu-se a ação discriminatória administrativa na área compreendida por esta fazenda provando-se que a mesma trata-se de terra pública e que o processo de apropriação se deus de modo fraudulento.
} 
217 mil hectares. Então eu me lembro bem da época, só que desse tempo para cá nós conseguimos ficar nesse local aqui ó (do lado direito do rio Arrojado). Desse tempo pra cá que eles correram com esse pessoal daqui (do lado esquerdo do rio Arrojado), nós viemos ficar aqui. Assim, não era que a gente aposseava desse lugar aqui. O gado comia. A gente tinha rancho aqui, que o gado, a gente tinha rancho aí, mas o ponto nosso era aqui, nesse bloco chamado Chiqueiro. Do Chiqueiro à Vereda Grande. Então nós, aí naquela época lá o pessoal teve uma revolta danada. $O$ pessoal tava com o gado lá e de uma hora para outra os home chegou e botou os cara pra correr e correram todo mundo. Aí vieram um cara, pessoal da firma, na época para negociar com os posseiros, parece que era um Inglês... acabou que não tinha ninguém que sabia conversar. Tinha o Pe. André. Tinha um padre aqui, muito conhecido aqui, que era da Holanda (diga-se, da Guiana Francesa), que entendia muito bem e fez a negociação. Aí na época o pessoal teve que vender. A única opção foi vender e barato. Aí ainda teve pessoas que tirou proveito também, né? Que na época eles chamaram as pessoas para somar forças para enfrentar eles, mas não teve jeito, porque realmente os homens era forte, tinha muitos pistoleiros, teve gente que saiu de lá correndo que perdeu até coisa de comer. Eles botaram foi para... formaram um tiroteio pra cima aqui os cara viram, os caras não tem costume de ver tiro.

Pergunta: quer dizer que quando vocês chegaram lá a sede já estava...

Resposta: não. Foi depois, a sede.

Pergunta: ah foi depois. Mas, quando teu pai criava gado aqui, criava lá também, ou não?

Resposta: era assim: um tempo era num canto, outro tempo era no outro.

Pergunta: já tinha o rancho lá e já criava naquele fecho, já criava nos dois?

Resposta: só que depois assim, não era assim, nessa época, não era cercado. Era na larga praticamente. Aí foi quando o pessoal chegaram.

Pergunta: quando fala larga é porque não é cercado?

Resposta: não é cercado.

Pergunta: antes do fecho, antes dessa cerca então era na larga...

Resposta: era na larga. Então tudo isso aqui, tem o galho grande, tem o, é, Entre Morros, Morrinhos, tudo isso ai era larga entendeu? O pessoal disse, não, esse lugar aí é... é legal, funciona bem. Aí então quando eles chegaram criaram a necessidade de fazer a cerca... vamos fechar isso aqui. Tanto é que o pessoal, nós fechamos uma parte, ele chegou e entrou mais ainda uma outra parte pra dentro. Andando lá, você vai perceber como que foi o processo que era de uma cabeceira reto na outra. Da cabeceira do Galho da Cruz como tá aqui, ó, reto na cabeceira do Gado Bravo.

Pergunta: mas porque que vocês fecharam?

Resposta: aí nós fechamos.

Pergunta: porquê?

Resposta: depois... porque tinham chegado. Aí nós fechamos para eles respeitar aquela área. Porque vendo cerca ali, nós era dono. Nós, o grupo né? Aí mesmo assim ainda eles invadiram a área, a base de umas 2 mil hectaras pra dentro.

Pergunta: mas como é que eles invadiram. Eles derrubaram a cerca?

Resposta: derrubaram a cerca, tiraram o arame todim, enrolaram, trator, até hoje você passa lá você ver pé de pequizeirão lá tombado. De raiz pra cima. Lá pro lado de fora. Aonde que eles não desmataram, dentro, da onde você sai aqui da cabeceira... do Galho da Cruz, chega aqui, faz assim, ó. Você faz assim. Foi aonde que eles entraram, entendeu?

Pergunta: depois que eles construíram a cerca vocês não mexeram não...

Resposta: não. Aí eles entraram para o lado nosso. Aí nóis pegou a cerca e colocou na posição que tinha deixado, que eles entrou. Que eles só entrou até um certo pedaço. Aí nós peguemos, o ano que eles, fechamo. Tá fechado até hoje. Aí, isso foi um acordo averbado entre posseiro e um grileiro lá. Você fica pra cá e nóis pra lá. Então de forma que lá onde você viu lá todo beneficiadim, que tem uns 6 anos de atuação lá dentro, aquilo ali é deles mesmo em documento. Não sei se é documento original. Mas ali é de acordo mesmo com os proprietários que ali é dele. E essa represa aqui que nós vimos lá, essa represa aqui era para geração de energia. Que lá funcionava para a sede. Coisa muito antiga. Só que quem passa lá hoje não dá para 
perceber mais que a sede ela foi toda demolida. O pessoal fizeram mesmo a capricho.

Pergunta: mas... morava gente lá?

Resposta: morava gente.

Pergunta: os criadores se organizaram e...

Resposta: nesse espaço aqui, ó, na época era um tal Cavalcanti, ele começou plantar caju. Só que não foi muito adiante, não teve muita, os mecanismo... a mecanização do solo não foi... para produzir. Aí ele entrou em falência total. Mas nesse período aqui que Cavalcanti, logo quando ele entrou, pegou toda essa larga aí, antes de fechar tudo, ele deu muito prejuízo posseiro. Inclusive meu avô foi 11 cabeça de gado. Assim, uns que ele matou e uns que ele baleou. O que ele via maior, mais gordo, ele...

Pergunta: ele próprio fazia isso?

Resposta: ele com os capangas dele, os funcionários dele. Então foi calculado 60 cabeça de gado que ele consumiu na época. Tinha uma... família, que usa essa área aqui, parece que só deles foi 60. Fora as outras. Então na época, foi nessa época, em 80 né, foi nessa época que eu acho que estava sendo gerado. Aí depois que eles começou aí, foi que criou a necessidade de criar o sindicato. Depois de dois anos, sindicato criado, presidente do sindicato, diretor ajudou, é... tirar bala de vaca lá na região nossa.

Pergunta: quem era o presidente?

Resposta: Ajudou tirar bala, de vaca que tava baleada lá ele conseguiu tirar bala, só que já cá na parte de baixo. Aí eles, tinha um processo também na justiça naquela época. Mas só não virou em nada, não pagou nada. Eles colocou assim, que ficava, é, quando a coisa foi apertando, que ficava o gado para pagar o prejuízo que os posseiros tinham dado a ele, né? Do tanto da cerca, da derruba todinha que deu, da casa que a sede dele era sede mesmo de... e aí tudo não virou em nada. Deu processo na justiça, ficou e não deu em nada (morador da comunidade de Buriti, trabalho de campo realizado em janeiro de 2012).

O relato deste morador traz importantes elementos, alguns já foram apresentados e outros merecem ser considerados. Esse tal de José Cavalcanti teria iniciado suas intervenções nas áreas dos criadores geraizeiros, executando os passos antes descritos. Construiu sede da fazenda que nos revides dos geraizeiros às suas agressões acabou por ser destruída, fez picadas, cercas e desmatou amplas áreas dos gerais. As cercas impediam o acesso dos animais às áreas de pastejo e às aguadas, o que provocou um clima de intenso conflito, na medida em que logo em seguida eram desfeitas pelas chamadas ventanias ${ }^{204}$. Os criadores, por sua vez, passaram a se preocupar com a delimitação mais precisa de suas áreas de criatórios e construíram cercas as quais também eram destruídas pelo grileiro. Para demarcar suas áreas, aproveitavam-se das barreiras naturais, no caso os galhos, pequenos afluentes ou subafluentes do rio Arrojado, para o "fechamento" do perímetro das suas áreas de criatórios. Como se pode ver no (figura 14), em um lado era "cercado" pelo rio Arrojado, em dois lados pelos afluentes, subafluentes ou

\footnotetext{
${ }^{204}$ Assim chamada pelos geraizeiros usuários dos fechos de gerais as ações diretas organizadas pelo grupo.
} 
galhos e no quarto lado o perímetro era e é fechado por uma cerca construída pelos criadores, embeiçando (ou fechando) de uma extremidade à outra dos galhos.

Então, da situação de uso livre das terras, onde criavam em até mais de uma área, passou-se ao total desassossego, havendo que enfrentar constantes ameaças, refazer o que era destruído pelos grileiros, sofrer baixas consideráveis nos rebanhos e contra-atacar, chegando ao ponto de demolir a casa (sede) do grileiro.

Conforme a (figura 14) mostra, a área de uso pecuário em comum pelos geraizeiros constitui-se de dupla territorialidade: a camponesa geraizeira e a capitalista. Isto pode-se ver na distribuição dos ranchos, nas cercas construídas embeiçando um galho a outro - elementos da apropriação camponesa da terra -, assim como o traçado retilíneo das picadas nos cerrados, ponte sobre o rio Arrojado, estradas, sedes, pistas de pouso de aeronaves e talhões desmatados - elementos da propriedade capitalista da terra -, demonstrando a discrepâncias das lógicas de apropriação dos gerais pelas partes em conflito. A primeira, em significativa concordância com o quadro natural, deixando praticamente intacta a cobertura vegetal e garantindo a preservação dos galhos e rio, e a outra, desrespeitando-o totalmente, removendo a totalidade da vegetação (ver quadrantes desmatados), desmatando os cerrados até as cabeceiras dos galhos, como se pode ver na área das Fazendas Conquista e Mombim, além dos traçados retos e outros elementos. $O$ curioso é que o judiciário nunca sentenciou favorável ou contra a qualquer uma das partes em conflito, possivelmente apostando na superioridade da força dos grileiros, capaz de se expandir territorialmente e mantendo, assim, a invisibilidade da gritante situação dos geraizeiros, extremamente injustiçados pela opressão, não só do grileiro, mas também de todo o aparelho estatal que o acolhe e acoberta suas ações, executando, assim, o modelo brasileiro de desenvolvimento capitalista de produção no campo.

Conforme já referi, o advento da grilagem culminou em maior ordenação territorial da área em conflito no lado direito do rio Arrojado. Da parte do grileiro, foram construídas sedes, estradas, picadas e desmataram-se alguns talhões dos cerrados; da parte dos geraizeiros, foi providenciada a melhor demarcação de cada fecho, a partir da construção de cercas, tanto para evitar mistura dos rebanhos aumentados, quanto para defenderem-se das perseguições dos grileiros, sobretudo, com as matanças de gado. 
$\mathrm{Na}$ área em conflito, o grupo CFM-Agropecuária adquiriu 29 mil hectares de terra ${ }^{205}$ com o objetivo de formar fazenda para a produção de touros selecionados os quais se destinarão aos mercados em expansão para o centro-oeste do país aproveitando-se dos baixos preços das terras, o que the permitirá, segundo declarações do seu presidente, oferecer facilidades na distribuição dos animais a seus clientes.

\begin{abstract}
O rebanho bovino está subindo em direção do Norte do Brasil e a CFM está indo junto, objetivando fortalecer seu projeto de produção de touros de qualidade genética com CEIP (Certificado Especial de Identificação e Produção) para contribuir para o aumento da oferta de carne bovina de qualidade, informa David Makin, presidente da CFM. Com o investimento, a CFM planeja fortalecer ainda mais sua posição de liderança na comercialização de touros melhoradores. "Além disso, considerando o valor da terra e as características de pastagens dessas regiões, reduziremos os custos de produção e agilizaremos o transporte até as fazendas dos clientes", ressalta Makin. Cerca de $70 \%$ de nossa safra anual de touros são comercializados na região Centro-Oeste. A localização estratégica permitirá que continuemos oferecendo diferenciais importantes aos produtores, como o frete rodoviário gratuito para cargas fechadas de touros para qualquer região do país. ${ }^{206}$
\end{abstract}

Este grupo contabiliza 11 fazendas espalhadas pelos Estados de São Paulo, onde se localiza a matriz, Mato Grosso, Mato Grosso do Sul e Bahia (Oeste). Como se pode ver, a expansão de suas atividades realiza-se com vista a atuar nas regiões de fronteira, onde é praxe no país a apropriação ilícita da terra, o que é muito comum na atividade pecuarista brasileira e na que se expande no Oeste da Bahia não é diferente. Nesta região, onde o Estado tem realizado discriminatórias de suas terras, a conclusão não é outra, senão a apropriação fraudulenta por meio da grilagem combinada com a expulsão violenta dos posseiros, com o uso da pistolagem. É utilizando-se desses meios que os poderosos, as elites econômicas, imprimem a sua marca no território, a qual Ihes garante a sua reprodução e a acumulação de lucros sempre maiores. É a terra de trabalho violentamente tomada das mãos de quem dela necessita para trabalhar e conseguir a reprodução da vida, cedendo lugar à terra de exploração, pondo em prática, a partir do pacto do Estado com as elites, o modelo de desenvolvimento do capital.

...nos últimos anos ficou cada vez mais reduzida a extensão da terra possuída por quem nela trabalha e maior o número de pequenos proprietários, arrendatários,

\footnotetext{
205

Conforme

matéria divulgada

em: http://www.fazendaparedao.com.br/_images/publicacoes/Reportagem_Oeste_Baiano.pdf (acessado em 17.04.2012)

${ }^{206}$ Correio de Uberlândia, 2012.
} 
parceiros, posseiros e índios expulsos violenta ou sutilmente pelo latifúndio ou pela grande empresa capitalista. ... o lavrador conhece e identifica cada dia melhor as forças de alteração, ameaçadas do mundo camponês: "os ricos", "o gado", "as cercas", "o governo" e "os bancos". Quando elas atingem o fator terra, o equilíbrio está comprometido definitivamente e o lavrador sente a terra fugir sob os próprios pés. Ele desmascara a política econômica que leva os bancos a distribuírem dinheiro apenas para os latifundiários que desta forma conseguem lucros e são aliados aos comerciantes da cidade que exploram a ignorância do agricultor (CAMERMAN, 1980, pp. 22-23).

A área em apropriação pelo grupo CFM-Agropecuária é exemplar do contexto em discussão. A prática do antigo grileiro, um tal de José Cavalcanti, em boa parte foi assimilada e está em execução pelo grupo. Na mesma matéria citada, a empresa informa que "a propriedade consumirá US\$ 7,5 milhões, somando a aquisição da terra e a infraestrutura necessária para alojar o rebanho (formação da pastagem, piquetes, currais, entre outros)". De fato, esta transferência de domínio resultou no aumento da infraestrutura na área, até porque, se faz necessário, em um contexto de intenso conflito e demandas judiciais, demonstrar que pelo menos o mínimo investiu-se na área.

Em visita à área, em trabalho de campo em 2010, constatei que uma ponte sobre o rio Arrojado e casa relâmpagos ${ }^{207}$ (guarita onde permanecem os "seguranças") haviam sido construídas recentemente. A ponte, inclusive, substituía a antiga de madeira que se incendiou em uma das tempestades noturnas que frequentemente ocorrem no clima conflituoso. Foi construída também nova sede em substituição à antiga que foi incendiada, pista de pouso de avião e formou-se um talhão de pastagem.

É digno de nota o controle que é realizado no acesso à área. A travessia da ponte, inclusive uma enorme fortaleza construída com espesso vigamento de ferro e concreto, é impedida aos não autorizados por meio de corrente e cadeado, os quais só são abertos, inclusive aos antigos usuários da área, mediante explicações aos "seguranças", que "coincidentemente", quando da minha passagem, tratava-se de um civil e um policial militar, que, presume-se, "fazia bico" no seu dia de folga. Quando retornei à área, em julho de 2011, a chegada foi comunicada pelos "seguranças" ao gerente da fazenda, o qual tentou seguir-nos, enquanto

\footnotetext{
${ }^{207}$ Assim chamadas devido a rapidez com que se realiza as construções. Inclusive se utilizando da distração de um feriado prolongado de carnaval.
} 
percorríamos os fechos, e, não conseguindo, dirigiu-se à sede do STR de Correntina a fim de saber o que fazíamos na área. ${ }^{208}$

O clima de conflito permanece tenso e intensificou-se ainda mais em 2012. Além do conflito travado com a Fazemda Mombim, nos quatro primeiros meses do ano, outro grileiro, um tal de João Branco, pretenso proprietário da Fazenda Neli aumentou sua investida, ao contratar um grande número de seguranças privadas, os quais visavam garantir as intervenções na área, tais como aberturas de picadas, construção de cercas, pontes, desmatamentos e destruição de cercas, ranchos e mangueiros dos geraizeiros. A este respeito, o trecho de matéria jornalística que segue elucida:

A consolidação do setor da segurança privada nos últimos anos e a exacerbação de seu poder deve-se muito à presença de militares ainda em atividade ou aposentados. A conduta repressiva contra cidadãos, de acordo com Ivan, é sintoma do autoritarismo herdado do período ditatorial. Para ele, "há uma ligação direta entre ditadura e empresas de segurança porque vários torturadores, civis e militares, são donos dessas empresas".

O professor de história e integrante da UNEafro-Brasil Douglas Belchior vê na escravidão as raízes dos excessos que são cometidos hoje. Para ele, as empresas de segurança não substituem as forças militares do Estado, mas atuam de forma complementar. "Os capitães do mato foram a primeira polícia da história. Eles tinham a função de correr atrás dos negros rebelados. Essa lógica se repetiu ao longo dos anos e, quando os policiais migraram para a segurança privada, levaram consigo essas práticas abomináveis. Daí a razão de os negros serem as principais vítimas da truculência, ao lado dos camponeses e indígenas (BRASIL DE FATO, acessado em 02/06/2012).

A pistolagem não é uma prática nova, mas o que se refere a matéria, é de certo modo uma institucionalização dessa prática, o que é muito mais grave, pois, trata-se do que se chama "empresas de segurança" e, assim sendo, imagina-se que podem ser registradas, autorizadas pelo Estado, que se promete de direito, para agirem via de regra fora da lei. É muito comum, como afirma a matéria, essas "empresas" pertencerem aos agentes da polícia, geralmente aposentados, mas que muitas vezes se servem dos serviços de policiais da ativa e que se prestam ao serviço promíscuo, demonstrando, assim, mais uma contradição na ação do Estado que, também de modo contraditório, se servem dessa forma à reprodução das elites autointituladas modernas. Martins também faz referência a casos que demonstra o envolvimento de policiais compondo bando de pistoleiros na repressão aos camponeses em favor de grileiros na Pré-Amazônia maranhense: São Pedro da Água Branca, no município de Imperatriz, e Floresta, no município de Santa Luzia:

\footnotetext{
${ }^{208}$ Nesta visita usávamos o veículo do Sindicato dos Trabalhadores Rurais de Correntina.
} 


\begin{abstract}
$\mathrm{Na}$ época da pesquisa esses dois povoados estavam vivendo momentos de grande tensão, sob ameaça constante de grileiros e pistoleiros. Em São Pedro, pouco tempo antes, houve um combate nas próprias ruas do povoado, entre os posseiros e um grileiro e seus capangas. Algumas das entrevistas que fiz com as crianças foram realizadas ao lado de imenso tronco, arrastado pelos posseiros para perto do rancho que servia como escola, e utilizado como uma das trincheiras durante a luta. Desse confronto, os posseiros saíram vitoriosos, expulsando o grileiro e um grupo de soldados da Polícia Militar do Pará que, agindo ilegalmente como força policial privada, dava apoio e complementava as violências do grileiro de terra (MARTINS, 1997, pp.120-121).
\end{abstract}

No caso do conflito com os geraizeiros, é também beneficiária da pistolagem uma empresa multinacional cujo marketing que ostenta e propaga é o de fazer uso do que há de mais moderno em sua atividade. No entanto, se isto é verdade, mistura-se com práticas comuns aos regimes ditatoriais, aplicando-se na usurpação da terra até então acessível àqueles que dela se utilizam para o trabalho e o sustento familiar.

Desde início de 2012, a investida de um grileiro, um tal de João Branco, por meio de seus seguranças, intensificou-se na área de criatórios dos geraizeiros. Muitas queixas foram registradas na polícia e nenhuma providência foi tomada; ao contrário, segundo informaram os criadores, foram praticados abusos por parte da polícia na repressão às suas manifestações, decretando prisão a integrante do grupo.

No mês de março de 2012, um grupo de criadores abordou funcionários do grileiro executando serviços na área de fechos sob a guarda dos seguranças. Após pedidos de interrupção dos serviços e ameaças de seguranças fortemente armados, esta contenda teve como resultado uma tempestade que provocou o incêndio das estacas que seriam usadas pelo grileiro na construção de uma cerca.

O grileiro apresentou queixa na polícia e foi marcada uma audiência, na qual os intimados seriam interrogados na delegacia. Mas esta audiência foi suspensa porque compareceram mais de 100 camponeses e a parte queixosa não se apresentou.

Nos dias seguintes, entretanto, as intervenções deste tal de João Branco continuaram avançando de forma mais intensa, e sem contar com qualquer atitude da polícia em atenção às inúmeras queixas registradas, os geraizeiros se reuniram em grande número, segundo afirmam, cerca de 150 criadores, e seguiram ao encontro dos executores dos serviços destrutivos em suas posses. 
No final do mês de fevereiro deste ano os grileiros invadiram as áreas dos fechos, iniciando a derrubada de cercas coletivas centenárias, abertura de variantes, construção de estradas, abertura de novas cercas, e desmatamento. E, dia $19 /$ março/2012, os posseiros/criadores, ao chegar em seus fechos para "dar manutenção aos seus animais", foram surpreendidos por um grupo de 08 (oito) homens, fortemente armados, que os revistaram e ameaçaram dizendo que "matariam o gado, e se eles voltassem à área poderiam morrer também". Essa ocorrência foi registrada na Delegacia de Polícia de Correntina e pedido diligência de constatação da existência de pessoas armadas e levantamento dos prejuízos causados pelos pistoleiros nas áreas dos fechos de pasto dos agricultores.

Diante de tantas ameaças e, tendo que levar, cuidar, buscar animais na área, no dia 29 do mês de março, cansados da omissão da Polícia, os 150 trabalhadores resolveram ir até a área tentar entender o que de fato estava acontecendo, quando lá chegaram se depararam com seus barracos cortados com motor serra e incendiados, e, mais uma vez depararam-se com 15 pistoleiros. Ficaram muito indignados e revoltados com o quadro que encontraram, então, renderam os 15 pistoleiros e entregando-os à Policia do Município de Correntina - BA (CPT-BA, 2012) ${ }^{209}$.

Entretanto, alegando ausência de flagrante, a polícia os soltou. Os criadores que participaram do confronto acrescentam que os pistoleiros usavam coletes à prova de balas, soltaram bombas de efeito moral, spray de pimenta, rádios, etc., sugerindo tratar-se de policiais ou, pelo menos, terem ligações com a polícia, conforme a matéria jornalística aseguir:

Segundo informações dos posseiros os supostos pistoleiros se apresentavam como fiscais ambientais. Eles andavam com coletes à prova de bala, o que reforça 0 entendimento de que são policiais que prestam segurança as empresas - prática essa comum na região. Os seguranças ameaçavam os pecuaristas com armas de fogo proibindo a prática deles de soltarem seus animais, gados, nos fechos de gerais, posses das associações. $\mathrm{Na}$ área as empresas construíram uma estrada de mais de sete $\mathrm{km}$, uma ponte e vinham derrubando todas as cercas construídas pelos agricultores e fizeram ameaça de morte a quatro vaqueiros e mataram dois cachorros deles. $^{210}$

$\mathrm{Na}$ certeza de tratar-se de apropriação fraudulenta das terras por parte dos grileiros, há muito tempo os geraizeiros pediram ao Estado a realização de ações discriminatórias das terras objeto do conflito e sobre o qual não foram atendidos.

Após o confronto, têm ocorrido audiências com o órgão de terras do Estado, a Coordenação de Desenvolvimento Agrário, quando o pedido foi reforçado e, mesmo assim, o órgão não prevê o atendimento sob alegação da pouca e precária estrutura a seu dispor e de se tratar apenas de uma autarquia ligada à Secretaria Estadual de Agricultura, com pouca autonomia de ação. De fato, o referido órgão estatal de terras integra o atual governo, o qual tem como política agrícola o total apoio à

209 Trecho da Nota Pública assinada pelas Associações de Fechos de Pasto de Correntina e Comissão Pastoral da Terra - Centro Oeste da Bahia, de título: Cansados do descaso das autoridades policiais, trabalhadores prendem pistoleiros em Correntina, publicada em 03/04/2012.

${ }^{210}$ Nova Fronteira, Barreiras, 30.03.2012. (Por: Maurizan Cruz e Denílson Neves). 
grande propriedade capitalista da terra e ao agronegócio, cuja fraude na apropriação das terras públicas é a sua base de expansão. $O$ apoio governamental pode ser constatado na sempre presente e numerosa comitiva protagonizada pelo governador do Estado e seu secretariado, destacando-se a Secretaria de Agricultura na promoção do principal evento estadual do agronegócio, o Bahia Farm Show, que anualmente ocorre na cidade de Luiz Eduardo Magalhães.

Sob constantes ameaças de perdas de suas frações territoriais, os criadores vêm travando ferrenha luta e como parte dela outras ações se encontram em andamento. Há pedidos de intervenção do Ministério Público; recentemente, o juiz da comarca de Correntina fez vistoria na área e os criadores estão à espera de audiência com o mesmo para que apresente o laudo do que constatou e indique os encaminhamentos futuros.

\subsubsection{Os cercamentos das áreas de fechos de gerais}

Com o aperto causado pelo avanço da grilagem sobre as terras de criatórios dos geraizeiros, uma contradição veio à tona, pois os solos das áreas de sítio seguiam em um progressivo enfraquecimento; os tradicionais cultivos nas veredas do Arrojado, na montante, foram proibidos; a população cresceu em progressão geométrica. Nestas condições, só restou aos geraizeiros a alternativa de intensificar a prática agrícola nas áreas de sítio com o uso da irrigação; ampliar as pastagens nas parcelas e aumentar seus rebanhos o que, consequentemente, resultou na necessidade de aumentar o uso das terras livres, pois, assim, supririam o aperto que aumentava também nas áreas parcelares em função da extrema minifundização das parcelas.

Além desses processos, as transferências de muitos criadores expulsos dos fechos do lado esquerdo do Arrojado para o lado direito convergiu para o maior adensamento do rebanho nas áreas de criatórios soltos, quer sejam nas soltas e/ou nos gerais. Porém, a área receptora dos criadores egressos do lado esquerdo também se encontrava e ainda se encontra em ferrenha disputa com os grileiros, sendo que, no auge do conflito, a matança indiscriminada de gado resultou em baixas de dezenas de cabeças pertencentes a apenas um criador.

Nesta situação, visando demarcar melhor as suas posses e proteger o seu rebanho, os criadores decidiram organizarem-se e providenciar o cercamento de 
seus fechos. Para tanto, o grupo associou-se para arcar com os custos da cerca de duas maneiras: uns dividiram o comprimento da cerca pela quantidade de criadores e cada um construía a parte que Ihe tocava; outros dividiram o comprimento da cerca pela quantidade de criadores, cada um comprava o arame necessário para cercar a sua parte, e o trabalho para a construção da cerca total se realizava em conjunto. De uma forma ou de outra, a partir da construção da cerca, cada um se responsabiliza pela manutenção: correção de avarias praticadas por grileiros, de desgastes naturais, periodicamente fazer aceiros para protegê-la das queimadas, e outros cuidados que se fazem necessários. Este ponto, entretanto, merece algumas considerações, pois são frequentes as reclamações de uns a outros, devido aos descuidos com as partes que lhes são devidas. Conforme já referi, aqueles criadores cujo tamanho do rebanho é desproporcional à extensão da área formada com pastagem na parcela de modo negativo, são mais dependentes dos gerais, e com maior frequência necessitam soltar o gado, levar para os gerais. Outros, que dispõem de maiores pastagens formadas em relação ao tamanho do rebanho, dependem menos de soltar o gado nos gerais, e isso ocorre, a bem dizer, quase ou somente nos anos ruins de chuva. Estes últimos tendem a ser menos cuidadosos com as suas cercas e isto gera muitas reclamações da parte dos primeiros. Como a situação de queima de uma parte da cerca do fecho devida a falta de aceiro e a não reposição a tempo, pode causar prejuízo para parte do grupo, pode-se notar o quanto é relevante o cumprimento do que é acordado pelo coletivo para a totalidade do grupo.

Ainda, no que diz respeito às cercas, os criadores vêm enfrentado problemas adicionais em função das intervenções realizadas pelos grileiros. Refiro-me aos desmatamentos que fazem invariavelmente em total desrespeito às fragilidades do ambiente, provocando nele graves desequilíbrios, principalmente quando desmatam indiscriminadamente as áreas de cabeceiras dos galhos. São os casos dos grandes talhões desmatados pelas empresas Conquista e CFM-Agropecuária, comprometendo gravemente as cabeceiras dos galhos, do Gado Bravo, da Cruz e do Lodo. Além da acentuada mudança no regime fluvial na jusante, provocando os problemas já mencionados, as cabeceiras dos galhos, onde a cerca embeiça, sofrem contínuo recuo e, por isso, os criadores se obrigam a alongamentos das cercas ao encontro do curso d'água, na busca de impedir a dispersão do gado. 
Estes reveses de distintos processos de territorialização são marcados por diferentes concepções de relação com a natureza. Da parte dos geraizeiros, 0 trabalho que se realiza nesta porção do território baseia-se em relações sociais de produção (RAFFESTIN, 1993, p.144), cuja finalidade maior é o sustento do trabalhador e de sua família, não se evidenciando, em função disso, estresse considerável ao ambiente. Ao contrário, da parte das empresas, a apropriação territorial se destina a acumulação de capital e, por ser assim, de escopo infinito, podendo até chegar ao ponto de exaurir as riquezas naturais. Nas áreas de

criatórios dos geraizeiros, vê-se 0 desenvolvimento desses processos de territorialização sobrepostos e em conflito, materializando a luta de classe (OLIVEIRA, 2002, p.74) sob mediação do Estado capitalista. Não tem restado assim, aos geraizeiros alternativa, senão lutarem o quanto for preciso para conseguir 0 direito de reproduzirem-se socioterritorialmente e, da terra de trabalho, extrair os seus meios de vida.

\subsection{Os saberes e a organização dos camponeses geraizeiros para o uso pecuário da terra}

O uso em comum das áreas livres, dos gerais, requer, do grupo de usuário de cada fecho, uma série de arranjos organizativos para a sua viabilização. Esta organização, tal como outros fatores sobre os quais já discorri, mantém estreita relação com os processos sociais que se desenvolvem e interferem na territorialização camponesa geraizeira em suas tradicionais terras de trabalho.

Assim, o maior ou menor uso dos gerais dependeu e depende do quanto as áreas parcelares dos criadores dispõem de condições de suporte à permanência dos animais durante a estação seca. Cabe, portanto, considerarmos duas situações: na primeira, conforme já me referi, o rebanho era menor e praticamente inexistiam pastagens nas áreas parcelares. Nessas condições, logo no início da estação seca, geralmente mês de maio, a vegetação de mata (da qual o gado alimentava-se) secava e o gado se dispersava para as áreas de gerais próximos, as chamadas soltas, as quais tinham capacidade de suporte limitada, em função da pouca disponibilidade de pasto bom, e do secamento das grotas, obrigando aos criadores, logo no mês de junho, a deslocar seu rebanho para os fechos de gerais, só retornando no mês de outubro, quando se iniciava as primeiras chuvas, as matas 
enverdeciam-se e as grotas enchiam. Nesse manejo, ocorriam consideráveis perdas, pois nem todo o rebanho se encontrava em condições de permanecer nos gerais, tal como o animal que se encontrasse fraco (doente) e sequer resistia os desgastes da viagem, caindo e não mais se levantando ${ }^{211}$ ou das reses que se encontravam com bezerros novos ou prestes a parir. Nos últimos casos suas crias submetiam-se ao grande risco de serem devoradas pelas onças.

A segunda situação está relacionada ao processo de expansão da pecuária nas atividades dos geraizeiros, aumentando significativamente o rebanho bovino, com vistas a compensar o saldo negativo da relação necessidade de produção de alimento/capacidade produtiva das parcelas superfracionadas, em função do alto crescimento populacional, acarretando, assim, maior demanda de uso dos gerais. Conforme demonstrado, além dos avanços técnicos na agricultura, também incorporaram novas técnicas no manejo pecuário. Dentre as quais, se destaca a formação de pastagens nas terras de culturas no interior das parcelas de uso exclusivo familiar. Isto proporcionou alternativas de pastejo na estação seca a, pelo menos, uma parte do rebanho - aquela que devido aos motivos citados não podia ou não devia ser levado para os gerais.

Nesta nova situação, o gado a ser levado para os gerais passou a ser escalado ${ }^{212}$.

Hoje a gente escala pelo fato de... a gente leva aquele gado mais forte porque ele aguenta. Ele já sabe, sabe das manhas e ele aguenta... se por acaso cair ele levanta. A vaca magra não aguenta. A vaca magra se entrar... a vaca gorda entra, dá pra sair... se cair em um buraco a vaca gorda levanta. E a vaca magra se ela entrar na lama ela fica lá. E aí antes a gente tinha muito prejuízo, né? Quando a gente levava tudo. Levava tudo até que tava esperando para produzir a gente levava. Lá a gente tinha muito prejuízo. Onça comia bezerro... às vezes a vaca paria em condições, ela não tava em condições de parir, de ter um parto assim, normal... tinha vaca que, acontece dela não despachar direito, não ter o parto normal. Aí hoje a gente prefere deixar as prenhas que tá para parir, a gente deixa em casa, principalmente aquelas que tá mais próximas de parir (Jamilton Magalhães, morador da comunidade de Buriti e criador do fecho de Gado Bravo. Trabalho de campo realizado em janeiro de 2012).

Cabe lembrar que os referidos transtornos no manejo relacionam-se também com as mudanças ocorridas no processo produtivo - e, dentre outras, cito a mistura que se realizou nas raças adaptadas aos gerais ao longo dos tempos, envolvendo o gado pé duro, o gir, nelore e holandês. Antes, o gado criado era o pé duro ou

${ }^{211}$ Esta preocupação é de grande relevância, tendo em vista as longas distâncias a percorrer chegando a até próximo de $100 \mathrm{~km}$, como é o caso daquelas comunidades localizadas no baixo vale Arrojado e que soltam seus animais nos fechos distantes da montante.

${ }^{212} \mathrm{O}$ mesmo que selecionado. 
curraleiro, melhor adaptado às condições ambientais da região. Eram criados soltos durante o ano todo, aproveitavam, como alimento, a diversidade da vegetação natural, consumiam muitas ervas medicinais, sobe nos pau para comer a folha ${ }^{213}$, entra no buraco para comer barro ${ }^{214}$, tem lugar que o boi entra e fica escondido ${ }^{215}$, e desfrutavam de melhor saúde.

Um grande impedimento, porém, trata-se do toque ou mal de toque, que Macedo (1952) explica:

Suspeita-se que o "toque" seja consequente à ingestão da areia que cobre a vegetação recém-nascida pelo efeito das primeiras chuvas. A queda d'água sôbre o solo sêco faz espargir areia sôbre êstes rebentos vegetais e que mesmo assim são avidamente pastados pelas reses, sequiosas do "verde", pois durante longo tempo só se alimentaram de capim sêco, duro e fibroso. Assim elas ingerem grande quantidade de areia, cuja permanência no estômago e intestino determinaria o sintoma do "toque" (MACEDO, 1952, p.9).

Ou, conforme Jamilton, numa determinada época do ano (após a queima dos cerrados, seguida das primeiras chuvas, quando o capim brota) o pasto é pequeno, brota, o gado vai pegar ali, pega muita terra. Aquela terra dá aquele mal de toque. Aquele mal enfraquece o gado.

Como corretivos ou cura para este mal e outras doenças que comprometem a saúde dos animais, utilizam-se de seus próprios remédios.

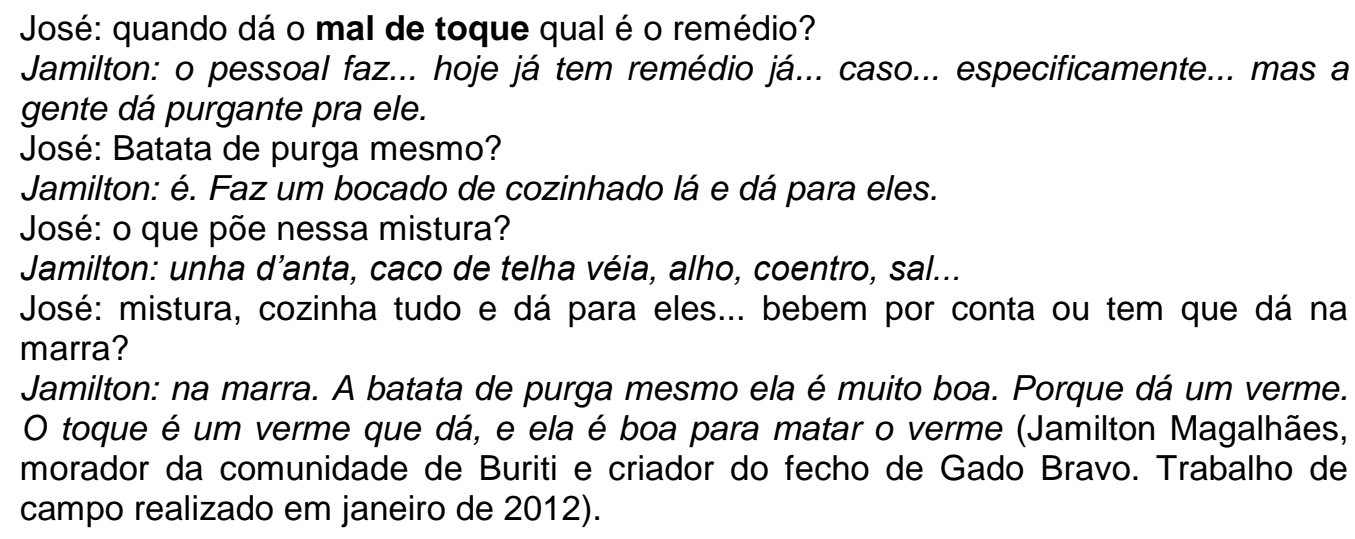

Vê-se, pois, as soluções caseiras constituintes dos saberes tradicionais e que têm como fonte o próprio ambiente, qual seja, o da casa (a horta) ou dos próprios cerrados, onde o gado também pode, pastando, "automedicar-se".

\footnotetext{
${ }^{213}$ Além das gramíneas, o gado se alimenta das folhas das árvores ao seu alcance e dos arbustos que os rebaixam forçando-os com o peito.

${ }_{214}$ Refere-se ao lambedor. Mancha de solo de alto teor salino aproveitado pelo gado pé duro.

${ }^{215}$ Sr. Izaurino, morador da comunidade de Jatobá e criador do fecho de Morrinhos. Trabalho de campo realizado em outubro de 2010.
} 
Dos aprimoramentos técnicos, consta também a formação das pastagens (mangas), em alguns casos divididas em piquetes, nas quais o gado não habilitado para soltura nos gerais pode permanecer alimentando-se do pasto na estação seca o que, por vezes, é complementado com o capim de planta (forrageira), cultivado por alguns criadores, como a palma, ou com biomassa oriunda da agricultura do regadio.

Para formação das pastagens, várias espécies de capim foram experimentadas. Inicialmente, testaram o capim colonião, o qual não apresentou resultados satisfatórios. Jamilton Magalhães afirmou que: o colonião era difícil de formar e ele era mais fácil de acabar. Experimentaram também o capim pangola - e sobre ele, dizem: ele é muito bom... mas dá muito trabalho para formar. ${ }^{216}$

O que apresentou melhores resultados foi o capim agropolo, o que mais aguenta... é um capim assim, sobe rápido entendeu? É um capim mais resistente. ${ }^{217}$ Ele é ligeiro. ${ }^{218}$ O agropolo ta brotando agora. Quando a chuva vem mesmo assim, chega no tempo mesmo, começa nevoar ele começa brotar. E não é tão morredor igual o colonião e Jaraguá, não.

Das espécies de capim testadas, as citadas avaliações indicam que a mais adequada para as condições ambientais do vale ocupado pelas comunidades é o agropolo. E, como vantagem, destacam a facilidade em formá-lo e o seu rápido crescimento em condições de baixa umidade, tal como foi dito: começa nevoar ele começa brotar... ...e não é tão morredor... ...o que mais aguenta. Ressaltam também o fato de ser ligeiro, subir rápido.

Em vista disto, compreende-se que, em condições de minifúndio - e por isso de extrema exiguidade das áreas em que formam as pastagens - necessitam atingir uma relação de grande volume de biomassa por área cultivada. E, nestas condições, o capim mais adequado deve ser aquele que se desenvolva com rapidez, de modo a atender a necessidade que surge imediatamente após permanência do gado nos gerais, que é de no máximo três meses. Como exemplo, cito o período de outubro a dezembro, no qual o gado deixa as parcelas rumo aos fechos de gerais para permitir que o capim saia a brota. Após este período, até três meses, o gado

\footnotetext{
${ }^{216}$ Jamilton Magalhães. Criador do fecho de gerais de Gado Bravo e morador da comunidade de Buriti. Trabalho de campo realizado em julho de 2011.

${ }^{217} \mathrm{Idem}$.

${ }^{218}$ Sr. João Magalhães. Criador do fecho de gerais de Gado Bravo e morador da comunidade Pombas, trabalho de campo realizado em julho de 2010.
} 
precisa retirar-se dos fechos e voltar às parcelas de uso familiar, onde já deve ter capim formado - e o agropolo atende esta exigência. ${ }^{219}$

Entretanto, o capim agropolo também apresenta desvantagens. Os criadores alegam que ele é menos nutritivo que os outros e, quando seca, o talo torna-se demais duro para ser consumido pelo gado. E, além disso, na densa e abundante biomassa, depois que o capim seca, qualquer chuva provoca o mofo; ele fede e o gado não quer nem saber. ${ }^{220}$ Ele é rápido! Se você não cortar baixo ele cria mundão velho aí. Depois seca não presta, o gado não come. Olhe como ele ta aí. Ta tudo seco já. Eis o motivo que faz o gado berrar pedindo para ir para os gerais nos meses de setembro para outubro, se já caiu alguma chuva que provoca o mofo na pastagem cultivada e, concomitantemente, começou a sair o broto novo e mole nas gramíneas dos gerais após as queimadas, atraindo-o pelo cheiro. ${ }^{221}$

Estes aprimoramentos, entretanto, acrescentaram, à prática pecuária, outra variável; pois, da anterior dependência ao ciclo climático e da vegetação, acrescenta-se o ciclo do capim. Assim, no mês de março, o gado precisa deslocarse para os gerais para permitir que do capim caia a sementeira. Os animais retornam no mês de maio a partir de quando se alimentam da farta biomassa do capim agropolo. Em função da prolongada seca característica do regime climático da região, o capim seca, e se exaure pelo pastejo por volta do mês de outubro. Isto obriga a remoção do gado para os gerais, onde pastarão o broto verde que rebenta após as queimadas. Enquanto permanecem nos fechos, geralmente de outubro a dezembro, o agropolo beneficia-se das primeiras chuvas e sai a brota, para novamente alimentar o gado durante os meses de dezembro a março (figura 15).

Este engendramento, como se pode ver, combinou o ciclo do capim com o ciclo dos gerais, dos cerrados. Nesta nova dinâmica, as matas perderam importância até porque grande parte delas foi desmatada para dar lugar às pastagens ou cultivos agrícolas.

\footnotetext{
${ }^{219} \mathrm{~A}$ areia "chapiscada" nas folhas do capim pela ação das gotas d'água da chuva provoca o mal de toque nos animais e por esse motivo devem ser retirados dos gerais.

${ }^{220}$ Jamilton Magalhães. Criador do fecho de gerais de Gado Bravo e morador da comunidade de Buriti. Trabalho de campo realizado em julho de 2011.

${ }^{221} \mathrm{Sr}$. João Magalhães. Criador do fecho de gerais de Gado Bravo e morador da comunidade Pombas, trabalho de campo realizado em janeiro de 2010.
} 
Figura 15 - Calendário dos criatórios

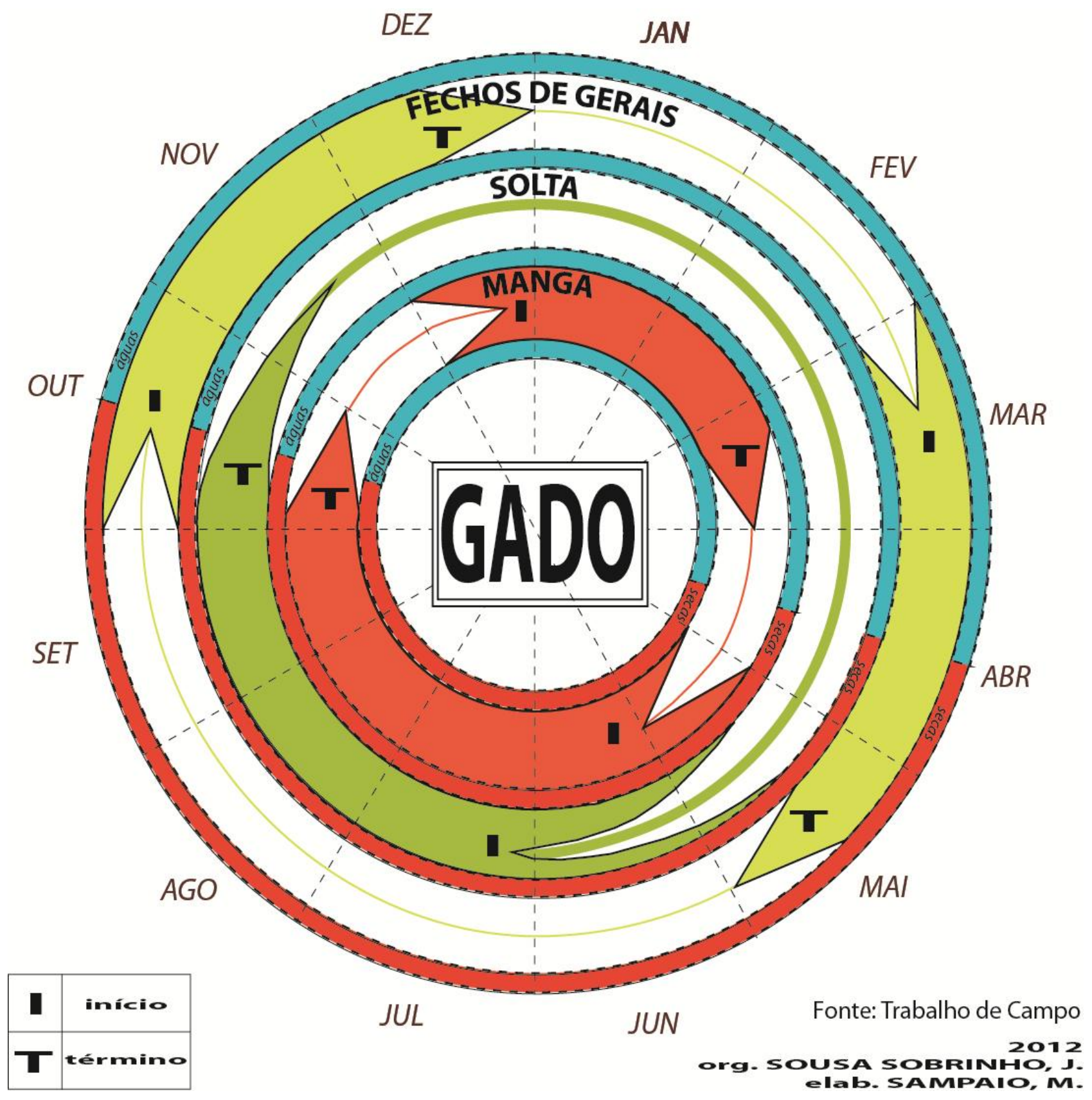

Dito isto, cabe destacar a diferente quantidade de trabalho exigida dos criadores em cada período de estada nos gerais. Dos meses de março a maio, o gado é retirado da pastagem devido a uma necessidade de reprodução do capim, 
em obediência ao seu ciclo. Conforme me referi antes, nos anos bons de chuva, os criadores cuja relação pastagem/tamanho do rebanho é positiva intercalam o pastejo nos diferentes piquetes e não levam o gado para os gerais, mas se obrigam a levar aqueles cujo quociente da relação é desfavorável.

Porém, nesses anos, nos gerais, apesar da escassez de brotos novos e moles, a vegetação é farta e o gado se dispersa nas partes altas, o que demanda poucos cuidados do criador, por estarem livres dos atolamentos. Conforme já referido, uns vão lá só de vez em quando, ver se está tudo bem ${ }^{222}$, e outros apenas sabem das notícias e se não houver ocorrências, só retornam ao fecho para buscar o gado.

No período de outubro a dezembro, quando as chuvas chegam regularmente, a situação anterior praticamente se repete, não demandando intensa vigilância do criador.

O contrário ocorre nesse período, quando o ano é ruim de chuva. A pastagem da parcela rapidamente chega à exaustão. Teve um certo período aí que, de setembro, outubro, aqui pra nós a coisa é feia! É um sertão véi fei, fei mesmo! $A$ mata não tem nem folha, caba tudo. Aí as manga fica só na terra ${ }^{223}$. Nessas condições, tal como antes, se obrigam a levar o gado todo para os gerais, pois, na parcela, não há qualquer condições de alimentá-lo. E, mais, já no mês de agosto o leva e, nos gerais, fica à procura de broto verde e mole, que rebenta primeiro nas áreas úmidas, onde é grande o risco de atolamentos. Dizem que o gado mais traquejado, o pé duro ou curraleiro, incorre menos nesse risco. Mas a raça nelore e outras já estão bastantes presentes e a vigilância deve ser intensa, pois, nessas condições, o gado concentra-se nas veredas e os riscos são constantes, muito em função da falta de adaptação dos animais.

\subsubsection{A organização enquanto permanecem no rancho}

Conforme se viu, o uso de cada fecho é realizado por grupos de afinidades, quais sejam parentesco, compadrio, vizinhança ou amizade. Os integrantes desses grupos de criadores pertencem às comunidades da jusante e em suas parcelas

\footnotetext{
222 Jamilton Magalhães, criador do fecho de gerais do Gado Bravo e morador da comunidade do Buriti; trabalho de campo realizado em janeiro de 2012. 
desenvolvem uma infinidade de tarefas que são comuns aos integrantes das comunidades camponesas.

Vimos também que o ritmo climático e suas oscilações interferem na intensidade de usos dos fechos pelos geraizeiros. Por sua vez, seria demais dispendioso ou até inviável permanecer nos fechos por longas temporadas, tal como determinadas situações exigem.

Em vista disto, de comum acordo, o grupo estabelece uma organização entre si, que pode ser mais ou menos sistematizada, conforme o grau de exigência das condições ambientais da área de criatório no respectivo período do ano. Dentre as tarefas que demandam organização, cito a construção das cercas sobre a qual já me referi; o transporte do gado para o fecho; os cuidados com o gado enquanto lá permanece, e por fim, o abastecimento de alimentos e sua preparação para ser consumido durante a temporada de permanência dos criadores na área de criatório.

$\mathrm{O}$ trabalho que se realiza na atividade pecuária, enquanto o gado permanece nos fechos de gerais, constitui-se de tarefas essencialmente masculinas, a ponto de afirmarem que mulher nunca vai para os gerais.

$E$, em função das exigências de se frequentar a escola, que invariavelmente localiza-se nas comunidades ou nos povoados (primeiras séries até ensino fundamental) ou na cidade de Correntina (ensino médio), não é numerosa a quantidade de jovens que frequentam os fechos de gerais, constituindo-se, pois, dominantemente, uma atividade de adultos chefes de famílias. Assim, cabe aos jovens arcarem com as tarefas das parcelas enquanto os adultos permanecem nos fechos.

Quanto ao transporte do gado, a organização inicia-se na medida em que a pastagem das parcelas torna-se insuficiente para o sustento do rebanho e/ou quando as áreas de soltas saturam-se e se tornam inviáveis à permanência do gado. Em função disso, algum criador toma a iniciativa de convidar alguns companheiros que, como ele, necessitem levar o gado para o refrigério dos gerais. Formado o grupo, juntos tocam seus animais. As saídas geralmente ocorrem nas primeiras horas das manhãs, para aproveitarem o sol frio. Cito, como exemplo, moradores das imediações da comunidade do Buriti que soltam seu gado no Fecho de Gado Bravo: estes percorrem cerca de $50 \mathrm{~km}$ e, conforme relato de um deles, andam durante todo o dia, pernoitam no rancho da Associação dos Criadores de 
Entre Morros e Morrinhos, onde, no respectivo mangueiro deixam o gado preso durante a noite. No dia seguinte, logo cedo continuam a viagem e chegam ao Fecho de Gado Bravo por volta das dez horas da manhã.

Se forem os primeiros a chegar, fazem uma vistoria nas condições das cercas e das aguadas. No caso das cercas, se tem algo a ser feito na parte de outro, eles mesmo fazem a manutenção, caso tratem-se de pequenos reparos. Do contrário, dão conhecimento do fato a seu dono, que deverá tomar providências. No caso das aguadas, providenciam a limpeza dos acessos, para diminuir os riscos de atolamentos. Feito isto, cumprindo o que foi previamente combinado, parte do grupo retorna, a fim de suprir as demandas de trabalho em suas parcelas. Se outros grupos também partem para os gerais, combinam um rodízio com os companheiros que lá se encontram, sendo que, o primeiro que veio para a parcela, a princípio, retornará primeiro para os gerais, a fim de liberar seus companheiros para os trabalhos em suas parcelas. Fica a cargo do grupo que se encontra nos gerais, a vigilância a todo o rebanho e a prestação dos serviços de cuidados. $O$ dono de algum animal só é chamado em casos especiais, tal como o parto de uma rês que necessite de cuidados intensos com o bezerro.

Este, entretanto, é um esquema um tanto geral; pois, de fato, muitas negociações e concessões são feitas aos companheiros, aos amigos, em função das circunstâncias do momento em que cada um está envolvido. A depender da necessidade e do grau de afinidade de algum ou de alguns companheiros para com os outros, seus animais até podem ser levado por outros e zelados no fecho, por todo o tempo que ele necessitar dessa ajuda.

Da diversidade de fechos existente, vê-se que uns têm maiores áreas do que outros e, de modo geral, preserva-se a proporção numérica de criadores/áreas dos fechos. Porém, naqueles fechos maiores e providos de grande número de sócios, grupos afins se formaram e construíram rancho nas proximidades de onde seus animais pastam, de modo que não é comum aglomerar-se grande quantidade de criadores em um mesmo rancho. Isto favorece a organização do grupo para os revezamentos, sem que seja necessária uma rigorosa organização e controle por meio de um cronograma pré-estabelecido e sistematizado.

Quanto ao abastecimento e à preparação dos alimentos a serem consumidos pelos criadores, enquanto permanecem no fecho, tal como as demais atividades, 
demandam menor ou maior organização, conforme o número de criadores presentes no rancho, que, por sua vez, se relaciona com o período do ano e a respectiva situação do clima.

No ano de normalidade climática, os criadores costumam ir aos fechos em grupos menores, pois, parte deles não leva seu gado, e sendo assim, a quantidade de animais a ser cuidada é menor. Deste modo, cada um leva a sua tralha de cozinha, constituída de panelas e outros utensílios que se fazem necessários para a preparação dos alimentos.

Cada vaqueiro, cada um tem que levar a sua panela, pequena ou grande, mas de preferência a comida tem que dar para mim e para mais dois. Então, que dar para comer meio dia e de noite. Então que dar para mim e outras pessoas que tiver. $E$ assim é os outros. Tem gente que leva um caldeirão, que dá para cozinhar para uma família. E aí escolhe o cuca como eu ia falando. Aí o pessoal vai pro mato trabalhar, o cara fica cuidando da comida, dá no horário, vem, almoça, torna voltar de novo (Jamilton Magalhães, morador da comunidade de Buriti e criador do fecho de Gado Bravo. Trabalho de campo realizado em janeiro de 2012).

Em condições normais, em que o público do rancho não é numeroso, o cuca (cozinheiro) pode ser sempre a mesma pessoa que também cuida do gado, geralmente aquele que tem maior habilidade para os ofícios da cozinha, ou, na falta deste, se decide diariamente quem será o cuca.

Entretanto, noutras situações em que o público do rancho é numeroso - em casos de construção de cercas ou em período de seca - o cuca é previamente escolhido entre os integrantes do grupo - geralmente o mais habilidoso - e a este cabe complementar a tralha que se faça necessária para preparar maior quantidade de alimento. Se o trabalho consiste em construção de cercas, o cuca leva o arame, e o grupo faz a sua parte do cercamento. Da mesma forma, se o trabalho é campear o gado, seus companheiros se encarregam disso, cuidam do seu rebanho.

As relações que se estabelecem no âmbito do trabalho e da oferta de condições para a preparação dos alimentos, dos utensílios domésticos, também se realizam na oferta dos alimentos a serem consumidos.

Cada criador encarrega-se de levar para os gerais os alimentos a serem consumidos enquanto lá permanece, e estes são misturados aos dos demais e preparados para o coletivo.

A dieta dos geraizeiros, enquanto permanecem nos cuidados aos rebanhos, constitui-se de arroz, feijão e carne, alimentos que são preparados diariamente para serem consumidos no rancho, no almoço e no jantar. Porém, outros são levados de 
casa já preparados, os quais se somam aos do rancho, onde também são consumidos, mas também são levados pelo vaqueiro para o campeio do gado. Trata-se de café, bolo, queijo, requeijão, rapadura e farinha de mandioca, com a qual fazem a farofa com carne seca, e, junto com a rapadura, constitui-se a comida típica do vaqueiro enquanto campeia o gado nos gerais.

Logo de manhã, o vaqueiro sai para o campeio e necessita estar prevenido, pois, se o campeio é nas partes altas, o gado geralmente fica muito disperso e o trabalho é dificultado, havendo de seguir o rebanho a partir das pegadas ou batida do gado - e o encontro pode demorar, nesta paciente procura nos amplos gerais. Se o campeio é feito nas veredas, no período seco, apesar de o gado ficar mais junto, nem por isso o trabalho é menor, pois a incidência de atolamentos é muito grande e o esforço no trabalho de socorro ao animal atolado é titânico e demorado.

Inclusive, em períodos de incidência de atolamentos, os vaqueiros costumam campear em duplas ou em quantidades maiores, pois, assim, tem-se maior garantia de condições de salvamento do gado.

Nos períodos em que o campeio visa outros cuidados com o gado, a quantidade de vaqueiros no rancho é bem menor, o emprego do cuca permanente é dispensável, e a dieta costuma ser mais simples, geralmente desprovida do feijão - alimento que demanda muito tempo na preparação.

Um ponto que demonstra o grau de coesão das relações que se efetivam ente os geraizeiros é o seguinte: no cercamento dos fechos, o cumprimento da cerca é dividido em partes iguais para cada um dos integrantes do grupo de criadores. No entanto, sabe-se que o tamanho do rebanho de cada um varia significativamente. Tem-se usuários proprietários de 5 , outros de 10 , de 50 ou até 300 ou mais cabeças de gado. Os custos com a construção e a manutenção do fecho, entretanto, são divididos em partes iguais e sobre isto assim, afirmam, não temos usura.

Assim, se demonstra o grau de organização dos geraizeiros com vista a viabilizar o uso em comum dos fechos de gerais. A interdependência entre seus pares e a solidariedade, que se manifesta na totalidade do processo de trabalho de uso pecuário dos fechos de gerais, os liga entre si e com a terra de trabalho de onde retiram os meios de vida e, em grande medida, tem garantido à terra condições com alto grau de preservação das riquezas naturais, o que poder-se-ia permitir a reprodução socioterritorial camponesa geraizeira. 


\subsection{O uso das soltas}

Conforme venho demonstrando, os usos da terra pelos geraizeiros mantêm importante relação com a configuração natural. Venho demonstrando também que ao longo do tempo essas relações sofrem alterações a partir da incorporação de técnicas que favorecem o aprimoramento dos usos.

No que diz respeito à prática pecuarista, inicialmente se realizava utilizandose de técnicas simples, no caso, aproveitando-se majoritariamente da pastagem natural em que os animais eram soltos e se misturavam nos amplos gerais desprovidos de cercas, de apropriação privada, eram livres. Eram raras as parcelas que contavam com pastagens formadas, e, quando era o caso, se constituíam de variedades de capim pouco adaptadas para as condições edafoclimáticas locais, redundando em grande dependência da pastagem natural.

As manchas de terras de cultura eram encobertas pelas matas que permaneciam verdes durante a estação chuvosa, dos meses de outubro a maio. Apesar da inexistência de cercas, o gado concentrava-se ali, se aproveitando da farta e diversificada vegetação como alimento e, além disso, se beneficiando das grotas como bebedouros ou (bebedor) e das manchas de solos salinos, como lambedores (ou lambedor).

Era o seguinte: eles mexiam por aí, quando sentiam saudade vinha, a gente tinha uns cochos aí, botava o sal, todo mundo pegava, lambia, tinha um corredorzão aqui que era numa grotinha que tem aí, hoje acabou tudo, descia no rio, bebia, lambia barro aí numas locas que tinha, né? Tornava ir embora. Era desse tipo (Sr. João de Castro e Silva, morador da comunidade do Jatobá, trabalho de campo realizado em outubro de 2010).

A partir do cessar das chuvas, no mês de maio, as matas perdiam a folha e as grotas secavam, escasseando-se, deste modo, as condições de sobrevivência do rebanho no ambiente imediatamente próximo à comunidade. Assim, se iniciava a dispersão do gado. Em um primeiro momento, espalhavam-se pelos gerais próximos na cata dos brotos verdes que pudesse encontrar. Apesar da grande amplitude dessas áreas, os rarefeitos brotos verdes não demoravam escassearemse e já no mês de junho o gado era levado (ou por iniciativa própria) partia para os gerais distantes na montante, onde havia alimento em maior quantidade nas amplas veredas úmidas, tais como as de Vereda do Rancho, Morrinhos, Entre Morros, Gado 
Bravo, Lodo, Vereda Grande, dos Sete Galhos, Lençol, Cabrera, Vaca, Pau Terra e Roncador, onde mais tarde formaram-se os fechos de gerais.

Quando do início das chuvas, geralmente nos meses de outubro ou novembro, era tempo da volta do gado para as áreas de matas já enverdecidas e também à procura de sal. Este era o ciclo de criatório do gado nos gerais.

\begin{abstract}
No tempo dos mais velhos levava para lá era no mês de junho, panhava agora em outubro depois que chovesse, né? E hoje nóis mudou o esquema. Nóis só leva depois que... uns leva em antes da chuva e outros só levam depois que chove. Porque tem aquelas beiras de vereda, igual vocês foi lá, no ano que queima, atola muita criação. Se a gente não tiver de cima morre demais né?

Hoje nóis leva em outubro, entrada de novembro, e já panha tanto de dezembro, né? Antigamente só soltava uma vez. Agora nóis solta duas vez, né? De outubro a dezembro e de março a maio. No período para cair a sementeira (de março a maio), ter a semente para poder voltar. Que as arinha da gente aqui olha, tudo é uns corredorzinho (Sr. João de Castro e Silva, morador da comunidade de Jatobá, trabalho de campo realizado em outubro de 2010).
\end{abstract}

Em função disso, mudaram o esquema. Da antiga dependência do ciclo climático, passou-se a depender também do ciclo do capim, havendo que retirar o gado no período de março a maio, para cair e/ou colher a sementeira necessária à reprodução da pastagem no ano seguinte, e de outubro a dezembro, quando das primeiras chuvas, para sair a brota do capim, pois, o pisoteio do gado não o deixaria formar-se.

Neste novo esquema, o movimento de dispersão do gado descrito antes também sofreu alterações.

\title{
4.14.1 Comunidades do baixo vale do rio Arrojado e o uso das soltas
}

Para discutir os usos das soltas - áreas de uso comum próximas às comunidades, onde os criadores soltam seu gado durante alguns períodos do anoé de fundamental importância remeter-se ao traçado dos cursos d'água, os quais se relacionam com a forma de relevo.

Nas comunidades do baixo vale do rio Arrojado, os usos da terra se fazem mais intensos nas áreas ribeirinhas onde se pratica a agricultura irrigada e, em seguida, em direção ao interflúvio, nas terras de cultura, na qual se pratica a agricultura de sequeiro e formam-se também talhões de pastagens. Estas atividades são realizadas nas áreas cercadas das tiras de terra enquanto se encontra terras de cultura. Dali em diante, os solos arenosos dos cerrados vão ganhando espaços 
e, quando os geraizeiros não conseguem mais formar pastagens, constroem as cercas delimitando as suas parcelas de uso exclusivo familiar.

A situação descrita se apresenta a partir da calha do rio Arrojado em direção ao interflúvio, assim como a partir das áreas ribeirinhas dos seus afluentes mais importantes em direção ao respectivo divisor de águas. Nas manchas de solos de cerrados que se encontram nos interflúvio - em alguns casos, extensas - situam-se as soltas. Estas, com os recentes adventos dos cercamentos, ocorrem de serem divididas por uma cerca, delimitando a área de uso da comunidade, que se encontra de um lado e de outro do interflúvio. Tal como o caso já referido dos fechos de gerais, estas cercas são construídas pelos parceleiros das comunidades situadas de cada lado. Para tanto, estes se associam e cada um se encarrega de cercar o trecho de fundo da sua parcela. Assim a área de solta passa a compreender o extenso vão formado entre a extremidade das parcelas e a divisa, geralmente no cimo do divisor de águas, com os vizinhos criadores e moradores da área ribeirinha do outro afluente.

É muito significativo, neste sentido, o que se constata em uma extensa área de solta usada pelos moradores das comunidades de Tatu, Buriti, Cabeceira Grande, Corredor, Caixeiro, Bonito e Boa Vista.

A quem passa pela BR-349 é visível, em um trecho de aproximadamente 5 $\mathrm{km}$, algumas sinalizações, constituídas de pneus velhos, pedaços de tubos de PVC e bolsas velhas, todos pendurados na cerca, distando uma da outra $700 \mathrm{~m}$. Ao procurar saber dos interlocutores do que se tratavam, os mesmos afirmaram que aquela área é uma solta das referidas comunidades - e os objetos sinalizavam nas cercas os trechos que cada grupo de 10 criadores devem se responsabilizar pela sua manutenção. Devem fazer frequentes vistorias nas cercas, pois qualquer avaria pode causar acidentes fatais na movimentada rodovia, acarretando também prejuízos para os criadores. Além dessa atenção nos cuidados com a cerca, anualmente, há que fazer aceros para protegê-la dos incêndios nos cerrados que são frequentes na estação seca, muitas vezes provocados por transeuntes da rodovia, cujas bitucas de cigarros acesas lançadas pelas janelas dos carros são, provavelmente, as maiores causadoras.

Os criadores das comunidades dispõem, portanto, de três áreas de criatórios, a saber: a manga (pastagem formada na parcela), a solta (gerais próximos) e os 
fechos de gerais (áreas de criatórios afastadas à montante do vale). Cito como exemplo o caso mais recorrente no conjunto das comunidades do baixo vale do rio Arrojado, na qual, durante o ano, geralmente estabelecem a seguinte ordem de uso das áreas: no mês de maio, quando o rebanho retorna dos fechos de gerais, primeiro pasta nas mangas o capim vedado que se formou até produzir a semente (figura 15, p. 287). Após o esgotamento desta pastagem, o criador arranca os grampos dos fios de arame da cerca do fundo da parcela e libera o rebanho na área de solta. Ali o gado permanece por mais alguns dias, a se alimentar dos rarefeitos brotos verdes dos cerrados.

Estes dias nos quais o gado permanece nas soltas, próximas às comunidades, são muito significativos, pois enquanto ali está, pode ser cuidado concomitante à realização de outras tarefas na parcela. Mas em pouco tempo a solta, a depender da sua extensão poderá superlotar-se e o alimento torna-se escasso, obrigando o geraizeiro a deslocar o seu rebanho para os fechos de gerais distantes, na montante do vale, geralmente no mês de outubro, quando caem as primeiras chuvas e as mangas devem estar livres do pisoteio do gado para o capim sair a brota. Desta retirada, o gado só retornará às parcelas em meados de dezembro, permanecendo nas mangas até março, quando carece ser retirado para que o capim creça e produza a sementeira, cumprindo-se o ciclo anual.

\begin{abstract}
Enquanto tá utilizando esse aqui dos gerais tá preservando o outro. E vice-versa. Quando ele sai daqui também (dos gerais para as parcelas), esse aqui tá preservando o outro também. É uma relação assim... muito interessante nesse trecho aqui também (na solta), pelo seguinte: eles têm certeza de que vem a reserva de capim aqui (nos gerais), outra certeza que eles têm é que não vão derrubar os gerais, não é para derrubar os gerais, os gerais ficando em pé a gente tem certeza que tem água cá em baixo, é muito simbiótico! (Iremar Barbosa de Araújo, Professor da Rede Municipal de Ensino, lotado na comunidade de Couro de Porco. Trabalho de campo realizado em outubro de 2010).
\end{abstract}

Neste relato, o interlocutor destaca elementos para a compreensão da dinâmica do rebanho, expondo a sintonia desta dinâmica com o ciclo da vegetação dos cerrados. Destaca a importância dos cerrados sem desmatá-los, tanto nas soltas quanto nos gerais, pois, assim, tem-se a certeza de que durante todo ano poderá contar com os cerrados como área de refrigério para o gado, no momento em que nas exíguas parcelas, as pastagem formadas, as mangas, comumente chegam à exaustão. Merece destaque, ainda, o fato de se usar os gerais, ou a vegetação de cerrados em pé, na montante, e a partir disto se ter garantida a oferta 
de água nas áreas a jusante, nos sítios das comunidades, o que tradicionalmente proporcionou fartas colheitas lembradas nostalgicamente pelos camponeses geraizeiros.

Neste sentido, pode-se entender o porquê das manifestações até desesperadas do Sr. Antonio José de Araújo, do Brejo Verde, ao poder público, pedindo socorros para que possa preservar as áreas de cabeceira, das nascentes do córrego Santana. Nesta comunidade, o referido córrego tem suas nascentes nas áreas de soltas, e o mesmo abastece cinco regos que irrigam os cultivos da comunidade.

Após ampliação das pastagens nas parcelas, os geraizeiros podem selecionar - gado que partirá para os gerais. E, como costumam afirmar, levam preferencialmente o gado solteiro, aquele que se encontra forte - ao contrário do passado, quando levavam tudo e tomavam muito prejuízo. Atualmente, o gado não habilitado para o deslocamento e permanência nos gerais fica nas mangas se alimentando de algum pasto reservado e complementam a alimentação com algum capim de ração (ou forrageira) cultivado no regadio, com restos da lavoura irrigada e ainda com farelo de soja e milho misturados. ${ }^{224}$

Há que ressaltar, entretanto, que esta possibilidade vem diminuindo a cada dia, pois, a partir do fracionamento das parcelas, os víveres tanto das pastagens cultivada quanto da área de regadio vêm escasseando-se e os geraizeiros que se encontra nesta situação, tal como no passado, se obrigam a levar todo o rebanho para os gerais logo após a escassez dos brotos verdes na solta e acaba por se submeter ao risco de todas as perdas que incorriam no passado. Ao contrário destes, aqueles que ainda dispõem de parcela considerável de terra na qual a relação tamanho do rebanho/área de pasto formada é positiva, nos anos em que as condições climáticas são consideradas normais, podem até não levar seu gado para os gerais. Isto representa uma grande vantagem para o criador, pois, poderá permanecer durante toda a estação chuvosa em sua parcela, dedicando-se às diversificadas tarefas que são constantes na unidade de trabalho familiar camponesa. Neste sentido, faz-se oportuno o que afirmou Chayanov:

\footnotetext{
${ }^{224}$ Estes produtos geralmente são oriundos das lavouras modernas do agronegócio. Possivelmente, são geneticamente modificados, o que interfere na tradicional qualidade da carne bovina, e, além disso, representa o incremento de custos de produção no processo produtivo da pecuária geraizeira.
} 
Mais importante para a estrutura de exploração natural é que a intensidade do cultivo e suas formas organizativas dependem em grandíssima medida da extensão de terra utilizável, do tamanho da família trabalhadora, e da extensão de suas necessidades, ou seja, de fatores internos (tamanho e composição da família proporcionalmente à extensão de terra cultivada). A densidade populacional e as formas de utilização da terra tornam-se assim fatores sociais extremamente importantes, que determinam fundamentalmente o sistema econômico (CHAYANOV, 1981, p.145).

A forma de uso pecuário da terra, constituindo-se o que se chama de solta, é muito comum nas comunidades do baixo vale do rio Arrojado (figura $7 \mathrm{~b}$ ). Porém, conforme já assinalado, o grau de uso da pastagem formada, da solta e dos gerais, relaciona-se com o regime climático e o ciclo do capim, mas também vem a calhar com as assertivas de Chayanov, sobretudo no que diz respeito à extensão da área parcelar e da extensão da família, influindo, assim, na quantidade de trabalho aplicada nos variados espaços que compõem a base territorial dos geraizeiros.

Aquelas comunidades situadas mais a montante das áreas, onde se encontram o conjunto de comunidades, por estarem em contato mais imediato com as áreas de cerrados, apresentam casos diferenciados de usos da solta. A comunidade de Brejo Verde, escolhida no conjunto para o estudo com maior profundidade, localiza-se neste setor e, por isto, à ela darei especial atenção.

\subsubsection{O Brejo Verde: a territorialização do seu "fecho" ou solta}

Conforme já referi, a comunidade de Brejo Verde situa-se no vale do Córrego Santana, afluente da margem direita do rio Arrojado. A ocupação humana desta comunidade fez-se mais densa na margem direita do referido córrego, pois, na margem esquerda, os solos arenosos dos cerrados estendem-se até a sua margem imediata, impossibilitando o uso agrícola da terra com as técnicas que são acessíveis às comunidades camponesas estudadas.

Diferentemente de outras comunidades, os moradores do Brejo Verde comumente se referem à sua área de criatório anexa como "fecho" e esta denominação relaciona-se com a situação geográfica da área da comunidade, na zona de transição com os gerais propriamente ditos. Em função desta localização, apesar de os moradores da comunidade de Brejo Verde a usarem como solta, os criadores de outras comunidades a usavam como fecho de gerais. Ou seja, os últimos ali soltavam seu gado, depois do uso da manga e das suas respectivas soltas, sendo, então, a sua terceira área de uso. Em grande parte, isto se deve ao 
fato de que a mesma era totalmente livre e incluída no continuum dos amplos gerais, livre para o uso dali à montante a fora no vale.

As comunidades mais a jusante contam com maior oferta de terras de cultura e provavelmente, em função disso, grandes extensões das encostas são exploradas pela agricultura ou pelas pastagens, adentrando-se em considerável profundidade em direção dos interflúvios. Disto resulta que restaram áreas não muito amplas de cerrados para serem usadas como soltas pelas comunidades situadas de um lado e de outro do interflúvios. Aliás, nas partes mais abaixo do vale, vê-se que nos interflúvios dos afluentes do Arrojado elas até inexistem. Isto implica em uma grande dependência dos gerais para a soltura do gado, sobretudo aqueles criadores que em suas parcelas de uso exclusivo familiar dispõem de pastagem insuficiente para alimentar o seu rebanho.

O caso da comunidade de Brejo Verde diferencia-se neste aspecto. $\mathrm{Na}$ margem esquerda do córrego Santana se encontra uma extensa área de cerrados, a qual se estende até à comunidade de Catolés e, já na altura do médio vale do riacho desta comunidade, torna-se contínua gerais a dentro.

Em uma similaridade com o caso das comunidades já descritas, a encosta oeste do interflúvio, a partir do picadão, há pouco tempo transformado em estrada construída pela prefeitura municipal, recentemente foi delimitada como solta de uso exclusivo da comunidade de Catolés, enquanto a encosta leste, entre o referido picadão e o córrego Santana, foi definida como área de solta de uso exclusivo da comunidade de Brejo Verde.

Alegando a necessidade de se precaver contra as investidas dos grileiros, cuja ameaça de fato ocorre, as comunidades de Catolés e Brejo Verde decidiram organizarem-se, com vista a cercar a área de solta que reconhecem como de direito pelo uso costumeiro.

\footnotetext{
era uma área naturalmente em aberto, né? Mas como a gente ver muita gente de fora chegando, apertando, comprando, né? E até botando preconceito para ninguém ter mais acesso naquelas áreas que eles compraram, e muitos, até mesmo eu, conheci muita área aqui pra frente, que a gente ia caçar naqueles geraizão de lá, né? E hoje ninguém tem mais como andar lá porque pessoas de fora chegaram, compraram e aí proibiu as pessoas daqui do lugar ter habitação lá dentro, né? $E$ aí hoje ficou muito difícil. E aí nóis vendo que a coisa ia apertando, né? E só restava essa área aqui de 2.500 hectares, os donos, os 35 donos, e a gente achou que de qualquer forma a gente tinha que cercar essa área, né? Tinha que cercar. Porque ficar assim aberto, fica meio inseguro, né? E aí foi que nós cercamos, né? Para ter mais uma garantia, para mostrar que nós é o dono, né? (Sr. Antonio José de Araújo, morador da comunidade de Brejo Verde, trabalho de campo realizado em janeiro de 2012).
} 
De modo idêntico ao que se fez nas soltas descritas e nos fechos de gerais, reuniram-se os criadores da área, moradores das respectivas comunidades, dividiram o comprimento da cerca pelo número de usuários e cada um se encarregou da construção da parte que lhe coube, comprometendo-se também a garantir a manutenção da sua parte, daquele momento em diante.

\begin{abstract}
José: e como é que vocês se organizaram para cercar? Porque a cerca é longa e tem um custo, como é que vocês fizeram?

Sr. Antonio: nós reunimos as pessoas, através de reunião, né? A gente fez reunião, como podia fazer aquela cerca, né? Aí depois que nós fez a reunião, fez um levantamento de quanto gastava de arame, de quanto gastava de madeira, né? E aí cada um desses donos, que são 35 donos, né? Cada um desses donos fizemos seu pedaço, né? (Sr. Antonio José de Araújo, morador da comunidade do Brejo Verde, trabalho de campo realizado em janeiro de 2012).
\end{abstract}

Cabe ressaltar que se 0 intuito era evitar demanda com grileiros que ameaçam expandir suas frações territoriais sobre as referidas áreas de soltas, esta medida - os cercamentos - não vem fazendo-se eficiente ao que se pretende, pois, em áreas já cercadas pelos criadores, quando os grileiros decidem pela tomada, contratam os serviços de quem se presta ao ofício, os quais, sob a proteção de pistoleiros, põem as cercas abaixo, assim como outras construções a mais que possa haver na área pretendida. Com isso, entretanto, não se quer deixar de reconhecer a importância da cerca enquanto uma benfeitoria que possa reforçar 0 direito de posse.

Quero demonstrar também que se esta medida de alguma forma teve ou tem validade para se defenderem dos grileiros, serviu também para suscitar conflito com seus pares, os antigos criadores de outras comunidades, os quais, por não terem sido convidados para a sociedade, com vistas à construção da cerca, a partir do cercamento, foram proibidos pelos moradores da comunidade de Brejo Verde de soltarem seus animais na área que tradicionalmente usavam. ${ }^{225}$

Este conflito, inclusive prolongou-se a ponto de recorrerem à mediação da ordem jurídica, conforme relato que segue:

olha, pra começar, para nós começar cercar essa área aí, teve conflito, teve preconceito, teve pessoas, que, porque soltava gado aí, que eles nunca foi dono, né? Soltava gado aí, quando nós começou, resolveu cercar aí queriam impedir, né? Eles queriam impedir que nós não cercasse, né? Esse pessoal que queria impedir nós cercar, o primeiro que cercou foi esse fecho aqui, era comum, daqui até o Catolé, né?

\footnotetext{
${ }^{225}$ Os moradores da área ribeirinha, tradicionalmente, entendem como direito seu, o uso da área da encosta, nos fundos do terreno onde moram e praticam a agricultura e daí surge o termo fundo de pasto, o qual por vezes também os usa em referência à solta.
} 
Passava da rodage aí, mas aí, como a rodage é a extrema, aí o pessoal do Catolé, que é até seu Deca, né? Seu Deca cercou primeiro a área dele, da rodage pra lá. Depois que seu Deca cercou, eu falei, seu Deca cercou de lá, e ficou da rodage aqui que é nosso, vamos cercar também né? E esses senhores começou impedir, aquele povo lá do Catolé, começou impedir nós de cercar também, que o gado deles comia aqui, que eles não eram donos não, né? Isso foi uma batalha forte, isso teve uma reunião no juiz, e foi para o advogado, advogado não resolveu, aí falei assim, ninguém vai mais envolver com advogado, que nós já gastou dinheiro aí com advogado, já não resolveu, quem vai resolver é nós. E aí nós cercamos aí, mas depois que nós botemos as caras mesmo, que era nosso, nós não tava cercano nada dos outro, nós não tava invadindo, e aí nós cercamos, depois que nós cercamos esses invasores afastaram, né? (Sr. Antonio José de Araújo, morador da comunidade do Brejo Verde, trabalho de campo realizado em janeiro de 2012).

Outro interlocutor detalha o grau de acirramento em que chegou o conflito:

Essa terra vem dos antigos, né? Fundo de pasto, né? Que a comunidade... tinha um povo aí dentro também que não era daqui da comunidade, saíram, saíram fora. Botaram nós no juiz, nós ganhemos a questão. Que é fundo de pasto. Isso aqui tudo é fundo de pasto. Cada um que sai na propriedade, que imbica lá entrou no fecho daqui. Daqui há 2 mil metros, que a rodagem vai para o Ribeirão, lá é a extrema nossa. Do tempo do Prefeito Almir Bispo, ele fez uma rodagem aí, da Prainha, ele rodou para sair no Ribeirão. Agora nós era em conjunto com o povo do Catolé. Aí entrou, entrou em questão. E o povo do Catolé queria atravessar a rodagem para cá e nós foi mexendo com ele aí, mexeu, virou, veio o povo do sindicato, presidente, entramos aí em questão com esse povo, tiremos eles da rodagem para cá. Jogamos pra lá. Fizemo a extrema ser da rodagem. Nós daqui até a rodagem e eles do Catolé até a rodagem também. Ficou extremado.

Eles vai faz a cerca deles, como é que a rodagem é um becão. Eles fez a cerca deles de fora a fora, 7 mil e tantos metros, né? E depois nós fizemos a nossa. ...botaram na lei, juiz mandou derrubar a cerca (do povo do Catolés que havia construído-a abarcando uma área depois da estrada), coisa, e nós fiquemos de cá, né? E aí a polícia veio aí, derrubou a cerca deles, eles é um povo muito brabos, né? Entraram, fizeram audiência, hoje quetou, né? Eles tornou levantar a cerca. Já tem uns... mais de cinco anos essa cerca aí. Eles quetaram. Aí nós fizemos a nossa beirando a rodagem de forma que a rodagem tá sendo um beco. Aí nós fizemos a nossa daqui das propriedades, fizemos as picadas, isso aí é tudo cheio de picada, cada fundo, de propriedade sai na rodagem lá (Sr. Lázaro de Souza Brito, morador da comunidade de Brejo Verde, trabalho de campo realizado em janeiro de 2012).

No direito costumeiro predominante na região, aqueles moradores das áreas ribeirinhas, os quais fazem usos mais intensos das terras próximas às moradias, sentem-se portadores do direito às terras das encostas mais afastadas no prolongamento das tiras de terra em direção ao interflúvio. No referido caso, ao decidir cercar a área de solta e limitar o seu uso às comunidades de um lado e do outro do interflúvio, se fez surgir o desentendimento entre as comunidades de Brejo Verde e Catolés, que até então faziam uso comum de toda a área. A causa do conflito foi a discordância quanto ao estabelecimento da divisa. A comunidade de Brejo Verde entendia que a mesma deveria obedecer ao traçado do picadão, transformado em estrada, o qual não obedece à linha do divisor de águas. A não aceitação dessa divisa pela comunidade de Catolés deflagrou o conflito que, 
conforme o relato anterior, recorreu à ordem jurídica na tentativa de saná-lo, culminando até em intervenção da polícia. Após o prolongamento da demanda no campo jurídico, e a não solução, a comunidade do Brejo Verde decidiu cercá-la seguindo a linha do picadão e a comunidade de Catolés cedeu, embora permaneça o mal-estar entre as comunidades vizinhas.

Casos como este são exemplos de que a expansão da propriedade capitalista da terra se faz de forma conflituosa com o modo camponês de apropriar-se da terra e, além disso, provoca conflitos entre os próprios camponeses, abalando a organização comunitária nos tradicionais usos que fazem em comum das riquezas naturais. Nota-se nos relatos do Sr. Lázaro, a referência à área de criatório comum como fundo de pasto. Cabe ressaltar que o mesmo se destaca como liderança no meio comunitário; inclusive participou da fundação do Sindicato dos Trabalhadores Rurais de Correntina - e talvez devido a ligação com as lutas dos camponeses em escalas mais amplas em suas atividades sindicais, em nível estadual, carregue para a comunidade esta representação e significado para o caso de suas áreas de criatórios, as soltas. Em consequência disto, tanto o Sr. Lázaro como alguns vizinhos traçaram variantes alongando a extensão de sua parcela e incorporando extensões da área de solta. Seguindo a orientação do que preconiza o fundo de pasto, estes entendem que o uso comum da área deva restringir-se ao pecuário e os demais, como as diversas coletas que fazem, cada qual deve realizar apenas na área de projeção da sua parcela, solta a dentro.

Observou-se, porém, que este entendimento não é consensual e nem majoritário. Quando existe, restringe-se àqueles conhecedores de outras lógicas de apropriação camponesa da terra no Estado da Bahia e/ou detentores de extensa área parcelar (em relação à média da comunidade) e, por isso, se beneficiariam do que preconiza o fundo de pasto, ampliando em muito a extensão de sua parcela.

Aqueles parceleiros que, devido às transferências possessórias, tiveram suas parcelas reduzidas à estreita tira de terra, a grande maioria, não defendem a variantação e a restrição dos usos das soltas, o que poderia comprometer a subsistência, e, por isso, defendem o pleno uso comum de toda área de solta por todos da comunidade. Ressalto que não se observaram discussões e muito menos demandas no meio comunitário suscitadas por este ponto, talvez devido à sua prematuridade na região. 
Além do conflito suscitado com o povo do Catolé no estabelecimento da divisa da aérea a ser cercada, a decisão de restringir o seu uso às comunidades do entorno, de Brejo Verde e Catolés, cerceou o tradicional uso que outras comunidades do baixo vale do Arrojado, sobretudo a comunidade de Praia. Os criadores da Praia, conforme já informado, soltavam ali o seu gado, usando-a como fecho de gerais, mas, contrariando o interesse da totalidade do grupo, "venderam" uma parte da área de criatório sem consultar os demais integrantes do grupo.

\begin{abstract}
Com o povo da Praia também foi o seguinte: o povo da Praia, a maioria deles vendeu uma área para uma empresa aqui em cima, nós tiremos eles da área aqui, porque o fecho era comum daqui no Ribeirão. Eles pegaram o deles e vendeu, e ficou nóis aqui. Aí nós tiremos eles da sociedade. ...eram pessoas que moravam fora e tinha aquele despejo de botar criação ali, né? Aí depois que fizemos a cerca, não botemos eles na sociedade, eles ficaram de fora. Também não soltam mais. Ainda vieram, vinha pedir, coisa, outros soltavam aí, a gente mandava tirar. Ainda teve deles aí que veio, pediu, a gente ainda arrumou. Agora esse ano já não atentaram mais não (Sr. Lázaro de Souza Brito, morador da comunidade de Brejo Verde, trabalho de campo realizado em janeiro de 2012).
\end{abstract}

A "venda" de uma área de solta usada por um grupo nunca é realizada de modo consensual, a partir da qual se poderia culpar, a totalidade do grupo, como faz transparecer no relato anterior. O que se vê, de fato, é que, para o cercamento, foram convidados a se associarem apenas os moradores da comunidade de Brejo Verde, os considerados donos, enquanto os demais, sendo beneficiados ou não com a "venda", conforme relata o Sr. Lázaro, foram sumariamente excluídos do direito tradicional de uso da área.

É ilustrativo, neste sentido, o processo conflituoso envolvendo um grupo de criadores usuários de uma área anexa ao Brejo Verde, abrangendo as cabeceiras dos riachos formadores do Córrego Santana, a saber: Galho do Pichico e Galho Forquilha.

A referida área era usada por um grupo de 18 criadores. O conflito iniciou-se depois que um interessado fez negócio de "compra" com a aceitação de 8 dos integrantes do grupo ${ }^{226}$. Mas, na outra parte, os 10 não concordaram com a "venda", não assinaram qualquer documento de transferência e resistem, continuando a

${ }^{226}$ A grande maioria dos negócios de terras na região trata-se de transações ilegais, pois os tradicionais usuários das áreas são posseiros, portanto não detentores de qualquer documento que valide a propriedade legal da área. Quando se fala em venda pode-se dizer que a parte que vende não tem a prerrogativa para isso e que a adquirente, sabendo disso, age de má-fé, com vista a usurpar as terras públicas contando com os serviços dos órgãos oficiais. As poucas ações discriminatórias administrativas que se tem realizado na região invariavelmente tem chegado à conclusão de que as transações de transferências de terras se constituem em operação de grilagem da parte do adquirente, geralmente, personagem do grande capital "moderno". 
soltar seus animais na área. A situação de conflito tende a se agravar, porque o suposto adquirente tem projeto para em breve desmatar boa parte da área em conflito, o que, se levado adiante poderá inviabilizar totalmente o uso pelos criadores discordantes do negócio.

\subsubsection{A organização comunitária do brejo verde para uso do "fecho"/solta}

A solta da comunidade de Brejo Verde caracteriza-se com peculiaridades em relação às demais usadas pelas comunidades do baixo vale do Arrojado. Dentre os elementos que a diferencia, pode-se citar:

- localização no contato imediato com os amplos cerrados ou gerais livres;

- uso por integrantes de diversas comunidades até recentemente;

- localizar-se na frente de contato com as investidas dos grileiros;

- área com grande extensão ${ }^{227}$ em relação às demais à jusante.

Devido ao fato de se localizar no contato imediato com os gerais, até recentemente (2006), muitos criadores de outras comunidades a usavam na condição de fecho de gerais, ou seja, como terceira área de pastagem dos animais, após o uso da manga e da solta anexa às suas áreas parcelares. Ainda por este motivo, sentem-se mais ameaçados pelos grileiros, os quais investem com maior intensidade nas áreas livres dos gerais desprovidas de moradias e residências permanentes, o que a priori poderia significar menor resistência dos posseiros usuários da área apenas sazonalmente. Ainda em função das ameaças de grileiros $^{228}$, decidiram tomar medidas preventivas, destacando-se, entre elas, os

\footnotetext{
${ }^{227}$ A área da solta do Brejo Verde ainda não foi medida, mas os usuários estimam que sua extensão atinja 2500 ha.

${ }^{228}$ A comunidade do Brejo Verde até o presente não se encontra em situação de conflito direto com invasores de fora. Entretanto sentem-se ameaçados pela expansão das investidas privatistas de grileiros já diminuindo a extensão de sua área de soltura do gado e até mesmo da aproximação de equipe de gente de fora desconhecidas fazendo medições nas áreas de sua solta.

"E aí nós vimos que aquela grande área que é umas duas léguas pra frente, né? O pessoal foi comprando lá e cercando, foi comprando e cercando, e lé vai apertando e o gado daqui não tem mais liberdade de comer lá, porque já foi cercado, né, e só restou mesmo essas duas partes, foi ficando pequeno, né. E aí já tendo um pouco de ameaça de pessoa de fora, né? Já passaram, mediram, né, não tinha nada a ver que não era dono e nem nada, mediram aí, ninguém de nós vendemos isso pra eles, eles passaram medindo, já invadindo! E aí nós diz tem que cercar mesmo por que senão os de fora vai tomar esse trem nosso aí, né? Aí cercamos, o pessoal do Catolés cercou primeiro, logo em seguida nós cercamos o nosso" (Sr. Antonio José de Araújo, morador da Comunidade do Brejo Verde, trabalho de campo realizado em janeiro de 2012).
} 
cercamentos, excluindo assim os usuários da área como fecho de gerais, restringindo o uso àqueles que, em função da antiga apropriação da frente, têm reconhecido direito da comunidade de Brejo Verde à apropriação da extensão de sua posse em direção ao interflúvio, procedimento seguido da mesma forma pelos moradores da comunidade de Catolés.

Feito o cercamento da área, uma segunda medida restritiva tomada pelos criadores com direito reconhecido ao uso foi a instalação de uma placa na entrada da solta, na qual consta a lista das marcas (ou ferro) que sinalizam os animais, seguida do nome do respectivo dono da marca.

José: e o gado fica misturado, mas ele é marcado?

Sr. Lázaro: é marcado. Todo mundo tem a marca. Cada gado tem a marca do dono. Tanto aqui quanto na Agência Estadual de Defesa Agropecuária da Bahia. Criador que cria gado aqui que tem o cadastro lá ele tem que... a marca dele tá lá.

José: e a marca como é que é, que marca é essa?

Sr. Lázaro: a marca é o número que o criador quiser, né? A minha mesmo é um Lê, (letra L) é a primeira letra do meu nome, é um lezinho. O gado daqui na Cabeceira da Forquilha que você ver com o Lê é meu. Outros têm número 15, outro é o nome da pessoa, a primeira letra do nome com o sobrenome, e assim por diante. Outro é um J, um I e tem essa marca de todos donos numa placa. Nós fizemos uma placa grande $e$ todos os donos... outro chegou, olhe, tá lá na placa, lá no fecho. E também na ADAB. José: se tiver algum gado com outra marca...

Sr. Lázaro: não é do fecho. Quando encontra gado estranho, acontece que é alguém que botou por confiança para vir tirar logo. Logo bota e avisa a um daqueles donos, olhe tal gado que tá assim estranho é meu. Eu pus aí porque vinha trazendo de cima - que eles vai trazendo lá pra cima, né? Pro Lodo, pra cima, pra lá, - vinha trazendo, não deu jeito, abri o colchete e pus pra dentro do fecho seus. Aguarde aí que amanhã ou depois eu venho panhar. Aí vem, panha, é muito respeitado, né?

José: e marca em qual lugar do gado?

Sr. Lázaro: é na... uns costumam marcar na anca (parte superior dos membros traseiros). Agora os meus é tudo na perna, do lado direito, bateu a marca ali, é tudo na perna. A marca de anca fica feio. Outros marca na taba do pescoço, outros marca na cara, é uma judiação. Gado meu só ver na perna (Sr. Lázaro de Souza Brito, morador da comunidade de Brejo Verde, trabalho de campo realizado em janeiro de 2012).

Estas medidas visam, sobretudo, a demarcação territorial àqueles de reconhecido direito ao uso da solta, pois a área é tangenciada pela estrada que transita o gado entre as comunidades da jusante e as áreas de fechos de gerais na montante. Costumeiramente, se, por algum motivo, alguma rês ou grupo não podia prosseguir viagem, era deixado ali provisoriamente, sem qualquer impedimento. A partir da restrição de uso da área, até se permite a prática costumeira, mas sob a condição de ter que avisar aos usuários de direito reconhecido, os da comunidade de Brejo Verde, conforme relato do Sr. Lázaro. 
Quanto à dinâmica do uso da área durante o ano, segue-se, grosso modo, a mesma sistemática já descrita quando referi aos fechos de gerais da montante. Entretanto, na comunidade de Brejo Verde, por contar com área mais extensa de solta, muitos dos seus integrantes fazem uso apenas da manga e da solta, não necessitando deslocar o gado para uma terceira área de criatório, o fecho de gerais, embora alguns o façam, preferindo usufruir das vantagens dos fechos dotados de amplas veredas com farta oferta de gramíneas, abrindo mão, em contrapartida, de estar continuamente voltado aos afazeres da parcela, a ter que se dedicar aos cuidados com o fecho de gerais e com o criatório enquanto lá permanece. Alguns destes inclusive se eximiram de participar da associação para o cercamento da solta, de modo que a parte da cerca da sua parcela, que lhe cabia construir, ficara inclusa no cômputo geral, entre os associados, os quais se encarregaram de construí-la. Inclusive é significativo o número de integrante da comunidade Brejo Verde não participante da sociedade para o cercamento e uso da solta. Estes, conforme já informado, usam diretamente os fechos de gerais, ou participam de outro grupo de criadores da solta ou fecho do Vira Saia usado pela comunidade de Passagem Funda localizada no interflúvio à direita do córrego Santana. Isto explica o fato de que a área do Brejo Verde ser habitada por 80 famílias (equivalente a 313 pessoas) ${ }^{229}$ e apenas 35 famílias soltarem seus animais na solta da comunidade.

Em função da longa extensão da área da solta em sentido norte-sul, de modo similar ao que se verifica nos fechos de gerais, o gado dispersa-se geralmente em grupos pertencentes a certo conjunto de vizinhos, de modo geral, constituídos de parentes. Este rebanho costuma pastar em certas áreas da solta e beber na mesma aguada no Córrego Santana, localizada, quase sempre próxima às moradias de seus respectivos donos. Ao longo do Córrego Santana, encontram-se 4 aguadas, ou bebedores, e ali os criadores disponibilizam cochos também chamados de salinas, nos quais oferecem o sal para o gado, reforçando, com isso, a convergência de seus rebanhos para este ponto.

$\mathrm{O}$ ato da oferta de sal para o gado, assim como a organização dos criadores para o funcionamento da solta, contém elementos significativos para a

\footnotetext{
${ }^{229}$ Dados de 2012, fornecidos pela Secretaria Municipal de Saúde de Correntina.
} 
compreensão do sentido e grau de organização do grupo de criadores e nesse sentido cito um conjunto de relatos que merecem destaque.

José: seu Antonio, mas o senhor disse que tem criador que solta 10 cabeças de gado, e tem criador que solta até 200. Mas, e na hora de dividir a cerca, porque...

Sr. Antonio: a cerca? Nós fizemos assim: nós fez parte igual. E foi assim sem orgulho, né? Nóis foi fazeno assim, parte igual. Porque da forma que muitos queriam, assim, para cada um dividir o seu, né? Aí cada um fazer sua cerca assim, dividido, pedaço em pedaço, né? Por área, vamos dizer assim, né? Mas assim não ia ficar bom porque a área ficava apertada, né? A área ficava apertada e não ficava muito bom, né? E assim como eu fui o indicado para levar às pessoas essa idéia de que realmente nós tinha que cercar porque de repente podia chegar uma invasão, né? E ia até arrumar problema pra nós, né? Porque nós cercando tinha mais uma garantia, né? Seria mais uma prova que nós cercando, nós é dono, né? E aí nós reuniu o pessoal, né? E fizemos assim por parte igual, cada tanto, e tanto. Tanto por tanto, né? Parte igual (Sr. Antonio José de Araújo, morador da comunidade de Brejo Verde, trabalho de campo realizado em janeiro de 2012).

Assim, o aperto provocado pela privatização provoca a resistência (no ato de cercar), por meio da qual surge uma relativa soltura, na medida em que se organizam comunitariamente com vistas à defesa de suas frações territoriais e à garantia da reprodução do tradicional uso comum da terra. Tornam-se, assim, menos apertados se comparados a outros grupos que não se organizaram a tempo, e suas soltas ou fechos foram tomados.

José: e o gado, quando ele está nessa área de solta, do que ele precisa? Ele não precisa comer mais nada...

Sr. Antonio: o capim chama capim agreste; e depois tem o tucum, a palha de tucum que é uma alimentação boa para o gado também, até que não tem proteína, né? Mas dá para viver. E depois tem os lugar também das bebidas, né? E depois a gente põe sal na cocheira, né? Sempre mantém sal, né?

José: mas aí como é que faz na cocheira para colocar o sal, porque tem gente que tem 10 e tem outros que tem 200.

Sr. Antonio: é mais faz o seguinte: para começar já é uma coisa sem orgulho, né? Aqui na área de 2.500 hectares nós temos 4 bebidas, né? 4 ponto de bebidas para o gado descer e beber, né? Então em cada bebida, nós coloca uma saleira, aí vai come o gado meu, o gado de um irmão lá, de um vizim, de mais, de mais, né? Por exemplo, o dia que o gado desce para a bebida, lá ta o sal né? O gado de todo mundo come lá, né? Chega numa outra bebida lá embaixo, no meio, lá tem saleira, e assim por diante. É uma coisa que a gente faz a saleira lá, né? Põe o cocho de sal, e aí todos gado que chegar ali eles come, né?

José: quem tem 10 põe sal e quem tem 200 põe sal também. Mas quem tem 10 põe menos e quem tem 200 põe mais, como é que é?

Sr. Antonio: é igual. Por exemplo, nós têm um cocho lá, né? Você pega um saco de sal e põe naquele cocho lá, né? Por exemplo, eu uso botar na minha frente, na minha terra aqui, tá o sal lá, aí o gado que chegar lá vai comendo, né? Assim que termina a gente põe mais. E assim por diante. E assim cada um... (Sr. Antonio José de Araújo, morador da comunidade de Brejo Verde, trabalho de campo realizado em janeiro de 2012). 
Outro interlocutor reafirma esse caráter da organização comunitária mediada pela necessidade e não pela quantidade de trabalho mobilizada na operação do cercamento:

José: Seu Lázaro, enquanto o gado está no fecho, como é que vocês cuidam do gado?

Sr. Lázaro: bom, o gado tano no fecho, é como diz, eles tão lá e nós tem o sal no cocho direto. Remédio aquele... é o que mais nós cuida é com sal no cocho.

José: mas e como é que... que o gado está misturado, né? O gado está todo junto... não tem cerca que separa... o Sr. leva o sal e põe no cocho, vem o gado do Sr. e come mas vem dos outros e come também. Como é que vocês ajeitam aí?

Sr. Lázaro: a gente combina. Esse ano a gente aí, nós combinou. Tem um irmão meu ali, um sobrinho, diz, olhe o gado seus tá num cocho nosso aí, que o gado nosso aqui quase que é só no bebedor aí, mas o gado deles aí vinha também pro bebedor, né? Gado desse povo de cima, já bebe noutro bebedor pra cima. O nosso é quase separado. Mas a gente avisa eles tudo. Que tem um cocho aí, cada um que for levar sal bota para o seu e pro dos outros. É uma sociedade aqui. Meu mesmo esse ano botei um bocado de sal aí. Vinha umas novilhas dele, bebia... as vezes nós panhava sal aqui levava, quando chegava lá já tinha sal. Eles botava, o gado vinha comia, dos outros também vinha e comia...

José: quem era o menino?

Sr. Lázaro: o Tõe de compadre Bidias ali. Digo, olhe, vamos largar a usura pra fora, o que que é você botar um saco de sal, um saquinho de sal lá pro seu gado? Se o do outro vem e come... um outro vai e bota, e seu vem e come. Vamos fazer a sociedade. Assim nós fazia. Comeram sal aí direto, quase todo dia tinha sal no cocho. Vinha os meus comia, vinha os do outro comia, vinha os do outro comia, quando chegava lá tinha sal, o outro botava, outro botava e assim até tiremo o gado.

José: e esses criadores, qual é a quantidade de gado que cada um tem?

Sr. Lázaro: varia. Uns tem mais, outros tem menos. Todos eles têm um gadinho, né? Tem deles que têm 2 vaquinhas, outros têm 10, outros têm 15, outros têm 50 gado, outros têm 80. É assim. Uns mais, outros menos. Mas ninguém faz numeração não. Outros não solta o gado tudo, só solta uma parte, deixa os outros cá e é assim.

Aqui em cima tem um pessoal que faz parte do fecho aí também que quase não tem gado. Tem 2 vaquinhas, uma pareinha de bezerros e outros têm mais, outros como esse Nego mesmo, o gadinho dele é pouco. Mas ele já tem o fecho lá, tem vez que ele leva pra lá, fica parte dele aí sem gado né? Outros já bota e é assim.

José: e quanto ao sal, o sal ou outros cuidados. Tem um que tem duas cabeças de gado, outro tem 80 , como é que organizam para oferecer o sal?

Sr. Lázaro: acontece que aquele que tem duas não bota nada. Deixa o gadinho dele lá. Ele também não faz numeração, porque é pouquinho. Além do que a parte dele (da cerca construída) é a mesma minha que tem mais gado. Então não tem numeração. Tem um menino lá em cima, até afilhado meu, senhor de Valdo. Ele, depois que aposentou, comprou duas vaquinha, comprou uma pareiazinha de garrote, e, como diz, ta criando o gadinho dele aí, ele tem o direito dele do fecho que é direitos iguais. A gente tem mais terra, mas a cerca, nós fizemos uma sociedade na cerca para todo mundo fazer aquela quantia. Acontece que eu tenho tantas hectaras, ele tem tantas hectaras, mas a cerca ficou uma coisa só. A terra é mais, mas a cerca é aquela quantia. Eu mesmo não empato ninguém criar. E o sal é quem tem mais. Quem tem menos ninguém também exige, né? Deixa o gadinho dele aí, não tem problema não. Come o sal aí. A gente não faz numeração não. É muita união, né? José: e tem gente que não solta o gado todo, solta uma parte?

Sr. Lázaro: é. Porque tem um resto de pasto lá, as veiz... solta aquele gado mais forte pro fecho e deixa os outro lá pro resto do pasto, comendo o resto do pasto lá (Sr. Lázaro de Souza Brito, morador da comunidade de Brejo Verde, trabalho de campo realizado em janeiro de 2012). 
Abordo com ênfase também a questão da disposição do sal para o gado porque, conforme o Sr. Lázaro, nós não bota sal branco pra o gado não, e isto significa que o fornecimento do sal enseja cuidados fundamentais para o bom estado de saúde do rebanho total dos criadores, numa situação em que o gado está submetido a previstos riscos de saúde, conforme as citações adiante:

José: lá no fecho do senhor qual a estrutura montada que tem para a assistência ao gado?

Sr. Lázaro: bom o maior cuidado com o gado nosso aí no fecho é o sal no cocho. Não tem outro cuidado. Porque se o gado às vezes adoece tem uma injeção, alguma coisa... sal também nós não usa sal branco não. Nós não bota sal branco pra gado não. Tem que ter qualquer uma mistura ali. Um remédio, que seja um remédio nosso aqui mesmo da roça, são uma batata de purga, um caboclo, machuca, mistura, joga no sal eles come, ou então compra uns mineral, aquele Forbol, uma mistura, eles come, aí eles mulece a obra (fese), né? Que o gado quando ele vai para os gerais que ele não usa sal e nem remédio ele empreda a obra dele lá, e tem vez que é preciso pegar e dar remédio, ele vai obrar, sai as pelotinha e aquele livro dele resseca que não, o gado não remói, seca a boca, não resmói e se o senhor tá vendo ele não usando a obra, como diz, mole e coisa, cuida dele! Que ele ta intoxicado.

José: o que o senhor compra é o Forbol.

Sr. Lázaro: é o que nóis mais usa aqui. Mistura no sal e eles come.

José: e esse preparado que o senhor faz aqui?

Sr. Lázaro: aqui tem a batata de purga, que é uma erva que dá purgante, né? Que é para gente. E um purgante que minha mãe sempre dava para os filho dela, muito sadio porque é que tira as verme da barriga. Essa batata de purga. E tem um tal de caboclo. Eu conheço ele com dois nomes. Uns trata ele de caboclo e outros trata ele de tiú.

José: é o cipó caboclo?

Sr. Lázaro: não. Eles trata ele de tiú. E outros trata ele de caboclo. Ele cresce. Fica assim dessa alturinha, tem a folha despontada, tem uma batata dessa grossura assim ó. O Sr. tira ela, corta as rodeirinha, bota no sol para secar e mói no pilão. Mistura no sal ou na farinha, ali é remédio! Mistura no sal e dá o gado. Ou que seja o tiú, ou que seja a batata de purga.

José: serve também tudo para isso...

Sr. Lázaro: tudo para isso. Para o pêlo, para o verme, tira o verme, tem gado que dá verme, né? E esses dois remédios servem para isso. Aqui o gado que usa, o pêlo é igual lontra. Que usa esses remédios. E a gente aqui, sempre de vez em quando a gente mexe com esses remédios. Mas, o mais é esses que a gente compra. De vez em quando a gente faz um desses e dá para o gado, para não ficar só naquele, né? José: o que vocês usam para o gado é só isso...

Sr. Lázaro: só. Só. Tirando da vacina... Tem a vacina contra Aftosa, tem a vacina contra aquele mal que chama Gangrena, a gente de vez em quando, de ano em ano aplica, né? A Aftosa, essa tá acabano. Agora mesmo esse ano, a ADAB, lá, eu fui lá, eles disse, não, abasta vacinar o gado novo. Gado de 2 anos e meio abaixo. Os gado grande não precisa vacinar mais contra aftosa não. Certamente é que acabou, né? (Sr. Lázaro de Souza Brito, morador da comunidade de Brejo Verde, trabalho de campo realizado em janeiro de 2012).

Esses relatos demonstram os tipos de cuidado com o gado criado solto nos gerais. Merece destacar o fato da inclusão de tratamento com produtos artificiais e que isto, provavelmente, deva-se à adoção de outras raças de gado menos adaptadas ao ambiente, mas que vêm ganhando o lugar do gado pé duro 
tradicionalmente criado na região. Porém, mesmo assim, insistem no uso dos tradicionais preparados a partir das ervas naturais dos próprios cerrados.

Possivelmente em função da inclusão de outras raças nos criatórios, e da inadaptação destas ao tradicional manejo a partir da pastagem natural, atualmente também consideram os alimentos dos gerais pouco nutritivos para o gado e supervalorizam o pasto manso (pastagem formada), em detrimento do que sempre usaram; pois, no passado, praticamente inexistiam as pastagens que atualmente se têm nas mangas e o gado, durante todo o ano, permanecia solto. Assim, o tratamento do mal do toque a partir das misturas descritas, passa a constituir-se em uma produção que se conhece atualmente como orgânica, e é até possível que muitas das doenças que necessitam de serem tratadas por métodos modernos, no passado, o próprio alimento da pastagem natural continha o tratamento ou até os imunizavam.

Merece destacar, também nos relatos anteriores, as frases que considero muito significativas: é uma coisa sem orgulho, vamos largar a usura pra fora, ninguém faz numeração não, é muita união, né? elas reforçam a decisão do grupo em se organizar para defesa de sua fração do território, através da combinação entre os 35 associados de não permitir a transferência de qualquer parte da terra (da área de solta) para alguém de fora. Caso alguém queira sair da sociedade, deve transferir o seu direito para alguém da comunidade, pretendendo-se com isso, preservar a área de solta da intromissão de interesses divergentes.

Estes elementos demonstram o grau de organização do grupo, com vista a permitir e socializar o acesso às riquezas naturais que lhes possam ser acessíveis. Possivelmente, esta organização mantém relação com os vínculos de parentescos, compadrio e vizinhança que se destacam de modo considerável a contribuir para a manutenção da coesão do grupo, pautando, no meu ver, a lógica da comunidade camponesa geraizeira engendrada com vista à apropriação comunitária das riquezas naturais. Podem ser vistos também como medidas preventivas visando impedir possíveis desvios de integrantes do grupo, tal como já experienciaram no passado a existência de "espertos" na comunidade, os quais atuaram vendendo terras dos gerais, conforme afirmação já referida do Sr. Abdias.

Ainda no que diz respeito à alimentação do gado, os geraizeiros reclamam da diminuição da oferta a partir da proibição pelos órgãos ambientais das tradicionais 
queimadas que faziam nas áreas de soltas e nos fechos de gerais, objetivando o aumento da oferta de brotos novos mais palatáveis para o gado.

Nós têm um fecho bom aí só que esse ano tá um fecho... curvo. Não tem queimada, que a gente não queremos botar fogo. Que o fecho de gerais é bom queimado! O gado come naquelas brotas de queimado. Ali o gado engorda. E cru o gado não prevanece não né? Mas a gente com medo desse IBAMA com esse negócio dessa... esse negócio, a gente não tem um queimado. É um fecho grande mas não tem um queimado. Mas serve! Que a gente solta aí sossegou... fica, come uma bage de trem, como uma folha de tucum, uma folha de pau, tudo ta vivendo, né? Encosta numa vereda como agreste ali, coisa, e, mas não tem queimada não (Sr. Lázaro de Souza Brito, morador da comunidade de Brejo Verde, trabalho de campo realizado em janeiro de 2012).

A proibição das queimadas, conforme reclama o Sr. Lázaro, tem impactado o regime de criação costumeiro. Vê-se, por outro lado, que as queimadas desordenadas continuam ocorrendo e devastando de modo indiscriminado os cerrados, enquanto o aparelho estatal, que proibiu aos geraizeiros de efetuá-las, não se aparelhou para combatê-las quando ocorrem, tal como a iniciada em outubro de 2011 e que, durante quase um mês, devastou grande parte dos cerrados do município de Correntina: o Estado não se fez presente a ponto de impedi-la. E nem mesmo quando a ele, de modo desesperado, pede-se socorro, tal como os relatos do Sr. Antonio, não demonstrou qualquer disposição ao atendimento. O Sr. Lázaro relatou o quanto são devastadoras as queimadas que continuam ocorrendo:

veio um fogo aí que esse fogo aturou quase trinta dias. Não teve quem apagasse esse fogo! Passava de uma propriedade para outra e o povo irriba, irriba, irriba, e não tinha jeito. Parou aqui na Vereda Seca, que ataiaram com água, coisa, mulher chorando, e vem esse fogo estalando... apagaram! Muitos dias que esse fogo vinha de cá desse lado de Jaborandi. Mas de noite ele parava, quando amanhecia o dia se via fumaceiro. (Sr. Lázaro, morador da comunidade de Brejo Verde, trabalho de campo realizado em janeiro de 2012).

Assim, se pode afirmar que as proibições, impostas aos criadores geraizeiros, não se efetivam como parte de uma política de preservação ambiental. Até porque, conforme referi antes, as queimadas sempre ocorreram nos cerrados e estes, em grande medida, desenvolveram a capacidade de autorrecuperação, reproduzindo, assim, as condições propícias à recarga dos aquíferos nos extensos chapadões. $\mathrm{O}$ que não ocorre com os desordenados desmatamentos, realizados com o uso de correntões e máquinas pesadas, as quais removem a totalidade da cobertura vegetal e compactam os solos, produzindo impactos irreparáveis no nível dos aquíferos e provocando a morte de centenas de córregos e ribeirões. Impacto este 
que se potencializa com a aplicação indiscriminada de veneno nos solos, o qual tem como destino o aquífero, tornando estéreis os cursos de água restantes na região. Absurdamente, estas intervenções querem impor-se como o modelo viável e moderno, parte da política de desenvolvimento financiada pelo Estado. Este reprime o tradicional uso dos gerais pelos camponeses, e, na medida em que incentiva a devastação, característica da expansão da monocultora, demonstra uma declarada política de desestruturação das condições que possibilitem a reprodução socioterritorial dos geraizeiros.

Mas a resistência faz-se efetiva, no que se pode ver tanto nos sábios engendramentos quanto na disposição dos geraizeiros em se organizarem para a luta com a intensidade necessária à defesa de suas frações do território, conforme demonstrado ao longo desta tese. Isto é visível nos avanços que se tem conseguido, demonstrando os absurdos cometidos pelas forças privatistas da terra em suas fraudes. Desmascarados os métodos espúrios, dos quais lança mão o capital moderno em sua expansão, resta agora, aos geraizeiros, fortalecerem-se ainda mais, para questionar o papel classista do Estado, que tem se pautado como inteiro aparelho a viabilizar a reprodução desta elite econômica.

\subsection{O uso geraizeiro da terra e a luta pela preservação ambiental}

A possível concretização do projeto da empresa grileira que vem se apropriando das terras de cabeceiras do córrego Santana, tem causado muita preocupação aos moradores da comunidade de Brejo Verde, pois o arraso que possa ser feito nas áreas de cabeceiras dos referidos galhos certamente será desastroso para o córrego Santana, do qual, conforme já demonstrado, a comunidade de Brejo Verde tem total dependência para continuar sobrevivendo e mantendo suas frações territoriais a partir dos usos agrícolas e do aproveitamento das águas dos regos.

Pra cá tem o fecho do povo de Jaborandi, venderam aqui um pouco. Um bocado deles venderam... ...um fecho grande que esse povo tinha aí, venderam agora para um empresário aí, nós não sabe nem no que vai dar isso aí, porque nós não vamos aceitar ele desmatar a beira da Furquilha, né? Que é a mãe do córrego. Nós não vamos aceitar! Eles faz extrema na cabeceira da Furquilha. Que a cerca nossa sai na cabeceira da Furquilha. Se eles desmatar, os enxorro vem tudo para a cabeceira nossa. E eles venderam, venderam para esse empresário aí. Mas o empresário tá por lá, tá, não ainda veio pro lado de cá. Quando vim cá nós é obrigado... destacar para não acabar com o córrego. O córrego é como diz: é pai de muitas propriedades aqui 
que vem desse córrego (Sr. Lázaro de Souza Brito, morador da comunidade de Brejo Verde, trabalho de campo realizado em janeiro de 2012).

Mesmo em condições normais, a comunidade já vem afirmando-se como guardiã das condições ambientais que favoreçam a existência da água do córrego, conforme os relatos do Sr. Antonio, ao mostrar a sua incansável luta pela defesa da vegetação das áreas de cabeceiras contra as periódicas queimadas que atingem a vegetação de cerrados na região nos períodos de seca.

Quero mostrar para o senhor como nós vêm defendendo as águas. A nascente, né? A natureza, que a gente tem muito amor pela natureza. Pois é, o senhor tá vendo aqui esta linda natureza, né? (a mata ciliar) mas porque que tá aí? Todo começo de verão começa os fogos, né? E assim que começa os fogo eu tô em cima, fazendo acero, manual, apagando fogo, até debaixo de fogo, para que o fogo não entre no brejo para não queimar. Por isso que tá essa natureza tão linda desse jeito porque eu venho assim mantendo esse interesse, esse grande amor com a natureza que o senhor tá vendo aqui que tá bem conservada, não, tá? É através de nós. E como ontem eu falei para o senhor, agora no início, setembro, de agosto para setembro, a gente viu fogo para toda banda ardendo de redor, né? Aí eu comecei me preocupar, o que que eu fiz, eu fui até a Secretaria do Meio Ambiente, né? E conversei com a Secretária que nós tava precisando de um apoio deles, né? Precisava de eles vir aqui ver, precisava de eles vir aqui para tirar uma área, dar o limite da quantidade que ia ficar para conservação do meio ambiente, né? Que nós até pensou de fazer mas que podia dar uma coisa errada que podia até acusar a nós, né? Mas aí nós fomos procurar a Secretaria do Meio Ambiente, falei para eles que precisava de um socorro, comparei com uma pessoa doente que estava em estado grave, que tinha que levar para socorro, se não morre. Eu tava comparando como se fosse assim, né? Porque se entrasse um fogo numa reserva dessa aqui, ia acabar tudo né? Essa reserva acabava tudo. E até a água também secava né? Que eles viessem o mais rápido possível! Foi assim que eu fiz e nada foi feito, né? E aí, como nada foi feito pelo meio ambiente, a gente resolveu defender a natureza, nós mesmo aqui, né? Fizemos acerim, manual, de enxada, né?

José: aonde é que o senhor faz acero aqui?

Sr. Antonio: é aí por cima. E aí nós defendemos, né? Como há muitos anos nós vêm fazendo assim, né? Quando começa entrar fogo aí, a gente começa entrar de baixo de fogo, apaga, e vai chama gente, nós acera de enxada, né?

...o senhor ver a vareda, que a vareda é que conserva a água, né? Nada melhor do que tirar uma área grande, por exemplo, assim uma área de $1000 \mathrm{~m}$ da nascente acima, do cerrado, né? De redor. Aí tira uma picada de trator, né? E aí passa um acero de trator de redor das nascentes, né? Porque o fogo que vem de lá, não vem na vareda.

Então se nós perdemos essa natureza aqui, a gente pode dizer que a água já era, né? E aí, como é que nós vamos fazer. Acabando a água vamos pra onde? Se cabar a água nós tem que mudar. Mudar pra onde mesmo? Porque a gente não tem como comprar uma terra mais melhor, uma terra, vamos dizer assim que nós não temos condição de comprar uma terra beira-rio, não é verdade? E o que precisa mesmo é nós ter o maior interesse de preservar a natureza, né? (Sr. Antonio José de Araújo, morador da comunidade de Brejo Verde, trabalho de campo realizado em janeiro de 2012).

Estes relatos do Sr. Antonio apresentam elementos importantes que revelam a consciência da necessidade de preservação das condições ambientais naturais dos cerrados como condição necessária à garantia da reprodução da comunidade 
territorializada. Embora demonstre também as dificuldades crescentes em dias de enfrentamentos no limite para preservar as condições que possam favorecer à oferta de água, sem a qual, dificilmente terão como reproduzirem-se nas áreas parcelares onde vivem na jusante. Nesta incansável luta, as vezes, de forma um tanto desesperada diante da degradação dos cerrados, das veredas, pede socorro ao poder público que sempre ignora o seu desespero. Dessa maneira, ganham ainda maior gravidade, os suspeitos motivos do descaso: retaliação do governo municipal em exercício a opositores políticos, revelando assim a maneira abominável da política comumente feita no país e potencializada na região.

Entretanto, o que cresce entre os geraizeiros é a consciência da necessidade de se preservar os cerrados para que possam usufruir da água do modo que sempre usaram. Neste sentido, são frequentes também os reclames quanto ao arraso que o uso capitalista da terra provoca nas áreas das montantes. Ele já se faz sentir nas mortes de muitos riachos e córregos ou pelo menos, na considerável baixa do volume da água de muitos, o que, para os moradores das áreas ribeirinhas, não significa menos, na medida em que não mais são suficientes para abastecer os regos tão fundamentais à atividade agrícola que praticam em suas parcelas.

\subsection{A comercialização da produção pecuarista dos geraizeiros}

Se muitas das questões até aqui discutidas ganharam maior relevância a partir da intensificação do processo de expansão da pecuária, cabe demonstrar seu significado para os geraizeiros, pois, conforme já demonstrado, ela vêm ocupando significativamente as áreas nas quais tradicionalmente praticavam a agricultura. Entretanto, os produtos agrícolas, em um primeiro momento, em função das dificuldades de transporte (havia poucas estradas e veículos de transportes), em maioria, eram vendidos aos tropeiros que percorriam as comunidades comprando a produção para levarem até ao Porto de São José, onde eram escoados pelos gaiolas. Após o encerramento da circulação dessas navegações, passou-se a destinar a produção para a feira municipal ou das cidades vizinhas, utilizando-se de carros-de-boi no transporte. Esses comerciantes eram das próprias comunidades, e muitas vezes, era o próprio produtor que levava seu produto para comércio na feira, pois, a grande maioria dos geraizeiros tinha seu próprio transporte mais comum no 
meio comunitário: o carro-de-boi. Nos dias atuais, apesar da produção agrícola a ser comercializada ter diminuído, vê-se que, com o aumento e a ligeira melhoria das estradas e do trânsito nos carros de linha ${ }^{230}$ para a cidade de Correntina, os produtores que dispõe de algum produto para comércio, levam-no para a feira camponesa da cidade, onde comercializam diretamente com os consumidores. Outras vezes, em função do aumento da circulação do dinheiro que ocorreu nas comunidades, devido principalmente às aposentadorias, parte importante é comercializada ali mesmo.

Quanto à produção pecuária, no passado era bem menor e parte era comercializada nas próprias comunidades - onde geralmente os próprios criadores abatiam os animais e distribuíam - ou era escoada para a cidade de Correntina ou outras do entorno, onde era abatida nos matadouros.

Atualmente, na comercialização da produção pecuária, participam, no primeiro momento, o criador, o faisqueiro ${ }^{231}$, o açougueiro $^{232}$ (da própria comunidade $^{233}$ ou da cidade) e o matadouro da cidade de Correntina. Nesse processo, era muito comum aos faisqueiros comprarem o gado na perna ${ }^{234}$, pois não havia balanças na zona rural. Nessa transação, o produtor em geral ficava em desvantagem. Aproveitando principalmente dos períodos ruins (de seca em que faltava alimentação para o gado com a secagem das matas), o faisqueiro valia-se de dois artifícios para explorar o produtor. Sabendo da sua necessidade, estipulava preços da arroba inferiores ao corrente e subestimava o peso do animal, subtraindo até mais de duas arrobas do peso real.

Com o aumento da atividade pecuária, criou-se alguma estrutura para, pelo menos na transação descrita, se minimizar a exploração sobre o criador. Em algumas comunidades, já se encontram balanças nas quais o gado pode ser pesado

\footnotetext{
${ }^{230}$ Camionetes e/ou ônibus que diariamente transportam passageiros e mercadorias do campo para a cidade e vice-versa.

${ }^{231}$ Assim chamado o atravessador que fazia e faz a compra da produção diretamente do produtor e a repassa para terceiros, comerciantes da cidade. Com o fechamento do matadouro de Correntina, apareceu um segundo faisqueiro que compra o gado do primeiro e freta carretas que o transporta para outras praças (municípios vizinhos onde tem frigorífico ou para as cidades do agreste ou do litoral do Nordeste).

${ }^{232}$ Comerciante de carne, integrante da comunidade ou da cidade, que compra o gado, abate-o, e vende no varejo.

${ }^{233}$ Era e ainda é comum o próprio criador, ou algum integrante da comunidade comprar gado, abater, e vender no varejo.

${ }^{234}$ Assim chamada a transação comercial em que o gado não é pesado no ato. Estima-se seu peso e a partir disto é vendido.
} 
e vendido por arrobas. Mas, muitas comunidades ainda não têm o equipamento de pesagem dos animais e isto favorece ainda a ocorrência da compra na perna.

Além disso, o maior rigor da fiscalização da vigilância sanitária tem impactado no processo de comercialização. Cito o fechamento do matadouro da cidade de Correntina e a proibição dos tradicionais abates para venda de carne no varejo nas comunidades. Muitos desses açougueiros têm tido prejuízos com a aplicação de multas e apreensões da carne do gado abatido para a venda, embora, em função do crescente consumo de carne nas comunidades, relacionado ao aumento da monetarização, os açougueiros incorrem ao risco e o comércio continua como antes e até tem aumentado em volume.

Mas em consequência da complexificação do processo de escoamento para outras praças, surgiu um segundo faisqueiro e isto tem sido por vezes prejudicial para os criadores. Conforme descrito, o primeiro faisqueiro (não raro gente das comunidades) comprava o gado dos criadores e o vendia nas praças próximas. $\mathrm{Na}$ medida em que o gado é escoado para localidades distantes, o primeiro faisqueiro o compra e repassa para um segundo que comercializa com os grandes frigoríficos. A venda para o faisqueiro conhecido geralmente se realiza a prazo, para pagamento em trinta dias, quando este recebe do segundo e faz o pagamento aos criadores. No entanto, tem sido frequente os faisqueiros desconhecidos darem calotes no faisqueiro que compra o gado diretamente nas comunidades e o prejuízo é repassado para os criadores. Este conjunto de ocorrências, no âmbito das trocas envolvendo o principal produto comercial da produção camponesa geraizeira, se coaduna, pois, com o que afirma Kautsky:

\footnotetext{
Quanto maiores eram a distância e a duração dos mercados para os quais o camponês produzia, e mais lhe era impossível vender diretamente aos consumidores, tanto mais tinha necessidade de um intermediário. O comerciante tomou então lugar entre os consumidores de um lado e os produtores de outro. Era esse mesmo comerciante que, com uma vista d'olhos, abarca o mercado bem melhor que os demais, que o domina numa certa medida e que dele se utiliza para explorar 0 camponês (KAUTSKY, 1980, p.33).
}

A subordinação camponesa, deste modo, tem aumentado, pois não são pagos os preços correntes da arroba; o peso do gado, quando vendido na perna (o que ainda ocorre) é subestimado; são punidos com multas ou perdas da carne quando flagrados pela fiscalização; e podem não receber o pagamento da venda quando os golpistas de fora não pagam ao faisqueiro que lhes comprou. 
Mas sei,

Mas sei

e saberei

Do rei são amigos três o que tem e não faz

o que faz porque tem

o que tem e quer mais

O primeiro

grileiro

O segundo

tem domínios feudais

grileiro

tem incentivos fiscais

O terceiro

grileiro

Ave Maria, rogai por nós

tem favores oficiais

Ave, Ave, Avestruz.

Trabalhador perseguido

pela doença abatido

tem três favores reais:

trabalhador escravo ao grileiro,

miséria pro seu terreiro

e terra pra nunca mais.

EUGÊNIO LYRA, janeiro de 1977. 
CAPÍTULO 5 


\subsection{As comunidades do médio vale do rio Arrojado}

No vale do rio Arrojado, propus-me a estudar duas situações de conflitos. Em uma delas, as comunidades geraizeiras envolveram-se parcialmente no conflito territorial e, em outra, elas se envolvem totalmente. Na primeira situação, o conjunto de comunidade tem assegurada a apropriação de parte de suas terras onde praticam a agricultura e a pecuária e retiram os meios de vida - das parcelas de uso exclusivo familiar. No segundo caso, as comunidades foram envolvidas em uma situação de total desterritorialização, em que a empresa grileira das terras de centenária posse dos geraizeiros, investe na sua expulsão, com vista a tomar-Ihes todas as possibilidades de obtenção dos meios de vida diretamente da natureza e não mais permitir ali a sua morada.

Buscando atender a primeira demanda, discorri sobre a problemática referente às comunidades situadas no baixo vale do rio Arrojado e agora me atenho à problemática relacionada às comunidades situadas no médio vale do rio Arrojado, as de Couro de Porco ${ }^{235}$, Bebedor (ou Bebedouro), Passaroto e Cajueiro, nesta ordem, situadas na faixa ribeirinha do referido rio, da jusante para a montante.

Este conjunto de comunidade dista $105 \mathrm{~km}$ da cidade de Correntina (sede do município), com estrada vicinal de acesso saindo da BR-349 nas proximidades do posto de combustível Cachoeira ${ }^{236}$, à distância de $90 \mathrm{~km}$ de Correntina, adentrandose $15 \mathrm{~km}$ até a comunidade de Couro de Porco, percorrendo-se cerca de $15 \mathrm{~km}$ a mais para se chegar à comunidade de Cajueiro.

Diferentemente do conjunto de comunidade do baixo vale do Arrojado, este se localiza nos altos gerais, onde predominam a vegetação e os solos de cerrados e, por esta razão, as atividades agrícolas praticadas pelos moradores, dominantemente se realizam nas áreas imediatamente ribeirinhas (veredas), aproveitando-se do acúmulo de turfas ali depositado. A pecuária tem como área dominante de uso as soltas, nas quais o rebanho permanece solto por períodos do ano, intercalando-se com estadas nas pastagens mansas que são cultivadas nas proximidades das moradias. Este conjunto de comunidades tem 148 famílias (tabela 2).

\footnotetext{
${ }^{235}$ Tendo em vista o uso corriqueiro na localidade da antiga denominação do povoado, adoto-a nas referências que a ela faço no presente texto.

${ }_{236}$ Nos arredores do referido posto, do lado esquerdo da BR-349, se encontra o loteamento Cidade Treviso, sede de um projeto de colonização destinado à atração de sulistas.
} 
Tabela 2 - População e equipamentos sociais das comunidades do médio vale do rio Arrojado

\begin{tabular}{c|c|c|c|c|c}
\hline $\begin{array}{c}\text { Família/ } \\
\text { Equipamentos }\end{array}$ & Couro de Porco & Bebedouro & Passaroto & Cajueiro & Total \\
\hline Famílias & 115 & 13 & 18 & 2 & 148 \\
\hline $\begin{array}{c}\text { Escolas } \\
\text { Municipais }\end{array}$ & 1 & - & 1 & - & 2 \\
\hline $\begin{array}{c}\text { Igreja Católica } \\
\text { Igreja } \\
\text { evangélica }\end{array}$ & 1 & - & - & - & 1 \\
\hline $\begin{array}{c}\text { Açougue } \\
\text { Bares }\end{array}$ & 1 & - & - & - & 1 \\
\hline $\begin{array}{c}\text { Farinha } \\
\text { Sindicato }\end{array}$ & 1 & - & - & - & 7 \\
\hline Salo do & 2 & - & - & - & 3 \\
\hline
\end{tabular}

Fonte: CDA-SEAGRI, 2009.

Cabe lembrar que o número de integrantes das comunidades de Passaroto e Cajueiro sofreu significativa baixa a partir de 2006, em função do acirramento do conflito travado com a empresa Planta 7 e com outros grileiros menores. Em dezembro de 2011, a pedido do juiz da Comarca de Correntina, o Sindicato dos Trabalhadores Rurais daquele município fez levantamento do número de famílias destas comunidades e acusou o número de 165. Este aumento, em grande parte deve-se ao constatado início do retorno das famílias às comunidades após a diminuição das violências praticadas pelos jagunços da empresa grileira. Não adotei nesta tabela o número mais recente porque o mesmo não está desagregado.

Tal como a configuração de uso da terra que se estabelece nas comunidades da jusante, as referidas comunidades mantêm estreita relação dos usos com as características do quadro natural da localidade em que se situam (figura 16). 


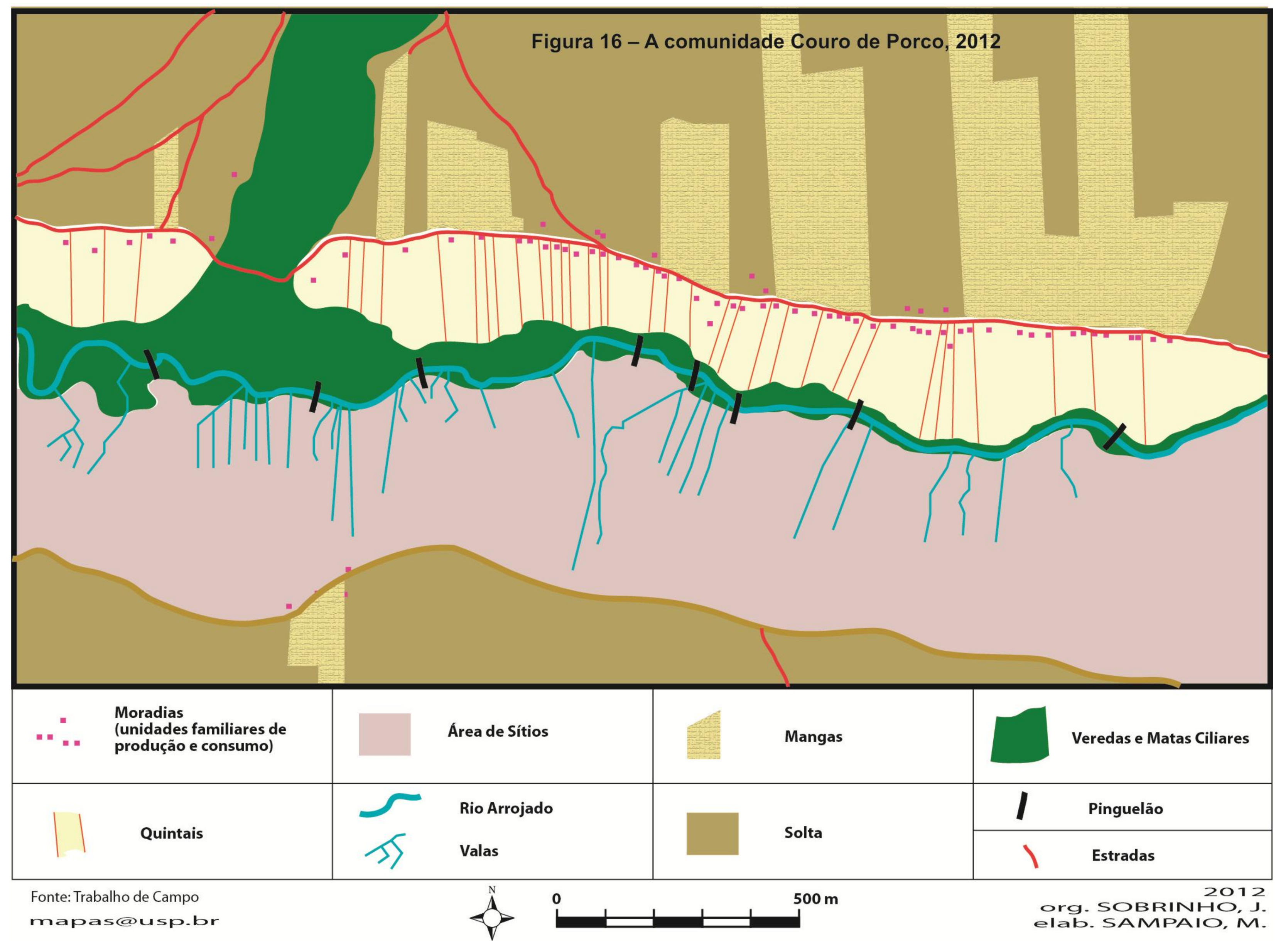




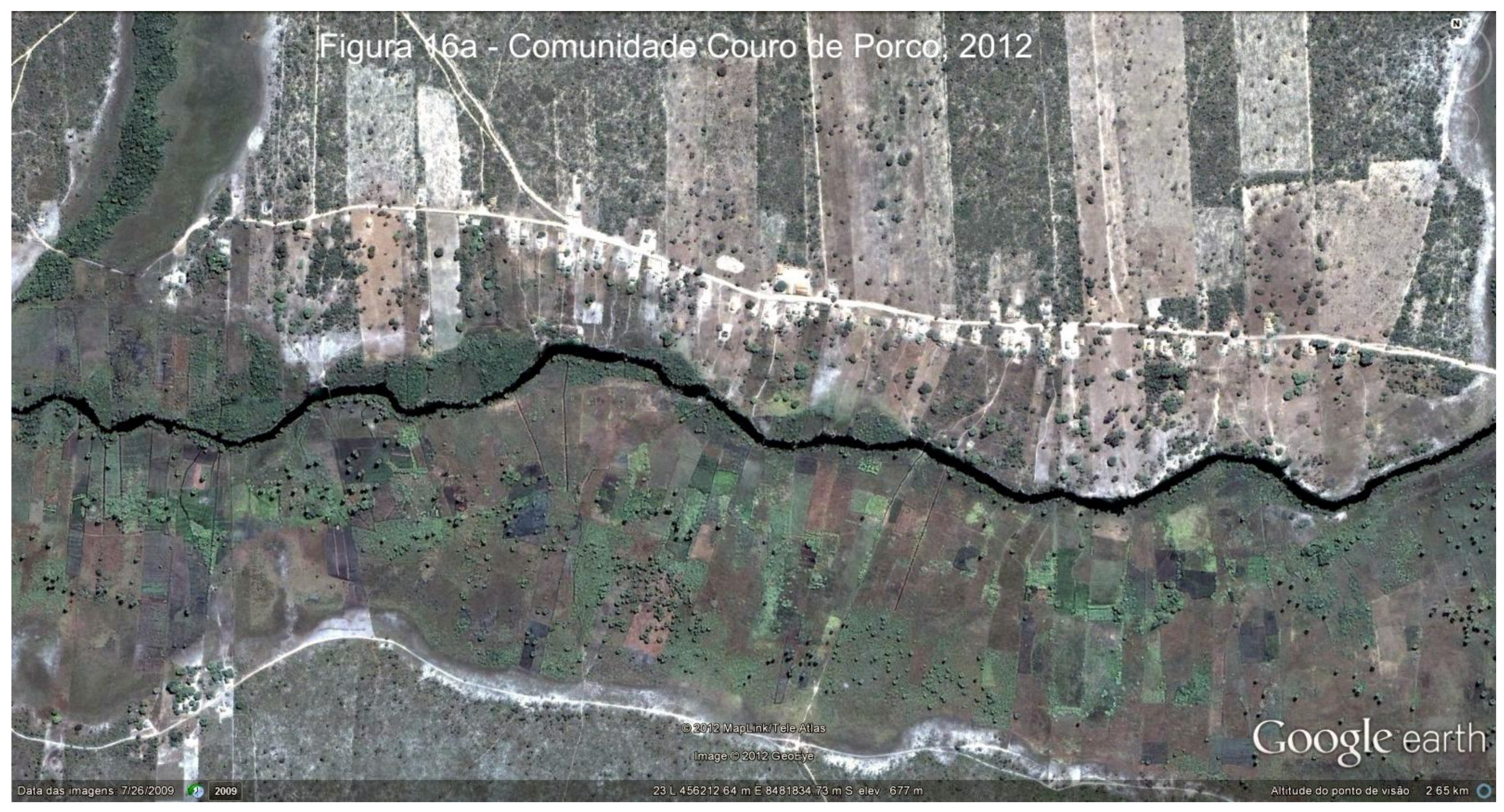


Atendo-me ao caso da comunidade de Couro de Porco, pode-se notar que do lado direito do rio Arrojado se encontram áreas mais extensas com acúmulo de matéria orgânica (turfas). É, pois, ali que se pratica a agricultura de produtos alimentícios, tais como feijão, arroz, milho, mandioca e uma grande variedade de legumes, frutas e verduras, denominada de sítio (foto 24).

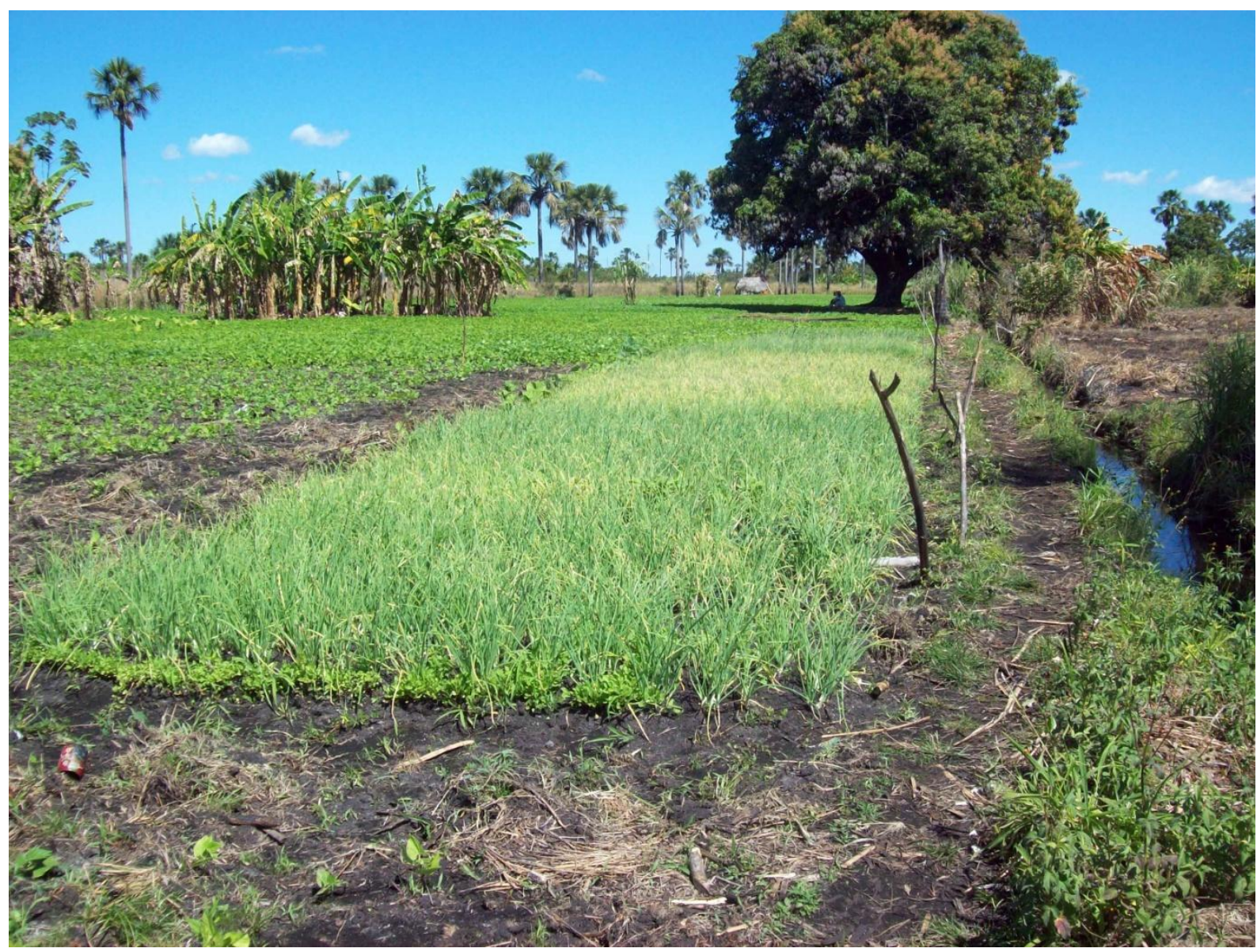

Foto 24 - Àrea de sítio com roça de alho ao centro; à esquerda, roça de feijão; à direita, a vala; e aos fundos, bananal. Comunidade de Couro de Porco. Correntina - BA. Araújo, Iremar Barbosa (jul. 2011).

Do lado esquerdo do rio, os solos arenosos dos cerrados expandem-se até sua margem imediata. Nos primórdios da ocupação, ali se instalavam as casas de morada. Nas duas últimas décadas, entretanto, iniciaram-se as práticas de atividades pecuárias, e, devido à necessidade de complementação alimentar ao rebanho, intercalando-se durante o ano com as pastagens naturais, necessitou-se ocupar novas áreas para a formação de pastagens. Em função disso, na medida em que os moradores necessitavam renovar as casas, as construíam mais distanciadas do rio, liberando assim, a área mais próxima ao rio para a formação de pequenos 
pastos, em se tratando de criadores. E, se não, para cultivos principalmente de mandioca e feijão catador, ou de corda, cultivos mais apropriados aos solos arenosos desta localidade. Esta última área denomina-se quintal, e à sua frente encontra-se as casas seguindo o alinhamento da estrada de acesso às quatro comunidades. Naquelas localidades de maior adensamento populacional, mais comum na comunidade de Couro de Porco, encontram-se descontínuas fileiras de casas (foto 25) também do lado esquerdo da estrada, decorrentes do crescimento da família correspondente à posse da tira de terra. Dali em diante, o uso dominante é o pecuário, de modo geral em regime de solta, e no caso da comunidade de Couro de Porco, já se formaram muitas áreas de pastagens, a dar suporte ao seu maior rebanho em períodos de necessária retirada da solta.

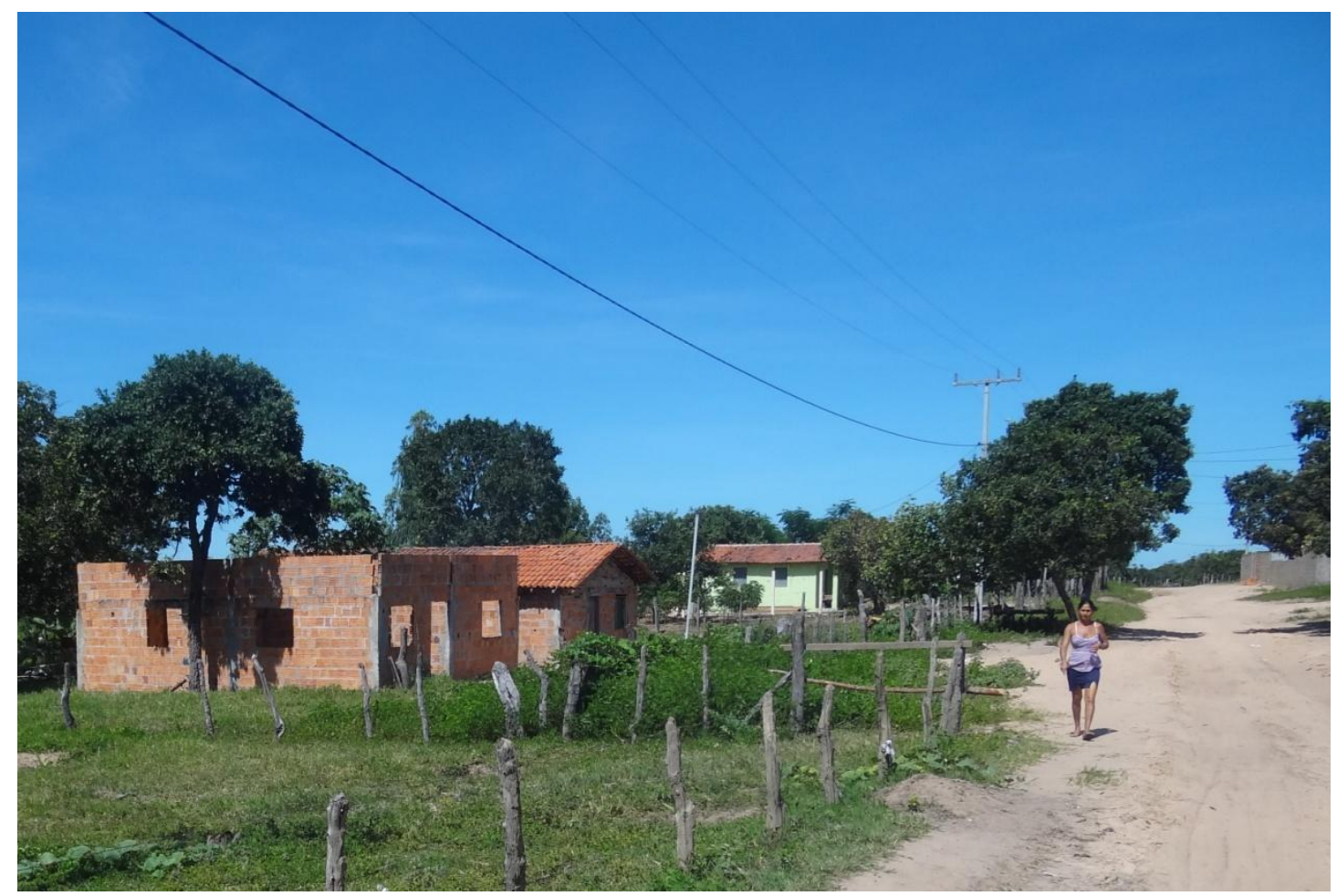

Foto 25 - Disposição das casas junto à estrada na Comunidade Couro de Porco, Correntina - Bahia. Sousa Sobrinho, J. (jan. 2012).

Do exposto, pode-se concluir que nesta fração camponesa do território da comunidade configuram-se as áreas de uso exclusivamente agrícola (a de vereda na margem direita do rio) ou sítio, a de uso agrícola e/ou pecuário, conforme a atividade do posseiro da parcela (o quintal), a da casa de morada, no entorno da qual se encontra uma variedade de pequenos cercados ou chiqueiros, onde ficam 
fechados os animais de pequeno porte, e a área de uso exclusivo de criatório, quer seja em pastos formados e cercados.

Transcorridos mais de trinta anos de envolvimento em disputas pelo território com empresas grileiras, tem restado aos integrantes destas comunidades a área entre a extremidade leste, divisando com a cerca da Fazenda Cabana Plus, e a extremidade oeste, divisando com a cerca da Fazenda Igarashi (ambas contida na área que a ação discriminatória, realizada pela CDA-SEAGRI 2008/2009, afirma ser de comprovado grilo). De uma extremidade a outra são $19,5 \mathrm{~km}$ em linha reta ou cerca de $21 \mathrm{~km}$ seguindo a estrada que liga as quatro comunidades.

Em sentido norte-sul, a fração territorial camponesa da comunidade encontrase em acirrado conflito com a empresa Planta 7, envolvendo a linha do picadão localizado na parte alta da serra, cujo detalhamento maior apresentarei em outra parte do texto.

\subsection{A territorialização geraizeira do médio vale do Arrojado: o uso agrícola das terras ribeirinhas}

De acordo com repetidas menções dos próprios geraizeiros, a ocupação camponesa dos gerais baianos que hoje se configura tem origem nos idos da povoação indígena da região. Assim afirmam: eles colocavam a roça ali no Coro de Porco... (...) e o pessoal não era muitão, era pouca gente, só é que eles... é descendência de índio mesmo, que vive da pesca e da floresta, embora tenha relação também com as atividades que os colonizadores estabeleceram no além São Francisco, quais sejam a mineradora e a pecuarista. Em seus relatos, também transparece a evolução econômica na qual remetem à economia natura ${ }^{237}$, baseada preponderantemente no extrativismo vegetal e animal ganhando importância maior, ao longo dos tempos, a agricultura e a pecuária. E, na atualidade, tomou-se a economia camponesa sob a crescente intervenção da apropriação capitalista da terra.

Nas comunidades de Couro de Porco, Bebedouro, Passaroto e Cajueiro, os anciões de hoje, muitos deles já com idades de 70, 80 anos ou mais, afirmam que

${ }^{237}$ Conforme Rosa Luxemburgo, esta modalidade de economia é "característica das comunidades camponesas primitivas" que adotam "a propriedade comunitária da terra" e a produção, preponderantemente, "se destina à satisfação das próprias necessidades" (LUXEMBURG, 1988, p.31). 
eram criança quando ali chegaram e já encontraram moradores, dentre os mais lembrados, os senhores Ezequiel, Francisco, Jovino, Teotonio, Quinca, Raimundo, Fernando, Gregório, Valentin e outros, já falecidos, em grande maioria, oriundos das comunidades por eles citadas de Bom Sucesso, Catolés e imediações, habitadas em grande parte por moradores de ascendência indígena.

\begin{abstract}
Então quando chegamos aqui, já tinha nossos pais, já trabalhava aqui, já tinha propriedadezinha de arroz, essas coisas, que já tinha prantado, já via que a terra produzia, e aí nóis fomo cuiê essas coieta, coiê essas rocinha, mas com prano de sair, nosso pai ainda saiu, ainda foi aqui no lugar aqui chamado Terra Ronca pro lado de Formosa, pra li, aqui pra Goiás. Lá achou que era a mesma produção, que o que tava dano lá era a mesma que tava dano aqui, ele ficou por aqui mesmo. É vamo ver se aqui produz. E aí é como nós tamo falando. E aí nós foi prantano o arroz, prantano a mandioquinha, foi localizano um lugar que podia trabaiá e que podia ter mais um resultado. Que nem bem essa aqui tudo era mata, era só brejaria, muita água, muita aqui, é, assim, aliás, de criação não, só tinha bichim do mato, né? Bichim mesmo. Mas tinha muita água, tinha muita fartura d'água que deu pra envolver o tempo da gente (D. Anália Cardoso dos Santos, moradora da comunidade de Bebedouro, trabalho de campo realizado em janeiro de 2010).
\end{abstract}

Estes deslocamentos de levas populacionais constituem a tradicional territorialidade geraizeira que, a dispor de amplas terras livres, arribavam-se periodicamente, geralmente em grupos, à procura de terras que as exploravam, no primeiro momento, em cultivos de arroz, e, se julgassem favorável, formavam sítio, ou seja, fixavam-se ali, se sedentarizavam, constituindo pois uma fração do território camponês fundada no trabalho dominantemente agrícola, diversificando a produção no início e em seguida se expandia a partir do uso pecuário das localidades que julgassem favorável para tanto nos arredores.

Para os cultivos, se serviam das áreas ribeirinhas dotadas de camada de matéria orgânica e com o grau de umidade propício ao cultivo de arroz. Para a formação das roças, deslocavam-se no mês de abril, quando faziam o desmatamento. Primeiro faziam a broca, o que corresponde ao corte da vegetação rasteira e de média altura com o uso de foice e em seguida derrubada das árvores de grande porte com o uso de machados. Feito isto, retornavam para seus sítios no conjunto de comunidade da jusante, onde também praticavam a agricultura e a pecuária, e só retornavam para a continuidade dos serviços da roça nos gerais no mês de setembro ou outubro, para fazer a queimada, quando a vegetação derrubada já se encontrava seca. Este momento coincide com o início da estação chuvosa. E, logo após a primeira chuva que assentava a cinza, semeavam o arroz. Diferentemente dos conhecidos métodos em que se usa enxada ou mesmo 
máquinas plantadeiras manuais para o plantio das sementes, informam que, devido à grande quantidade de tocos, se fazia mais eficiente o uso do chucho ${ }^{238}$. Assim, costumeiramente, as crianças seguiam à frente lançando ao chão as sementes no alinhamento das becas ${ }^{239}$, e os adultos as acompanhavam enterrando-as com o uso do chucho.

Ali permaneciam na vigilância do cultivo até o arroz começar dobrar a folha, e, em seguida, retornavam para seus sítios.

Neste sistema agrícola, a variedade de arroz mais utilizada pelos geraizeiros era 0 arroz de prefeitura ${ }^{240}$, o qual tem ciclo produtivo de 6 meses. Por conseguinte, parte dos integrantes da família retornava somente em finais de janeiro ou em fevereiro quando o arroz já estava parindo ou soltando o cacho. Deste momento em diante, ali permaneciam a pastorar (ou vigiar) o arroz contra o ataque dos pássaros. O mesmo grupo fazia a colheita e o término coincidia com a chegada de outros membros da família com o carro de boi para transportar o arroz. Neste momento, encerrava-se a lida com aquela roça e a mesma sequência de labuta se repetia no ano seguinte, porém em outro lugar, pois afirmam que a roça formada por repetidos anos no mesmo lugar requer muito trabalho nas limpas, na medida em que a variedade de arroz melhor adaptada às áreas de alagadiço, o de prefeitura, é tardão ${ }^{241}$, seu ciclo produtivo dura 6 meses e se cultivado em terra mansa já povoada por grande quantidade de ervas daninhas, requer muitas limpas e torna inviável compatibilizar os trabalhos no sítio de morada, com a roça formada, por vezes, a 20, 30, 50 ou mais quilômetros de distância.

Nas conversas com os interlocutores, tanto das comunidades da jusante quanto das comunidades de Couro de Porco e vizinhas, era lembrada, com admiração, a grande produtividade das roças formadas nos fundos de vale:

quando eu plantava brejo, eu e meu irmão aí uma época, nóis batemo 150 saca, forante o que perdeu no brejo, lá no Cajueiro, naquela baixa... plantemo 24 prato de prefeitura, deu 150 saca. Forano o que desperdiçou e nóis trabalhava era com cinco, seis pessoas quase dez pessoa todo dia (Sr. Claudomiro Pereira de Jesus, morador da Comunidade de Couro de Porco, trabalho de campo realizado em janeiro de 2012).

\footnotetext{
${ }^{238}$ Pau de ponta com que o lavrador abre na terra preparada um buraco onde se deposita a semente (FERREIRA,1999).

${ }_{239}$ Fileiras que se semeiam ou plantam-se os cultivos.

${ }^{240}$ Variedade de arroz, cujo ciclo produtivo, dura seis meses.

${ }^{241}$ De ciclo produtivo longo.
} 
Passados longos tempos de incursões gerais afora, desenvolveram técnicas de drenagens dos solos e isto Ihes possibilitou formar sítio, sedentarizando-se, pois, passaram a beneficiar-se da mesma viabilidade agrícola dos solos também para produtos, tais como feijão, mandioca, milho e uma série de outros, somados ainda à farta quantidade de caças e peixes nos rios. Desta antiga dinâmica de apropriação territorial e das respectivas evoluções nas técnicas de exploração das riquezas naturais surgiram as comunidades ao longo do rio Arrojado, tal como o conjunto delas que ora me ocupo.

Esta territorialização camponesa constituiu-se em função da exiguidade das terras agricultáveis nas localidades de ocupação antiga resultando em um adensamento populacional. Deste modo, complementavam seu sustento ampliando as terras de trabalho gerais afora. Entretanto, nas últimas décadas os órgãos ambientais do Estado têm proibido esta ocupação nos fundos de vale dos gerais, permitindo a permanência apenas daquelas comunidades que fizeram sítio, embora impondo limitações aos usos das riquezas naturais nestas localidades. Como medidas para compensar as perdas territoriais, os geraizeiros têm intensificado os usos das áreas de sítio das comunidades, a partir da construção dos regos, e intensificado a prática pecuarista nas soltas e nos fechos de gerais.

Nas viagens que faziam à procura de brejos bons para se fazer roça, levavam sal e farinha, o que lhes bastava para sobreviver enquanto realizavam serviços de formação das roças, pois, a fauna e a flora dos cerrados Ihes proviam dos víveres que lhes sustentavam enquanto se ocupavam no amanho. Rocha (1983) descreve a paisagem geraizeira, enfatizando a abundância da fauna:

Com a crise da borracha, o látex da mangabeira coagulado perdeu completamente o valor, e aqueles campos, que são terras devolutas, passaram a ser viveiros de caça que constituem verdadeiro paraíso para os amadores do esporte de que é padroeiro Sto. Humberto. As perdizes pululam em tais campinas. Bandos e bandos de veados galheiros, munidos de chifres multíplices, pastam nos campos, e como são animais de curta vista e apurado faro, permitem que os viandantes deles se aproximem quando marcha em sentido contrário ao vento. As emas velozes caracoleiam pelas campinas, descrevendo ziguezagues diante dos cavaleiros que as perseguem. Os tapires, vestígio talvez de animais pré-históricos, os tamanduás de várias espécies, vivem nas margens dos rios de águas límpidas que correm em direção às suas grandes bacias centras do Brasil. Bandos de araras de variadas cores, com gritos estridentes, esvoaçam dos cimos dos elegantes buritis, emprestando à paisagem uma vida impressionante. Às vezes se encontra ainda um exemplar de servo com as dimensões dos seus semelhantes europeus, tendo também enormes galhadas. É um animal de porte imponente, pesando talvez duzentos quilos (ROCHA, 1983, pp.126127). 
Esta descrição se refere ao quadro constatado pelo autor em sua obra publicada na década de 1940, mas, a este respeito, os moradores da comunidade de Couro de Porco fazem semelhantes referências. Inclusive informam que o nome Couro de Porco, dado à comunidade, deve-se ao acúmulo de peles de porcos do mato em uma localidade à beira da atual estrada de acesso à comunidade.

Há que se ressaltar a importante diferença na relação estabelecida com a fauna pela comunidade de Couro de Porco e demais geraizeiros, frente àquela dos amadores relatada com naturalidade pelo autor. Os geraizeiros dela se servem como meio de vida. Inclusive, em determinado momento de sua territorialização, serviam-se como alimentação fundamental na relação no âmbito do imediato com a natureza. Ao contrário dos primeiros que dela faziam e fazem uso como objeto de prática esportiva. Nas áreas de fecho de gerais, na jusante, seus usuários relatam com indignação o fato de serem impedidos de caçar pelos órgãos de fiscalização do governo, o que vem provocando o abandono desse costume pelos criadores. Entretanto, é muito comum, expedições formadas por granfinos: funcionários públicos, bancários e outros integrantes das camadas média e alta da sociedade do município, deslocarem-se para os gerais nos finais de semana a fim de realizarem matanças nas competições predatórias da fauna.

Os geraizeiros fazem longos relatos sobre as dificuldades enfrentadas nos primórdios de sua territorialização para se conseguir sal, muitas vezes tendo que se deslocar a pé para Correntina. As primeiras "sementes" ou "ramas" (caule da mandioca utilizado no plantio) foram conseguidas em comunidades distantes, como a de Pratudão, localizada na bacia do rio Formoso.

Aqui nós era um pessoal liberto. Nós aonde nós interessasse colocar uma roça, a gente colocava. Por exemplo, saía aqui em mutirão aqui, vamos colocar um brejo de arroz em tal lugar assim, assim vamos. Nós só fazia, aqui só encontrava aqui só caça nessa época só tinha caça, e peixe aqui na região. Não tinha nem a farinha para a gente comer com a carne, assim era difícil. Para ir buscar esses meios de sobrevivência aqui, a gente tinha que ir daqui 12 légua, deixa eu ver quantos quilônte mais ou menos a gente tinha (...) (...) para ir buscar, a única coisa, transporte aqui nessa época, era o animal. Uns tinha outro não. E o mais era trazido alceado. Do tipo do índio, né? Até hoje eu sei fazer, do tipo de um saco para carregar de um canto para oto, muito bem feito. Aprendi com os antigos. Você faz um tipo, com esse buriti mermim, um saco trança, quando não tem um saco desses outos, e faz do tipo assim de uma mochila, nas costas assim, e a gente guenta viajar assim umas 12 léguas. Umas 12 légua tranqüilo. Descansa assim nos pouso... é foi aonde eles foi buscar os plantio de mandioca, que não existia aqui, pra comer com as carne das caças, foi daqui a um lugar chamado Pratudão. É retirado daqui umas 12 léguas. E aí é aonde é que eles foram e trazia os fechim de mandioca destamanin, porque já vinha com muito peso. Lá buscar o alimento de sobrevivença que era a farinha, pra comer com a 
carne do peixe, a carne da caça, né? Era a carne do viado, da anta, do peixe, de muitas qualidade tem aqui, né? Nessa época a gente não usava... quando faltava $o$ anzol, pra lhe dizer a verdade. Quando faltava o anzol que não tinha condições, a gente fazia um ganchim de pau. Os velhos me falava que era de toda certeza, fazia um ganchim depau assim, bem tipo um anzol, chegava naqueles lugar que tinha aqueles monte de peixe grande, enganchava qualquer um pouquim de carne assim, sabe, e aí o peixe pegava com toda vontade, e o cabra puxava no gancho pra fora igual o anzol. Porque tinha muito. Outra hora se não tinha rede, pegava um saco, saía naquelas represa, naquelas lagoas nos brejo, tava assim de curimatá, ia com a saca assim, ó, uns tocava e outros enchia. Despejava fora, trazia o sacão de peixe. Antes de inventar as rede, né? Era assim. E aí foi assim mais ou menos uns 10 a 15 anos que eu peguei assim essa tranquilidade (Sr. Claudomiro Pereira de Jesus, morador da comunidade de Couro de Porco, trabalho de campo realizado em janeiro de 2010).

A este respeito, Pierson (1972) relata o que constataram os integrantes da sua equipe de pesquisadores na comunidade de Couro de Porco em sua estada na década de 1950.

\begin{abstract}
Uma linha de tucum vista nos Gerais, fina, de mais ou menos 13 braças, fora feita pelo próprio pescador. Equipada com uma anzol de 7 centímetros de comprimento era usada na pesca do dourado e outros peixes de porte, inclusive a traíra. Crianças que pescavam piaba em Sucuriú usavam uma folha de buriti com cabelos de cauda de um animal amarrados na ponta e, na extremidade desta, um anzol grosseiro feito de um pedaço de lata dada a elas pelos nossos pesquisadores dias antes. Um dos meninos possuía em casa um anzol comprado, "mas para usar na pesca de piau, e não de piaba," explicou. Um garoto falou de um anzol que fizera com uma corda de violão; outro disse que um alfinete poderia ser usado, "se tivesse um". Um homem que pescava piaba usava um anzol feito de corda de rabeca. [...] A isca usada com anzol e linha para pescar piaba nos Gerais foi identificada, num caso, como um pedaço de mandioca e, no outro, um bolo de farinha (PIERSON, 1972, pp.388-389).
\end{abstract}

Da situação de utilização de técnicas alternativas para extrair da natureza os seus meios de vida, com o passar dos tempos, concomitante ao aumento populacional e a respectiva minifundização das parcelas agricultáveis, foram engendrando outros meios pelos quais conseguiram diversificar os cultivos e aumentar a produtividade dos solos, e, atualmente, a atividade agrícola é praticada por muitos, conjugada à pecuária, conforme se verá em tópico adiante.

Para propiciar à formação de sítios nas áreas embrejadas, necessitou-se realizar adaptações e dentre outras se pode citar a construção de regos ou valas, que, diferentemente das comunidades da jusante já referidas, em que se destinam à irrigação das terras de cultura de modo a possibilitar a ampliação das áreas agricultáveis, no presente caso visam drenar os solos da superumidade das áreas, muitas delas naturalmente alagadas. Inclusive uma das condições determinantes para que estabelecessem sítio em uma localidade era a declividade das áreas margeantes a se permitir o escoamento da água para o rio. Assim, formar sítio significa criar condições propícias à realização de mais trabalho e, por conseguinte, 
extrair maiores resultados deste, em uma situação de limitadas ofertas de terras agricultáveis. A partir disto ali, se constituíam moradias. Nesta localidade, no sítio, a partir das adaptações realizadas, ao invés de apenas uma safra por ano, tal como nas roças que formavam ao longo das ribeiras do Arrojado, passaram a conseguir duas, um na estação chuvosa, beneficiando da expansão da área agricultável a partir das valas de drenagem - explorando as baixas para o cultivo de feijão e arroz, e as mais elevadas para o feijão catador, milho, mandioca e uma variedade de outros - e, na estação seca repete-se toda a variedade de cultivos, conferindo aos geraizeiros importante fonte de víveres, apesar da exiguidade das parcelas.

No caso da comunidade de Couro de Porco, as valas foram escavadas perpendicularmente ao leito do rio Arrojado. É comum, inclusive, servirem de limites demarcatórios das divisas entre as pequenas parcelas agricultáveis.

Estas valas (com cerca $30 \mathrm{~cm}$ de largura por $40 \mathrm{~cm}$ de profundidade) têm dimensões suficientes para a drenagem do talhão, de modo a permitir, de certa forma, a oferta hídrica necessária ao cultivo. Embora, em condições de excessiva umidade, possam ser aprofundadas e em períodos de déficit hídrico para as plantas (geralmente em situação de prolongamento da estação seca), façam o represamento da água a permitir a necessária irrigação da roça. Seu cumprimento pode variar de 100 a 400 m, conforme a extensão da área agricultável entre o rio e os solos arenosos de cerrados (figuras 16 e 16a). Todo ano, antes de iniciar os plantios, é necessário limpar as valas e isto requer combinações entre os vizinhos de parcelas para a limpeza das valas limítrofes. Assim, de comum acordo, cada uma das partes limitantes se encarrega de limpar metade do percurso da vala. Se uma das partes preferir, pode pagar para o vizinho limpar a que é de sua obrigação, ou ainda, não pagando, aquele que limpa a vala toda tem o direito de cultivar 50 metros ao longo de toda a vala na gleba do vizinho. Este código costumeiro, entretanto, por vezes ocorre de ser descumprido por uma das partes, o que gera descontentamento à outra em desvantagem. Mas, segundo interlocutores, não se tem notícia de se recorrer à ordem jurídica para a mediação de conflitos dessa natureza, pois, na sociabilidade camponesa, as relações no âmbito da comunidade têm como fundamentos que as norteiam os "laços afetivos e diretos [isto] define as relações de sociabilidade vigentes entre os membros" (SANTOS, 1978, p.161). 
Esta técnica de drenagem do solo e a respectiva organização interagricultores justificam-se, pois, com vista a tornar apropriada para a formação do sítio, uma área com características naturais (no caso, o excesso de umidade no solo) que, sem ela seria inviável. Por outro lado, visando sanar o que advém do processo de minifundização das parcelas agricultáveis e recuperar a fertilidade dos solos, perdida nos inúmeros anos de ininterruptas formações de roças no mesmo local. $E$, além disso, diminuir a labuta no amanho, com muito senso criativo, os geraizeiros recorrem a uma variedade de formas consorciativas, a partir da combinação entre vários cultivos, algumas das quais descrevo a seguir.

Primeiro, há que se lembrar que o calendário agrícola dos produtos que se cultiva nas áreas dessas comunidades em muito coincide com o já apresentado, concernente às áreas de regadio das comunidades da jusante. Diferenciando-se apenas o do arroz, o qual se cultiva tanto na estação seca quanto na chuvosa, sendo que, no cultivo que se realiza na estação chuvosa, não se permite consorciação (os demais cultivos não prosperam em terras alagadas).

Mas, quero citar também, a combinação que fazem envolvendo o cultivo do feijão, do milho e do arroz, iniciando-se no mês de junho. Primeiro, planta-se o feijão e, após 8 ou 10 dias planta-se o milho. Três meses depois, colhe-se o feijão e limpase o milho. Na terra limpa planta-se o arroz junto do milho já crescido. Quando o arroz encontra-se um pouco crescido, colhe-se o milho e estende suas palhas no meio das becas do arroz. Isto serve para fertilizar o solo com a decomposição da palha, inibir o crescimento da babuja ou ervas daninhas que costumam nascer em grande quantidade nas terras por muito tempo cultivadas ${ }^{242}$ e, ao mesmo tempo, preserva boas condições de umidade na terra. Isto é de considerável importância, principalmente nas estações de prolongadas estiagens. Se decidir não colher 0 milho, dobra-se o pé, deixando as espigas de cabeça para baixo, conservando-as por longo período, e colhe-as quando achar conveniente.

Outra técnica de cultivo consorciado envolve a mandioca e o arroz. Planta-se a mandioca mais espaçada e o arroz com espaçamento normal. Quando a mandioca cresce e sua sombra começa a afinar o arroz (atrapalhar seu desenvolvimento), dá

\footnotetext{
${ }^{242}$ Ressalte-se que os geraizeiros sempre evitaram cultivar arroz em terras mansas, devido o inconveniente do grande trabalho nas limpas. Proibidas as formações de roças em novas terras todo ano, como era de costume, desenvolveram técnicas de manejo que visam diminuir a quantidade de trabalho no cultivo, tal como a que ora me refiro.
} 
uma despaiadinha na mandioca (retira parte de suas folhas) [...] pra não dá muita sombra [...] [...] e joga no meio das becas, desempenhando as mesmas funções do exemplo anterior.

Quando o arroz atinge o ponto de colheita, corta-o. Porém, nesse caso, o crescimento da mandioca impede o desenvolvimento da soca ${ }^{243}$ (segunda colheita) do arroz. Assim, com a enxada, cortam-se as touceiras dos pés do arroz e espalham-nos em meio as becas da mandioca e, da mesma forma que nos outros exemplos, se potencializa o aproveitamento da terra e torna menos trabalhoso o cultivo. E aí, tinha vês que não aproveitava a soca né? Aí vinha cortano aquela paiada dento, só dano uma gorpiação nela ali prô mode... E aí dexava no pé da mandioca. Aí as raiz ó... (Sr. Claudomiro Pereira de Jesus, morador da comunidade de Couro de Porco, trabalho de campo realizado em janeiro de 2012).

A palha do arroz, após batido, é depositada nos pés das bananeiras servindo como excelente adubo.

Outro consórcio envolve os cultivos de feijão, milho e mandioca. $A$ mandioca, a gente tá de vez que tá com a terra pouca e a terra é muito boa pra plantar mandioca e plantar o feijão e o milho, igual eu tenho uma ali e, neste consórcio, planta-se o feijão e a mandioca, se possível, no mesmo dia.

Quanto ao referido consórcio, Pierson (1972) assim o descreve:

No plantio do feijão, covas de cerca de 5 centímetros de profundidade são abertas a enxada, mais ou menos a dois palmos uma da outra. Dois grãos são lançados em cada cova e cobertos com o pé. Nesta área a mandioca é consorciada com o feijão, sendo, porém, plantada antes, na distância de um metro mais ou menos entre os montículos. Às vezes são plantados alguns pés de milho no mesmo terreno, mas à considerável distância um do outro (PIERSON, 1972, p.467).

O Sr. Claudomiro confirma, detalhando a sequência:

no mesmo dia, planto o feijão, quando termino de plantar o feijão, eu vou coviano a mandioca e minhas menina ou minha esposa vai jogano a rama, atrás né? ${ }^{244} \mathrm{Eu}$ gosto de ir plantano na frente e elas atrás. As bequinhas todas marcadas né? Elas vai jogano ali, ela corta direitim, assim um parmo, ou até mesmo um poquim, as rama e vai jogano. E aí... nas bequinhas de feijão. Aí quando eu terminei de plantar o feijão,

${ }^{243}$ Crescimento de brotos a partir das touceiras do arroz colhido, produzindo novos cachos e uma segunda colheita.

${ }^{244}$ A unidade familiar camponesa se caracteriza enquanto unidade de produção e de consumo (CHAYANOV, 1981, p.139), mas também, como afirma Santos (1978, pp.33-34): "cada pessoa da família camponesa desempenha um trabalho útil e concreto, segundo o momento e a necessidade. Desse modo, estrutura-se no interior da família uma divisão técnica do trabalho articulada pelo processo de cooperação, resultando numa jornada de trabalho combinada dos vários membros da família. Nesse sentido, a família camponesa transforma-se em um trabalhador coletivo." (grifo meu). 
no mês de junho, a mandioca passa uns oito ou dez dias pra nascer. Aí ela nasce. Aí o feijão cresce, o feijão cresce e fica dessa altura aqui (Sr. Claudomiro Pereira de Jesus, morador da comunidade de Couro de Porco, trabalho de campo realizado em janeiro de 2012).

Pierson (1972) também descreve:

A fim de preparar a mandioca para o plantio, um informante dos Gerais cortava a facão pedaços de 5 a 10 centímetros de comprimento, batendo no caule e torcendo-o para "picar a maniva", como se diz. O filho pequeno enchia uma gamela com as manivas em pedaços. Em seguida, seguia o homem para o campo com a gamela sob o braço, tirava um ou dois pedaços, colocava-os em covas rasas adredemente preparadas, combrindo-as com o pé (PIERSON,1972, p. 467).

Após 8, e no máximo em 15 dias, quando o feijão já está cruzano, planta-se o milho.

É. Planto o feijão. Com oito dias de nascido, quando o feijão já tá cruzano, aí eu planto o milho, por último. Primeiro o feijão, segundo a mandioca e terceiro o milho. $O$ milho tem que ter uma diferença de dez a quinze a dia. O milho tem que ter uma diferença do feijão, porque quando o feijão tá cruzano, a gente tem que plantá o milho, porque o milho é mais rápido, então ele cresce mais. Ali na hora que eu tirar o feijão a mandioca fica um poquinha fina... caneluda (Sr. Claudomiro Pereira de Jesus, morador da comunidade de Couro de Porco, trabalho de campo realizado em janeiro de 2012).

A mandioca fica um pouquinho fina porque o feijão, adensado, assombrou-

Ihe. Colhe-se o feijão e, se o bater do lado, joga a palha entre o milho e a mandioca.

Se o transportar na palha para o outro lado do rio, para o entorno da casa, onde será batido, joga-se a palha para o gado.

Depois nóis ou dá ao gado ou nóis joga no meio da beca. Hoje tá usando assim né? Pra apodrecer, pra adubar. Ali agora, o milho e a mandioca agora ela empretece todim, e ela sobe! Porque nóis não pode plantar muito junto. A mandioca é larga e o milho mais largo, tudo tem que ter o espaço. Só é que é tudo embolado. É um acasalamento que nóis faiz assim uma, uma sociedade ali... (Sr. Claudomiro Pereira de Jesus, morador da comunidade de Couro de Porco, trabalho de campo realizado em janeiro de 2012).

Assim, os dois cultivos seguem viçosamente desenvolvendo-se, beneficiandose dos engendramentos que também continuam a lhes fortificar.

É um consórcio das três qualidades de feijão, milho e mandioca. E aí ela cresce caneluda aí ela vai rolano, quando a chuva bate minino! Ela vai engrossano e vai empreteceno e agora o milho, iguali eu pego o milho e dobro, iguali eu fiz ali, e a gente vem com a limpa, vai despaiano. Ranca o milho pela raiz e leva pra dar as paias pro gado, quando quebrar, ou deixa no meio da mandioca a paiada. Aí é de primera! (Sr. Claudomiro Pereira de Jesus, morador da comunidade de Couro de Porco, trabalho de campo realizado em janeiro de 2012). 
Estes foram três exemplos dos vários consórcios que os geraizeiros fazem. Como se pode ver, buscam a reprodução da família a partir do pequeno quinhão de terra que Ihes resta, espremidos pelo latifúndio e pelas políticas do Estado classista, capitalista.

Estes saberes são dignos de nota, pois, por meio deles, consegue-se da minúscula parcela de terra agricultável da qual têm acesso, o sítio, assim definido pelo Sr. Claudomiro: sítio porque é regado por natureza, a gente precisa até tirar a água pra poder dá o plantio, que é chei de água - o sustento das famílias não raro numerosas pois, aquela parcela de terra onde se imprime maior trabalho, torna-se adequada para a produção de quase ou tudo que a vida demanda, sendo assim, a Terra de Trabalho e a Morada da Vida, a partir do que se pode ver o quanto diverso são os cultivos que ali se pratica.

\begin{abstract}
Ali a maioria planta. Inclusive ali é área de sobrevivência desde quando nóis chegou pra qui. Que o senhor pode assuntá que pocas pessoas têm uma mandioca, uma coisa aqui (no quintal), mais é lá. Ali ó, é que aqui nóis não vê, mais ali é área de mandioca mansa, área de bananeira, é área de cana, é área do feijão, do milho e do arroz. Só é plantá que dá! Só que pouco! Não é igual era há muito tempo, que era muito bom pra produzir, agora já rareou mais. Mais aí ó, nesse sítio aqui, mesmo do jeito que tá aí, deu cana de cinco metros esse ano, cana com três anos, ela dava com cinco metros, Paulo! Deu cinco metros de gome, contano só o gome, forano o oi! Estirasse assim, estirasse no chão assim ó...

Ali de primero óia: o alho, alface, verdura em geral. Repolho beterraba, cenoura, rabanete, mostarda, couve, jiló, quiabo, maxixe, abrobora é pra encher caminhão, se cê tratar direitim... abroba, coisa boa abroba! Cana, capim de ração, melancia, a melancia nessa areia é melhor do que lá. Mas planta, dá também a melancia. É, o que mais, manga, olha os pé de manga lá carregadim, laranja, laranja lá eu tenho uns pé que tá assim! Abacaxi, bom também pro abacaxi, dexa eu ver, tem mais coisa aí, mandioca mansa... (Sr. Claudomiro Pereira de Jesus, morador da comunidade de Couro de Porco, trabalho de campo realizado em janeiro de 2012).
\end{abstract}

Tudo se planta e colhe que não dá vencimento. A grande biomassa, do que sobra do consumo direto da família, alimenta galinhas, galinhas de angola, porcos, patos, perus e o gado, principalmente nos períodos de seca, nos quais as pastagens tornam-se menos fartas.

Quando o fracionamento das parcelas chega ao ponto extremo e a largura destas é projetada para o lado esquerdo do rio, para o quintal, atravessam a estrada e se alongam até o topo da serra, chegando-se ao picadão, formando as tiras ou cordas de terra como bem costumam denominar. A fração que constitui o sítio se notabiliza como domínio da agricultura com grande diversificação, conforme assinalado. A fração do quintal, ora se ocupa com pequenas pastagens, ora com cultivos de mandioca e feijão de corda ou catador, bem como plantas frutíferas nos 
arredores da moradia, onde se encontram também os cercados ou chiqueiros onde aprisionam animais de pequeno e médio porte para não incomodar os vizinhos que, em função da pouca largura da tira de terra situam-se muito próximos. Inclusive, também em função disso, é muito comum a segunda ou a terceira moradia de membros da família localizar-se do outro lado da estrada, por não cabê-las no estreito terreno. Após a travessia da estrada, aqueles que criam gado formaram talhões de pastagem para o gado se alimentar no revezamento com a solta e, aqueles que não criam, geralmente a deixam aberta, compondo a área de uso comum, somando-se à solta.

Assim, são muitas as estratégias engendradas pelos geraizeiros com vistas a sanar as dificuldades causadas em grande parte pela expansão do uso capitalista da terra, sobretudo a propriedade privada capitalista da terra que vem lhes deixando no aperto e Ihes tirando a liberdade, conforme assevera Martins (1984):

Trata-se, portanto, como já foi dito, de um problema de uso da terra, esta forma de
usar a terra, esta forma livre de ocupar a terra. Mas se trata também de uma outra
coisa, uma coisa que é essencial na vida do migrante, do migrante-posseiro. Ele luta
radicalmente pela sua liberdade, a terra e a liberdade. Eu não vejo como falar só na
terra. Freqüentemente, tenho ouvido pessoas discutindo a problemática das novas
regiões em termos estritamente da terra porque, de fato, a pedra de toque está na
terra, mas já este outro elemento, ideológico, que marca muito a existência e os
movimentos dos posseiros que é o problema da sua liberdade, a sua liberdade de
trabalho familiar, a sua liberdade de trabalho autônomo, a sua liberdade de
locomoção, a sua liberdade de decisão (MARTINS, 1981, p.131).

Neste sentido, têm procurado promover no âmbito da própria comunidade aprimoramentos das forças produtivas que lhes permitam a produção e a reprodução camponesa apropriando-se da maior gama possível de meios que lhes sejam disponíveis enquanto tem-Ihes garantido o acesso ao principal instrumento de trabalho, a terra. É importante salientar que ao mesmo tempo em que passa a ocorrer uma tendência ao aumento do dinheiro mediando a obtenção dos meios de vida a partir da adoção da atividade pecuarista, ao mesmo tempo também se observa a dependência desta atividade à agricultura que vem se tornando a cada dia mais diversificada ao incorporar os cultivos de hortaliças e de frutas. Isto se verificou nas comunidades do baixo vale do Arrojado e ocorre também na comunidade de Couro de Porco. Portanto, não ocorre nas comunidades estudadas uma tendência à especialização das atividades produtivas como geralmente ocorre em situação de contato com as relações sociais que o capitalismo traz. 
Observa-se também uma variedade de estratégias que culminam no maior aproveitamento das terras a cada dia mais fracionadas, escassas e enfraquecidas. Para tanto, desenvolvem combinações de cultivos consorciados a fim de aumentar a produtividade por área, de várias maneiras procuram repor a fertilidade da terra e conservar a sua umidade enquanto dura o ciclo produtivo e, ao mesmo tempo, procuram reduzir a quantidade de trabalho nestas atividades, sobretudo nas limpas, (a partir da técnica de inibição do desenvolvimento de ervas daninhas espalhando no solo os restolhos (biomassa) produzidos pelos próprios cultivos em muitos casos integrantes do conjunto consorciado), pois tem decrescido de modo considerável nas unidades familiares, em função da migração de braços, principalmente de jovens. Aqueles que permanecem trabalhando na terra carecem ainda dividirem o seu tempo com a atividade pecuarista que vem ganhando importância na ocupação da jornada de trabalho, como também no sustento da família. Terras alagadas que, no primeiro momento da ocupação, serviam apenas para o cultivo, por meio de sulcos de drenagem, tornaram-se agricultáveis para uma grande gama de plantios propiciando uma boa alimentação para a família.

Estes engendramentos que se estabelecem no âmbito da unidade de produção camponesa podem ser entendidos como uma forma de resistência a garantir o acesso à terra, pois, isto Ihes garante liberdade e importante autonomia em relação às condições degradantes e de extrema opressão que pretende subordina-Ihes sempre mais as relações capitalistas de produção que os cercam e que em parte já estão inseridos.

\subsection{A conservação dos mantimentos}

Alguns produtos agrícolas, todavia, pós-colheita, necessitam ser armazenados para consumo nas entressafras. E, para se preservar em boas condições, não deixá-los encarunchar, também engendraram eficientes técnicas de conservação, dentre as quais cito algumas.

No caso do feijão, são cinco as técnicas de conservação. Antes, porém, se deixa exposto ao sol uns dois dias, mais uma noite no sereno, seca-o novamente ao sol e se embala das seguintes formas:

a) Ensaca-o misturado com uma porção de cinzas. 
b) Tritura-se no pilão a folha de eucalipto, deixa-a secar e ensaca junto com o feijão.

c) Ensaca-o junto com parte da munha (palha das vargens).

d) Embala-o em tambores plásticos de 200 litros com o tampo bem vedado.

e) Embala-o em garrafas PET com o rosqueamento da tampa bem apertado.

Quanto ao milho, em função da pouca disposição de terras, costumam cultivar em pequenas quantidades e o consumo tanto humano quanto animal é tamanho que não requer muito empenho na sua conservação.

Sendo assim, de modo geral, a conservação se faz na própria roça, dobrando o pé e entornando para baixo a ponta da espiga. Ou, como diz o Sr. Claudomiro:

A gente armazena dento de casa mesmo. Bate ele, ensaca, ou então dexa na espiga, e vai sustentando aí, quando não dexa na roça. Inclusive eu tenho uma parte mesmo que tá na roça. A gente dobra ele, que a chuva bate e a água escorre... ele dá pra ficar um ano, um ano tranquilo, seis mês, três mês... e vai catano conforme a necessidade (Sr. Claudomiro Pereira de Jesus, morador da comunidade de Couro de Porco, trabalho de campo realizado em janeiro de 2012).

Quanto ao arroz, o Sr. Claudomiro explica como se garante a sua preservação:

O arroz é uma coisa mais fácil, que eu sou um dos que já plantei muito, que colhi muito, graças a Deus. $O$ arroz tem diversas qualidades. Tem diversas qualidades $o$ arroz. Eu costumo fazer isso: bater o arroz, colocar no sol, secar. Costumo colocar no sol e aí a gente faz o seguinte: Coloca numa lona, seca direitin e ensaca. Ensaca ele. Passa até cinco anos (Idem).

Antes, porém, quando não dispunham de sacos, armazenava-se no paiol.

De primeiro quando não tinha saco, era no paiol. Fazia o paiol da própria palha do arroz. Fica três, quatro anos, cinco anos aí, se souber fazer. De vara. Fazer o assoalho por baixo, tipo um paiol que se faz pra colocar milho. E a gente forra, faz as esteiras, todas certinha, guarda a quantidade que quer em um cômodo (Ibidem).

Por fim, a mandioca. Para esta não dispõem de condições de conservação in natura depois de colhida, assim como não se descobriu meios que garanta boas condições para a farinha por longo tempo.

Sendo assim,

O jeito é secar ela bem e sempre trazer ela num local fechado. Que ela também ataca caruncho. Então, esse negócio, farinha tem que vender mais rápido. Não pode ficar guardando muito, porque o jeito melhor que nóis armazena a farinha aqui... o paiol é na roça. A gente deixa ela lá, só faz quando tem necessidade, né? Tá com vontade de fazer uma... por exemplo: eu tenho uma roça que dá, igual antigamente eu plantava, uns 20 ou trinta saco de farinha, ou 50 saco de farinha. Não só eu, os otos. Deixa ela lá na roça. Precisa fazer 10 sacos, vai lá, desmancha e faz. Vai fazendo aos poucos (lbidem). 
Nas conversas com interlocutores, verifiquei que muitas das técnicas adotadas, quais sejam na adequação da terra à exploração agrícola, nos cultivos ou na conservação do que se colhe, são resultantes de longos tempos de experimentações feitas pelos camponeses, os quais socializam as experiências adquiridas com os demais, possibilitando, assim, a sobrevivência na lida constante com a natureza no limite imediato. Essas experimentações, da mesma forma, realizam-se na lida com os animais criados, tal como se pode verificar a seguir.

\subsection{0 uso pecuário da terra e os tratos aos animais}

Até o início da década de 1990, as atividades dos geraizeiros integrantes das comunidades de Couro de Porco, Bebedouro, Passaroto e Cajueiro concentravamse nos cultivos de roças nas áreas de sítio das respectivas comunidades, na margem direita ou esquerda do rio Arrojado, conforme o caso, e/ou nas outras que formavam em áreas afastadas com distâncias de até mais de $50 \mathrm{~km}$. A esta atividade somavam-se a extrativa animal (caça e pesca) e vegetal de frutos dos cerrados, tais como buriti, pequi, caju, cascudo e muitos outros.

Daí em diante, porém, em função de fatores como aumento populacional, empobrecimento dos solos de suas áreas de sítio, proibição dos órgãos ambientais do Estado, da tradicional prática de cultivos nas veredas ao longo dos $\operatorname{rios}^{245}$ e do aperto provocado pela "farra" da grilagem de terra, integrantes de algumas comunidades, de modo mais intenso os de Couro de Porco, aumentaram a prática pecuarista, como forma de complementação da renda. Inicialmente, quando os rebanhos eram numericamente inexpressivos, algumas cabeças de gado alternavam o uso da solta (que abrangia continuamente as áreas de cerrados do alinhamento das moradias para cima interflúvio a dentro) com as pequenas plantações de capim situadas na localidade chamada de quintal (entre as casas de moradia e o rio). ${ }^{246}$ Enquanto permaneciam no quintal, alimentavam-se de pastagem mansa ${ }^{247}$, assim como dos víveres oriundos da área de sítio.

\footnotetext{
${ }^{245}$ Cabe lembrar que estas proibições devem-se ao fato destas áreas terem-se tornado reservas naturais das empresas grileiras de terras que se proliferaram na região.

${ }^{246}$ Os períodos de permanência na solta e de pastejo na manga coadunam com os já descritos, quando me referi à dinâmica pecuarista praticada pelos criadores das comunidades da jusante.

${ }^{247}$ Pasto cultivado.
} 
$\mathrm{Na}$ medida em que o rebanho foi sendo ampliado, os criadores formaram talhões de pastagens projetados à frente, preservando a largura do quintal em linhas paralelas e expandindo-se cerrados a dentro, formando as tiras de terra (figuras 16 e 16a). Da mesma forma, as áreas de cerrados com vegetação natural ganharam novos significados, tornando-se também áreas de criar no regime de solta em contínua expansão. ${ }^{248}$ Os criadores da comunidade de Couro de Porco, por exemplo, mantêm seu gado solto em uma ampla área de pastagem natural nas amplas veredas do galho de Couro de Porco, próximo à comunidade, nas áreas de veredas dos vários galhos do lado esquerdo do rio Arrojado à montante, assim como nas áreas elevadas (conforme a época do ano) e nas mesmas formações vegetais à jusante, predominantemente nas proximidades do galho do Pau Terra.

Essas áreas de criatórios comuns caracterizam-se, sobretudo, pela sobreposição de conflituosas territorialidades, pois todas são objeto de apropriações fraudulentas por parte de empresas, se notabilizando, nesse caso a Planta 7, e mais uma infinidade de outros grileiros de áreas menores. Estes em grande maioria, forjaram escrituras de transferências de direitos possessórios dos antigos posseiros moradores das comunidades, para si, a partir de procurações que obtêm, de modo geral, fazendo uso de má fé, aproveitando da falta de conhecimento daqueles, e muitas vezes até por métodos violentos. Este assunto será melhor abordado adiante e a ele faço referência aqui com intuito de demonstrar as condições conflituosas em que os posseiros das comunidades estão submetidas no uso cotidiano de suas terras, pois estes pretendentes às áreas que os posseiros usam como soltas, não raro traçam picadas, constroem cercas, contratam pistoleiros que fazem constantes rondas e ameaças aos criadores. Estes últimos, inclusive, enfrentam grandes dificuldades nos cuidados diários do seu gado, não podendo instalar pontos de apoio, tais como os referidos ranchos das comunidades da jusante já referidos, tendo que, por vezes, se esconder de pistoleiros fortemente armados. Estes inclusive em momentos de conflito mais intensos, atentaram contra suas vidas atirando-Ihes, queimando casas, promovendo um clima de medo e terror, situação esta que muitos moradores, principalmente das comunidades de Passaroto e

\footnotetext{
${ }^{248}$ Este novo componente reforça o caráter de posse dos tradicionais territórios de uso geraizeiro, contraditoriamente, concomitante às investidas dos grileiros, intensificando as disputas territoriais por personagens constituintes de classes sociais com interesses opostos, quais sejam, os camponeses geraizeiros e as empresas capitalistas privatistas das terras.
} 
Cajueiro, não conseguiram resistir e abandonaram suas posses, mudando-se para as cidades ou para outras comunidades próximas, principalmente a de Arrojadinho. Nestas condições, os cuidados com o gado, enquanto se encontra na solta, é dificultado, conforme relato do Sr. Claudomiro:

Nóis costuma levar (o sal) na solta onde eles tão numa queimada, onde eles tão mais... que tem uma pastage boa, a gente costuma colocar. A gente pega aquelas conca de buriti, dá uma conca, chama conca aqui, a gente leva de vez de oito em oito dia, leva e coloca lá. Porque é o que a gente ver, a gente não pode fazer uma cochera muito boa, que tem o conflito. Porque os cabras (pistoleiros) passam ali e vê, bagunça e tora né? Aí a gente vai aonde o gado tá colocado, tem medo até de colocar um produto lá pro gado, a gente vai aonde é mais escondido, que o gado sabe, o gado é inteligente iguale a gente. E coloca onde ele maia mais, aí ele lambe aquele supremento, aí fica bom. Agora, mesmo o que a gente gasta mais é aqui (no quintal). Aqui tem que colocar direto (Sr. Claudomiro Pereira de Jesus, morador da comunidade de Couro de Porco, trabalho de campo realizado em janeiro de 2012).

Refere-se ao quintal, local que se destaca como o principal ponto de apoio onde os cuidados com o gado são realizados. Quando tem queimada boa em localidades afastadas o gado se distancia. E, enquanto permanece na soltas, em lugares distantes das moradias, é feita uma combinação entre criadores com laços de afinidades (parentesco, compadrio e/ou vizinhança), conforme o relato a seguir, amenizando assim, sobremaneira as dificuldades de compatibilização das ocupações em cuidados do rebanho e os afazeres do sítio, num sistema muito parecido com o já referido quando me ative ao caso dos usuários de fechos de gerais integrantes das comunidades da jusante.

O meu tem vez que eu passo de até dez dia. Por exemplo, se nóis samo uma sociedade igual eu mais meu irmão e meus vizim que tem gado, né? Aí nóis controla. Eles vai hoje, passa tres dia eu vô. Aí já vai dar seis. Aí ele a mesma coisa. Fecha os seis dia, aí eu vou. Aí ele faia tres pra oiá o dele. Quando dá um problema lá eu laço o dele e xinxo na burra e puxo com pau, cutuco, quando é uma coisa mais fácil... Quando é um problema mais difícil, eu toco o gado todo e nóis encurrala ele aí e... como é bom a sociedade né? Facilita (Idem).

Realmente, o sistema de cooperação que se estabelece entre os criadores é muito significativo para tornar possível a concomitância de atividades agrícolas com a pecuária no regime de soltas, pois os animais pastam muito em localidades pantanosas e não são raros os atolamentos, cujo transtorno para os criadores é demais trabalhoso, a ponto de ser impossível a lida individual, dificuldade que é sanada por meio do revezamento em grupos.

A gente com todo cuidado que tem, mais a gente toma prejuízo, a época que, por exemplo: se o gado a gente solta ele, passa dois dias sem oiá, três dia sem oiá; se 
atolar uma vaca ali é muito difícil ela escapar com três dias atolada. Muito difícil. Aí o empatamento, é quase trinta dia pra tornar, voltar o que era e tem que zelar! Quando ela cai tem que levantar, duas, três vez por dia. E não levanta com dois home, tem que ser uns quato home. Quato seis home. Conforme o tamanho duma vaca dessa aí, pesa demais! (Ibidem).

Facilita muito os trabalhos, quando o gado, mesmo na solta, permanece nas localidades próximas, geralmente nas imediações do galho do Couro de Porco. Quando ali está, constantemente se aproxima da casa de morada (do quintal), à procura de sal e de outros víveres que são ofertados pelo criador e pode ser visto e contado frequentemente. Assim, o colchete de acesso ao quintal permanece aberto com livre acesso ao gado. E, no período em que o gado é preso, na área de pastagem imediatamente à frente do quintal e da casa de morada, as porteiras (geralmente colchetes) da área de pasto cercada e de acesso ao quintal são abertas algumas vezes durante o dia para o gado beber no rio Arrojado e lamber o sal disposto em cocheiras (foto 26).

Conforme já me referi, o quintal se destaca como ponto em que se concentram os cuidados com o gado. Pretendo, entretanto, demonstrar que, de modo semelhante às experimentações que os geraizeiros fazem no âmbito da agricultura, anteriormente descritas, também nos tratos aos criatórios - e aqui dou especial atenção ao gado bovino.

Uma grande variedade de víveres, proveniente das roças do sítio, é servida para o gado: sobras de verduras, legumes, frutas, a palha ${ }^{249}$ do milho, do arroz, do feijão, a cana-de-açúcar, a capineira ou capim de planta (capim de ração) e a rama (o caule) de mandioca. Esta última, entretanto, antes de ser oferecida como alimento para o gado, precisa murchar - perder o leite - o que ocorre deixando-a exposta ao sol por cerca de três dias para

Murchar o leite com as foia e a gente chegar, o meu gado não precisa porque eu
trenei eles. Eu trenei eles fazer o seguinte: como eu não tinha motor, desde pequenim
quando comprei os primeiros, o quê que eu fazia com eles? Eu chegava lá, arrancava
a mandioca e dexava lá e vinha com as rama mais fina. Jogava. Aí eles ia comendo,
treinando remoer, remoer. Hoje esses gado aí e até os bezerrim, quando vai
nascendo, quando começa comer, aí quando eles ver os otos encostando eles já
encosta lá e já pega os pauzim mais fino e começa, já vai remoeno. Então esse gado
aí não precisa passar no motor, porque ele é treinado. Ele pega uma rama de
mandioca do pé, come ela até em cima, remoeno e comeno os pedaço e quando
pensa tá com a barriga aqui! Porque treino! Já tem uns lá em Correntina, na onde é
que tem o motor, não sabe. Que esse exemplo eu vi lá um amigo meu me amostrou
lá. O meu come e ele tem um outro lá que come porque é treinado. Treinou dessa
maneira. Lá come ela muito mais é no motor. Ele corta ela com o capim ou com o

${ }^{249}$ Trata-se da totalidade do pé de milho. 
milho e coloca no estruturador e mistura, molha e é uma vitamina rica, mais tem que colocar no sol pra murchar. ...E não pode deixá dormir, o que fazer hoje, o gado tem que comer tudo hoje. ...Pra não empanzinar, pra não fazer coisa errada, né? Não dá dor de barriga no gado e não azedar. (Sr. Claudomiro Pereira de Jesus, morador da comunidade de Couro de Porco, trabalho de campo realizado em janeiro de 2012).

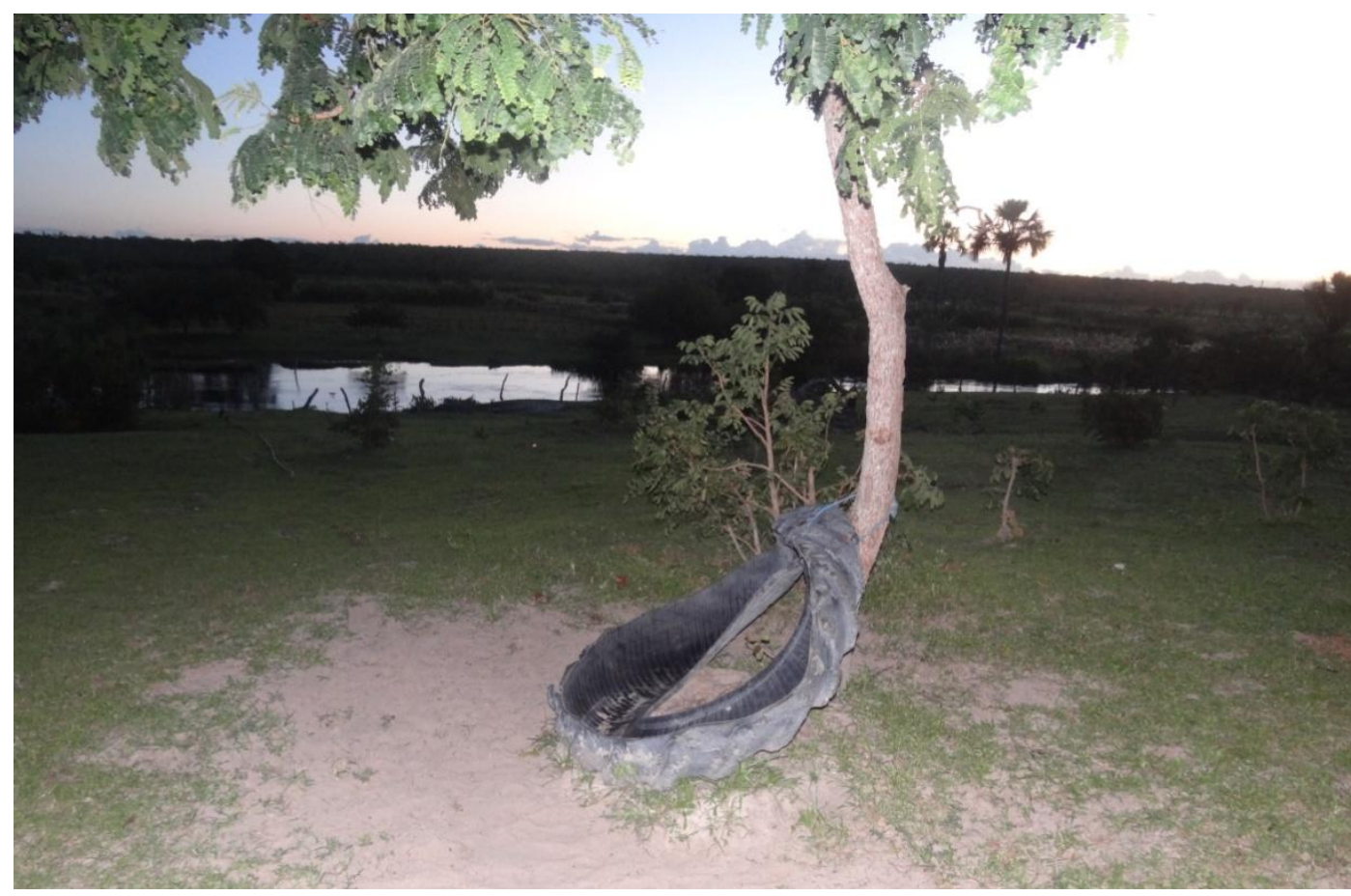

Foto 26 - Cocho e quintal, Comunidade Couro de Porco, Correntina - Bahia. Sousa Sobrinho, J. (jan. 2012).

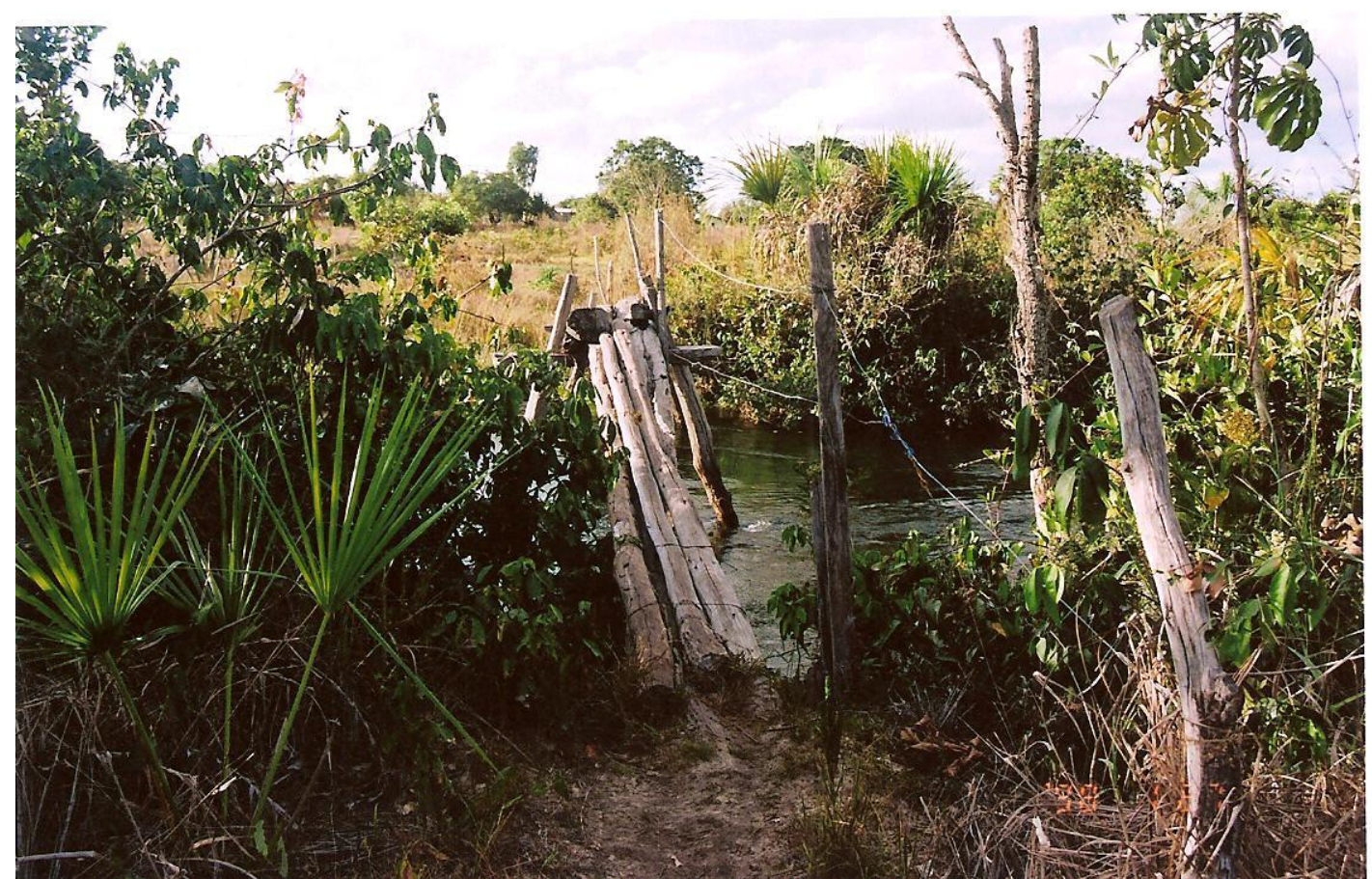

Foto 27 - Pinguelão, Comunidade Couro de Porco, Correntina - Bahia. Sousa Sobrinho, J. (jan. 2010). 
Segue a demonstração, pelo Sr. Claudomiro, da introdução de uma variedade de alimentos na dieta de seus animais, algumas introduzidas por ele mesmo e outras transmitidas a si pelos seus companheiros criadores.

não é qualquer coisa que o animal come né? Bom, se é... aliás é quase todas coisas, mais a gente tem que acostumar o animal. Por exemplo esse gado meu aí, eu vou alembrar as coisas que eles come e os que eles não sabia comer e pela seca eu ensinei (Idem).

Quanto à cana-de-açúcar, sabe-se que habitualmente o gado come a folha e o caule, geralmente triturados ou, quando é o caso, após ser moído no engenho. Mas o Sr. Claudomiro condicionou o gado a comê-la inteira.

Mesmo assim é a cana. Cana eu corto dessa ali 114, e jogo aí 20, 30 feixe, não nas água, eles não come agora. Muito poquim, só a palha. Mais quando pega do mês de junho pra lá, mês de agosto, eles, se botar uns 50 feixe aí, enquanto eles tiver aguentano comer, não fica uma (Ibidem).

O depoimento a seguir mostra a adoção de outras técnicas mais modernas no processo de trabalho envolvendo a atividade pecuarista e suas vantagens:

Pega a palha e o olho e chupa tudo! Remói tudo! Fica tudo com a barrigona! Não precisa desse estriturador! Agora quando tem estriturador, que o rapaz me arrumou aqui esse ano. Logo no início eles não gostou. Que tinha um rapaz que me emprestou aqui, no início eles não gostou. Eu colocava a mandioca, o capim de ração e a cana. Aí eles comia muito pouco. Moço! Mais quando eu dei a ração durante quinze dias, quando o motor zuava aqui, o gado que tava uns quinhentos metros, já vinha que vinha! Tava com o barrigão aqui assim, e comendo naquela maior vontade! Aí eu estruturava, bem aqui debaxo dos pé, o motor era bem debaxo do pé de cajú, onde quebrou aí, o vento levou. Era o capim de ração, rama de mandioca e cana. Isso aí, eles come muito bem. E aí agora o que fazia? Se 40 feixes de cana dava pra eles manter, a quantidade de 30, 40 gado, com 10 feixe de cana no motor, dava pra mode eles comer pra deixar (Ibidem).

O Sr. Claudomiro informa que, por não dispor de um triturador ou de engenho, ensinou seus animais a remoer a cana sem passar pelos referidos processos. Isto foi conseguido oferecendo-a inteira nos períodos de seca, em que o gado se depara com escassez de alimentos.

Tem outra comida que eles come, que eu ensinei que um amigo me ensinou, é a banana... as folhas da banana com a madeira, cortano assim ó, vai cortano com o facão. Eles... os meu come! (Ibidem).

Vê-se, deste modo, o quanto se pode aproveitar de toda a biomassa produzida no sítio a partir da convergência de alto senso intuitivo com uma situação de escassez, mas também, acredito, conjugados a um modo de se relacionar com as riquezas naturais, tirando delas o maior proveito possível, com vista a aproveitar 
do pequeno quinhão de terra que lhes resta o máximo que possa garantir o sustento da unidade familiar e, por assim dizer, a reprodução social camponesa.

A grande maioria dos produtos, quais sejam de consumo humano ou animal, é produzida no sítio. Para transportá-los, os geraizeiros constroem os pinguelões para a travessia do rio Arrojado (foto 27). Se volumes menores, transportam nas costas; se quantidades maiores, utilizam-se de animais, geralmente burros e jumentos, para a condução da roça até a margem direita do rio. A travessia se faz na balsa, construída a partir de um feixe de talas da palmeira buriti, a qual suporta carga de até cerca de meia tonelada, variando conforme a quantidade de peças usadas na construção.

Da margem esquerda para a moradia, a carga pode ser transportada em lombo de animais ou com uso de carroças.

Assim, demonstro alguns fatores do modo de vida geraizeiro com vista à reprodução socioterritorial a partir das condições naturais de seu ambiente de vivência e das técnicas que até a atualidade Ihes têm sido possibilitadas.

\subsection{A fração territorial comunitária dos camponeses geraizeiros do médio vale do rio Arrojado em disputa}

Aí tinha uma velha ali, que ela estudava as profecia antiga. Aí ela vestia igual um padre. Chamava ela, tratava de Maria Saião. Porque a roupa dela era até lá embaixo. Ela conhecia a profecia igual um padre desse, conhece e fala hoje. Falava olhe filho, Mirim, ela me chamava Mirim. Olha Mirim, cê pode ta na certeza que vai acontecer. Essa terra nossa aqui vai ser retalhada igual carne nos açougue. Vai vir os grande capitalista, e vai mandar nessas terra, e vocês vão ficar esprimido nessas terra sem ter pra onde vai. Eles, o que que eles faz, meu filho, eles compra advogado especialista, eles ajeita primeiro o advogado especialista da lei, ajeita, vem o advogado, com o pouco saber nosso que tem dessa região, incorrompe as leis, os delegado de polícia, eles domina tudo a classe dominante, eles domina tudo, domina com a força, com o dinheiro, nós vamo passar... Nós vamo comer o que é nosso escondido. Vocês vão ter de colocar uma rocinha aí escundido, porque vocês não vai ter como brigar com esse povo. Que vai ser muito forte a pressão. Vai vim um avião, vai vim um avião, um transporte, carro de todo modelo... e nisso na minha 
idade aqui, ela falava não era só pra mim não, era quando nós tinha um reisado, uma coisa assim. Essas fasição de reisado, que ela era doutrina, assim os reisados deles, os festejo, a devoção dela era de São Sebastião, teve um filho que foi mestre aqui na região, né? Chamava Massuo. Então isso aí vai ta desapareceno tudo. E aí vocês vão luitar num pedacinho de

terra desse aí, e vai ser a maior dificulidade. Vai vim a grilage forte, a opressão, e aí vocês não vai... e aí nós conversemos aquilo. Uns falava, não essa véia não ta falano certo não, não acreditava. E a véia vem... quando pensou que não chegou a empresa. Mas logo ela morreu. Aí chegou uma empresa chamada Florestamina, chegou a empresa Forestamina, né? Chamava Florestamina, essa empresa (Sr. Claudomiro Pereira de Jesus, morador da comunidade de Couro de Porco, trabalho de campo realizado em janeiro de 2010).

Os dizeres da epígrafe deste tópico sugerem e anunciam previamente a expansão das relações sociais capitalistas de produção sobre as frações territoriais comunitárias das comunidades geraizeiras, na forma que foi adotada pelas políticas do Estado brasileiro com vista à promoção do desenvolvimento capitalista no campo. Dela, pode-se destacar os elementos estruturais constituintes, tais como: expropriação dos camponeses posseiros dos gerais, apropriação privada e fraudulenta da terra com total respaldo dos poderes do Estado, superminifundização da terra dos posseiros e a consequente dificuldade para se obter os meios de vida, alterações na jornada de trabalho camponesa tornando-se impedidas a realizações dos eventos comunitários. Assim, o Sr. Mirim (ou Claudomiro) confirma o cumprimento da profecia, representada pela chegada da empresa chamada Florestamina (ou Florestaminas), com todo requinte de truculência. Ou seja, a partir da década de 1970, intensificou-se, no âmbito das comunidades, a ressignificação das relações sociais de produção, alterando de modo significativo a territorialização, na medida em que os conflitos de classe fizeram-se mais intensos.

As profecias de D. Maria Saião apontam uma modificação central representada pela expansão da propriedade privada capitalista da terra, a saber: a mudança no âmbito da propriedade da terra. Dessa forma, há um rompimento da situação em que o camponês tinha acesso às amplas terras livres dos gerais para, através do seu trabalho e de sua família, e extrair da natureza diretamente o sustento familiar. Este sentido da apropriação camponesa da terra é freado pela 
expansão do capitalismo. Ou seja, a expropriação das condições materiais de reprodução do trabalhador estava estabelecida. Martins (1981) esclarece esta realidade:

O trabalhador só pode se converter em empregado, em assalariado, quando é expropriado, quando deixa de ter a propriedade dos instrumentos de trabalho. Não ser proprietários da terra, das ferramentas, das sementes, dos adubos, é condição básica para que o agricultor se converta em empregado (MARTINS, 1981, p.141).

Isto porque, a condição primordial para que se realize o modo capitalista de produção é ter o trabalhador expropriado, ou seja, despido de qualquer propriedade a não ser a propriedade da sua força de trabalho, tornada mercadoria, para assim se realizar efetivando-se a troca com aquele detentor dos meios de produção, de capital - o capitalista - cuja condição para assim se reproduzir é dispô-los no processo produtivo, trocando o seu capital, dinheiro, com o trabalhador pelo salário. Este, passa a depender única e exclusivamente do salário para sobreviver e se reproduzir como trabalhador (MARTINS, 1981, p.141), aquele só aumentará o seu capital - meios de produção e dinheiro convertido em salário -, só o reproduzirá submetendo o trabalhador ao processo produtivo, pagando-lhe salário. Este aumento de capital obtido pelo capitalista que não participou diretamente no processo produtivo, com trabalho, apenas com os meios de produção e o pagamento de salário, deve-se ao fato de o salário não corresponder à totalidade do que foi produzido, representando apenas uma parcela e a outra converter-se em mais-valia, trabalho não pago apropriado pelo capitalista, o que permite a acumulação.

Entretanto, Martins (1981) faz uma ressalva à particularidade do modelo brasileiro de desenvolvimento do capital:

no caso brasileiro, o capitalismo não exproprie radicalmente o agricultor, ele o expropria indiretamente, mediante a concentração de muita terra nas mãos de pouca gente. O cadastro organizado pelo INCRA revela essa concentração muito claramente (MARTINS, 1981, p.141).

Esta assertiva tem, nos casos estudados, os das comunidades geraizeiras, situação exemplar. Conforme já me referi, no caso das comunidades à jusante, em que as parcelas de uso individual familiar, onde fizeram sítio e as ocupam desde tempos remotos, não sofrem ameaças diretas de expropriação (exceto das áreas de criatórios, qual sejam do entorno, as soltas, ou os fechos de gerais afastados). 
Entretanto, estão cada dia mais apertados, sem que as gerações mais jovens possam se reproduzir socioterritorialmente, pois a privatização capitalista da terra com os seus impedimentos fazendo uso das cercas e das armas impedem a expansão territorial geraizeira. Assim, aos jovens, e até mesmo à boa parte dos chefes de famílias, só lhes resta como alternativas se assalariarem sazonalmente, geralmente nas fazendas próximas, mas também noutras regiões, ou migrarem definitivamente para outros lugares onde, de modo geral, expropriados, oferecem sua força de trabalho para a reprodução do capital.

No caso das comunidades de Couro de Porco e vizinhas, a expansão do modo capitalista de produção, não fosse a tremenda resistência, já teriam lhes expulsado da terra. Mas, em função da grande disposição que as comunidades têm demonstrado para a luta, ali resistem em tenso conflito com as forças privatistas, mas com perdas territoriais significantes e, deste modo, também submetidas a situações de assalariamento e importantes índices de migração. Principalmente nos casos das comunidades de Passaroto e Cajueiro, mas também de modo significativo na de Couro de Porco, tem Ihes restado o lote, onde situa a casa de moradia, o quintal, e uma exígua área ribeirinha, na qual podem formar roças. Esta situação, inclusive, favorece as empresas, na medida em que assegura, nas proximidades, 0 "celeiro" de mão de obra que possa ser explorado conforme a conveniência do ciclo produtivo - quando produzem - e até os submetem ao trabalho degradante em condições de escravidão temporária (Barros, 2011, p.112).

\begin{abstract}
A expulsão não é direta. Ela se dá pela não-criação de condições para que o filho do agricultor se torne agricultor autônomo como o pai. A sua tendência é tornar-se um assalariado na cidade. Para o agricultor, o colono, é cada vez mais difícil ganhar o suficiente para que o filho o siga. A dependência cada vez maior em relação aos industriais, aos intermediários, aos bancos, aos fornecedores, faz com que parcelas crescentes do excedente econômico que produz sejam apropriadas pelos setores que instauram um jogo crescente sobre a agricultura. São as grandes empresas do capital industrial, comercial e financeiro que, sem se envolverem diretamente na produção, subjugam-no indiretamente (MARTINS, 1981, p.144).
\end{abstract}

Certamente, estas são as relações temidas e anunciadas nas profecias de D. Maria Saião. Ou seja, em função do assalariamento, a sua jornada de trabalho foi radicalmente alterada, não mais permitindo as costumeiras celebrações, tal como os reisados, nos quais, inclusive, D. Maria Saião podia anunciar suas profecias e muito mais, com respeito à vida em comunidade, cultivando-a. Há cerca de dez anos, não mais se festeja o reisado na comunidade de Couro de Porco e vizinhas, e isto, 
provavelmente, se explique pelo assalariamento a que se submete boa parte dos seus membros, pois encontraram-se rodeados por empresas que, contratam alguma força de trabalho como caseiros das sedes, para feituras de picadas, de cercas, ou, contraditoriamente, para os ofícios da pistolagem.

Este quadro de relações em muito compromete a unidade da comunidade, causando um complexo emaranhado que impõe uma dinâmica muito variada e cheia de surpresas no que diz respeito à disposição para a luta em defesa dos interesses comuns.

Conforme já me referi, a territorialização geraizeira do Oeste da Bahia tem origem na ocupação comunitária indígena do território. Devido às características geográficas do vale do rio Arrojado, assim como as dos vales dos demais rios da região, a maior concentração populacional situou-se nos baixos vales dos rios, onde se encontram as terras de cultura, enquanto o médio e o alto vale tiveram como uso predominante o pecuário no regime de fechos de gerais, pelos criadores residentes nas áreas de maior concentração populacional de leste (Bahia) e de oeste (Minas Gerais, Goiás e Tocantins) dos gerais.

O passar dos séculos culminou num forte adensamento populacional nas áreas de ocupação dos baixos vales, tornando-as insuficientes para dar suporte à população crescente.

Disto resultou a expansão territorial geraizeira, com finalidade de exploração agrícola, somando-se a mais antiga, de uso pecuário. Expansão esta, só possível em condições de terras livres de propriedade privada, nas quais os geraizeiros podiam usufruir livremente das riquezas que a natureza lhes dispunha: a possibilidade de plantar nas esparsas e poucas manchas de terras agricultáveis, as veredas; de criar nos amplos gerais aproveitando-se da vegetação dos cerrados que servissem de alimento para o gado; da caça e da pesca abundantes nos primórdios das chegadas e da coleta de frutos e outras riquezas que Ihes serviam para a construção das moradias, dos instrumentos de trabalho, de utensílios domésticos e muito mais.

Anciões moradores das comunidades de Couro de Porco, Bebedouro, Passaroto e Cajueiro, grande parte deles originários das comunidades da jusante, como, por exemplo, de Catolés, Bom Sucesso e Busca Vida, relatam as condições em que incursionavam rio acima à procura de terras agricultáveis nas quais 
pudessem formar roças, cuja colheita complementava a do amanho nas terras onde centenariamente tinham sítio. Conforme já me referi, naquelas localidades que julgavam apropriadas para a formação de sítio, se instalaram e daí em diante outros egressos da jusante a eles se somavam. Ali se territorializavam, sedentarizando-se, fazia caçada. Todo mundo tinha a liberdade de caçar, fazia aqueles fardão de carne e voltava pra trás. Matava muita caça que tinha e não guentava levar nas costas. Era mata bonita, muito cedro ${ }^{250}$ e diversificavam, com o passar do tempo as atividades agrícolas e pecuárias complementares às extrativistas.

Mas, nestas localidades, também as terras agricultáveis (no fundo de vale imediatamente ribeirinho - as veredas) não eram amplas e logo prosseguiam as incursões em direção à montante e à jusante do rio Arrojado e até mesmo de outros, como rio das Éguas (ou Correntina), Arrojadinho, galhos da Lama, do Venturino, do Pau Terra e outros da região, à procura de condições que lhes possibilitassem à formação de roças para a complementação do sustento.

\begin{abstract}
Nóis aí é o seguinte: aqui nóis plantava mais nos brejos, lá. Ninguém explorava isso aqui esse alto (as terras de cerrados que antigamente eram soltas e atualmente algumas partes estão cercadas e com pastos formados). Somente pra solta coletiva dos animal, soltava eles ai, os animal. Não tinha, vamos dizer assim uma demarcação era onde... por exemplo: nóis vamo colocar uma roça... eles colocava a roça 50 quilômetro ou até mais de lá da região de onde tava morando... o pessoal. De um rio eles colocava a roça no outro. Por que eles plantava a roça de arroz num ano aqui, aí a roça de arroz no primero ano que coloca, ela não dá mato, no brejo virge, aí eles plantava a roça de arroz e aí saía, vivia da roça de arroz, da caça e da pesca. Aonde tinha muita caça, eles fazia uma roça ali, muito peixe, fazia uma roça ali... e num... precisava só do sal... que não tinha como buscar, tinha vez que ia... daí pra Correntina de animal outras vez a pé, buscar o sal... ...de 100 quilômetro mais ou menos... 116 quilômetro... que é de lá do último morador do Cajuero, que é os primero habitante do véi Jovino. E aí, ou ia lá, ou ia no Pratudão ou em Posse, era onde iam comprar o sal. Aí vei essa nova geração, que já foi no meu tempo. Conheci muito, aqui a... a... mais não... de certeza, tá com 30 anos que aconteceu isso. Tô com 53 anos, eu me lembro muito bem... eles colocava a roça num lugar chamado 21. Sr. de Paulim colocou uma roça lá, muito grande, deu muito arroz na bera de Reberãozim subindo o gaio que tem chamado 21. Então por esse... do asfalto lá, pelo o lado do rio Correntina, é 15 quilômetro, nesse Gaio, lá esse pessoal... nóis todo plantava lá a roça, colocava lá a roça, né? Outros, noutros lugar. Outros plantava no Gai da Lama, que é onde nóis vamo, lá no Cajuero, pra lá mais ou menos uns 50 quilômetros de lá de casa. Doca, esse pessoal todo, plantava roça lá... (Sr. Claudomiro Pereira de Jesus, morador da comunidade de Couro de Porco, trabalho de campo realizado em janeiro de 2012).
\end{abstract}

Alguns elementos se destacaram como constituintes dessa territorialidade gerazeira e, dentre eles, ressalto a disposição de amplas terras (devolutas) livres de

\footnotetext{
${ }^{250} \mathrm{Sr}$. Doca, morador da comunidade de Couro de Porco, trabalho de campo realizado em janeiro de 2012.
} 
apropriação privada. Nestas, devido à ausência de cercas, tradicionalmente os criadores oriundos da borda leste e da oeste da chapada soltavam e soltam seu gado a pastarem, misturados livremente nos gerais. Livre, nos amplos cerrados, o gado podia e pode escolher o pasto bom e aguada boa onde existam. Com a mesma liberdade, os geraizeiros podiam e ainda podem - embora em menor proporção e em acirrado conflito com a expansão da propriedade privada da terra que também lá se territorializa - cultivar roças à montante ou à jusante de modo a complementar o parco rendimento do sítio onde fez moradia. ${ }^{251}$ Podem também caçar, coletar o peixe, os frutos dos cerrados e demais riquezas que lhes possam servir.

Com frequência, os camponeses afirmam que Deus fez o mundo e não inventou cerca, não dividiu. O geraizeiros assim se fizeram, se fazem e se refazem, seguindo esta premissa, sua territorialização se processa na luta pelas condições que possam permitir se reproduzirem, pois sabem que sua reprodução social só será possível a partir da sua reprodução territorial.

Quando se sentiram ameaçados pelas cercas, que muitas vezes não são feitas apenas de estacas e arame, desde finais da década de 1960, a comunidade de Passaroto tratou de delimitar sua fração territorial traçando um picadão nas proximidades da borda da chapada na parte alta da escarpa, na vertente esquerda do Arrojado. Logo em seguida, a ameaça ganhou concretude, como mostra o relato de D. Anália:

a Florestamina ela vei primeiro. Ela foi, primeiro foi na época que a gente juntou e fez aquele dividimento e apartou do picadão pra nós separar delas né? Depois disto, aí já com uns pouca de tempo aí, já entra essa Planta 7 que ela passou aqui na frente da minha casa que é ali, ali tem uma peda, bem ali ó, ela vinha passano que isso aqui, minha casinha era bem aí ó, esse moitinho aí que isso aqui era pra onde morava a véia. Ela fez o nivo de lá pá passar aqui. E eu cheguei da roça, cansada, que minha luta é roça, eu não tem boemia, meu serviço é trabalhar pá adquirir o pão, né? Cheguei da roça tá, essa máquina vinha rasgano aqui, não tinha nenhum home, tinha meu pai que ele morava bem ali também naquela ota terrinha ali também, e eu cheguei que eu vi essa máquina aí, os filho tudo doido pá cumê e cansada e aquela luta... é sabe o que é a gente chegar cansada e ainda tá lutano com ota coisa? E aí eu cheguei lá inté ele, e o que é que vocês tá fazeno aqui? Ah mais isso aqui a gente tá fazeno essa estrada... você já viu fazer estrada dentro de brejo em benefício dos oto? Riba essa lâmina! Faz favor e suma daqui da minha frente! Que eu num tô mutio boa não, além de eu chegar da roça cansada, aguniada pá dá o pão pá não ser preciso robar, ainda se vê aguniada como eu tô sentino aqui! Não eu não tô satisfeita,

${ }^{251}$ Ressalto que apesar dos impedimentos das cercas dos latifúndios e da fiscalização dos órgãos estatais de meio ambiente, moradores da comunidade de Couro de Porco e vizinhas praticam a agricultura nas veredas a jusante na localidade chamada llha ou em áreas ribeirinhas do rio Arrojadinho nas proximidades da barra com o Arrojado. 
por favor, riba! Riba! Sozinha. Fisso uma vez de doida! Sozinha e eles ficou assim (falas rápidas e inaudíveis). Por favor, suma! Que eu não to boa não! Os menino chorano, quereno comer, né? E eu sem saber se eu conversava com essas peste lá, ou se eu ia fazer coisa pra dá meus fio. (risos). Aí ele ficou... não dona, nós ta fazeno é uma estrada, uma divisa. Não mas isso aqui, nada de divisa dento do que é meu. Isso aqui eu tenho documento. Isso aqui é meu! Estado não! Estado já foi! Isso aqui é meu! Eu pago isso aqui, tirei meus documento, venho pagano muitos tempo e além de mim tem muitos, vários pessoa que paga! Isso aqui nós num tamos de graça não! isso aqui, nós tamos aqui, nós precisamos da terra e ocupamos a terra para tirar o pão de cada dia! Pá não ser preciso robar. Aí (palavras inaudíveis), você tá agoniada também, vamo passar a máquina por ali, eu não! Mas eu não dou esse direito não! Eu já fiquei foi goniada que nessa hora passava por riba de tudo até! Porque a gente sabe que a gente fica né?... aí ele disse: não, não precisa ficar assim muito nervosa não, a gente vai dar um jeito. Aí saiu. Foi no tempo que eles sairo pra lá... Ajuntou mais um povo daqui de baixo que aí nós já juntou todo mundo, que o povo não tava na casa, né? Messias? É os... perguntava na casa que ajuntou com todo mundo, que essa dita Florestamina, floresta não, Planta 7, que ela vinha passano aqui, ela tinha um nome, mas nós não conhecia mesmo o projeto dela, né? Aí evem passano aqui, aí juntou todo mundo na máquina, ajuntou todo mundo deixô a máquina ali irriba, no oto dia vamo atacar eles aí. Só o jeito que tem é nós atacar! Que não tem jeito não, brigar só de unha, que não tem nada! E de cuié de riba e abaixo nós teve que juntar pra mode dar um soco nesse home lá, nessa máquina. Também por favor ele ribou a lâmina,... (inaudível). Se viu apertado, mandou pedir socorro aqui no Oeste, Wilson falava, né? E ela pegou, passou e nunca mais ela vei. Esqueceu. Só de certo tempo pra cá o pau quebrou. E agora tá direto. Tá direto. Tão quereno mexer essa área aqui, luta várias reunião, e várias coisa que nós tamo lutano aí pra defender e nós seguino aí, né? Apertada, apertada. E o único pensamento deles eu não sei, é querer tirar nós que nem onte mesmo eu fui no campo lá em cima, vi vários piquetes. De cimento. Você não sabe, né? Pois é, já tem muitos piquetes aqui de cimento. De cabeça arriba. No correr dessa estrada, onte eu fui lá no campo, vi uns três ou quato pilar de cimento. Não sei quem que tá encolocano, quem num tá (Anália Cardoso dos Santos, moradora da comunidade de Bebedouro, trabalho de campo realizado em janeiro de 2010).

Após este episódio, trataram de fazer um picadão, seguindo o exemplo da vizinha Passaroto. Como não podia ser diferente, o grilo que se fez na absurda retificação de área não cumpriu o que determina a lei: a feitura de vistoria na área e a respectiva elaboração de laudo a ser apresentado ao juiz para que ele aprovasse ou não o pedido de retificação de área. Nada foi feito, como de costume, as centenárias comunidades não foram consideradas e, mesmo assim o juiz aprovou o absurdo pedido de retificação de área.

Frequentes episódios, similares ao relatado, constituem a história, não somente das referidas comunidades, mas também, conforme pude observar nas localidades visitadas nos gerais baianos, da totalidade das comunidades geraizeiras. Como medidas destinadas à defesa de suas frações territoriais, obrigam-se, contraditoriamente, a delimitá-la ou recortá-la a partir da construção de picadões ou cercas, como se tem visto nos casos das comunidades criadoras em soltas e fechos de gerais na jusante. 
Então aí fizemo, aqui, na hora daqueles conflito fizemo eles abrir né? As pessoas de antigo fez, de herança antiga, aqueles velho fez alevantar a lâmina do trator pra cima. Nós ficamos, aqueles meninin, né? Ali, só com uma vazia d'água, se precisasse ir num canto a gente levava, as água pra tirar uma estrada, trabalhei muito nisso aí... aí os velho falou, não, pode arribar e não volta mais não. Eles arribaro. Falou: mais moço vamo entrar nisso aí, falou mas não, nós não tem acordo não. $O$ acordo de você é pra lá. E nós é aqui. O grupim nosso é pequeno nós não pode misturar. Os véio sempre falava isso aí. Nós não tem força. A força nossa é isso aqui. Sossego nosso é essas terras para colocar nossas roça. Aí eles arribaro, mas não foram embora não. Arribaro a lâmina do trator, e nisso aí, daquele eixão pra lá tinha um lugar chamado Pouso do Tiagua. Que era onde nós fazia a viagem pro oto rio e discançava com o pessoal. Discançava com o pessoal e aquilo ali era um pouso de nóis almoçar, merendar, comer, conforme o horário que nós chegava lá, apiava a tropa, desincangava os bois, ali era chamado Pouso do Tiagua, naquele pau lá. Aí bem assim nós fez, né? Fiquemo aqui tranqüilo. Quando pensou que não vai um pessoal viajano pra lá pra oto rio. Aí quando chegou lá no Pouso do Tiagua, ta eles tudo abarracado lá. Pegaro aqui, sabe, pegaro a estradinha velha que nós tinha, e pegou todos equipamento que tinha aqui embaixo, as máquinas, e levaro tudo pra lá. Levou pra lá e começou trabalhar lá. Nesse meão lá. Aí o rapaz voltou da estrada. Chegou aqui avisou pra nós. Não sei mais nem quem foi esse, da comunidade. Falou ói não se dá de mais nós ir pra lá, de nóis facilitar aqui não, que os home, a tendência dos home é descer, pra cá. Os home já tá com máquina, os maquinaro tudo lá, tá quebrano o cerradão, lá e disse que é pra plantar um tal de pinho, caju, otas coisa lá, indústria deles. Disse que lá eles vai fazer mesmo, que lá a área é deles, lá eles veio com autorização do governo, do presidente, disse que lá vocês não é dono de nada aqui não e que lá é deles, eles falou, já disse otras manera já dificil pra nós lá. Falou óia, eles ia deixar nós aqui até sem lugar de dormir. Eles expulsarão de nossas área pra fora. Os velho, né? Que que nós vamo fazer? Vamos fazer o seguinte, é tirar nosso limite. É delimitar a área. Nós não tinha condição de delimitar área, nem documento, que ninguém tinha esse conhecimento, né? ...Aí falamo, vamo delimitar a área. Eu me lembro, que parece, Iremar, que tem hora que me falha a memória. Parece que foi em 72, nóis foi tirar essas picada. Delimitar a área. Foi uma coisa por aí, né, foi em 1972. Aí nóis fomo delimitar a área, aí os véio, saiu o véio Valentin, o véio Francisco, que foi um dos primeiro habitante, saiu Doca ali, saiu desses mais véio, saiu o véio um... Oleriano, muitas pessoas, saiu eu, eu levava até água. Meu trabalho era levar água e as foice de algum quando tava muito dividido. Meu trabalho era esse. Quando eles me pedia, de toda vida eu era esperto um pouco no trabalho, né? Oh menino traz isso pra mim, eu já saia correndo. Eles gostava de minha participação. Eu tinha o dom pra mode ficar, apesar que meu pai tinha morrido, só tava minha mãe, mas eles gostava porque pra mexer com carro-de-boi para alguma coisa assim, eu tava mais eles junto. Aí vai desincangá aqueles boi ali, na hora! Vai desarriar aquele cavalo ali, eu mesmo pequenin mas eu tava junto. Vai levar água pra nós, aí eu ia. Aí eu me lembro que nós pegou umas vazia d'água aqui e nóis subiu a serra. Quando nós chegamo ali, no canto daquela cerca, não sei aonde seu Amaro mostrou pra vocês. Cheguemo ali no canto da cerca, numa estrada velha que nós tinha aqui por dentro que ia pra Velha da Galinha, um véi foi falou: daqui tá bom demais. O véio Francisco. Aí chamou os otos. Ein compade Valentin. Senhor acha que aqui tá bom demais essa picada aqui? Ele falou eu acho que pelo... pelo valor dessa terra aqui em cima, pra nóis aí já chega. Terra tá bom demais. Aí eu me alembro que eu como menino e otos do meu níve falou assim óia, os mais novo, igual Doca, esses otos que era mais novo. Deu opinião. Falou, não, aqui ta muito perto. Esses home vai nos atacar. Vamo delimitar essa área mais longe um poquim.

Então seu José, ai eles foi e falou assim: vamos delimitar mais um poquim, aí eles respondeu pra nós assim: meu filho nós fazer o que com essas terra aí, nós não tem condição de beneficiar nem o sítio nosso lá. Eles falou, mais vamo, vamo alembrar do que a véia Maria falou. Do que ela falava: isso aqui vai ser retalhado igual, já tá chegano o momento. Vai ser retalhado igual carne nos açougue. A mãe do seu Massuo. Falava pra nós e nós peguemo isso aí. Aí começou provar o que a velha tinha dito pra nós. Vamo estanciar. Mais eles não estaciou, num chegou mais do que 
1000 metro. Eles queria fazer quase na serra. Pra riba da serra um pouquim. Aí nóis mesmo assim ainda fomo mais 1 mil metro pra frente. Aí demarquemo o picadão. Desceu um grupo de home dividiu a turma, um grupo desceu pra ilha, e o oto subiu pra o Cajueiro. Que é onde tá o conflito acirrado até hoje. Aí nóis foi. Uns subiram pra o Cajueiro e otos desceram pra llha. Dois grupo de pessoa. Nisso aí, a liderança desse grupo que subiu na frente chamava Wilson Martins Furtado que foi o expresidente do sindicato que foi um home que não era pelego, era um home de rocha. Era um home que era um sindicato forte. O home tinha corage e tinha como se organizar. Tinha como se organizar, Wilson. Tava mais nós junto. Era um home moderno mais era um home, ele veio de uma organização de terra, era um home que tinha um estudo superior, um home formado, um home educado, que sabia entrar e sair, né? De qualquer lugar. Então eles se pegou a liderança. Aí falou ó Mirim, vamo subir mais eu. Aí eu subi mais ele, no grupo dele. E os otos desceram. Que a distenção de baixo, da llha era mais curta. Então nós precisava de mais gente porque a distenção de lá de onde tá aquela casinha pra cima é muito longe até chegar no Cajueiro. E nós subimo, é quase uns 18 quilômetro de distenção e nós subiu até o final. Trabalhemo mais ou meno uns, não era muito home, trabalhemo mais ou meno uma semana. Na verdade foi uma semana. Nós demo conta disso aí, né? Era mais ou meno uns 20 home. Ou era mais ou meno. Mais tá com muito tempo, a gente pode não falar aquilo que era a quantidade. Era mais ou menos 20 pessoa entre home e menino assim, rapaizin novo. Aí subimo, dividimo a área, delimitemo a área todinha, $e$ aí, nessa dividição que nóis feiz, dividimo, ficamo como o picadão. Aí o que que eles fizero, eles correro, eles correro lá e arranjaro otos documento. Arranjaro otos documento. E nesses documentos que eles arranjaro esses documento, isso aí já foi em 82 por aí. Aí eles já vei falano que tal, que essas terra aqui eles era dono, que ia deixar nós trabalhar aqui pá mode não abusar nóis, mas que era dono, ia trazer muito emprego pra nós, ia ter muito serviço, né? la fazer uns plantio, ia mexer com esses plantio de pinho, né? De eucalipe, né? Plantio, grande plantio de mandioca, né? Aí, ia ser uma fonte de renda pra nós que tava aqui na região. Não ia ser aquele trabalho escravo, ia ser um trabalho de organização, né? E ia vim. E nesse momento, quando eles começou a plantar pinho, teve gente que foi aí. E otos lugar era torturado... pela própria empresa. Como eles trouxe gente de fora, pra prestar o serviço, não pagava as pessoa direito, deixava passar forme, inclusive, logo que instalou o sindicato que chegou muita gente aqui, ó, corrido. Colocava pistoleiro, sabe? Pra se, a gente fala assim acho que era pra mode não pagar, acho não que era pra não pagar o que 0 cara tinha, começou com essas harbitrariedade por aí, fazendo coisa injustiça, né? Aí se começemo a organizar o sindicato nessa época aqui. Wilson e o padre André, né? Foram dos afundadores do sindicato, que é a mesma associação, que é o sindicato. Aí precisava, como nós viu esse tanto de perigo arredor de nós, precisava de organização. Aí esse Wilson Martins Furtado, né? Sobrenome dele, organizou o sindicato mais o padre André e Wilson e a Cecília, é, me lembro como hoje. Até quem foi na casa do Wilson, primeirim foi eu, mais a Cecília e o padre André. E a Irmã. Nós quatro, mermim (Sr. Claudomiro Pereira de Jesus, morador da comunidade de Couro de Porco, trabalho de campo realizado em janeiro de 2012).

A partir da construção do referido picadão (em 1972), prosseguiu-se uma ferrenha luta dos geraizeiros pelo reconhecimento deste por parte da empresa grileira e dos órgãos estatais. Daí em diante, foram várias as investidas da empresa na construção de cercas e picadas ultrapassando-o, bem como a elaboração de laudo por técnicos do órgão de terra do Governo Federal (INCRA), desconsiderando-o e, além disso, seguidas decisões judiciais, embasadas tanto em laudos tendenciosos de técnicos quanto em pareceres do Ministério Público local, em desfavor dos geraizeiros (figura 17). 
Dentre as picadas que na situação de conflito destinaram-se à demarcação territorial, cito: a primeira, construída pelo pessoal do Passaroto, na década de 1960 e sob a liderança do comunista Wilson Martins Furtado, traçava uma reta na altura do atual campo de avião da empresa Planta 7. A segunda foi construída pelo referido grupo, incluindo também o comunista, no ano de 1972 e motivada pela abordagem violenta da empresa grileira. Na década de 1990 a empresa avançou além desta picada tomando para si uma área de 940 hectares de terra. Nesta mesma década construiu cerca nesta picada e em seguida as comunidades a destruiu (foto 28). No ano de 2006 um perito do INCRA elaborou um laudo técnico no qual constava como delimitação da área das comunidades a estrada que as interligam e passa imediatamente às portas das moradias. Amparado neste laudo e em pareceres do Ministério Público o juiz da Comarca de Correntina expediu ordem judicial de interdito proibitório em favor da empresa a partir do referido limite. Beneficiada por essa decisão judicial a empresa ousa construir uma cerca seguindo a estrada "limítrofe". Quando a construção atingia $15 \mathrm{~km}$ de extensão as comunidades reuniram-se e obrigaram a empresa construtora destruí-la. Adiante apresento depoimento com detalhado relato sobre este evento.

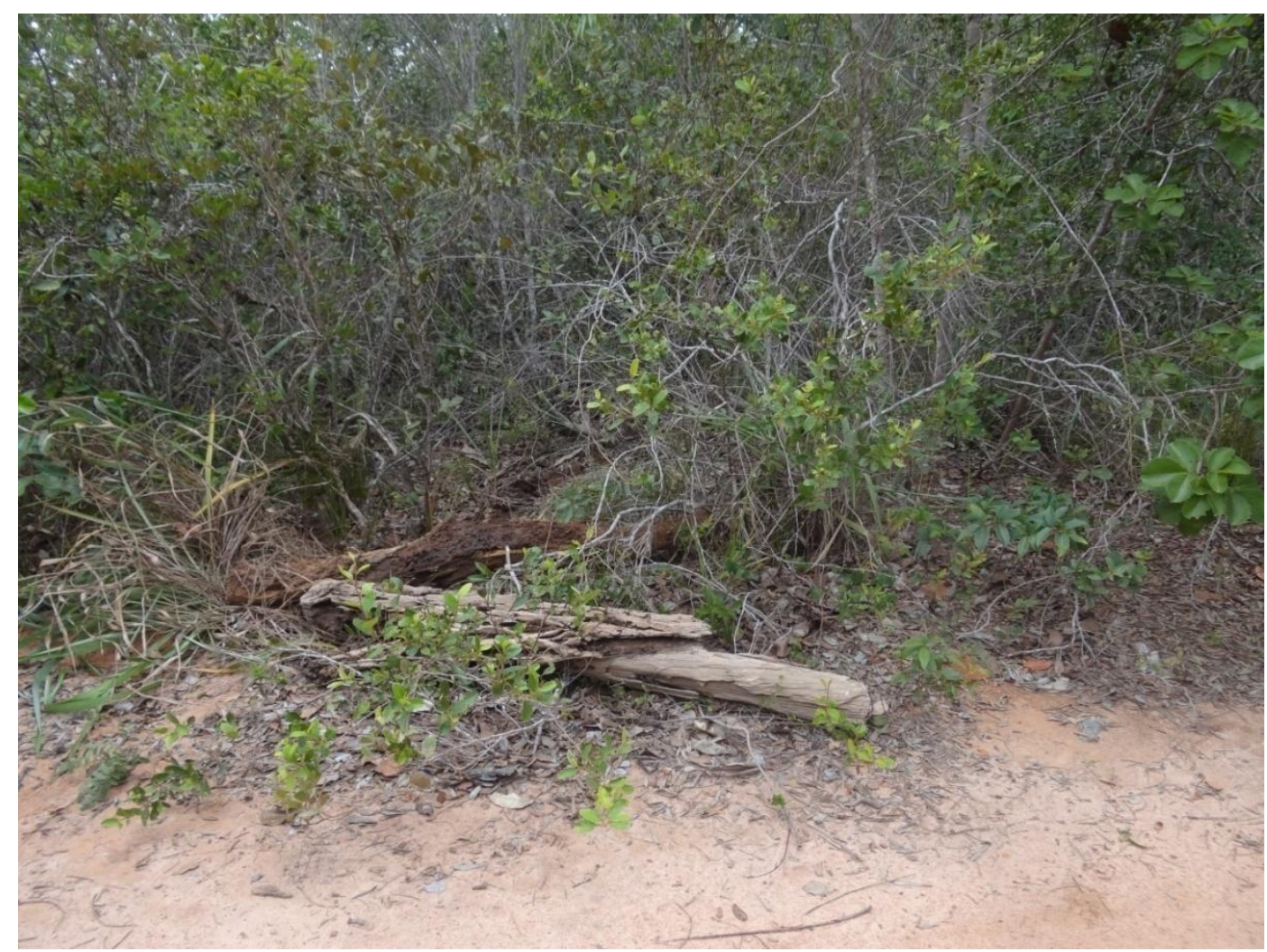

Foto 28 - Cerca destruída na década de 1990. Comunidade Couro de Porco, Correntina - Bahia. Sousa Sobrinho, J. (jan. 2012). 
Figura 17 - Disputas territoriais na comunidade Couro de Porco, 2012

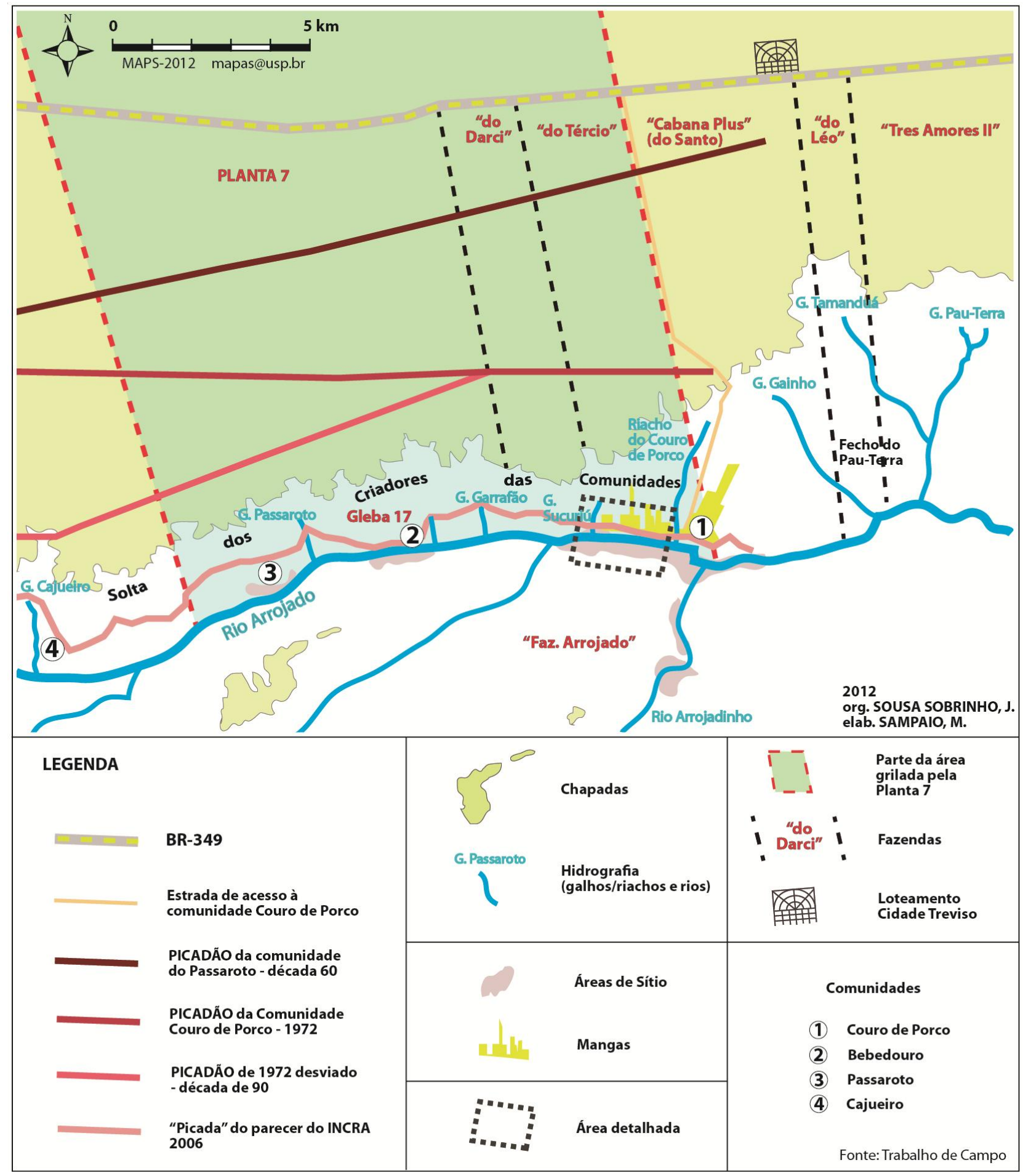


Entretanto, em uma situação parecida com a estudada por Oliveira (1991, pp. 82-91) na Fazenda Mirassolzinho no Estado do Mato Grosso, os geraizeiros, na força da ação direta, fizeram valer os seus direitos, não permitindo a tomada de suas terras de trabalho pelas empresas grileira capitalistas ${ }^{252}$. Em Mirassolzinho, os posseiros há muito haviam se apropriado dos quinhões de terra com as respectivas áreas proporcionais à capacidade de trabalho de cada família. Após vitória em longa disputa com a fazenda pretendente à área, passou-se a disputar com o INCRA a racionalidade da distribuição da terra e a localização dos lotes. Este, desconsiderando a lógica camponesa de apropriação da terra - a qual se evidencia também na decisão dos geraizeiros ao delimitar a extensão de suas terras - insistiu em fazer a partilha igualitária da terra, sem considerar a racionalidade dos posseiros. Postura de tamanha resistência, similar a dos geraizeiros, foi adotada pelos posseiros de Mirassolzinho, fazendo valer o direito do "mato", o costumeiro, em detrimento do direito da "rua", o jurídico positivo, o qual, sem sucesso, foi insistentemente e com uso da violência, tentado impor-se pela superestrutura, o Estado.

Apesar de entender que o depoimento do Sr. Claudomiro em muito se autoexplica, eu quero mesmo assim tecer alguns comentários, com vistas a realçar aqueles pontos que embasam o enfoque valorizado na pesquisa.

Em uma situação de súbito e truculento ataque, com o propósito de thes desterritorializar totalmente, a estratégia de defesa mais imediata foi aquela que the garantisse minimamente a sua reprodução a partir das forças produtivas vigentes, embora caiba discutir se aqueles sujeitos tomadores de decisão detinham a devida consciência das dimensões territoriais que Ihes seriam suficientes. O que se sabe é das suas noções, a partir da relação que estabelecem com a terra como instrumento de trabalho, em seu tempo, do quanto são capazes de usar, embora, possivelmente em decorrência da súbita situação, não tenham se atentado para a dimensão territorial necessária à sua reprodução social, o quão se fazia necessário no futuro.

Não se sabe exatamente a população das comunidades no início dos anos 1970, mas, se considerado que, em 2000, habitava um contingente populacional de

\footnotetext{
${ }^{252}$ MARTINS (1991), especialmente capítulo III.
} 
100 famílias; em 2006, 140; e em 2012, $165^{253}$, pode-se ter uma ideia do quanto se fazia insuficiente a estimativa territorial estabelecida pelos senhores que decidiram 0 traçado do picadão. Mas também cabe ter em consideração se detinham as condições suficientes para lutarem e conseguirem o necessário para a sua reprodução socioterritorial.

Cabe destacar o que expressa os dizeres nós não pode misturar. É possível que expresse o entendimento de que se trate de lógicas diferentes, em que uma pretende incluir a outra, subordinando-a ou sujeitando-a. E quando dizem a força nossa é isso aqui. Sossego nosso é essas terras para colocar nossas roças, isto possivelmente expressa a consciência do que para eles representava e representa o acesso à terra, instrumento de trabalho do qual, por meio do trabalho, retiram seus meios de vida e através da qual podem ser uma comunidade camponesa geraizeira que pode ser forte pela união expressada nos relatos de muitos interlocutores. Mas, neste conjunto de força, é inegável a dominância daquela que tem garantido a parcela do território ao alcance da comunidade, a da organização para a resistência às forças expropriatórias do capital. Grande capital que se confunde com o Estado classista e em sua maior expressão no caso baiano dito pelos comparsas dos grileiros que vieram com autorização do governo, do presidente, sem reconhecer a existência ali dos camponeses, pois, não eram donos de nada aqui não e que lá é deles, e eles ia deixar nós aqui até sem lugar de dormir, pretendiam, portanto, expulsá-los.

Martins (1981) ${ }^{254}$ oferece uma importante contribuição, ao pontuar na história da questão agrária brasileira, o papel que foi atribuído aos posseiros no desenvolvimento do modo capitalista de produção e ao mesmo tempo demonstra o tratamento a eles conferido pelas elites ao longo da história desde o período colonial, quando em voga o regime de sesmarias na política de concessão de terras públicas apenas àqueles que tivessem posses de escravos e fossem dotados de sangue limpo (MARTINS, 1981, p.110). Aos mestiços de índios e negros, era negado o acesso à terra, restando a eles a opção de embrenharem-se nas matas, desbravando-as para formar suas roças das quais retiravam os seus meios de vida,

\footnotetext{
${ }^{253}$ Em 2012, chega-se a este número, afora a imensa quantidade de pessoas que migraram, principalmente em 2006; uma vez que, em função do acirramento do conflito, somente da comunidade de Passaroto, migraram 15 famílias.

${ }^{254}$ Especialmente os capítulos II e III.
} 
"limpando" as terras no confronto direto com os nativos e, sem qualquer sustentáculo jurídico, as cediam para as fazendas que se instalavam em seguida. Esta dinâmica de apropriação privada da terra no Brasil e da ocupação camponesa da terra, no regime de posse, foi geradora de grande parte das comunidades rurais no Brasil afora (p. 110) e de diversas revoltas camponesas as quais, nem sempre ocupam o devido lugar na história do Brasil que se conta. Martins esclareceu:

Os mestiços e os seus descendentes e os índios destribalizados foram colocados
numa situação social peculiar: ou se retiravam para regiões distantes dos lugares
dominados pelos brancos, constituindo pequenas comunidades de lavradores pobres,
ou sobreviviam no interior das grandes fazendas como agregados, como pessoas que
nem eram escravas, nem eram empregadas nem eram proprietárias. Sempre que o
fazendeiro precisava da terra podia remover essas pessoas. Mesmo quando chegava
a uma nova região já ocupada por essa população, podia removê-la com facilidade,
transformando cada um em agregado da sua fazenda. Muitas fazendas foram abertas
utilizando essa mão-de-obra (MARTINS, 1981, p.110).

É possível que o desdém e a violência da empresa no processo de investida para a tomada das terras dos posseiros expliquem-se a partir da persistência do ranço das oligarquias e das elites brasileiras em geral da condição social que querem determinar e perpetuar aos índios, negros, mestiços, pobres e, dentre eles, aos posseiros.

Nos planos da empresa grileira, até certo ponto não seria inconveniente a existência da comunidade anexa à fazenda, porém quase totalmente expropriada (restando-lhe apenas um reduzido quinhão de terra do qual pudesse retirar o seu sustento durante os períodos em que não necessitasse de sua força de trabalho), como de fato tem ocorrido com parte de seus integrantes que tiveram, das mais variadas formas, suas terras tomadas pelos grileiros e só lhes restaram submeterem-se ao trabalho assalariado nos empreendimentos capitalistas que se instalaram no entorno.

A consumação do grilo, com a aprovação da referida "retificação de área" pelo juiz, se deu em 1980, conforme documentação da ação discriminatória administrativa realizada pela CDA do Estado da Bahia na área, documento este que o Sr. Claudomiro se refere como o segundo, no seu entendimento, conseguido pela empresa em 1982 (imagens 1, 2, 3 e 4). 


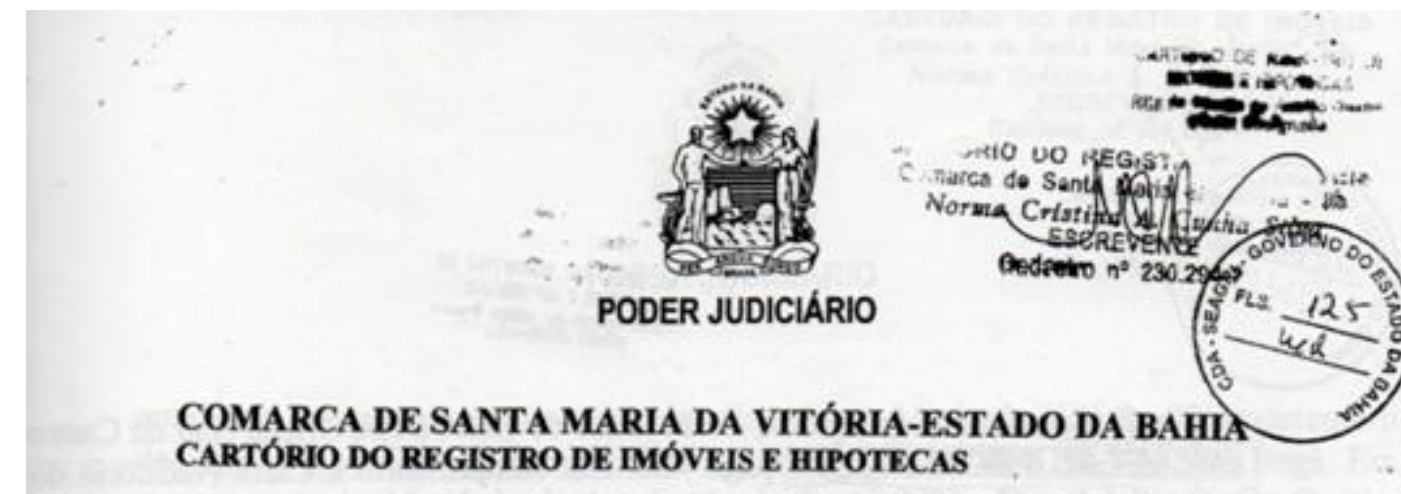

\title{
CERT ID Ã O FILIACÃO DE DOMÍNIO CINOUENTENÁRIA (50ANOS)
}

\begin{abstract}
RITA dE CÁSSIA dE ARAUJO CASTRO ALVES, OFICIAL DESIGNADA DO REGISTRO DE IMÓVEIS E HIPOTECAS,DESTE TÊRMO, SÉDE DA COMARCA DE SANTA MARIA DA VITÓRIA-ESTADO DA BAHIA, NA FORMA DA LEI, ETC.
\end{abstract}

CERTIFICO que foi feito no livre 3-C TRANSCRIÇốES DA TRANSMISSOES, às FLS. 68 v 69 sob 2.280 de ordem, registro feito a 10 de abril de 1945pelo qual se verifica que: HAVERÁ na parte de terra com água de rega e terreno seco, cercado de achas, na fazenda PASSAGEM FUNDA, deste Têrmo, avaliada por cem cruzeiros, somente a quantia de trinta e um cruzeiros CRS 31,00 Haverá na parte de terra da Fazenda Buriti, no lugar denominado Tamarama, deste Têrmo, avaliada por setenta cruzeiros, somente a quantia de vinte e cinco cruzeiros e cinquenta centavos, CRS 75,50 . HAVERÁ na parte de terra da Fazenda Passagem Funda no lugar denominado Malhadinha, deste Têrmo, avaliada por oitenta cruzeiros, somente a quantia de trinta cruzeiros e vinte centavos $\mathrm{Cr} \$ 30,20$. Haverá na casa velha coberta de telhas, dois lances, situada na mesma parte de terra da Fazenda Buriti, no lugar denominado Tamarama, avaliada por quarenta cruzeiros, somente a quantia de vinte cruzeiros $\mathrm{Cr} \$ 2$ 20,0qAVERBACAO=AV. 01 Prot. N 4.279 , fls. 419. Em cumprimento ao Mandado e Alvará do Exmo. Sr.Dr. Fernando de Souza Castro, M.M. Juiz de Direito da Comarca de Carinhanha, Substituto desta Comarca, faço a seguinte averbação: Cujo pedido foi ouvido o Órgão do Ministério Público, foi homologada a retificação de área do imóvel rural Fazenda Buriti, no lugar denominado TAMARAMA, com área de 217.000has(duzentos e dezessete mil hectares0. Obedecendo as seguintes confrotaçø̃es: Ao Norte, com Antonio Joaquim da Trindade, João Gomes dos Santos e o Rio das Éguas; Ao Sul, com Severino Vilas Boas e Raimundo Alves de Oliveira; Ao Leste, com Domingos Nunes e a Oeste, com o lugar denominado Mato Grosso e o Rio Pratudão. Era só o que tinha a averbar, do

250.00000

Imagem 1 - Certidão Filiação de Domínio Cinquentenário (50 anos), fls. 125 (frente), constante da ação discriminatória Gleba Arrojelândia, município de Correntina-BA. Biênio: 2008/2009. CDASEAGRI. 


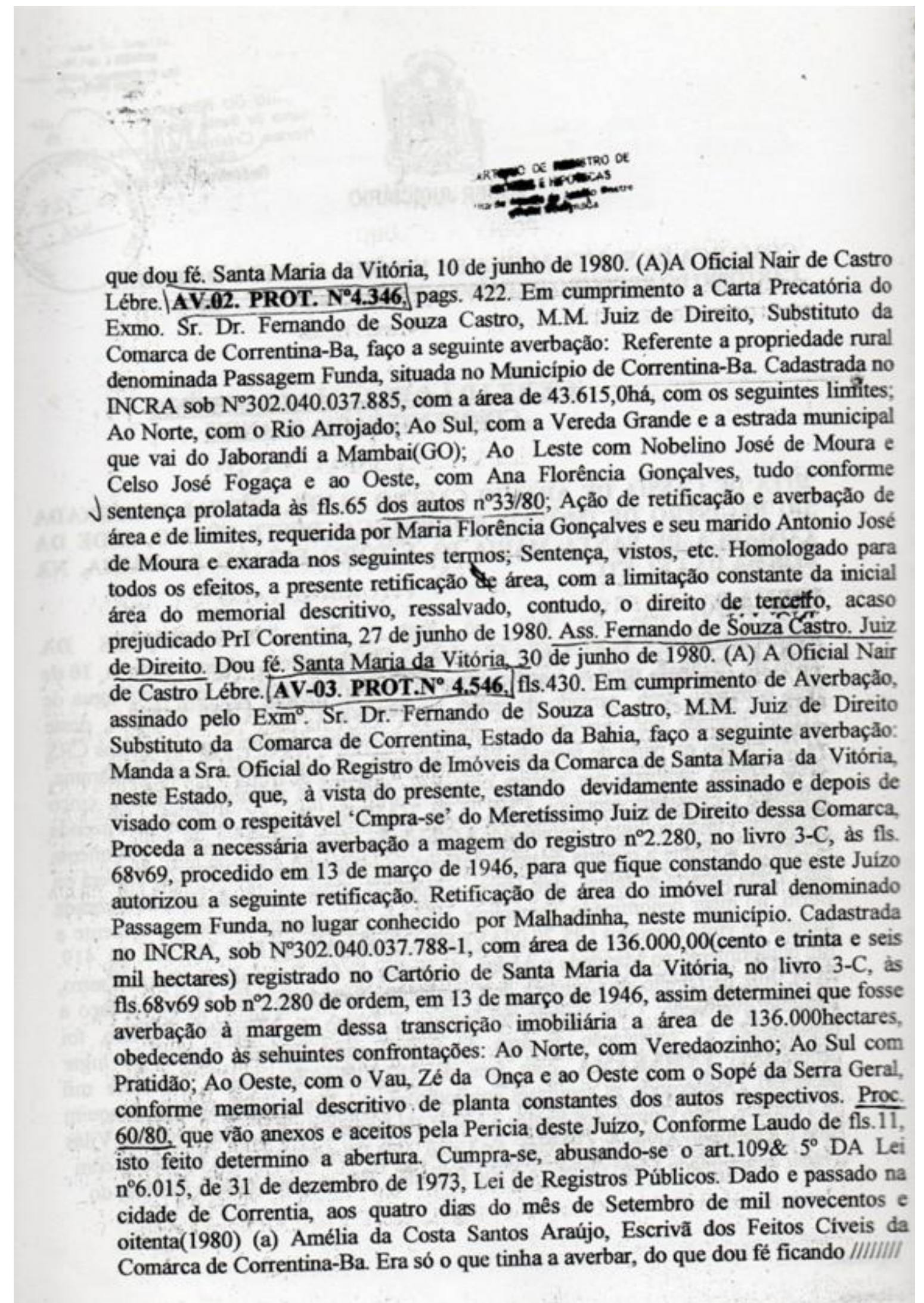

Imagem 2 - Certidão Filiação de Domínio Cinquentenário (50 anos), fls. 125 (verso), constante da ação discriminatória Gleba Arrojelândia, município de Correntina-BA. Biênio: 2008/2009. CDASEAGRI. 


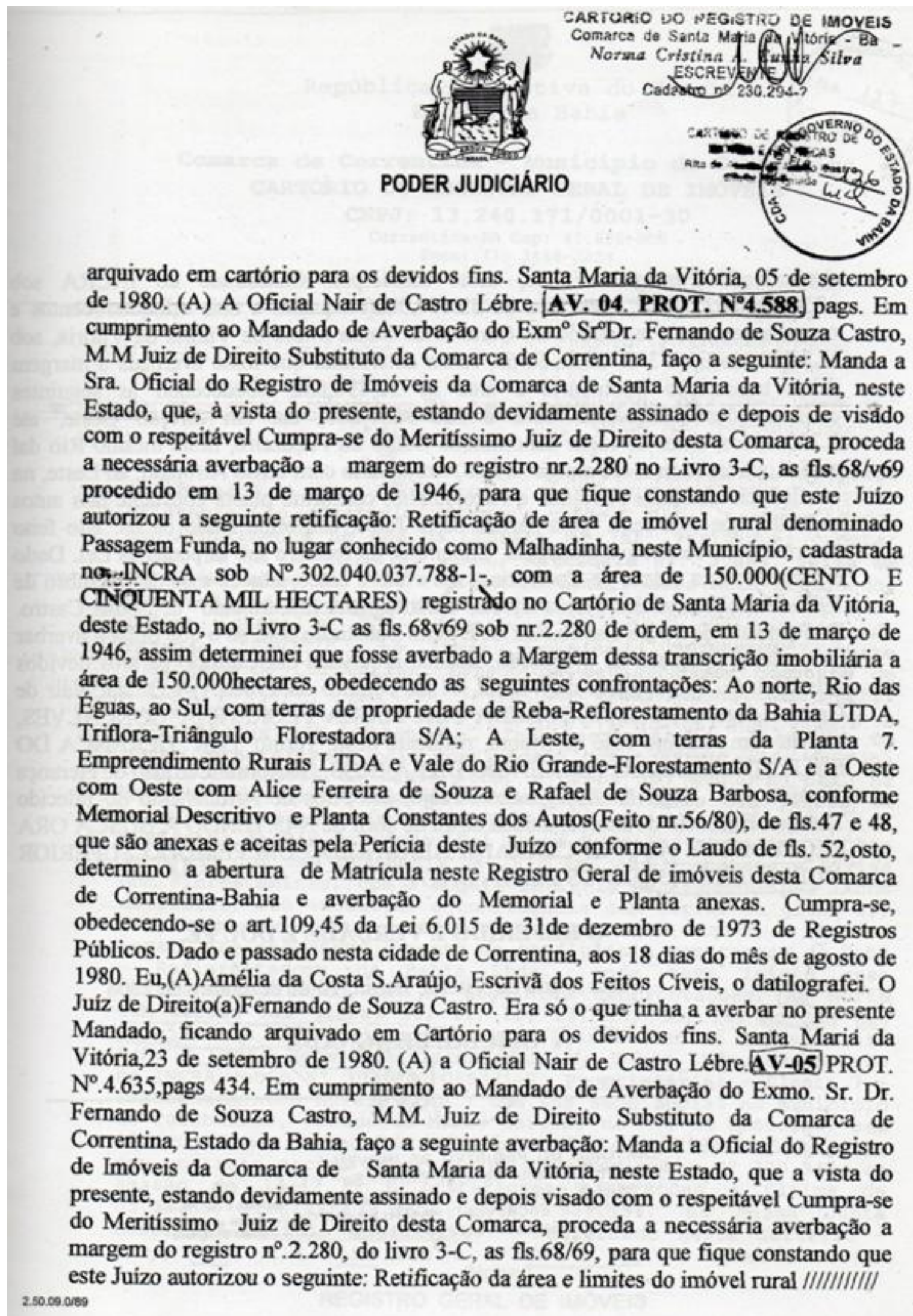

Imagem 3 - Certidão Filiação de Domínio Cinquentenário (50 anos), fls. 126 (frente), constante da ação discriminatória Gleba Arrojelândia, município de Correntina-BA. Biênio: 2008/2009. CDASEAGRI. 
denominado Passagem Funda, deste município. Cadastrado no INCRA sob $\mathrm{n}^{\circ} .302 .040 .037 .788-1$, com área de $52.490,0$ há(cinquenta e dois mil,quatrocentos e noventa hectares), registrado no Cartório de Santa Maria da Vitória da Vitória, sob $\mathrm{n}^{\circ} .2 .280$, no livro 3 -C, as fls. $68 / 69$, assim determinei que fosse averbada a margem dessa transcrição imobiliária a área de $52.490,0$ há, obedecendo as seguintes confrontaçőes: Ao Norte, com o Rio Arrojado, dai em direção Oeste, até 3.250metros, antes do lugar denominado Galho do Puçazeiro, neste mesmo Rio daí ao Sul, em linha reta, até atingir o Rio Arrojadinho com o Rio Arrojado; ao Leste, na confluência dos Rios Arrojado e Arrojadinho, conforme planta constante dos autos nr.78/80, que foia ceita pela perícia deste Juizo, conforme laudo de fls. Isto feito determino da respectiva matricula. Cumpra-se na forma e sob as penas da Lei. Dado e passado nesta cidade de Correntina, ąs vinte e cinco dias do mês de setembro de 1980. Eu(a)Escrivã dos Feitos Cíveis, o datilografei (a)Fernando de Souza Castro. Dr.Fernando de Souza Castro.Juiz de Direito Substituto. Era só o que tiinlia á averbar no presente mandado de averbação, ficando arquivada em Cartório para os devidos fins. Dou fé. Santa Maria da Vitória, 01 de outubro de 1980.(A)A Oficial Nair de Castro Lébre A) FOI ADQUIRIDA POR MARIA FLORÊNCIA GONÇALVES, casada com Antonio José de Moura, residente neste Têrmo. POR HERANÇA DO FALECIDO TIMOTEO FLORÊNCIO DE BARROS, Conforme Certidão de Herança extraida pelo Escrivão Aldegundes Araújo, dos Atos de Arrolamento do falecido Timoteo Florêncio de Barros, datada de 10 de abril de 1945.TENDO A BUSCA ORA PROCEDIDA E AQUI ENCERRADA ABRANGIDO UM PERIODO SUPERIOR A CINQUENTA (50) ANOS DESTA DATA.

\section{O REFERIDO É VERDADE E DOU FÉ.}

Santa Maria da Vitória, Bahia, 10 de dezembro de 2008

A OFICIAL DESIGNADA
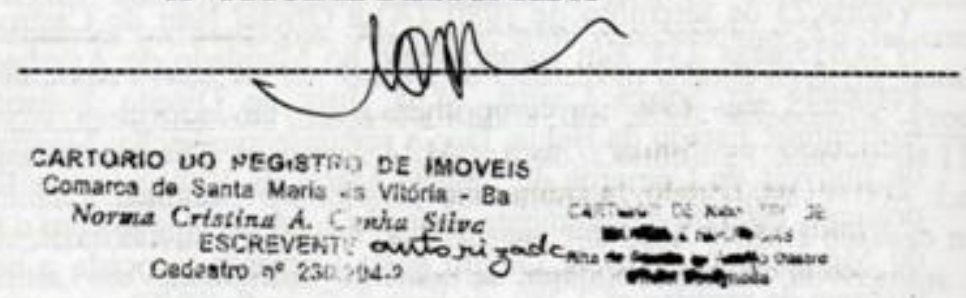

Imagem 4 - Certidão Filiação de Domínio Cinquentenário (50 anos), fls. 126 (verso), constante da ação discriminatória Gleba Arrojelândia, município de Correntina-BA. Biênio: 2008/2009. CDASEAGRI. 
Se desde 1972, os pistoleiros das empresas já atormentavam os posseiros da região, isto pode ser um indicativo de que os trabalhos de gabinete no âmbito dos cartórios e do judiciário já estavam em andamento. E se Wilson Martins Furtado, quadro do Partido Comunista do Brasil, já havia sido destacado para atuar na área desde a segunda metade da década de 1960, é possível que o grilo se iniciasse antes dos anos de 1970 e, sabendo disso ${ }^{255}$, o Partido tomou iniciativa de atuar na área. Esta possibilidade é reforçada a partir da antecipação de Wilson, posseiro da comunidade de Passaroto, no traçado do primeiro picadão, à frente da sua comunidade, na década de 1960. Dada a forte influência desse mediador social, não só nas comunidades, mas também no município à época, e depois na região Oeste da Bahia e no próprio Estado (de 1998 a 2002 o mesmo foi designado para atuar na FETAG em Salvador). A decisão da comunidade de Couro de Porco, em estabelecer seu limite territorial por meio do picadão, resultou da sua intervenção, pois o mesmo participou diretamente na sua construção, conforme relatou o Sr. Claudomiro.

A atuação desse quadro do Partido, morador da comunidade de Passaroto, foi relevante na organização dos camponeses para o enfrentamento da grilagem na região e, cabe frisar, importante também foi a participação da Igreja Católica neste processo, nas figuras do padre André Frans Bérénos e das Irmãs Zélia Brandão e Neide Costa. Destacaram-se como expoentes atuantes na politização dos camponeses para o enfrentamento da expansão da propriedade privada e capitalista da terra, os quais fundaram o STR-Correntina e, por isto, são merecedores da enfática menção do Sr. Claudomiro.

De posse do documento fraudulento, a empresa iniciou suas atividades a partir de financiamentos bancários, cujos investimentos, conforme rezava os referidos comprovantes, não eram destinados a atividades na área grilada e sim a outra empresa, a Italmagnésio Nordeste S.A., do ramo de mineração. A área grilada servia de penhora para uma série de empréstimos, muitos deles no valor de 6 milhões de dólares, realizados no Banco América do Sul S.A., a partir do início da década de 1990, sob a "responsabilidade da devedora Italmagnésio Nordeste S.A." (CDA-SEAGRI, 2009, fls. 149-154). Assim, o papel de reserva patrimonial era realizado pela propriedade privada capitalista da terra grilada (imagem 5).

\footnotetext{
${ }^{255}$ Refiro-me à política de "reflorestamento" do governo militar destinada á área.
} 


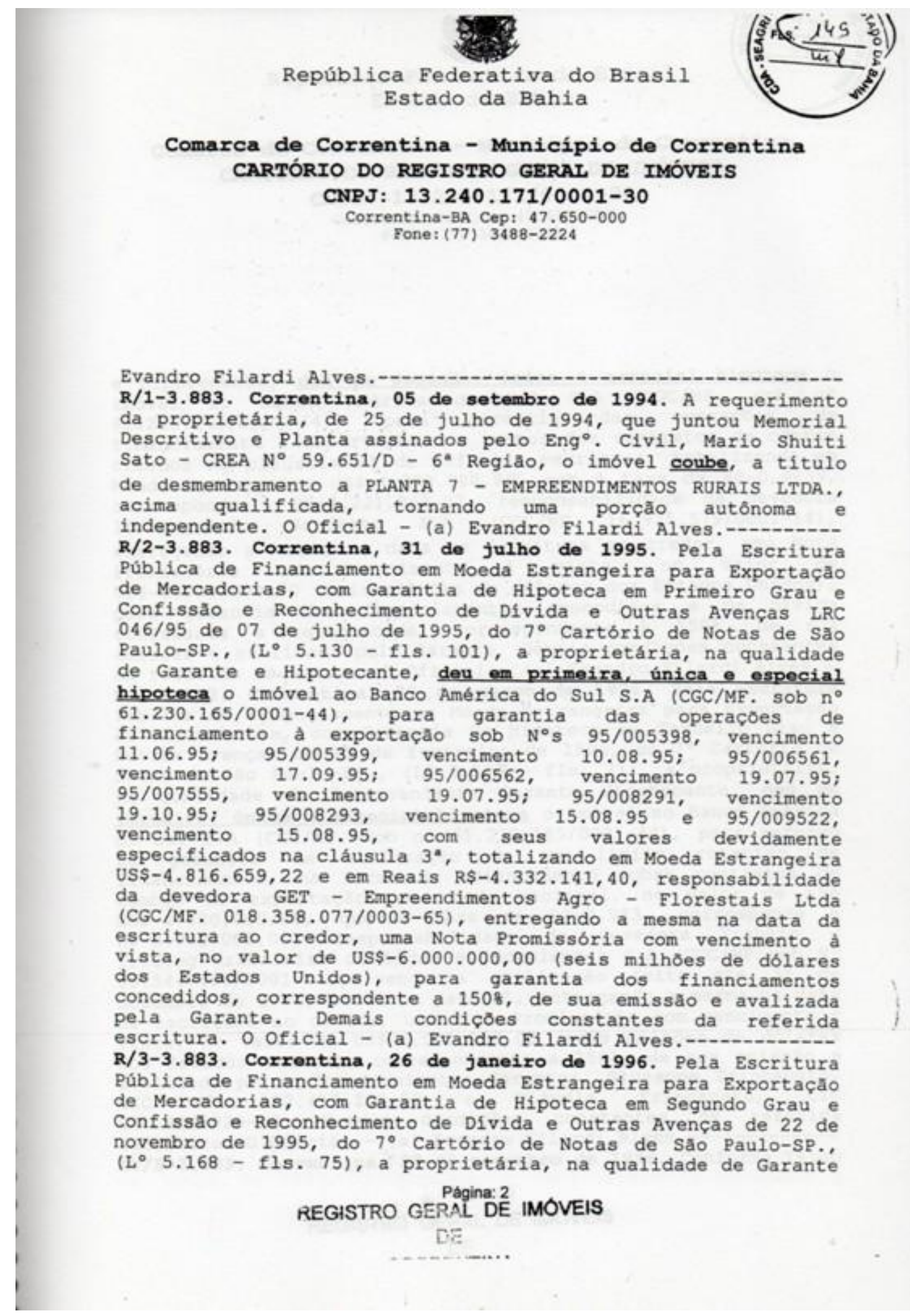

Imagem 5 - Documento de penhora constante na ação discriminatória Gleba Arrojelândia, município de Correntina-BA. Biênio: 2008/2009. CDA-SEAGRI 
O Sr. Claudomiro fez referência também às promessas da empresa Planta 7 às comunidades, dentre as quais: ia trazer muito emprego pra nós, ia ter muito serviço, né?... ...Aí, ia ser uma fonte de renda pra nós que tava aqui na região.

Apesar de usufruírem da fartura conseguida no trabalho em suas terras, para a empresa, os integrantes das comunidades careciam de seus "empregos", pois lhes proporcionariam melhores condições de vida. O Sr. Caudomiro, entretanto, denuncia o que ocorreu e até hoje ocorre: a existência de trabalhadores nesta e nas fazendas vizinhas, em condições precárias, flagradas pelos órgãos fiscalizadores do Governo.

Tanto os integrantes das comunidades, quanto trabalhadores vindos de outros Estados, se ocupam nos parcos "empregos" oferecidos pelas empresas grileiras da região e não são raros os casos de serem submetidos a todo tipo de violência no regime de trabalho escravo.

É utilizando-se destes métodos nas relações de trabalho que as relações sociais de produção capitalistas se expandem pelos gerais do Oeste da Bahia, caracterizando o modelo de desenvolvimento ditado pelo agronegócio.

\subsubsection{Grilagens, conflitos e violências. As tentativas de expulsão dos posseiros}

Aparentemente, não há uma ordenação clara, uma linha nítida, nos conflitos que podem ser observados no meio rural brasileiro. Há disputas pela terra entre grandes empresas multinacionais e posseiros pobres; entre fazendeiros tradicionais e os mesmos posseiros; entre as próprias grandes empresas; entre arrendatários e índios. Não há luta unicamente entre ricos e pobres; há lutas entre ricos e ricos; entre pobres e pobres...

(MARTINS, 1981, p.109).

O conjunto de comunidades que ora me ocupo apresenta um importante grau de diferenciação socioeconômica. Na medida em que se desloca da comunidade de Couro de Porco para a de Cajueiro, nota-se que as casas tornam-se mais simples, preservando as condições de tempos passados. Em meados da década de 1990, a comunidade de Couro de Porco foi contemplada com casas-padrões, construídas em alvenaria pela Fundação Nacional de Saúde (FNS), com a finalidade de combater epidemias de doença de Chagas causadas pelos barbeiros que 
infestavam as casas construídas em taipa. Em toda a comunidade, restam apenas duas casas do padrão antigo, preservadas por seus donos, apesar de terem sido contemplados com a casa da FNS. Da comunidade de Bebedouro, em diante, as casas melhoradas foram construídas a partir de iniciativas dos próprios moradores e, conforme se aproxima do Cajueiro, tornam-se mais frequentes as moradias do padrão antigo, as quais podem ser representadas pela última casa da última comunidade, Cajueiro, com paredes de pau a pique e cobertura de palha.

A diferenciação possivelmente se explique pelos seguintes fatores: as três comunidades situam-se mais próximas da área em que a empresa Planta 7 expande-se e, por isto, são submetidas a conflitos mais intensos, constantes ameaças, maior instabilidade, culminando em maior migração; a ocupação é menos densa em relação à comunidade de Couro de Porco; parte maior de seus integrantes assalariam-se, quer seja nas empresas grileiras do entorno ou noutras mais afastadas, e estes fatores dificultam a organização para a resistência; os criatórios, atividade que aufere renda complementar à unidade de produção, são menos praticados em relação à Couro de Porco, e isto deve ter relação com o assalariamento, pois, dificulta a dedicação que requer os criatórios.

Aqui pra cima já deu tiro ali no rumo daquela casa de Zequinha ali, onde que nós tava, teve um tiroteio aí que os povo que vinha não tava sabendo, os posseiros, aí agora foi passando, eles pegou uns ainda, prendeu lá em Correntina, precisou botar devogado para tirar... aí agora lá em Raimundo Prudêncio no Bebedor, teve oto tiroteio que eles rancou os poste lá, umas madeira de Remundo, rancou botou fogo, queimou e deu uns tiro pra lá ainda, aí em nóis, eles passava armado... é pistolero da Planta 7, levou véi Zequinha, levou Silva, tudo preso daí pra lá, aí quando dei fé Raimundo Prudencio chegou em um berreiro mode o filho que tinha ido preso, o véi morava ali no Bebedor, mode isso o véi desgostou... eles queria dá uns contra vapor no véi, o véi ói, vocês é que sabe, daí pra lá vocês pode me bater, o véi tava veim, né? Eles deixou o véi. Agora em Silva eles ainda dero uns contra vapor. Silva era novo, né? ...eles tava fazendo a campanha deles, né? Na estrada mode ninguém passar... pistoleiros que tava no piso de Bastião, aí agora que Bastião tava querendo entrar nas terra aí, e o véi Manel falou que o sangue podia dá no joelho, mas não entrava. O menino é vinha de mota, fecharo. Pensaro que ia parar eles. Fechou o véi Zequinha e o menino. Tinham os gado dele, que nem eu mostrei a cerca ali, vinha para oiá o gado, botar sal pros gado, era assim. Aí agora, Manel, filho de comade Tereza aí vinha mais a muié pa ir pa firma. Ele é ia. Que quando deu fé, toc. E ele botou a mota aqui dento do mato aqui, e eles metero fogo por riba, pá! Atirano e manel, ó, mais a mulé e o menino, correro. E eles pegou a moto. E a moto era do Gasolina. Aí agora Gasolina trabaiava aí, né? Era gerente da empesa aí, no oto dia que nós cheguemo lá pa arrumá o devogado pa soltar o véi Zequinha e Silva, aí o Gasolina chegou também e entrou, o devogado rancou a mota dele de lá. Tirou da delegacia. Foi um rolo! Aí quando pensou que não, a cercona (José Florêncio dos Santos, 63 anos, morador da comunidade de Passaroto, trabalho de campo realizado em janeiro de 2012). 
O quadro de violência tem gerado um duradouro estado de instabilidade, resultando em alto índice de migração. Os conflitos, que o Sr. José se refere, ocorreram a partir de 2006, quando a empresa foi favorecida por uma liminar emitida pelo juiz da Comarca de Correntina, determinando como divisa de "sua propriedade" a estrada que interliga as comunidades, passando imediatamente às portas das moradias. A partir disso, a investida dos pistoleiros se intensificou e parte significativa das famílias, 15 das 50 , deixou suas posses. Dos 56 alunos que haviam matriculados na escola local, atualmente restam apenas 30 , conforme relatos de interlocutores da própria comunidade.

Este desaquietamento abalou o regime de posse da terra pelos moradores das comunidades. Muitos deles, em situação de desespero e por desinformação, sem saber se trinta metros é trinta hectares, e se trinta hectares é trinta mil hectares. Eles não têm conhecimento, então eles não venderam a terra, eles deram a terra! Praticamente abandonaram suas terras, entregando-as à cobiça de grileiros menores que se somam à Planta 7 , formando um complexo emaranhado, pois os referidos grileiros menores, denominados na ação discriminatória, por aventureiros, "compraram" documentos de transferências possessória de pequenas áreas dos antigos posseiros das comunidades, $20,30 \mathrm{ha}$, e, a partir desses, fabricaram muitos outros documentos nos cartórios de Posse (GO), laciara (GO) e Guarani (GO), com áreas variando entre $300,500,1.000,5.000$ ha (CDA, 2009). Certamente, não há lastro territorial para tanto documento e a confusão instala-se, na medida em que esses grileiros querem fazer picadas ou cercar "suas" áreas. A este emaranhado, soma-se a grileira maior, a Planta 7 , a qual, sempre que um aventureiro começa uma picada ou constrói cerca, aciona seus pistoleiros para barrá-la violentamente ou desfazer o serviço e, concomitante a isto, leva a causa para o judiciário de Correntina, que, invariavelmente, tem favorecido à grileira maior. Os aventureiros não desistiram e continuaram investindo nas "suas terras" e recorrendo às decisões judiciais.

A partir do desaquietamento das comunidades pela Planta 7 e pelos grileiros de áreas menores, o regime de posse foi conturbado, concomitante ao das soltas, e o Sr. Claudomiro, importante usuário delas, em uma audiência com o juiz, externa sua indignação: 
eu dexei bem claro lá na audiência, que esses que comprou as terras dessas pessoas que não conhece os direitos que eles têm, projudica eles e os outros. Não vendeu as terras, foi alesados por esses tipos de pessoas. Que esses coitado não sabe se a terra... se trinta metros é trinta hectares, e se trinta hectares é trinta mil hectares. Eles não têm conhecimento, então eles não vendeu a terra, eles deram a terra! Deram a terra achando que vendeu ${ }^{256}$ e troxe problema pra comunidade porque, eles quer... eles vendeu trinta hectares e o cara está com mil hectares... com oitocentos hectares, tem condições disso aí? Então como é que é, que esse cara vai tirar mil hectares em um a área coletiva, fundo de pasto, que nóis vêm há mais de cem anos, o gado nosso e todas as fontes de rendas que nóis têm, dotô? E aí o senhor tá vendo o gado nosso comendo aí dotô, é a sobrevivência do gado nosso, do cavalo, de nós panhar uma lenha, de nóis panhar uma fruta, de nóis panhar umas... o piqui, buriti, a croadinha, o puçá, outras fruta... o cascudo. É nossa sobrevivência, tanto do nosso animal... (Sr. Claudomiro Pereira de Jesus, morador da comunidade de Couro de Porco, trabalho de campo realizado em janeiro de 2012).

Nas frentes de todas as comunidades, nas áreas de cerrados, o uso que se efetiva de modo mais intenso é o pecuário. Por haverem menos criadores nas comunidades de Passaroto e Cajueiro, as mesmas usam menos as áreas e também devido à situação de maior instabilidade que enfrentam, as "vendem". Isto abala o regime de criatório solto, pois os aventureiros constroem cercas, as quais a Planta 7 derruba e, quando não, os criadores de Couro de Porco ou das demais, reclamam, tal como demonstra o relato anterior do Sr. Claudomiro. Para os geraizeiros, os usos que fazem das áreas de cerrados são de fundamental importância para garantir o sustento familiar e a posse da terra para todos. No entanto, aqueles que "vendem" agem em desacordo com o interesse da comunidade e, desta forma, delineia-se o rol de contradições que compõe o processo de luta e resistência, embora, de forma até surpreendente, quando se envolvem em eventos que ameaçam a sua desterritorialização total, a maioria faz-se presente e disposta à incondicional defesa de sua porção do território. Dentre os vários eventos em que esta afirmação foi posta à prova, cito um ocorrido em finais da década de 1990, quando a empresa ousou construir uma cerca seguindo o picadão feito pelas comunidades no início da década de $1970^{257}$. Apesar dos seguidos pedidos da comunidade para a não

\footnotetext{
${ }^{256}$ Os chamados aventureiros se intrometem nas comunidades, na maioria dos casos, mediados por membros de uma família de ex-moradores. Estes, atualmente residem na cidade de Posse (GO) e, por conhecer bem as pessoas, em grande maioria analfabetas, e o respectivo território, as coagem a concederem a eles procurações, Ihes conferindo poderes a cometer todo tipo de fraude envolvendo as antigas posses dos membros das comunidades como um todo, mas principalmente nas comunidades de Bebedouro, Passaroto e Cajueiro, cujas áreas de cerrados à frente são costumeiramente usadas principalmente pelos criadores, em maioria, da comunidade de Couro de Porco, mas também por alguns deles.

257 No decorrer de muitas demandas judiciais, as comunidades tomaram conhecimento dos documentos fraudulentos da empresa, não mais restando dúvidas de que se trata de grilo e, por isto, tal como a empresa nunca aceitou a comunidade fazer benfeitorias acima do picadão, a comunidade também, na expectativa de conseguir a necessária expansão territorial, após grande crescimento
} 
continuidade do serviço, a empresa prosseguiu e concluiu a cerca com extensão de $1.800 \mathrm{~m}$. Logo em seguida, a comunidade se organizou, reunindo-se em grande número, e arrancou todas as estacas, ateou fogo nelas e cortou todo arame em pequenos pedaços.

Logo após esta ação, o Sr. Claudomiro, Vice-Presidente da associação da comunidade à época, recebeu a ameaçadora "visita" de pistoleiros em sua casa, conforme relato:

Chegou na minha porta aí e falou assim, ó, vocês derrubou a cerca lá em cima, igual vocês falou. Vocês derrubou a cerca lá em cima. Agora eu vou te avisar aqui Mirim (Sr. Claudomiro). Você mais seus amigo, vocês não vai lá não. Porque vocês derrubou lá, a cerca lá, ficou derrubada, mas se a firma mandar nós matar, nós mata. Se ela mandar não é para voltar um, não vai voltar um lá.

A esta ameaça, assim respondeu o Sr. Claudomiro:

Aí eu fui reunir pros menino, tinha uma base de uns 8 home aí. Vocês ta ouvindo, os menino? Eles falou, tá. Posso falar também Sr. é de Hernande. Posso falar também? Eles falou: pode. O Sr. tá no seu direito. Pois é, eles dentro de meu... nem do lado de fora, uns ficou, e ele tava dento de minha propriedade. Daquela cerca pra dento. Eu falei e agora... falar a verdade. O Sr. é poliça mas o Sr. tem que ouvir a verdade. É, tratei ele como poliça. Ele era um policial. Era um cabo aposentado. Mas o mandato dele perante a justiça legal, não tava legal com a justiça. Ele tava trabalhano de pistoleiro, sabe? Ele tava expulso do... e aí o que é que aconteceu? Agora vamo falar pro Sr. a verdade. É um cidadão que não entende muito coisa, mas é bom falar para o Sr. a verdade. Nós estamo em cima do que é nosso. O senhor pode apreparar para matar muita gente. Porque de lá nós não abre a mão. Se você fazer mil vez, mil vez nós bota no chão. O Sr. ta bem armado aí, eu não tenho nem um canivete, mais vou te falar a verdade, o Sr. mata um, mas o Sr. não vai dar conta de matar tudo. E a coisa vai ser ruim. Nós vai botar tudo no chão. Não adianta o Sr. ganhar esse dinheiro mal ganhado, Sr. Hernande. Esse dinheiro ta sendo um dinheiro mal ganhado, e nóis tamo defendendo um interesse de uma comunidade de criança, aí eu falei: Não adianta o Sr. ganhar esse dinheiro mal ganhado porque isso vai te prejudicar. $\mathrm{O} S \mathrm{Sr}$. também tem família pra sobreviver. O Sr. ver como é que é doído. Se por exemplo eu impedisse seus filho de comer, falei muita coisa acertada assim no meu modo assim, simples. Aí os menino falou, é o que ele ta falano aí, o que o menino disse aí o que ele ta falando aí nós vamos se mobilizar e vamo, vamo se defender os interesse nosso. Aí eles tornaro voltar (Sr. Claudomiro Pereira de Jesus, morador da comunidade de Couro de Porco, trabalho de campo realizado em janeiro de 2012).

Conforme já referi, em 2006, um perito do INCRA esteve na área de conflito fazendo medições e, a partir destas, elaborou um laudo informando que o picadão delimitante das posses das comunidades seria a estrada que Ihes dão acesso, a qual passa imediatamente às portas das moradias.

Amparado neste laudo, o juiz da Comarca de Correntina na época, emitiu liminar de interdito proibitório favorável à empresa Planta 7 , referente à toda

populacional, também não aceita qualquer inovação na área por parte da empresa, até mesmo desobedecendo a decisões judiciais (em favor da empresa). 
extensão à frente das comunidades, onde se localizam as áreas de soltas, as pastagens cultivadas, e onde fazem os usos extrativistas de madeiras, frutos e outros.

Beneficiada por esta liminar, a empresa não tardou iniciar a construção de uma cerca, desde a extremidade oeste da área restante para as comunidades, seguindo margeando a estrada que passa imediatamente à frente das moradias em sentido leste, em alguns lotes ${ }^{258}$ ou quintais, atravessando até mesmo o terreiro das casas.

Muitas mensagens na forma de clamores desesperados das comunidades (aprovadas em assembleias) foram, por meio das lideranças, endereçadas aos representantes da empresa. A seguir, cito uma delas e o que se deu em função do não atendimento do pedido por parte da empresa, conforme relato.

\begin{abstract}
Mas só que eles conseguiu uma liminar pra fazer essa cerca da estrada. Aqui beradinha da estrada aí. Ali ta acima de Dona Anália ali mais ou menos uns 30, 50 metros pra cima. Que é onde nós barramo, né? Aí vinha a cerca quando foi um dia nóis tamo aí, mais ou menos uns três anos, três anos é, dois anos. Mais ou menos uns dois anos aí nós maicemos, quando pensa que não ta vindo um trator em cima da comundiade, vem quebrando, aí vem o avisador, falou, oi, lá no Passaroto já vem com a cerca. Vamo lá! E nóis mandemo pra lá. Cheguemo lá, tava os cara trabalhando. Quem é vocês, ta fazeno por orde de quem? É orde de Hernande, da empresa. Um senhor de Ailton, um rapaz assim, o nome dele é meio complicadin. Parece que era esse nome, rapaz. Aí um fortão alto, aí encostamo de junto dele falamo moço, vamos pedir vocês aqui que não faça isso que essa terra não é da empresa, essa terra é nossa. Aqui tem 150 família pra sobreviver dessa terra. Você toca uma cerca dessa aí e não tem aonde nós criar um cavalo, não tem aonde nós criar uma vaca pra dar leite a um filho, não tem aonde nós criar uma galinha, não tem aonde nós cria nada? Como é que nós vamo sobreviver disso aqui? Falaro, é, os menino, aí não é nóis. Nós tamo aqui é pra isso. Pra fazer a cerca. Vocês têm que reunir e procurar justiça. Porque do contrário não tem outra solução não. Aí voltemos. Nessas alturas já tava aqui mais nós professor da comunidade. Aí esses dois ano. E a associação junto aí mais a comunidade, organizemo, né? Falei o que é que nós vamos fazer, a cerca já vem aí? E nisso continuou a semana. Aí nós reunimos e falemos assim, vamo deixar fazer mais. Porque tano fazeno mais o serviço é mais bem feito. É mais bem feito e aí a gente vai ter como eles achá que tem home aqui dento. Aí eles falava é moço, o gerente sempre falava não, lá moço, nós pode cercar aquilo lá, ali só tem mulé. Lá quando a gente bate na porta corre todo mundo. Eles não vai com isso não, lá já foi o tempo. Vamo segurar aqui na justiça aqui, que lá nós garante. Os pistoleiros colocaro junto lá e botaro a máquina pra riba, dois trator, três trator, duas toyotas, colocaro uns 14 home, funcionário lá pra trabalhar. Era quase dia e noite. Quase dia e noite trabalhano. E vai, e vai, e vai e nós balançamo pra lá. Até eu falei uma conversinha que os menino... não esqueço disso, quano eu falo eles sorri. Eu falei os menino, vamo fazer uma advertência os cara? Lá do Passaroto. Os menino já tava de cabeça baixa. É aqui isso aqui vai dar coisa demais, vai dar coisa dificil. Mas vamo lá uns quatro ou cinco home vamo lá pedir pra ele, fazer uma dvertência lá comunitária. Pra vocês lá de Bebedouro, de Passaroto, faz de conta que
\end{abstract}

\footnotetext{
${ }^{258}$ Expressão usada geralmente para referir-se ao que restou àqueles que "venderam" a sua posse à frente, o que corresponde a área de solta, Ihes restando apenas a área da moradia e seu entorno imediato da estrada ao rio, o seu lote.
} 
nós avisemo em grupo. Pra quando nós entrar, entrar em grupo. Muito bem, vamo. Reuniu aí uns 8, nessa hora só foi 3. Muntemo numa moto e fomo lá, inté eu, e mais um rapaz e oto de... nós 3. Cheguemo lá, tava os home trabalhando, Falei quem é o chefe aí? Ele falou sou eu. O Sr. quer falar o que? Eu quero falar, pedir ao amigo, com carinho, o chefe era um senhor, era Hernande, mas ele não mandava, Hernande. Eles me passava um nome errado lá. Uma hora falava que era Gilson, e outro dia falava que era Milton, Ailton, era um nomin assim. Parece que tava... não queria descobrir o nome, mas a gente notava assim. Né? Aí ele falou: sou eu. O Sr. quer o que? Eu falei: eu quero que o Sr. pare a cerca. Esse é um pedido não é meu, dessa pessoa, isso é um pedido comunitário. De 150 família! Eu vou pedir ao Sr. pelo amor de Deus pare essa cerca, essa cerca, essa cerca, ta cheirando coisa mal, essa cerca. Não vou enganar procês, essa cerca num ta boa não. Ela ta, vocês ta ganhando muito dinheiro aí, mas nós não tamos arremediado com nada. Nós tamos só prejudicado. Vocês procura um dinheiro, esse dinheiro desse serviço aí não dá. Nem pra vocês e nem pra nós. Se vocês sorrir nós chora, então esse aí não vai dar certo. Fez boca de riso, mas nós não pode falar isso. Nós não pode parar isso aqui, que isso aqui é nosso sustento. Eu falei, bom, o recado eu dei, né? E até logo. Virei a moto e voltei. Cheguei, já me perguntou, da associação, né? E os menino aí junto, reuni a comunidade. Falei ó, quem subir agora, nós não vamos deixar descer não, é. $E$ É quem subir nós não pode deixar descer. Subiro, entraro por lá e tal, a estrada daqui. E nós fomos pra lá. Reunimos um trator com uma carreta, uma $F 4000$ aí, e um ônibus. Um ônibus que tem aí de puxar aluno. E umas trinta moto, ninguém nem sabe o tanto das moto. E muntemo aí, e as muié e as mininada e nós corremo pra lá. Quando cheguemo aqui no primeiro galho aqui que chama Sucuriu, né? O nome Sucuriu, o primeiro galho, cheguemo no Sucuriu encontremo os dois carro, do cara, pistoleiro, do Hernande, junto com o cabra que era o empreiteiro. Esse empreiteiro chamava inté, inté o nome dele, tava lembrando, empreiteiro das máquina. Paulo, senhor de Paulo. Empreiteiro com as máquinas de esteira. E um carro, carrão dele daquele... né? Não sei se era uma ranger, era um carro bem... importado. Aí, paremo o carro. Paremo o carro e falamo, meu amigo, nóis queria conversá com vocês um pouquim. É nóis não tem muito tempo não, que é que vocês qué? Dentro do carro. Falei, não, vocês têm tempo pra tudo, pra entrar dentro da terra nossa, porque é que não tem tempo pra falar com nóis. Vocês têm que ter tempo. Aquilo ele já foi tentando negoçar, nós abrimo aqui o carro a direita, já peguemo na mão deles, já rudiaro por aqui, fecharo, tomaro conta do carro, a gente cutucou os menino, os menino já foi lá furou os pneu tudo, os quatro, arriou tudo, né? Falou: agora é o tempo de nós falar: vai voltar com o trator, você tem que dar a orde daqui, vai voltar com o trator daqui até no final. Quantos quilometro tem de cerca? Tem uns $14 . .$. pois é tem que voltar daqui lá. A única chance!... Não, mas vocês tem que procurar a justiça! Não! A justiça aqui é Deus e nós agora! Não tem ota não, já procuremo demais! Nós avisemo vocês! Vocês disse que aqui não tinha home, agora chegou os home! Aí, é mais nós não faz isso! Pelo amor de Deus, mais nós, não faz isso desse jeito com nós não! Deus ta invitano, que nós não faz isso! Mas porque que o Sr. não invitou inhantes? Isso aqui é força mesmo de Deus! Nós não tamo aqui com arma... Ah não vou não! não vou não, não vou não, quano pensou que não um companheiro já tava com ele assim já, no jeito! Você vai ou como é que vai ser? Ah então pode deixar que nós vai! E um cara muntou, um cara pegou nele aqui já foi empurrano pra lá ele... entrar no carro, ele falou não, vamo mandar voltar tudo pra trás. E nós seguremo o mais perigoso ${ }^{259}$, falemo vamo lá pro salão. Vamo prender ele la dentro, trancar ele lá que, num pode, não tem pra onde ele vai não, senão vai, esse cabra vai matar nois aí. Vai mandar matar, não pode soltar ele não. Treuxemo ele e tranquemo ele aí dento. Aqui só sai com a orde da polícia, a polícia pegano ele aqui e levano. Cerrado ${ }^{260}$. Tem que vir o Cerrado. Só confia mais se vim o Cerrado que essas otas aí, nós num tamo confiano muito não. Que quano a gente vai dar uma denúncia lá, eles recebe de um jeito, quano eles chega aqui já é de oto, então esse negócio tem, esse leite aí ta errado. Aí tamo por ali, né? Aí com esse negócio... coloquemo pra lá. Coloquemo ele pra lá e, e

${ }^{259} \mathrm{O}$ pistoleiro chefe.

${ }^{260}$ A polícia do Cerrado. Não mais confiam na Polícia Militar. 
vai, e vai, e vai... e quando pensou que não o cara ${ }^{261}$, é moço, agora nós temo que quetar. Se não a coisa vai dar pior pra nós. A coisa vai ser bem pior. Aí o cara, os menino tocou ele na frente. Sobe irriba do trator! É, não! sobre irriba! Ou vamo botar fogo em tudo! E subiro irriba do trator e foi derrubar. Derrubou quase 15 quilômeto de cerca! Tudo zerada, com madeira tudo lapidada. É o próprio trator. Foi obrigado nóis fazer isso aí mesmo. Foi obrigado nóis fazer... colocar na história. Né? Na história. E aí derrubaro tudo, ia uns pra Correntina e otos lá. E nessas alturas, nossos amigos tudo acompanhou, né? Aí de perto. Inté quando num terminou o último poste, não, a turma não dismoreceu. Isso aí, daqui pra, quase 15 quilômeto, quinze, quatorze quilômeto, parecia Correntina a noite. Aluminado. Vê aquelas fogueirinha tudo acendida, da lenha. E aí agora eles embalançaro tudo! E falemo ó, e tem uma coisa: se você voltá aqui, nós vamo lá na sede. Vamo fazer o serviço bonito é na sede mesmo e daqui a pouco. Quando liberemo os trator os cara da sede também já se mandaro tudo. Num ficaro nenhum na sede. Terminou aí, chamaro nós em Correntina, prestamo nossos depoimento, fizemo as nossa defesa, eles procurou arrestituir os bens que foram né? Pra ver se recomperava (entrevista - trabalho de campo realizado em janeiro de 2010).

Este depoimento dá o tom do grau de tensão que, por vezes, atinge o conflito e do quanto as comunidades se dispõem a defender sua parcela do território. Possivelmente visando evitar a repetição de eventos como os descritos acima, o atual juiz da Comarca de Correntina, embasado na ação discriminatória administrativa realizada pela CDA em 2009, a qual comprova a grave fraude realizada pelas empresas do entorno das comunidades, tenha, ele mesmo, feito vistoria nas áreas conflituosas com vista a comprovar o que as empresas põem no papel e o que os advogados das partes dizem nas audiências. A postura deste juiz tem deixado as comunidades otimistas quanto aos passos futuros na conquista de suas frações do território.

\subsubsection{A contraditória intervenção do estado no processo de grilagem das terras públicas}

A seguir me proponho a demonstrar como a propriedade capitalista da terra é forjada no Oeste do Estado da Bahia.

Conforme tenho afirmado, o conflito iniciou-se a partir da apropriação fraudulenta de todas as terras que circundam as sedes das comunidades (incluindoas), as quais se constituem de antigos posseiros que há mais de cem anos territorializam-se naquelas paragens dos gerais.

O desassossego dessas comunidades iniciou-se, conforme relato citado, a partir do aparecimento súbito e brutal de equipes a serviços dos grileiros, com

${ }^{261}$ O chefe empreiteiro da cerca. 
maquinário pesado rumando sobre suas casas, ao fazer picadas demarcatórias de terras. Estas eram empresas silvicultoras atraídas para a região pela política dos governos militares (e dos que a eles se seguiram) de ocupação dos espaços vazios.

O conflito prolongou-se em uma ferrenha luta das comunidades contra as forças do capital, aparecendo-lhes nas figuras das grandes empresas capitalistas modernas e do Estado classista, o qual oferta incentivos fiscais e vários outros aos interventores na porções geraizeiras do território. Atenderam, desta forma, aos anseios da oligarquia agrária que, assim, edifica seu poder, quer seja diretamente no executivo ou no legislativo, com forte poder de pressão aos sucessivos governos ao longo da história do país (MARTINS, 1999, p.50). Da mesma forma, o poder judiciário tem feito "vistas grossas" ou favorecido diretamente em suas decisões as operações fraudulentas dos grileiros que se apropriam das terras públicas. Mas, lentamente, e com muita persistência, apesar das forças do poder público no sentido de impedir que a extrema opressão e perversidades ganhem visibilidade, a comunidade tem resistido e suas causas e seus clamores chegaram às instâncias federais do Ministério Público e dos direitos humanos. Isto tem ecoado na forma de audiências públicas, as quais têm contribuído para aumentar a visibilidade de suas causas.

aí nisso, teve uns companheiros aí que começou em cima, no lugar chamado Cajueiro, começou entrar numas área lá de uns posseiro, comprou a área dos posseiro, e aí lá também os cara tentou fazer uma cerca. No tentar fazer uma cerca, eles foi pra lá... Foi pra lá, pegou um cara num caminhão lá, dos...? Pegou o cara lá e moeu o cara no cacete e até de tiro. Deram um tiro que a bala passou de raspão, o cara saiu meio lá meio cá, e entrou de baixo de uma gameleira e se escapou. O rapaz chamava até Macaro, o que levou o tiro, sabe, chamava de Macaro, o moço. Aí nós já fiquemos mais alerto. Os home ta na intenção de matar mesmo. Que já fez o teste lá. E aí nós já têm que aprevenir, a coisa não vai ser fácil não. Eles só ameaçano que ia fazer a cerca, que ia descer nas casas que ia descer. E até um dia quando foi agora, ta tudo marcadin, quando foi agora, depois disso aí que teve várias audiência, né? fizemos encaminhamento pra Brasília, fomo pra Brasília, lá, nos direitos humanos, fizemos queixa nos direitos humanos, teve uma audiência aí, lá em Correntina, na Câmara Municipal, na Câmara lá, junto com os vereador, veio um desembargador, Sr. Gersino, Dr. Gersino, um presidente dos direitos humanos, esqueci o nome dele. Uma pessoa muito bem educada, falou muito bem a favor nosso lá. (...) na hora da audiência que teve lá, ele falou de segurar os direitos humanos nosso de uma maneira, de segurar a força econômica da empresa, dela não ter poder pra se movimentar nada. Aí eu como uma pessoa que não tinha, como uma pessoa que não tinha muito conhecimento achei aquilo interessante. Porque se ele segurasse essa administração dessa grilagem aí, os nossos direito tava seguro, porque tinha mais um, vamos dizer assim, mais uma força, da própria empresa fazer uma força de fazer um acordo, de fazer um direito de beneficiar as duas partes. Então eu achei que se ele segurasse o que ele falou lá na reunião lá, na persença de mais de 300 pessoas, né? Isso ta filmado, tem câmera, tem vídeo... (Sr. Claudomiro Pereira de Jesus, 
morador da comunidade de Couro de Porco, trabalho de campo realizado em janeiro de 2010).

Nos anos 2008 e 2009, em função do estágio em que chegou o conflito (conforme relatos de interlocutores), o Governo do Estado da Bahia, de modo contraditório, como se perceberá, não mais conseguindo resistir às pressões, decidiu fazer uma ação discriminatória administrativa na área em conflito. Embora, em meu entendimento, esta se caracterize mais como uma tentativa de inibir a repercussão que o conflito ganhou do que resolver 0 problema que atinge gravemente as comunidades.

Comprova-se esta afirmação a partir dos rumos que a ação discriminatória tomou. A documentação levantada pela equipe da CDA revela o seguinte: a "retificação" originária da matrícula-mãe, de número 2.280 - livro 3-C fls. 68 e 69 de 10/04/1945 - CRI de Santa Maria da Vitória (BA) é a que as empresas buscam lastro territorial nas frações camponesas do território ocupadas pelas comunidades. Mas, na verdade, a totalidade das "retificações" (grilos) realizadas a partir desta matrícula, e aprovadas pelo Juiz de Direito da Comarca de Correntina, Fernando de Souza Castro, nos autos do processo números 033/80 e 60/80 CDA-SEAGRI (2009) soma uma área de 419.490, assim constituídos:

\begin{abstract}
A margem da transcrição que abriga os quinhões, sem área nem confrontações ${ }^{262}$, já agora com área, confrontações e limites (AV1) com relação a Fazenda Buriti, no lugar Tamara, 217.000,00 ha (duzentos e dezessete mil hectares); (AV4), com relação a Fazenda Passagem Funda, no lugar Malhadinha, 150.000,00 ha (cento e cinquenta mil hectares); (AV5), com relação a Fazenda Passagem Funda, com área de $52.490,00$ ha (cinqüenta e dois mil e quatrocentos e noventa hectares). O total de área retificada nos três imóveis é de $419.490,00$ (quatrocentos e dezenove mil, quatrocentos e noventa hectares) (CDA-SEAGRI, 2009, fls. 10) (nota minha).
\end{abstract}

As referidas fazendas citadas no grilo (Buriti e Passagem Funda), de onde provêm as "retificações", localizam-se a cerca de 100 km de distância da área onde as empresas grileiras até os dias atuais procuram lastro territorial para o documento fraudado (entorno das comunidades), com isto potencializando ainda mais o absurdo do grilo.

\footnotetext{
${ }^{262}$ Nos registros contidos nos processos assim se transcreve a "matrícula-mãe" ( $n^{0}$ de ordem 2.280, Liv. 3-C de 10 de abril de 1945) dos quinhões dos herdeiros nos imóveis:

Na parte de terra com "água de rega" da Fazenda Passagem Funda, avaliada por CR $\$ 100,00$, nela CR\$ 31,00 (trinta e um cruzeiros);

Fazenda Buriti, no lugar Tamara avaliada por $C R \$ 70,00$ (setenta cruzeiros) a quantia de CR $\$ 25,50$; Na parte de terra de Fazenda Passagem Funda, no lugar Malhadinha, avaliada em CR $\$ 80,00$, somente $C R \$ 30,20$.
} 
Há que observar o seguinte: se as heranças tinham área suficiente para a permissão de "retificação" desta monta, qual seria a extensão das referidas fazendas? Isto seria inconcebível em outras situações e, nas localidades de Malhadinha e Tamarana, isto se pode dizer impossível, pois situam-se em uma região de antigo povoamento e ocupação comunitário camponês, inclusive, anexas (Malhadinha e Tamarana) à comunidade de Brejo Verde, por mim estudada nesta pesquisa. Trata-se, pois, de uma região retalhada por minifúndios localmente denominados tiras ou cordas de terra.

É bastante provável que seja este o motivo do seu grande deslocamento à procura de lastro territorial para o documento fraudado de modo mais fácil.

A autoria do grilo está em nome de 5 empresas do ramo silvicultor, as quais cito: Triflora - Triângulo Florestadora S/A, Reba - Reflorestamento da Bahia Ltda, Florestaminas - Florestamento de Minhas Gerais S/A, Planta 7 - Empreendimentos Rurais Ltda e Vale do Rio Grande Reflorestamento S/A.

Este grupo de empresas beneficiou-se do grilo referente à Fazenda Buriti, perfazendo a área de 217 mil hectares, e constituíram um condomínio o qual perdurou até 1984. Neste ano, o condomínio desmembrou-se, cabendo a cada condômino 43.400 hectares. Na documentação constante da discriminatória encontra-se a descrição perimétrica e das confrontações de quatro quinhões (referentes à Triflora, Reba, Planta 7 e Vale do Rio Grande) e, surpreendentemente, não consta do quinto condômino (a Florestaminas), nas referidas descrições, o que sugere a falta de condições que permitisse a mensuração/descrição. De oeste para leste, os quinhões situam-se na seguinte ordem, a partir da divisa com a Companhia de Integração Florestal (CIF): 1ํ. , Triflora - Triângulo Florestadora S/A; $2^{0}$, Reba Reflorestamento da Bahia Ltda; 3으. Planta 7 - Empreendimentos Rurais Ltda; 4으, Vale do Rio Grande Reflorestamento S/A.

Todas as transações cartoriais referentes a este condomínio eram realizadas pelo procurador das empresas, o Cel. Arione de Oliveira Castro, residente na capital mineira, Belo Horizonte. Outros casos de envolvimento de militares nestas transações fraudulentas são citados por interlocutores, tal como os seguintes relatos:

na época, estava sendo implantado o projeto de reflorestamento do oeste baiano, que era iniciativa da CNE (Comissão Nacional de Energia). Que era ligado a uma junta de militares. Na época ainda na vigência da ditadura militar, não é, do governo 
Figueiredo (Paulo Oisiovici, professor de história da rede estadual e municipal de Correntina. Trabalho de campo realizado em julho de 2008).

O Sr. Walmir, do STR de Barreiras, detalha:

nós temos uma região aqui que é do quilômetro 40 até o 90 (BR-242), que é no Luiz Eduardo. O senhor coronel Aroldo que veio lá do Paraná, para aquela banda do Mato Grosso, sei lá de que inferno é que veio, o nome dele era coronel Aroldo, que ele era do exército, coronel reformado. Da BR, dessa 242, que é essa pista que vai para Luiz Eduardo, daí para o rio, tudo era dele. Mas era medido, marcado de boca assim, aqui é meu e pronto. Ai daqueles que entrassem. Quando aí tem, mais... aí tinha muito posseiro. Tinha mais umas 100 pessoas, umas 100 famílias, nesse território. Que é Sanguera, Porto da Umburana, Mata do Puba, Porto Alegre, era as comunidadezinhas deles, né? Parecia um bocadinho dentro desse cerrado. E aí tinha um deputado federal na época chamado Domingo Leoneli, que mantia, dava força, outro rapaz aqui, que era revolucionário, chamava Jorge Figueiredo. Então que eles trouxera a comissão da terra naquelas épocas, e mantinha esse povo no lugar. Mais o coronel Aroldo, resistindo, atirando, querendo matar muitas pessoas (diretor do STR-Barreiras, trabalho de campo realizado em janeiro de 2010).

Após o desmembramento do condomínio, as empresas providenciaram a divisão de seus quinhões em áreas menores, com vistas à comercialização para interessados, alguns deles, a pô-las a produzir. No caso da Planta 7, esta divisão foi realizada em 1994, desdobrando-se em 17 glebas, sendo 16 com áreas entre 1.800 e 2.700 hectares e a última, a 17, na qual se encontra as comunidades de Couro de Porco, Bebedouro, Passaroto e Cajueiro, mede 8.681,00 hectares, conforme CDASEAGRI (2009, fls. 139).

Diferentemente das transações anteriores, o requerimento deste pedido de desmembramento foi feito pelo italiano que se apresenta como gerente geral da empresa, o Sr. Giuseppe Tricanato.

Embora a gleba 17 contenha $8.681,00$, e o grilo total praticado a partir da matrícula 2.280 abarque uma área de 419.490,00 ha, conforme documentação levantada pela própria CDA, surpreendentemente o órgão de terras do Governo da Bahia decidiu submeter à ação discriminatória apenas uma porção da gleba 17 (uma "ponta" do documento), qual seja, a área de 7.512 ha 50 a e 71 ca.

Sobre esse assunto, matéria do jornal A Tarde, de Salvador, traz o depoimento do assessor jurídico da Procuradoria da Justiça, advogado Vilobaldo Bastos de Magalhães, o qual fez minuciosa investigação sobre as grilagens de terras públicas localizadas nos municípios de Correntina, Cocos e Carinhanha, junto às Comarcas de Santa Maria da Vitória, Correntina e Carinhanha. Os resultados de suas investigações, inclusive, mostram maior potencialização dos absurdos das grilagens em relação aos apresentados pelos levantamentos da ação discriminatória 
administrativa realizada pela CDA. Sobre as fraudes absurdas envolvendo a totalidade dos grilos que o Estado da Bahia deveria desvendar e tomar as medidas cabíveis na lei, informa:

Alguns casos inacreditáveis de grilagens com o apoio das autoridades judiciais de Correntina e Carinhanha. Maria Florência Gonçalves, casada com Antônio José de Moura, herdara do espólio de Timóteo Florêncio de Barros frações ideais de terras no município de Correntina, assim descriminadas: a) a quantia equivalente a $\operatorname{Cr} \$ 31,00$ da avaliação de $\operatorname{Cr} \$ 100,00$ da Fazenda Passagem Funda; b) a quantia de $\operatorname{Cr} \$ 30,20$ na avaliação da Fazenda Passagem Funda no lugar conhecido como Malhadinha; c) a quantia de 25,50 na avaliação de $\operatorname{Cr} \$ 70,00$ da Fazenda Buritiy. Como era uma posse sem qualquer legalização, usava-se o sistema de avaliação em cruzeiros, e as quantias insignificantes, de 1977 a 1980, mostram que praticamente nada representavam. Mas, pelo processo de retificação 33/80, a parte da Fazenda Passagem Funda, no valor de Cr\$31,00 transformou-se em 43.615 hectares, todos registrados em livros nos cartórios. A parte da fazenda em Malhadinha, avaliada em $\mathrm{Cr} \$ 30,20$, passou a ter 136.000 hectares. A Parte da Fazenda Burity, avalida em Cr\$ 25,50 , cresceu para 217.000 hectares. Depois fizeram novas retificações, todas registradas em livros, embora legalmente nulas, e a parte herdada por Maria Florência passou a ter 599.105 hectares. Tudo foi requerido por condôminos de uma empresa com sede fora da Bahia. ${ }^{263}$

A matéria jornalística continua apresentando os extremos absurdos constatados na investigação do procurador Vilobaldo:

O advogado Vilobaldo de Magalhães cita, na sua denúncia à Justiça, dezenas de fraude e grilagem quase inacreditáveis praticados de modo grosseiro e sem qualquer respeito sequer às aparências. Uma fazenda foi vendida em pedaços e cada pedaço teve sua área depois retificada. A soma das áreas da fazenda, após retificação, atinge a cifra astronômica de 2.002 .672 hectares. ${ }^{264}$

Outros exemplos de grilagens, resultantes da investigação do representante da Procuradoria Geral da Justiça, citados na mesma matéria:

Processo $n^{0}$ 59/80 - Uma área de terra avaliada em $\operatorname{Cr} \$ 165,00$. Comprada a Camilo Pereira de Abreu e sua esposa, foi transformada em 85.580 hectares, registrados no Livro 3-B sob número 1.717.

Processo $n^{0}$ 29/80 - Uma área avaliada em $\operatorname{Cr} \$ 4.500,00$ cruzeiros da Fazenda Rio Corrente, foi transformada em 28.753 hectares.

Processo $n^{0} 35 / 80$ - Uma posse avaliada em 7.300 réis, na Fazenda Pedrinhas, foi reavaliada em $91.154,35$ hectares.

Processo $n^{0} 57 / 80$ - Uma posse avaliada em $\operatorname{Cr} \$ 100,00$ da Fazenda Cabeceira Grande, foi transformada em 31.277 hectares. $^{265}$

São dezenas de casos denunciados pelo assessor jurídico. E, interlocutores das comunidades do baixo vale do rio Arrojado, também denunciam uma grande quantidade de moradores que se envolveram em "vendas" de procurações a sujeitos

\footnotetext{
263 Jornal A Tarde, s/d, p.3.

${ }^{264}$ Idem.

${ }^{265}$ Ibidem.
} 
estranhos que apareciam nas comunidades interessados em negócios de terras. Inclusive, por conta disso, não são poucos aqueles que enfrentam dificuldades em conseguir aposentar-se, em função da ligação de seus nomes a latifúndios na região.

Para que não fique dúvida sobre o papel que o Estado tem desempenhado nesses processos fraudulentos, a viabilizar a apropriação capitalista da terra sobre as terras de trabalho camponesas dos geraizeiros, Vilobaldo Bastos de Magalhães aponta os sujeitos chaves, integrantes da máquina do Estado, que participam dos processos fraudulentos de apropriação ilícita e de modo grosseiro das terras públicas. Segundo ele,

Ninguém faz grilagem sem contar com o apoio de três cúmplices: o juiz da comarca, o promotor da comarca e o representante do Interba ${ }^{266}$. As acusações extraoficiais aos três, na Comarca de Correntina, são generalizadas, alguns chegando a dizer que receberam aviões, tratores e apartamentos de presente dos grileiros, geralmente empresas nacionais, sediadas fora da Bahia, que contavam também com financiamentos agrícolas dos maiores ${ }^{267}$.

Pelo que tudo indica, as fraudes nos processos de apropriação capitalista da terra devem cobrir a quase totalidade da região, que tradicionalmente se constituía de terras devolutas usadas pelos geraizeiros ao seu modo, corroborando com o que afirmam muitos interlocutores: em todos esses gerais tem marcas de posses ${ }^{268}$, quais sejam cemitérios, vestígios de casas, de roças formadas e outras. Embora em significativa porção já apagadas pelas arrasadoras correntes e trabalho de maquinário pesado do latifúndio que se apresenta em nova versão no que se conhece como agronegócio.

Couro de Porco e comunidades do entorno resistem. Tão logo o órgão de terras do governo baiano anunciou o início dos trabalhos de discriminação das terras griladas, os representantes da empresa Planta 7, que nunca haviam acenado com acordo, contando com a mediação dos técnicos do governo (CDA), propuseram acordo (detalhes na citação que segue) às três comunidades: Couro de Porco, Bebedouro e Passaroto (deixando Cajueiro de fora - considerando-a a mais fragilizada). A esta proposta, na presença da equipe executora da discriminatória, a assembleia rechaçou.

\footnotetext{
${ }^{266}$ Órgão de Terras do Estado da Bahia, extinto pela Lei 꾸 7.435, de 30 de dezembro de 1998. 267 Jornal A Tarde, s/d, p.3.

268 Relato de Iremar Barbosa de Araújo, ativista do MAB, diretor do SINDITEC e professor na comunidade de Couro de Porco.
} 
Após a deflagração do procedimento Discriminatório Administrativo Rural, advogados e representantes da empresa agroindustrial denominada Planta 7 Empreendimentos Rurais Ltda. - principal envolvida nos conflitos rurais fundiários em questão compareceram à sede da Comissão Especial, com a finalidade de apresentar proposta de acordo, com vistas a resolver o litígio, que perdura há tantos anos.

Pela proposta, a área objeto da contenda judicial, seria dividida da seguinte forma: 4.378 ha 36 a 00 ca iniciando da margem direita do rio Arrojado até a área da proposta na planta, da empresa litigante, ficaria para os posseiros de Arrojelândia, Bebedouro e Passaroto. Daí, até o local denominado picadão, perfazendo um total de 4.378 ha 36 a 00 ca ficaria sob o domínio da empresa supra mencionada.

Levada ao conhecimento e apreciação dos trabalhadores rurais em Assembléia Geral Extraordinária realizada na sede da Associação dos Pequenos Produtores Rurais de Arrojelândia, a proposta foi vigorosamente rejeitada pela maioria dos posseiros associados presentes (CDA-SEAGRI, 2009, fls. 011).

Esta proposta não mereceu sequer consideração pelos posseiros e pode ser vista como uma provocação da empresa, acuada pela possibilidade de sua fraude ganhar publicidade. Mas, ainda assim, a fez, na expectativa de que a comunidade pudesse aceitá-la e tê-la como "celeiro" de mão de obra nas suas proximidades, pois feita a conta do quanto caberia a cada família não chegaria a 30 ha, porção de terra abaixo do módulo rural (60 ha) e demais insuficiente para sustento de uma família, em função da ínfima porção agricultável em cada quinhão desses.

$\mathrm{Na}$ hipótese de aceitação dessa proposta, estaria, pois, satisfeito o projeto da empresa e do Governo para a comunidade - torná-la "celeiro" de mão de obra para - agronegócio nas condições de trabalho caracterizadas como escravidão temporária, tal como já vem submetendo-se parcela importantes das comunidades. Carlos Juliano Barros, a partir das discussões a respeito realizadas por Martins (1995) e Oliveira (1997), define escravidão temporária:

Em nossa opinião, a noção de "escravidão temporária" transmite com mais propriedade o cerne desse fenômeno: trata-se de uma relação de curta duração, de espaço de tempo determinado pela vontade do empregador, que define como e quando o empregado pode deixar o trabalho. Em outras palavras o conceito de "escravidão temporária" dá a devida ênfase ao tempo em que o empregador se julga no direito de controlar a vida e o corpo do seu empregado e não apenas a sua força de trabalho (BARROS, 2011, p.112).

O processo discriminatório foi deflagrado e sua investida se ateve à feitura de planta da área (parte da gleba 17), de memorial descritivo do perímetro da área discriminada com respectiva lista de coordenadas em Sistema Universal Transverso de Mercator (UTM), de portarias e editais, de ofícios expedidos às partes envolvidas, de relação de ocupantes da área em conflito, relação de presumíveis detentores de domínios, relação de detentores de domínios com títulos do Estado, relação de não 
habilitados e não cadastrados, ajuntamento de documentos cartoriais e outros apresentados pelos presumíveis detentores de domínios, ajuntamento de documentos apresentados por terceiros interessados e de ofício comunicando o encerramento da Comissão Especial (CDA-SEAGRI, 2009, fls. 002).

Além do especificado anteriormente pode-se afirmar que o centro de atuação da ação discriminatória administrativa situou-se nas disputas territoriais envolvendo a Empresa Planta 7 e os chamados aventureiros, cuja ação tem contribuído de modo significativo para aumentar a complexidade do conflito, pois disputam as frações territoriais camponesas com a empresa e com os antigos posseiros das comunidades. Dentre os antigos posseiros, também se nota os desentendimentos entre aqueles que fazem ou facilitam a transferência de posses para os aventureiros e os que defendem a ampliação das terras que possibilite a expansão territorial da comunidade, assegurando a fixação territorial às próximas gerações.

Encerrados os trabalhos, o presidente da Comissão Especial, nos Encaminhamentos Finais, indicou:

\footnotetext{
* Considerando a grandiosidade do conflito fundiário existente nestes imóveis rurais;

* Considerando que a função social da propriedade preconizada pela Constituição Federal não foi atendida, por aqueles que se dizem proprietários;

* Considerando as irregularidades apresentadas nas retificações cartoriais das áreas e dos registros dos imóveis;

* Considerando, finalmente, a temerosa possibilidade de explosão de violência entre os trabalhadores rurais e os pretensos proprietários na área litigiosa...

“...Recomendamos que a Coordenação de Desenvolvimento Agrário CDA, encaminhe este expediente à P.G.E (Procuradoria Geral do Estado), para que esta egrégia instituição adote os procedimentos necessários, no sentido de promover a anulação das decisões judiciais que proporcionaram aos cartórios imobiliários da Região Oeste, as retificações das áreas e dos registros absolutamente irregularese que, após a adoção e conclusão das medidas judiciais cabíveis, serem caracterizadas como terras devolutas, quando então serão arrecadadas e matriculadas como patrimônio do estado e destinadas a Regularização Fundiária, favoráveis aos posseiros, no caso dos lotes individuais, e à Associação de Pequenos Produtores de Arrojelândia, no caso da área coletiva, explorada em sistema de Fecho de Pasto" (CDA-SEAGRI, 2009, fls. 18-19).
}

Assinam estes "Encaminhamentos Finais", Estácio Marques Dourado (Procurador do Estado e Presidente da Comissão Especial), Maria Amélia Ferreira da Silva (Membro Técnico da Comissão Especial) e Catia Bonfim (Secretária da Comissão Especial) (CDA-SEAGRI, 2009, fls. 19).

Cabe destacar a ênfase dada pelo órgão do governo aos fatores conflito e explosão de violência. Tudo leva a crer que são estas ocorrências que motivam a intervenção do Estado na contenda. Ao contrário, não é movida pelo saque às terras 
públicas. Se fosse este o motivo, não haveria como não expandi-la para toda a área de comprovado grilo. Na região estudada, todas as investigações, dedicadas a verificar a situação jurídica das terras, não chegam a outra conclusão senão de utilização de métodos fraudulento (grilagem) no processo de apropriação.

Há que se ter em consideração que tal decisão representa uma grande vitória para os geraizeiros em luta, porém, ressalte-se este quinhão de terra não Ihes representa muito do ponto de vista de sua reprodução socioterritorial; pois 7.512 ha a ser dividido pelas 165 famílias atualmente residentes, afora as que migraram em função do desassossego do conflito e que prometem retornar a suas posses tão logo a situação se acalme, caberia a cada uma 45,5 ha, extensão de terra abaixo do módulo rural e, sendo assim, se faz inconstitucional ${ }^{269}$ a sua regularização.

Ainda sobre os encaminhamentos do órgão de terras do governo, por se fazer de difícil entendimento, cabe mencionar o seguinte: passados alguns dias do encerramento dos trabalhos, da publicação dos dois volumes da ação discriminatória administrativa rural, um grupo de mediadores sociais foi chamado para uma reunião com o referido Procurador do Estado que presidiu a Comissão Especial. Nesta reunião, o procurador propunha ao grupo a realização de um acordo com a empresa. A esta proposta, o grupo respondeu que não dispunha de qualquer autorização da comunidade para decidir em seu nome. Não satisfeito, o Procurador do Estado da Bahia marcou uma audiência com a presença do Juiz da Comarca de Correntina, com representantes da empresa Planta 7, e com lideranças das comunidades para que nesta buscassem um acordo entre a empresa grileira e as comunidades. Nesta audiência, a empresa manifestou-se disposta a ceder a gleba 17 inteira, 8.681,00 ha. Mas, sabendo antecipadamente da pauta da referida audiência, as lideranças das comunidades para lá já foram com a decisão dos seus representados de não fazer qualquer acordo com a empresa. E, sobre isto, assim relatou uma das lideranças:

o que eu acho horrível da história é que nóis estamos tratando de acordo com quem não é dono da terra. E acho que no momento a gente deve tratar de acordo com o Estado. Quem tem em mãos essas terras é o Estado e não a empresa. Então eu acho o seguinte: uma vez que as terras voltou para o Estado, é lógico, que é o Estado quem vai dizer melhor ou que vai fazer melhor com as terras... com essas áreas, mas eu falo pros meninos, olha Mirim, depois que o Estado regularizar a situação, que o juiz sentenciar, aí nóis vamos ter uma briga com o Estado. Porque as terras é do

${ }^{269}$ Conforme Artigo 16 da Lei n. 4.504, de 30 de novembro de 1964. 
Estado. Não é nossa ainda. Então aí é que nóis vamos tá então vendo um acordo com o Estado. Pra ver onde nós vamos, é, ter o nosso direito, até aonde vai o nosso direito na área. Porque hoje, no momento, é lógico, foi o próprio Estado que fez isso. Nem nóis nem a empresa, temos terra. Os nossos limites acabou. Então os nossos limites falta ser definido (Manoel Messias Souza dos Santos, morador da comunidade de Couro de Porco, trabalho de campo realizado em janeiro de 2012).

Continuando a desqualificação da empresa a pretender as terras, afirmou:

Nós temos pelo menos o direito de posse e a empresa tem direito de que? As benfeitorias como diz o juiz na audiência, foi depois do conflito. Até mesmo o desmatamento, o plantio de mandioca, foi depois do conflito. Então ela não tem nada, ela não tem nem posse. E nóis sim temos posse. Nóis sim somos moradores de verdade, tanto é que se trata de uma comunidade. Comunidade, não se faz comunidade tradicional ribeirinha, não se faz em vinte anos. Se faz em sessenta, setenta, oitenta, cem anos, se faz uma comunidade. Então é totalmente diferente (Manoel Messias Souza dos Santos, morador da comunidade de Couro de Porco, trabalho de campo realizado em janeiro de 2012).

No que diz respeito ao processo de constituição de uma comunidade, em uma resposta do Sr. Claudomiro (Mirim) a uma pergunta do Juiz, assim ele afirmou:

Ceis luita por esse picadão? Eu falei: nóis não luitamo por esse picadão, nóis luitamo
por nosso território. É provável que nossa área da associação, o limite tá muito na
frente do picadão. Agora lá é um picadão... é lá. O picadão eles grilaram e entraram.
Só que o nosso picadão vem nessa direção, ficou novecentos e quarenta hectares
que eles comeu......porquê? Porque é fundamental nóis herdar né? (falas inaudíveis).
Em seu Zé o senhor não se lembra que eu falei lá na audiência pro juiz que nóis
num... que a nossa vontade é ir no nosso... é adquirir o nosso território? Aonde nóis
caçava, nóis pescava, nóis fazia... ... Né seu Zé? Eu falei pra eles isso, seu Zé. O
senhor pode informar igualmente a eu, ou mais, que nóis era costumado colocar roça,
há cinquenta quilômetros da onde nóis mora em outra região, ou mais, né cumpade?
(Sr. Claudomiro Pereira de Jesus, morador da comunidade de Couro de Porco,
trabalho de campo realizado em janeiro de 2012).

Além de apontarem para a luta pela sua fração camponesa territorial tradicional, suas pautas ainda vão mais além. Reconhecidos pelo Estado como de direito à terra discriminada, discordam da proposta de concessão de direito de uso.

Neste sentido, pretendem pleitear, junto ao poder público, a concessão de domínio. Quanto ao fato de não haver leis na legislação baiana que legalizem este tipo de concessão, estão juntando-se ao movimento camponês de fundo de pasto, com vista a apresentar projetos de lei de iniciativa popular, dentre os quais, que contemplem o caso específico dos geraizeiros, pois já têm a consciência de que o Estado concede domínio a grileiros que não compram terra e nem são posseiros. Eles, sendo posseiros se acham portadores do direito em detrimento do grileiro. No entanto, não são portadores do poder econômico e político que detêm os grileiros. Por isso, o seu caminho é o da mobilização mostrando que têm o poder de exercer 
pressão, por meio da disposição para a luta que for necessária. E, como disse Messias, a luta agora é com o Estado.

A luta das comunidades do vale do rio Arrojado, com grande destaque para Couro de Porco e vizinhas, vem dando sua contribuição para que se venha à tona o processo fraudulento de apropriação das terras públicas, historicamente, pelas oligarquias agrárias e, após os governos militares, incluindo-se o grande capital que se autointitula moderno.

CONVITE I

Plantemos novas sementes, colhemos frutos maduros, rompamos todas as frentes e os obstáculos futuros.

Sejamos mais conscientes

e, juntos, onipotentes, prostremos todos os muros.

EUGÊNIO LYRA 14/04/1971 


\section{CONSIDERAÇÕES FINAIS}

Esta pesquisa significou um passo na aproximação dos problemas relacionados ao Oeste do Estado da Bahia, e se soma aos passos anteriores, nas pesquisas na graduação e no mestrado, no sentido de desvendar os processos sociais, concernentes a uma região mais ampla - a do vale do rio São Francisco.

O Oeste da Bahia se destaca no vale do rio São Francisco como uma região de relevante importância para a recarga hídrica do principal rio da bacia, o São Francisco. Isto se deve à predominância da cobertura vegetal dos cerrados associada à importante pluviosidade da região, sobretudo na porção oeste, nas proximidades da Serra Geral de Goiás. Esta região caracteriza-se também como de antiga ocupação camponesa, cuja marca relevante é o costumeiro uso difuso das áreas de maior importância para a recarga dos aquíferos, garantido a preservação da cobertura vegetal e, consequentemente, das condições propícias à preservação dos rios e da biodiversidade em geral.

A ocupação camponesa faz-se mais intensa nas áreas ribeirinhas dos baixos vales da região, onde praticam a agricultura para o autoconsumo e comercializam os excedentes. Nestas áreas também praticam a atividade pecuária combinando temporadas em que o gado permanece em pastagens formadas nas parcelas de uso exclusivo familiar, com outras em que é solto em áreas próximas e encobertas pela vegetação dos cerrados, as soltas, e, ainda, em outros períodos do ano, o rebanho é deslocado para áreas mais afastadas, na montante do rio, nos fechos de gerais.

Quanto à agricultura praticada pelos geraizeiros, é uma importante combinação entre 0 uso da terra das áreas ribeirinhas, tanto nas áreas imediatamente margeante aos rios, nas áreas de sítio ou regadio, quanto nas 
imediatamente mais elevadas, onde praticam a agricultura de sequeiro, nas terras de cultura.

Nas áreas de sítio, cabe destaque ao uso que fazem da água para a irrigação das roças que formam na estação seca, por meio de canais de irrigação, os regos (construídos e usados comunitariamente), cuja captação faz-se geralmente nas áreas de cabeceira, quer seja do rio e de seus afluentes, os galhos. Estes regos percorrem a vertente imediatamente mais elevada, irrigando as áreas ribeirinhas na estação seca. Este uso da terra e da água tem se destacado como de fundamental importância para a reprodução da unidade familiar camponesa e tem sido possível graças à preservação dos cerrados, tanto na montante do rio principal - o Arrojado - quanto de seus afluentes, os galhos. Isto se deve ao uso pecuário que fazem das áreas encobertas pelos cerrados sem desmatá-las, garantindo, pois, a oferta de água para os usos que realizam na jusante em áreas ribeirinhas.

Assim, os geraizeiros usufruem de duas colheitas anuais da quase totalidade dos produtos que costumeiramente cultivam. Do mesmo modo, o uso pecuário tem se destacado como importante fonte de renda, sem, entretanto, representar impactos significativos às riquezas naturais. Os usos pecuários das áreas de soltas e fechos de gerais são praticados em terras de uso comum. Em função da organização dos grupos de criadores, para viabilizar a compatibilização dos usos pecuário e agrícola da terra, isto tem representado um importante elo de consolidação dos laços comunitários interparentes, compadres, vizinhos, amigos. Do mesmo modo, esta combinação de usos das terras acessíveis às comunidades proporcionou, até a década de 1970, importante preservação das riquezas naturais, tais como rios caudalosos, abundância de peixes, frutos silvestres, mel de abelha, madeira e uma rica biodiversidade.

Nas áreas à montante dos rios, constatei que a ocupação camponesa dos gerais revela algumas particularidades em função dos engendramentos que estabeleceram para viabilizar a apropriação das riquezas naturais ali existentes. Nestas áreas, situadas no médio vale do rio Arrojado, as comunidades utilizam de estreita área ribeirinha, as veredas, por eles também chamadas de área de sítio. Ali cultivam uma grande variedade de produtos alimentícios: arroz, milho, feijão, mandioca, cana-de-açúcar, uma diversa quantidade de produto de hortaliças e frutas, os quais integram uma rica dieta dos geraizeiros. Ainda na margem do rio, 
instalam as moradias, geralmente cercadas no entorno, formando os quintais importantes áreas onde, aqueles que criam gado, o deixam em pequenas pastagens e/ou para a realização de cuidados.

Imediatamente à frente do enfileirado de casas, das moradias, do outro lado da estrada de acessos às comunidades ribeirinhas, encontram-se outras áreas empregadas nos criatórios, as mangas, constituídas de pastagens formadas, onde o gado permanece por períodos intercalados com aqueles em que ficam soltos, nas áreas de amplos cerrados próximos, as soltas.

Dada a insuficiência das terras tradicionalmente cultivadas para o sustento das famílias crescentes, os geraizeiros tanto do baixo quanto do médio vale do Arrojado, também costumeiramente fizeram uso de áreas ribeirinhas longínquas para a agricultura.

Nas últimas décadas, entretanto, estes usos foram proibidos pelos órgãos ambientais do Estado, pois, muitas dessas áreas transformaram-se em reservas naturais das empresas do agronegócio que expandem seu domínio preponderantemente nas chapadas, nos interflúvios.

Este outro uso da terra concentra-se nos altos gerais, e se expande de oeste para leste, entrando em choque com os tradicionais usos camponeses da terra que, de modo geral, expandiu-se de leste para oeste. O primeiro uso caracteriza-se pela degradação indiscriminada das riquezas naturais, eliminando a totalidade da biodiversidade, na medida em que desmatam integralmente a vegetação dos cerrados, compactam e envenenam os solos, desviam, fazem barramentos e poluem os cursos d'água; por meio de poços profundos, sugam a água dos aquíferos e não poupam sequer as áreas das nascentes dos rios, geralmente aterrando-as para o uso contínuo na monocultura.

Diferentemente do uso camponês da terra, que se destina à produção de alimentos voltados ao sustento das famílias e ao abastecimento das localidades próximas, o uso feito pelo agronegócio destina-se à produção de grãos em grande escala, geralmente destinados a abastecer mercados externos.

Já se observa com clareza os impactos provocados por esta outra racionalidade dos usos das riquezas naturais, na morte de muitos rios e riachos, os quais são assoreados - e quando ainda não foram, em suas águas praticamente não mais existe peixe, sendo impróprias para o consumo humano e animal. $\mathrm{O}$ tipo 
de uso pelo agronegócio tem se refletido negativamente também no regime dos rios, dos quais as comunidades da jusante usam as águas para suas atividades produtivas, comprometendo a sua produção e, também no regime do rio São Francisco, no qual, nas estações secas, em vários trechos do seu curso, o fluxo da água beira à interrupção.

Nos aspectos sociais, também este modelo de ocupação do Oeste da Bahia revela um quadro desolador, na medida em que expulsa/expropria a população que secularmente ocupa as terras geraizeiras, as quais são forçadas a migrarem para as cidades da região ou de outros estados, e, expropriadas das condições que possam adquirir diretamente da natureza os seus meios de vida, tornam-se, quando conseguem ocupação, assalariados nos empreendimentos empresariais, como bóias-frias ou em condições ainda mais degradante - como aqueles análogos aos escravos.

Cidades da região nas quais esse modelo de ocupação dos gerais se faz mais intenso, como Barreiras e Luis Eduardo Magalhães, destacam-se ao concentrar as mazelas, as quais são submetidos os geraizeiros, que tiveram as condições de reprodução socioterritorial impedidas pela violência da expansão do que se denomina de agricultura moderna, intensificada a partir da década de 1970.

Isto, porém, tem provocado a resistência dos camponeses tanto no âmbito da sua organização em sindicatos, apoiados por setores progressistas da Igreja Católica e do Partido Comunista, quanto em ferrenhos conflitos e confrontos envolvendo os interesses privatistas das terras, aliados ao aparelho estatal contra os camponeses geraizeiros.

Estes conflitos se generalizaram em toda a região do Oeste da Bahia. Mas, merece destaque, o que é considerado o principal, envolvendo um conjunto de comunidades estudadas, dentre elas a de Couro de Porco, no médio vale do rio Arrojado. Situadas nas áreas de grande pressão da expansão privatistas das terras, durante mais de trinta anos têm resistido e, inclusive nos últimos anos, conseguiram alguns avanços no sentido de forçar o Estado a reconhecer um absurdo grilo das terras que ocupam, assim como a de uma grande área no seu entorno. Possivelmente, esta conquista contribua para potencializar a mobilização tanto no âmbito das referidas comunidades quanto de outras que também se encontram em 
situações similares, não somente no vale do rio Arrojado, mas também no Oeste da Bahia, e, quiçá, em outros estados do país.

O estudo dos processos de territorialização e desterritorialização traz à tona o conflito que se trava entre os interesses de classes, as quais em disputas ferrenhas se territorializam, muitas vezes, como se nota no Oeste da Bahia/vale do rio Arrojado, simultaneamente e de modo sobreposto em uma mesma porção do território. Sendo este, conforme a assertiva de Oliveira, a base que comporta "a contínua luta da sociedade pela socialização da natureza" (OLIVEIRA, 2002, p.74), conflitando-se, pois, diferentes relações sociais de produção e constituindo-se um processo "simultaneamente de construção/destruição/manutenção/transformação" (OLIVEIRA, 2002, p.74). 


\section{BIBLIOGRAFIA}

ABBAGNANO, Nicola. Dicionário de Filosofia. São Paulo: Martins Fontes, 2000.

ABRE. O Reflorestamento no Oeste da Bahia, 1980.

AB'SÁBER, Aziz Nacib. Sertões e sertanejos: uma geografia humana sofrida. Estudos Avançados, São Paulo v. 13, nㅜ 36, 1999, p.7-59.

. Os domínios da natureza no Brasil: potencialidades paisagísticas. São Paulo: Ateliê Editorial, 2003.

ALAVI, Hanza. Las Clases Campesinas e Las Lealtades Primordiales. Barcelona: Editorial Anagrama, 1973.

ALCÂNTARA, D. M., GERMANI, G. I. As Comunidades de Fundo e Fecho de Pasto na Bahia: Luta na Terra e suas Espacializações. Revista de Geografia, Recife, Vol. 27, n.1, 2010, p. 40-56.

ALCÂNTARA, Denilson Moreira; GERMANI, Guiomar. Fundos de Pasto: espaços comunais em terras baianas. Anais do X Encontro de Geógrafos da América Latina - Universidade de São Paulo, 2005.

ALVES, Vicente Eudes Lemos. Mobilidade e Modernização nos Cerrados Piauienses: Formação Territorial no Império do Agronegócio. Tese (Doutorado em Geografia Humana) - Faculdade de Filosofia, Letras e Ciências Humanas da Universidade de São Paulo, 2006.

ANDRADE, Manoel Correia de. Tradição e Mudança: a organização do espaço rural e urbano na área de irrigação do Submédio São Francisco. Rio de Janeiro: Zahar, 1983.

- Construção de Grandes Represas e os Impactos Ecológicos e Sociais Provocados. Geonordeste, ano I, nº 1, 1984, p.1-11.

. A Questão do Território no Brasil. São Paulo: Hucitec, 2004.

. A terra e o homem no Nordeste: contribuição ao estudo da questão agrária no Nordeste. Recife: Editora Universitária da UFPE, 1998. 
ARAÚJO, F. S., MARTINS, F. R. e SHEPHERD, G. J., Variações Estruturais e Florísticas do Carrasco no Planalto da Ibiapaba, Estado do Ceará, in Revista Brasileira de Biologia, São Carlos, vol.59, n.4, nov. 1999.

ASSOCIAÇÃO BAIANA DE REFLORESTAMENTO-ABRE. O Reflorestamento no Oeste da Bahia, 1980.

BAIANO, Hélverton. História de Correntina. Goiânia: Ed. do autor, 2006.

BARBOSA, Altair Sales. Elementos para entender a transposição do rio São Francisco. Cadernos do CEAS, Salvador, n. 227, jul/set, 2007.

BARROS, Carlos Juliano. O sonho se faz a mão e sem permissão: escravidão temporária e reforma agrária no sudeste do Pará. Dissertação (Mestrado em Geografia Humana) - Faculdade de Filosofia, Letras e Ciências Humanas da Universidade de São Paulo, São Paulo, 2011.

BECKER, B. K. A Amazônia e a Política Ambiental Brasileira. In: SANTOS, M.; BECKER, B.K. (orgs) Território, territórios: ensaios sobre ordenamento territorial. Rio de Janeiro: Editora Lamparina, 2007.

BERNARDES, Nilo. As caatingas. Estudos Avançados, São Paulo, v. 13, n.36, 1999, p.7-59.

$\mathrm{BLOCH}$, Didier. As frutas amargas do velho Chico: irrigação e desenvolvimento no vale do São Francisco. São Paulo: Livros da Terra, 1996.

BOMBARDI, L. M. Campesinato, luta de classe e reforma agrária (a Lei de Revisão Agrária em São Paulo). Tese (Doutorado em Geografia Humana) Departamento de Geografia, Faculdade de Filosofia, Letras e Ciências Humanas da Universidade de São Paulo, 2005.

BOURDIEU, Pierre. O Desencantamento do mundo: estruturas econômicas e estruturas temporais. São Paulo: Ed. Perspectiva, 1979.

. O poder simbólico. Tradução de Fernando Tomaz. Rio de Janeiro: Bertand Brasil; Lisboa: Difel, 1989.

. Esboço de uma teoria da prática. In: ORTIZ, R. (org.). São Paulo: Ática, 1994.

BRANDÃO, Carlos Rodrigues. Partilha da Vida. São Paulo: Cabral Editora, 1995. 
. O que é educação. São Paulo: Brasiliense, 2003.

- Sobre a Tradicionalidade Rural que Há em Nós. In: OLIVEIRA, Ariovaldo Umbelino; MARQUES, Marta Inez Medeiros (orgs.) O Campo no Século XXI: território de vida, de luta e de construção da justiça social. São Paulo: Casa Amarela; Paz e Terra, 2004.

BRUMER, Anita. Previdência social rural e gênero. Sociologias. Porto Alegre, ano 4, n. 7, jan/jun 2002, p. 50-81.

CALABI, Donatella; INDOVINA, Francesco. Sobre o uso capitalista do território. In: Archivio di studi urbani e regionali. Veneza, anno IV, n. 2, junho 1973. (Mimeografado)

CAMERMAN, Cristiano. Terra de trabalho e terra de exploração. In: MATIAS M. LENZ, S.J. (coord). A Igreja e a propriedade da terra no Brasil. São Paulo: Edições Loyola, 1980.

CAMPOS, Nazareno José de. Terras Comunais em Santa Catarina. Florianópolis: FCC/EDUFSC, 1991. . Terras de Uso Comum no Brasil: Um Estudo de Suas Diferentes Formas. Tese (Doutorado em Geografia Humana) - Faculdade de Filosofia Letras e Ciências Humanas da Universidade de São Paulo, São Paulo, 2000.

CANDIDO, Antonio. Os parceiros do Rio Bonito: estudo sobre o caipira paulista e a transformação dos seus meios de vida. São Paulo: Duas Cidades; Ed. 34, 2001.

CARVALHO, Franklin Plesmann de. Fundo de Pasto: organização política e território. Dissertação (Mestrado). Faculdade de Filosofia e Ciências Humanas da Universidade Federal da Bahia, 2008.

CAPPIO, Luiz Flávio; MARTINS, Adriano; KIRCHNER, Renato (orgs.). Rio São Francisco: uma caminhada entre vida e morte. Petrópolis: vozes, 1995.

CASTRO, Osório Alves de. Porto Calendário. São Paulo: Edições Símbolo, s/d.

CEAS. A Luta do STR de Santa Maria da Vitória e Coribe. Cadernos do CEAS, Salvador, n. 98. jul/ago, 1985.

CHANG, M. Y. Faxinais no Paraná. Geografia. Londrina. v. 3, 1985/1986, p. 84-103. 
CHAYANOV, Alexander V. La organización de la unidad econômica campesina. Buenos Aires: Ediciones Nueva Visión, 1974. , Sobre a teoria dos sistemas econômicos não capitalistas. In: GRAZIANO da SILVA, J. STOLCKE, V. A Questão Agrária. São Paulo: Brasiliense, 1981. CODEVASF. Relatório 1985-1998. Brasília, 1989. , Inventário dos Projetos de Irrigação. Brasília, 1991. , Irrigar para Superar a Recessão. Petrolina, agosto de 1992. , A Codevasf na transformação do Semi-Árido São Franciscano 1993-2000. Brasília, 1993.

CÓDIGO FLORESTAL. Lei Federal n 4.771, de 1965.

COHN, Amélia. Crise Regional e Planejamento: O Processo de Criação da Sudene. São Paulo: Perspectiva, 1978.

DIEGUES, Antonio Carlos Santana. O mito da natureza intocada. São Paulo: Hucitec; NUPAUB; USP, 2001.

GOVERNO do Estado da Bahia, CDA-SEAGRI. Ação discriminatória administrativa rural, Gleba Arrojelândia, Município de Correntina, 2008/2009.

DUMONT, Louis. Ensaios sobre o individualismo: uma retrospectiva antropológica sobre a ideologia moderna. Lisboa: Don Quixote, 1992.

ECO, Humberto. Como se faz uma tese. São Paulo: Perspectiva, 2003.

ENGELS, Friedrich. A Origem da Família da Propriedade Privada e do Estado. In: Obras Escolhidas, Tomo 3. São Paulo: Alfa-Omega, 1987.

ESTADO DA BAHIA. Capítulo 03, art. 184, janeiro de 1999. Dispõe sobre a política agrícola, fundiária e da reforma agrária.

ETGES, Virgínia Elizabeta. Sujeição e Resistência: os camponeses gaúchos e a indústria do fumo Tese (Doutorado em Geografia Humana) - Departamento de Geografia, Faculdade de Filosofia, Letras e Ciências Humanas da Universidade de São Paulo, 1989. 
FERNANDES, Bernardo Mançano. M.S.T.: Movimento dos Trabalhadores Rurais sem Terras: formação e territorialização em São Paulo. São Paulo: Hucitec, 1999.

FERRARO JR., Luiz Antonio. Entre a invenção da tradição e a imaginação da sociedade sustentável: estudo de caso dos fundos de pasto na Bahia. Tese (Doutorado). Centro de Desenvolvimento Sustentável, Universidade de Brasília, Brasília, 2008.

FERRARO, JR., Luiz Antônio; BURSZTIN, Marcel. Das Sesmarias à Resistência ao Cercamento: razões históricas dos Fundos de Pasto. Caderno $\mathrm{CRH}$, Salvador, vol. 23, n. 59, p. 385-400, mai/ago, 2010.

FERREIRA, Aurélio Buarque de Holanda. Novo Aurélio Século XXI: o dicionário da língua portuguesa. Rio de Janeiro: Nova Fronteira, 1999.

FONSECA, Gondin da. Os Gorilas, o Povo e a Reforma Agrária: Manifestos dos Bispos do Brasil. São Paulo: Fulgor, 1963.

FOUREZ, Gerard. A Construção das ciências: introdução à filosofia e à ética das ciências. Tradução de Luiz Paulo Rouanet. São Paulo: Unesp, 1995.

FREITAS, Antonio Fernando Guerreiro de. Oeste da Bahia: Formação Histórico Cultural. Cadernos do CEAS, Salvador, n.181, mai/jun, 1997.

. Oeste da Bahia: Formação Histórico Cultural (Segunda Parte). Cadernos do CEAS, Salvador, n.182, mai/jun, 1999.

GARCEZ, Angelina Nobre Rolin; MACHADO, Hernano Augusto. Leis de Terras do Estado da Bahia. Secretaria de Agricultura-SEAGRI, Coordenação de Desenvolvimento Agrário - CDA, Associação para o Desenvolvimento da Agronomia - DESAGRO, Faculdade Ruy Barbosa - FBR, Salvador, 2001.

GARCIA Jr., Afrânio Raul. Terra de Trabalho: trabalho familiar de pequenos produtores, Rio de Janeiro: Paz e Terra, 1983.

VEGA, GARCILADO de La. Formas de repartição da terra entre os Incas. In: BELLOTTO, Manoel Lelo e CORRÊA, Anna Maria Martinez. América Latina de colonização espanhola. São Paulo: Hucitec, 1991. 
GAUDEMAR, Jean Paul de. Mobilidade do trabalho e acumulação do capital. Lisboa: Estampa, 1977.

GIROTTO, Eduardo Donizeti. O processo de modernização / conservação do discurso regionalista, a transformação espacial e a destruição do patrimônio histórico espacial na cidade de Barra, Bahia. Relatório de Iniciação Científica - Departamento de Geografia da Faculdade de Filosofia da Universidade de São Paulo, São Paulo, 2004.

GONÇALVES, Carlos Walter Porto. Os (Des)Caminhos do meio ambiente. São Paulo: Editora Contexto, 1990.

, Geografia da Riqueza, Fome e Meio ambiente: pequena contribuição crítica ao atual modelo agrário/agrícola de uso dos recursos naturais. In. OLIVEIRA, Ariovaldo Umbelino; MARQUES, Marta Inez Medeiros (orgs.). $O$ Campo no Século XXI: território de vida, de luta e de construção da justiça social. São Paulo: Casa Amarela; Paz e Terra, 2004.

, O desafio ambiental. Rio de Janeiro: Record, 2004.

- As Minas e os Gerais: Breve Ensaio sobre Desenvolvimento e Sustentabilidade a partir da Geografia do Norte de Minas. In: LUZ, C.; DAYRELL, C. Cerrado e Desenvolvimento: Tradição e Atualidade. Montes Claros: Rede Cerrado, 2000.

GRAZIANO DA SILVA, José. O desenvolvimento do capitalismo no campo brasileiro e a reforma agrária. In: STÉDILEA. João Pedro et al. A questão agrária na década de 90. Porto Alegre: UFRGS, 2004.

GRUPO DE ESTUDOS AGRÁRIOS, A Questão Agrária na Bahia, Salvador, 1980.

HAESBAERT DA COSTA, Rogério. "Gaúcho" no Nordeste: Modernidade, desterritorialização e identidade. Tese (Doutorado em Geografia Humana) Faculdade de Filosofia, Letras e Ciências Humanas da Universidade de São Paulo, 1995.

. Concepções de Território para entender a desterritorialização. In: SANTOS, M. e BECKER, K. B. (orgs.) Território, territórios: ensaios sobre ordenamento territorial. Rio de Janeiro: Editora Lamparina, 2007. 
HEREDIA, Beatriz Maria Alásia de. A Moradia da Vida: Trabalho Familiar de Pequenos Produtores do Nordeste do Brasil. Rio de Janeiro: Paz e Terra, 1979.

HOBSBAWM, E. Formações econômicas Pré-capitalistas. Rio de Janeiro: Paz e Terra, 1991.

HUBERMAN, Leo. História da Riqueza do Homem. Rio de Janeiro: Guanabara, 1986.

IBGE. Diagnóstico da qualidade ambiental da bacia do rio São Francisco: subbacias do Oeste Baiano e Sobradinho/Primeira Divisão de Geociências do Nordeste. IBGE, Rio de Janeiro, 1994.

IOKOI, Zilda Márcia Grícoli. Igreja e Camponeses: teologia da libertação e movimentos sociais no campo - Brasil e Peru, 1964 - 1966. São Paulo: Hucitec, 1996.

JOSÉ, Emiliano. A Expansão da Fronteira Agrícola: a marcha para o Oeste do São Francisco. Cadernos do CEAS, Salvador, n. 74, jul/ago, 1981.

JULIÃO, Francisco. Que São Ligas Camponesas? Rio de Janeiro: Civilização Brasileira S.A, 1962.

KAUTSKY, K. A Questão Agrária. São Paulo: Proposta Editorial, 1980.

KLUCK, Erick Gabriel Jones. O trabalho vai para o brejo: mobilização, migração e colapso da modernização. Dissertação (Mestrado em Geografia Humana) Departamento de Geografia, Faculdade de Filosofia, Letras e Ciências Humanas da Universidade de São Paulo, 2011.

KRAYACHETE, Gabriel; COMEFORD, J. C.. A Nova Face Agrária do Oeste Baiano: Diversidade e Ambiguidades. Cadernos do CEAS, Salvador, n. 132, março/abril, 1991.

- Oeste Baiano: os movimentos sociais face ao novo cenário regional. Cadernos do CEAS, Salvador, n. 131, jan/fev, 1991.

KROPOTKIN, Piotr. O Estado e Seu Papel Histórico. São Paulo: Imaginária, 2000.

LEFEBVRE, Henri. A Revolução Urbana. Tradução de Sérgio Martins. Belo Horizonte: Ed. UFMG, 1999. 
, O direito à cidade. Tradução Rubens Eduardo Frias. São Paulo: Centauro, 2001.

LENIN, V. I. O Estado e a Revolução. A doutrina do marxismo sobre o Estado e as tarefas do proletariado na revolução. In. Obras Escolhidas. Tomo 2. São Paulo: Alfa Ômega,1980.

. Sobre o Estado. Conferência na Universidade de Sverdlov. (11.07.1919), In. Obras Escolhidas. Tomo 3. São Paulo: Alfa Ômega, 1980.

. O desenvolvimento do capitalismo na Rússia. São Paulo: Abril cultural, 1982.

LINS, Wilson. O Médio São Francisco. Uma sociedade de pastores e guerreiros. São Paulo: Nacional; Brasília: INL, Fundação Nacional Pró-Memória, 1983.

LISBOA NETO, Joaquim. Reforma agrária baiana começa em Angical. In: 0 Posseiro, ano VII, n. 62, set-1986, p.6.

LUXEMBURG, Rosa. A Acumulação do Capital: contribuição ao estudo econômico do imperialismo. São Paulo: Nova Cultural, 1988.

MACEDO, Jozé Noberto. Fazendas de Gado no Vale do São Francisco. Documento da vida rural $n^{0}$ 3. Rio de Janeiro: Ministério da Agricultura, 1952.

MARCOS, Valéria de. Comunidade sinsei (u)topia e territorialidade. Dissertação (Mestrado em Geografia Humana) - Departamento de Geografia, Faculdade de Filosofia, Letras e Ciências Humanas da Universidade de São Paulo, 1996.

MARQUES. Marta Inez de Medeiros. Modo de vida camponês sertanejo e sua territorialidade no tempo das grandes fazendas e nos dias de hoje em Ribeira-PB. Dissertação (Mestrado em Geografia Humana) - Departamento de Geografia, Faculdade de Filosofia, Letras e Ciências Humanas da Universidade de São Paulo, 1994.

. Geografia, movimentos sociais e teoria: o conceito de espaço rural em questão. Terra Livre, São Paulo, n 19, jul./dez. 2002, p.95-112.

- Lugar do Modo de Vida Tradicional na Modernidade. In: OLIVEIRA, Ariovaldo Umbelino e MARQUES, Marta Inez Medeiros (orgs.). O Campo no 
Século XXI: território de vida, de luta e de construção da justiça social. São Paulo: Casa Amarela; Paz e Terra, 2004.

MARTINS, José de Souza. Capitalismo e tradicionalismo: estudos sobre as contradições da sociedade agrária no Brasil. São Paulo: Pioneira, 1975.

- Terra de negócio e terra de trabalho. Contribuição para o Estudo da Questão Agrária no Brasil. Cadernos do CEAS, Salvador, mai/jun, 1980.

. Os camponeses e a política no Brasil. Petrópolis: Editora Vozes, 1983.

. A Reforma Agrária e os Limites da Democracia na "Nova República". São Paulo: Hucitec, 1986.

. Expropriação e Violência: a questão política no campo. São Paulo: Hucitec, 1991.

. O Poder do Atraso: Ensaio de Sociologia da História Lenta. São Paulo: Hucitec, 1994.

. O Cativeiro da Terra. São Paulo: Hucitec, 1996.

- Fronteira: a degradação do Outro nos confins do humano. São Paulo: Hucitec, 1997.

. O Poder do Atraso: Ensaio de Sociologia da História Lenta. São Paulo: Hucitec, 1999.

- A sociabilidade do Homem simples: cotidiano e história na modernidade anômala. São Paulo: Hucitec, 2000.

. A sociedade vista do abismo: novos estudos sobre a exclusão, pobreza e classes sociais. Petrópolis: Vozes, 2002.

MARX, K. Processo de trabalho e processo de produzir mais valia. In: O capital, Livro I, Vol. I, Terceira Parte, Rio de Janeiro: Ed. Civilização Brasileira, 1971. - Critica da Economia Política. In: O Capital, Livro Primeiro, Vol I, Rio de Janeiro: Ed. Civilização Brasileira, s/d.

. Salário, Preço e Lucro. São Paulo: Ed. Abril. 1974.

. O Capital: crítica da economia política. Vol. I, Livro primeiro, Tomo I. São Paulo: Nova Cultural, 1988. 
, Formações econômicas Pré-capitalistas. Rio de Janeiro: Paz e Terra, 1991.

MENEZES, S. S. M.; CRUZ, F. T.; MENASCHE, R. Queijo de Coalho e Queijo Artesanal Serrano: identidades de produtores e de consumidores associadas a atributos de qualidade. VIII Congresso Latinoamericano de Sociologia Rural, Porto de Galinhas, 2010.

MINISTÉRIO DA INTEGRAÇÃO NACIONAL. Projeto de Integração do Rio São Francisco com Bacias Hidrográficas do Nordeste Setentrional, Relatório de Impacto Ambiental, Brasília, julho de 2006.

MIRANDA, Avelino Fernandes de. Tradicionalismo e Modernização. Goiânia: Editora da UCG, 2000.

. A Época de Ouro do Corrente: tempos (re)construídos. Goiânia: UCG, 2002.

MORAES, Antonio Carlos Robert. Território: o que é? In: Orientação. São Paulo, Nov. 1985.

- Território e História no Brasil. São Paulo: Editora Hucitec / Annablume, 2002.

. Território, poder e justiça: comentários a partir da experiência brasileira. In: CRITSCH, Raquel; RICUPERO, Bernardo (orgs.). Força e Legitimidade: novas perspectivas? São Paulo: Humanitas, 2005.

. Nação e território: ideologias geográficas na formação histórica do Brasil. In: Fórum Fumos da Cidadania - Instituto Prometheus de Estudos Ambientais, Culturais e Políticos - Fundação Lima Maria Aguiar, Campos do Jordão, São Paulo, 2010.

MORAIS, Clodomir Santos. Antonio Lisboa de Morais: esboço histórico. In: $O$ Posseiro, ano IX, nํ․ 64, 1987, p.8.

MOURA, Margarida M. Os Herdeiros da Terra: Parentesco e Herança Numa Área Rural. São Paulo: Hucitec, 1978. . Camponeses. São Paulo: Ática,1988.

OLIVEIRA, A. Umbelino de. Renda da Terra Diferencial I, in Orientação, Instituto de Geografia, No. 6, USP, São Paulo, 1985. 
. Modo capitalista de produção e agricultura. São Paulo: Ática 1986.

. Espaço e Tempo: compreensão materialista dialética. In: SANTOS, M. (org.)

Novos Rumos da Geografia Brasileira. São Paulo: Hucitec, 1988.

. A geografia das lutas no campo. São Paulo: Contexto/Edusp, 1988.

. População e Território. In: XII Simpósio de História do Vale do Paraíba:

Migração no Vale do Paraíba (anais). São José dos Campos, 1994.

. Agricultura Camponesa no Brasil. São Paulo: Contexto, 1996.

- (prefácio). In: FERNANDES, Bernardo Mançano. MST: Formação e Territorialização. São Paulo: Hucitec, 1999.

- A Longa Marcha do Campesinato Brasileiro: Movimentos Sociais, Conflito e reforma Agrária. In Estudos Avançados, 15 (43), setembro/dezembro, 2001.

- A Geografia Agrária e as transformações territoriais recentes no campo brasileiro. In Novos Caminhos da Geografia. São Paulo: Contexto, 2002.

- Agricultura Brasileira: transformações recentes. In: ROSSI. Jurandyr L. Sanches (org). Geografia do Brasil. São Paulo: Edusp, 2003.

OLIVEIRA, Nelson. O Capitalismo no Oeste Baiano. Cadernos do CEAS, Salvador, n. 86, jul/ago, 1983.

- Investimento e Pauperização: números da miséria em sub-regiões da Bahia, Cadernos do CEAS, Salvador, n.176, jul/ago, 1998.

PAULINO, Eliane Tomiasi. Capitalismo rentista e luta pela terra: a fragilidade do parâmetro de renda monetária no estudo dos assentamentos rurais. Revista Nera, Presidente Prudente, ano 9, n. 8, jan/jun de 2006.

, Eliane Tomiasi e FABRINI, João Edmilson. (Orgs). Campesinato e Territórios em Disputa. São Paulo: Expressão Popular, 2008.

PIERSON, Donald. O Homem no Vale do São Francisco. Tomo I. Tradução, Prefácio e Maria Aparecida Madeira Kerberg. Rio de Janeiro: Ministério do Interior (SUVALE), 1972.

PIETRAFESA DE GODÓI, Emília. O trabalho da memória: cotidiano e história no sertão do Piauí. Campinas: Unicamp, 1999. 
PRADO JÚNIOR, Caio. A Questão Agrária. São Paulo: Brasiliense, 2007.

PROENÇA, Manoel Cavalcanti. Ribeira do São Francisco, Rio de Janeiro: Gráfica Lammert, 1944.

PROJETO NOVA CARTOGRAFIA SOCIAL DOS POVOS E COMUNIDADES TRADICIONAIS DO BRASIL FASCíCULO 2. Fundo de Pasto, Lago de Sobradinho, Bahia. Brasília, 2007.

PROUDHON, Pierre Joseph. Qué es La Propriedad?: Investigaciones sobre el principio del derecho e del gobierno. Libros dês Anarres: Buenos Aires, 2005.

RAFFESTIN, Claude. Por Uma Geografia do Poder. São Paulo: Ática, 1993.

RECLUS, Élisée. O Homem e a Terra: a Cultura e a Propriedade. Tradução de Plínio Augusto Coelho, São Paulo: Expressão e Arte;Imaginária, 2010.

. O Homem e a Terra: O Estado Moderno. Tradução de Plínio Augusto Coelho, São Paulo: Expressão e Arte; Imaginária, 2010.

REGO, Luiz Flores de Morais. O Vale do São Francisco. Rio de Janeiro: Livraria Acadêmica, 1935.

RIBEIRO DE SOUZA, Dilson. No Reino dos Tecnocratas. Brasília: Eixo, 1980.

RIZZI, Franco. A Internacional Comunista e a questão camponesa. In: História do Marxismo VI: o marxismo na época da terceira internacional: da internacional comunista de 1919 às frentes populares. São Paulo: Paz e Terra, 1985.

ROCHA, Geraldo. O Rio São Francisco: fator precípuo da existência do Brasil. São Paulo: Ed. Nacional; Brasília, CODEVASF, 1983.

ROVEDDER, Ana P. et. al. Análise da Composição Florística do Campo Nativo Afetado pelo Fenômeno da Arenização no Sudoeste do Rio Grande do Sul. In: R. bras. Agrociência, Pelotas, v. 11, n. 4, out-dez, 2005, p. 501-503.

SABOURIN, Eric \& MARINOZZI, Gabrio. Recomposição da agricultura familiar e coordenação dos produtores para a gestão de bens comuns no Nordeste brasileiro. Política e trabalho, $\mathrm{n}^{0}$ 17, set. 2001, p. 80-90.

SAMPAIO, Theodoro. O Rio São Francisco e a Chapada Diamantina. Salvador: Livraria Progresso Editora, 1955. 
SANTOS, Cirlene Jeane Santos e. Fundo de Pasto: tessitura da resistência, rupturas e permanências, no tempo-espaço desse modo de vida camponês. Tese (Doutorado em Geografia Humana) - Departamento de Geografia, Faculdade de Filosofia, Letras e Ciências Humanas da Universidade de São Paulo, 2010.

SANTOS, Milton. O Retorno do Território. In: SANTOS, M.; SOUZA, M. A. A.; SILVEIRA, M. L. (orgs.). Território, Globalização e Fragmentação. São Paulo: Hucitec, 1996.

. A Natureza do Espaço: Técnica, Tempo, Razão e Emoção. São Paulo: EDUSP, 2002.

. O dinheiro e o Território. In: SANTOS, M.; BECKER, B. K. (orgs.) Território, territórios: ensaios sobre ordenamento territorial. Rio de Janeiro: Editora Lamparina, 2007.

SCHIFFER, Sueli T. Ramos. Petrolina: Política e Crescimento Urbano, Dissertação (Mestrado em Geografia Humana) - Faculdade de Arquitetura e Urbanismo da Universidade de São Paulo, 1983.

SEI. Mudanças sociodemográficas recentes: Região Oeste. Salvador: SEI, 2000.

SHANIN, Teodor. Naturaleza y lógica de la economía campesina. Barcelona: Editorial Anagrama, 1976.

. La clase incómoda. Madrid: Alianza Editorial, 1979.

- Campesinos y sociedades campesinas. México: Fondo de Cultura Econômica, 1979

- La clase incómoda: sociología política do campesinado en una sociedad en desarrollo (Rusia 1910 - 1925). Madrid: Alianza Editorial, 1983.

SILVA, Lígia Osório. Terras Devolutas e Latifúndio. Campinas: Editora da Unicamp, 2008.

SINDICATO DOS TRABALHADORES RURAIS DE CORRRENTINA. O que é o Reflorestamento no Oeste Baiano. Correntina, s/d.

SOUSA SOBRINHO, José de. Submédio São Francisco: seus projetos e seu povo. Trabalho de Graduação Individual - Departamento de Geografia da 
Faculdade de Filosofia, Letras e Ciências Humanas da Universidade de São Paulo, 1999.

- Brejos da Barra-BA: comunidades camponesas no processo de desenvolvimento no Vale do São Francisco. Dissertação (Mestrado em Geografia Humana) - Faculdade de Filosofia, Letras e Ciências Humanas da Universidade de São Paulo, 2006.

SPÓSITO, Eliseu Savério. Geografia e Filosofia: contribuição para o ensino do pensamento Geográfico. São Paulo: Editora Unesp, 2004.

STR-CORRENTINA. O que é o Reflorestamento no Oeste Baiano. s/d. s/e

SUPERINTENDÊNCIA DE ESTUDOS ECONÔMICOS E SOCIAIS DA BAHIA. Mudanças Sócio Demográficas Recentes: Região Oeste. Salvador: SEI, 2000.

TAVARES DOS SANTOS, José Vicente. Colonos do Vinho: Estudo Sobre a Subordinação do Trabalho Camponês ao Capital. São Paulo: Hucitec, 1978.

TAVARES, Luis Almeida de. As formas de propriedade da terra nos Faxinais. In: III Simpósio Nacional de Geografia Agrária - II Simpósio Internacional de Geografia Agrária. Jornada Ariovaldo Umbelino de Oliveira - Presidente Prudente, 11 a 15 de novembro de 2005.

- Campesinato e os Faxinais do Paraná: as terras de uso comum. Tese (Doutorado em Geografia Humana) - Faculdade de Filosofia, Letras e Ciências Humanas da Universidade de São Paulo, 2008.

THOMPSON, E. P. Costumes em comum. São Paulo: Companhia da Letras, 1990. . Senhores e Caçadores: a origem da Lei Negra. São Paulo: Paz e Terra, 1997.

UNGER, Nancy Mangabeira. Da foz à Nascente: o recado do rio. São Paulo: Cortez; Campinas: Unicamp, 2001.

WOODCOK, George. História das idéias e movimentos anarquistas. São Paulo: L\&PM. Volume 1, 2002. 
WOORTMANN, Ellen F. Sitiantes e Roceiros: a produção camponesa num contexto de pecuarização. Dissertação de Mestrado em Antropologia na Universidade de Brasília. Brasília, 1981. . Herdeiros, Parentes e Compadres: colonos do sul e sitiantes do nordeste. São Paulo: Hucitec; Brasília: Edunb, 1995.

WOORTMANN, Ellen F. e WOORTMANN Klaas. O Trabalho da Terra: a lógica e a simbólica da lavoura camponesa. Brasília: Universidade de Brasília, 1997.

. O Saber Tradicional Camponês e Invenções. In. OLIVEIRA, Ariovaldo Umbelino e MARQUES, Marta Inez Medeiros (orgs.). O Campo no Século XXI: território de vida, de luta e de construção da justiça social. São Paulo: Casa Amarela; Paz e Terra, 2004.

WOORTMANN, Klaas. Com Parente Não se Neguceia. O Campesinato como Ordem Moral, Anuário Antropológico/87, Brasília, Universidade de Brasília, 1990, p. 11-73.

ZARUR, Jorge. A Bacia do Médio São Francisco (Uma Análise Regional). Rio Janeiro: IBGE, 1947. 


\section{SÍTIOS ACESSADOS:}

JORNAL NOVA FRONTEIRA, 10.06.2008.

http://www.jornalnovafronteira.com.br/LerArquivoNf.php?id=1537. Acesso em 21/02/2009. GEOCITIES

http://www.geocities.com/ptreview/17-sabourin-marinozzi.html. Acesso em 25/03/2010.

IRPAA (Instituto Regional da Pequena agricultura Apropriada)

http://www.irpaa.org/noticias/44/coordenador-do-cda-defende-fundos-de-pasto-na-caatinga. Acesso em 27.01.2009.

JICA. 50 Anos de Cooperação Brasil Japão.

http://www.jica.go.jp/brazil/portuguese/office/publications/pdf/50anos.pdf. Acesso em 21/02/2010.

\section{MINIDICIONÁRIO TUPI-GUARANI}

http://povodearuanda.wordpress.com/2007/12/03/mini-dicionario-tupi-guarani/. Acesso em $12 / 04 / 2012$.

REDE GLOBO DE TELEVISÃO, Programa Globo Rural, 2000, in: http://www.youtube.com/watch?v=UANmCWTBRFw. Acesso em 15/05/2009.

http://www.cppse.embrapa.br/lista_de_eventos/projeto-balde-cheio. Acesso em 16/03/2011. http://www.seagri.ba.gov.br/nota_tecnica_regiao_oeste.pdf. Acesso em 17/03/2011

SEAGRI-Secretaria da Agricultura, Irrigação e Reforma Agrária - Superintendência de Política do Agronegócio. http://www.seagri.ba.gov.br/nota_tecnica_regiao_oeste.pdf.. Acesso em 17/03/2011.

http://www.seagri.ba.gov.br/nota_tecnica_regiao_oeste.pdf. Acesso em 17/03/2011.

\section{JORNAIS ELETRÔNICOS:}

CÓDIGO CIVIL DOS ESTADOS UNIDOS DO BRASIL. Lei № 3.071, de 1ำ de janeiro de 1916.

http://www2.camara.gov.br/legin/fed/lei/1910-1919/lei-3071-1-janeiro-1916-397989-normapl.html. Acesso em 26/08/2012.

OLIVEIRA, 2008.

http://www2.fct.unesp.br/nera/artigodomes/2artigodomes_2008.pdf. Acesso em 02/09/2012. 
PREFEITURA MUNICIAPAL DE CORRENTINA:

http://www.correntina.ba.gov.br/admin/app_index.php?chave=065516d055102af3faeb0719d 737f7e4e4b9956a\&acao=exibir_composicao. Acesso em 06/05/2012.

MINISTÉRIO DO DESENVOLVIMENTO SOCIAL E COMBATE À FOME:

http://www.mds.gov.br/bolsafamilia. Acesso em 11/10/2012.

ARTIGO 231 CONSTITUIÇÃO DA REPUBLICA FEDERATIVA DO BRASIL 1988:

http://www.jusbrasil.com.br/legislacao/busca?q=ARTIGO+231+DA+CONSTITUI\%C3\%87\%C 3\%830+FEDERAL\&s=legislacao. Acesso em 26/06/2012.

CORREIO DE UBERLÂNDIA, 21/05/2008

http://www2.correiodeuberlandia.com.br/imprimirMateria. php?tid=23521\&pubDate=2006-1217. Acesso em 17/04/2012.

OESTE DA BAHIA, NOVO ELDORADO DA PECUÁRIA, agosto de 2009.

http://www.fazendaparedao.com.br/_images/publicacoes/Reportagem_Oeste_Baiano.pdf. Acesso em 17/04/2012.

COMISSÃO PASTORAL DA TERRA BAHIA.

http://www.cptba.org.br/joomla15/attachments/794_NOTA\%20PUBLICA\%20DOS\%20FECH OS\%20DE\%20PASTO.pdf. Publicado em 03/04/2012. Acesso em 04/04/2012.

JORNAL NOVA FRONTEIRA, 30/03/2012.

http://www.jornalnovafronteira.com.br/?p=MConteudo\&i=5810. Acesso em 30/03/2012.

JORNAL NOVA FRONTEIRA, 10.06.2008.

http://www.jornalnovafronteira.com.br/LerArquivoNf.php?id=1537. Acesso em 21/02/2009.

JORNAL NOVA FRONTEIRA, 31.03.2008,

http://www.jornalnovafronteira.com.br/LerArquivoNf.php?id=1370. Acesso em 21/02/2009.

JORNAL NOVA FRONTEIRA, 02/09/2009

http://www.jornalnovafronteira.com.br/LerArquivoNf.php?id=1708. Acesso em 21/02/2009.

JORNAL NOVA FRONTEIRA, 22/05/2007,

http://www.jornalnovafronteira.com.br/LerArquivoNf.php?id=597. Acesso em 21/02/2009.

JORNAL NOVA FRONTEIRA, 03/09/2009.

http://www.jornalnovafronteira.com.br/LerArquivoNf.php?id=2729. Acesso em 21/02/2009. 
JORNAL NOVA FRONTEIRA, 09/05/2008.

http://www.jornalnovafronteira.com.br/LerArquivoNf.php?id=1463. Acesso em 21/02/2009. JORNAL NOVA FRONTEIRA, 26/09/2008.

http://www.jornalnovafronteira.com.br/LerArquivoNf.php?id=1761. Acesso em 21/02/2009. JORNAL NOVA FRONTEIRA, 18/04/2007.

http://www.jornalnovafronteira.com.br/LerArquivoNf.php?id=495. Acesso em 21/02/2009. JORNAL NOVA FRONTEIRA, 30/11/2008.

http://www.jornalnovafronteira.com.br/LerArquivoNf.php?id=1927. Acesso em 21/02/2009. JORNAL NOVA FRONTEIRA, 21/11/2008.

http://www.jornalnovafronteira.com.br/LerArquivoNf.php?id=1735. Acesso em 21/02/2009. JORNAL NOVA FRONTEIRA, 09/06/2007.

http://www.jornalnovafronteira.com.br/LerArquivoNf.php?id=648. Acesso em 21/02/2009.

JORNAL IMPRESSO:

O POSSEIRO, Santa Maria da Vitória - BA, nํ40, 1983.

O POSSEIRO, Santa Maria da Vitória - BA,nํ62, 1986.

O POSSEIRO, Santa Maria da Vitória - BA, $n^{0}$ 64, 1987.

O POSSEIRO, Santa Maria da Vitória - BA,nํ 65, 1987.

JORNAL A TARDE, s/d 


\section{ANEXO}

http://www.novoeste.com/uploads/file/mat anexo 2.pdf (Acessado em 25.06.2012, às 21:00h) 


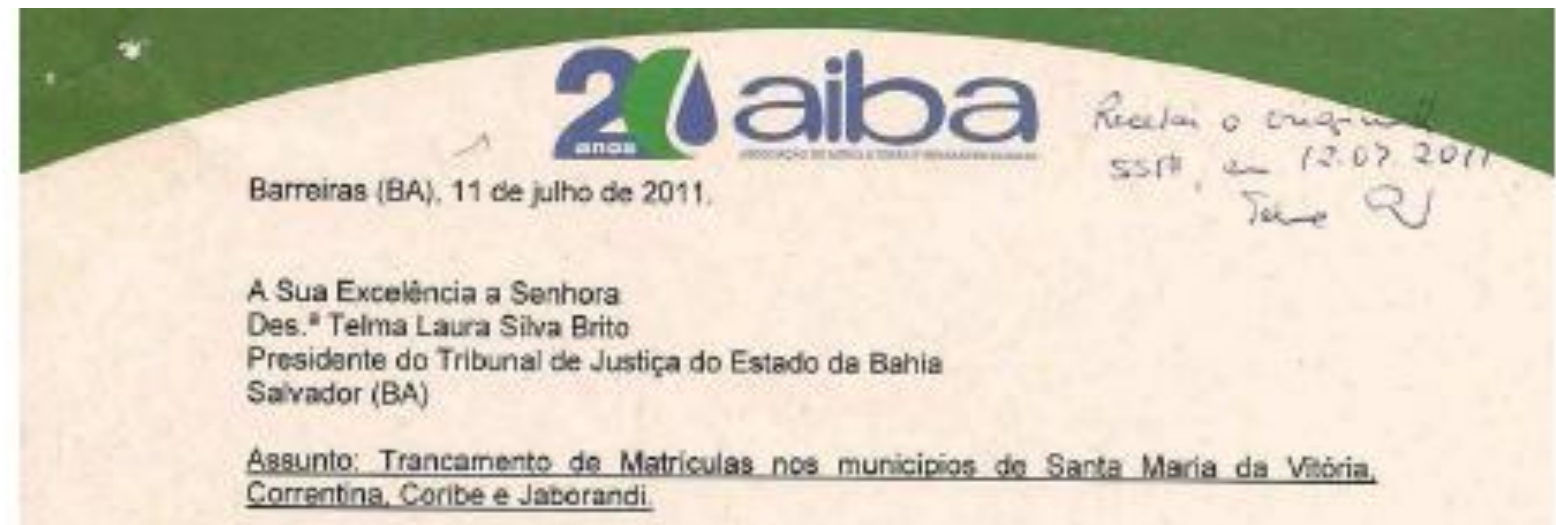

Senhora Presidente,

Em atença aos últimos acontecimentos envolvendo a titularidade de áreas rurais localizadas no Oaste Baiano, mais precisamerte nos Municipio de Santa Maria da Vitória, Correntina, Corbe e Jaborandi, a Associaçio dos Agricuitores e Irrigantes da Bahia, na concliça de Representente de vários dos produtores atingid os pela Ordem Judicial em referéncia, reporta-se a Vossa Exceléncia, no intuito de apresentar, mesmo que de forma breve e sintetizada, os fatos e decisces juridicas que tazem parte da realidade do caso, assim vejamos.

O inóvel rural que dá ensejo ao contito instaurado no Poder Judiciário do Estado da Bahia, tem sua ongem na MATRícULA $n^{\circ} 2280$, regiatrada no Cartb́rio de imóveis e Hipotecas da Comarca de Santa Maria da Vitória, Livro 3-c das Tranecriç̄es das Transmissōes, folhas $69 v e r s o$ o 69 , detado de 10 de abril de 1945 , entao denominada FAZENDA PASSAGEM FUNDA, de propriedade de TIMOTEO FLORÉNCIO de BARROS.

A referida propriedade, a exemplo da maioria dos registros (matriculas) dos imóveis daquela épcca. nà possuía a sua extensăo definida por alqueire. léguas, hectares, enfim, os limites das propriedades eram descritos por avaliaçoes, parte de terras, acidentes geograficos elou benfítorias (imóveis), porventura existantes sobre a area que compunha a extensão da propriedade.

Com o falecimento do Sr. TIMOTEO FLORÉNCIO de BARROS, a sua herdeira, Sra. MARIA FLORÊNCIO GONÇALVES, em conjunto com seu Esposo, ANTONIO JOSÉ DE MOURA, que entrăo davam contnuidade a posse e propriedade do imovel desde 1945, resolveram retificar a área da FAZENDA PASSAGEM FUNDA.

Para tanto, inauguraram perante o Poder Judiciário, aços de retificacóes de áreas. que foram analisadas, periciadas o Julgadas pela Juizo da Comerca de Correntina/Bahis, no ano de 1980, realizando a homologaçao dos amitee apresentados ao Poder Judiciário, conforme decisces judiciais praferidas pelo Julzo de Correntina por intermédio do Doutor Juiz FERNANDO DE SOUZA CASTRO, que mandou expedir os competentes mandados que foram devidamente cumpricos. awerbando as retificaçbes a margem da MATRICULA 2280.

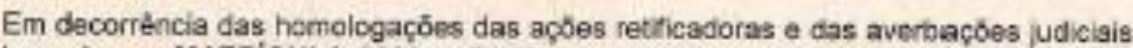
lancadas na MATRICULA 2280, a FAZENDA PSSAGEM FUNDA, pas sou a tor area de 598.000 ha (quinhentos e noverta e oito mil hectares), assim descritas na margem da MATRICULA: 1) AV-01-2280 (Área de 217.000ha); 2) AV-02-2280 (Área do 43.615ha); 3) AV-03-2280 (Área de 136.000ha); 4) AV-04-2280 (Área de 150.000ha) e 5) AV-05-2280 (Área de 52.490ha) 


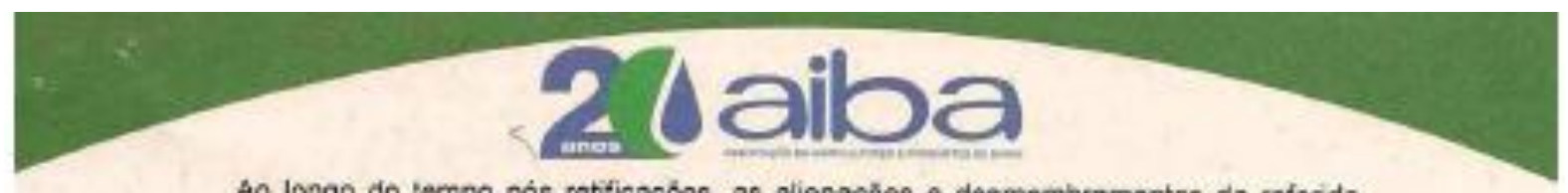

Ao longo do tempo pós ratificaçbes, as alienaçōes e desmembramentos da referide MATRICULA, deram origem a cutras tantas matriculas de áreas de terras de diversas cxtensbes, que invariaveimente também foram alienadas e desmembradas, numa cadeia sucessória de posse e dominio ininterruptos, gerando vultosos investimentos, financiamentos, produçdes, empregos, impcstos, enfim, uma enorme cadeis sccial de deveres e direitos, contribuindo de forma ampla com o desermuclvimento económico e social do Oeste da Bahia, regilaso hoje que se desponta como rejerência de crescimento nacional e internacional

Contudo, até o fim do ano de 2010, nâo havia quaicuer dívida sobre o histónco primitivo das áreas, havendo uma cadeis sucessória imaculada de aproximadamente 66 (sessenta e ses) ance (1945-2011). sem qualquar noticia de interferéncia ou problema sobre a origem das areas desmembradas da MATRICULA 2280.

Porèm em decorráncia da divisào entre os Municipios de Correntina e JaborandivBahia, os referidos processos de retificaçăo de áreas, foram transfenidos para a Camarca de Coribe/Bahia, ato realizado em 16 DE AGOSTO DE 2010, pelo entalo Juiz Substituto de Correntina, Doutor JOSE LUIS PESSOA CARDOSO.

Os autcs foram retombados pela Secretaria da Vara Civel da Comarca de CoribeiBahia, recebendo novos nimeros processuais, tendo sido encontrados os processos de números 0000227-19.2010.805.0068 (AV-03-2280VÁrea de 43.615ha). 0000228-04.2010.806.0068 (AV-03-2260iAres de 136.000ha) e 0000229. 86.2010.805.0068 (AV-04-2280/Área de 150.000ha)

Em 18 DE AGOSTO DE 2010, o Julzo de Coribei'Bahis, na pessoa do Juiz Substituto, Doutor EDUARDO PEDRO NOSTRANI SIMẢO, ap bs exatos 30 (trinta) anos, proferiu decisáo nos autos das Açōes de Retificaçōes da FAZENDA PASSAGEM FUNDA, dignando "(..,) trancamento da matricula de todos os imoveis registrados nesta Comarca, desmembrados da matricula 2.280, Livro 3-C. f. 68V/69.".

A referida decissäo, seria reiterada em 17 DE MAIO DE 2011, pelo Juiz de Direito, Doutor SÉRGIO LUIZ ROCHA PINHEIRO HEATHROW, primeiro momento em que os possuidores e proprietários das ăreas rurais dosmembradas da MATRICULA 2280, tiveram conhecimento dos fatos e dos atos processuais que envolviam suas propriedades, estando evidente e indubitável a existéncia da boa fe nos negćcios juridicos realizados pelos proprietérios e sucesscres das áreas originadas na matricula en comento.

Assim, compulsando os autos dos processos em refaréncia, verifica-se que em MAIOI1985, em decorréncia do recurso de apelaçăo apresentado pelo MiNISTÉRIO PÚBLICO do ESTADO, o Juiz de Direito, Doutor VALMIR SANTOS de OLIVEIRA. recebeu 08 recursce de apelaçás em seus respectivos autos, aplicando seus efeitos $\mathrm{e}$ dignando a expediçao de notificaçăo as oficial do registro de imóveis de Correntina. informando que aquele deveria abster-se de praticar quaisquer atos referente ao registrolmatricula da FAZENDA PASSAGEM FUNDA, ressalvando tratar-se de parte da referida propredacie.

Contudo, ao que constam os históricos dos processos acima informados, as homologaçóes $E$ averbaçōes das retificaçbes realizadas em JUNHO/1980, foram contestadas pelo MINISTERIO PÚBLICO do ESTADO da BAHIA que, em peliçóes protocolizadas em ABRIU1985, tomava ciéncia das homologaç6es e apresenta recurso de apelaça contra as mesmas, fevelando a possibildade de prejuzzo ao, património público. 


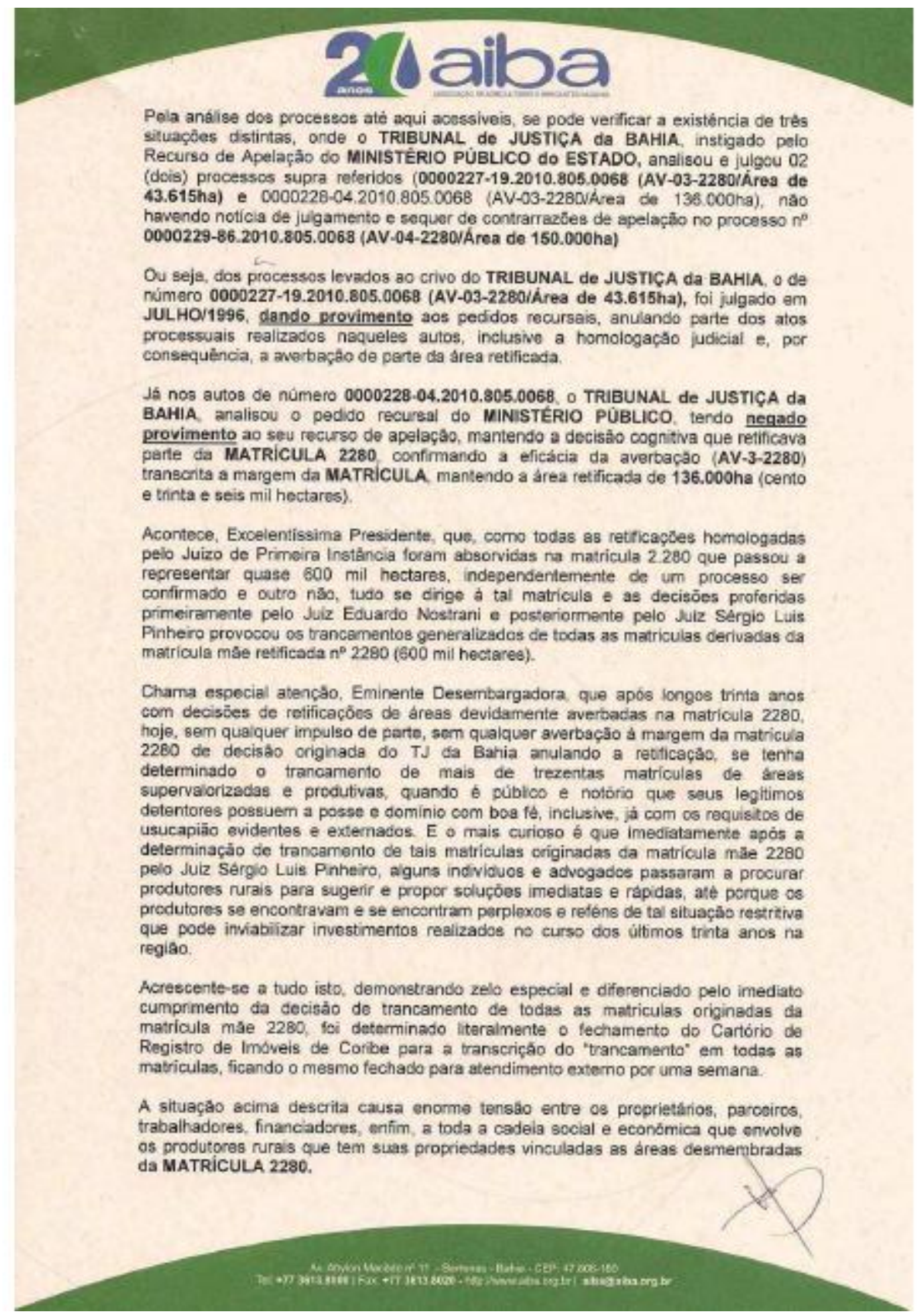




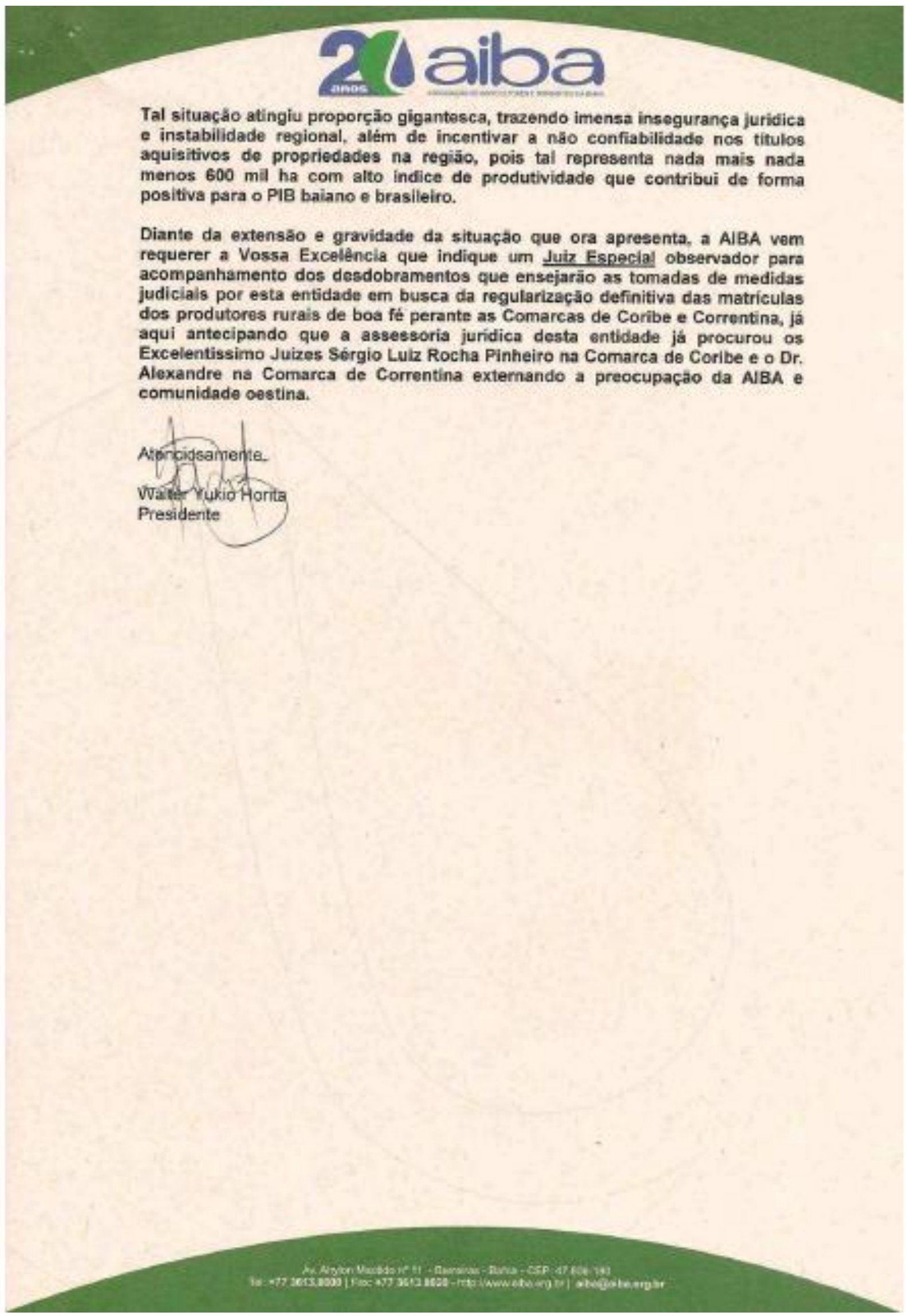

